NovosCadernos Naed Volume 18-Número 3 set-dez.de 2015 


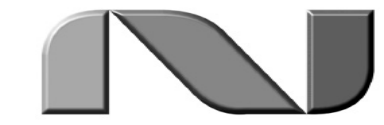

Norros Cadernos NAEA

v. 18, n. 3 • set-dez. 2015 


\section{UNIVERSIDADE FEDERAL DO PARÁ}

Reitor: Carlos Edilson de Almeida Maneschy

Vice-Reitor: Horácio Schineider

Pró-Reitor de Pesquisa e Pós-Graduação: Emmanuel Zagury Tourinho

\section{NÚCLEO DE ALTOS ESTUDOS AMAZÔNICOS}

Diretor Geral - Durbens Martins Nascimento • Diretor Adjunto - Armin Mathis

\section{NOVOS CADERNOS NAEA}

Publicação do Núcleo de Altos Estudos Amazônicos (NAEA) Universidade Federal do Pará (UFPA)

Periodicidade semestral, volume 18, número 3, setembro-dezembro de 2015

Print ISSN: 1516-6481 - Eletrônica ISSN: 2179-7536 - DOI:10.5801/S21797536

\section{EDITOR CIENTÍFICO}

Edna Maria Ramos de Castro

Doutora em Sociologia, Professora do NAEA/UFPA

\section{COMISSÃO EDITORIAL • NAEA}

Edna Ramos de Castro $\bullet$ Sociologia | Francisco de Assis Costa $\bullet$ Economia

Luís Aragon Vaca $\bullet$ Geografia | Oriana Trindade $\bullet$ Economia

Raimundo Heraldo Maués • Antropologia | Silvio Figueiredo • Sociologia

\section{CONSELHO EDITORIAL}

Alfredo Wagner de Almeida - Universidade do Estado do Amazonas, Manaus, Brasil

Andréa Zhouri • Universidade Federal de Minas Gerais, Belo Horizonte, Brasil

Brasilmar Ferreira Nunes • Universidade de Brasília, Brasília, Brasil

Célio Bermann • Universidade de São Paulo, São Paulo, Brasil

César Barreira • Universidade Federal do Ceará, Fortaleza, Brasil

Christian Azais • Université d'Amiens, Amiens, França

Clóvis Cavalcanti • Fundação Joaquim Nabuco, Recife, Brasil

German Palacio • Universidad Nacional de Colômbia, Letícia, Colômbia

Eduardo José Viola • Universidade de Brasília, Brasília, Brasil

Elmar Altvater • Instituto Hudson, Berlin, Alemanha

Emilio Moran • Indiana University, Indiana, Estados Unidos

Geraldo Magela Costa • Universidade Federal de Minas Gerais, Belo Horizonte, Brasil

Henri Acselrad • Universidade Federal do Rio de Janeiro, Rio de Janeiro, Brasil

Heloisa Costa $\bullet$ Universidade Federal de Minas Gerais, Belo Horizonte, Brasil

Ignacy Sachs • École dês Hautes Etudes em Sciences Sociales, Paris, França

Jose Ricardo Ramalho • Universidade Federal do Rio de Janeiro, Rio de Janeiro, Brasil

José Vicente T. dos Santos • Universidade Federal do Rio Grande do Sul, Porto Alegre, Brasil

Marcel Bursztyn • Universidade de Brasília, Brasília, Brasil

Marcelo Sampaio Carneiro • Universidade Federal do Maranhão, São Luís, Brasil

Maria Manoel Batista $\bullet$ Universidade de Aveiro, Aveiro, Portugal

Marilene da Silva Freitas • Universidade Federal do Amazonas, Manaus, Brasil

Martin Coy • Universität Innsbruck, Innsbruck, Áustria

Pedro Jacobi • Universidade de São Paulo, São Paulo, Brasil

Pierre Salama • Université Paris XIII, Paris, França

Pierre Teisserenc • Université Paris XIII, Paris, França

\section{EQUIPE TÉCNICA}

Assistentes editoriais: Rafaela Carmo Ramos, Jondison Cardoso Rodrigues, Cleyson Alberto Nunes Chagas Revisão: Albano Rita Gomes, Iraneide Silva, Maria Stella Pessoa Guimarães

Editoração eletrônica: Ione Sena

Capa: Editoração do NAEA 
Universidade Federal do Pará

Núcleo de Altos Estudos Amazônicos

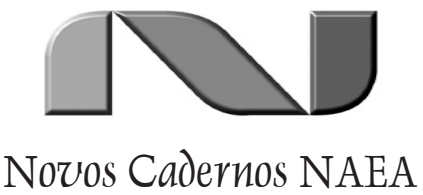

Novos Cadernos NAEA • v. 18, n. $3 \cdot$ p. 1-350 • set-dez. 2015

Print ISSN: 1516-6481 - Eletrônica ISSN: 2179-7536 - DOI:10.5801/S21797536 
A Revista Novos Cadernos NAEA é um periódico quadrienal, de caráter interdisciplinar, dedicado à publicação de trabalhos científicos e acadêmicos sobre temas relevantes às áreas do desenvolvimento, sociedade, economia e meio ambiente, com o objetivo de fomentar o diálogo entre as diversas áreas do conhecimento e suas competências, de pesquisadores e instituições de ensino e pesquisa do Brasil e do exterior.

A revista publica textos originais e inéditos em português, espanhol, inglês e francês. Adota a avaliação anônima por pares (peer review) para trabalhos submetidos às seções: artigos originais e de revisão, resenhas, notas de pesquisa, conferências e, eventualmente, dossiês temáticos, volumes especiais e/ou suplementos

\section{INDEXADORES}

Latindex - Crossref - Portal de Periódicos da CAPES - Google Scholar - Research Bib - e-Revistas/Plataforma Open access de Revistas Científicas Electrónicas Espanholas y Latinoamericanas - Directory of Open Acess Journals (DOAJ) - DRJI - Directory of Research Journal Indexing

\section{IDENTIFICADORES}

Univrsal Impact Factor - Journal For Free - Portal para Periódicos de Livre Acesso na Internet - LivRe Diretório Luso-Brasileiro IBICT - Sumarios.org - Repositório Científico de Acesso Aberto de Portugual Microsoft Academic Search - Library of Congress/HLAS Online - Elektronische Zeitschriftenbibliothek (EZB) - Georgetown University Library - SEER IBICT - Cibera: Iberoamérica/España/Portugal - Library Catalog - University of Texas at Austin - WordCat - Diadorim - Diretório de Políticas de Acesso Aberto das Revistas Científicas Brasileiras

\section{CONTATOS}

Núcleo de Altos de Estudos Amazônicos/Universidade Federal do Pará

Rua Augusto Corrêa, nº 1, Campus Universitário do Guamá

CEP: 66.075-900, Belém, Pará, Brasil

Tel: (+55-91) 32018515

e-mail: revistancnaea@ufpa.br

\section{SUBMISSÃO DE ARTIGOS}

http://www.periodicos.ufpa.br/index.php/ncn

Homepage do NAEA: www2.ufpa.br/naea

Dados Internacionais de Catalogação na Publicação - CIP

(Câmara Brasileira do Livro, SP, Brasil)

Novos Cadernos NAEA, v. 18, n. 3 - set-dez. 2015 - Belém. Núcleo de Altos Estudos Amazônicos/UFPA, 2015

Quadrienal

ISSN Print 1516-6481

ISSN Eletrônico 2179-7536

DOI: $10.5801 / \mathrm{S} 21797536$

O vol. 1, no 1 desta Revista foi publicado em junho de 1998. 1. Desenvolvimento - Periódicos. 2. Meio Ambiente - Periódicos. 3. Amazônia - Periódicos.

(C) Copyright/Direitos de cópia para este número: NAEA/UFPA

Título e textos amparados pela Lei 5.988, de 14 de dezembro de 1973.

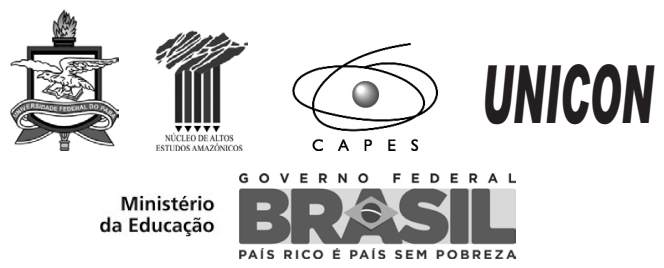




\section{S U M Á R I O}

\section{Editorial}

\section{Artigos}

9 A medida do decidir: atuação do STF nos processos de demarcação territorial pósjulgamento da Terra Indígena Raposa Serra do Sol

The extent of decide: The performance of the STF in territorial demarcation processes post-judgment of the Raposa Serra do Sol

Anabelle Santos Lages, Wendell Ficher Teixeira Assis

29 Políticas e estratégias empresariais de controle territorial: a VALE S.A e os embates na Serra do Gandarela/MG

Corporate policies and strategies of territorial control: VALE S.A and the conflicts in the Serra do Gandarela/MG

Claudia Marcela Orduz Rojas, Doralice Barros Pereira

51 Mineração, neo-extrativismo e conflitos em Barcarena

Mining and neo- extractive and conflicts in Barcarena

Eunápio Dutra do Carmo, Edna Ramos de Castro, Júlio Cezar dos Santos Patrício

73 Mineração e desenvolvimento em Minas Gerais na década 2000-2010

Mining and development in Minas Gerais in the decade 2000-2010

Julio Cesar Reis, Harley Silva

101 A crítica nas margens. Péricles Morais e as representações literárias da Amazônia

Region, tradition and criticism. Péricles Morais and literary representation of Amazon

Marco Aurélio Coelho Paiva

129 Da rede urbana às redes virtuais: acesso à internet e expansão do ciberespaço em Parintins e Itacoatiara From the urban network to the virtual network: access to the internet and the expansion of ciberspace in Parintins and Itacoatiara

Heitor Paulo Pinheiro, Tatiana Schor

147 As coletividades ambivalentes em contextos de justiça social

Collectivities ambivalent contexts of social justice

Alex Pizzio da Silva

179 Pesca artesanal e manejo: conflito socioambiental em uma área de unidade de conservação do Parque Nacional do Cabo Orange, Oiapoque, Amapá

Artisanal fisheries and management: environmental conflict in a protected area National Park Cabo Orange, Oiapoque, Amapá

Uriens Maximiliano Ravena Cañete, Voyner Ravena Cañete, Sônia Maria Simões Barbosa Magalhães Santos 
199 A construção social da qualidade da farinha de mandioca em comunidades rurais na amazônia paraense

Social construction of the quality of cassava flour in rural communities in paraenese amazon Fagner Freires de Sousa, Marc Piraux

223 Compartimentação morfológica de uma planície costeira dominada por mesomaré em Almofala Ceará

Morphological subdivision of a coastal plain dominated by meso-tide of Almofala - Ceará Ponciana Freire de Aguiar, Maâmar El-Robrini, George Satander Sá Freire, Juliana de Sá Guerreiro

251 Janela para o mundo: a TV no cárcere feminino em Belém

Window to the world: the case of female prison on TV in Belém

Nara Cristina Moura Pessoa, Wilson José Barp, Fernanda Valli Nummer

271 Capacidade estatal e implementação de política de desenvolvimento regional sustentável na Amazônia State capacity and sustainable regional development policy in the Amazon

Marília Silva Oliveira

293 Mazzaropi e a indústria de cinema do Brasil: a importância da comédia caipira para a cinematografia brasileira nos anos de 1950-1980

Mazzaropi and Brazil's cinema industry: the importance of caipira comedy forbrazilian cinematography from 1950's to 1980's

Thais Valvano

\section{Resenhas}

309 Desenvolvimento, planejamento e governança: expressões do debate contemporâneo Jondison Rodrigues, Simone S. C. Hoshi, Wanderson Curcino, Vanessa S. Amaral

\section{Teses e Dissertações do NAEA}




\section{EDITORIAL}

A Revista Novos Cadernos $N A E A$ tem a satisfação de encerrar o ano de 2015 com o lançamento do volume 18, n. 3. e inaugurar, neste volume, a periodicidade como revista quadrienal, visando contribuir ainda mais com a produção de conhecimento na área interdisciplinar. A expectativa para o ano de 2016 é de continuar publicando resultados de pesquisa de ponta sobre temas relacionados aos processos de transformação das sociedades, às preocupações e aos desafios do desenvolvimento e do meio ambiente; questões sobre as quais cada vez mais as pesquisas se debruçam no sentido de oferecer chaves de interpretação e de entendimento das sociedades complexas do presente.

Teorias, conceitos e categorias formuladas no campo das ciências humanas e sociais apontam para rupturas epistemológicas e busca de novos paradigmas explicativos face às intensas mudanças das estruturas, das práticas e dos contextos sociais. Enfim, se o mundo cientifico tem mudando, e ainda bem, as ciências humanas e sociais assistem a uma enorme transformação nas relações e estruturas que conformam as sociedades, movimento inusitado que revela a própria insuficiência das epistemologias que constituíram, ao longo dos últimos séculos, suas orientações principais. Ainda que seja fundamental, a perspectiva da interdisciplinariedade, ou da transdisciplinariedade, requer o olhar sobre a construção transversal de problemáticas de pesquisa.

E essencial inverter o olhar, e captar processos, agentes, praticas antes supostamente vazios de interesse e possibilitar a reflexão e entendimento das mudanças profundas que ocorrem de forma avassaladora no mundo contemporâneo, e que colocam em questão os diferentes saberes sobre o presente e o futuro das sociedade. Estas observações, ainda que gerais, apontam para desafios epistemológicos, teóricos e científicos da interdisciplinariedade no inicio do século XXI diante de questões cruciais como mudanças climáticas e desastres ambientais. A perspectiva que privilegia a observação transversal pode fertilizar a emergência de novos agentes e novas questões para além do olhar disciplinar. Os debates de confrontação de perspectives, de sujeitos e de subjetividades imbricadas nos processos coletivos, partem, crescentemente, de uma outra matriz na construção do conhecimento e do debate de ideias. 
A intensificação dos processos de globalização, no contexto de um capitalismo financeiro e hegemônico que se distancia dos modelos de produção consagrados pelo capitalismo industrial, ocorre junto com um enfraquecimento dos mecanismos de exercício de poder dos estados-nação, e das formas de controle social, mudanças que envolvem as trocas culturais e coloca em questão as antigas dinâmicas nacionais e internacionais.

Este número de NCNAEA traz artigos de pesquisas a partir de várias perspectivas teóricas e abordagens metodológicas. Alguns textos apresentam convergência temática, não necessariamente de orientação teórica, embora se destaque a preocupação do olhar interdisciplinar. $\mathrm{O}$ artigo inicial tem como interesse os desdobramentos sociopolíticos e jurídicos decorrentes da decisão do Supremo Tribunal Federal sobre a demarcação da Terra Indígena Raposa Serra do Sol e a relação com as estratégias de mobilização de povos indígenas. Tal decisão do STF tornou-se emblemática ao definir parâmetros de julgamento, e abrir novas questões no campo da jurisprudência. Cresceram, neste inicio de século, os interesses privados sobre as terras indígenas, notadamente sobre os recursos minerais e o potencial hídrico, como verificado na Amazônia. O tema da mineração é examinado em três artigos. Eles analisam agentes, ações e estratégias empresariais, formas de controle do território e mobilizações da sociedade, transformações na dinâmica econômica e conflitos entre empresas e grupos locais e, ainda, análisa a economia mineral em Minas Gerais e seus efeitos na produção do desenvolvimento.

Sob outra perspectiva, mas interessados em interpretações sobre os conceito de região e de identidade nacional, são publicados dois artigos no campo do pensamento social brasileiro. Um deles discute a dimensão explicativa dos processos de representação regional formulados na Amazônia nos anos 1920 e 1930, e o outro, a partir da produção cinematográfica brasileira, cuja questão central é a identidade nacional. Neste caso, a autora analisa a produção de representações e de estereótipos que atravessaram por muito tempo as narrativas e explicações do Brasil rural, com a figura do caipira.

Em outra dimensão temática, dois artigos discutem a pesca artesanal e os espaços de Unidades de Conservação e a construção social da qualidade da farinha de mandioca, elemento fundamental na estrutura alimentar do pais. Alguns artigos abordam ainda problemáticas urbanas como o acesso aos bens e serviços da sociedade, no estudo de redes - virtuais e físicas - e ainda, interpretação das formas de produção e reprodução das desigualdades sociais e da dominação. A cidade é também estudada na relação com o sistema prisional e o papel da televisão no processo de sociabilidade das mulheres em situação de cárcere.

Novos Cadernos NAEA tem a satisfação de dar acesso a esses trabalhos que expressam resultados de pesquisas, e artigos de revisão, conformando um quadro de realidades extremamente interessantes e vistas por diferentes perspectivas.

Edna Ramos de Castro

Editora Cientifica 


\section{A medida do decidir: atuação do STF nos processos de demarcação territorial pós-julgamento da Terra Indígena Raposa Serra do Sol}

The extent of decide: The performance of the STF in territorial demarcation processes post-judgment of the Raposa Serra do Sol

Anabelle Santos Lages - Doutora em Sociologia. Bolsista PNPD do Programa de PósGraduação em Sociologia da Universidade Federal de Alagoas. E-mail: anabellelages@ yahoo.com.br

Wendell Ficher Teixeira Assis - Doutor em Planejamento Urbano e Regional. Professor Adjunto do Instituto de Ciências Sociais da Universidade Federal de Alagoas. E-mail: wwficher@yahoo.com.br

\section{Resumo}

$\mathrm{O}$ artigo analisa os desdobramentos sociopolíticos e jurídicos decorrentes da decisão do STF sobre a demarcação da Terra Indígena Raposa Serra do Sol, sobretudo, no que tange às disputas políticas para ampliar a abrangências das dezenove condicionantes formuladas no âmbito do julgamento. Para tanto, expõe as estratégias mobilizadas pelas populações indígenas na tentativa de sensibilizar a opinião pública, ao mesmo tempo em que procuram influir na decisão dos Ministros do Supremo. De maneira complementar, o trabalho escrutina os debates no âmbito do STF que compuseram o julgamento sobre a demarcação de duas terras indígenas que ocorreram pós-decisão do caso Raposa, a saber; Terra Indígena Porquinhos dos Canelas e Terra Indígena Guyraroka. A partir da análise comparativa, pode-se indicar que longe de uma neutralidade jurídica inerente ao ato de decidir, estão em jogo tanto um intricado uso dos instrumentos do direito, como a capacidade de incidência e pressão política levadas a cabo pelas populações indígenas.

\section{Palavras-chave}

Demarcação; Supremo Tribunal Federal; Terra Indígena; Raposa Serra do Sol.

\begin{abstract}
The article analyzes the socio-political and legal developments arising from the decision of the Supreme Court on the demarcation of the Raposa Serra do Sol, especially when it comes to political disputes to expand the scopes of the nineteen conditions formulated under the trial. Therefore, it exposes the strategies deployed by the indigenous populations in an effort to raise public awareness, while seeking to influence the decision of the Ministers of the Supreme. In a complementary way, the work scrutinizes the debates that made up the decision on the demarcation of two indigenous lands, namely; Indigenous Land of Porquinho dos Canelas and Indigenous Land Guyraroka. From the comparative analysis, it can be stated that far from legal neutrality inherent in the act of deciding, are at stake both an intricate use of the right tools, such as the incidence capacity and political pressure carried out by indigenous peoples.
\end{abstract}

\section{Keywords}

Demarcation; Federal Supreme Court; Indigenous Land; Raposa Serra do Sol. 


\section{INTRODUÇÃO}

No dia 19 de março de 2009 o Supremo Tribunal Federal - STF declarou constitucional o modelo contínuo da demarcação da Terra Indígena Raposa Serra do Sol, derrubando a liminar que garantia a presença dos não índios na região. A decisão pode ser considerada jurídica, sociológica e politicamente emblemática. Do ponto de vista jurídico, desde o caso Krenak, em 1993, o STF não julgava o mérito de uma ação demarcatória indígena. Até então as decisões se restringiam a questões processuais (YAMADA, 2010), isto é, sequer adentravam na discussão sobre o direito dos indígenas à posse de determinado território.

Do ponto de vista sociológico, o valor analítico do caso se referenda nos debates decorrentes da decisão. Para citar alguns exemplos, pode-se dizer da sempre presente problemática da disputa fundiária no Brasil, dos discursos que advogam a integração do índio à sociedade (ao mesmo tempo em que lhe retira direitos exatamente pelo fato de considerá-lo integrado), dos questionamentos sobre a recente e midiática evidência dos ministros do STF, dando à sociedade mais uma oportunidade para interrogar sobre a figura desses que são os últimos intérpretes da lei, autorizados a decidir sobre os valores sociais em vigência (REPOLÊS, 2003).

No plano político imediato, a demarcação da Terra Indígena Raposa Serra do Sol foi um compromisso de campanha do Presidente Luis Inácio Lula da Silva nas eleições presidenciais de $2002^{1}$. Apontada como uma das "situações graves que afetam populações indígenas, configurando flagrante desrespeito aos direitos humanos" (COMPROMISSO COM OS POVOS INDÍGENAS DO BRASIL, 2002, p.9), a homologação da Terra Indígena Raposa Serra do Sol foi apresentada como uma medida primordial da futura administração. No documento, elaborado com a participação de diversas lideranças, a política indigenista do governo Fernando Henrique Cardoso foi apresentada como lamentável, em razão das precárias condições de funcionamento da FUNAI, bem como a demora para a criação de um novo Estatuto das Sociedades Indígenas.

Além disso, a repercussão internacional dos mais de trinta anos de lutas por reconhecimento e violências sofridas pelas comunidades da Terra Indígena Raposa Serra do Sol certamente ajudou a formar o convencimento de que seria interessante mostrar para o mundo que o Brasil não era o país "que pior tratava seus índios", como era dito de tempos em tempos, retirando da opinião internacional a impressão de que o Brasil era um país bárbaro (LIMA, 1995). O fato, como

\footnotetext{
As expectativas em relação ao governo Lula restaram frustradas no que se referiu à demarcação de terras indígenas. A própria homologação da TIRSS só veio a ocorrer em 2005, mas, com o processo judicial, só foi formalmente concluída em 2009, com a decisão do Supremo.
} 
argumentou Silva (2009, p. 153), à época do julgamento, é que estava “em jogo não apenas uma pendenga entre índios e não-índios na sociedade de Roraima, [mas estavam] na berlinda todos os brasileiros, em sua capacidade de proteger, pelas mãos do Estado, a preciosa esfera dos valores culturais e imateriais da nação".

Pelo exposto, não parece demais inferir que a atmosfera ao redor do julgamento tinha ares de imprescindibilidade de uma decisão favorável aos indígenas. Além do direito propriamente dito, sua legitimidade sociopolítica resultava da conjugação de particularidades como o tempo de luta pela causa, forte pressão internacional e um movimento indígena profundamente articulado e organizado. Juntos, todos esses elementos culminaram num fato político capaz de corroborar a afirmação de Lassalle (2001), que afirma a insustentabilidade das regras constitucionais quando a arena política não fornece o necessário suporte à sua aplicabilidade. De acordo com essa perspectiva, no limite, os próprios fundamentos da democracia e do estado de direito necessitam desse aporte político para se materializarem de fato (WEINGAST, 1997). Da Ros (2007) sintetiza, afirmando que as "regras são cumpridas porque há interesse dos demais agentes da arena política em observá-las - especialmente daqueles atores capazes de intervir no sentido de modificar essas mesmas regras".

Após seis anos do reconhecimento da legalidade da demarcação contínua da terra Indígena Raposa Serra do Sol, arrefecido o debate midiático, algumas considerações sobre os desdobramentos jurisprudenciais daquele julgamento já podem ser feitos com maior clareza. Por essa razão, neste artigo, nosso olhar se dirigirá às respostas dadas pelo Supremo aos casos posteriores ao da Raposa Serra do Sol. O objetivo é compreender se a afirmação de Lassale (2001) sobre a aplicabilidade das normas constitucionais (aqui entendido como reconhecimento de direitos) dependeria mesmo de um ambiente disposto a receber determinada decisão. A esse entender, as análises de algumas decisões tendem a concordar com Carrió (1986), quando afirma que, a despeito dos Tribunais serem compreendidos como a instância garantidora dos direitos das minorias os casos concretos não validam essa apresentação. Ao contrário, sua atuação contramajoritária restaria facilitada quando não mais existissem maiorias adversárias na arena política. A constatação faz surgir um questionamento que, percebemos, tem estado presente nos recentes estudos sobre os Tribunais Superiores (WERNECK VIANNA, 1999; VIEIRA, 2002), não apenas o brasileiro, mas que aqui poderia ser expressa da seguinte maneira: seria o Supremo Tribunal Federal um ente organicamente político?

Dito isso, convém apresentar a dinâmica norteadora deste trabalho. Primeiro, a análise ponderará sobre a relevância de contextos extraconstitucionais para a formação de sensibilidades que orientam as decisões judiciais. Nesse 
sentido, nos limites destas linhas, será feito um apanhado das circunstâncias históricas que forneceram os elementos político-simbólicos que atravessaram todo o arranjo jurídico e discursivo presente no acórdão proferido na demarcação da Terra Indígena Raposa Serra do Sol. Em seguida, serão abordados dois litígios sobre demarcação levados ao Supremo após 2009: o caso da Terra Indígena Porquinhos dos Canelas - Apãnjekra, localizada no Estado do Maranhão ${ }^{2}$ e o caso da Terra Indígena Guyraroka, pertencente à etnia Guarani Kaiowá3 ${ }^{3}$, situada em área do Estado do Mato Grosso do Sul.

Em tempo, vale destacar que a perspectiva analítica do artigo se ancora em uma abordagem interdisciplinar que realçando o diálogo entre o direito e as ciências sociais procurará fazer emergir uma melhor compreensão dos fundamentos argumentativos que balizam as decisões do STF, mormente, no que tange às demarcação de terras indígenas que ocorreram após o emblemático caso da Terra Indígena Raposa Serra do Sol.

\section{OS ACESSÓRIOS SEGUEM O PRINCIPAL: A DECISÃO DA RAPOSA SERRA DO SOL E DOIS CASOS SUBSEQUENTES}

Ao longo do debate que circundou a tomada de decisão dos Ministros do Supremo no caso da demarcação da Terra Indígena Raposa Serra do Sol, seu aspecto modelar foi exaltado quase que de forma absoluta. Espécie de regramento geral utilizado para balizar as futuras demarcações e decisões judiciais sobre a matéria, "deixando fundadas as bases jurídicas para o contínuo reconhecimento aos povos indígenas das terras que tradicionalmente ocupam" (BRASIL, 2008, p. 760). Para compreender essa ambição jurisprudencial, quase normativa, dos Ministros faz-se necessário desviar o olhar das quase oitocentas páginas do processo e redirecioná-lo senão para a inteireza de sua história, mas para os pontos que lhe legaram o nem sempre definível predicativo de paradigmático.

Localizada na porção nordeste do estado de Roraima, a Terra Indígena Raposa Serra do Sol possui área de 1.743,089 hectares e pertence à chamada Amazônia brasileira, composta pelos estados do Amazonas, Acre, Amapá, Pará, Rondônia, Roraima e Tocantins (BRASIL, 2009). Um dos argumentos levantados pelos oponentes da demarcação contínua dizia respeito ao que se poderia chamar de mito da faixa de fronteira, uma vez que a terra indígena encontra-se na tríplice fronteira entre Brasil, Venezuela e República Cooperativista da Guiana. As disputas envolvendo terras amazônicas são carregadas de estratégias que visam a

Recurso ordinário em mandado de segurança 29.542, de 30 de setembro de 2014.

Recurso ordinário em mandado de segurança 29.087, de 19 de abril de 2014. 
deslegitimação de direitos. A despeito de serem refutadas antropológica e legalmente, as reclamações levadas ao STF possuem certa capilaridade entre a população leiga. Assim, dependendo da situação apresentada, um ou outro argumento costuma ser vivificado por aqueles que são contrários à demarcação pretendida.

O processo de reconhecimento da Terra Indígena Raposa Serra do Sol teve início em 1917, quando foram estabelecidas algumas práticas de governo que visavam à demarcação. Naquele ano, o governo do estado do Amazonas editou a lei estadual n. 941, que destinava as terras que se localizavam entre os rios Surumu e Contigo aos índios Macuxi e Jaricuna. Em 1919, o Serviço de Proteção aos Índios dá início ao processo de demarcação da área tendo em vista as constantes invasões de fazendeiros. A contradição reside no fato de que a ampliação e/ou criação de fazendas, inclusive por meio de doações de terras, era uma política do governo federal para incentivar a ocupação do Território e fazia parte de um projeto migratório para a região, existente desde os tempos coloniais, em função da considerada baixa densidade demográfica. A chamada colonização pela "pata do boi" fazia parte desse processo de avanço sobre os territórios indígenas, com a ampliação das fazendas na proporção do aumento do rebanho bovino (COSTA SILVA, 2012). Expedido em 1925, o título de concessão dessas terras não reverberou entre as autoridades locais; a demarcação iniciada pelo SPI não foi finalizada (CARVALHO; MAIOR, 2008).

Após idas e vindas, avanços e retrocessos, o processo de demarcação da Terra Indígena Raposa Serra do Sol foi concluído no primeiro semestre de 2005. No dia 20 de maio de 2005, foi ajuizada Ação Popular (Petição 3388/RR) em desfavor da União. Os autores da ação foram os então senadores da República Augusto Affonso Botelho Neto e Francisco Mozarildo de Melo Cavalcanti (Arena, PFL, DEM). Os autores populares pediam a declaração de nulidade da Portaria 534/2005, emitida pelo Ministro de Estado da Justiça, bem como do Decreto do Presidente da República. Daquele ano em diante, "inicia-se então a mais importante batalha jurídica pelos direitos indígenas desde a redemocratização do Brasil" (DUARTE DO PATEO, 2009, p. 166); o caso da demarcação da Terra Indígena Raposa Serra do Sol foi ganhando cada vez mais destaque na imprensa brasileira. Manobras judiciais que pretendiam reverter a homologação das terras e discursos inflamados sobre os riscos à segurança nacional e ao desenvolvimento do país eram continuamente intercalados por atos de violência física praticados principalmente pelos partidários da demarcação em ilhas.

Tão logo a ação foi impetrada, o Conselho Indigenista de Roraima iniciou uma forte campanha nacional e internacional a favor da demarcação contínua. No âmbito interno, um dos alvos foi o próprio órgão responsável por proferir a 
decisão. Assim, ao longo dos quase quatro anos de duração do processo, foram solicitadas audiências com os ministros do STF pelos representantes indígenas, com o intuito de defender a demarcação nos moldes como havia sido realizada. Essa estratégia de sensibilização da opinião pública e de pressão política sobre o Supremo pode ser desprendida do fragmento de entrevista ${ }^{4}$ disposto a seguir no qual uma liderança Wapichana discorre sobre as estratégias de luta política levada a cabo pelas populações indígenas durante o processo de julgamento da demarcação;

[...] a gente queria chamar a atenção do mundo para o julgamento do STF. Da imprensa principalmente, a gente queria chamar a atenção da imprensa, para saber o que ia passar, né? Nós conseguimos atingir nosso objetivo, porque ao mesmo tempo que a gente estava fazendo essa campanha na Europa, aqui as lideranças estavam em Brasília e as comunidades estavam mobilizadas aqui. Foi uma rede que nós criamos para chamar a atenção. Essa campanha teve como objetivo levar lideranças para conversar com os ministros do STF. Nós fomos várias vezes conversar com os ministros para colocar também a nossa versão. Levando vídeos, fotos, mapas, demonstrando como era nossa vida dentro da terra para mostrar a importância das terras contínuas. [...] Cada vez ia uma comitiva falar com os ministros, né? Como é um trabalho coletivo, chegava e dizia, olha, ele é assim, assim, assim. Então, assim, já dava para saber quem era quem, quem eram os ministros mais favoráveis, quem tinha mais resistência. Eles até recebiam, mas tinham uns que não queriam ouvir muito. Eles ouviram assim... Claro que alguns receberam por mais tempo, assim como [teve] ministro que recebeu a documentação no corredor. E a gente já entendia porque que era aquele recebimento no corredor. (Entrevista com liderança indígena Wapichana, Boa Vista-RR, julho de 2012).

As estratégias de atuação do Conselho Indigenista de Roraima - CIR, ${ }^{5}$ desenvolvidas para a obtenção de um julgamento favorável à demarcação contínua, mostram que conhecer a dinâmica do campo jurídico (BOURDIEU, 1989), sobretudo sua porosidade, apresenta-se fundamental para colocar em prática a observação de Arendt (1979) de que o direito não é dado, mas construído. Os pedidos de audiências particulares com os ministros do STF significam que as lideranças indígenas, da mesma forma que os autores da ação popular, conheciam certos costumes do métier. Bourdieu (2001) nomeia de illusio esse conhecimento tácito, não escrito da lógica e das regras do jogo, cuja aquisição pelo sujeito vincula-se à presença naquele universo.

4 Durante a realização da pesquisa que originou o presente artigo foram realizados trabalhos de campo na região da Terra Indígena Raposa Serra do Sol, que objetivaram captar as percepções e estratégias políticas utilizadas pelas populações indígenas na defesa de seus direitos.

5 À época da decisão, o CIR estava sob a coordenação de Joênia Wapichana, primeira mulher indígena advogada do Brasil. Tanto a coordenadora, como a própria organização contaram com a assessoria jurídica dos advogados do Instituto Socioambiental durante todo o processo. 
Levando em conta a impressão de habitualidade fornecida pelo relato, a leitura do trecho acima nos permite perceber que os membros das comitivas indígenas mapeavam o perfil dos ministros do STF de uma maneira sistemática. O repasse das informações de um grupo a outro antes dos encontros permitiulhes identificar os posicionamentos de alguns ministros em relação ao caso.

No dia 19 de março de 2009, na segunda sessão do julgamento, o STF declara constitucional o modelo contínuo da demarcação, derrubando a liminar que garantia a presença dos não-índios naquelas terras. A ação foi julgada parcialmente procedente, nos termos dos fundamentos do voto do Ministro Relator, Carlos Ayres Britto, acrescido pelas condicionantes, ou, nos termos de alguns Ministros, salvaguardas institucionais, elaboradas a partir do voto-vista do Ministro Menezes de Direito. Ainda, a leitura do acórdão nos fornece a extensão do debate realizado, que foram desde o significado do substantivo "índios" na Constituição da República, passando por discussões sobre as terras indígenas como parte essencial do território brasileiro, a velha contenda acerca do falso antagonismo entre a questão indígena, desenvolvimento e meio ambiente, além de questões sobre os direitos originários, as fronteiras, a atuação do exército e a teoria do fato indígena. Na próxima seção veremos em que medida tais teses, debatidas no caso da Raposa Serra do Sol, alcançaram decisões posteriores ao emblemático caso.

\section{TERRA INDÍGENA PORQUINHOS DOS CANELAS E TERRA INDÍGENA GUYRAROKA}

A escolha dos casos da Terra Indígena Porquinhos dos Canelas e da Terra Indígena Guyraroka não foi aleatória, ao contrário disso, pode-se constatar na análise desses processos que o STF resgatou pontos polêmicos estabelecidos na ocasião do julgamento do caso Raposa Serra do Sol. No primeiro tem-se o resgate da condicionante de número dezessete, que versa sobre a proibição do aumento do território para aquelas comunidades que já passaram pelo procedimento administrativo de demarcação e, no segundo, observa-se a teoria do fato indígena, que estabelece a data da promulgação da Constituição da República de 1988 como marco temporal válido para o reconhecimento de suas terras.

Sobre as condicionantes anexadas à decisão da demarcação da Terra Indígena Raposa Serra do Sol pelo Ministro Menezes de Direito, os argumentos em prol delas ${ }^{6}$ dizem respeito tanto a uma suposta necessidade de esclarecer o

\footnotetext{
6 Após a decisão, foram opostos Embargos de Declaração para esclarecer a extensão da aplicabilidade das condicionantes. No dia 23 de outubro de 2013, o Supremo voltou atrás e decidiu que sua validade seria apenas para a TIRSS, não tendo, portanto, efeito vinculante. De toda sorte, não se pode evitar que a decisão passe a integrar o entendimento daquela Corte sobre a questão indígena, notadamente por não haver reiteradas decisões a esse respeito.
} 
direito do usufruto indígena, como também de operacionalizar a própria decisão a partir do que seria uma "proposição criativa", nos termos utilizados pelo ministro Carlos Ayres Britto (BRASIL, 2008, p. 634). A maioria dos Ministros preferiu considerá-las uma inovação ao invés de inconstitucionais, mesmo que seus termos tenham ultrapassado os limites de discussão delineados pelo pedido inicial dos autores populares, qual seja: a nulidade do processo administrativo que determinou a demarcação contínua da área da Terra Indígena Raposa Serra do Sol. Aqueles que se posicionaram contra anteviram desdobramentos indesejáveis em casos vindouros, posto que a medida tomada pelo Supremo tem significado de uma atividade normativa que, a rigor, coloca em questão os princípios do Estado Democrático de Direito e a separação dos poderes, deixando de lado qualquer discussão com as partes interessadas (art. $5^{\circ}$, LIV, CR) ou mesmo com o restante da sociedade.

A condicionante dezessete inviabiliza de forma tácita a correção de eventuais erros ou vícios nas demarcações, sempre que desse ajuste resulte a ampliação de terras. Macula o princípio da imprescritibilidade do direito, além de desconsiderar os esbulhos e violências praticados ainda hoje contra as populações indígenas. Em específico, juridicamente, o apêndice esvazia o disposto no artigo $231 \mathrm{da}$ CR/88, que assegura de forma permanente aos povos indígenas as terras por eles habitadas, bem como aquelas "imprescindíveis à preservação dos recursos ambientais necessários ao seu bem-estar e as necessárias à sua reprodução física e cultural, segundo os seus usos e costumes e tradições".

Por reconhecer que a demarcação da Terra Indígena Porquinhos dos Canelas restou prejudicada pela ocorrência de pressões políticas e vícios no procedimento, a FUNAI constituiu grupo técnico para a realização de novos estudos para a remarcação das terras da etnia Apãnjekra. A primeira demarcação foi iniciada na década de 1970 e homologada pelo Decreto n. 88.599, de 9.8.1983. Os novos estudos realizados confirmaram a legitimidade da reivindicação da população indígena e culminaram com a publicação da Portaria n. 3.508/2009, que determinava que a Terra Indígena passaria de 79.520 ha (setenta e nove mil e quinhentos e vinte hectares) para $301.000 \mathrm{ha}$ (trezentos e um mil hectares). A objeção veio por parte dos municípios de Fernando Falcão, Formosa da Serra Negra e Barra do Corda, todos do estado do Maranhão, que recorreram ao STF por discordarem da ampliação pretendida.O principal argumento dos recorrentes se assentou, exatamente, na condicionante de número dezessete.

É preciso dizer que, inicialmente, os recorrentes ingressaram com mandado de segurança no Superior Tribunal de Justiça. O objetivo era neutralizar os efeitos da Portaria n. 3.508/2009, que reconhecia a ampliação daquele 
território. Não obstante, a Ministra Relatora do processo reconheceu a existência de vícios e irregularidades no processo, como, por exemplo, a ausência de laudo antropológico, entendendo que o procedimento administrativo que deu origem à contestada Portaria tinha por objetivo corrigir os erros do passado, nessa instância se manteve, portanto, a decisão estatal que determinara o alargamento das fronteiras da Terra Indígena.

Inconformados pela derrota no Superior Tribunal de Justiça, os municípios de Fernando Falcão, Formosa da Serra Negra e Barra do Corda recorreram da decisão no STF. Ainda que tenha reconhecido a ausência de força vinculante, em sentido técnico, da decisão da Petição 3.388/RR, do caso Raposa Serra do Sol, o acórdão proferido no Recurso Ordinário proposto pelos municípios maranhenses contra a ampliação da Terra Indígena Porquinhos dos Canelas, deixa clara a ocorrência do que os Ministros do STF consideram a eficácia subjetiva daquela decisão, "especialmente pela força jurídico-constitucional do precedente histórico, cujos fundamentos influenciam direta ou indiretamente na aplicação do direito pelos magistrados em casos semelhantes" (BRASIL, 2014, p. 12). Portanto, a partir desse reconhecimento da eficácia da decisão da Terra Indígena Raposa Serra do Sol, mesmo salientando a inexistência de efeito vinculante, o STF, ancorando-se na condicionante número dezessete, julgou improcedente a ampliação da demarcação Terra Indígena Porquinhos dos Canelas.

Tanto a decisão da Terra Indígena Raposa Serra do Sol, como a da Terra Indígena Porquinhos dos Canelas, consideraram a possibilidade, nos casos de necessidade de ampliação de área já afetada pelo procedimento demarcatório, de o Poder Público se valer de outros instrumentos capazes de satisfazer os anseios das comunidades indígenas. Trata-se da aquisição de novas terras pelos meios tradicionais do direito civil, devidamente resguardadas pelos artigos 32 e 39, III, da Lei 6.001/73. No entanto, não deixa de ser irônico que a desconsideração de vícios nos procedimentos demarcatórios, estabelecidos constitucionalmente e a partir de uma legislação protetiva, especial e específica, possa conduzir as populações indígenas a buscarem a solução desses erros no regramento comum do direito civil, que remonta aos procedimentos correntes de compra e venda no mercado de terras.

A condicionante dezessete foi trazida de forma incidental em um processo no qual a ampliação de terras indígenas não estava em questão. $\mathrm{Na}$ prática, a proibição de aumento na extensão de terras indígenas já demarcadas representou uma atuação normativa do STF. Atuação essa que sequer oportunizou às comunidades indígenas, tanto da Raposa Serra do Sol, como de outras localidades, o direito de contestar a condicionante. Não seria exagero 
afirmar, portanto, que o novo regramento pretende atingir, sem os pressupostos de legitimidade e contrariando o princípio da separação dos poderes, a própria norma constitucional que trata dos direitos dos índios a seus territórios, artigos 231 e 232 da Constituição da República.

O segundo caso selecionado para mapear os efeitos resultantes da decisão da Terra Indígena Raposa Serra do Sol, sobre outros litígios envolvendo demarcação de terras indígenas, vem do Mato Grosso do Sul. O Recurso Ordinário em Mandado de Segurança ${ }^{7}$ foi julgado pelo STF no dia 19 de abril de 2014. Como no caso anterior, o recurso foi interposto contra acórdão proferido pelo Superior Tribunal de Justiça. Igualmente, trata-se de Mandado de Segurança impetrado contra ato do Ministro da Justiça (Portaria 3.219, de 7.10.2009), que reconheceu a posse permanente da Terra Indígena Guyraroka, à etnia Guarani Kaiowá, ao mesmo tempo em que estabeleceu as glebas do recorrente (Avelino Antônio Donatti) como sendo de ocupação tradicional indígena. O STJ decidiu que "a existência de propriedade, devidamente registrada, não inibe a FUNAI de investigar e demarcar terras indígenas". Afirmou ainda que o instrumento legal manejado pelo impetrante não permitia a produção de provas ou mesmo fazer contra prova ao laudo elaborado pela FUNAI.

O laudo da FUNAI atestou que os Guarani Kaiowá tinham a posse da terra até o início da década de 1940 e que as pressões dos fazendeiros locais, bem como as compras de terras, tornaram inviável sua permanência na região. Ainda, conforme informação constante no laudo antropológico e reconhecido pelo STJ, desde meados do século XVIII os Kaiowás encontram-se na região em disputa. Mesmo o desapossamento de suas terras nos anos 1940 por parte dos fazendeiros não impediu que alguns indígenas continuassem na região (invariavelmente trabalhando nas fazendas), mas sem perder a relação tradicional que mantinham com o lugar.

Ao perder a ação no STJ, o recorrente ingressou com recurso no STF. Sob um argumento de natureza processual, o Ministro Relator, Ricardo Lewandowisk, entendeu que a pretensão não poderia ser acolhida, já que não teria respaldo na documentação juntada nos autos. Valeu-se dos precedentes do STF para dizer que apenas a produção de provas poderia contradizer o laudo elaborado pela FUNAI, mas que o instrumento jurídico manejado pelo recorrente (mandado de segurança) não permitia a apreciação adequada do contexto fático-probatório que envolvia o caso, razão pela qual negou provimento ao recurso. Entretanto, sustentando haver um problema de atualização da jurisprudência do STF à luz do decidido no caso da Raposa Serra do Sol e da necessidade de se provar a presença

\footnotetext{
Recurso Ordinário em Mandado de Segurança nº. 29.087.
} 
indígena no local na data do dia 5 de outubro de 1988, o Ministro Gilmar Mendes pediu vistas do processo.

Ao devolvê-lo para julgamento, o Ministro expressou sua discordância em relação à decisão do STJ argumentando que embora o laudo tenha dito sobre a presença indígena nos anos de 1750-1760, esse fato seria insuficiente para se pretender a demarcação nos novos moldes pretendidos. $\mathrm{Na}$ visão do Ministro Gilmar Mendes, "se esse critério pudesse ser adotado, muito provavelmente teríamos de aceitar a demarcação de terras nas áreas onde estão situados os antigos aldeamentos indígenas em grandes cidades do Brasil, especialmente na região Norte e na Amazônia" (BRASIL, 2014, p 23).

O Ministro resgatou o entendimento de terras "tradicionalmente ocupadas" pelos índios, nos termos do art. 231, \ $1^{\circ}$, da Constituição Federal, bem como a Súmula 650, que dispõe que "os incisos I e XI do art. 20 da Constituição Federal não alcançam terras de aldeamentos extintos, ainda que ocupadas por indígenas em passado remoto". De acordo com precedentes do $\mathrm{STF}^{8}$, a palavra tradicionalmente não se refere à posse imemorial, mas à forma de possuir. O que importa, portanto, são as relações de pertencimento estabelecidas entre a comunidade indígena e a terra e não o tempo da ocupação. Essa relação anímica deveria vir acompanhada da presença indígena na localidade à data da promulgação da Constituição da República de 1988. A essa exigência se convencionou chamar de Teoria do Fato indígena.

O Ministro relembrou o decidido no caso Raposa Serra do Sol, cujo "entendimento da Corte então assentado deve servir de apoio moral e persuasivo a todos os casos sobre demarcação de terras indígenas". No julgamento desse caso paradigmático, decidiu-se que a data da promulgação da Constituição é referencial insubstituível do marco temporal para verificação da existência da comunidade indígena e da efetiva e formal ocupação fundiária pelos índios. Ao reavivar a Teoria do Fato indígena, o Ministro Ayres Brito, relator da Petição 3.388/RR, afirmou que ela, a um só tempo, evitaria fraudes em razão da proliferação de comunidades indígenas, coibindo, inclusive, o recrutamento de índios de outras regiões ou países; e também tentativas de descaracterizar a tradicionalidade da posse das suas terras a partir de práticas de violência e expulsão dos índios.

Uma das características que tornou a decisão da Terra Indígena Raposa Serra do Sol paradigmática foi que, nela, discutiu-se a própria substância do direito indígena, deixando de se restringir a questões de natureza processual, em tese, de caráter mais periférico. Em termos práticos, pode-se dizer que a decisão do Supremo reconheceu os direitos daquelas comunidades indígenas sobre o

Ministro Nelson Jobim: RE 219.983, julgamento em 9.12.1998. 
seu território. Reconheceu também as práticas de violências e os esbulhos que impediram que à data da promulgação da Constituição da República de 1988 a posse indígena naquela região não estivesse configurada em sua plenitude. Isso significa que, naquele caso, o marco temporal de 1988, que se consolidou no entendimento da Teoria do Fato Indígena, não retirou dos índios o reconhecimento dos seus direitos originários às terras que tradicionalmente ocupam ainda que sejam apresentados títulos de propriedade mais antigos, posto que conquistados à custa dos deslocamentos e das expulsões forçadas sofridas pelos indígenas.

Ancorado na Teoria do Fato Indígena consolidada no interior do processo da Raposa Serra do Sol, o Ministro Gilmar Mendes afirmou a impossibilidade de demarcação da Terra Indígena Guyraroka, utilizando-se do argumento segundo o qual o título de propriedade apresentado pelo recorrente demonstrava a não presença dos Guarani Kaiowá na região desde há setenta anos. O Ministro deu provimento ao recurso ordinário e concedeu a segurança para declarar a nulidade do processo administrativo de demarcação, bem como da Portaria n. 3.219/2009, do Ministro de Estado da Justiça. O voto proferido pelo Ministro Gilmar Mendes coloca em realce as disputas políticas no que tange a interpretação da Teoria do Fato Indígena, uma vez que há na formulação de seu argumento um emprego parcial dessa tese, não considerando, como no caso Raposa Serra do Sol, que a inexistência de indígenas no território na data de promulgação da Constituição é uma decorrência direta de violência, ameaças, grilagens e esbulhos perpetrados contra as populações indígenas. Sobre esse aspecto, o laudo da FUNAI juntado no processo já salientava a existência de continuas e reiteradas expulsões sofridas pela etnia Guarani Kaiowá no transcurso do processo de colonização e de avanço da fronteira de exploração agropecuária.

O voto do Ministro Gilmar Mendes provocou reação imediata do Ministro relator do processo, Ricardo Lewadowski, que tinha decidido pela improcedência do recurso amparando-se na impossibilidade do rito judicial escolhido. O mandado de segurança requer que o litígio não necessite da produção de provas, ademais, o laudo antropológico apresentado pela FUNAI já atestava que a etnia, estava presente na região desde o final do século XVIII e fora expulsa por fazendeiros em meados dos anos 40 do século XX. Entendeu, portanto, o Ministro relator que a decisão do Ministro Gilmar Mendes extrapolava os requisitos exigidos para o manejo de mandado de segurança. De acordo com Lewandowiski, se fosse o caso de se examinar o momento da saída dos índios da terra, essa seria uma matéria a ser decidida em outra via, mas não em mandado de segurança, uma vez que tal instrumento não contempla espaço para o debate e apresentação de novas provas. Assim, a decisão haveria de se ater tão somente à documentação 
já constante no processo administrativo de demarcação conduzido pela FUNAI, aliás, como já havia decidido o STJ. A partir daí, seguiu-se um debate entre os dois Ministros. Embora, a primeira vista possa parecer uma questão de mero formalismo processual, pedimos licença para reproduzirmos integralmente a discussão, por avaliarmos que esse debate esclarece pontos nefrálgicos que perpassam as disputas prático-jurídicas que integram as decisões referentes à demarcação ou ampliação de terras indígenas:

\section{CONFIRMAÇÃO DE VOTO O SENHOR MINISTRO RICARDO} LEWANDOWSKI (RELATOR) - Senhor Presidente, quero apenas chamar, respeitosamente, a atenção do douto Colegiado de que se trata de um recurso ordinário em mandado de segurança. O mandado de segurança, como se sabe, exige prova pré-constituída, direito líquido e certo. O acórdão combatido no STJ traz uma ementa e, desta ementa, eu quero destacar apenas dois itens, que são os seguintes: "A ocupação da terra pelos índios transcende ao que se entende pela mera posse da terra, no conceito do direito civil. Deve-se apurar se a área a ser demarcada guarda ligação anímica com a comunidade indígena. Precedente do STF. Pretensão deduzida pelo impetrante que não encontra respaldo na documentação carreada aos autos, sendo necessária a produção de prova para ilidir as constatações levadas a termo em laudo elaborado pela FUNAI, fato que demonstra a inadequação do writ [mandado segurança]. Lá se denegou o mandado de segurança. Eu, analisando com um longo voto todo o alegado neste recurso, acabo por dizer o seguinte: "Como bem observado na decisão impugnada, o exame de todas as alegações expostas na exordial da impetração, bem como nas razões recursais, em face da complexidade da discussão que a permeia, não se revela possível sem apreciação adequada do contexto fático-probatório que envolve a controvérsia, inexequível, todavia, nos estreitos limites do mandamus". Aí eu cito, aqui, uma copiosíssima jurisprudência, inclusive, data venia, do próprio Ministro Gilmar Mendes, em que se assenta isso com toda a clareza. Aqui, por exemplo, eu cito, dentre outros, um voto num mandado de segurança do Ministro Moreira Alves, sempre muito cuidadoso, em que, num trecho da ementa, disse o seguinte: "MANDADO DE SEGURANÇA. DECRETO 94.603, DE 14.7.87, QUE HOMOLOGOU A DEMARCAÇÃO DA ÁREA INDÍGENA PANKARARU. SABER SE AS ÁREAS OCUPADAS PELOS IMPETRANTES SÃO, OU NÃO, TERRAS INDÍGENAS PARA EFEITO DE SUA INCLUSÃO NO DECRETO QUE HOMOLOGOU A DEMARCAÇÃO DA ÁREA INDÍGENA PANKARARU É QUESTÃO DE FATO QUE, POR SER CONTROVERTIDA, NÃO PODE SER DESLINDADA EM MANDADO DE SEGURANÇA. AUSÊNCIA DE DIREITO LIQUIDO E CERTO”. E há um caso muito parecido com esse, que foi julgado, aqui, também, tendo como Relator o Ministro Marco Aurélio, de cuja ementa se extrai o seguinte: “[...] DECRETO HOMOLOGATÓRIO DA DEMARCAÇÃO ADMINISTRATIVA DA ÁREA INDÍGENA 
DENOMINADA “GUASUTI”, NO ESTADO DE MATO GROSSO DO SUL. ALEGADA ILEGALIDADE, POR TRATAR-SE DE TERRAS PARTICULARES, DETIDAS POR PRODUTORES RURAIS, COM BASE EM TÍTULOS DE DOMÍNIO QUE REMONTAM A 1920. CONTROVÉRSIA CUJA DILUCIDAÇÃO IMPLICA A NECESSIDADE DE APURAR-SE, CONQUANTO DESOCUPADAS PELOS ÍNDIOS HÁ CERCA DE 50 ANOS, COMO ALEGADO, AS TERRAS EM QUESTÃO, EM ALGUMA ÉPOCA, TERIAM SAÍDO DO DOMÍNIO DA UNIÃO, CIRCUNSTÂNCIA SEM A QUAL NÃO SE PODERIA RECONHECER LEGITIMIDADE A ALIENAÇÃO QUE, SEGUNDO SE ALEGA, DELAS FEZ O ESTADO-MEMBRO [...]". Então, o Ministro Marco Aurélio, que é extremamente cuidadoso em matéria de desapropriações para efeito de reforma agrária e, também, para efeitos de terras indígenas, ele, aqui, com muita precisão, num caso, exatamente idêntico a esse. Trago outra jurisprudência, aqui, em que se mostra que o precedente da Raposa Serra do Sol não pode ser estendido para além daquele caso, não tem nenhum efeito vinculante. De maneira que, para examinar se os índios saíram, ou não, há muito tempo da terra, isto é matéria a ser decidida nas vias ordinárias, nas vias apropriadas, mas não em mandado de segurança - como bem decidiu o STJ - e, muito menos, em recurso ordinário, em que se não aduz nenhuma prova nova, como não poderia, aliás, aduzir. Mas, discute-se, simplesmente, matéria já repisada no processo expropriatório. Mantenho meu ponto de vista, data venia, em que pese o brilhante voto do Ministro Gilmar Mendes. Estou negando provimento ao recurso ordinário e julgando prejudicado o pedido de medida liminar. Essa é uma questão muito séria, realmente, para se decidir em mandado de segurança. A Constituição, com todas as letras, no art. 231, reconhece a posse das terras tradicionalmente ocupadas pelos índios; e o $\int 4^{\circ}$ diz o seguinte: "S $4^{\circ}$-As terras de que trata este artigo são inalienáveis e indisponíveis, e os direitos sobre elas, imprescritíveis". É uma expressão que o constituinte usa, um conjunto de palavras das mais fortes no texto constitucional como um todo. Nós sabemos que o que está havendo, hoje, em todo o Brasil, lamentavelmente, é um novo genocídio de indígenas, em várias partes do país, em que os fazendeiros, criminosamente, ocupam terras que eram dos índios, e posse dos índios, os expulsam manu militari, e depois os expedientes jurídicos, os mais diversos - depois de esgotados os expedientes, evidentemente, ilegais e até criminosos -, acabam postergando o cumprimento desse importante dispositivo constitucional. Apenas essas breves considerações que faço, até com bastante ênfase, para reforçar o meu ponto de vista.

CONFIRMAÇÃO DE VOTO O SENHOR MINISTRO GILMAR MENDES - Presidente, só para deixar claro as questões que foram agora pontuadas. Em primeiro lugar, o precedente de Raposa Serra do Sol não se dirige apenas ao caso de Raposa Serra do Sol. Basta ler os enunciados para saber que muitos deles não se aplicam à Raposa Serra do Sol, até porque já estava realizado. Na verdade, o Tribunal, ali, modulou os efeitos para não anular aquela demarcação, tendo em vista as suas implicações, 
mas quis dizer, por exemplo, não se pode fazer demarcação sem a participação de estados e municípios, porque aquilo era um caso surreal em que a área inteira do município foi colocada dentro da demarcação da área demarcada -, acabando com uma unidade toda. Então, o que se assentou em Raposa Serra do Sol? Que nas novas demarcações - claro, é para as novas demarcações - tem que haver a presença, no processo demarcatório, de estados e municípios. Isso, claro, não se aplica ao caso de Raposa Serra do Sol, até porque o Tribunal não quis conceder a ordem naquele caso, não quis anular, em função da repercussão que isso teria e dos inconvenientes.

O SENHOR MINISTRO RICARDO LEWANDOWSKI (RELATOR) Vossa Excelência me permite uma questão?

O SENHOR MINISTRO GILMAR MENDES - Sim.

O SENHOR MINISTRO RICARDO LEWANDOWSKI (RELATOR) - A Raposa Serra do Sol era um caso atípico, em que lá se reivindicava, praticamente, dois terços de um Estado-membro da Federação brasileira.

O SENHOR MINISTRO GILMAR MENDES - Exatamente.

O SENHOR MINISTRO RICARDO LEWANDOWSKI (RELATOR) - Agora, eu pergunto - e faço uma pergunta retórica: será que no caso de uma fazenda de pequeno, médio, ou até grande porte, o município e o estado devem ser chamados como litisconsortes? Data venia, penso que é uma demasia, com todo o respeito.

O SENHOR MINISTRO GILMAR MENDES - No caso de Mato Grosso do Sul é exatamente essa conflagração que existe, em função de se estar fazendo demarcação de áreas altamente produtivas. Então, por isso que a questão se coloca. Claro, Copacabana certamente teve índios, em algum momento; a Avenida Atlântica certamente foi povoada de índio. Adotar a tese que está aqui posta nesse parecer, podemos resgatar esses apartamentos de Copacabana, sem dúvida nenhuma, porque certamente, em algum momento, vai ter-se a posse indígena. Por isso que o Tribunal fixou o critério, inclusive em relação aos aldeamentos extintos que pegariam uma boa parte de São Paulo. Hoje, um dos maiores municípios, e talvez um dos maiores orçamentos e dos maiores PIBs, é o de Guarulhos. Então se esse argumento pudesse presidir, tivesse valia, certamente nós teríamos que voltar, e isso contraria, inclusive, a Súmula do Supremo sobre os aldeamentos extintos. Esse é um ponto importante. Agora, vamos dizer que, não obstante a área deva ser concedida aos índios ou a área dos índios, já concedida, deva ser expandida, porque é a questão do conflito no Mato Grosso do Sul. Neste caso, faz-se o caminho da desapropriação, foi o que foi dito em Raposa Serra do Sol. Agora, de longe, as hipóteses de Raposa Serra do Sol, claro, nós dissemos: tecnicamente era um processo de caráter concreto, era uma ação popular, logo não teria efeito, mas isso não teria efeito "vinculante". 
O SENHOR MINISTRO RICARDO LEWANDOWSKI (RELATOR) Foi o que eu disse: vinculante.

O SENHOR MINISTRO GILMAR MENDES - Mas, não significa que nós fizemos lá uma boutade, que estivéssemos brincando ao julgar aquilo; até porque, o que nós dissemos? A União não pode amanhã retirar territórios a seu bel talante, e nós sabemos como isso é feito, esses laudos, laudo da FUNAI. E, veja, agora quanto à técnica, laudo da FUNAI dizendo que houve índio em algum momento, e isso é suficiente para retirar cidades inteiras de um dado local. Veja o risco que isso envolve para todos, quer dizer, infelicitando inclusive os índios que vão ser, na verdade, não sujeitos, mas objeto desse tipo de insegurança. E mais: nós estamos julgando só com base nos dados postos nos autos. É mandado de segurança, sim; mas nós estamos julgando com base nos dados postos nos autos. O que é? Uma demarcação depois do nosso julgamento, portanto sob essa diretriz. E nós estamos julgando com base nos dados que já, a priori, atestam que a comunidade indígena já não estaria lá há mais de 70 anos. O próprio título; esses são os dados, e esses dados são insuprimíveis, são inquestionáveis, dados assumidos pelo próprio STJ.

O SENHOR MINISTRO RICARDO LEWANDOWSKI (RELATOR) Desculpe. Não, da ementa aqui do STJ, diz o seguinte: pretensão deduzida pelo impetrante que não encontra respaldo na documentação carreada aos autos.

O SENHOR MINISTRO GILMAR MENDES - Não. Mas, a documentação probatória é a do laudo.

O SENHOR MINISTRO RICARDO LEWANDOWSKI (RELATOR) - Mas nós nos valemos do acórdão. Se o acórdão diz que a pretensão não tem respaldo...

O SENHOR MINISTRO GILMAR MENDES - Não. O acórdão está calcado no laudo da FUNAI, e o laudo da FUNAI diz que há mais de 70 anos não havia famílias indígenas.

O SENHOR MINISTRO RICARDO LEWANDOWSKI (RELATOR) Mas são terras tradicionais, a Constituição assim o diz.

O SENHOR MINISTRO GILMAR MENDES - Terra tradicional é Copacabana, terra tradicional é Guarulhos.

O SENHOR MINISTRO RICARDO LEWANDOWSKI (RELATOR) Bem, mas Copacabana não chamou a atenção da ONU, e Mato Grosso do Sul chamou, interessante isso, não é?

O SENHOR MINISTRO GILMAR MENDES - Agora, a ONU é o argumento para o quê?

O SENHOR MINISTRO RICARDO LEWANDOWSKI (RELATOR) Não, Copacabana é o argumento para o quê?

O SENHOR MINISTRO GILMAR MENDES - É a posse tradicional. 
O SENHOR MINISTRO RICARDO LEWANDOWSKI (RELATOR) Para mostrar um argumento ad absurdum? Isso é o que estou dizendo, é como a questão das terras quilombolas, há de se fazer a devida distinção. Eu ouvi dizer que existem quilombolas que reivindicam as terras lá da Lagoa, onde existem condomínios de luxo, é claro que modus in rebus [há um limite nas coisas].

O SENHOR MINISTRO GILMAR MENDES - A solução jurídica está na desapropriação, segundo os parâmetros. Agora, os dados que estão no acórdão são claramente dados de que não havia posse indígena há mais de 70 anos, e para isso o próprio acórdão do STJ diz que alguns índios continuaram, com base no laudo da FUNAI, a prestar serviço como peões.

O SENHOR MINISTRO RICARDO LEWANDOWSKI (RELATOR) - Mas, o agronegócio quer isso mesmo: expulsa os índios e depois os contrata como boias-frias. É assim que está acontecendo no Brasil todo.

O SENHOR MINISTRO GILMAR MENDES - Recentemente, Ministro, nós encontramos índios aqui em Brasília reivindicando a área do Noroeste. Certamente, nós que moramos em Brasília há muitos anos sabemos que não tinha índio em Brasília desde pelo menos a fundação, mas, se retornarmos no tempo, vamos achar, como em outras áreas do Brasil todo. Agora, recentemente houve uma discussão sobre índios no Noroeste, em função de um bairro que estava sendo criado. Certamente, vamos encontrar índios na construção civil, nas atividades de futebol, nas atividades industriais, nem por isso se diz que eles, na origem, estavam naquele local. Ora, então a questão posta no mandado de segurança, e é própria do mandado de segurança, porque as provas estão préconstituídas, por isso que entendo que, no caso, segundo os parâmetros que nós estabelecemos, não havia posse indígena em 5 de outubro. Isso segundo o próprio laudo da FUNAI que lastreia, depois, a portaria, e que lastreia também a decisão do STJ. Por isso que estou dando provimento ao recurso.

Com votação majoritária o STF deu provimento ao recurso ordinário e concedeu a segurança para declarar a nulidade do processo administrativo da demarcação da Terra Indígena Guyraroka, bem como da Portaria n. 3.219/2009, nos termos do voto do Ministro Gilmar Mendes. O Ministro ainda afirmou que o procedimento específico da desapropriação por interesse social ou por utilidade pública, deveria ser seguido, com o pagamento de justa e prévia indenização ao seu proprietário, caso a União considerasse a necessidade de terras para as populações indígenas.

O debate entre os ministros espelha o que argumentávamos sobre a relevância de contextos extraconstitucionais para a formação de sensibilidades que orientam as decisões judiciais. As justificativas jurídicas manejadas no caso da Terra Indígena Raposa Serra do Sol que alcançaram as decisões proferidas depois 
desta, mostram o peso da força política nas decisões de determinados processos. Observamos o que Atienza (2002) chamou de argumentos consequencialistas a orientarem com relativa presteza a atuação decisória dos julgadores. A utilização de argumentos dessa natureza com vistas a orientar a tomada de suas decisões nos leva a questionar a atuação da Corte Superior brasileira no que diz respeito à efetiva proteção dos direitos indígenas quando lhes é dada a oportunidade para decidir a favor dessa minoria, vez que "não decidem apenas conforme as regras formais do ordenamento jurídico" (DA ROS, 2007, p.96).

O caso da Terra Indígena Guyraroka nos permite pensar em uma teoria da prática jurídica. A recomendação de Bourdieu (1989) de tomar a própria ciência do direito como objeto nos faz perceber que mesmo interpretações de cunho processual podem ser utilizadas para criar obstáculos quando da efetividade dos direitos indígenas. Nesse sentido, impõe-se "O afastamento das ideias de neutralidade e de universalidade também em relação aos instrumentos que a priori são apresentados como sendo de natureza puramente formal, nos quais estariam inscritos esquemas legítimos de interpretação e aplicação do direito" (SHIRAISHI NETO, 2007, p.125). Trata-se do monopólio de um formalismo que na verdade sinaliza um poder invisível de controle social, que reveste de técnica jurídica um debate essencialmente político. A partir dessa análise e ao modo do que nos sugere Bourdieu (2014), trata-se de dar corpo a um projeto de universalizar as condições de acesso ao universal, escapando, portanto, a essa cultura que aparentemente une, mas, na verdade, divide.

\section{CONSIDERAÇÕES FINAIS}

Ao longo dos debates orientadores da decisão proferida no âmbito da Petição 3.388/RR não foram raras as afirmações que exaltavam as possibilidades de se replicar os seus termos, material ou substantivamente, a outros casos de demarcação de terras indígenas que porventura fossem levados ao Tribunal. Por essa razão, não é estranho encontrar nas decisões subsequentes à Raposa, argumentos que sustentam sua precedência jurisprudencial.

Além da chamada "força moral subjetiva" a que se referem alguns Ministros em relação aos desdobramentos da decisão da Raposa Serra do Sol, também é preciso ter à vista suas implicações formais em relação à demarcação de territórios indígenas. A tentativa da Advocacia-Geral da União de fixar, por meio da Portaria 303, um entendimento argumentativo com base nas condicionantes do caso Terra Indígena Raposa Serra do Sol, bem como o recrudescimento para a aprovação do Projeto de Emenda Constitucional (PEC) 215-A de 2000, que 
pretende alterar o artigo $231 \mathrm{da} C R / 88$, transferindo do governo federal para o Congresso Nacional a atribuição de aprovar a demarcação, além da necessidade de ratificar as terras já homologadas (BRASIL, 2000), mostram um desejo de se deslocar a demarcação do campo do direito para uma arena política, em geral instável e desfavorável.

\section{REFERÊNCIAS BIBLIOGRÁFICAS}

ARENDT, Hannah. As Origens do Totalitarismo. Trad. Roberto Raposo. Rio de Janeiro: Forense, 1979.

ATIENZA, Manuel. As razões do argumento: teorias da argumentação jurídica. São Paulo: Landy, 2002.

BOURDIEU, Pierre. O Poder Simbólico. Rio de Janeiro: Bertrand Brasil, 1989. . Meditações Pascalianas. Rio de Janeiro: Bertrand Brasil, 2001. Sobre o Estado. São Paulo: Companhia das Letras. 2014.

BRASIL. Supremo Tribunal Federal. Súmula n. 650 do STF, de 24 de setembro de 2003. Dispõe sobre Bens da União. Brasília, 2003. Disponível em: http://www.dji.com.br/ normas_inferiores/regimento_interno_e_sumula_stf/stf_0650.htm. Acesso em: 15 jun. 2012.

BRASIL. Supremo Tribunal Federal. Petição n. ${ }^{\circ} 3388 /$ RR. Relator Ministro Carlos Ayres Britto. Brasília: TSF, 2008. Disponível em: http://www.stf.jus.br/portal/principal/ principal.asp. Acesso em: 11 mar. 2010.

BRASIL. Câmara dos Deputados. Comissão Especial destinada a apreciar e proferir parecer à Proposta de Emenda à Constituição no 215-A, de 2000. Disponível em: http://www.camara.gov.br/proposicoesWeb/prop_mostrarintegra; jsessionid=71D9A6B18F95C303F0C816F4CB491918.node1 ?codteor=1076126\&filena $m e=$ Tramitacao-PEC+215/2000. Acesso em: 22 ag. 2013.

BRASIL. Supremo Tribunal Federal. Recurso Ordinário em Mandado de Segurança.n. 29.542 . 2014. Disponível em: http://redir.stf.jus.br/paginadorpub/paginador. jsp?docTP=TP\&docID=6937880. Acesso em 25 de março de 2015.

BRASIL. Supremo Tribunal Federal. Recurso Ordinário em Mandado de Segurança.n. 29.087 . 2014. Disponível em: http://redir.stf.jus.br/paginadorpub/paginador. jsp?docTP=TP\&docID=7218303 Acesso em 25 de março de 2015.

CARRIÓ, Genaro R. Notas sobre derecho y lenguaje. Buenos Aires: Abeledo-Perrot, 1986.

CARVALHO, Joênia Batista; MAIOR, Ana Paula Souto. Requerimento para serem incluídos na Petição 3388 como Litisconsórcios Ativos. 2008. Disponível em http:// www.socioambiental.org/ inst/esp/raposa/?q=documentos. Acesso em: 10 mar. 2011. 
COMPROMISSO COM OS POVOS INDÍGENAS DO BRASIL. Disponível em: http://www. construindoumnovobrasil.com.br/images/downloads/compromisso comospovosindigenas.pdf. 2002. Acesso em: 22 mar. 2013.

COSTA SILVA, Marcelle Ivie. Raposa Serra do Sol: agentes políticos, conflitos e interesses. Tese de doutorado. UNICAMP, Campinas, 2012.

DA ROS, Luciano. Tribunais como árbitros ou como instrumentos de oposição: uma tipologia a partir dos estudos recentes sobre judicialização da política com aplicação ao caso brasileiro contemporâneo. Direito, Estado e Sociedade. n. 31, Rio de Janeiro, 2007.

DUARTE DO PATEO, Rogério. A Demarcação de Terras Indígenas no Brasil e o Caso Raposa Serra do Sol. In: MIRAS, Julia Trujillo et al. (org.). Makunaíma Grita! Terra Indígena Raposa Serra do Sol e os Direitos Constitucionais no Brasil. Rio de Janeiro: Beco do Azougue, 2009.

LASSALLE, Ferdinand. A essência da constituição. Rio de Janeiro: Lumem Juris, 2001.

LIMA, Antonio Carlos de Souza. Um olhar sobre a presença das populações nativas na invenção do Brasil. In: SILVA, Aracy Lopez da; GRUPIONI, Luiz Donisetti Benzi (org.). A Questão Indígena na Sala de Aula: novos subsídios para professores de $1^{\circ}$ e $2^{\circ}$ graus. Brasília: MEC, 1995.

SILVA, Marina. A Demarcação de Terras Indígenas no Brasil e o Caso Raposa Serra do Sol. In: MIRAS, Julia Trujillo et al. (org.). Makunaima Grita! Terra Indígena Raposa Serra do Sol e os Direitos Constitucionais no Brasil. Rio de Janeiro: Beco do Azougue, 2009.

REPOLÊS, Maria Fernanda Salcedo. O Papel Político do STF e a Hermenêutica Constitucional: considerações a partir da teoria, da cultura institucional e da jurisprudência. Jus Navigandi, Teresina, ano 8, n. 150, 3 dez. 2003. Disponível em: http:/ /jus.uol.com.br/ revista/texto/4570. Acesso em: 8 fev. 2011.

SHIRAISHI NETO, Joaquim. O Campo Jurídico em Pierre Bourdieu: a produção de uma verdade a partir da noção de propriedade privada nos manuais de Direito. 2007. Disponível em: http://www.uff.br/ppgsd/confluencias/revista_confluencias_vol_02. pdf. Acesso em: 15 ago. 2007.

VIEIRA, Oscar Vilhena. Supremo Tribunal Federal: jurisprudência política. São Paulo: Malheiros, 2002.

YAMADA, Érika M.; VILLARES, Luis Fernando. Julgamento da Terra Indígena Raposa Serra Do Sol: todo dia era dia de índio. Revista de Direito GV, São Paulo, n. 6, p. 143-158, jan./jun 2010

WERNECK VIANNA, Luiz; CARVALHO, Maria Alice Rezende de; MELO, Manuel Palacios Cunha; BURGOS, Marcelo Baumann. A judicialização da política e das relações sociais no Brasil. Rio de Janeiro: Revan, 1999.

Texto submetido à Revista em 30.04.2015 Aceito para publicação em 23.09.2015 


\section{Políticas e estratégias empresariais de controle territorial:}

\section{a VALE S.A e os embates na Serra do Gandarela/MG}

\section{Corporate policies and strategies of territorial control: VALE S.A and the conflicts in the Serra do Gandarela/MG}

Clandia Marcela Orduz Rojas - Mestre em Geografia pela Universidade Federal de Minas Gerais (UFMG).E-mail: claudiaorduzrojas@gmail.com.

Doralice Barros Pereira - Graduada e mestre em Geografia pela Universidade Federal de Minas e doutora em Geografia pela Universidade de Montréal. Professora Associada III da Universidade Federal de Minas Gerais. E-mail: pereiradb@yahoo.com.br

\section{Resumo}

Estimulada pela demanda externa de minério e pelos altos preços das commodities minerais, a Vale S.A tem adotado políticas e estratégias de controle territorial visando monopolizar as principais províncias minerárias do Brasil. A partir de consultas documentais e entrevistas com comunidades locais, analisamos as políticas e estratégias empresariais utilizadas pela Vale S.A na Serra do Gandarela/MG, uma região ainda inexplorada do Quadrilátero Ferrífero. Suas políticas de controle territorial podem ser divididas em dois grupos: o primeiro reúne políticas formais de compra e aquisição de terras na região objetivando a instalação de projetos minerários bem como a criação de áreas protegidas. O segundo agrupa políticas e estratégias para garantir o apoio local, conquistar segmentos sociais específicos e fragilizar e/ou eliminar manifestações de resistências. Concluímos que por meio dessas iniciativas, conduzidas de maneira simultânea, a mineradora tem assegurado o acesso e controle territorial e a reprodução do seu espaço de produção.

\begin{abstract}
Stimulated by global ore demand and the high prices of mineral commodities, Vale SA has adopted policies and strategies of territorial control in order to monopolize the main mining provinces of Brazil. From documentary research and interviews with local communities, we analyzed Vale's corporate policies and strategies applied to the region of Serra do Gandarela/MG, an unexplored mineral deposit of the Quadrilátero Ferrífero. Their territorial control policies can be divided into two groups: the first one gathers formal policies of purchase and acquisition of land properties in the region aiming the establishment of mining projects and the creation of protected areas. The second one groups policies and strategies that seeks to ensure local support, win specific social segments and weaken and/or eliminate manifestations of resistance. We conclude that through these initiatives, conducted simultaneously, the mining company has guaranteed territorial access and control and the reproduction of its production space.
\end{abstract}

\section{Palavras-chave}

Controle territorial, Serra do Gandarela, Quadrilátero Ferrífero, Vale S.A

\section{Keywords}

Territorial control, Serra do Gandarela, Quadrilátero Ferrífero, Vale SA 


\section{INTRODUÇÃO}

"Essa Serra toda que você olha, que você enxerga é da Vale. Aqui está ficando só o miolo. Só o miolo da rua" (Morador, Comunidade de Socorro, junho 2013)

As lutas pelo uso, apropriação e controle dos recursos naturais e do território têm marcado profundamente a história do Brasil desde os tempos coloniais até nossos dias. Elas têm se intensificado nas últimas quatro décadas do século XX, período auge da globalização neoliberal (MARTÍNEZ ALIER, 2007; PORTO-GONÇALVES, 2006), com a urbanização de países emergentes com expressivas áreas territoriais, alta densidade demográfica e alto Produto Interno Bruto (PIB), como o Brasil, a Rússia, a Índia e, principalmente a China. Nesse período, a produção de minério de ferro - uma das principais commodities brasileiras - experimentou um crescimento logarítmico sem precedentes como resultado da valorização das commodities minerais no mercado internacional e o crescimento da demanda global (IBRAM, 2012). Entre 2000 e 2011, a produção de ferro passou de 212 milhões de ton/ano para 390 milhões, contribuindo para que o Brasil se tornasse o segundo maior produtor de minério de ferro no mundo, e um dos mais importantes global players na produção mineral mundial após a China e Austrália (CNI et al., 2012).

Sintonizado com a perspectiva de manutenção da "inclusão internacional" nos mercados globais, o Brasil experimenta nas últimas décadas o aprofundamento de políticas desenvolvimentistas dirigidas a estimular os investimentos nesse setor (MALERBA et al., 2012). Tais investimentos estão concentrados nas maiores províncias minerais do País: Minas Gerais e Pará, responsáveis por 67\% e 23\% da produção brasileira de minério de ferro (IBRAM, 2012). No estado de Minas, a garantia da manutenção da produção tem contribuindo para a abertura e expansão de "novas fronteiras da mineração". Uma dessas áreas é a Serra do Gandarela, uma região localizada na porção centro/nordeste do Quadrilátero Ferrífero, que concentra importantes depósitos de minério de ferro ainda inexplorados em grande escala. Nesse cenário grandes empresas transnacionais que atuam na região - como a Vale S.A - tem adotado políticas e estratégias objetivando o acesso, apropriação e controle do território e dos recursos nele presentes.

Nesse artigo analisamos justamente essas políticas e estratégias empresariais utilizadas pela transnacional para garantir o controle territorial da/ na Serra do Gandarela. É importante salientar que não foram analisadas aqui as reações e respostas das comunidades afetadas para evitar e/ou frear o avanço desse processo nos seus territórios. Essas reações foram amplamente analisadas 
em outro trabalho (ROJAS, 2014) que as mostrou como grupos sociais que se organizaram, mobilizaram e lutam para defender seus territórios.

Os dados foram coletados em trabalhos de campo entre outubro de 2012 e setembro de 2013, em duas fases. A primeira fase, exploratória, objetivou o reconhecimento e aproximação com a área de estudo, o estabelecimento dos primeiros contatos com os moradores locais e a identificação dos atores-chave para a realização de entrevistas semi-estruturadas. A segunda fase compreendeu a realização de um estudo de caráter etnográfico em sete comunidades: três localizadas no interior do Sinclinal Gandarela (André do Mato Dentro, Cruz dos Peixotos e Socorro) e as outras quatro localizadas nas bordas externas do Sinclinal (Conceição do Rio Acima, Vigário da Vara, Paiol, Galego).

No total, foram efetuadas 31 entrevistas semi-estruturadas com apicultores, coletores de musgo, agricultores, moradores mais velhos e lideranças locais objetivando conhecer como os moradores das comunidades locais percebem o processo de controle territorial da Vale S.A. na região. As informações coletadas nos trabalhos de campo foram complementadas com a análise de documentos como: o Estudo de Impacto Ambiental (EIA) e Relatório de Impacto Ambiental (RIMA) do projeto da Mina Apolo; a Ata e os Documentos Síntese dos dois Grupos de Trabalho (GT 1 e GT 2) instituídos pela Secretária Estadual de Meio Ambiente e Desenvolvimento Sustentável de Minas Gerais (SEMAD) voltados a apresentar as propostas de usos futuros para a região; o Relatório de Sustentabilidade da Vale S.A de 2012; e o Informativo trimestral da Vale S.A. em Mariana, Ouro Preto e Catas Altas (Abril-Junho 2013).

Esse artigo traz reflexões divididas em três seções. Na primeira apresentamos uma contextualização regional da Serra do Gandarela elencando os principais atributos geográficos, naturais e sociais da região. Na segunda seção analisamos as políticas denominadas formais ou legais de compra e aquisição de terras utilizadas pela Vale S.A. para a instalação de projetos minerários e criação de áreas protegidas. $\mathrm{Na}$ terceira seção nos debruçamos sobre as políticas e estratégias aplicadas pela mineradora para garantir o apoio local, conquistar segmentos sociais específicos e fragilizar e/ou eliminar as manifestações de resistências. Nessa seção, tentamos compreender a forma complementar do modus operandi da empresa.

\section{A SERRA DO GANDARELAE O PROCESSO DE INTENSIFICAÇÃO E EXPANSÃO DA MINERAÇÃO NO QUADRILÁTERO FERRÍFERO}

Localizada na porção centro/nordeste do Quadrilátero Ferrífero, a Serra do Gandarela possui uma extensão de 466,6 $\mathrm{Km}^{2}$ abrangendo parcialmente 
seis municípios: Santa Bárbara, Barão de Cocais, Caeté, Rio Acima, Raposos e Itabirito (LAMOUNIER, 2009). A região possui dois distritos: Conceição do Rio Acima e Socorro, e cinco povoados: André do Mato Dentro, Cruz dos Peixotos, Paiol, Galego, e Vigário da Vara. De acordo com o último censo do IBGE, a população residente em 2010 nas sete comunidades locais contabilizava 742 habitantes (IBGE, 2010).

Figura 2 - Localização da Serra do Gandarela no Quadrilátero Ferrífero

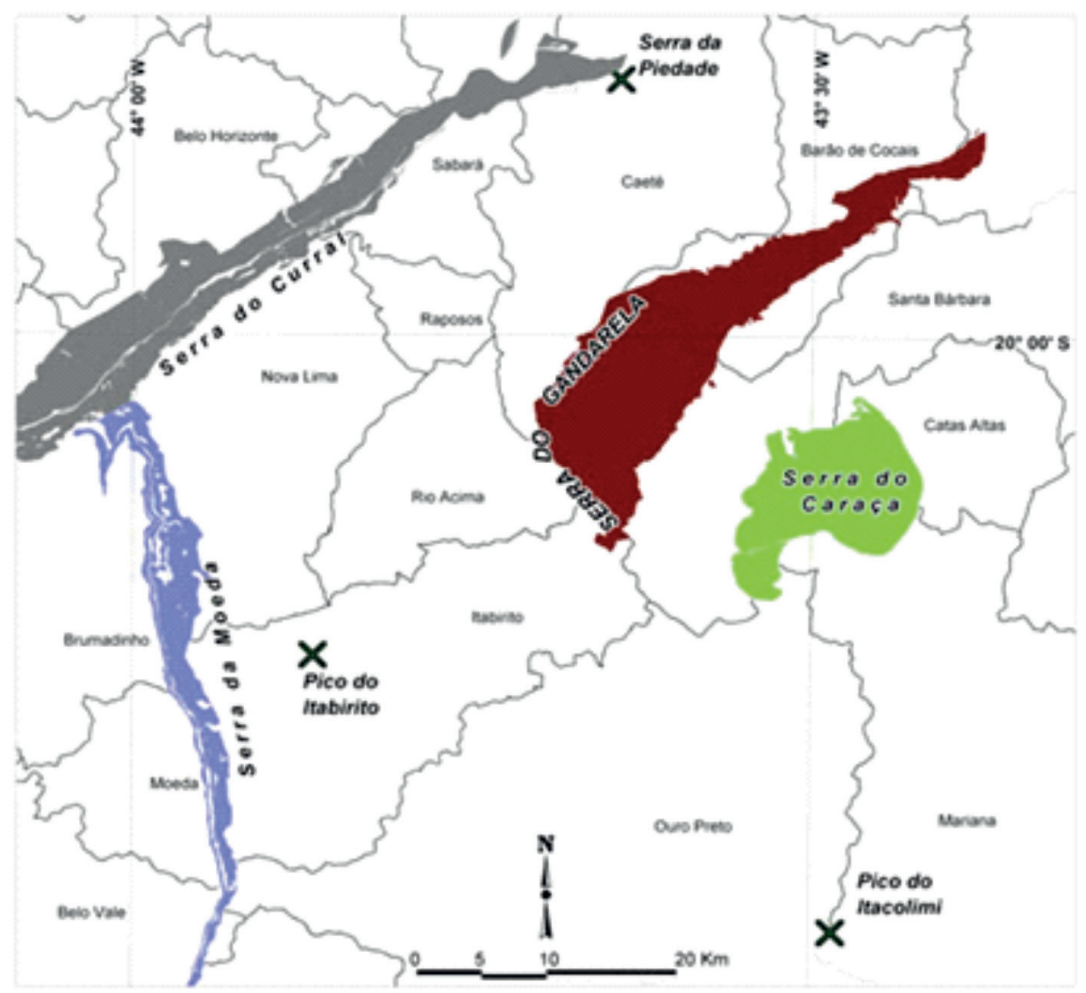

Fonte: ROJAS, 2014

Em termos geológicos, a região é formada por rochas do Supergrupo Minas que concentram importantes depósitos de minério de ferro como, também, depósitos de ouro, ocre limonita, bauxita, brita, calcário e urânio (LAMOUNIER, 2009; ROJAS, 2014). A região apresenta a maior área de afloramentos ferruginosos - comumente conhecidas como cangas - do Quadrilátero Ferrífero que além de congregar um elevado número de espécies raras e endêmicas, contribuem para a recarga hídrica dos aquíferos (IGEL et al., 2012).

Devido as suas especificidades geomorfologias, a Serra do Gandarela detém uma riqueza hídrica excepcional observada pela grande quantidade 
e qualidade de águas superficiais e subterrâneas que contribuem para o abastecimento público de água da capital e da Região Metropolitana de Belo Horizonte (Ibid., p. 50). Para além do rico patrimônio geomorfológico, na região também podem ser encontradas paisagens de beleza cênica, fragmentos de Mata Atlântica e Cerrado - com elevada biodiversidade e altos níveis de endemismo - e sítios paleontológicos de importância nacional e mundial (IGEL et al., 2012; LAMOUNIER, 2009).

A ocupação da Serra do Gandarela remonta ao período conhecido como "ciclo de ouro", uma vez que a região foi um caminho de convergência e ligação entre Santa Bárbara e Ouro Preto. Embora a exploração aurífera na área durante este ciclo não teve a mesma intensidade que em outras "áreas das minas", o trânsito pelos caminhos da mineração e a exploração de ouro nas cidades próximas fomentaram o surgimento de povoados na região que serviram tanto como base para os garimpeiros, como locais de produção de alimentos para as minas.

A presença humana na região tem sido responsável tanto pela conservação da natureza como pela introdução de novas espécies vegetais. A rica diversidade da flora local, a ocorrência de matas de candeia e a elevada disponibilidade hídrica têm permitido às populações locais da Serra do Gandarela desenvolver atividades econômicas agrícolas e extrativistas pouco impactantes, como a apicultura, a coleta de espécies vegetais e a agricultura familiar. A multiplicidade de usos, nos quais a terra aparece como um fator primordial, tem resultado na criação e recriação de formas sociais de forte inscrição local e na existência de territorialidades intensas (MARQUES, 2002).

A formação social e econômica da região também está ligada às atividades de reflorestamento e ao desenvolvimento da cadeia produtiva da indústria minero-metalúrgica e siderúrgica, caracterizada pela articulação entre mineração (exploração de jazidas minerais) e produção de carvão vegetal (extrativismo vegetal). Apesar de a Serra do Gandarela conterricas jazidas minerais, poucos e pequenos empreendimentos de mineração foram instalados no seu interior no transcurso do século XX. Por causa dessas características esses empreendimentos não afetaram significativamente a paisagem nem comprometeram as riquezas naturais da área (LAMOUNIER, 2009).

Desse modo, por um longo período a Serra do Gandarela permaneceu "protegida" e "resguardada", ainda que parcialmente, dos interesses das empresas de mineração. Contudo, essa situação privilegiada pode ser transformada, uma vez que o Gandarela constitui-se hoje como uma importante fronteira de expansão da mineração no Quadrilátero Ferrífero (AMPLO, 2009). Nos últimos anos, a Vale S.A. demonstrou interesse na implantação e expansão de três projetos minerários 
na região. O primeiro deles é o projeto da Mina Apolo, o mais importante dos três projetos em função da magnitude/porte do empreendimento. A mina Apolo é o maior investimento previsto pela transnacional em Minas Gerais e visa a substituição de minérios provenientes de outras minas de propriedade da empresa, localizadas no Quadrilátero Ferrífero, que se encontram em fase de exaustão (Ibid., p. 5).

O projeto deverá ocupar uma área total de 1.758 ha e prevê como atividades principais a lavra, beneficiamento e carregamento de minério de ferro. Segundo o EIA/RIMA a mina deverá produzir 24 milhões de toneladas de minério de ferro por ano (Mtpa) durante os próximos 17 anos (Ibid., p.14). No entanto, informações divulgadas recentemente pela mineradora, a produção da mina deverá atingir 37.5 Mtpa durante os próximos 30 anos (COELHO DE SOUZA, 2013).

Além do projeto da Minas Apolo, a Vale S.A também demonstrou interesse na expansão de outros dois projetos de exploração mineral de menor porte na região: o primeiro é a expansão da Mina Capanema, um empreendimento de extração e beneficiamento de minério de ferro (SEMAD/MG, ICMBio, 2011). O segundo é a reativação e ampliação da mina Baú, uma mina localizada nas proximidades da comunidade de Cruz dos Peixotos. Assim, com importantes projetos minerários previstos para a Serra do Gandarela e considerando sua importância geográfica/econômica significativa, perguntamos: Quais políticas e estratégias tem sido adotadas pela Vale S.A. para garantir o controle territorial e viabilizar seus empreendimentos de mineração na região?

\section{ESTRATÉGIASE POLÍTICASLEGAISOU FORMAIS DECONTROLE TERRITORIAL DA VALE S.A NA SERRA DO GANDARELA}

Conforme mencionamos, o Quadrilátero Ferrífero é uma das principais províncias minerais do Brasil e do mundo. Na região, a exploração e comercialização de ferro e outros minerais (principalmente ouro) está concentrada em poucas empresas - estrangeiras e nacionais - que lideram a produção nacional e mundial de minério de ferro e ouro. A principal empresa que opera hoje na região é a Vale S.A, possuindo um total de 18 minas em atividade (BRASIL MINERAL, 2013).

A forte presença da Vale S.A no Quadrilátero Ferrífero tem sido resultante da política de aquisição de grandes glebas de terras, iniciada na década de 1940, pela compra direta de terrenos ou pela incorporação de pequenas mineradoras que atuavam na região (ROJAS, 2014). Essa estratégia teve por finalidade, por um lado, impedir a instalação/concorrência com outras mineradoras de grande porte e criar 
um monopólio e, por outro, "reservar" áreas para serem exploradas em momentos de conjuntura favorável (escassez do minério, flutuação de preços das commodities minerais e inovações tecnológicas). Essa estratégia tornou a mineradora um dos principais agentes que potencializou/potencializa transformações espaciais, sociais, ambientais, econômicas e políticas na região (Ibid., p.34).

A construção de um "Espaço da Mineração" (WANDERLEY, 2005) onde a mineradora se estende territorialmente e impõe sua racionalidade não é um fenômeno isolado/raro. Pelo contrário, trata-se de um dos aspectos centrais que configuram as novas relações de poder em curso no período da globalização neoliberal (PORTO-GONÇALVES, 2006). Por meio do controle do território, entendido na sua dupla conotação - material e simbólica - a transnacional exerce a dominação/posse de "áreas geográficas" estratégicas para sua reprodução.

O território não se limita à posse, embora muitas vezes, com ela identifiquese. Controla-se uma "área geográfica", ou seja, um "território" visando "atingir/ afetar, influenciar ou controlar pessoas, fenômenos e relacionamentos" (SACK, 1986, p. 6 apud HAESBAERT, 2005, p. 22). Assim, estrategicamente por meio do controle do território - da sua dominação e apropriação - a transnacional brasileira cria, mantêm a ordem e dota de significado grande parte do contexto geográfico necessário para a reprodução do seu espaço de produção.

No Quadrilátero Ferrífero, observa-se que nas últimas décadas, a Vale S.A vem utilizando-se de estratégias formais ou legais de monopolização da terra, ora para a instalação de empreendimentos minerários de grande e pequeno porte, ora para a criação e manutenção de áreas protegidas visando atender as exigências e políticas ambientais internacionais e nacionais. Por meio dessas estratégias, a transnacional garante pelo menos duas diretrizes: a implementação de seus projetos no curto e médio prazo, ou seja, - a exploração de importantes jazidas minerais bem como o controle sobre reservas minerais a serem exploradas futuramente (ROJAS, 2014).

A análise do projeto da mina Apolo ilustra claramente as estratégias de concentração de terras na/da Serra do Gandarela, ora para viabilizar o projeto minerário, ora para a criação de áreas protegidas. Conforme pode ser observado na Tabela 1, a Vale S.A. detém grandes extensões de terras na região e continua adquirindo mais propriedades nos últimos anos. Segundo o EIA/RIMA a área destinada à implantação do projeto da mina Apolo é composta por um mosaico de propriedades constituído por 14 registros de imóveis que somam uma área total de 11.937,27 ha (Tabela 1). Segundo o mesmo estudo das propriedades que compõem a área do projeto, sete pertencem à mineradora e sete correspondem as áreas de terceiros em fase de negociação para aquisição (AMPLO, 2009). 
Tabela 1 - Projeto mina Apolo, descrição das propriedades - 2009

\begin{tabular}{|c|c|c|c|}
\hline Propriedades & Nome & Proprietário & $\begin{array}{c}\text { Área } \\
\text { Propriedade (ha) }\end{array}$ \\
\hline 1 & $\begin{array}{ll}\text { Fazenda } & \text { Serra } \\
\text { Maquiné } & \\
\end{array}$ & \begin{tabular}{|lr} 
Mil melhoramentos \\
Indústria & $\mathrm{e}$ \\
Investimentos Ltda.
\end{tabular} & $2,413,55$ \\
\hline 2 & Fazenda Maquiné & $\begin{array}{l}\text { Sizino Pontes de Paula } \\
\text { Lima }\end{array}$ & 1128,5 \\
\hline 3 & Fazenda Cutão & \multirow[t]{2}{*}{ Vale S.A } & 1833,97 \\
\hline 4 & Fazenda Cachoeira & & 993,9 \\
\hline 5 & Fazenda Nascentes & $\begin{array}{ll}\text { Carlos } & \text { Antônio } \\
\text { Macelani } & \\
\end{array}$ & 330.61 \\
\hline 6 & $\begin{array}{l}\text { Fazenda Arroio } \\
\text { Grande }\end{array}$ & Irineu Cecacci & 346,05 \\
\hline 7 & Fazenda Mato Grosso & \multirow[t]{2}{*}{ Vale S.A } & 470,01 \\
\hline 8 & Fazenda Gandarela & & 1326,83 \\
\hline 9 & $\begin{array}{l}\text { Fazenda Lopes ou } \\
\text { José Pereira }\end{array}$ & \multirow[t]{2}{*}{ Novelis } & 43,91 \\
\hline 10 & Fazenda Mato Grosso & & 21,22 \\
\hline 11 & Fazenda Mato Grosso & \multirow[t]{2}{*}{ Vale S.A } & 359,7 \\
\hline 12 & Fazenda Lopes & & 32,19 \\
\hline 13 & $\begin{array}{l}\text { Fazenda Vargem do } \\
\text { Lima e Água Limpa }\end{array}$ & $\begin{array}{l}\text { Mineração Morro } \\
\text { Velho }\end{array}$ & 2516,78 \\
\hline 14 & Fazenda Lopes & Vale S.A & 119,71 \\
\hline Total & & & $11.937,27$ \\
\hline
\end{tabular}

Fonte: AMPLO (2009, p. 69)

A tabela acima registra que a concentração de glebas de terra pela transnacional inicia-se anteriormente à divulgação do projeto da Mina Apolo e consequentemente, precede o início do processo de licenciamento ambiental. A aquisição de terras é, portanto, uma das estratégias adotadas pela empresa visando constituir uma fronteira na expansão da mineração. Essa estratégia permite a empresa explorar áreas que lhe pertencem justamente no momento em que as suas melhores jazidas estão em fase de exaustão e em momentos favoráveis para os preços das commodities minerais nos mercados internacionais.

Apesar de que o projeto da mina Apolo deverá utilizar somente uma área total de 1.758 hectares onde serão realizadas as atividades de lavra, beneficiamento e carregamento de minério de ferro (Ibid., p.14), a empresa espera adquirir um total de aproximadamente 12.000 mil hectares na região conforme se observa na tabela 1. Cabe mencionar que para atender as as exigências da legislação ambiental (MINAS GERAIS, 2002), a transnacional precisa de no mínimo o dobro da área do projeto, ou seja, 3.516 ha. Caso a Mina Apolo seja ampliada/ 
expandida - aumentando sua produção de 24 para $37.5 \mathrm{Mtpa}$ - o projeto minerário deverá ocupar uma área total de 3.552 ha (SEMAD/MG, ICMBio, 2011). Isso significaria a utilização total de 7.000 hectares prevendo a compensação ambiental do empreendimento. Ainda assim restariam 5.000 mil hectares em poder da empresa, o que ilustra a estratégia de monopolização da terra na região, por parte da transnacional brasileira.

Note-se também que todas as propriedades que a empresa já adquiriu ou estavam em processo de aquisição, eram fazendas que abasteciam os centros urbanos próximos. Com a posse dessas propriedades, reduziu-se consideravelmente a produção agrícola na região, diminuíram os postos de emprego de mão de obra local e gerou-se um amplo e profundo reordenamento territorial na Serra do Gandarela. Ilustrando esse processo, um morador da comunidade de Socorro declarou o seguinte: "A serra toda é da Vale. Ela já comprou. Ali tem projeto para 180 anos de serviço”. E acrescentou:

(...) a Serra do Maquiné, que é conhecida como Apolo, lá chama Maquiné. Essa serra pega lá e faz essa volta e termina ali. A Vale acabou de comprar um terreno ali, de (morador), que mora em Barão. Porque? Por que encontrou muito material (minério de ferro). Tem um projeto de 180 anos só dessa Serra ... Essa serra toda que você olha, que você enxerga é da Vale. Aqui (Socorro) está ficando só o miolo, só o miolo da rua. Meu terreno aqui faz divisa com ela (a Vale). Eu não vendi para ela (a Vale). Ela (a Vale) me propôs mas eu não quis vender. Eu não tenho interesse nenhum de vender, fica ai para os netos (Morador, comunidade de Socorro, junho 2013)

Com relação aos preços auferidos com a venda dos terrenos, um apicultor respondeu que desconhecia os valores pagos pela empresa e acrescentou que "se ela interessa paga bem, agora, se ela não tem interesse é tudo banana”. Questionado a propósito do tamanho das terras adquiridas pela empresa, o apicultor revelou o seguinte: "Eles (os representantes da Vale) querem assim: compra 30 ha aqui, na frente mais 40, depois mais 100. Vai ligando, vai fazendo um corredor, sófechando nós (os apicultores)". Como se observa, existe uma falta de informação mais precisa quanto aos reais valores auferidos no mercado imobiliário que combinado ao silêncio em relação aos valores pagos pela terra e ao tamanho das áreas sobre as quais existe "supostamente" interesses gera incertezas e desconfianças. Também percebemos que os moradores desconheciam os reais objetivos da compra e concentração de terras da região nas mãos da empresa. Apesar dos representantes da Vale S.A terem realizado algumas reuniões nas comunidades locais, eles não foram perguntados em momento nenhum se aceitavam e concordavam com o empreendimento. 
Verificamos também que a maioria dos moradores desconhecia a magnitude dos projetos, as informações sobre os impactos ambientais e sociais dos empreendimentos restringia-se a impactos nos cursos d'água. Além disso, os moradores locais não tinham clareza em relação ao tamanho e localização das áreas que seriam atingidas diretamente pelo projeto minerário, nem quanto as áreas que seriam destinadas às reservas ambientais. Os depoimentos revelaram que os moradores tinham ciência de que seu território estava ficando cada vez menor e de que a Vale S.A estava se tornando a "dona do pedaço".

Os efeitos da compra e concentração de terras da região, em poder de uma única mineradora, modificaram a dinâmica de reprodução e os modos de vida das comunidades locais. Essa situação gerou repercussões e desequilíbrios na oferta de postos de emprego na região:

(...) acho que o que está acontecendo é muito perigoso. A Vale não está procurando e comprando pequenas propriedades. Então ela está comprando as áreas dos empregadores e com isso vai gerando desemprego. Então na área onde ela pretende montar o projeto Apolo, ela comprou o terreno de Carlos Mackillaine, que tinha lá uns 40 funcionários, ele trabalhava com eucalipto. Então esses funcionários ficaram desempregados, são tropeiros, são serradores, são pessoas que trabalham na desgalha do eucalipto, com o roçado, tem mulheres que 'roçam'. Então essas pessoas para mim não tem chance de emprego nas mineradoras e estão desempregadas. $\boldsymbol{E}$ já ocorreu aqui na região que eles prometem gerar dois mil empregos mas eles já desempregaram muita gente. Na região toda talvez deve ter uns mil desempregados por essas compras de terra, porque quando compram para fazer reserva também na reserva da Vale ninguém entra, ninguém faz nada. (Morador, comunidade de André do Mato Dentro, janeiro 2013)

O depoimento acima desmistifica um dos elementos centrais que legitimam o discurso do desenvolvimento minerário (COELHO, 2012) que é, justamente, a geração de postos de trabalho para os moradores locais onde as mineradoras operam. Ao contrário, a mineração trouxe desemprego para grande parte dos trabalhadores rurais ocupados em fazendas e propriedades de médio porte. Esses trabalhadores, com experiência tão somente nas atividades do campo, perderam seus empregos, perante a carência de qualificação e experiência para trabalhar em outros setores.

A implantação dos projetos de mineração na região da Serra do Gandarela (como o projeto da mina Apolo) reduziu não só os postos de trabalho no campo mas inviabilizou a prática de atividades econômicas dos moradores locais, tais como a apicultura e o extrativismo. O controle sobre o território - por meio do monopólio das terras - por parte da mineradora comprometeu suas formas de vida e a manutenção de conhecimentos, práticas e técnicas tradicionais de manejo 
da terra e dos recursos naturais - a sociodiversidade. Além dessas alterações no cotidiano dos moradores locais, percebemos que uma parte das terras adquiridas pela empresa - principalmente aquelas com fragmentos de mata atlântica e espécies animais em extinção - ficaram "paradas" sendo destinadas pela empresa para a criação e implantação de Reservas Naturais do Patrimônio Natural (RPPN).

O aumento considerável da quantidade dessas reservas naturais em poder da mineradora, um total de 17 no Quadrilátero Ferrífero (VALE, 2013), está relacionado não só às disposições previstas na legislação ambiental como também a viabilização e legitimação de empreendimentos "ecologicamente corretos" perante o conjunto da sociedade. A criação de áreas de proteção ambiental por parte das mineradoras funcionam como instrumento de marketing ambiental e servem como mecanismos de agregação de valor a suas mercadorias constituindo também espaços de reservas de commodities para o futuro (EUCLYDES, 2012; WANDERLEY, 2005). Desse modo, a incorporação do discurso e práticas da proteção ambiental por parte de empresas como a Vale S.A - por meio da criação de reservas ambientais - não só contribui para auferir vantagens como também para proteger seu espaço de produção no futuro (EUCLYDES, 2012).

Essas constatações são confirmadas por Wanderley (2005) quando averiguou a atuação de empresas mineradoras no estado do Pará. Segundo o autor, as transformações territoriais ocorridas nessa região são reflexos do jogo de interesses das empresas mineradoras que incentivam e apoiam a criação de Unidades de Conservação (UC) com o “objetivo de proteger seu entorno de futuras ocupações e preservar as reservas de capital ali existentes a partir de um discurso de proteção ambiental" (WANDERLEY, 2005, p.16460). Desse modo, as mineradoras - ao apoiarem a criação de UC - tornam-se órgãos fiscalizadores que promovem a segurança dos recursos naturais e do território, impedindo, portanto, a exploração dos recursos e a formação de novos territórios que poderiam vir a ameaçar os projetos de exploração mineral (Ibid., p.16460). Em outras palavras, trata-se de uma estratégia de reserva de mercado para futura exploração que pode ser comandada pelo próprio mercado ou conjunturas políticas e ambientais que exijam ou não a utilização dessas áreas mantidas em estoque.

$\mathrm{Na}$ Serra do Gandarela não foi diferente. Visando proteger as áreas destinadas às reservas ambientais, a Vale S.A adotou uma postura autoritária e intransigente conforme expresso no depoimento a seguir:

"Ela (a Vale S.A) não está dando conta de legalizar o que ela comprou. Ela comprou muita terra. Ela cresceu o olho. O patrimônio dela é grande demais ... tudo é da Vale. Ela estão querendo fazer reservas. Essa Serra aqui, que beira o Rio por baixo, faz divisa com o Caraça, vira lá 
no Capanema na Fazenda Coca-Cola, a volta para acá para a Serra do Gandarela é tudo da Vale. É para fazer reserva: não mexe com nada. Fizeram umas pesquisas dos bichos que existem ai dentro. No patrimônio da Vale tem muito bicho. Eu fiquei quase um mês andando com eles ai, mostrando as cavernas. Mas eles não gostam que ninguém entre. Tem uns motoqueiros que passam fazendo trilha, elas barram eles. Não gostam que passem nem os motoqueiros. Não deixam entrar para tirar musgo, areca. Ninguém pode explorar nada não. Eles não deixam entrar ninguém" (Morador, comunidade de Conceição do Rio Acima, julho 2013)

Da mesma maneira que esse morador, outros entrevistados afirmaram que nas áreas da Vale S.A. ninguém podia entrar, o acesso era vetado. Mesmo os moradores locais, que sobrevivem da extração e coleta de produtos naturais como atividades de complementação de renda, eram impedidos de ultrapassar os limites extensos das áreas da empresa que eram assegurados por meio de equipes de segurança privada, conforme relata uma moradora:

"Na área da Vale a vigilância é mais acirrada. Tem segurança que quando
encontra a gente tirando musgo nem pede para retirar. Eles chamam
a polícia, leva a pessoa pressa. Leva a mercadoria da pessoa. As vezes
querem fazer um papel que não é deles. Um papel que é da polícia militar
ou da polícia florestal" (Moradora, comunidade de André do Mato Dentro,
janeiro 2013)

Além de reduzir as fontes de renda das famílias, essas interdições constituiram também uma certa violência simbólica necessária para a transnacional se territorializar e inibir as visitas. Desse modo, por meio de políticas e estratégias formais ou legais de controle territorial, a mineradora progressivamente vai monopolizando as "áreas geográficas" necessárias aos seus empreendimentos minerários ou a criação de áreas protegidas, que garantiram e viabilizaram seus empreendimentos e as commodities futuras. Assim, atingindo, influenciando e controlando não só terras mas pessoas, fenômenos, eventos e relacionamentos a empresa impõe sua racionalidade, vontade, destino e se territorializa.

\section{ESTRATÉGIAS E POLÍTICAS "PARALELAS" DE CONTROLE TERRITORIAL: COMPLEMENTANDO O MODUS OPERANDI DA TRANSNACIONAL BRASILEIRA NA SERRA DO GANDARELA}

Para além da compra e concentração progressiva de terras na região, a Vale S.A. adotou políticas e estratégias que poderíamos chamar de complementares a fim de expandir seu controle territorial e legitimar sua presença na Serra do 
Gandarela. Observamos ser uma constante a cooptação de moradores locais, o atendimento direto e indireto às demandas das comunidades locais e o "diálogo administrado" visando influenciar e persuadir pessoas, processos e fenômenos. Segundo a empresa, tais políticas e estratégias fazem parte de um modelo de governança que integra "projetos e operações, possibilitando o planejamento e o tratamento mais eficaz de questões sociais" (VALE, 2012, p.45). As políticas e estratégias objetivam minimizar, mitigar e compensar os impactos sociais negativos das suas atividades e, na medida do possível, deixar um "legado positivo" nas regiões onde a empresa atua. Resta saber o que ela considera como positivo o que certamente não é compartilhado com os demais usuários e/ou moradores locais. Há então a construção/repetição de umdiscurso aurático, o discurso da continuação, da manutenção da ordem e das relações de poder.

Assim, por meio de um modelo de governança que inclui o gerenciamento das manifestações e demandas das comunidades, a promoção do desenvolvimento local e a garantia de mecanismos de diálogo, a empresa objetiva obter sua "licença social" (Ibid., p.45). Denominadas ações de "responsabilidade empresarial", essas estratégias objetivam a diminuição ou eliminação do "risco social" dos projetos de exploração aflorados e/ou acirrados de acordo com sua magnitude e comunidade afetada.Em outras palavras, por meio dessas políticas e estratégias a empresa visa fragmentar e/ou eliminar resistências deixando o "terreno limpo" para impor sua racionalidade e se territorializar. Em suma, essas iniciativas invisibilizam o outro em suas possibilidades de existência e reprodução.

Um primeiro conjunto de estratégias empreendidas pela Vale S.A identificado na Serra do Gandarela esteve relacionado à busca de apoio da população local para executar seus propósitos. Desse modo, seguindo o protocolo da empresa, as manifestações e demandas das comunidades locais passaram por um processo de "recebimento, análise, resposta e execução (ou negação), e conclusão" (Ibid., p.46). Das demandas das comunidades locais da Serra do Gandarela, oriundas a partir dos impactos gerados pelo projeto da Mina Apolo e de outros empreendimentos da empresa na região,contemplaram-se anseios diversos tais como: o apoio econômico para a realização das festas tradicionais locais; reformas das igrejas das comunidades; manutenção das estradas que dão acesso às comunidades; criação de programas de capacitação profissional; cursos de geração de emprego e renda para mulheres; instalação de equipamentos para controlar a qualidade do ar, dentre outros.

O resultado esperado pela mineradora ao atender as demandas comunitárias foi justamente o de estreitar as "relações comunitárias da empresa", conquistar a confiança e ganhar o apoio da população local atingida pelos empreendimentos 
minerários. A incorporação de "preocupações ambientais e sociais" e de ações de "responsabilidade ambiental e social" por parte da Vale S.A pode ser compreendida como uma característica da fase ecológica do capital que se expressa na conquista simbólica da natureza (por meio de criação de áreas protegidas) e nas parcerias e acordos com as comunidades locais (ESCOBAR, 1995).

Essas ações proporcionam a construção do marketing ambiental e social da empresa por meio de uma imagem social e ambientalmente correta. Dessa forma, por intermédio da internalização das condições de produção (natureza, trabalho humano, espaço urbano) para a reprodução do capital aliada às ideologias de proteção ambiental e/ ou criação de oportunidades de emprego a Vale S.A atinge o sucesso na proteção do seu espaço de produção e sua ampliação no futuro.

Conforme verificamos, essas ações de "responsabilidade social" promovidas pela mineradora não tiveram por objetivo principal a preocupação com a melhoria da vida das comunidades afetadas, mas pelo contrário, combater o risco de instabilidade institucional. Em outras palavras, essas ações denominadas também como "políticas de resignação" almejaram neutralizar a crítica social e o descontentamento popular. Elas ofertaram "respostas limitadas por meio de gestos simbólicos de compensação ou mitigação, aproveitando-se do vazio do Estado" na garantia de direitos básicos como saúde, educação, moradia, locomoção, etc (ACSELRAD, 2014). Tratam-se, portanto, de ações sociais ineficazes pois negligenciam os direitos sociais e geram cada vez mais injustiças sociais ao proporem muito mais uma distribuição de serviços que o próprio Estado deveria arcar do que o reconhecimento do cidadão de direitos.

Conformelembra Chauí (1994, p. 28), um direito difere-se de uma necessidade ou carência, como também de um interesse:

Uma carência é sempre específica e particular, não conseguindo generalizar-se num interesse comum nem universalizar-se num direito sem deixar de ser privilégio. Um privilégio é sempre particular e específico, não pode generalizar-se num interesse comum nem universalizar-se num direito sem deixar de ser privilégio. [...] Um direito, ao contrário de necessidades, carências e interesses, não é particular e específico, (...) [mas] válido para todos os indivíduos, grupos e classes sociais. [...] A democracia funda-se na criação, reconhecimento, garantia e consolidação de direitos. $\mathrm{O}$ autoritarismo social e a divisão econômica sob a forma da carência e do privilégio bloqueiam a emergência de uma sociedade democrática.

Além das ações que buscaram o apoio da população local, outra estratégia utilizada pela empresa na Serra do Gandarela foi a instalação de mecanismos de diálogo e negociação com segmentos sociais específicos visando legitimar sua atuação e viabilizar seus empreendimentos minerários. O diálogo com 
setores sociais definidos como "estratégicos" por parte da Vale S.A manifestouse no desejo em apoiar uma das principais atividades econômicas da região: a apicultura. Desse modo, a transnacional brasileira iniciou um processo de diálogo e negociação com apicultores de duas comunidades locais localizadas na Área de Influência Direta (AID) do projeto da Mina Apolo. As negociações objetivaram a retirada de "interferências" da sua área de produção mineral bem como conseguir aliados específicos nas comunidades. Essa empreitada alcançaria parte significativa dos trabalhadores livres sem os desenraizar de seu modo de vida e evidenciava ao mesmo tempo a situação de vulnerabilidade deles.

As negociações entre a transnacional brasileira e os apicultores da região iniciaram-se em 2010 e finalizaram em outubro de 2012 com a assinatura de um contrato - com duração de três anos. O contrato estipulava que os apicultores portassem camisetas e se identificassem com crachás para entrar nas áreas da empresa e também previa a realocação dos apiários localizados próximos da área da mina Apolo. Para efetuar a transferência dos apiários, os apicultores receberam um auxílio financeiro de $\mathrm{R} \$ 11.154,00$ para a compra de 150 caixas de madeira, a fim de proceder a mudança dos apiários para novas áreas oferecidas pela mineradora.

Apesar de os apicultores terem recebido recursos suficientes para comprar as caixas e, assim, facilitar a realocação dos seus apiários, o contrato parece não os ter deixado satisfeitos. Os apicultores reclamaram da atuação da empresa que ofereceu áreas para realocar os apiários, mas omitiu o fato de que essas áreas já possuíam abelhas. Desse modo, o discurso da empresa pautou-se pela dissimulação, isto é, um mecanismo de operacionalização das ideologias que oculta, nega e/ou obscurece informações importantes com o objetivo de manter as relações de dominação (THOMPSON, 1989).

Além disso, na tentativa de minimizar os impactos dos empreendimentos de mineração e de assegurar sua viabilidade, a transnacional brasileira acabou por ignorar as normas locais (termos/códigos) dos apicultores. Com tal postura, a empresa os colocou num clima de incertezas e tensão face à continuidade de suas atividades econômicas. Jogados a sorte, os contratos podem ser interpretados como concessões, e não direitos, posto que poderão ser alterados/revogados pela empresa quando assim o considerar necessário. As hesitações afloram incidindo negativamente no cotidiano dos apicultores já que encontram-se em relações desiguais de poder.

O contrato com os apicultores permitiu "limpar" a área de produção da mineradora de "interferências" e também pode ser interpretado como uma estratégia da empresa para ganhar aliados, viabilizar e legitimar social 
e politicamente seus empreendimentos. A atuação da mineradora pode ser entendida como uma estratégia de manipulação (HERMAN; CHOMSKY, 2003), uma vez que cria problemas e depois oferta soluções em conformidade com a conveniência de seus interesses. Nesse formato, ela mantém os apicultores numa relação de dependência e os nutre permanentemente com a insegurança sobre sua situação presente e futura. O depoimento de um apicultor explicita a estratégia de manipulação na região:

(...) é novidade essa negociação da Vale com os apicultores, deixando a apicultura dentro do terreno dela. Eu acho que é por um tempo. Eles já tentaram que o pessoal assinasse (um contrato) e fosse por três anos... porque quando o terreno era de particulares eles tinham as abelhas lá instaladas. Para (a Vale S.A.) não jogar essa comunidade, esse grupo de apicultores, essa atividade econômica contra eles, para ter eles como aliados, esses apicultores como aliados, é que eles estão fazendo essa concessão. Na minha visão é isso. No dia que eles já tivessem lá sacramentada a mina Apolo, já tivessem sacramentado os interesses deles, eu duvido que alguém permaneça com atividades na área da Vale S.A. Porque eles nunca deixaram, sempre cercaram tudo. Não deixam ninguém entrar, são intolerantes com qualquer atividade. Não deixam o pessoal tirar musgo (Morador, comunidade de André do Mato Dentro, janeiro 2013)

Os questionamentos acima reaparecem nas reclamações dos apicultores quanto a atuação autoritária da empresa que ignora os costumes locais e a liberdade desses apicultores. Ela os obriga a usarem crachás e vestirem camisetas da empresa para ingressar em seus terrenos. Os apicultores sofrem ainda obstruções nas práticas da apicultura nas áreas que a empresa concede para a realização da atividade. Os criadores de abelha revelam o descaso e a negligência quanto aos seus conhecimentos e experiência sobre o manejo de abelhas e a proibição da presença de apiários próximos as estradas vicinais, uma prática recorrente por décadas na região.

Verificamos, portanto, que os mecanismos de diálogo utilizados pela empresa para garantir a "licença social" para operar foram permeados por autoritarismo, silêncios e descaso com os apicultores locais. A empresa desconsiderou a relação dos apicultores com o território, seus aspectos simbólicos, morais e afetivos. Conforme reconheceuum morador local, essas práticas de "interação social inclusiva e participativa" e de "cooperação mútua" propagadas pela empresa, podem ser lidas como estratégias empresariais para reunir aliados nas comunidades locais e se territorializar com maior consenso.

Por último, outra estratégia aplicada pela transnacional na região da Serra do Gandarela objetivou a fragmentação da resistência e a minimização/anulação 
do "risco social". Para garantir o controle territorial na Serra do Gandarela, a transnacional implementou ações de "inteligência corporativa" (ACSELRAD, 2014) dividindo as comunidades e eliminando a capacidade de organização e mobilização dos moradores locais, ilustradas na declaração a seguir:

(...) muitos disseram que eles (a Vale) viriam dividir a comunidade. Que uma das estratégias deles era dividir a comunidade. E eu acredito que as pequenas mineradoras, com suas promessas (de geração de empregos), fazem parte dessa estratégia de divisão, quanto a todo um trabalho feito de longo prazo pela Vale. Eles (a Vale) puseram uma pessoa aqui (em André do Mato Dentro) que ficou um tempo falando que estava olhando poeira de caminhão para ver pontos onde ia jogar água. Essa pessoa pelo que eu ouvi dos outros, era um investigador, investigando quem era líder, quem não era, quem era quem, para depois ele saber em quem chegar, como chegar, quem aceitaria um apoio para a festa, para a igreja e trocaria esse apoio para a festa e para a igreja num apoio a mineração (Morador, comunidade de André do Mato Dentro, janeiro 2013)

A estratégia da Vale S.A de fracionar e dividir as comunidades onde atua delineia situações de intransigência, agressividade, autoritarismo, espionagem e violação aos direitos humanos e ao meio ambiente. Inúmeras são as denúncias de violações de direitos humanos no Brasil e em outros países onde a empresa mantém operações. Essas denúncias culminaram com a Articulação internacional dos Atingidos pela Vale S.A. que desde 2012 publica anualmente o Relatório de Insustentabilidade da Vale S.A em contraponto ao seu Relatório de Sustentabilidade (AIAV, 2014).

No Gandarela, a "inteligência corporativa" pretendeu obter informações sobre as lideranças locais com o objetivo de gerar divisões entre as lideranças locais mais críticas e as comunidades e cooptar as lideranças que demonstravam menor poder de resistência aos empreendimentos de exploração mineral. Além dessas ações, a transnacional também estimulou divisões entre as próprias famílias das comunidades colocando em oposição seus membros no que se refere a ponderação quanto aos empreendimentos da Vale na região e as "vantagens/ benefícios/custos" auferidos com esses projetos minerários em diferentes escalas: individual, familiar, comunitária e ambiental. Ações de espionagem emergiram também durante encontros e caravanas organizados por movimentos ambientalistas às comunidades locais da Serra do Gandarela (ROJAS, 2014).

Essas estratégias de administração e controle dos "riscos sociais", das resistências das comunidades e das vozes dissonantes contribuíram para fragmentar, desarticular e minimizar a organização e mobilização das comunidades locais e dos movimentos ambientais. Além de evitar que o empreendimento 
minerário fosse inviabilizado ou o projeto paralisado nas fases subsequentes, essas estratégias se voltaram a garantir o controle territorial da Serra do Gandarela.

A relação histórica das comunidades locais pesquisadas com a transnacional tem deixado marcas negativas, dúvidas e descrédito a respeito da sua atuação como assinala uma moradora:

(...) a gente foi numa reunião no André. Quem fez foi o pessoal da Vale. Eu lembro que o meu marido, chegou perto de um homem que estava nessa reunião e começou a falar com ele. Que o pessoal (da Vale) não ajuda muito, que por que a Vale não dá mais opção para outros apicultores, que o apicultor está ai para ajudar a preservar a natureza. Na hora que o homem saiu de perto do meu marido um outro chegou perto e falou assim: "Preocupa não, é besteira." Quer dizer, eles nem estavam prestando atenção para o que os apicultores estavam falando. $\mathrm{Na}$ hora que eu vi aquilo, pensei, ficar indo em reunião para que? O que esse povo quer é o quê. Tirar foto, pôr em mural, pôr em jornalzinho que está fazendo. Dão um lanchinho, adoram fazer uma reunião e dar um lanchinho, e ficar tirando foto da gente lá lanchando. Acabou que a gente não foi mais em reunião. Porque esse pessoal não dá muito ouvido para a gente. Esse pessoal da Vale parece que eles já vão com o princípio, o meio e o fim da reunião, o que vai ser decidido depois e pronto, e assim é complicado (Apicultura, comunidade de Socorro, janeiro 2013)

No depoimento acima podemos perceber que a apicultura reconhece, tece críticas e se indigna com as estratégias utilizadas pela Vale S.A de manipulação das reuniões com a comunidade ao ponto de colocar em questão a importância de se participar das mesmas. Ou seja, ela percebe que as reuniões não são realizadas com o intuito de resolver os conflitos e sim com o sentido de legitimar as estratégias de "marketing social e ambiental" da empresa. Conforme indica Leroy (2010) essas estratégias de cooptação, legitimação e busca de apoio comunitário executadas por grandes empresas como a Vale S.A são utilizadas tanto para aumentar o "marketing empresarial" como "para a governança e manutenção de uma certa paz social através do diálogo ao redor de detalhes e de ações pontuais, eliminando o exercício da política" (LEROY, 2010, p. 99).

\section{CONCLUSÃO}

Os embates da Vale S.A e o amplo processo de controle territorial na Serra do Gandarela nos últimos anos ilustram imbricações estreitas entre espaços, políticas e estratégias. Por meio de políticas e estratégias formais - compra de terra para instalação de empreendimentos minerários e/ou criação de áreas protegidas - e complementares - para garantir o apoio local, conquistar segmentos 
sociais específicos e fragilizar e/ou eliminar manifestações de resistências - a transnacional brasileira vem assegurando cada vez mais o acesso e controle territorial e a reprodução do seu espaço de produção no Quadrilátero Ferrífero.

Esse processo está vinculado à ampliação da demanda internacional por minerais e à valorização das commodities no mercado internacional. Nessa conjuntura de demanda internacional por minérios a Vale S.A se destaca por sua política expansionista e agressiva no Quadrilátero Ferrífero.A despeito do montante de minérios e capital mobilizados, o sucesso da mineradora não se repete nos indicadores sociais e ambientais dos municípios e comunidades locais onde opera. A instalação de grandes empreendimentos de mineração na região bem como a criação de espaços de reserva futura contribuem para interferir e alterar a continuidade e reprodução dos modos de vida das comunidades locais conforme analisado.Desse modo, territórios antes "resguardados da mineração" como a Serra do Gandarela, experimentam conflitos, pressões, tensões, negligências e violações de direitos em função de seu reordenamento territorial.

A politica surge no entre-os-homens; portanto, totalmente fora dos homens.

Por conseguinte, não existe nenhuma substância politica original. A politica surge no intra-espaço e se estabelececomo relação.

(Hannah Arendt)

\section{REFERÊNCIAS}

ACSELRAD, H. 2014. Estratégias empresariais e militares de controle de território. Le monde diplomatique-Brasil. São Paulo, Edição 82, Maio 2014.

ALAV, Articulação internacional dos Atingidos pela Vale. Disponivel em:https:/ / atingidospelavale. wordpress.com/. Acesso em: 02/02/2014

AMPLO, Treinamento e consultoria Ltda. Estudos de Impacto Ambiental e Relatório de Impacto Ambiental do Projeto Mina Apolo (EIA/RIMA PROJETO APOLO). Belo Horizonte, [s.n.], 2009, 2569 p.

ARENDT, Hannah. O que é Política? Rio de Janeiro: Bertrand, 2004; p. 21-24

BRASIL MINERAL. As maiores empresas do setor mineral (Edição Especial). São Pablo: Signus Editora Ltda, No. 331, Jul. 2013, 140 p. Disponível em: http:/ /www.brasilmineral. com.br/bm/revista/331/. Acesso em: 03/02/2014

CHAUÍ, M. Raízes teológicas do populismo no Brasil: teocracia dos dominantes, messianismo dos dominados. In: DAGNINO, E. (Org). Anos 90:política e sociedade no Brasil. São Paulo: Brasiliense, 1994, p. 19-30. 
CNI, DIRET, IBRAM. Mineração e economia verde. Brasília: CNI, 2012, 69 p.

COELHO DE SOUZA, C. Leituras de Henri Lefebvre para os estudos iniciais sobre o conflito ambiental na Serra do Gandarela: o espaço da resistência? In: XV ENCONTRO DA ANPUR, 2013, Recife. Anais... Recife: ANPUR, 2013,p. 1-17.

COELHO, T. Mineração e dependência no Quadrilátero Ferrífero - Aquifero: o discurso do desenvolvimento minerador e o projeto Apolo. 2012. 178 f .Dissertação (mestrado) - Programa de Pós Graduação em ciências sociais, da Universidade do Estado do Rio de Janeiro, Rio de Janeiro, 2012.

ESCOBAR, A. El desarrollo sostenible: diálogo de discursos. Ecologia Politica: Cuadernos de debate Internacional. Barcelona: Icara, n. 9, p. 7-26, 1995.

EUCLYDES, A. C. Proteção da natureza e reprodução da natureza: política, ideologia e diversidade na criação de unidades de conservação na periferia sul de metrópole Belo-Horizontina. 2012. 222 f. Dissertação (mestrado) - Programa de Pós-Graduação em Geografia, da Universidade Federal de Minas Gerais, Belo Horizonte, 2012.

HAESBAERT, R. Da desterritorialidade à multiterritorialidade. In: X ENCONTRO DE GEÓGRAFOS DA AMÉRICA LATINA, 2005. São Paulo.Anais... São Paulo: Universidade de São Paulo, 2005. p. 6774-6792.

HERMAN, E; CHOMSKY, N. A manipulação do público: política e poder econômico no uso da mídia. São Paulo: Editora Futura, 2003, 470 p.

IBGE. Censo 2010. Disponível em: http://www.censo2010.ibge.gov.br/>. Acesso em: 04/04/2013.

IBRAM. Informações e análises da economia mineral brasileira, $7^{\mathrm{a}}$. Edição, Brasília: IBRAM, dezembro 2012, 68 p.

IGEL, D; GAZZINELLI, G; CARVALHO, J; ROCHA, M; BAPTISTA, P; RODRIGUEZ, P. Parque Nacional da Serra do Gandarela. Oportunidade de riqueza limpa e para toda a vida. Belo Horizonte: [s.n.], 2012, 217 p.

LAMOUNIER, W. Patrimônio natural da Serra do Gandarela e seu entorno: análise ambiental como subsídio para a criação de unidades de conservação no Quadrilátero Ferrífero - Minas Gerais. 2009. 152 f. Dissertação (mestrado) Programa de Pós-Graduação em Geografia, da Universidade Federal de Minas Gerais, Belo Horizonte, 2009.

LEROY, J. P. Amazônia: territorios do capital e territórios dos povos. In: ZHOURI, A; LASCHEFSKI, K (Org). Desenvolvimento e conflitos ambientais. Belo Horizonte: Editora UFMG, 2010, p. 92-113.

MALERBA, J; MILANEZ, B; WANDERLEY, L. J. Novo Marco Legal da Mineração no Brasil: Para quê? Para quem?Rio de Janeiro: FASE, 2012, 162 p. 
MARQUES, M. I. O conceito de espaço rural em questão. Terra Livre, Ano 18, n. 19, p. $95-112,2002$.

MARTÍNEZ ALIER, J. O ecologismo dos pobres. São Paulo: Contexto, 2007, 379 p.

MINAS GERAIS. Lei no 14.309, de 19 de junho de 2002. Dispõe sobre as Políticas Florestal e de Proteção à Biodiversidade no Estado. Diário Oficial, Belo Horizonte, 20 jun. 2002. p.3.

PORTO-GONCALVES, C. W. A globalização da natureza e a natureza daglobalização. Rio de Janeiro: Civilização Brasileira, 2006, 461 p.

ROJAS, C. M. Os conflitos ambientais na Serra do Gandarela na perspectiva das comunidades locais. 2014. 200 f. Dissertação (mestrado) - Programa de Pós-Graduação em Geografia, da Universidade Federal de Minas Gerais, Belo Horizonte, 2014.

SACK, R. 1986. Human Territoriality:its theory and history. Cambridge : Cambridge University Press.

SEMAD/MG, ICMBio. ATA da Reunião GT 1. Belo Horizonte,2011

THOMPSON, J. B. Ideologia e cultura moderna. Petrópolis: Vozes, 1989, 427 p.

VALE S.A. Relatório de Sustentabilidade / 2012. Disponível em:http://www.vale. com/PT/aboutvale/sustainability/links/LinksDownloadsDocuments/relatorio-desustentabilidade-2012.pdfAcesso em: 05/08/2013

VALE, S.A. Informativo trimestral da Vale em Mariana, Ouro Preto e Catas Altas. Ano 3- No. 8- Abril/Maio/Junho2013

WANDERLEY, L. J. As múltiplas relações espaciais de poder no espaço da mineração. X ENCONTRO DE GEÓGRAFOS DA AMÉRICA LATINA, 2005, São Paulo.Anais... São Paulo:USP, 2005, p. 16449-16472 



\section{Mineração, neo-extrativismo e conflitos em Barcarena}

\section{Mining and neo-extractive and conflicts in Barcarena}

Eunápio Dutra do Carmo - Doutor em Ciências da Educação-PUC/RJ, pós-doutorado no Núcleo de Altos Estudos Amazônicos/UFPA. Professor do Centro de Estudos Superiores do Estado do Pará/CESUPA.

Edna Ramos de Castro - Doutora em Sociologia pela École des Hautes Études en Sciences Sociales/EHESS, França, pós-doutorado no Centre National de la Recherche Scientifique/CNRS, França, Professora do Núcleo de Altos Estudos Amazônicos/ UFPA, e pesquisadora do CNPq.

Júlio Cezar dos Santos Patrício - Professor do Centro de Estudos Superiores do Estado do Pará/CESUPA, Doutorando do Núcleo de Altos Estudos Amazônicos/NAEA/UFPA. Mestre em Economia pela Universidade da Amazônia/UNAMA.

\section{Resumo}

O papel da Amazônia, como fronteira de recursos naturais, faz com que a região tenha sua paisagem físico-natural e sociocultural modificada por processos de desestruturação espacial decorrentes da expansão do capital produtivo vigente $\mathrm{e}$ das tecnologias dele derivadas. No entanto, não obstante a presença da racionalidade empresarial que vem acompanhada pelos aspectos da competência, produtividade e eficiência, a região amazônica detém outras racionalidades em ação (autóctones), que se confrontam, chocam-se e disputam espaços com aquelas promovidas pela reestruturação produtiva. Destas racionalidades, emergem mobilidades e territorialidades que reconfiguram cenários históricos com forte simbolismo inscristos na região há bastante tempo.

\begin{abstract}
The role of the Amazon, as border natural resources, makes the region has its physical and natural, social and cultural landscape modified by spatial disintegration processes resulting from the expansion of existing productive capital and technologies derived from it. However, despite the presence of corporate rationality that comes with the aspects of competence, productivity and efficiency, the Amazon region has other rationales at work (indigenous), which clash, collide and compete for space with those promoted by the productive restructuring - These rationales emerge mobility and territoriality that reconfigure historical scenarios with strong inscristos symbolism in the region for some time.
\end{abstract}

\section{Palavras-chave}

Mineração. Conflito. Barcarena. Amazônia.

\section{Keywords}

Mining. Conflict. Barcarena . Amazon 


\section{INTRODUÇÃO}

O papel da Amazônia, como fronteira de recursos naturais, faz com que a região tenha sua paisagem físico-natural e sociocultural modificada por processos de desestruturação espacial decorrentes da expansão do capital produtivo vigente e das tecnologias dele derivadas. No entanto, não obstante a presença da racionalidade empresarial que vem acompanhada pelos aspectos da competência, produtividade e eficiência, a região amazônica detém outras racionalidades em ação (autóctones), que se confrontam, chocam-se e disputam espaços com aquelas promovidas pela reestruturação produtiva. Destas racionalidades, emergem mobilidades e territorialidades que reconfiguram cenários históricos com forte simbolismo inscristos na região há bastante tempo. A Amazônia contemporânea tem vivido novos desenhos socioespaciais em função de novos eixos logísticos de infraestrutura e da recomposição do campo político, trazendo à tona a tensão entre atores econômicos, sociais e institucionais.

Este trabalho se propõe a discutir algumas dimensões da dinâmica socioeconômica do município de Barcarena, na Amazônia Oriental, marcado pela presença de empresas transnacionais de mineração que determinam grandes transformações socioambientais no território. Esse processo tem implicado, nas três ultimas décadas, no aumento de disputas resultantes, entre outras configurações, da ampliação dos mercados acionados pelos agentes econômicos e da ação dos segmentos sociais e do poder público diante deste cenário, na medida em que todos os envolvidos querem afirmar as suas territorialidades no município. $\mathrm{O}$ trabalho expõe dados de pesquisa realizada no município de Barcarena, tendo como campo de observação as áreas de mineração e portuária do Distrito Industrial de Barcarena, e o entorno dessas áreas notadamente ocupadas por comunidades locais. Propõe uma análise dos vetores da transescalaridade dos sistemas produtivos locais em Barcarena e seus principais atores sociais e agentes econômicos no atual contexto das dinâmicas socioterritoriais.

Como todo espaço geográfico que vive relações sociais é um território, isso significa vê-lo como espaço em evolução social, reflexo de contextos econômicos, de suas instâncias culturais e político-institucionais, pois possui formas-conteúdo que, segundo Santos (1992) correspondem aos fluxos, às funções e aos fixos. Neste sentido, a análise teórica construída para este trabalho considera o debate sobre processos de expansão industrial em áreas de ocupação pré-existentes predominantemente por comunidades locais que construíram um conjunto diverso e rico de saberes produzidos socialmente em contato com o contexto físico-natural da floresta. Isso significa assumir, como fio condutor do estudo, a reatualização 
dos processos de expansão capitalista materializada em programas econômicos e logísticos em curso no município de Barcarena, esses pensados a partir das experiências sociais, privilegiando conceitos como territorialidade, redes e conflitos. Todas essas dimensões compõem, simultaneamente, momentos de tensão e reeditam a história de ocupação e de exclusão social presentes no município.

O trabalho está estruturado em três partes. A primeira discute a dinâmica socioeconômica em curso. Em seguida, são apontadas as tramas sociais referidas a territorialidades, atores e hierarquias de poder, apresentando, no final, considerações finais e novas agendas e pesquisa.

\section{1 - O ATUAL CONTEXTO DE BARCARENA}

O município de Barcarena está localizado a $40 \mathrm{~km}$ de Belém, capital do Pará, na região norte do Brasil, ocupando uma área de $401 \mathrm{~km}^{2}$ e é um dos municípios em grande expansão empresarial e de relações mercantis na Amazônia Oriental(mapa 01). Além da posição geográfica que facilita algumas atividades empresariais, este município constrói trajetória própria, considerando as suas histórias, seus eixos de produção, as relações políticas dos seus atores sociais, suas articulações administrativas e as suas opções de gestão e implementação de políticas públicas. Todos esses aspectos apontam singularidades que marcam trajetórias, contudo estão também relacionadas com outras dinâmicas e trajetórias de âmbito nacional e global, o que, metodologicamente, faz-nos operar com a noção que supera a ideia de considerar o município apenas como unidade administrativa, mas problematizá-lo como eixo de uma complexa rede de relações sociais, políticas, técnicas e informacionais circunscritas na dinâmica do sistema capitalista de produção. Por essa razão, entende-se que a história de Barcarena tem alcance na interação local-global, perpassa pela produção da economia à vida em sociedade e articula a assimetria entre a racionalidade da produção capitalista e a racionalidade das comunidades locais. Trata-se do espaço amazônico, suas fronteiras, singularidades e sociobiodiversidade, aspectos cruciais para a percepção global-local, dos fluxos, redes e poder.

Um aspecto interessante da história de Barcarena diz respeito ao modo de ocupação do espaço, referindo-se à posição estratégica ocupada pelos núcleos habitacionais e a instalação das empresas mineradoras. Tal posicionamento deuse no espaço social de populações e comunidades locais que, antes da chegada das grandes empresas, permitia o aproveitamento dos recursos da natureza em favor da sobrevivência, praticando a pesca, a caça, o extrativismo e a prática dos roçados, como também a extração de frutos típicos da floresta amazônica, 
como: bacuri, cupuaçu, pupunha, banana, dentre outros, os quais faziam parte da cultura das populações que habitavam aquelas áreas. Esta vida social dos vários segmentos da população nativa da região foi afetada consideravelmente com a implantação das empresas mínero-metalúrgicas, que passaram a atuar no município, incluindo-se aí a área do entorno dos empreendimentos minerais onde se localizam comunidades locais.

O município de Barcarena viveu (e vive) um processo de adaptação local/regional ao novo momento industrial, em decorrência da implantação do complexo fábrica-vila-porto referente à racionalidade instrumental das empresas de transformação mineral, explicando, dessa forma, as razões da emergência do município como Distrito Industrial de Barcarena, contribuindo para os impactos físico-ambientais, o que alterou, significativamente, a dinâmica socioespacial. A gênese do conjunto articulado dessas transformações que estão sendo vivenciadas na Amazônia Oriental teve seu início com o II Plano de Desenvolvimento (II PND, 1974-1979), sendo respostas imediatas ao padrão de desenvolvimento do modo de produção capitalista e a concepção de estratégicas à reestruturação da economia capitalista e à relocalização e reorganização dos processos da atividade industrial. São destas transformações que podem ser compreendidas as dinâmicas territoriais produzidas pelas estratégias de modernização do mercado, pela reestruturação dos municípios amazônicos, pelos desdobramentos do crescimento urbano, diretamente relacionados aos impactos da implantação de empresas de extração e de transformação mineral presentes na região e a forma de atuação dos vários segmentos sociais que se cruzam, confrontam, aproximam e negociam interesses em espaços de relações e de contato próprios. Essas populações têm sofrido as seguintes consequências: "deslocamento de parte da população para outras áreas periféricas do município, alterações em seu quadro físico-natural e, ainda, a poluição propagada por via atmosférica e hidrográfica" (COELHO et al., 2005: 112).

Os novos arranjos socioespaciais e as disputas que acompanham as dinâmicas sociais emergentes no município de Barcarena (Pará) são resultados do processo de avanço do capital na Amazônia, representado pela industrialização na região. Tal configuração emerge a partir das políticas de desenvolvimento concebidas pelo Governo Federal, na década de 70 e 80, políticas que foram determinantes para este processo de alargamento de fronteira do capital. São resultantes deste processo a implantação de grandes projetos mínero-metalúrgicos e a construção de infraestrutura apropriada para os novos empreendimentos (hidrelétrica, porto, rodovia e vila operária). A lógica dos processos econômicos marcados pela "eficiência, produtividade e competitividade" (CASTRO, 2001, p. 07), em marcha desde a década de 90, tem alcançado mercados até então não inseridos nessa nova 
dinâmica capitalista, como é o caso da Amazônia. Assim sendo, o padrão capitalista de produção expande-se para áreas de notável potencial de produção, obedecendo também à mudança do sistema produtivo em sua organização e ao fator de mercado instalado. Soma-se a isso o fato decisivo de que, com a globalização (expansão das relações de mercado e avanço tecnológico e informacional), o sistema capitalista, contando com ações em áreas diversas, como: competição interempresarial, estratégias de mercado, novos padrões de gerenciamento, mudanças no mundo do trabalho (cfe. CASTRO, 2001), todas essas questões imprimem ao Estado e à sociedade civil formas de atuação e de disputa presentes no jogo das correlações de força e dos interesses postos na região.

Mapa 1 - Localização do Município de Barcarena
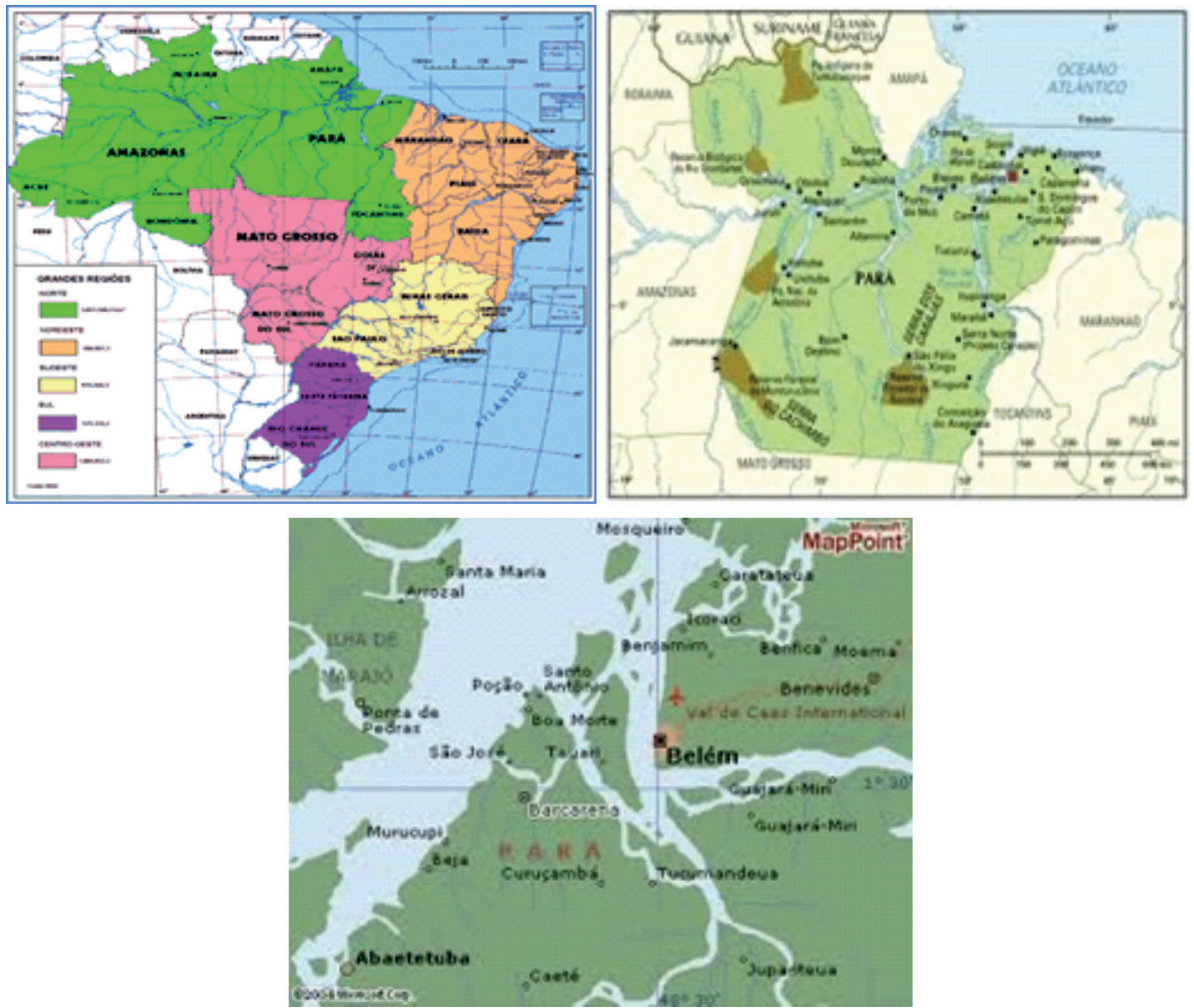

Fonte: Arquivo iconográfico da pesquisa (Mapa adaptado. GEDES, 2010)

Em Barcarena, há a uma área com grande concentração de empresas de extração e beneficiamento de minerais que pertence ao sistema minerário em expansão na região, que possui uma hitórica presença no município, e o mapa a seguir apresenta a localização dos empreendimentos no município (mapa 02). 


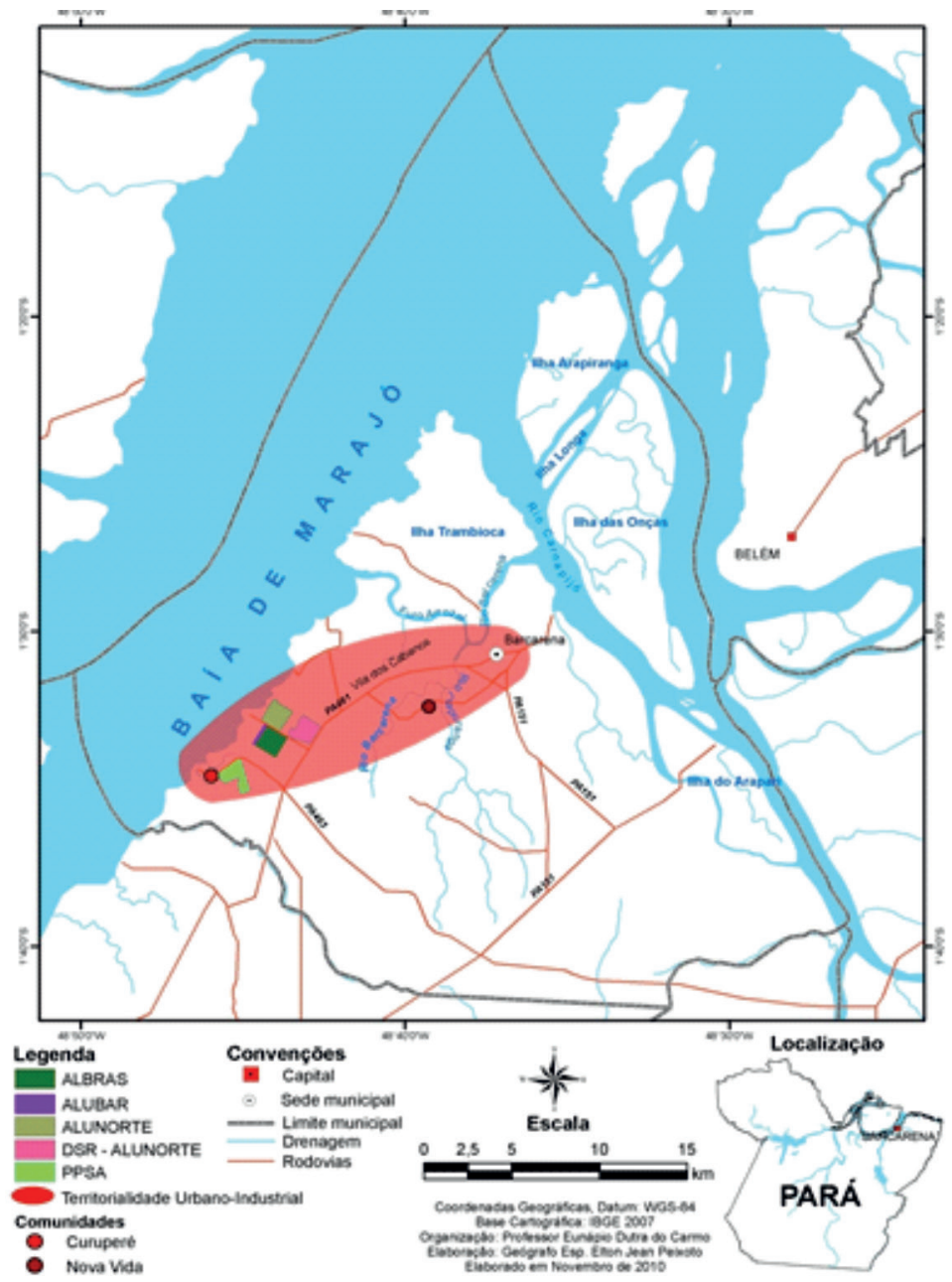

As áreas industrial e urbana complementam-se por estar nessas áreas as empresas de mineração (ALBRAS, ALUNORTE, PPSA e YMERIS) e a Vila dos Cabanos, espaço que foi construído para abrigar os funcionários das empresas e que hoje é ocupada também por outros moradores. As empresas receberam apoio do poder público (Prefeitura e Estado) e estão, cada vez mais, próximas de ações políticas que estruturam projetos de parceria. A área rural e as ilhas formam o entorno e representam os espaços mais afastados do centro industrial, onde se concentram as comunidades e os grupos sociais tradicionalmente ligados às atividades de pesca, agricultura e extrativismo. Essas populações locais, de um modo geral, recebem apoio e assessoria de movimentos sociais e de organizações 
não-governamentais (ONG'S), que atuam no campo democrático-popular, denunciando e viabilizando alternativas coletivas junto a esse quadro social. Algumas comunidades também mantêm relações com as empresas na medida em que estão participando de projetos de responsabilidade social, cujo enfoque é nas áreas de educação, cooperativismo e empreendedorismo.

A divisão socioeconômica e espacial explica também o movimento de articulação entre esses atores no campo de disputa. A configuração territorial do município revela o campo de atuação das forças sociais que se territorializaram a partir de interesses coletivos. Este campo reforça a representação social do "retalhado" a que se referiu Leonardo do Carmo". Segundo os dados do IBGE, a população do município é de 92.567 , sendo que $56,11 \%$ deste total habita na zona rural, que é o retrato na região de Tocantins ${ }^{2}$ (IBGE, 2009), e 43,89\% vive na área urbana. Para a população urbana do município, os equipamentos públicos são mais presentes, o que pode estar relacionado com a presença das empresas na área industrial. Para ilustrar a força das empresas, que compõem o polo industrial do município: a) Barcarena colaborou, em 2009, com o volume financeiro de US\$ 2.278.681.051 para a balança comercial do Estado do Pará (PARÁ, 2010); b) A receita orçamentária do município, em 2008, foi de $\mathrm{R} \$ 160.687 .681,70$, sendo a maior na região do Tocantins e do próprio Estado (PARÁ, 2010).

No caso da população rural, a situação é diferente. Os equipamentos públicos são mais escassos, com agravante para as áreas de educação, segurança e transporte. A população vive do trabalho do extrativismo e da agricultura, basicamente da extração do açaí e de outras frutas assim como da produção de farinha que são comercializadas na "beira da estrada" e na feira do centro. Além da produção doméstica e da comercialização, muitas pessoas ocupam-se de atividades sazonais ("bicos"), outros atuam no mercado informal, tendo que se deslocar para os núcleos urbanos, a fim de garantir as vendas dos produtos e serviços. Estas populações são organizadas com estruturas políticas próprias de representação e se mobilizam na defesa de direitos, apesar das dificuldades e contradições, que apontam rearranjos nas relações de poder.

As forças sociais em disputas "retalham" o município e representam divisão de poder econômico e das condições sociais presentes na região. As disputas são responsáveis por tensões, contradições e conflitos, mas também por negociação, cooptação e mediação. É nessa perspectiva, que podemos entender o processo de industrialização na Amazônia, em que Barcarena é um exemplo

Trabalhador local e sindicalista

A região de Tocantins é formada pelos municípios de Abaetetuba, Acará, Baião, Barcarena, Cametá, Iguarapé-Miri, Limoeiro do Ajuru, Mocajuba, Moju, Oeiras do Pará e Tailândia (PARÁ, 2010). 
emblemático. É nesse contexto que ocorrem as transformações da paisagem social e ambiental do município. As comunidades formadas por ribeirinhos e pequenos agricultores veem não apenas a inserção do território na economia globalizada, com a exportação dos produtos da região, mas também assistem e reagem à destruição do seu habitat historicamente construído: o ecossistema amazônico. O território passa então a ser disputado, situações de conflito instalamse. E o resultado tem apontado, não obstante, a organização, a mobilização e a resistência política, para o deslocamento compulsório de comunidades e grupos sociais, seu enfraquecimento e até mesmo o seu desaparecimento, como também a sua grande politização para continuarem a (r)existir, utilizando estratégias como a ampliação da formação, como é o caso da Comunidade Nova Vida que em dez anos viveu dois deslocamentos compulsórios e está na iminência de um terceiro deslocamento (CARMO, 2010). Nessa, teríamos aí a necessidade de correlação de forças presentes nas comunidades, movimentos sociais, prefeituras, empresas e Estado (representado pela SECTAM e CDI). E eles "retalham" o município com suas estratégias e formas de atuação.

No conjunto dessas reflexões, situa-se a história recente do município de Barcarena. Contudo, é preciso considerar que todo fato histórico é sociocultural. Essa perspectiva é central para este trabalho e nos traz para o campo da história social, que coloca o indivíduo, os grupos sociais e as situações por eles protagonizadas como importantes para a compreensão de outra história a partir da realidade local produzida pelos sujeitos sociais em seus cotidianos. As leituras de Revel (1998) nos ajudam a perceber que, apesar da riqueza dos estudos permanentes sobre a dinâmica econômica e as dimensões estruturais das macropolíticas da região amazônica, a prevalência e a abordagem da dimensão relacional (indivíduo e grupo) e sociocultural (compreensão dos significados do mundo social) nos impulsionam para outros campos de registros e formas de operar com a complexa realidade social.

No plano do Estado e das macropolíticas, essas constatações vindas das realidades sociais das comunidades não ganham a mesma importância, ou são, como ocorreu, invisibilizadas por uma escala de observação dominante em que o tempo e o espaço são ditados por questões e aspectos estruturais da economia. Numa outra perspectiva de escala microssocial, acreditamos que as especificidades históricas dos grupos sociais pré-exitentes na região, detalhadas em seus universos sociais, organizacionais, culturais e ecológicos, podem colaborar para uma interpretação da realidade sociopolítica e econômica da região, especialmente, por percebê-la no bojo das contradições sociais que são decorrentes de um longo processo histórico. 
No conjunto dessa discussão, há duas pautas de reflexão que ajudam a compreender uma parte significativa do campo empírico e do atual contexto de Barcarena: 1) os novos arranjos espaciais e as dinâmicas sociais que emergem, simultaneamente, com o processo de intensificação do neo-extrativismo empresarial da mineração industrialização na Amazônia; 2) a nova configuração sociopolítica como parte da tríade espaço de extração mineral, área da empresa e periferia (entorno), como espaços que se completam e são indivisíveis. Apresentá-los numa perspectiva integradora trará contribuições para a análise teórico-empírica em questão.

\section{2 - TERRITORIALIDADES EM CONFLITO: TENSÃO NAS REDES}

O território é "espaço humano, espaço habitado" (SANTOS et al., 1996, p.18) e, com base na funcionalidade existente, ele pode ser espaço local e espaço global, simultaneamente, afirma o autor. Para Santos (idem), o primeiro se refere ao "espaço vivido por todos os vizinhos" e o segundo é "habitado por um processo racionalizador e um conteúdo ideológico" (idem). Por sua vez, a nova macrotendência internacional considera os lugares com papéis importantes na definição das estratégias globais (VEIRA, E. e VIEIRA, M., 2004) e a discussão do processo de integração da Amazônia a esta dinâmica internacional do capital se atualiza pelo tema das experiências sociopolíticas e espaciais dos vários agrupamentos humanos atuantes na região, dando visibilidade às organizações sociais presentes nesse contexto que atuam sobre outra lógica, demonstrando a sociodiversidade da região. Evidencia-se, dessa forma, que o desenvolvimento do processo capitalista interfere no espaço-território.

A Amazônia, como fronteira de investimentos internacionais, insere-se no contexto da geoestratégia da economia global. Alguns municípios, como é o caso de Barcarena, atendem à dinâmica dos lugares-globais e são palcos de novas prioridades em infraestrutura, o que implica formação de novas estruturas de poder e redes no território. O entendimento dessa nova lógica, no atual momento da região e de seus municípios, é fundamental, inclusive para compreensão dos resultados. É a opção analisada por Castro, que destacamos a seguir:

(...) Para entender essa alteração [na Amazônia], é preciso considerar a interação entre os processos locais e a dinâmica de mercados globais, fundamental para identificar as conexões lógicas que explicam o complexo mercado transnacional e a pressão de agentes econômicos sobre os recursos naturais (CASTRO, 2007, p 2).

Os resultados desse processo de mobilidade do capital e do trabalho têm sido mostrados, seja pelo aumento do volume da produção 
madeireira, agropecuária e de mineração - ainda que as estatísticas sejam subestimadas e, portanto, exijam ponderação na confiabilidade - , seja pelo mapa de conflitos identificando atores e recursos em disputa, seja pelos graves problemas ambientais, como o desmatamento e a poluição de rios. Ou ainda, pela desigualdade social revelada no baixo índice de desenvolvimento humano (IDH) em quase todos os estados da Amazônia Legal (PNUD, 2002)[CASTRO, 2007, p. 3].

Em Barcarena, essa constatação é ainda maior. As razões passam pelos vários registros e comprovadas modificações na paisagem físico-social e humana. Essas modificações são em decorrência do modelo de desenvolvimento adotado pelo Estado nacional, que visaram, de forma estruturante, à promoção da região à reorganização econômica global. A utilização do espaço amazônico, nesta perspectiva, como estratégia de integração com o lugar-global, via "Grandes Projetos"3, principalmente os mínero-industriais, instalados estrategicamente em unidades produtivas locais no município, a qual afetou diretamente as populações tradicionais e nativas da região, com graves quadros sociais. As decisões tomadas no âmbito externo, seja por governantes, seja por corporações internacionais, determinaram a agenda de intervenção local sem a efetiva participação dos atores que construíram uma dinâmica própria de sobrevivência no "lugar-local", afetou o espaço físico, a vida social, a economia, a cultura e os laços de solidariedade construídos historicamente pelas comunidades locais, gerando problemas de todas as ordens no tocante ao processo de exclusão social. Essa condição materializa-se, pois o processo de exclusão social se manifesta territorialmente.

Para os fins deste artigo ainda????, é fundamental o alinhamento desta agenda investigativa com a complexa rede de transformações nacionais identificadas, por exemplo, com os eixos de integração e infraestrutura como projetos que interferem no ordenamento territorial brasileiro. O Governo Federal vem estimulando corredores de transporte que modificam consideravelmente a malha territorial brasileira mediante adoção de programas estratégicos com intenso impacto nas sociedades locais. Os portos são exemplos dessas "novas fronteiras de expansão territorial produtiva" (ACSELRAD, 2002,50) por razões econômicas e produtivas.

Também a agenda investigativa tem sua base de reflexão ancorada nas multiterritorialidades na Amazônia Contemporânea, o que exige, como sugere

\footnotetext{
Trabalha-se a ideia de Becker para a noção utilizada ao termo grandes projetos. Para a autora, um grande projeto é caracterizado pelos seguintes aspectos: "1) pela escala gigante da construção da mobilização de capital e mão-de-obra; 2) pelo isolamento, implantado-se geralmente como enclaves, dissociados das forças locais; 3) pela conexão com sistemas econômicos mais amplos, de escala planetária, de que são parte integrante; 4) pela presença de núcleos urbanos espontâneos ao lado do planejado, expressão da segmentação da força de trabalho, qualificada/ não-qualificada" (Becker, 1995, p. 63-64).
} 
Brandão (2009, P. 177), uma reflexão articulada entre o macro e micro: "as articulações entre microprocessos, microiniciativas versus macrodecisões nas várias escalas em que se estruturam e se enfrentam os interesses em disputa". Por esta razão, as mudanças estruturais e a ampliação do Porto de Vila do Conde em Barcarena é das mais significativas expressões dessa relação, pois é resultado das novas determinações territoriais do desenvolvimento produtivo nacional e internacional em que o sistema de portos assume uma nova configuração de "fixidez-fluidez do movimento concreto do capital e o uso que este faz do território em suas múltiplas e variadas escalas espaciais” (BRANDÃO, 2009, 167).

Por essas razões, o território vivido, disputado e gestado pelos atores sociais precisa ser investigado. Para Santos (1996), que inspirou a afirmação anterior, o território é uma construção social, resultado da necessidade dos atores sociais envolvidos. Por isso também, com este autor, concordamos e lançamos mão da sua importante reflexão sobre o território enquanto sentimento de pertencimento, sobretudo por corresponder a um lugar de marcas da memória, da história que forja a identidade e, muitas vezes, carregado de simbolismos, representações no imaginário coletivo (SANTOS, 2004).

A constituição do território se dá no espaço e pelo trabalho. Essa é a significativa percepção de Claude Raffestin. Na sua concepção, o espaço antecede o território, sendo este último produzido socialmente, apropriado pelo trabalho de um grupo social inscrito num campo de poder (RAFFESTIN, 1993). O exercício do poder, em suas muitas dimensões (Estado, empresas e sociedade civil), é revelador das múltiplas instâncias de poder existentes. O território é assim apropriação de atores sociais no espaço mediante a utilização de técnicas, tecnologias e estratégias em intensos processos sociais materiais e imateriais. São processos materiais aqueles vinculados ao controle, dominação políticoeconômica e os processos imateriais estão relacionados à cultura e à identidade. Esses processos (i)materiais são históricos e ontologicamente compõem as relações sociais de grupos sociais quando usam o espaço. Em síntese, para Raffestein, sendo o território "um espaço criado pelo homem" (CICHOSKI e SAQUET, 2013) ${ }^{4}$, quando este ator social se apropria do espaço, ele está constituindo o território. Logo o território é uma "fração do espaço apropriada socialmente" (CICHOSKI e SAQUET, 2013).

Outros autores, como Marcos Aurélio Saquet e Rogério Haesbert são importantes nestas reflexões por optarem por uma visão híbrida dos processos nas

4 São autores do esclarecedor artigo "Concepções de Geografia, espaço e território nos Anais do IV Seminário Estadual de Estudos Territoriais e II Seminário Nacional sobre Múltiplas Territorialidades" em que são evidenciadas as diferentes formas de uso dos conceitos nas pesquisas. 
formas de operar o conceito território e a categoria gestão territorial. Saquet (2007) sugere a abordagem híbrida e relacional do território, situando seu debate, dentre muitos enfoques, nas escalas. Para este autor, o território compõe a interconexão com lugares globais, conformando os espaços econômicos fragmentados. Já Haesbert (2004) vê o território com uma dupla dimensão: dimensão do poder simbólico tanto no sentido da dominação (político-econômico-disciplinar) quanto no sentido da apropriação (identidade-afetvidade). No encontro deste campo híbrido, a categoria território assume uma imbricação envolvendo o sentido funcional do território (utilidade) e o sentido identitário-simbólico (significados e expressividade) [HAESBAERT, 2004 ], gerando práticas sociais, territorialidades.

A territorialidade é decorrente das relações sociais (existenciais e de produção) que se dão na dinâmica do território. Para Raffestin, a territorialidade corresponde ao "conjunto das relações mantidas pelo homem; como ele pertence a uma sociedade, com exterioridade e alteridade através de mediadores ou instrumentos" (RAFFESTIN, 1993, p. 267). A territorialidade é o vivido no território em todas as suas dimensões (RAFFESTIN, 1993).

Propomos, assim, considerar a territorialidade como

a multidimensionalidade do vivido territorial por meio de um conjunto de relações fomentadas pelo homem que pertence a uma sociedade, geradora de exclusividades, com relações exteriores promotoras de alteridades e mediadas através de instrumentos tais como língua, religião, cultura, trabalho dentre outros (RAFFESTIN, 1993, p. 161)

O que se verifica é um movimento de confronto que coloca em choque concepções diferentes sobre o espaço e territorialidades, envolvendo empresas transnacionais e comunidades sociais, onde se questiona a intervenção do poder econômico e é estimulada a consciência dos membros das comunidades que reagem. A contraposição que se estabelece frente à racionalidade econômica excludente e promotora de exclusão social diz respeito à pluralidade do poder espacialmente localizado (FISCHER, 2002), descortina o debate sobre desenvolvimento e como os atores sociais podem questioná-lo, impondo reações pelo avesso daquela racionalidade. É o embate das forças sociais, suas alianças e conflitos que norteiam as matrizes de possibilidades políticas e outros programas possíveis de desenvolvimento local. São tramas que credenciam Almeida (1996) e Fischer (2002) e, principalmente, Santos (1996) a vislumbrar uma nova etapa na atuação das organizações e dos movimentos sociais.

O território de Barcarena sempre esteve em mutação. Porém, nos últimos cinco anos, o município vem vivendo intensos processos de mudança, 
afetando as lógicas das relações políticas, sociais, econômicas e culturais. Esses processos estão associados com as formas de ocupação e de apropriação do território, tendo como maior foco garantir a capacidade produtiva e logística em detrimento das políticas sociais e equipamentos urbanos favoráveis ao bem estar da população. O caráter dessas intervenções em Barcarena não é homogêneo e diferencia-se considerando as dimensões tempo-espaço na economia globalizada que pode ser explicada tanto pela ação dos atores sociais na fronteira, formando diversos cenários de interesses em disputa que revelam os projetos dos atores envolvidos num intricado jogo: "O que está em jogo não é o território em si, espaço físico apropriado ou pretendido, mas a territorialidade enquanto exercício de um domínio que se realiza ou se projeta pelas relações políticas, portanto historicizadas" (CASTRO, 2007, p. 37).

O debate acerca dos temas territorialidades, redes e conflitos são essenciais para a compreensão da transescalaridade dos sistemas produtivos locais em Barcarena. Para os efeitos deste artigo, a transescalaridade colabora para a compreensão das novas dinâmicas que estão sendo impostas ao município de Barcarena e que delineam novas territorialidades bem mais complexas e em escalas global, nacional regional e local, redefinindo o território-rede. Portanto, os múltiplos territórios de Barcarena, protagonizados pelos seus diversos atores sociais, expressam as diferentes forças de apropriação que se atualizam à medida em que novas possibilidades de uso são estratégicas para os projetos e atividades desses atores sociais. Nesta direção, a transescalaridade será entendida como campo de ação político-estratégico em que as ações de concepção e intervenção no funcionamento do território são desenvolvidas, ou seja, no seu sistema territorial. Para Raffestein (1993), o sistema territorial corresponde ao campo de relações de envolvimento do Estado, empresas/organizações e indivíduos. São dessas relações com as dinâmicas político-econômicas que se formam malhas, nós e redes, assim compreendidos: a) malhas - representam conexões, ligações heterogêneas entre diferentes atores sociais; b) nós - são pontos de encontro de relações sociais, sendo interdependentes, podendo estabelecer comunicação entre si e; c) redes - representam ligação entre dois ou mais atores sociais; “(...) a rede faz e desfaz as prisões do espaço, tornado território: tanto libera como aprisiona" (RAFFESTEIN, 1993, p. 204).

Nesse sentido, os atores sociais disputam o espaço, dividindo-o, criam os nós e articulam as redes, cabendo ao sistema territorial a coesão dos territórios e o domínio dos atores sociais, indivíduos e objetos, os quais são dispostos de maneira hierárquica, favorecendo o controle sobre o material a ser distribuído, demarcando os campos de ações (de poder) nas relações socioterritoriais (idem). 
As redes dão suporte para o controle do/no espaço mediante a mobilização, circulação e comunicação protagonizadas pelos atores sociais, desenhando suas territorialidades. Por essa razão, as redes são "instrumentos por excelência do poder" (RAFFESTEIN, 1993)

Como principal ator de intervenção no sistema territorial, o Estado divide o espaço em malhas, para melhor controlar e dominar processos, fazendo destas ações suas estratégias de gestão territorial. No entanto, outras organizações produzem territórios e processos de intervenção, criando suas próprias malhas (RAFFESTEIN, 1993). Para o autor, os atores sociais "produzem o território, partindo da realidade inicial dada, que é o espaço. Há, portanto, um 'processo' do território quando se manifestam todas as espécies de relações de poder, que se traduzem por malhas, redes e centralidades" (Raffestin, 1993, p. 7-8). Neste sentido, o Estado, as empresas e as demais organizações da sociedade civil se apropriam do espaço, territorializando-se, ocupando-se e se apropriando do espaço, mediante a implantação de malhas, nós e redes, recortando o território, ligando-o com outras escalas. Assim, também são produzidas desigualdades, conflitos, sobreposições no território-rede, um território em disputa permanente entre as forças sociais.

Daí porque território é concebido como manifestação de poder de atores sociais e as redes são um instrumento político-econômico e institucional deste processo. Logo, é fundamental compreender o poder no território para além do estatal, problematizando a existência e a emergência de outros poderes, ampliando a concepção do território para uma sociedade complexa e diversa. A leitura deste território do ponto de vista do Estado pressupõe, na maioria dos estudos ${ }^{5}$, em ação sobre o espaço com aparato jurídico que legitima a ação do poder público. Sendo assim, a "gestão é o exercício do poder estatal sobre o território” (Azevedo Junior e Silva, 2011, p. 131) no campo da dominação/ apropriação do espaço por um poder político-econômico. Importante também destacar o caráter da mediação neste campo, como possibilidade de atuação do Estado em sua interação com os demais poderes no território, inclusive em regiões interculturais e diversas como a Amazônia, onde se apresentam outras intermediações, provocadas pela presença de outros atores estratégicos que acabam gestando o território de acordo com seus interesses globais-locais.

Dentre as muitas intervenções do capital internacional e nacional no município, destacam-se as empresas transnacionais de alumina, alumínio, caulim

5 Azevedo Junior e Silva (2011) desenvolvem importante estudo sobre a utilização das categorias gestão e gestão territorial por parte dos autores dos artigos da Revista Brasileira de Geografia. Além da sistematização das principais publicações, o estudo consegue apontar as compreensões em curso sobre os temas. 
e cobre que são atores econômicos responsáveis pelas mudanças mais sensíveis no território com suas redes e escalas de atuação, especialmente as infraestruturas ligadas à produção, armazenamento e circulação de produtos. Assim como ocorreu em outros municípios da Amazônia Oriental, o contexto de ocupação de Barcarena tem relação direta com a questão mineral. A figura 03 situa a presença de grandes empresas mineradoras no município com suas estratégias de ocupação e reeditam novos processos de mobilidade do capital, reconfigurando os territórios de mineração (formado pela atuação em rede de grandes empresas de mineração que se apropriaram do território compondo a cadeia produtiva mineral), implicando em conflitos socioambientais decorrentes dos diferentes interesses dos atores sociais na dinâmica local-global com consequências diretas para o ecossistema.

Figura 3 - Mapa dos Territórios de Mineração.

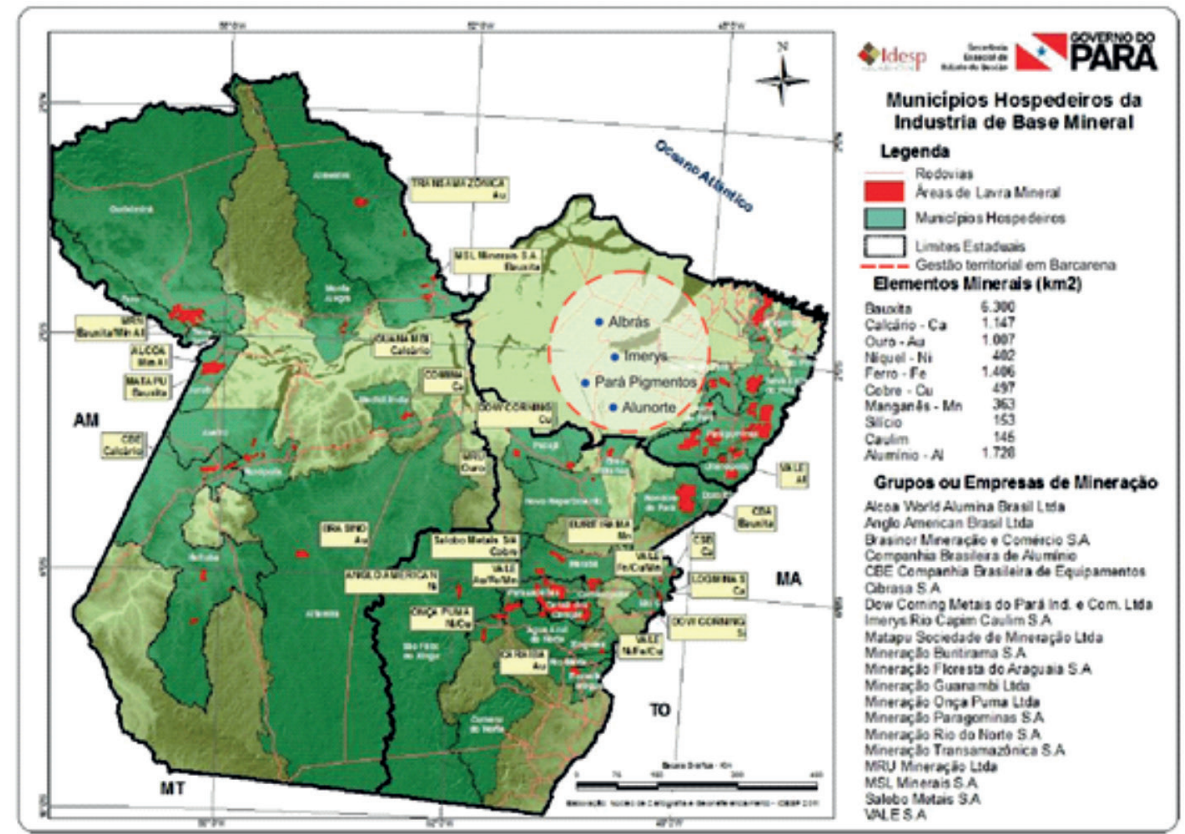

Fonte: Adaptado Estado do Pará (2011).

Os territórios de mineração estão associados aos megaprojetos de intervenção federal, a exemplo os Planos de Aceleração do Crescimento (PAC I e II) de caráter infraestrutural para integrar competitivamente a região aos mercados globais e aumentar níveis de investimentos e confiança produtiva do país. Castro (2012) chama atenção para o fato de que os incentivos na malha de transporte, energia e comunicação estão relacionados diretamente com a política de commodities, portanto, ainda centrada no crescimento econômico. 
Neste sentido, Barcarena é uma cidade estratégica e sua posição geográfica e contexto político de dominação/apropriação pelos territórios de mineração são importantes estruturas que constituem territórios com funções políticas e econômicas que insere o município no hall de lugares-globais com condições necessárias para a expansão dos negócios internacionais com rebatimentos para a indústria nacional. Essa função econômico-produtiva contrasta com a sua história, tradição e organização social pré-existente.

O desencadeamento de estratégias de racionalidade produtiva aliado a mecanismos políticos de modernização nas relações públicas e privadas vem se ampliando e se atualizando, simultaneamente, com as mudanças nos cenários macroeconômicos, principalmente considerando as estratégias de expansão e eficiência produtiva das mineradoras no município, somado aos seguintes acontecimentos: instalação de novas empresas, revisão das agendas ambientais, desapropriação de áreas, remanejamento de famílias, mudanças das forças políticas, resistência, desaparecimento e formação de comunidades, atuação de novas organizações da sociedade civil.

O município se reestruturou e foram introduzidas novas atividades econômicas, houve uma crescente urbanização intensiva combinada com um extraordinário boom demográfico transformando o sistema territorial do município e redesenhando as posições e estratégias dos atores sociais. Com isso, podemos considerar que há novos elementos que incidem na gestão territorial. Não obstante a CODEBAR (Companhia de Desenvolvimento de Barcarena), continuando com seu papel de controle territorial no município, faz-se mister notar que há novas condições estruturantes institucionais e territoriais de regulação social

A gestão territorial inscreve-se num campo de poder, redes e conflitos e se materializa nas relações institucionais e cotidianas ligadas às dinâmicas políticas, econômicas, culturais, as quais envolvem diversos atores sociais que protagonizam formas de acesso, disputas e negociações. Neste sentido, é pela apropriação econômica (material) e cultural (imaterial) que ocorre a territorialização, logo a gestão territorial deve considerar a complexidade dos interesses e o caráter de espaço econômico fragmentado que se intensificou em Barcarena como campo de produção e de poder, portanto de conflitos em razão das formas de apropriação local-global a que é contemporaneamente submetida. Essa dinâmica compreende também o fortalecimento das redes e, como analisa Raffestein (1993), elas têm o inacabamento como característica. É do inacabado que a rede "tira sua força no espaço e no tempo: adapta-se às variações do espaço e às mudanças que advêm do tempo" (RAFFESTIN, 1993, p. 204). Guardando as devidas diferenças entre os 
autores, destacamos em Santos e Silveira (2004) a noção de dialética do território como novos recortes no território engendrados pelos processos geopolíticos e econômicos da globalização, pois se trata de articulados sistema de fluxos, de circulação e produção em processos de transformação permanente. $\mathrm{O}$ resgate de ambos (RAFFESTEIN, 1993 E SANTOS E SILVEIRA, 2004) quer situar Barcarena como território inacabado e passando por intensas transformações contemporâneas no tempo-espaço da economia global, cujas dimensões são analisadas na perspectiva das novas reestruturações em curso.

Esta apropriação territorial de Barcarena é marcada pela expansão da economia mineral extrativista, pela ideologia de modernização e pelos mecanismos de integração nacional e internacional, transformando socioespacialmente o município em decorrência do sistema de produção econômica adotado, da mudança do padrão demográfico e forma de uso/ocupação do território e gerando conflitos de várias ordens. Neste sentido, a gestão territorial foi orientada para a exploração econômica do espaço, a fim de atender aos diversos interesses envolvidos e à lógica político-institucional e financeira de transformar Barcarena em fronteira de acumulação de capital mineral.

Os novos acontecimentos em Barcarena são resultantes da interface entre poder, redes e conflitos e revelam novos processos acelerados de transformação para novas agendas de pesquisa, a saber:

- O licenciamento ambiental passa também a ser uma prerrogativa do poder local (Prefeitura);

- O município integra a política estadual do Programa Município Verde;

- Foi pré-instalado o Fórum de Diálogo Intersetorial de Barcarena com a pré-adesão de empresas mineradoras, prefeitura e comunidades com objetivo de construir uma agenda de desenvolvimento local;

- Está ocorrendo a capacitação dos gestores públicos desenvolvida em parceria entre Prefeitura e empresas mineradoras;

- Há um montante de recursos calculados em torno de 160 bilhões de reais programados para o município oriundo do setor público e iniciativa privada;

Foi criada a Secretaria de Ordenamento Territorial com objetivo de acompanhar o processo de transformação no município;

\section{CONSIDERAÇÕES FINAIS}

As narrativas apontaram que a luta pela terra em Barcarena tem sido historicamente marcada pela disputa dos recursos provenientes da natureza, tanto para a comunidade quanto para a empresa. E no bojo desta disputa, emergem 
territorialidades, forjam-se o poder local, suas matizes e produções de consensos e embates, estabelecem-se jogos e acertos local-local e global-local, ricos em projetos de mobilização e interesses. A intensificação da dinâmica territorial na direção de conflitos socioambientais e disputa pelo território fizeram com que os grupos sociais em Barcarena reconstituíssem seus saberes para se mobilizarem e resistirem diante do quadro de desestruturação social e ambiental presentes e da real possibilidade de dispersão e extinção de suas comunidades. Mas fizeram também que os agentes econômicos sofisticassem e ampliassem seu domínio de atuação no município com a infraestrutura e novos modelos de gestão.

O encontro desses agentes (empresa e comunidade), no município, é marcado pelo contato entre culturas diferentes que revela o seguinte: de um lado, os valores culturais etnocêntricos (ideologia da modernização) de empresas transacionais e, de outro lado, os valores culturais da floresta (cultura vivida), representando as comunidades locais. $\mathrm{O}$ encontro dessas diferentes culturas não revela apenas dimensões socioprodutivas, mas especialmente, as representações simbólicas do que é produzido pelas relações concretas de contato. Certamente, revela também o jogo das relações de poder e de redes políticas que integram esta dinâmica territorial sob o qual se comunicam e se expressam códigos construídos coletivamente. Isso mostra que o território é convenção e confrontação e que ele se movimenta e se fixa. E essa sua constituição é materializada nas relações sociais que se somam, complementarmente, às dimensões imateriais do território (dimensões de poder e da cultura). A situação social e histórica do encontro de diferentes culturas provoca a produção de significados e representações e a mediação cultural tem a tarefa de compreendê-los na cena de novas territorialidades e movimento de confronto e convergência de interesses em situação.

Consequentemente, na realização desse estudo, percebemos no movimento dos investimentos em prol do crescimento econômico e a formulação constante de eixos de desenvolvimento para a Amazônia. Aqui, mesmo diante de tantos obstáculos, estudar as formas de relação de poder tem trazido contribuições significativas para a região, no sentido de ser possível catalogar experiências representativas na direção de uma maior e melhor compreensão das iniciativas favoráveis ao debate das condições concretas de desenvolvimento para a região amazônica, ou seja, a sistematização das experiências de diminuição dos altos índices de exclusão social nesta região de fronteira produtiva e a formação de trajetórias de mobilidade como fenômeno social de partidas, chegadas e retornos decorrentes das instalações de equipamentos de sistemas logísticos, como a estrutura portuária em Vila do Conde. Os indicadores do desenvolvimento resultantes revelam como as comunidades, as organizações sociais, as pessoas, 
no município de Barcarena, demandam por políticas públicas e programas de investimentos para além da implantação de infraestrutura que beneficie unicamente as grandes corporações, mas que se preocupem com os direitos básicos, que lhes permitam resistir e sobreviver dignamente diante de relações concretas de disputas de poder político e territorial, com força equitativa aos outros atores, como: o Estado, o governo municipal e grandes empresas transnacionais em especial nesse momento de grandes articulações e anúncios de investimentos pelo programa de aceleração do crescimento, a favor da ampliação da infraestrutura logística no Porto de Vila do Conde.

Nessa lógica, observamos que a malha da infraestrutura logística se expande no território de acordo com os interesses em disputa, concretamente influenciado pelo poder econômico-político, pela mobilidade socioeconômica, originando novas territorialidades em disputa no município de Barcarena. De outra forma, constatamos a relação existente entre os conceitos e teorias relidas com a prática, com a vida, o que permitiu afirmar que uma simples circunscrição de equipamentos, sistemas, no espaço ou num mapa, ou mesmo com a identificação de locais, áreas ou regiões, não se cria necessariamente, um território; isto porque a existência deste requer ação e controle de um determinado espaço e de todos os seus atributos.

Quanto aos resultados, percebemos atuações articuladas de grupos sociais organizados no sentido de demarcar espaço no contexto de resistência e negociação promovidas por esses grupos no bojo de suas lutas micropolíticas em direção ao bem-estar humano e coletivo. São conquistas lentas, mas forjadas nos movimentos de tensão marcados pelos acontecimentos de (des)construção e (des) continuidade vividos intensamente e gestados nas insistentes lutas da comunidade em continuar sendo o que são: "agricultores e pescadores da mata nativa, caboclos da região, gente da Amazônia" . O protagonismo, os conflitos e as lições das comunidades e dos grupos sociais são fruto das suas opções e decisões políticas em contextos de deslocamentos. Essas comunidades e grupos sociais conhecem, de fato, a realidade e têm identidade territorial com o local. Notamos que as contradições sociais e as iniciativas de diálogo e de colaboração entre múltiplos atores e setores da sociedade civil organizada (mediadores) abriram oportunidades inéditas para a mobilização de recursos e aquisição de novas competências. No entanto, o processo de transformação social em curso é veloz e intenso e gesta contextos políticos e novos desdobramentos sociais, que também desafiam as estratégias dos atores e dos agentes econômicos envolvidos no processo.

6 Informação fornecida por um trabalhador rural em 2012. 


\section{REFERÊNCIAS}

ACSELRAD, Henri. Território e Poder: as políticas das escalas. In: FISHER, Tânia (org). Gestão do Desenvolvimento e Poderes Locais: marcos teóricos e avaliação. Salvador: Casa da Qualidade, 2002.

ALMEIDA, Alfredo Wagner B. de. Os deslocamentos compulsórios de índios e camponeses e a ideologia do desenvolvimento. MAGALHÃES, Sônia B. Energia na Amazônia. Belém: Museu Paraense Emílio Goeldi/ Universidade Federal do Pará/ Associação de Universidades Amazônicas, 1996.

AZEVEDO JUNIOR, Roberto S. e SILVA, Renato Cândido da.Os Conceitos de "Gestão" na Revista Brasileira de Geografia entre 1980 e 2005. Revista de Geopolítica, Ponta Grossa - PR, v. 2, no 1, p. 129 - 136, jan./jun. 2011.

BECKER, Bertha. Redefinindo a Amazônia: o vetor tecno-ecológico. In: CASTRO. Iná Elias de et alli (orgs.). Brasil: questões atuais de reorganização do território, Rio de Janeiro: Bertrand Brasil, 1995.

BRANDÃO, Carlos. Desenvolvimento, territórios e escalas espaciais: Levar na devida conta as contribuições da economia política e da geografia crítica para construir a abordagem interdisciplinar. In: RIBEIRO, Maria T. F. e MILANI, Carlos Roberto S. Compreendendo a complexidade socioespacial contemporânea. EDUFBA, Bahia, 2009

BRASIL. Ministério do Planejamento, Orçamento e Gestão. Instituto Brasileiro de Geografia e Estatística. Contagem Populacional. Disponível em http://www.ibge.gov. br/popu. Acesso em jan. 2010.

CARMO, Eunápio D. do. O território educa e politiza na(s) Amazônia(s): os processos sócio-culturais da Comunidade Nova Vida e as dinâmicas de expansão industrial em Barcarena. Tese de Doutorado - Departamento de Educação, Pontifícia Universidade Católica do Rio de Janeiro. Rio de Janeiro, 2010, 226 p.

CASTRO, Edna M. R. Dinâmica socioeconômica e desmatamento na Amazônia. In: Novos Cadernos NAEA. Belém: NAEA/UFPA, vol. 8, n² 2, DEZ/2001.

Políticas de ordenamento territorial, desmatamento e dinâmicas de fronteira. Novos Cadernos NAEA, v. 10, n. 2, p. 105-126, dez. 2007

CASTRO, Edna M. R. Expansão da fronteira, megaprojetos de infraestrutura e integração sul-americana. CADERNO CRH, Salvador, v. 25, n. 64, p. 45-61, Jan./Abr. 2012

CICHOSKI, Pâmela e SAQUET, Marcos Aurélio. Concepções de Geografia, espaço e território nos Anais do IV Seminário Estadual de Estudos Territoriais e II Seminário Nacional sobre Múltiplas Territorialidades, 2013.

COELHO, Maria Célia Nunes et al. Regiões do entorno dos projetos de extração e transformação mineral na Amazônia Oriental. In: Novos Cadernos NAEA. Belém: NAEA/UFPA, vol. 8, n² 2, DEZ/2005. 
Estado do Pará: (di)visões territoriais, perspectivas sociais, econômicas, financeiras e ambientais - ocupação e uso do território, federalização territorial e recursos naturais/ Lúcia Cristina Andrade (coord.).- Belém: IDESP, 2011.

FISCHER,Tânia. Gestão do Desenvolvimento e poderes locais: marcos teóricos e avaliação. Salvador: Casa da Qualidade, 2002.

HAESBAERT, Rogério. O Mito da Desterritorialização: do "Fim dos Territórios" à Multierritorialidade. Rio de Janeiro: Ed. Bertrand Brasil, 2004.

RAFFESTIN, Claude. Por uma Geografia do Poder. São Paulo: Ática, 1993.

SANTOS, M.; SILVEIRA, M.L. O Brasil: território e sociedade no início do século XXI. 6.ed., Rio de Janeiro: Record, 2004.

SANTOS, Milton. A natureza do espaço. Técnica e tempo. Razão e emoção. São Paulo: Hucitec, 1996.

SAQUET, M. A. Abordagens e concepções sobre território. São Paulo: Expressão Popular, 2007.

VIEIRA, E. F., VIEIRA, M. M. F. A dialética da pós-modernidade: sociedade em transformação. Rio de Janeiro: FGV, 2004. 



\section{Mineração e desenvolvimento em Minas Gerais na década 2000-2010}

\section{Mining and development in Minas Gerais in the decade 2000-2010}

Julio Cesar Reis - Pesquisador da Embrapa Agrossilvipastoril. Mestre em Economia pelo CEDEPLAR/UFMG. E-mail: julio.reis@embrapa.br

Harley Silva - Doutorando em Economia pelo CEDEPLAR/UFMG. Mestre em Demografia pelo CEDEPLAR/UFMG. E-mail: harley74@gmail.com

\section{Resumo}

Neste trabalho retomamos a discussão sobre o desenvolvimento em economias periféricas com forte participação do setor primário exportador. Empregando o enfoque do economista brasileiro Celso Furtado, expusemos linhas gerais do desenvolvimento de economias pós-coloniais onde o veiculo de entrada na divisão internacional do trabalho foi a incorporação como fornecedoras de matéria prima, procurando evidenciar os efeitos dessa forma de articulação na formação do mercado interno e no perfil da demanda interna. Vimos que, segundo a formulação do autor, houve a constituição de pequena diversificação econômica e dependência externa, em especial, na forma de incorporação de progresso técnico. Procuramos também demonstrar que a despeito de modificações profundas transcorridas no mercado brasileiro no último quarto do séc. XX - as questões decorrentes da dependência, tal qual definida por Celso Furtado, não cessaram de ser pertinentes na economia brasileira. Este fato é particularmente verdadeiro no quadro da economia do estado de Minas Gerais.

\section{Palavras-chave}

Minas Gerais - Mineração - Subdesenvolvimento

\begin{abstract}
In this paper we return the discussion about development in peripheral economies with strong participation from the primary exporter. Employing the approach of the Brazilian economist Celso Furtado, exposed outlines the development of post-colonial economies where the way for entry into the international division of labor was the incorporation as suppliers of raw materials, seeking to highlight the effects of this form of articulation in the formation of market domestic and international demand profile. According Furtado's approach, there was the establishment of small economic diversification and dependence, particularly in the form of incorporation of technical progress. We also sought to demonstrate that - despite the profound changes that occurred in the Brazilian market in the last quarter century XX - the issues arising from dependence, as is defined by Celso Furtado, have not ceased to be relevant in the Brazilian economy. This is particularly true in the context of the economy of the state of Minas Gerais.
\end{abstract}

\section{Keywords}

Minas Gerais - Mining - Underdevelopment 


\section{INTRODUÇÃO}

A primeira década do século XXI foi de crescimento econômico no Brasil. A economia mineira também viveu expansão considerável ao longo desse período. Contudo, em função das características estruturais da economia do país e de Minas Gerais em particular, permanece a questão do quanto a economia mineira, historicamente capitaneada pela exportação de produtos intermediários, foi ou não modificada pelo fato de ter atravessado um período de crescimento.

Ao longo das três últimas décadas, 1980 a 2010, o país viveu taxas de crescimento econômico modestas ou anêmicas, prevalecendo um pequeno dinamismo e baixo nível de emprego. Ao iniciar o novo século, no entanto, uma série de condições internas e externas se somaram, tornando possível um período de expansão da atividade econômica. Entre essas novas condições esteve a estabilidade econômica, construída ao longo das décadas de 1980 e 1990¹, mas também o cenário externo modificado especialmente pela afirmação da China voraz importadora de produtos primários - como um dos atores principais da economia mundial.

Gráfico 1 - Minas Gerais e Brasil: evolução produto interno produto a preços correntes

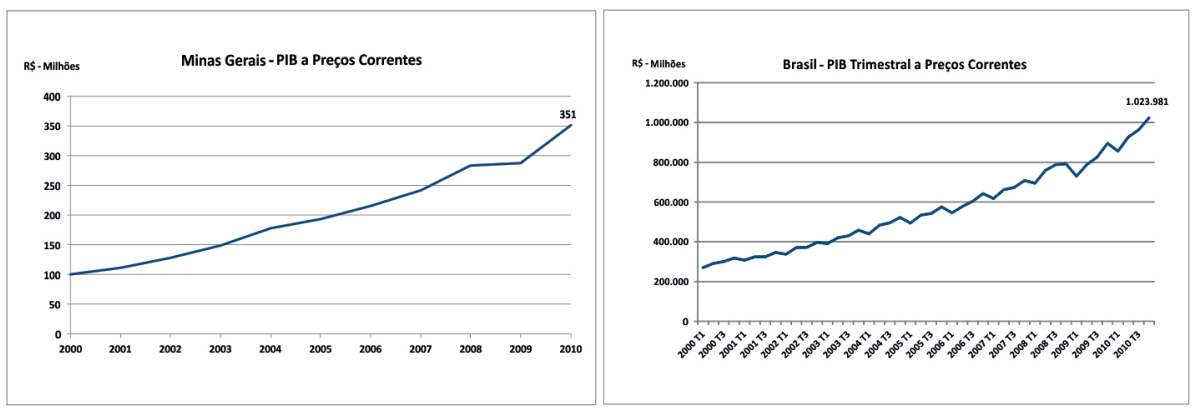

Fonte: SIDRA-IBGE

Segundo dados do Ministério da Indústria e Comércio (MDIC 2011), 47,8\% das exportações brasileiras em 2011 foram produtos básicos, contra 36\%

1 Pode-se dizer que a estabilidade foi uma construção que se estendeu ao longo de todo esse período, se se leva em conta o que houve de fato: um longo e duríssimo processo de aprendizado quanto a construção da estabilidade monetária. Sucessivos planos de estabilização construíram o ambiente institucional, social, politico e técnico que tornou possível o êxito daquele considerado o plano exitoso (Plano Real). Este na verdade se beneficiou do aprendizado de duas décadas, custeado por um verdadeiro laboratório social, a sociedade brasileira. 
de manufaturados e $14 \%$ de semimanufaturados. Os principais destinos das exportações do país foram China (17,3\%), Estados Unidos (10,1\%) e Argentina $(8,9 \%)$. Minas Gerais aparece como segundo estado com maiores exportações $(16,17 \%)$, atrás apenas de São Paulo $(23,4)$.

Um aspecto central nessa discussão é a importância do setor extrativo mineral na trajetória de crescimento da economia do Estado e do próprio País e, portanto a trajetória do setor em termos de geração de emprego, conexões estruturais com o mercado interno, tecnologia, investimentos, entre outros aspectos, torna-se totalmente crucial.

Pela escala de sua produção e as características histórico-estruturais do mercado no qual operam, as empresas do setor extrativo mineral cultivam conexões mais intensas com o setor externo do que com o mercado nacional, e ainda muito mais do que com o que se poderia chamar de mercados regionais ou locais, assumindo como tal as escalas do Estado e do município. Essa desconexão ganha complexidade e se aprofunda em várias dimensões, de política e socioeconômica a ambiental, na medida em que se reitera o caráter global das determinações que norteiam as decisões das grandes empresas do setor. Reafirma-se uma (quase) impossibilidade dos agentes locais em influir nesse campo decisório e por um lado se cristalizam no espaço local os desdobramentos físicos, ambientais e sociais do padrão de inserção econômica.

Nosso objetivo nesse trabalho não é avaliar as alterações conjunturais do crescimento econômico ao longo da década. A meta é avaliar como o cenário recente de crescimento econômico em Minas Gerais tem interagido com condições preexistentes de descasamento entre produção e absorção local da renda, baixa diversificação econômica e persistência de condições de pobreza e fraca infraestrutura local. Partiremos de uma retomada da discussão dos problemas peculiares ao desenvolvimento econômico de padrão periférico calcado na exploração de recursos naturais - no caso o minério - e voltado para o mercado externo.

Acreditamos que retornar a discussão da importância para o padrão de desenvolvimento da existência de uma economia baseada na exploração intensa de recursos naturais se faz necessário na medida em que persiste a condição brasileira de país periférico ao sistema capitalista mesmo atingindo a situação de uma das dez maiores economias do planeta. A desconsideração dessa realidade consiste em fator de confusão a respeito de nossas prioridades e interesses na 
superação da condição de atraso e subdesenvolvimento. No caso da economia do estado de Minas Gerais esse aspecto e patente nas condições de desigualdade regional, que são alteradas de forma importante pelo crescimento do setor econômico minerador, mas - diríamos - não na direção da real superação do subdesenvolvimento. É o que pretendemos investigar a seguir.

\section{DESENVOLVIMENTO E ECONOMIA BASEADA EM RECURSOS NATURAIS}

\section{PROBLEMAS ESTRUTURAIS DE ORIGEM}

É matéria conhecida o conjunto de consequências da entrada em situação de atraso e subordinação das economias periféricas na divisão internacional do trabalho. Absorvidas de forma heterônoma no sistema econômico internacional as economias dos países hoje não-desenvolvidos, em sua maioria ex-colônias das potências europeias, convive desde sua emancipação politica com aspectos estruturais que conformam o chamado subdesenvolvimento.

Integradas ao jogo das trocas internacionais sob regras desfavoráveis, ainda que frequentemente apresentadas em um arcabouço que enfatiza uma face logica e vantajosa, essas economias formaram a periferia do sistema, conjunto de espaços cuja ordenação econômica e territorial é feita a partir de fora ou de regras externas. O sistema econômico internacional foi organizado e ordenado por iniciativa e sob liderança de seu núcleo industrial, conjunto de países que saíram em condições vantajosas que remontam à reorganização do sistema colonial dos séculos XV a XVII, colocando-o sob a hegemonia das potencias industriais do séc. XVIII e XIX. Este núcleo do sistema se empenhava em ampliar os circuitos comerciais existentes e/ou criar novos, superando obstáculos físicos e socioeconômicos colocados ao avanço da acumulação (Furtado 1980).

Nesse processo forma-se o conjunto de economias dependentes. Sua integração a economia mundo, graças à heterogeneidade de sua dotação recursos naturais, tornava possível aos países centrais a ampliação e diversificação de seu consumo, a incorporação de mão de obra a baixo custo, e o acesso a extensas reservas de recursos naturais que foram mobilizados segundo os ritmos adequados as economias avançadas e apenas marginalmente resultaram em efeitos transformadores de longo prazo nos países dependentes (Furtado 1980).

A persistência deste padrão de relação entre países centrais e periféricos significou a instalação nos últimos de instituições sociais e econômicas inadequados a emancipação. As economias nacionais imbuíram-se de mecanismos 
perpetuadores da dependência econômica ${ }^{2}$ que se tornaram aspecto estruturante dos mercados nacionais e das relações entre agentes econômicos, processo em que se constituíram como sociedades subdesenvolvidas, não no sentido de sociedades desenvolvidas em embrião, mas como sociedades "presas" a um caminho de envolvimento na economia moderna o qual dificilmente desemboca no desenvolvimento entendido como estágio mais elevado de organização e bem estar econômico e social. ${ }^{3}$

A exploração de recursos naturais, uma das principais formas de incorporação de economias periféricas a economia mundial, constituiu-se num dos aspectos centrais da formação do subdesenvolvimento ${ }^{4}$. O controle de recursos naturais de natureza diversas daqueles encontrados no velho mundo foi um dos motores da integração econômica em escala planetária, e as mudanças técnico-científicas e institucionais das nações centrais permitiram a estas manter ascendência sobre estes recursos a despeito da perda direta do controle politico sobre os territórios onde estas se encontravam ${ }^{5}$.

Independentes de um ponto de vista governamental, as nações periféricas não alcançaram emancipação econômica efetiva. As instituições coloniais passaram por reformulações, mas algo de sua motivação se instala nas sociedades independentes permitindo a continuidade da transferência de excedentes econômicos formados localmente a centros decisórios externos.

Seja em função do controle externo dos capitais investidos, pela opção reiterada (e nem sempre livre) de absorção de tecnologia adquirida externamente, pela limitação as atividades de caráter primário (extrativas e não de transformação), e as vezes pelo conjunto dessas características, a economia centrada em recursos naturais não se prestou à alavanca de superação da dependência e do subdesenvolvimento. Essa foi, por exemplo, a experiência historicamente verificada na América latina por numerosos estudiosos (Furtado 2009; Santos 2003, Santos 2007).

Instaladas e dinamizadas de fora, as economias dependentes adquiriram feições peculiares na formação de mercados internos, tendendo a organizar-se

2 No Brasil esses mecanismos operaram e ainda operam por meio de matrizes culturais (Ribeiro 2006), ideias acadêmico-cientificas, instituições políticas e pela difusão, até o nível do senso comum, da conformidade em torno da visão liberal do estado e da sociedade, a qual se ajustou de forma contraditória à realidade de nossa economia.

3 Nesse sentido nada mais distante do que as expressões "países subdesenvolvidos" e "países em desenvolvimento" atualmente em voga e as vezes usadas como substitutas.

4 Obviamente isso não quer dizer que era a trajetória inevitável a se fazer na medida em que se partia de uma dotação de recursos naturais como a base para a entrada na divisão internacional do trabalho.

5 Muitos desses recursos, aliás, somente foram descobertos e incorporados enquanto tal em partes do mundo como a América Latina, após o encerramento do ciclo politico colonial. 
social e setorialmente desarticulada (De Janvry 1981) e a se estruturar como espaços econômicos com infraestruturas voltada para dar suporte economia exportadora (Furtado 2009).

De Janvry (1981) destaca os desdobramentos nas economias periféricas de contradições fundamentais da economia capitalista: a relação dialética (conflitiva, contraditória, mas inevitável) entre produção e circulação, o caráter não planejado da atividade produtiva e a natureza de classe das sociedades capitalistas. Em conjunto essas contradições atuam permanentemente, num mesmo movimento criando impulsos e barreiras ao crescimento econômico.

Produção e consumo, unidade contraditória, na medida em que após ser produzidas, as mercadorias precisam entrar num circuito comercial, serem vendidas e consumidas, para que se realizem lucros. Esse aspecto trivial do fenômeno econômico ganha importância específicas em contato com as duas características seguintes. A natureza de classe das sociedades capitalistas opõe os interesses das duas classes fundamentais, proprietários e não proprietários dos meios de produção. Se a oposição não se traduz em conflitos de abertos, não significa desconsiderar a divergência: os grupos concorrem pela apropriação de parcelas do excedente econômico, que se exprime na forma lucro para o primeiro grupo e na forma salario para o segundo. Assim, a competição e a busca por maiores lucros implica dois tipos de reação ao nível de cada capitalista individualmente: 1) introdução de novas tecnologias e racionalização dos processos de trabalho no sentido de aumentar a produtividade do trabalho e 2) manutenção de baixos os custos do trabalho, restringindo os salários ao mínimo permitido (subjetivamente) pelas forças sociais prevalecentes (De Janvry 1981, p. 24).

Estas medidas são lógicas no nível de um capitalista individualmente, mas contraditórias com a lógica do capital em geral, indicando o caráter não planejado dos mercados capitalistas, isso é o fato destes se organizam como um conjunto de ações atomizadas. A combinação de aumento da produtividade do trabalho, restrição ao crescimento da massa salarial via estagnação do nível de salários somado ao uso de tecnologias poupadoras de mão de obra implica o descasamento entre o avanço da produtividade por um lado e da capacidade consumo por outro. Abre-se caminho para crises de subconsumo, desde que para cada capitalista, a massa total de trabalhadores surge não como trabalhadores, mas como consumidores.

Tais contradições seriam, segundo De Janvry, verificáveis não apenas para cada economia isolada, mas na escala da economia-mundo. Elas, entretanto, evolvem para desfechos ao mesmo tempo distintos e articulados conforme tratar-se de economias centrais ou periféricas. Estando em condições de conduzir 
processos nas periferias, em função de possuírem hegemonia tecnológica, controlarem os recursos ali invertidos ou por instrumentos similares, as economias centrais (por meio de seus governos ou mais geralmente empresas privadas) tem condições de superar obstáculos à realização de lucros ampliando seu raio de ação aos mercados de consumo periféricos onde a existência de condições de dependência se manifesta, entre outros aspectos, na desarticulação social e setorial da economia.

Dividindo esquematicamente um sistema econômico em dois setores ${ }^{6}$, o autor procura demonstrar que a articulação entre ambos é função da importância do mercado de consumo para a produção interna, ao mesmo tempo em que indica que essa articulação é crucial para o desenvolvimento. Nas economias centrais, podese distinguir também dois setores de produção: setor de bens de capital e setor de bens de consumo. $\mathrm{O}$ funcionamento de ambos, no entanto tende a se estabelecer de modo articulado, setorialmente (entre os dois setores referidos) e socialmente, ou seja, entre proprietários - que buscam apropriar-se de lucros - e não proprietários cujo interesse volta-se para sua remuneração salarial. O setor de bens de consumo tem como espaço de circulação imediato o mercado interno, logo seu poder de compra não poderia ser mantido como mínimo ou ao nível de sobrevivência, indefinidamente, sob pena de tornar impossível a realização de lucros ${ }^{7}$.

As economias periféricas se integraram ao sistema internacional de comercio especialmente como exportadoras, seja a) de produtos agrícolas; b) de recursos minerais ou c) de bens manufaturados para o mercado externo. Desde o principio, portanto esses subsistemas econômicos se ligaram ao comercio externo de maneira intensa, e como consequência trilharam um caminho de pequena importância ao nível de distribuição interna da renda advinda setores principais de sua economia. Nesse quadro, a contradição fundamental entre lucratividade e formação de massa salarial a que se refere De Janvry como um aspecto geral da economia capitalista ganha um caráter especifico. Parcela não essencial a sobrevivência do sistema econômico, a expansão da parcela apropriada pela mão de obra como salários pode

6 O procedimento analítico de De Janvry é em verdade amplamente empregado por autores de variadas correntes teóricas de estudo do desenvolvimento/subdesenvolvimento e que chegam a intepretações também várias. Furtado (2009) atribui o pioneirismo no emprego das analises baseadas na visão de dois setores a Arthur Lewis, o qual o emprega na construção de sua hipótese economias com oferta ilimitada de mão-de-obra. Veja Lewis in Agarwala e Singh (2010).

Furtado (2009) demonstra que o processo de ampliação do grupo de países integrantes das economias centrais não se deu de forma alguma de modo automático via integração ao (livre) comércio internacional. Nessa situação o mais provável seria o prolongamento do cenário inicial na qual houve enorme distancia entre o nível de produtividade indústria inglesa e todos os demais países. A incorporação de outras nações - sobretudo da Europa e mais adiante, de EUA e Japão - ao grupo hegemônico deu-se com a adoção por estes países de politicas de deliberado fomento ao avanço econômico em geral e da indústria local em particular. $\mathrm{O}$ mesmo argumento é demonstrado à exaustão em Chang $(2004,2009)$ 
ser mantida próximo ao mínimo adequado a sobrevivência, pelo menos para uma parcela extenso da população assalariada. No caso extremo, argumenta Furtado (2009), em que a economia exportadora de recursos minerais se aproxima de uma situação de enclave no conjunto econômico:

...o núcleo exportador se mantém praticamente isolado das demais atividades econômicas. Sua infraestrutura é especializada e em nada ou quase nada contribui para aumentar a produtividade das atividades preexistentes. A absorção de mão-de-obra no setor exportador e pequena, daí resulta que sua contribuição para ampliar (ou formar) mercado interno é reduzida (p. 55. Grifos originais).

O autor indica ainda que nas situações onde existe exportação de produtos agrícolas, sejam eles tropicais ou adequados a áreas temperadas - a despeito de modificações importantes em cada caso - permanece um amplo setor da população e do território não articulado ao sistema principal, o exportador. A incorporação de mão de obra, a adoção de progresso técnico e a produção do espaço que dá suporte ao sistema econômico, se orientam por centros decisórios exteriores. No caso da economia de recursos minerais, assim como na exportação de produtos agrícolas tropicais "o fluxo de salários monetários é reduzido e a formação de mercado interno é lenta" (Furtado 2009). Persiste de formas variadas a reprodução de grande parte da população (e do território) em economia de subsistência, ou pior, como exercito de reserva de força de trabalho, passível de incorporação oportuna à manutenção de baixo nível salarial, ao que Arthur Lewis denominou mecanismo de oferta ilimitada de mão de obra.

Em suma, enquanto nas economias centrais "o comercio exterior constitui um meio de ampliar a base de recurso naturais e maximizar economias de escala de produção", nas economias periféricas constitui-se "meio de usar mais amplamente recursos primários disponíveis; recursos naturais e mão de obra" (Furtado 2009).

A interpretação, apresentada por Celso Furtado no ano de $1975,{ }^{8}$ parece ainda muito válida para o entendimento da dinâmica atual do fenômeno do desenvolvimento capitalista. Relacionando a constelação de recursos disponíveis em um sistema econômico - recursos naturais e mão de obra, os meios disponíveis para sua incorporação, artifícios tecnológicos e capitais invertíveis, e considerando a autonomia dos processos decisórios a respeito das resultantes dessa incorporação, o autor fornece uma abordagem abrangente dos fenômenos do desenvolvimento econômico.

"Economia do desenvolvimento", edição do ano de 2009 de material preparado para curso ministrado na PUC SP (Furtado 2009). 
Indica que o incremento de produtividade do sistema econômico assume principalmente três formas: acumulação de capital e progresso técnico em processos produtivos; realocação de recursos já existentes com maximização de vantagens comparativas e uso de recursos não renováveis. O subdesenvolvimento, destaca afinal, tem origem principalmente na prevalência das duas ultimas formas, nas quais as elevações de produtividade, mesmo que se traduza em elevação da renda, o faz em geral restrito a pequenas parcelas da sociedade, e não na forma de salario, mas de lucros ou rendas. Essa parcela do excedente, suposta a diversificação do consumo pelos que dele se apropriam, termina por converter-se em poder de compra de mercadorias vindas do exterior.

O caminho para a elevação e diversificação do consumo de bens, que nas economias centrais se dá com base na oferta interna - que se torna possível com a acumulação de capitais (e seu investimento) aliada ao progresso técnico aplicado aos processos produtivos - nas economias dependentes ocorre pela ampliação do consumo de "bens de luxo" importados. Esse gasto do excedente pode ser denominado consumo improdutivo, na medida em que não é aplicado de forma nenhuma à ampliação ou a sofisticação do aparelho produtivo. Além disso, a introdução de um padrão de consumo dessa natureza, ao mesmo tempo descolado de um consumo médio da população, trabalha em favor de uma articulação econômica e cultural contraria a formação de economias de escala, pelo lado da oferta de bens, e reforça o caráter funcional da concentração de renda, atuando duplamente contra a ampliação do mercado interno e pela continuidade da dependência (Furtado 2003).

Recuperada a argumentação sobre a teoria do desenvolvimento, importa conecta-la com o cenário econômico mineiro da década passada, marcada pelo crescimento econômico, avançar em nosso questionamento sobre a existência e alcance de mudanças estruturais na economia mineira, entendidas como indicadores dessas mudanças a capacidade de absorção de renda e a diversificação do sistema econômico.

\section{NOVOS DILEMAS: GLOBALIZAÇÃO, DESENVOLVIMENTO E ESCALA LOCAL}

Algumas mudanças importantes distinguem o cenário brasileiro - e mineiro - atual em relação ao ambiente econômico discutido até aqui, qual seja, a constituição histórica das economias periféricas baseadas em incorporação econômica de recursos naturais.

Entendidos como commodities de alto valor monetário e características muito distantes do consumo ordinário da população em geral. 
A economia brasileira não se restringe mais há um sistema econômico primário exportador. Entre as dez maiores economias do mundo, o aparelho econômico brasileiro é sem duvida diversificado setorial e tecnologicamente. Transcorrido um intenso processo de urbanização, ancorado na formação de núcleos urbanos de primeira grandeza e a incorporação de amplos hinterlands por uma rede urbana extensa, embora frágil em muitos aspectos, o mercado interno do país é hoje importantíssimo.

Por um lado, essa ampliação tornou-se possível graças a pesados investimentos em infraestrutura urbana e regional ao longo do séc. XX, ainda que quase que exclusivamente centrados na criação de condições gerais de produção e apenas residualmente em espaço de vida ${ }^{10}$ e reprodução da sociedade e ainda assim, distribuídos de forma muito desigual, considerando a extensão e a diversidade do território nacional.

Por outro, o país construiu, a duras penas, a estabilidade monetária, após um período de instabilidade inflacionaria radical que perdurou por mais de 20 anos e obteve êxito em meados dos anos 1990. Muito importante, por fim, é mencionar que ao longo do processo de construção da estabilidade econômica, que se deu ao longo de governos nacionais de opções politicas liberalizantes, houve um grande movimento de privatização de empresas até então publicas, entre elas aquela que é hoje uma das maiores empresas de mineração do mundo ${ }^{11}$.

$\mathrm{O}$ aspecto destacado anteriormente a respeito da privatização é que ele proporcionou ganhos de lucratividade gigantescos. Não há como nega-lo e nem é preciso fazê-lo. O fato, no entanto não encerra a questão a respeito do papel do setor minerador em um possível caminho para o desenvolvimento social e econômico. Os dados sobre o desempenho do setor em Minas deixam fora de questão a importância para a economia do estado. O minério de ferro figura como principal produto de exportação da pauta mineira, com uma produção que se espalha por um grande número de municípios do Estado.

Remetendo-nos ao arcabouço teórico que vimos de expor caberiam as questões: o crescimento da produção baseada nos recursos minerais tem se revertido em alavanca para o desenvolvimento mineiro, entendido esse desenvolvimento como ampliação do nível de vida da população, ampliação e

10 Condições gerais de produção: conjunto de estruturas espaciais e os correspondentes sócio-institucionais que dão suporte a instalação e funcionamento da economia capitalista contemporânea. Ver Lojkine (1981) e Lencione (2007). A ideia de espaço de vida - par dialético do espaço da produção - foi introduzida por Friedmann (2002), para destacar o caráter contraditório da convivência entre o espaço socialmente produzido como suporte de atividades econômicas capitalistas e ao mesmo tempo suporte da vida cotidiana.

11 Fundada em 1942 como Companhia Vale do Rio Doce (CVRD) e privatizada em 1997, a empresa passou recentemente (2009) a denominar-se VALE. 
diversificação do mercado interno e produção local de tecnologia incorporada em produtos e processos produtivos? Em uma palavra, a economia baseada em recursos minerais tem se constituído em base para a superação da dependência externa por meio da apropriação local do excedente produzido pela dotação natural de riqueza?

Obviamente não teremos condições de fornecer uma resposta conclusiva a nenhuma destas questões. Nossa pretensão é fornecer uma contribuição a discussão a partir da analise de dados sobre a economia mineral em Minas Gerais, no que diz respeito a retenção local da riqueza gerada pela atividade na forma de salários pagos pelo setor. Vimos acima que a desconexão entre o nível de produtividade e a remuneração do trabalho tem sido uma das características da atividade econômica em sistemas periféricos e indicador consistente de condição de dependência. Voltemos então nossa atenção para as informações do setor em Minas Gerais no período 2000-2010.

\section{DESEMPENHO ECONÔMICO E SISTEMA PRIMÁRIO EXPORTADOR MINERAL}

O desempenho econômico positivo de Minas Gerais nos últimos anos, à exceção do ano de 2009, ano marcado pelos reflexos da crise internacional, tem uma forte correlação com a trajetória das exportações, em especial, com a cadeia mínero-metalúrgica, e, consequentemente, com os resultados da balança comercial do estado.

De acordo com o Panorama Comex (2010) as exportações mineiras totalizaram US $\$ 31,2$ bilhões em 2010 . O crescimento das exportações de Minas Gerais, $60 \%$ em relação ao valor verificado no ano anterior, foi superior à variação nacional, que foi de $32 \%$, levando o estado a ampliar a sua participação sobre o total das exportações brasileiras para 15,5\%.

Ainda segundo esse documento, o saldo comercial mineiro foi positivo em US\$ 21,2 bilhões, valor 74,7\% superior ao registrado em 2009 . Vale destacar que o resultado mineiro em termos de superávit na balança comercial foi maior do que o apresentado pelo Brasil, que ficou na casa dos US\$20,2 bilhões para o ano de 2010. Esses resultados contribuíram para consolidar o estado de Minas Gerais, como o segundo estado brasileiro exportador, atrás somente de São Paulo. O desempenho comercial do estado nos últimos anos pode ser visto no Gráfico 2 abaixo: 
Gráfico 2 - Balança Comercial de Minas Gerais 2003-2010

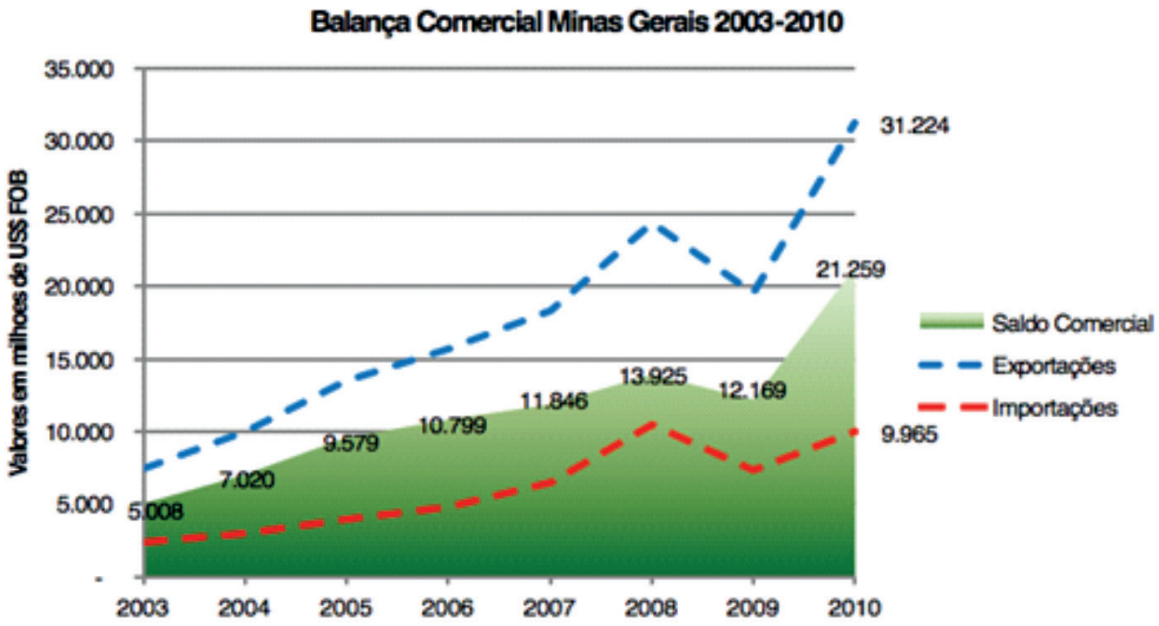

Fonte: SIDRA-IBGE

Todavia, analisando a pauta de exportações do estado, observa-se uma concentração de produtos oriundos do setor extrativo mineral, em especial os produtos da cadeia mínero-metalúrgica. Dados do Ministério do Desenvolvimento Indústria e Comércio (MDIC) mostram que para o ano de 2010, os produtos primários foram os mais relevantes no conjunto das exportações mineiras, representando $61,4 \%$ do valor exportado, e os produtos manufaturados ou semimanufaturados representaram cerca de $38 \%$.

Tendo em conta a categorização por intensidade de recursos utilizados na produção, os produtos intensivos em recursos naturais foram responsáveis por $72,9 \%$ do total exportado por Minas Gerais no ano de 2010, os intensivos em tecnologia 8,8\%, os intensivos em capital 17,6\% e os intensivos em mão de obra 0,7\%. Já considerando os setores das contas nacionais, os bens intermediários dominaram a pauta exportadora mineira de 2010 com a participação de 90,3\%.

A importância da cadeia mínero-metalúrgica para o estado de Minas Gerais fica ainda mais evidente ao se analisar o desempenho do estado em termos de comércio de produtos específicos. Além de ser o estado responsável por 44,3\% das exportações do Brasil da cadeia mínero-metalúrgica, Minas Gerais, no ano 2010, foi o líder no ranking dos estados brasileiros exportadores de ferro-ligas (86,4\% do total nacional); maior exportador brasileiro de minérios de ferro (46,8\% do total nacional); líder no segmento de ferro fundido bruto e ferro-gusa do país (31,8\% do total nacional); e maior exportador de laminados de ferro e aço $(34,2 \%$ do total nacional). 
Tendo em conta a predominância dos produtos da cadeia mínerometalúrgica na pauta comercial do estado, espera-se, como consequência, que os municípios/região com melhor desempenho sejam aquelas que possuem ligação direta com esse setor produtivo. Analisando os números para o ano de 2010, pode-se observar a grande concentração da atividade econômica na região central do estado. Essa região correspondeu a quase $60 \%$ do valor total exportado pelo estado. Importante ressaltar que essa conta considera o valor total exportado por região tendo como referência o valor por domić́lio fiscal da empresa exportadora.

No ranking dos municípios mineiros em termos de participação nas exportações, 6 encontram-se na região central do estado ( $1^{\circ}$ Itabira; $2^{\circ}$ Ouro Preto; $5^{\circ}$ Betim; $6^{\circ}$ Nova Lima; $7^{\circ}$ Ouro Branco e $10^{\circ} \mathrm{BH}$ ). Observando essa lista, merece destaque as posições de Itabira e Ouro Preto, municípios fortemente relacionados à cadeia mínero-metalúrgica, assim com de $\mathrm{BH}$, capital do estado, caracterizada como centro de serviços diferenciados.

Figura 1 - Exportações por regiões do estado de Minas Gerais

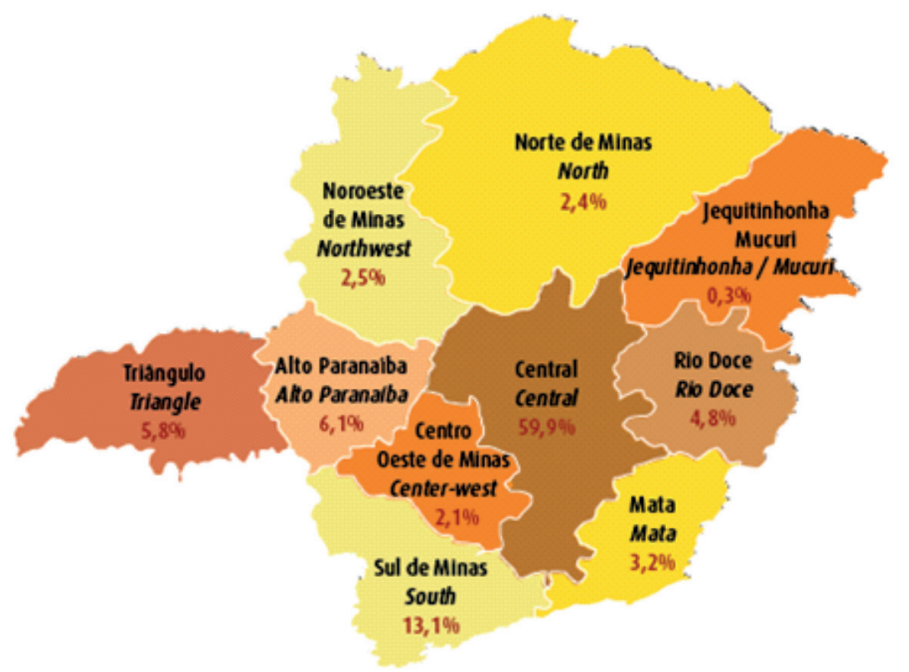

Fonte: MDIC/SECEX (Elaboração: SEDE / Central Exportaminas)

\section{MINAS GERAIS E DESEMPENHO DA ECONOMIA CHINESA}

O padrão de especialização da economia mineira, formado pelo processo histórico de constituição do estado, o coloca como um forte produtor de produtos primários e intermediários. Ainda, esse mesmo padrão de especialização confere à economia mineira interligação e dependência do setor externo. Nesse sentido, pode-se 
dizer que o desempenho econômico mineiro assume um caráter pró-cíclico em relação ao cenário econômico internacional, ou seja, em momentos de forte dinamismo internacional, quando a demanda internacional por commodities, em especial o setor mineral, apresenta uma trajetória ascendente, o desempenho da economia mineira mostra-se positivo. Ao contrário, em períodos de retração, como o ocorrido em 2008, os efeitos negativos em termos de crescimento econômico são percebidos de maneira clara. Essa dinâmica pode ser observada no Gráfico 3.

Gráfico 3 - Índice de Preço de Commodities - Mineral

Indice de Preso de Commodities - Mineral

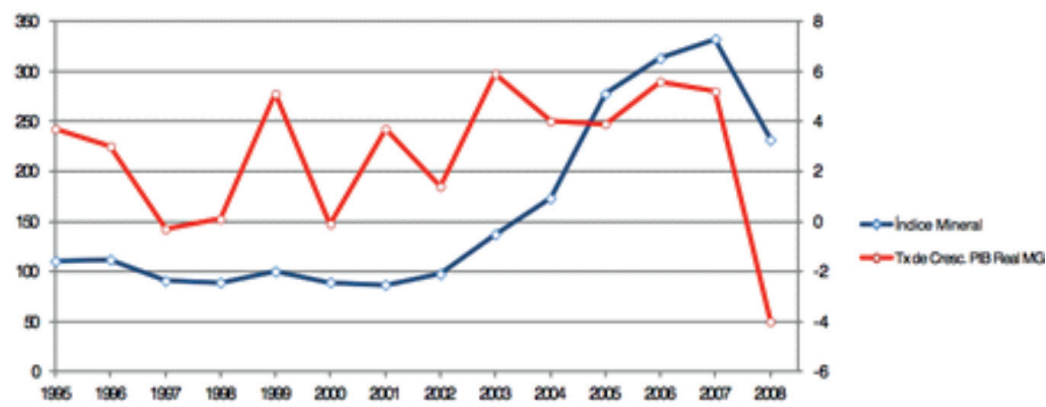

Fonte: UNCTAD/ Fundação João Pinheiro

Nesse contexto, merece uma avaliação mais detalhada a importância da China para o desempenho da economia mineira. Esse recorte se deve ao importante papel que esse país vez desempenhando no comércio mundial além do fato de ser, atualmente, o principal mercado consumidor externo dos produtos minerais mineiros. No ano de 2010, a China respondeu por quase 30\% das exportações mineiras, em decorrência da venda de minério de ferro (Panorama Comex, 2011).

De acordo com Libânio (2008) o crescimento chinês e sua presença maciça no comércio internacional têm causado intensa preocupação e impactos diferenciados sobre as economias ao redor do mundo. Tais impactos podem ser agrupados em duas frentes: i) a grande competitividade dos produtos manufaturados chineses no mercado mundial, que representa um desafio e uma ameaça a países/regiões cuja pauta de exportações seja baseada neste tipo de produto; e ii) a expressiva demanda da China por commodities, que tem provocado substancial elevação de seus preços no mercado internacional e beneficiado países/regiões exportadores de produtos primários.

Considerando esses apontamentos, tem-se que os efeitos da expansão chinesa são percebidos em função do padrão de especialização setorial das economias, sendo 
que os países/regiões mais penalizados são aqueles cujas estruturas produtivas competem diretamente com a China no comércio mundial (Libânio, 2008).

Dentro dessa perspectiva, os efeitos do segundo grupo, em especial, do mercado de commodities minerais, tem implicações diretas sobre o desempenho da economia mineira nos últimos anos. A característica estrutural da economia mineira, de ser baseada na exploração de recursos naturais, em especial do setor mineral, permite elevado grau de complementaridade em relação à economia chinesa. Esse aspecto é confirmado pela mudança observada nos últimos 10 anos em relação à participação da China na pauta de exportações mineiras.

Gráfico 4 - Principais Países de destino das exportações Mineiras: 2000-2010

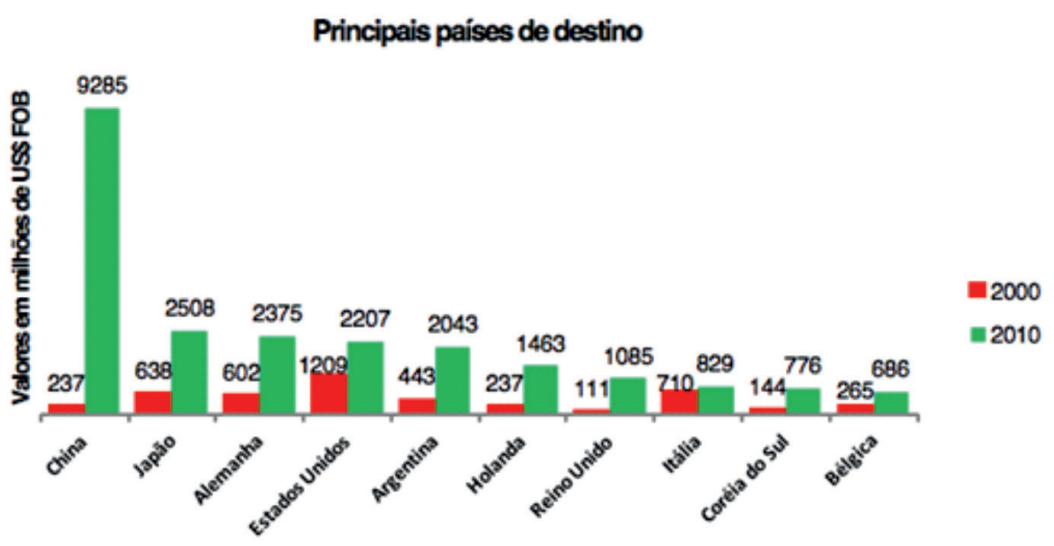

Fonte: MDIC/SECEX

Essa dinâmica e essa característica primário-exportadora se reflete no desempenho das principais empresas exportadoras do estado. Segundo o Panorama Comex (2010) as principais empresas exportadoras concentraram-se em municípios da região central, como Itabira, Betim, Ouro Branco, Congonhas e Ipatinga e atuam na cadeia mínero-metalúrgica. Destaque para a Vale S/A com 37,7\% de participação no valor total das exportações do estado. A participação da empresa é tão relevante que o segundo colocado no ranking, a Companhia Brasileira de Metalurgia e Mineração (CBMM) participa com cerca de 5\%. Ainda considerando as principais empresas exportadoras do estado, no ano de 2010 elas responderam por 61\% do valor total das exportações de Minas Gerais, valor 9\% maior do que o observado para essa estatística no ano de 2009. (Panorama Comex, 2010)

Esses números indicam a intensa concentração da pauta de exportações do estado, o que, se por um lado, considerando a complementaridade com a China, permite uma capacidade de aproveitar o boom de crescimento da demanda por 
commodities minerais, por outro, implica em um processo de aprofundamento da dependência do mercado externo de produtos primários, o que deixa a economia vulnerável às variações do desempenho da economia internacional.

\section{DESEMPENHO DA ECONOMIA MINERAL 2001-2005}

A Fundação João Pinheiro, em parceria com o Governo do estado de Minas Gerais publicou no ano de 2009 o documento "Perfil da Economia Mineral do Estado de Minas Gerais, 2001 a 2005”. Esse documento apresenta uma caracterização sistemática da atividade mineral do estado, identificando os municípios que apresentam algum tipo de atividade ligada a esse setor além de mostrar informações sobre mão de obra, valor da produção, produtos produzidos e investimentos realizados no setor extrativo mineral.

De acordo com o documento, registra-se em Minas Gerais, no período em questão, um total de 621 municípios com alguma atividade extrativa mineral onde podem ser encontrados dados referentes ao preenchimento dos Relatórios Anuais de Lavra (RAL), ao comércio exterior, à arrecadação de Imposto sobre a Comercialização de Mercadorias e Serviços (ICMS) ou de Compensação Financeira pela Exploração de Recursos Minerais (CFEM), ou ainda informações obtidas diretamente no sítio do Departamento Nacional de Produção Mineral (DNPM). Esses municípios então distribuídos em todas as regiões de planejamento do estado, como mostra o mapa a seguir.

Figura 2 - Perfil da Economia Mineral de Minas Gerais por região de Planejamento 2001-2005

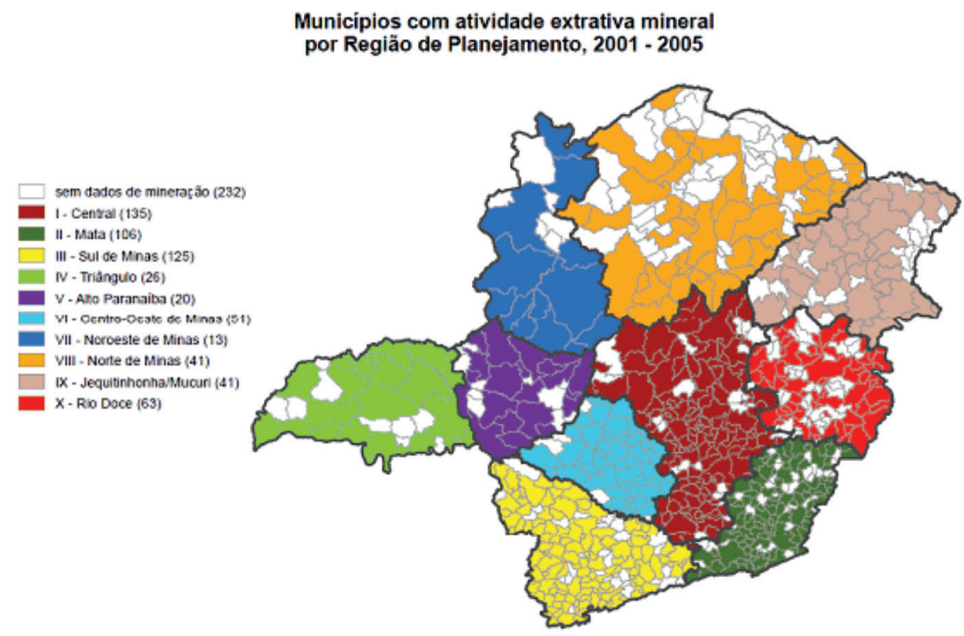

Fonte: Fundação João Pinheiro, 2009 
Como destacado, a região central do estado é a principal em relação à atividade extrativa mineral. Concentra as mais importantes reservas ${ }^{12}$ de minério de ferro, este que é o principal produto da pauta de exportações de Minas Gerais, estando ali, as principais empresas que atuam no setor. Ademais, está encravado nessa área o Quadrilátero Ferrífero. ${ }^{13}$

A concentração dos recursos naturais e da produção extrativa mineral na região central de Minas Gerais pode ser verificada pelos números do Valor Total da Produção Mineral (VTPM) ${ }^{14}$. Analisando as informações para o ano de 2005, observamos que dos 15 principais municípios do estado em relação ao (VTPM), apenas 4 não estão na região central: São Gonçalo do Rio Abaixo, Tapira, Poços de Caldas e Fortaleza de Minas. Ainda, merece destaque os municípios de Itabira e Nova Lima, os dois primeiros no ranking que, juntos, correspondem a cerca de 41\% do (VTPM) do estado de Minas Gerais para o ano de 2005. Importante ressaltar que o quadro observado para o ano de 2005 se mantém quando se leva em conta o período 2001 a 2005. De outra forma, além de concentrada, observamos uma tendência à estabilidade com relação aos principais municípios produtores do setor extrativo mineral.

12 Ou pelo menos as mais importantes entre as já incorporadas ao mercado.

13 O Quadrilátero Ferrífero é uma área de aproximadamente 7.000 km2 (Ruchkys 2009), englobando 25 municípios, uma população próxima a 3,9 milhões de habitantes. Localizado na porção central do Estado de Minas Gerais, o Quadrilátero é uma região de enorme importância natural e econômica para Minas Gerais e o Brasil . A região guarda uma admirável concentração de riquezas minerais, principalmente ouro, ferro e manganês, sendo internacionalmente conhecido por isso desde o séc. XIX. Em seu passado colonial se descobriram grandes riquezas auríferas. A exploração destas foi o que tornou possível a primeira e importantíssima ocupação urbana no país, no séc. XVII, durante o domínio português. Seu potencial natural para a exploração mineral determinou que ali fossem realizadas, também, as primeiras experiências de exploração comercial do minério de ferro e da transformação deste em material siderúrgico. Desde os estudos pioneiros do barão de Eschwege (1822, 1832, 1833), e mais tarde do cientista francês H. Gorceix (1881, 1884), o Quadrilátero Ferrífero tem sido alvo de inumeráveis estudos geológicos do mais variado caráter, cujo desenvolvimento contribuiu decisivamente para a evolução da ciência e das instituições cientificas entre nós, como testemunha o caso emblemático da nobre Escola de Minas de Ouro Preto (Carvalho, 2002). A exploração cientifica e econômica da região pode ser exemplificada com o fato de que termos do vocabulário cientifico da geologia, como itabirito, foram cunhados a partir da exploração ali realizada, Os recursos produzidos, e os ainda "guardados" na região, a tornaram também o coração da indústria e da economia mineira, cujo desenvolvimento esteve sempre - e continua a estar - marcado pela atividade mineradora e - mais tarde - siderúrgica. Fazem parte do Quadrilátero Ferrífero os seguintes municípios: Alvinópolis, Barão de Cocais, Belo Vale, Bonfim, Brumadinho, Caeté, Catas Altas, Congonhas, Contagem, Esmeraldas, Ibirité, Igarapé, Itabira, Itabirito, Mariana, Moeda, Nova Lima, Ouro Branco, Ouro Preto, Raposos, Rio Acima, Rio Piracicaba, Sabará, Santa Bárbara e Santa Luzia.

14 Seguindo a definição do documento corresponde ao somatório do valor de todos os minérios (bruto e/ou beneficiado, incluindo a água mineral) vendidos, consumidos e/ou transformados no ano, no município em questão, em reais correntes. Valores sem os respectivos dados de produção correspondem à comercialização de estoques. Valores insignificantes são meramente ilustrativos, pois o sistema eletrônico do Relatório Anual de Lavra (RAL) exige uma informação para dar andamento ao preenchimento. 
Mesmo considerando as especificidades do setor extrativo mineral, principalmente com relação à dimensão espacial da produção, que é fortemente determinada pela existência dos recursos naturais a serem explorados, a concentração do (VTPM) indica uma grande influência do fator demanda. Mais especificamente, a polarização em termos de importância dos municípios em relação ao (VTPM) pode ser explicada pela influência crescente da demanda chinesa pelos produtos minerais e, em especial, por minério de ferro. Esse ponto fica evidente quando se considera a diferença entre a magnitude dos valores apresentados pelos municípios caracterizados pela produção de minério de ferro para com municípios produtores de outros produtos minerais também relevantes na pauta de exportação mineira como alumínio, zinco, grafita e ouro.

Tabela 1 - Valor Total da Produção Mineral: Principais Municípios Mineiros 2005

\begin{tabular}{c|l|l|c}
\hline Ranking & \multicolumn{1}{|c|}{ Município } & Mesorregião Geográfica & VPMT 2005* \\
\hline 1 & Itabira & Metropolitana de BH & $2.826,87$ \\
\hline 2 & Nova Lima & Metropolitana de BH & $2.660,15$ \\
\hline 3 & Itabirito & Metropolitana de BH & $1.246,38$ \\
\hline 4 & Ouro Preto & Metropolitana de BH & $1.161,57$ \\
\hline 5 & Brumadinho & Metropolitana de BH & 992,24 \\
\hline 6 & Mariana & Metropolitana de BH & 935,65 \\
\hline 7 & São Gonçalo do Rio Abaixo & Sul/Sudoeste de Minas & 464,67 \\
\hline 8 & Barão de Cocais & Metropolitana de BH & 383,18 \\
\hline 9 & Congonhas & Metropolitana de BH & 354,80 \\
\hline 10 & Paracatu & Metropolitana de BH & 252,45 \\
\hline 11 & Rio Piracicaba & Metropolitana de BH & 214,22 \\
\hline 12 & Tapira & Noroeste de Minas & 203,74 \\
\hline 13 & Itatiaiuçu & Metropolitana de BH & 198,04 \\
\hline 14 & Poços de Caldas & Sul/Sudoeste de Minas & 193,15 \\
\hline 15 & Fortaleza de Minas & Triângulo /Alto Paranaíba & 165,70 \\
\hline
\end{tabular}

*Valores Correntes em milhões de reais

Fonte: Fundação João Pinheiro, 2009

Outra informação importante, que reforça essa perspectiva da concentração do produto mineral é o volume dos investimentos realizados no setor. Os dados dessa variável para 2005 mostram, assim como o discutido acima para o (VTPM), concentração na região central do estado. Dos 15 principais municípios em termos de volume de investimentos realizados no setor mineral, apenas três não 
se encontram na região central: Vazante, que possui uma das principais reservas de zinco do estado, Paracatu que é um importante produtor de ouro e também de zinco e Fortaleza de Minas que se destaca na produção de níquel.

Tabela 2 - Total dos Investimentos Realizados - Principais Municípios Mineiros 2005

\begin{tabular}{c|l|l|c|c}
\hline Ranking & \multicolumn{1}{|c|}{ Município } & \multicolumn{1}{|c|}{$\begin{array}{c}\text { Mesorregião } \\
\text { Geográfica }\end{array}$} & $\begin{array}{c}\text { Total Investimento } \\
\text { Realizado 2005* }\end{array}$ & $\begin{array}{c}\text { Média de } \\
\text { Crescimento }\end{array}$ \\
\hline 1 & Itabira & Metropolitana de BH & 227,56 & $29 \%$ \\
\hline 2 & Itabirito & Metropolitana de BH & 135,82 & $190 \%$ \\
\hline 3 & Congonhas & Metropolitana de BH & 122,00 & $187 \%$ \\
\hline 5 & Mariana & Metropolitana de BH & 116,58 & $95 \%$ \\
\hline 6 & Vazante & Noroeste de Minas & 105,25 & $51 \%$ \\
\hline 7 & Paracatu & Noroeste de Minas & 95,41 & $55 \%$ \\
\hline 8 & Nova Lima & Metropolitana de BH & 93,21 & $72 \%$ \\
\hline 9 & Santa Bárbara & Metropolitana de BH & 60,37 & $65 \%$ \\
\hline 10 & Brumadinho & Metropolitana de BH & 57,87 & $38 \%$ \\
\hline 11 & Tapira & $\begin{array}{l}\text { Triângulo /Alto Pa- } \\
\text { ranaíba }\end{array}$ & 40,41 & $163 \%$ \\
\hline 12 & Itatiaiuçu & Metropolitana de BH & 37,15 & $112 \%$ \\
\hline 13 & Sabará & Metropolitana de BH & 27,95 & $111 \%$ \\
\hline 14 & Fortaleza de & $\begin{array}{l}\text { Sul/Sudoeste de Mi- } \\
\text { nas }\end{array}$ & 18,82 & $17 \%$ \\
\hline 15 & Barão de Cocais & Metropolitana de BH & 18,57 & $32 \%$ \\
\hline
\end{tabular}

*Valores Correntes em milhões de reais

Fonte: Fundação João Pinheiro, 2009

Aqui, novamente, é possível fazer a relação entre a concentração dos investimentos e os efeitos da demanda chinesa. A pressão de demanda provocada pela China, elevando os preços das commodities minerais, como mostrado pelo comportamento do índice de preços mineral no GRAF.3 sinaliza aos produtores/ investidores no setor mineral perspectivas de resultados positivos em termos de lucratividade. Ou seja, as empresas do setor, ao observarem o comportamento dos preços dos produtos no mercado internacional, assim como as projeções futuras de demanda, tendem a aprofundar suas políticas de investimento para aproveitarem o boom de crescimento dos preços dos produtos.

Entretanto, é preciso ter em conta que a análise do processo de concentração do investimento deve ponderar, além do efeito demanda, a questão da escala produtiva como também a dotação de recursos minerais disponíveis nos municípios. Ainda assim, os resultados para as taxas médias de crescimento do investimento realizado no período 2001-2005 sugere a forte influência do 
efeito da demanda chinesa. A participação dos cinco primeiros municípios no total dos investimentos realizados no estado no ano de 2005 é da ordem de 51\%, ou seja, metade dos investimentos realizados no ano de 2005 foram realizados em Itabira, Itabirito, Congonhas, Mariana e Vazante. De outra forma, à exceção de Vazante, que é caracterizado pela produção de zinco, todos os demais são importantes municípios produtores de minério de ferro.

Somente o município de Itabira, local onde se iniciaram as operações da Vale S/A, ainda na década de 1940, respondeu, no ano de 2005, por $16 \%$ do total de investimentos no setor extrativo mineral do estado. Ademais, considerando os primeiros colocados no ranking, mostrado na TAB.2, esse município, líder do ranking, apresentou crescimento médio de $29 \%$ no período 2001 a 2005. No entanto, analisando em termos absolutos, o volume de investimentos realizados no ano de 2005 nesse município foi quase 100 milhões de reais a mais do que o observado para o segundo colocado. Além disso, a grande maioria dos municípios listados mostra média de crescimento acima de 50\%, com alguns chegando à casa dos 200\%, como Itabirito, Congonhas e Brumadinho, locais com importantes áreas de exploração de minério de ferro.

\section{LIMITAÇÕES: A INDÚSTRIA EXTRATIVA MINERAL E O DESENVOLVIMENTO DE SEU HINTERLAND}

Tendo em conta a importância do setor extrativo mineral para a economia de Minas, como já retratado pela relevante contribuição deste para os resultados positivos do estado nos últimos anos em termos de crescimento econômico, é fundamental considerar em que medida e de que maneira esse setor contribui (ou não) para o processo de desenvolvimento econômico dos municípios mineiros.

Nesse sentido, podemos observar que, em que pese sua pujança em termos de retornos econômicos, com expressivos resultados positivos em termos de balança comercial, geração de lucros, volume de investimentos e geração de receita para os cofres públicos, via impostos, como o ICMS e a CFEN ${ }^{15}$, esse setor tem uma contribuição limitada para a geração de emprego e renda assim como para a superação dos problemas estruturais que tendem a reforçar o caráter periférico e dependente de inserção da economia mineira no sistema econômico

15 A Compensação Financeira pela Exploração de Recursos Minerais (CFEM), royalty criado pela Constituição de 1988 e regulamentado a partir de 1991, tem a função de compensar a União, o Estado e o Município pela exploração do subsolo. É calculada sobre o valor do faturamento líquido obtido, considerando-se este como o total das receitas de venda, excluídos os tributos incidentes sobre a comercialização do produto mineral (ICMS, PIS/PASEP, COFINS, IOF e ISS), as despesas de transporte e as de seguro. 
internaciona ${ }^{16}$. Essa dinâmica pode ser observada ao se analisar algumas especificidades apresentadas pelos municípios mineiros que mais contribuem para os resultados positivos apresentados pelo setor nos últimos anos.

Tendo ainda como referência os dados do documento "Perfil da Economia Mineral do Estado de Minas Gerais 2001 a 2005” podemos identificar a pequena conexão do setor extrativo mineral com a geração de empregos nos municípios mineiros. À execessão de Fortaleza de Minas que exerce liderança na produção de Níquel; Tapira, com importante contribuição na produção de Fosfato e São Gonçalo do Rio Abaixo, única das três primeiras que apresenta como produto mais relevante o minério de ferro, podemos observar uma relação muito pequena entre quantidade de mão de obra empregada no setor minerador no ano de 2005 e o tamanho da população nesse mesmo ano ${ }^{17}$.

Tabela 3 - Relação entre mão de obra empregada no setor mineral e população residente - 2005 Municípios selecionados

\begin{tabular}{c|l|l|c|c|c}
\hline Ranking & \multicolumn{1}{|c|}{ Município } & Mesorregião Geográfica & $\begin{array}{c}\text { Mão de } \\
\text { Obra } \\
(2005)\end{array}$ & $\begin{array}{c}\text { Popu- } \\
\text { lação } \\
(2005)\end{array}$ & $\begin{array}{c}\text { MO/ } \\
\text { POP }\end{array}$ \\
\hline 1 & $\begin{array}{l}\text { Fortaleza de } \\
\text { Minas }\end{array}$ & Sul/Sudoeste de Minas & 589 & 3.733 & $15,78 \%$ \\
\hline 2 & Tapira & $\begin{array}{l}\text { Triângulo /Alto Para- } \\
\text { naíba }\end{array}$ & 353 & 3.549 & $9,95 \%$ \\
\hline 3 & $\begin{array}{l}\text { São Gonçalo do } \\
\text { Rio Abaixo }\end{array}$ & Metropolitana de BH & 756 & 8.550 & $8,84 \%$ \\
\hline 4 & $\begin{array}{l}\text { São Thomé das } \\
\text { Letras }\end{array}$ & Sul/Sudoeste de Minas & 515 & 6.520 & $7,90 \%$ \\
\hline 5 & Itatiaiuçu & Metropolitana de BH & 560 & 9.238 & $6,06 \%$ \\
\hline 7 & Mariana & Metropolitana de BH & 2760 & 52.054 & $5,30 \%$ \\
\hline 8 & Santa Bárbara & Metropolitana de BH & 1338 & 25.474 & $5,25 \%$ \\
\hline 9 & Vazante & Noroeste de Minas & 842 & 19.009 & $4,43 \%$ \\
\hline 10 & Brumadinho & Metropolitana de BH & 1254 & 31.191 & $4,02 \%$ \\
\hline 11 & Cedro do Abaeté & Central Mineira & 48 & 1.218 & $3,94 \%$ \\
\hline 12 & Catas Altas & Metropolitana de BH & 133 & 4.507 & $2,95 \%$ \\
\hline 13 & Ouro Preto & Metropolitana de BH & 1995 & 68.635 & $2,91 \%$ \\
\hline
\end{tabular}

16 Obviamente sempre se pode assumir que o problema reside de fato num descasamento entre a oferta de mao de obra local e a demanda característica do setor. Este fato, no entanto, não esgota a questão. Havendo transbordamentos positivos em direção a economia local esse "desajuste" se sanaria no mínimo pela transferência de população de mais elevada escolaridade para as referidas localidades.

17 Vale ressaltar que esse resultado é observado para esse conjunto de municípios ao longo o período 2001 a 2005. Ainda, esses dados são referentes ao total de mão de obra empregada na mineração, compreendendo as áreas de lavra das minas e as usinas de beneficiamento e são considerados três tipos de contrato: vínculo empregatício de trabalho, terceirizado e cooperativado. 


\begin{tabular}{c|l|l|c|c|c|c}
\hline 14 & Papagaios & Metropolitana de BH & 396 & 13.946 & $2,84 \%$ \\
\hline 15 & Barão de Cocais & Metropolitana de BH & 617 & 25.333 & $2,44 \%$ \\
\hline \multicolumn{6}{|c|}{} \\
\hline 26 & Itabira & Metropolitana de BH & 1999 & 106.289 & $1,88 \%$ \\
\hline 22 & Nova Lima & Metropolitana de BH & 1540 & 71.897 & $2,14 \%$ \\
\hline 16 & Itabirito & Metropolitana de BH & 985 & 41.541 & $2,37 \%$ \\
\hline
\end{tabular}

Fonte: Fundação João Pinheiro, 2009

Destaque especial merecem os três principais municípios mineiros em termos de (VPTM): Itabira, Nova Lima e Itabirito. Nesse conjunto, a relação entre a mão de obra empregada no setor e a população local é extremamente baixa, cerca de $(2 \%)$. Ainda, considerando a proximidade dessas localidades da capital do estado, é provável que alguns dos trabalhadores mais qualificados e com maiores salários não residam nesses municípios. ${ }^{18}$

Esse efeito da baixa geração de empregos na localidade está diretamente relacionado ao fato da atividade extrativa mineral ser capital intensiva além da característica dessa ser conectada ao mercado consumidor externo de produtos primários. De outra forma, o conjunto de empregos gerados pela atividade mineradora estão relacionados, somente, ao início da cadeia produtiva, ou seja, ao processo de extração e preparação primária dos minerais para exportação. Essa fomatação faz com que uma enormidade de empregos relacionados ao beneficiamento dos produtos sejam gerados externamente.

Esse aspecto é central para entender as limitações do setor mineral em relação sua capacidade de desenvolver seu hinterland. A pouca conexão com o setor interno de serviços associados ao beneficiamento da produção mineral faz com que os efeitos de transbordamento do setor seja limitado. Ademais, essa pouca conexão faz com que as demais atividades econômicas que poderiam ser impulsionadas por um mercado consumidor interno forte permaneçam inertes. Dessa forma, ao gerar poucos empregos, o setor extrativo mineral, mesmo apresentando expressivos resultados econômicos, não consegue desencadear um processo de transformação interna consistente que possibilite superar o atraso econômico histórico característico dos municípios especializados na produção primária de produtos minerais.

Outra característica importante relacionada à limitação do setor extrativo mineral em desencadear o processo de transformação explicitado acima pode ser identificada pela avaliação da relação entre a dimensão da renda gerada no município (PIB per capita) e a renda apropriada pela população local (renda

18 Espera-se que esse efeito também aconteça nos demais municípios, por outro lado, temse como hipótese que esse comportamento seja observado de maniera mais intensa nos municípios mais próximos de Belo Horizonte. 
domiciliar per capita) ${ }^{19}$. De acordo com Pereira e Ruiz (2006) essa relação permite identificar as regiões caracterizadas pela geração de renda e as que podem ser caracterizadas como apropriadoras de renda. . Mais especificamente, pode-se avaliar, ainda que de maneira aproximada, em que medida a renda gerada pelo município é apropriada pela população local, em especial na forma de salários, isso é a remuneração de mão de obra.

A TAB 4 apresenta informações para ambas as dimensões da riquesa discutidas. Os dados para o PIB municipal são da Fundação João Pinheiro e as informações sobre a renda domiciliar per capita são do IBGE. Ainda, para evidenciar a tendência de baixa apropriação local da riqueza aliado ao processo de intensificação da geração e absorção externa dos resultados econômicos do setor extrativo mineral são mostrados dados para o PIB per capita de alguns anos selecionados ${ }^{20}$, assim como as informações da renda per capita municipal calculadas a partir das informações dos Censo do ano 2000 e $2010^{21}$. Os resultados são apresentados para os municípios mineiros mais representativos no ranking do (VPMT) apresentado na TAB.1. A título de comparação, trazemos também dados para Belo Horizonte, centro mais dinâmico do estado, município com economia diversificada, em especial no setor de serviços.

Considerando o problema pela ótica da produção, observamos um salto considerável para os principais municípios especializados na produção produtos minerais. Itabira, líder do ranking do (VPTM), por exemplo, quase que triplicou seu PIB per capita no período 2000 a 2009. Considerando os cinco primeiros, o município que apresentou pior desempenho foi Brumadinho, com uma variação positiva da ordem de 60\%. Ainda, chama atenção os resultados para São Gonçalo do Rio Abaixo e Itatiauçu. O PIB per capita de São Gonçalo do Rio Abaixo cresceu no período 2000-2009 2061\%, ao passo que o PIB per capita de Itaiaiuçu cresceu 492\%. \%. Mesmo considerando um pequeno número como ponto de partida, é sem duvida um aumento impressionante. Dado a relevância do setor extrativo mineral para essas localidades, pode-se atribuir esses resultados ao desempenho do setor nos últimos anos. A título de comparação, Belo Horizonte apresentou, no período, uma taxa de crescimento do PIB per capita da ordem de 159\%, ao passo que a média estadual de crescimento do PIB per capita foi de $153 \%$.

19 "O método de cálculo do PIB dos Municípios consiste num processo descendente de repartição, pelos municípios, do valor adicionado das 15 atividades das unidades da federação: primeiro, estima-se o valor estadual de cada agregado; em seguida, reparte-se esse valor pelos municípios, ou seja, uma vez estimado o valor adicionado por atividade de cada estado, procede-se à distribuição para as atividades municipais, segundo indicadores escolhidos para este fim.”(IBGE, 2004, p.15).

20 O último dado disponível para o PIB municipal é para o ano de 2009.

21 As informações para o ano de 2010 forma obtidas por meio das publicações especiais lançadas no site do IBGE uma vez que os microdados do Censo ainda não estão disponivéis. 
Avaliando em termos absolutos, os resultados são ainda mais expressivos para o conjunto apresentado. Apenas Rio Piracicaba fica abaixo da média estadual, considerando o ano de 2009. Ao passo que, considerando Belo Horizonte como parâmetro de comparação, apenas cinco (Brumadinho, Barão de Cocais, Conginhas, Paracatu e Rio Piracicaba) dos quinze municípios apresentados tinham PIB per capita, no ano de 2009, menor do que a capital estadual. No outro extremo, alguns municípios apresentaram resultados muito acima da média estadual assim como de Belo Horizonte. Destaque para Itabira, Nova Lima, Ouro Preto, São Gonçalo do Rio Abaixo, Tapira, Itaiaiuçi e Fortaleza de Minas, todos com PIB per capita, no mínimo, 150\% maior do que a média estadual para o ano de 2009.

Analisando a dimensão da renda apropriada, os resultados são completamente distintos. Inicialmente, pode-se considerar que os municípios analisados apresentaram um crescimento importante, da ordem de 50\%, ligeiramente superior à média estadual que foi de 48\% no período 2000 - 2010, e acima de Belo Horizonte que apresentou um crescimento de 37\%. Nesse ponto, merecem destaque os municípios de Nova Lima que apresentou crescimento da ordem de 109\% $\%^{22}$, Brumadinho 85\% e São Gonçalo do Rio Abaixo com 95\%.

Todavia, observando os valores em termos absolutos, os resultados evidenciam o processo de desconexão entre a geração e a apropriação da riqueza nos principais municípios mineiros especializados na atividade extrativa mineral. Para o ano de 2010, apenas Nova Lima apresentou valor superior à Belo Horizonte. Ainda, para o conjunto dos demais municípios, à exceção de Poços de Caldas e Brumadinho, todos os outros apresentaram renda per capita pelo menos $50 \%$ inferior ao valor observado em Belo Horizonte; além de possuírem valores bem próximos do observado para a média estadual.

Essas constatações indicam que além de gerar um pequeno impulso de geração de postos de trabalho no nível local, tendo em conta a relação mão de obra empregada e população do município, o setor extrativo mineral apresenta uma estrutura de remuneração que limita a apropriação local dos resultados econômicos apresentados. Em que pese as fortes trajetórias de crescimento do produto no período avaliado, a ordem de grandeza dos recursos gerados vis a vis à pequena proporção de mão de obra empregada pela atividade, torna difícil negar a muito baixa apropriação local da riqueza gerada pela atividade, a qual se realiza fora da localidade de produção. A especialização na exportação de

22 O resultados de Nova Lima com relação à renda devem ser ponderados pela estreita ligação que esse município tem com a Belo Horizonte, em especial por se colocar como um novo vetor de expansão de servços diferenciados além de ser a froteira de expansão do setor imobiliário voltado para a população de alta renda renda que ha mais de duas décadas tem mantido um fluxo de migração rumo aquele município. 
produtos primários configura-se como um canal direto de exportação da riqueza gerada pela atividade.

Esses resultados reforçam as perspectiva anterior de que o setor extrativo mineral, apesar de apresentar vultosos resultados econômicos, apresenta limitada capacidade de ser um vetor de transformação da realidade local. Ao contrário, dado sua conexão com o mercado externo, além do processo de não apropriação local da riqueza como discutido acima, reforçar o caráter periférico e dependente dos municípios especializados na atividade mineral.

Tabela 4 - Geração e apropriação da riqueza nos principais municípios mineradores do estado de Minas Gerais: anos selecionados

\begin{tabular}{|c|c|c|c|c|c|c|c|}
\hline Município & $\begin{array}{c}\text { Rendi- } \\
\text { mento } \\
\text { domiliciar } \\
\text { per capita } \\
2010^{*}\end{array}$ & $\begin{array}{l}\text { Renda } \\
\text { per } \\
\text { capita } \\
2000^{*}\end{array}$ & $\begin{array}{l}\text { Renda } \\
\text { per } \\
\text { capita } \\
2010^{*}\end{array}$ & $\begin{array}{c}\text { PIB per } \\
\text { capita } \\
\text { (R\$/Hab) } \\
2000^{* *}\end{array}$ & $\begin{array}{c}\text { PIB per } \\
\text { capita } \\
\text { (R\$/Hab) } \\
2005^{* *}\end{array}$ & $\begin{array}{c}\text { PIB per } \\
\text { capita } \\
(\mathrm{R} \$ / \mathrm{Hab}) \\
2007^{* *}\end{array}$ & $\begin{array}{c}\text { PIB per } \\
\text { capita } \\
(\mathrm{R} \$ / \mathrm{Hab}) \\
2009^{* *}\end{array}$ \\
\hline Itabira & 618,00 & 516,37 & 737,35 & $11.576,51$ & $22.786,00$ & $23.096,29$ & $30.932,13$ \\
\hline Nova Lima & $1.361,00$ & 790,11 & $1.653,47$ & $13.549,38$ & $22.672,00$ & $27.210,16$ & $27.681,76$ \\
\hline Itabirito & 643,00 & 492,28 & 743,33 & $10.726,84$ & $17.951,00$ & $19.121,94$ & $18.661,78$ \\
\hline Ouro Preto & 601,00 & 495,34 & 736,85 & $10.248,59$ & $23.622,00$ & $25.039,75$ & $35.869,10$ \\
\hline Brumadinho & 819,00 & 535,07 & 988,56 & $8.455,17$ & $17.689,00$ & $18.695,70$ & $13.813,42$ \\
\hline Mariana & 561,00 & 420,44 & 679,51 & $10.434,83$ & $19.821,00$ & $24.299,96$ & $26.422,59$ \\
\hline $\begin{array}{l}\text { São Gonçalo } \\
\text { do Rio Abaixo }\end{array}$ & 420,00 & 256,06 & 498,68 & $2.735,29$ & $16.321,00$ & $46.692,62$ & $59.112,47$ \\
\hline $\begin{array}{l}\text { Barão de } \\
\text { Cocais }\end{array}$ & 499,00 & 339,86 & 595,82 & $6.657,73$ & $14.211,00$ & $15.367,55$ & $12.437,22$ \\
\hline Congonhas & 614,00 & 432,52 & 697,06 & $4.793,61$ & $10.422,00$ & $13.715,27$ & $18.056,36$ \\
\hline Paracatu & 561,00 & 435,39 & 677,91 & $5.506,77$ & $9.084,00$ & $10.688,28$ & $14.673,18$ \\
\hline Rio Piracicaba & 479,00 & 354,68 & 550,57 & $6.662,75$ & $8.524,00$ & $8.889,94$ & $7.999,19$ \\
\hline Tapira & 686,00 & 469,73 & 763,60 & $27.238,35$ & $45.847,00$ & $44.926,15$ & $51.466,03$ \\
\hline Itatiaiuçu & 451,00 & 328,87 & 528,98 & $5.952,21$ & $15.344,00$ & $22.030,27$ & $35.216,65$ \\
\hline $\begin{array}{l}\text { Poços de } \\
\text { Caldas }\end{array}$ & 820,00 & 850,25 & 964,11 & $12.152,10$ & $17.072,00$ & $18.649,49$ & $18.609,32$ \\
\hline $\begin{array}{l}\text { Fortaleza de } \\
\text { Minas } \\
\end{array}$ & 505,00 & 374,74 & 580,31 & $25.994,95$ & $30.040,00$ & $51.511,86$ & $33.488,23$ \\
\hline $\mathrm{BH}$ & $1.226,00$ & $1.088,17$ & $1.493,21$ & $7.008,21$ & $11.951,00$ & $15.866,60$ & \\
\hline Média & 463,41 & 374,28 & 552,47 & $4.171,68$ & $8.542,02$ & $9.278,02$ & $10.548,80$ \\
\hline
\end{tabular}

*Em reais a preços de agosto de 2010

**Valores correntes

Fonte: Fundação João Pinheiro, 2009 / SIDRA - IBGE. 


\section{CONSIDERAÇÕES FINAIS}

Neste trabalho retomamos a discussão sobre o desenvolvimento em economias periféricas com forte participação do setor primário exportador. Empregando o enfoque do economista brasileiro Celso Furtado, expusemos linhas gerais do desenvolvimento de economias pós-coloniais onde o veiculo de entrada na divisão internacional do trabalho foi a incorporação como fornecedoras de matéria prima, procurando evidenciar os efeitos dessa forma de articulação na formação do mercado interno e no perfil da demanda interna. Vimos que, segundo a formulação do autor, houve a constituição de pequena diversificação econômica e dependência externa, em especial, na forma de incorporação de progresso técnico.

Procuramos também demonstrar que - a despeito de modificações profundas transcorridas no mercado brasileiro no ultimo quarto do séc. XX - as questões decorrentes da dependência, tal qual definida por Celso Furtado, não cessaram de ser pertinentes na economia brasileira. Este fato é particularmente verdadeiro no quadro da economia do estado de Minas Gerais.

O estado de Minas Gerais é província mineradora desde as suas origens, e, no momento atual, aprofunda a importância do setor minerador no contexto do crescimento econômico do país e da voraz demanda chinesa por minério de ferro.

Dito isto empregamos informações relativas ao desempenho da economia mineira no período 2000-2010, evidenciando o papel de enorme destaque alcançado pelo setor de exportação de minérios. Constatamos que essa ampliação do papel de exportador de matéria prima tem um impacto real e forte no tamanho da economia de alguns municípios em especial, nos quais está sediada a produção, e que se concentram na área central do estado. Entretanto, os dados que organizamos para o trabalho nos disseram também que o impacto deste crescimento da produção em termos da modificação da renda per capita nesses municípios foi muito pequeno - em especial quando comparamos as medidas PIB per capita e renda per capita, pondo em evidencia que há enorme distância entre o primeiro índice - que indica a produção local de riqueza - e o segundo que seria uma proxy para a apropriação local na forma de salários.

Esta abordagem esta longe de ser conclusiva no tocante a afirmar que o crescimento econômico propiciado pela expansão da economia mineradora não tem se traduzido em desenvolvimento econômico e social. Outros esforços se fazem necessários, principalmente nas dimensões da diversificação da economia e dos mercados e da produção local de inovações tecnológicas, fatores apontados por Furtado como essenciais na superação da dependência, searas que esperamos ainda alcançar em trabalhos futuros. 


\section{REFERENCIAS}

AGARWALA, A. N.; SINGH, S. P. A economia do subdesenvolvimento.: Contraponto: Centro Internacional Celso Furtado, Rio de Janeiro, 2010.

CARVALHO, Jose Murilo de. A Escola de Minas de Ouro Preto: o peso da gloria. 2. ed. rev. Belo Horizonte: Ed. UFMG, 2002.

CHANG, H. J. Maus samaritanos: o mito do livre-comércio e a história secreta do capitalismo. Rio de Janeiro: Elsevier, 2009.

CHANG, H. J. Chutando a Escada: a estratégia do desenvolvimento em perspectiva histórica. São Paulo: Editora UNESP, 2004.

DE JANVRY, Alain. The agrarian question and reformism in Latin America. Baltimore: Johns Hopkins University, c1981..

FJP - Fundação João Pinheiro. Perfil da Economia Mineral do Estado de Minas Gerais, 2001 a 2005. Belo Horizonte, 2009. Documento impresso e "MINERAL" - Software de Recuperacao de Informações.

FRIEDMANN, J. Life Space and Economic Space: Essays in Third World Planning. Brunswick, NJ: Transaction Books, 2002.

FURTADO, C. Economia do desenvolvimento. Rio de Janeiro: Centro Celso Furtado / Editora Contraponto, 2009

FURTADO, C. Raízes do subdesenvolvimento. Rio de Janeiro: Civilização Brasileira, 2003.

FURTADO, C. Pequena introdução ao desenvolvimento: enfoque interdisciplinar. Rio de Janeiro: Cia. Editora Nacional, 1980.

LENCIONI, S. Condições gerais de produção: um conceito a ser recuperado para a compreensão das desigualdades de desenvolvimento regional. Scripta Nova - Revista Electrónica de Geografía y Ciencias Sociales. Vol. XI, n 245 (07), Universidad de Barcelona, Barcelona, 2007.

LEWIS, A. O desenvolvimento económico com oferta ilimitada de mão-de-obra. In: AGARWALA, A. N.; SINGH, S. P. A economia do subdesenvolvimento.: Contraponto: Centro Internacional Celso Furtado, Rio de Janeiro, 2010.

LIBÂNIO, G. O crescimento da China e seus impactos sobre a Economia Mineira. Anais do XIII Seminário sobre a Economia Mineira, 2008.

LOJKINE, J. O Estado capitalista e a questão urbana. São Paulo: Martins Fontes, 1981.

MDIC - Ministério do Desenvolvimento Industria e Comercio. Balança Comercial Brasileira - Dados Consolidados. Brasília, 2011. 
PANORAMA COMEX 2011. Minas Gerais - Secretaria de Estado de Desenvolvimento Econômico, Belo Horizonte 2001. Disponível em http:/ /www.exportaminas.mg.gov.br/ pdf/panorama_comex/Panorama_Comex_2011_baixa.pdf

PEREIRA, F.B.; RUIZ, R.M. As Periferias nos centros: um estudo das estruturas metropolitanas brasileiras. XII Seminário sobre a Economia Mineira Economia. Diamantina, 2006.

RIBEIRO, Darcy. O povo brasileiro: a formação e o sentido do Brasil. São Paulo: Companhia das Letras, 2006.

RODRIGUEZ, Octavio. O estruturalismo latino-americano. Rio de Janeiro: Civilização Brasileira, 2009.

SANTOS, Milton. Economia espacial: críticas e alternativas. 2. ed. São Paulo: Edusp, 2003.

SANTOS, Milton. Ensaios sobre a urbanização latino-americana. São Paulo: Edup, 2007.

SIDRA-IBGE. http://www.sidra.ibge.gov.br/. 


\section{A crítica nas margens. Péricles Morais e as representações literárias da Amazônia}

\section{Region, tradition and criticism. Péricles Morais and literary representation of Amazon}

Marco Aurélio Coelho Paiva - Doutor em Sociologia (USP); professor associado do Departamento de Ciências Sociais da Universidade Federal do Amazonas (UFAM), Manaus-AM. E-mail: macp40@ufam.edu.br

\section{Resumo}

Este artigo intenta explicitar como os processos de representação regional da Amazônia estavam diretamente vinculados às novas configurações de ordem política e intelectual geradas nos anos 1920 e 1930. Considerando-se que o movimento modernista no Brasil deflagrou um rearranjo no campo da cultura e as alianças envolvendo uma gama de intelectuais de diferentes regiões do país acabaram por gerar efeitos substanciais nos modos de representação regional. A partir da análise de algumas obras e textos do crítico amazonense Péricles Moraes, objetiva-se demonstrar como a sua afirmação como um autor local, autorizado a estabelecer os critérios de um regionalismo amazônico, rejeitou o experimentalismo estético modernista e buscou preservar uma tradição literária passadista como chave de entendimento da realidade amazônica.

\section{Palavras-chave}

Crítica literária. Intelectuais. Modernismo. Regionalismo.

\begin{abstract}
This article attempts to explain how the processes of regional representation of the Amazonia were formulated in the years 1920's and 1930's and how they were directly linked to the new political and intellectual configurations in that period. Considering that the modernist movement in Brazil had furthered a rearrangement within the field of culture, a series of alliances including a range of authors from different regions of the country had generated substantial effects on the modes of regional representation. From the analysis of some works and critical texts of Péricles Moraes, the paper attempts to demonstrate how his affirmation as a local author authorized to establish criteria of a regionalism Amazonian has rejected the modernist aesthetic experimentalism and preserved a literary tradition of understanding about the reality of the Amazonia.
\end{abstract}

\section{Keywords}

Amazonia. Intellectuals. Literary criticism. Modernism. Regionalism. 


\section{INTRODUÇÃO}

Em setembro de 1931, Mário de Andrade publicou uma carta aberta no Diário Nacional, endereçada a Raimundo Moraes. O autor de Pauliceia desvairada agradecia o apoio do escritor paraense, então estampado no seu segundo volume de $O$ meu dicionário de coisas da Amazônia, que se justificava em função das acusações que pesavam sobre o autor paulista no que dizia respeito à forma e ao conteúdo do romance Macunaíma. Ao referir-se a Theodor Koch-Grünberg em seu livro, Raimundo Moraes assim argumenta:

[...] Os maldizentes afirmam que o livro Macunaima, do festejado escritor Mário de Andrade, é todo inspirado no Von Roraima Zum Orinoco do sábio [alemão]. Desconhecendo eu o livro do naturalista germânico, não creio nesse boato, pois o romancista patrício, com quem privei em Manaus, possui talento e imaginação que dispensam inspirações estranhas. Infelizmente o brasileiro só crê e exalta a obra do ádvena. É uma falba do nosso caráter (MORAES, 1931, p. 147, grifos nossos).

Os boatos salientados por Raimundo Moraes insinuavam a existência de uma cópia do livro do etnógrafo alemão em Macunaíma. No entanto, segundo o próprio Mário de Andrade na carta supracitada, e em tom jocoso, não era equivocada ou enganosa tal acusação, e isso na medida em que houve, de fato, a intenção deliberada de se fazer uma cópia de tudo o que havia não só na obra do estudioso germânico, mas também de outros autores. Inclusive o próprio Raimundo Moraes teria sido um dos autores copiados. Segundo argumenta Mário de Andrade:

Copiei, sim, meu querido defensor. O que me espanta e acho sublime de bondade é os maldizentes se esquecerem de tudo quanto sabem, restringindo a minha cópia a Koch-Gruenberg (sic), quando copiei todos. $\mathrm{E}$ até o Sr. na cena da Boiuna. Confesso que copiei, copiei às vezes textualmente. Quer saber mesmo? Não só copiei os etnógrafos e os textos ameríndios, mais ainda, na "Carta pras icamiabas", pus frases inteiras de Rui Barbosa, de Mário Barreto, dos cronistas portugueses coloniais, e devastei a tão preciosa quão solene língua dos colaboradores da Revista de Lingua Portuguesa. Isso era inevitável, pois que o meu [...], isto é, o herói de Koch-Gruenberg $(s i c)$, estava com pretensões a escrever um português de lei. O Sr. poderá me contradizer afirmando que no estudo etnográfico do alemão, Macunaíma jamais teria pretensões a escrever um português de lei. Concordo, mas nem isso é invenção minha pois que é uma pretensão copiada de 99 por cento dos brasileiros. Dos brasileiros alfabetizados (ANDRADE, 2008, p. 233).

A carta de Mário de Andrade endereçada a Raimundo Moraes converteuse, por sua vez, em uma oportunidade para que o autor de Macunaima elucidasse 
publicamente a forma e o conteúdo da sua polêmica obra, ressaltando, por exemplo, o seu aspecto de rapsódia, ao coletar lendas e modos de falar existentes no Brasil. A alusão ao capítulo "Carta pras icamiabas" faz realçar, também, a paródia de um falar douto, que impregnava fortemente a intelectualidade nacional, alvo prioritário de críticas por parte dos modernistas do primeiro momento e que, ao mesmo tempo, revelava as pretensões da revolução estética então em curso.

Mas a tomada de posição por parte de Raimundo Moraes a favor da obra de Mário de Andrade não deve ser interpretada como uma atitude meramente reativa a uma provável injustiça então cometida no plano da imaginação. O próprio Raimundo Moraes, em seus argumentos para elucidar a originalidade da obra do autor paulista, esclarece que, a despeito de nunca ter lido o livro do "sábio alemão", poderia garantir que o herói do romance/rapsódia não era o mesmo retratado por Koch-Grünberg. Tal alinhamento de Raimundo Moraes a Mário de Andrade em um momento decisivo de inflexão do movimento modernista no Brasil, na realidade revela como as diferentes posições no âmbito de um campo literário ainda incipiente encontravam-se baralhadas e em processo de consolidação, principalmente quando se ressalta a relação entre a questão regional e os debates atinentes a uma identidade nacional (PAIVA, 2008). Neste sentido, Mário de Andrade salienta em sua carta a Raimundo Moraes que o Macunaíma de Koch-Grünberg "era um ser apenas do extremo-norte e sucedia que a minha preocupação rapsódica era um bocado maior que esses limites" (ANDRADE, 2008, p. 232). Poderíamos extrair desse raciocínio de Mário de Andrade o fato de a sua obra mais famosa poder representar não só uma radicalização do experimentalismo estético do modernismo, mas também uma espécie de divisor de águas no âmbito do movimento, caso tomemos a sua periodização como bifurcada entre uma fase estética e outra política (LAFETÁ, 2000). Dessa forma, como demonstrou Lafetá (2000), fica claro que a fase propriamente estética já traz consigo implicações mais abrangentes de ordem política.

As mudanças e alterações estilísticas levadas a cabo pelos literatos que então encabeçavam o modernismo no Brasil não podiam deixar de reverberar seus efeitos nas diversas e distantes regiões do país, como a Amazônia de Raimundo Moraes. Embora a relação entre centro e periferia não possa ser simplificada como uma via de "mão única", principalmente quando essa relação é tratada em termos estritamente econômicos e/ou políticos (termos estes, por seu turno, facilmente transplantados para o plano da cultura, gerando equívocos analíticos de toda ordem), é indubitável o papel simbólico de dominação exercido pelas obras então forjadas em centros culturais mais dinâmicos, o que acaba por propiciar o surgimento de abordagens que seguem o novo paradigma estético 
ou buscam contestá-lo a partir da viabilização de novas propostas (acerca dos problemas implicados na relação entre centro e periferia no âmbito da produção artística) (CASTELNUOVO; GINZBURG, 1991, p. 5-93).

Mas, na medida em que novas e diversificadas versões de nacionalidade e brasilidade eram forjadas a partir de cisões internas ao próprio modernismo, faziase necessário agregar elementos simbolicamente representativos do conjunto da nação, para se consolidar uma ideia genuína de identidade nacional. Se a intenção de Mário de Andrade em seu romance/rapsódia Macunaíma era precisamente contrapor-se a um academicismo já envelhecido, reagrupar e embaralhar toda uma tradição da língua falada no Brasil, e que se espelhava, por exemplo, nos usos variados da linguagem em suas diferentes regiões, vale salientar que o seu antiherói surge da Amazônia para peregrinar por toda a diversidade geográfica do país, sempre a alterar a sua aparência, sem, portanto, firmar uma definição precisa do seu "caráter" e da sua forma. Ora, não deixa de causar certa estranheza a observação de Raimundo Moraes em seu livro, ao acusar os críticos brasileiros de valorizarem somente autores estrangeiros e negligenciar autores nacionais como uma "falha do nosso caráter".

A primeira impressão é que o autor paraense, em seu afã de defender e demonstrar proximidade com o autor paulista, ("[...] com quem privei em Manaus [...]", diz ele em seu livro), não tenha compreendido plenamente as intenções da obra de Mário de Andrade e, de fato, tenha cometido um deslize interpretativo quando da sua observação, ao reduzir a concepção de caráter a um dado estritamente ético e moral, negligenciando o aspecto propriamente estético aí implicado. Mas, por outro lado, nao é improvável que o autor de $O$ meu dicionário de coisas da Amazônia tenha se valido de certo tom irônico, típico do ambiente modernista, não só para posicionar-se frente ao embate que se travava na cena cultural brasileira, mas também para atacar certos críticos ainda aferrados a uma tradição literária.

Mas, se for assim, quais seriam as motivações para o uso dessa suposta ironia por parte de um autor então reconhecido publicamente como ensimesmado? Quais autores Raimundo Moraes buscava atingir quando ressaltou a "ausência de caráter" de nossos críticos? Tendo em vista que o autor de Na planície amazônica nunca se ausentou por longo tempo da região no decorrer da sua conturbada trajetória política e intelectual (BITTENCOURT, 1973), e que não o impedia de inteirar-se do que ocorria nos centros culturais do país, resta-nos buscar respostas para tais questões no âmbito propriamente regional das relações entre intelectuais e literatos. Se em seu romance/rapsódia Mário de Andrade desconsiderava deliberadamente os aspectos específicos de cada região em prol de uma noção 
mais complexa e totalizadora de nacionalidade, por sua vez, ao longo das décadas de 1920 e 1930, os intelectuais e literatos da Amazônia buscavam ocupar determinadas posições consideradas mais vantajosas nesse cenário cultural, para assim alcançar maior legitimidade, no sentido de promulgar os possíveis preceitos de um regionalismo amazônico. Não é raro identificar no plano regional os mesmos balizamentos então fincados por uma disputa simbólica que ocorria nos centros culturais, acerca das novas legitimações do trabalho intelectual e literário desencadeadas precisamente pelo modernismo. Conforme salienta Bourdieu (1989), o jogo das representações está diretamente atrelado ao conjunto dos atores sociais legitimados para a formulação de tais representações.

\section{DA POLÍTICA PARA AS LETRAS}

No início da década de 1920, o escritor Coelho Neto enviou uma carta ao crítico literário amazonense Péricles Moraes, aconselhando-o a não publicar o estudo que havia empreendido acerca da sua copiosa obra. Segundo os argumentos do autor de $A$ conquista, seria um erro crucial para quem pretendesse ingressar no mundo das letras, logo de início, tomar partido de um autor como ele, alguém que se havia tornado o alvo preferencial de críticos e escritores que se arvoravam de inovadores literários. Apesar das ponderações e aconselhamentos de Coelho Neto, o seu pedido não foi atendido. A obra sobre o afamado autor foi publicada em 1926.

Mas a troca de correspondências entre Coelho Neto e Péricles Moraes revela o tipo de filiação que o crítico amazonense havia estabelecido com o cultuado autor, vale ressaltar, que se havia transformado, ao longo das décadas de 1900 e 1910, na principal referência intelectual e literária do país (CANDIDO, 2000a; LOPES, 1997), a despeito das controvérsias que suas obras sempre provocaram em críticos literários mais antigos, como, por exemplo, a José Veríssimo (VERÍSSIMO, 1977, p. 9-20). Saliente-se que, por conta dessa notoriedade então desfrutada pelo autor maranhense, sua visita a Manaus em agosto de 1899 foi ansiosamente aguardada pelos intelectuais e políticos locais, e que foi por ele retribuída com um discurso proferido de improviso no Teatro Amazonas (BRAGA, 1983, p. 35-50). Foi durante essa viagem de Coelho Neto ao Norte do país que, ao passar por Belém rumo a Manaus, o ainda adolescente Péricles Moraes pôde conhecer o laureado escritor, de quem já era um admirador e leitor entusiasmado.

Coelho Neto fazia o papel de protetor e incentivador de Péricles Moraes ao avaliar e abalizar seus artigos e estudos literários, bem como se dispunha a 
encaminhá-los para eventual publicação em diversos jornais do Rio de Janeiro, além de recomendar os livros do crítico amazonense para determinadas editoras portuguesas. Ao enveredar por um minucioso estudo da volumosa obra de Coelho Neto, a empreitada de Péricles Moraes cumpria, a princípio, um papel estratégico para a sua legitimação literária e intelectual, e isso na medida em que buscava explicitar e estreitar os vínculos com um autor já reconhecido e que vinha ocupando o panteão das letras nacionais, embora com uma reputação já em declínio no decorrer da década de 1920. Tal aproximação, por seu turno, e em consonância com outros fatores de ordem política e intelectual, deveria redundar na consolidação do nome do crítico amazonense como principal referência no âmbito da cena literária regional.

No entanto, vale salientar que ao longo da década de 1920 ainda não se vislumbrava claramente os desdobramentos do modernismo como um movimento artístico e literário relativamente vitorioso, a deflagrar uma pretensa ruptura com a tradição acadêmica, tradição que se tornava visível justamente nas obras e na figura de Coelho Neto. As abordagens e os estudos críticos de Péricles Moraes, estampados em seus diversos e variados artigos e livros ao longo das décadas de 1920 e 1930 não deixam dúvidas quanto às suas opções estéticas e, de fato, escancaram a sua aversão aos princípios de uma arte e literatura modernistas.

Da mesma forma que o campo intelectual e literário ainda buscava consolidar-se como um espaço social relativamente autônomo em relação às ingerências da política, e as disputas internas então deflagradas entre modernos e passadistas podem ser percebidas como um dos momentos decisivos para a configuração e conquista de tal autonomia, a crítica literária também acompanhava esse desdobramento do jogo literário e estampava seus futuros delineamentos como atividade intelectual específica, precisamente a partir do modo como essa conflagração se intensificava e se reconfigurava. Mesmo tomando-se as obras de Sílvio Romero e José Veríssimo como referências importantes para a definição dos contornos de uma crítica literária mais autônoma, inclusive do ponto de vista dos embates acerca da relevância ou não dos fatores extraliterários para deslindamento de aspectos internos das obras e dos textos (BARBOSA, 1996), o caso de Alceu Amoroso Lima, como um primeiro perfil de crítico literário a ressaltar essa ambiguidade de uma crítica literária cindida entre passadistas e modernos, é expressivo e definidor dos rumos tomados posteriormente pela atividade crítica no Brasil (LAFETÁ, 2000; GOMES JÚNIOR, 2011; RODRIGUES, 2012).

Péricles Moraes, por seu turno, a despeito de pertencer à mesma geração de críticos literários como Agripino Grieco e Alceu Amoroso Lima (além do próprio 
Mário de Andrade, para seguir alguns dos nomes estudados por LAFETÁ [2000]), sempre buscou esquivar-se de qualquer tipo de ambiguidade quanto às opções de seu exercício crítico, recusando-se a reconhecer algum valor na proposta modernista e, ao mesmo tempo, aferrando-se a um modo de avaliação artística e literária conforme os moldes de uma abordagem impressionista. Tal postura tomada por Péricles Moraes se manteve inclusive ao longo da década de 1930, a despeito dos desdobramentos estéticos e políticos do modernismo, quando a visada crítica do autor de Coelho Neto e sua obra identificou nos textos e abordagens de Euclides da Cunha o modo mais adequado para um entendimento da realidade regional amazônica. A mescla entre estética e ciência presente nos escritos do autor de Os sertôes convertia-se, conforme Péricles Moraes, como o modo adequado para desvelar a peculiaridade da realidade amazônica (MORAES, 1935, p. 9-68).

A participação efetiva de Péricles Moraes como protagonista na vida cultural amazônica o catapultou para uma posição de referência para a intelectualidade regional, e que perdurou ao longo da década de 1950 (PINHEIRO, 1999). Essa atuação, por sua vez, fez com que uma representação literária da Amazônia então se consolidasse. Uma visão fortemente emoldurada pela tradição literária e pelos escritos amazônicos de Euclides da Cunha, que concebiam o espaço regional como um espaço dominado pela natureza (GONDIM, 2002, p. 83-125).

Péricles Moraes nasceu em Manaus, em abril de 1882, filho de uma tradicional família local, com o pai voltado para os afazeres da política e no desempenho de cargos públicos de certa relevância dentro do sistema oligárquico regional. Dada a exiguidade de informações biográficas, não é possível identificar os motivos determinantes que levaram o jovem Péricles Moraes a optar por uma carreira intelectual incerta em detrimento de uma carreira política mais estável. Sabe-se simplesmente que fez seus estudos primários e secundários em Manaus e Belém, com um crescente envolvimento na vida intelectual nas duas capitais amazônicas, quando ambas as cidades vivenciavam seu apogeu de belle époque. Participou de cenáculos literários tanto em Belém, fazendo parte, por exemplo, do Apostolado Cruz e Souza, agremiação pioneira do movimento simbolista no Brasil, quanto em Manaus, onde foi um dos fundadores da Sociedade dos Homens de Letras do Amazonas, e que mais tarde se transformaria na Academia Amazonense de Letras, entidade com a qual manteve um forte vínculo no decorrer da sua vida intelectual, servindo-lhe como lastro institucional importante, na medida em que se convertia em uma instância local de consagração (BITTENCOURT, 1973, p. 408-410).

Assim como a influência da poesia simbolista não deixou indiferente o jovem estudante, o aprendizado precoce da língua francesa também se converteu em fator determinante para a carreira do futuro crítico literário. A possibilidade 
de viajar para Paris com certa frequência, de imediato viabilizou a sua atividade como professor de francês em Manaus, além de manter uma atuação constante nos jornais e revistas literárias locais como divulgador da literatura francesa (tal como Alceu de Amoroso Lima, Péricles Moraes encontrava-se em Paris quando da eclosão da Primeira Guerra Mundial em 1914). O ingresso na vida política foi inevitável na medida em que a atividade intelectual e a política ainda imbricavamse de maneira decisiva no decorrer desse período.

Mas aqui se faz necessário ressaltar que, se a vida intelectual ainda encontravase muito adstrita à vida política, tal fato se dava em função da inviabilidade de se pleitear uma carreira intelectual fora do alcance do sistema oligárquico (MICELI, 2001). No caso de Péricles Moraes, a sua filiação a uma família que já vinha enfronhada no jogo político em muito contribuiu para a sua nomeação para as prefeituras de pequenas cidades do interior do Amazonas e a respectiva consolidação de seu nome como intelectual. Muito provavelmente os reveses políticos ocorridos ao longo da década de 1920, tanto no âmbito nacional quanto regional, acabaram por restringir as suas possibilidades de uma carreira política mais promissora e, por conta dessas barreiras e percalços, uma opção específica pela carreira intelectual vislumbrou-se não só como um caminho provável, mas como uma via que poderia restar, a princípio, para certos grupos sociais decadentes (MICELI, 2001). No decorrer dos anos 1930 e 1940, Péricles Moraes ainda manteve níveis de atuação política junto ao aparato estatal-burocrático local, mas o seu papel foi aí definido, já em função da sua reputação como intelectual.

Mas como identificar nos variados escritos do crítico literário amazonense os modos de sua filiação e alinhamento a posições até então supostamente mais bem consolidadas no jogo literário e intelectual da década de 1920, levando-se em consideração, por exemplo, o fato de, nesse momento preciso, estar em processo uma redefinição não só o entendimento da realidade nacional, mas também uma nova formulação estética acerca dessa realidade? Como compreender o pretenso cosmopolitismo de uma crítica literária marcada por feições passadistas, de um lado; e ainda fortemente amarrada, de alguma forma, a um regionalismo "sertanista" típico de finais do século XIX de outro? Não é difícil identificar nos textos de Péricles Moraes a tentativa de ocupação dessa posição instável e incerta, caso consideremos o acirramento do contexto político e cultural por disputas entre autores atrelados a uma tradição academicista e o ímpeto de outros autores a pregar um suposto vanguardismo modernista, destinado a embaralhar e redefinir os liames existentes entre o regionalismo e o nacionalismo literário e artístico. Mesmo ao longo da década de 1930, quando o modernismo já havia se consolidado como uma nova perspectiva para apreensão da realidade nacional, 
embora com um viés menos estético e mais político-ideológico (LAFETÁ, 2000), a concordância de Péricles Moraes com o delineamento da Amazônia tal como levado a cabo por Euclides da Cunha em seus pequenos textos reunidos em À margem da história, justificava-se precisamente em função da linguagem rebuscada em associar estilo e ciência, portanto, refutava as diferentes obras e os variados autores que porventura se filiavam de alguma maneira aos princípios estabelecidos pelo experimentalismo modernista. Péricles Moraes manteve-se avesso ao modernismo tanto na sua fase de contestação estética quanto na sua fase ideológica e, no seu entendimento insistia em considerar os ganhos até então logrados por uma tradição artística e literária, segundo ele, como crucial para deslindar os meandros da própria Amazônia como realidade singular.

Faz-se necessário, portanto, seguir de perto os argumentos e os métodos de abordagem adotados por Péricles Moraes tais como eles vão se desdobrando no decorrer de seus textos e análises, além de identificar os caminhos pelos quais o autor passou desde a sua compreensão acerca do significado da crítica literária e artística, da sua filiação ao estilo art nouveau de Coelho Neto (PAES, 1985, p. 64-80), do seu entendimento acerca do modernismo e do papel desempenhado pelos textos de Euclides da Cunha sobre a realidade regional amazônica.

\section{PÉRICLES MORAES E A CRÍTICA LITERÁRIA}

Em seu livro de estreia, publicado em 1923, Figuras e sensações, dedicado a Coelho Neto, Péricles Moraes debruça-se em um dos seus ensaios sobre o controverso livro do escritor russo Tolstoi, $O$ que é arte? O entendimento distorcido de Tolstoi acerca do papel a ser desempenhado pela crítica de arte, tal como esquadrinhado em sua polêmica obra, segundo Péricles Moraes, deve ser refutado, para que se esclareçam quais os verdadeiros caminhos que a crítica literária e artística deve seguir. O crítico aproveita-se da polêmica então deflagrada por Tolstoi em seu argumento para que ele mesmo, Péricles Moraes, posicione-se quanto ao entendimento da crítica literária e artística. O autor de Figuras e sensações, como afiliado ao método de Sainte-Beuve, salienta inicialmente a importância do conjunto da obra do autor de Ana Karenina não só para a Rússia de seu tempo (na medida em que a compreensão crítica bem fundamentada não pode desvincular o autor e sua obra do contexto social e histórico imediato), mas também para a própria literatura europeia contemporânea. A partir de um empreendimento artístico e literário que tomou como ponto de partida as agruras do povo russo, Péricles Moraes salienta que a obra de Tolstoi acabou por refletir aspectos mais abrangentes da própria condição humana. O viés destoante da reflexão crítica 
de Tolstoi, por sua vez, ganha contornos mais expressivos justamente porque deixam de corresponder àquilo que o próprio autor de Guerra e paz levou a cabo em suas obras consagradas.

Se o princípio de criação artística tal como apregoado por Tolstoi não for cumprido, isto é, se a arte não desempenhar o seu papel precípuo como elemento a intermediar e propagar os sentimentos entre os homens, simplesmente não pode ser arte. Para o autor russo, diz Péricles Moraes, a arte não pode definir-se somente pelo critério da beleza, tal como estabelecido pelos princípios comandados pela razão. Este teria sido precisamente o suposto desvirtuamento perpetrado pela crítica moderna. Essa intervenção racionalista da crítica, por seu turno, teria provocado uma suposta elitização do próprio entendimento da arte como algo apenas relegado a eruditos. Tolstoi condena em seu livro toda a crítica, indistintamente, e isso na medida em que a sua compreensão de uma obra de arte não pode desvencilhar-se do sentimento como elemento de unificação entre os homens, sentimento este, vale notar, profundamente arraigado em bases místico-religiosas.

Ora, em seu texto, Péricles Moraes vale-se desse posicionamento do autor de Ressurreição para defender o papel da atividade crítica como exercício crucial para o entendimento pleno das obras de arte. Se Tolstoi condena certas obras e autores como obscuros e herméticos, alheios aos sentimentos genuínos que perpassam as massas sociais rebaixadas, de fato, lembra Péricles Moraes, a crítica de arte teria atuado justamente no esclarecimento e no desvelo de obras e autores que, sem a atuação de críticos atentos, passariam despercebidos do grande público. Portanto, o papel da crítica não pode ser tomado como uma tarefa intelectual negativa, porque racional e obscura, como argumenta Tolstoi, mas sim de maneira positiva, na medida em que lhe cabe desvelar autores e obras que, invariavelmente, poderiam passar despercebidos do público.

Segundo Péricles Moraes, a atividade crítica deve esclarecer, portanto, pela via da razão, as diferentes perspectivas então eventualmente vislumbradas pelas distintas obras de arte, e isso na medida em que tais obras não podem ser confinadas a preceitos oriundos meramente do sentimento, a despeito da sua importância. Ao refutar os argumentos do autor russo, Péricles Moraes reafirmava, de fato, o espaço próprio que cabe à atividade crítica como um exercício intelectual legítimo de reflexão, a promover uma junção equilibrada entre sentimento e razão. Se Tolstoi direciona os seus argumentos no sentido de demonstrar como a racionalização da crítica acaba por promover uma elitização dos sentimentos suscitados pelas verdadeiras obras de arte, e, ao revés, também acabam por valorizar obras de arte que, de fato, nada possuem em termos de valor artístico, porque destinadas somente a alguns, o autor russo deixa transparecer 
a sua compreensão da atividade artística como uma prática mística com a finalidade de promover uma congregação humana mais harmoniosa. Tal como um mistagogo, Tolstoi apregoa um retorno às origens da função das obras de arte, quando a estética ainda encontrava-se estreitamente associada aos princípios definidores da mensagem religiosa. A relação entre o campo artístico e o campo religioso, tal como pode ser apreendida a partir dos argumentos do autor russo, em muito corrobora com as análises de Max Weber acerca de seus estudos sobre a religião, demonstrando como o processo de racionalização gerado dentro da própria esfera religiosa afeta todas as demais esferas sociais, inclusive a esfera estética (WEBER, 2000, p. 279-418; TOLSTOI, 1994).

Do ponto de vista de Péricles Moraes, por seu turno, o que fragiliza ainda mais a concepção de arte, tal como alardeada pelo livro de Tolstoi, é o fato de o autor russo apegar-se em demasia, e de maneira acrítica, a uma concepção imutável de beleza como o fundamento último de toda e qualquer obra artística. Não que o crítico amazonense desconsidere este aspecto como algo crucial para o entendimento da obra de arte, mas a noção de beleza não pode ficar alijada do processo histórico em curso, que promove constantes mudanças. É nesse sentido que Péricles Moraes faz referência à crítica de arte, pois são essas abordagens críticas que, no decorrer do tempo, podem sempre lançar novas bases acerca dos processos de avaliação das diferentes obras literárias e artísticas destinadas a responder aos distintos anseios reclamados pelos surtos periódicos de inovação estética. A noção de beleza, portanto, não pode ser concebida como uma categoria a ser posta acima e fora do tempo histórico. Eis aí a necessidade da crítica em esclarecer os possíveis ganhos entranhados em certas obras e ainda não desvelados, na medida em que o exercício crítico deve buscar explicitar, de maneira racional, os processos de criação artística.

No entanto, este entendimento de Péricles Moraes acerca do papel da crítica literária e artística, a despeito de insinuar uma atenção para os processos de mudança, não está desvinculado do método por ele considerado o mais adequado para se responder a essa necessidade sempre premente de entendimento de cada autor e obra. Até mesmo para fugir de possíveis noções que possam insinuar certo aprisionamento para a compreensão mais acertada de um autor e sua obra, o método por ele considerado o mais adequado, e praticado com essa intenção em seus escritos, escora-se nas concepções de Sainte-Beuve, como referência para um exercício crítico mais seguro. Mas esse método, por seu turno, está assentado em bases impressionistas, que realçam "retratos" (portraits) dos autores, ou seja, é um método que tende a resvalar do julgamento da obra em si e invariavelmente descambar para outros aspectos extraliterários, portanto, um método de análise 
que a própria arte moderna considerará avessa aos seus reclamos por autonomia (SAINTE-BEUVE, 2011; LAFETÁ, 2000).

O livro de estreia de Péricles Moraes, Figuras e sensaçoes, além de ancorarse nesse método de análise literária até então largamente praticado e consagrado no Brasil, debruça-se sobre um conjunto de autores estrangeiros, em sua maioria franceses, investidos de certa legitimidade no meio intelectual, pois eram autores comentados e consumidos pela intelectualidade brasileira da época. Camillec Mauclair, Mirbeau, La Sizeranne, Edmond Rostand, Maupassant, Alfredo Capus e Paul Bourget compõem a lista de estudos e análises levados a cabo por Péricles Moraes em seu livro. A preferência por tais autores franceses em muito reflete não só as inclinações pessoais de Péricles Moraes, mas explicitam o tipo de influência literária que a intelectualidade brasileira do período vinha sofrendo desde o final do século XIX, principalmente ao longo da década de 1920, caso atentemos para o momento de crise política pelo qual passava o sistema oligárquico de dominação e seus impactos sobre a intelligentsia nativa (PRADO, 2010). Embora Antonio Candido (2000a) ressalte o fato de o período compreendido entre 1900 e 1920 ser uma fase em que a literatura brasileira caracterizava-se por certo espírito de permanência, com fortes tendências a um academismo conservador, também é possível identificar no plano intelectual e literário, segundo Prado (2010), a busca por novas formas expressivas que insinuam as rachaduras em curso no plano político.

A crítica literária, a despeito de sofrer os efeitos políticos do período, buscava distanciar-se de uma herança intelectual que se pautava pelo princípio da nacionalidade como critério único de avaliação das diferentes obras. Tais estudos, no entanto, tendiam a atrelar-se a princípios críticos advindos de outras paragens e contextos culturais, revelando-se, quase sempre, como mero decalque a dar vazão a um verbalismo excessivo, e que os autores modernos, contestadores do academicismo ainda reinante, já identificavam. Vale notar aqui o fato de o livro de Péricles Moraes, Figuras e sensações, ter sido de imediato identificado pelos editores da Revista do Brasil, uma publicação adepta do modernismo, como uma obra já envelhecida, em função desses aspectos que predominavam até o final do segundo decênio do século XX.

O Sr. Péricles de Moraes - já o dissemos aqui - é, por certo, um crítico de quem se pode esperar muito. Mas é vítima da mesma obsessão da sonoridade verbal que nos revela este seu pródigo encomiador. O tempo há de lhe repetir a lição que tão tardiamente se fez ouvir a esse grande espírito que é Coelho Neto. (Revista do Brasil apud MARTINS, 1983, p. 508)

De imediato, pode-se identificar um paradoxo e certo contrassenso entre os argumentos desfiados pelo próprio Péricles Moraes contra as teses defendidas 
por Tolstoi quanto à arte moderna e o fato de o crítico amazonense filiar-se a uma "corrente literária" avaliada como envelhecida e decadente. Portanto, uma ambiguidade se faria presente na obra de estreia do crítico literário nortista. A despeito disso, Péricles Moraes estaria condenado a sofrer os mesmos reveses então sofridos pelo seu patrocinador, Coelho Neto. Se for papel da crítica literária desvelar o valor de obras e autores que rompem determinados parâmetros quanto às concepções correntes de entendimento do belo, em função das exigências do tempo, como entender essa vinculação e afiliação de Péricles Moraes, um pretendente a tornar-se um guia e suscitador de obras ainda não plenamente compreendidas em seu valor intrínseco, a um autor em franca decadência como Coelho Neto? Talvez o crítico amazonense em seus argumentos para refutar as teses de Tolstoi não tenha levado em conta o fato de que cada escolha tomada pelos diferentes autores e artistas, assim como pelos próprios críticos, também depende do modo de associação e aliança entre uns e outros.

É precisamente em função de tais movimentações e associações de parte a parte, incluindo-se aí todo um aparato institucional a subsidiar certa legitimidade artística e intelectual, que as diferentes concepções estéticas ganham força ou desvanecem-se enquanto parâmetro definidor da própria arte. Todavia, essa provável cegueira de Péricles Moraes, não deve ser interpretada como uma eventual incapacidade de um intelectual alojado na província em avaliar os desdobramentos de uma carreira literária então almejada, mas sim como uma tomada de posição viável e avaliada como mais certeira, sem a necessidade de correr riscos maiores. Uma vinculação inicial com Coelho Neto e a opção pelo leque de autores franceses analisados em sua primeira obra já demonstram que Péricles Moraes buscou ocupar uma posição segura dentro desse instável jogo que caracteriza o campo intelectual e literário da década de 1920 no Brasil.

Mas, por outro lado, caso analisemos o primeiro ensaio de seu livro de estreia, "Camille Mauclair sacerdote do ritmo", é possível relativizar aqueles argumentos utilizados contra Tolstoi e sua concepção de obra de arte. Se ali a razão convertia-se em um princípio crucial para o exercício correto da crítica, avaliando e suscitando os prováveis elementos presentes na obra de arte eventualmente interditados à compreensão geral, neste ensaio de abertura do livro o que predomina é precisamente certa argúcia crítica por parte de Camille Mauclair ao tratar o tema da música. Na visão de Péricles Moraes, o mérito do crítico francês residia na sua capacidade de transcender os aspectos materiais e prosaicos da técnica musical, identificando o elemento sublime, próprio da música, como o alvo a ser atingido pelo exercício crítico. Tal fato era ignorado pelos próprios músicos, ao demonstrarem certa indiferença pelo sentimento de 
enlevo gerado pela música. Ou seja, a música é analisada pelo crítico francês de modo a destacar o caráter sublime, próprio de uma manifestação artística singular, a partir do papel desempenhado, ao longo do tempo, por um conjunto de compositores tomados como canônicos dentro da tradição musical ocidental. Ao atribuir um peso excessivo a esse elemento de sublimação e sensibilidade da música, o caráter racional que em princípio deveria presidir a avaliação então levada a cabo pelo crítico, põe-se a reboque do aspecto estritamente sentimental, como se este fosse o único elemento possível a dar conta de uma avaliação mais ajustada a uma manifestação artística peculiar. Toda a argumentação de Péricles Moraes, tal como um decalque crítico, segue os argumentos do crítico francês.

Ora, tal fato, por si só, seria suficiente para demonstrar a aversão por parte de Péricles Moraes contra os princípios já então reclamados pela crítica moderna em arte e literatura, quando apregoava a necessidade de levarem-se em conta os aspectos propriamente estéticos como elementos de avaliação. Ainda nesse ensaio consagrado às obras de CamilleMauclair, quando Péricles Moraes estabelece uma relação entre a música e a pintura como recurso retórico para realçar os parâmetros de análise do crítico francês, evidencia-se a posição do crítico amazonense quanto ao seu entendimento da arte moderna. Assim argumenta Péricles Moraes:

[...] Ouvindo-lhe [de Bach] as fugas, os prelúdios e os corais interpretados por quem lhe compreendia e traduzia a arte emotiva de alegorias delicadas e piedosas, depurou-se a sua sensibilidade artística. Daí a sua aversão sistemática por toda música que não fosse clássica. As outras cambiantes da música, a "caricatura perversa" da música que lhe refinara o temperamento quintessenciado, ofendiam-lhe a auditiva caprichosa. Essa música desagradável e deformadora preferida pelas assistências incultas desapontava-o profundamente. Dava-lhe a sensação, ouvindo-a, da decepção de um indivíduo que depois de ter purificado a visão num arrojo de Tintoreto, de Rembrandt ou de Watteau, se encontrasse de súbito em frente a um arremedo de arte do engenho escalavrado de um cubista. [...] (MORAES, 1923, p. 34)

A despeito das diferenças e rupturas possíveis de ser identificadas em compositores tão díspares como Mozart, Beethoven, Wagner e Chopin, todos são considerados pelo crítico francês como clássicos e, dessa forma, tratados na chave de gênios cujas vidas e obras eternizaram e enriquecerem cumulativamente a música ocidental. Em nenhum momento se questiona, pelo menos conforme o andamento da análise de Péricles Moraes, o fato de eventuais rupturas terem sido logradas por alguns, em detrimento das obras dos outros. Para reforçar tal argumento e dotá-lo de contornos visuais, Péricles Moraes salienta e compara 
o acúmulo levado a cabo pelos compositores citados por CamilleMauclair com artistas vinculados a outra modalidade artística a encarnar aquele aspecto inefável da forma musical à pintura. Mas, vale frisar, sem realçar ou atentar para o fato de que Rembrandt é bem diferente de Tintoreto ou de Watteau, muito embora todos devam diferenciar-se de um cubista. Se aqueles, a despeito de suas diferenças, expressam os ganhos já logrados pela arte, um cubista reduz-se a um farsante a deturpar os ideais de beleza já consagrados. Péricles Moraes também permanece em um terreno estável e seguro, ocupado por artistas tomados como clássicos, portanto, aferrado a uma concepção de arte tradicional que não questiona ou levanta problemas acerca da estética.

\section{COELHO NETO E O COMBATE AO MODERNISMO}

Já o livro de Péricles Moraes publicado em 1926, e então dedicado ao estudo da obra de Coelho Neto, apenas reforça esse posicionamento passadista tomado logo de início na sua trajetória como crítico, além de reproduzir e reforçar o seu entendimento acerca do fazer artístico e literário. Coelho Neto e sua obra acaba por revelar-se mais como um panegírico do que propriamente uma análise crítica fundamentada do conjunto da obra do autor maranhense. O próprio Péricles Moraes reconhece as dificuldades e os percalços para qualquer crítico que se aventurasse a percorrer a obra completa de Coelho Neto. Seria extremamente difícil apreender esse volumoso conjunto de obras não só em função do aspecto quantitativo, mas também em função da variedade de gêneros e de experimentos estilísticos levados a cabo pelo então afamado autor. No entanto, o volume e a variedade de gêneros literários experimentados por Coelho Neto não podem desviar a atenção do crítico para o elemento fundamental a dar corpo e unidade ao conjunto da obra: o fato de Coelho Neto ser um cultivador do estilo e da palavra.

A admiração e a reverência por parte de Péricles Moraes em relação ao autor de $A$ conquista justificava-se ainda mais quando, segundo o próprio crítico, Coelho Neto teria exercido papel pioneiro no Brasil, de viver exclusivamente da sua produção literária. Embora o crítico não faça referência a qualquer aspecto contextual a fim de explicitar os fatores de ordem estrutural da sociedade brasileira que possibilitaram tal fato, ou seja, de como se tornou viável o ofício de escritor a partir do crescimento da atividade jornalística e do aumento do número de leitores nos centros urbanos em expansão, no decurso das décadas de 1910 e 1920, é precisamente disso que se trata quando a literatura de Coelho Neto é abordada nesses termos quantitativos tão expressivos. Mas, mesmo premido pelos prazos sempre exíguos, segundo Péricles Moraes, a sua literatura 
não teria se rebaixado no que dizia respeito às questões de estilo. Para o crítico, a maior garantia de um lugar destacado para Coelho Neto no âmbito da literatura brasileira residiria na sua alegada qualidade propriamente estilística e não no aspecto meramente volumoso da sua obra.

No entanto, a relação entre o volume e a qualidade literária da obra de qualquer autor sempre suscitou, no âmbito da crítica, fortes suspeitas quanto a um eventual e inescapável empobrecimento estilístico. No inquérito literário de João do Rio (s/d), Coelho Neto relata a acusação que pesava sobre ele de ser um mercenário das letras. Dentro desse novo contexto de modernização então vivenciado pela sociedade brasileira ao longo da década de 1920, a atividade literária impunha gradativamente aos escritores a necessidade de viver dos ganhos logrados pela própria produção literária. O crescimento da atividade jornalística, tanto como meio de divulgação de material literário, mas também como fonte de renda decisiva para enredar a carreira de um número crescente de intelectuais, além da expansão do número de leitores, findou impondo um ritmo cada vez mais célere para a circulação das diferentes modalidades de escritos, exigindo dos escritores uma dedicação mais específica para a tarefa e o problema literários. A mudança então operada no âmbito da crítica literária também deve muito a essas alterações de ordem estrutural. Mas, a despeito da necessidade de se escrever cada vez mais em função das novas demandas, há uma preocupação por parte de Péricles Moraes em preservar e valorizar o estilo de Coelho Neto como uma referência importante das letras nacionais. Mesmo fazendo incursões por múltiplos e diversificados gêneros (conto, romance, drama, comédia, pastoral, etc.), a escrita de Coelho Neto é tomada pelo crítico nortista como algo que permanece dentro desse novo processo dinâmico das letras nacionais, portanto preservada das exigências mais urgentes do trabalho literário moderno.

Vale notar, no entanto, que nessa abordagem panorâmica da obra de Coelho Neto, Péricles Moraes acaba por desfazer-se, mais uma vez, dos princípios que deveriam comandar a sua abordagem crítica em seu livro de estreia, quando refutou os argumentos de Tolstoi e, diferentemente do autor russo, valorizou o juízo racional, em detrimento de aspectos meramente sentimentais para a definição da obra de arte. A adesão ao estilo rebuscado da literatura de Coelho Neto é abertamente assumida pelo crítico e tomada como justificativa suficiente para uma empreitada dessa monta:

O escritor, em nosso ensaio, é visionado apenas dentro da grandeza de sua obra. E foi não só da visão de suas modalidades infinitas, como das emoções recebidas nos seus diferentes espetáculos, que de nós se apoderou a veleidade de fixar num lance único a sua beleza, reproduzindo-a tal como 
nos impressionou, mais com a paixão estética do contemplador do que com as acrimônias da crítica insensibilizada a esgaravatar inferioridades para diminuir a perfeição do conjunto (MORAES, 1926, p. VII, grifos meus).

Conforme os argumentos introdutórios do próprio crítico, a análise a ser levada a cabo acerca da obra de Coelho Neto também deve, na medida do possível, estar despida de qualquer referência contextual a indigitar algum elemento estranho ao texto literário, valorizando-se, assim, aquele aspecto já de antemão eleito pelo crítico como o dado crucial da obra: o estilo. No entanto, a adoção deste princípio analítico faz com que o crítico também descarte o seu próprio partido teórico de análise literário, então ancorado no método impressionista, o qual passa a ser dispensável para os objetivos intentados. Talvez esse anunciado descarte do elemento contextual justifique-se pela necessidade de defender e preservar o laureado autor das avaliações negativas já perpetradas por outros críticos menos afeitos ao estilo tortuoso da literatura de Coelho Neto.

No entanto, a despeito do alardeado distanciamento a ser adotado em relação aos aspectos contextuais possíveis de mobilização para se entender a obra de Coelho Neto, Péricles Moraes, inevitavelmente, acaba por ressaltar tais elementos extraliterários para justificar o valor próprio da obra do autor sob sua investigação. A partir de uma breve comparação entre diferentes gerações de escritores nacionais, o crítico tenta demonstrar o quanto a obra de Coelho Neto pode ser destacada do seu tempo, do ponto de vista literário, tomandose como referência a geração imediatamente anterior, e mesmo levando-se em conta autores contemporâneos, o ambiente literário onde vicejou a produção literária de Coelho Neto é retratado como "apático". Havia certo "culto supersticioso ao medalhão" representado por Machado de Assis que, segundo o crítico, e conforme as leituras prevalecentes na época, se não era possível atribuir algum brilho ao conjunto da sua obra, deveria ser preservado como uma figura importante devotada aos "primores do vernáculo" (MORAES, 1926, p. 27). Mesmo as corriqueiras importações de modelos e modismos literários, como o naturalismo de Émile Zola que, embora tenha impulsionado uma fornada de obras polêmicas, segundo a avaliação de Péricles Moraes, não teria efetivamente redundado em inovação literária expressiva e de certo valor. A obra de Coelho Neto emerge dentro desse quadro.

O enfoque centrado na questão da linguagem como o elemento fulcral que conduz a análise possibilita ao crítico não só realçar a importância do seu autor na cena literária nacional, mas também viabiliza a defesa de eventuais críticas e desentendimentos acerca do conjunto da sua obra. Dessa forma, toda a abordagem levada a cabo pauta-se primordialmente pelo realce a ser 
conferido à linguagem bastante peculiar alinhavada pelo autor dos contos de Sertões. É o manejo dessa linguagem que se converterá em elemento crucial para o entendimento e enaltecimento literário de Coelho Neto e que, por sua vez, irá desempenhar um papel determinante como elemento delineador da realidade. $\mathrm{Na}$ medida em que suas principais obras são analisadas uma a uma em ordem cronológica, a sempre alegada capacidade e habilidade na utilização da linguagem faz emergir um elogio corriqueiro: é um psicólogo e um revelador de almas.

Para os objetivos aqui propostos, vale ressaltar o modo como Péricles Moraes aborda o livro de contos Sertões, e isso na medida em que Coelho Neto deve ser destacado como alguém também devotado aos modos de representar literariamente a realidade brasileira, então definida em virtude da configuração dos sertões e de uma natureza nativa que revela a autenticidade da nação e de suas regiões ${ }^{1}$. Segundo a proposta de Péricles Moraes, o modo com que são retratadas as duas principais vias dramáticas nesse livro de contos de Coelho Neto, a vida e a natureza, teria propiciado um aclaramento da singularidade da realidade brasileira que nenhum outro autor teria conseguido.

[...] Nesse livro, no transcorrer de lances sucessivos, há o entrechoque de dois dramas, cada qual mais imprevisto e trágico. O drama da vida, no interior da selva, projetado por uma alma de meridional exaltado, alma que é um reservatório de reações psicológicas; e, na ardentia de seus painéis rebelados, o drama da natureza. O artista, à contemplação da flora exsicada pela canícula inclemente do sertão, pinta-lhe o contorcido amargor. A sua paisagem proteiforme, os seus segredos, os seus mistérios, os seus ardores equatoriais, estão em correspondência íntima com o temperamento que lhes anima a congérie tumultuária. No sertão palpita a alma panteística do artista patrício. A natureza que nos mostra o Sr. Coelho Neto tem os estremecimentos e as eclosões dos epinícios virgilianos (MORAES, 1926, p. 52)

Segundo Péricles Moraes, o modo como a paisagem sertaneja é retratada no conjunto de contos de Sertões, faz com que haja um rebatimento da natureza sobre os dramas humanos vivenciados em cada entrecho. Nos quatro contos desse livro de Coelho Neto, e brevemente analisados na obra do crítico nortista, predomina em todos eles esse esforço em se demonstrar a capacidade da linguagem, quando bem manejada, de fazer com que a natureza, em si mesma, seja percebida e delineada em conexão direta com os dramas vivenciados pelos personagens. Para o crítico, tal abordagem teria propiciado um rendimento analítico mais proveitoso do ponto de vista da inteligibilidade da realidade sertaneja brasileira, quando comparada às obras já conhecidas de outros autores

Para uma discussão sobre a importância do espaço para o pensamento social brasileiro, ver Lima (1999) e Maia (2008). 
que se dedicaram ao tema do sertão: Euclides da Cunha e Afonso Arinos. Se Euclides da Cunha orientou a sua obra a partir de pontos de vista "etnológicos e topográficos" dentro do tempo histórico, e se a obra de Afonso Arinos está em muito associada a uma visão aristocrática forjada a partir de "modelos alheios, sob inspiração de panoramas que não eram os nossos", Coelho Neto teria atingido o âmago da realidade sertaneja, segundo Péricles Moraes, justamente por ter forjado de maneira mais adequada o intricado jogo da imaginação, como que se alojando em uma posição intermediária entre os outros dois autores.

\section{DE COELHO NETO A EUCLIDES DA CUNHA: UMA INTERPRETAÇÃO LITERÁRIA DA AMAZÔNIA}

É fácil notar que, ao empreender uma análise ambiciosa da obra de Coelho Neto, Péricles Moraes buscava consolidar-se como um crítico literário, com pretensões a ocupar uma posição mais vantajosa não só no âmbito de um precário sistema intelectual regional, mas, fundamentalmente, projetar-se no cenário nacional, apesar de ainda crer no papel a ser desempenhado pela tradição literária como chave privilegiada de entendimento da realidade regional e nacional. Mas os desdobramentos do movimento modernista ocorridos ainda nos anos 1920, e que fora reconfigurado após 1930, como reflexo da alteração na correlação de forças no jogo político, já haviam insinuado e firmado os limites de um entendimento centrado unicamente na tradição literária. O fazer literário nos moldes tradicionais não mais poderia propiciar rendimentos analíticos vigorosos para uma compreensão substanciosa da realidade brasileira, tal como demandados pelo novo contexto político e cultural, inclusive do ponto de vista do fornecimento de um material singular para delinear a peculiaridade das diferentes regiões do país. O processo de esboroamento e de redefinição de todo um aparato oligárquico de dominação política até então hegemônico fez com que a movimentação e o baralhamento de diferentes posições de um ainda incipiente campo intelectual e literário fossem paulatinamente tensionados.

Caso consideremos a recorrente contraposição entre passadistas e modernos, ganhou realce dentro daquele novo ambiente político e cultural a tendência em valorizar-se a incorporação ao fazer literário de dados mais concretos oriundos de uma cultura popular existente para demarcar eventuais singularidades regionais expressivas e, por essa via, entender melhor a peculiaridade brasileira em seu conjunto (CANDIDO, 2000b, p. 181-198). A despeito de uma radicalização política à esquerda e à direita, pode-se afirmar que essa incorporação foi o ganho maior propiciado pelo experimento estético 
do modernismo dos anos 1920. Mas outras posições em disputa, por sua vez, tendiam a manter-se ainda apegadas aos modos tradicionais do fazer literário, portanto, não abrindo mão de um acúmulo literário propiciado pela civilização ocidental que, segundo Candido (2000b), servia menos como fonte de inspiração para o deslindamento da realidade local, e mais como um pretenso invólucro civilizacional. Essa era a postura de Péricles Moraes no decorrer dos embates da década de 1920, em face da efervescência do modernismo, daí advindo a sua filiação à visão literária tradicional de Coelho Neto quanto ao entendimento dos sertões brasileiros e em detrimento da perspectiva tomada como etnográfica e histórica de Euclides da Cunha.

Tal postura, por sua vez, sofreu sutis e importantes modificações em inícios da década de 1930, justamente em função da alteração no jogo político perpetrada pelos eventos que culminaram na Revolução de 1930, causando forte impacto no plano cultural. Embora não viesse a renegar, em momento algum, os vínculos e alinhamentos de ordem intelectual mantidos com Coelho Neto no decorrer da década de 1920, é possível perceber uma redefinição de rumo por parte do crítico nortista quanto ao peso a ser atribuído não só às questões regionais, mas também ao reavaliar aquela concepção dos sertões brasileiros, tal como alinhavada por Euclides da Cunha, e em contraste com a perspectiva de Coelho Neto.

Classificada como etnográfica e histórica (portanto, avaliada como de menor relevância do ponto de vista literário, na medida em que incorporava o conhecimento cientificista vigente à literatura), a abordagem de Euclides da Cunha passou a ocupar, para Péricles Moraes, o primeiro plano para o deslindamento da realidade regional amazônica, que, dada a nova conjuntura política e cultural, emergia como uma parte significativa e constitutiva do território nacional e exigia, por seu turno, a definição de um quadro de intérpretes devidamente autorizados a proclamar a própria existência da região ${ }^{2}$. Se a obra do autor de À margem da história, de um lado ainda estava fortemente marcada pelo uso de uma linguagem tradicional, rebuscada e tortuosa; e, de outro, a associação entre literatura e ciência presente em seus escritos carrega o peso de alguma inovação possível de ser resgatada para um entendimento da realidade brasileira, dentro do novo contexto político e cultural, na medida em que empreende um esforço para desvelar aspectos até então não devidamente explorados por parte da intelectualidade nativa ${ }^{3}$. Essa mesclagem entre literatura e ciência, por seu turno,

2 Acerca dos fundamentos sociológicos de uma identidade regional, ver Bourdieu (1989, p. 107-132).

3 Sobre a escrita de Euclides da Cunha como cindida entre literatura e ciência, ver Lima (1997), Hardman (2009) e Nascimento (2011). 
será agora parcialmente valorizada por Péricles Moraes, não com o intuito de render-se às resoluções estéticas levadas a cabo pelos modernistas quando da associação entre os dados de realidade e os novos modos de fatura literária, mas, ao inverso, ela servirá para marcar a sua posição como um crítico ainda afeito aos moldes tradicionais de se pensar e fazer literatura e, portanto, contraporse aos alegados abusos da postura modernista. A obra de Euclides da Cunha, mais especificamente os seus escritos amazônicos, foi apreendida e reaproveitada por Péricles Moraes como uma espécie de anteparo protetor contra a voga modernista, já agora em nova fase nos anos 1930, e que começava a contaminar a produção literária e ensaística acerca da região amazônica.

No ensaio "Os intérpretes da Amazônia", capítulo de abertura de seu livro Legendas e águas-fortes, de 1935, um ano após a morte de Coelho Neto, Péricles Moraes toma uma posição bastante firme e típica de um crítico literário já com um nome consolidado no âmbito regional e, em função dessa legitimidade e autoridade reconhecidas, promove uma ordenação e classificação de obras e autores que ao longo dos anos debruçaram-se sobre a realidade amazônica com o objetivo de deslindá-la literária e/ou cientificamente. O parâmetro tomado como medida e referência para avaliar cada obra e cada autor é justamente o conjunto de escritos de Euclides acerca da Amazônia contido em À margem da história, obra publicada postumamente em 1909, além do prefácio ao livro de contos de Alberto Rangel, Inferno verde, publicado em 1908. O que chama a atenção, no entanto, quando dessa apreensão dos escritos de Euclides da Cunha por parte do crítico nortista, é o realce atribuído aos aspectos estritamente literários desses textos, e não uma valorização dos elementos advindos de uma visada científica, tal como intentada pelo próprio Euclides (CUNHA, 1975, p. 228-253). A Amazônia como realidade peculiar, e em tudo avessa a qualquer possibilidade de uma apreensão totalizante, é resultado do modo como, literariamente, Euclides da Cunha delineou esse espaço de "horizontes sempre iguais".

[...] A natureza por ele objetivada, sendo exatamente a mesma que servira às lentes dos outros escritores e cientistas, aparece-nos, entretanto, agitada pelos fluxos e refluxos de uma imaginação ardente, que poreja sangue e lhe dá a medida, a extensão e a superioridade do espírito. Porque, não há negar, o cientista, isoladamente, fora da têmpora febril do escritor, não obstante a sua visão introspectiva, não teria impressionado dessa maneira. Foi a sua arte de escrever, refletindo-lhe, em lampejos, o trabalho da alma e do cérebro, as fermentações e conflitos interiores, que operou o prodígio. Euclides viu a Amazônia com a consciência do artista e a profundeza do cientista, deixando-nos algumas páginas de tão grande fertilidade de observações, que não se pode hoje emitir qualquer opinião neste domínio sem consultar-lhe a autoridade [...] (MORAES, 1935, p. 10). 
Contudo, o simples aparelhamento analítico propiciado pela ciência não se converteria em atributo suficiente, segundo Péricles Moraes, para que o observador que pretendesse compreender a realidade amazônica alcançasse êxito na sua empreitada. Todos os autores, entre nacionais e estrangeiros, que intentaram empreender análises as mais diversas acerca da região não conseguiram desfazerse dos efeitos que uma natureza singular e imponente da região causava em suas abordagens e deslumbramentos. Segundo a perspectiva analítica do crítico, somente Euclides da Cunha conseguiu reunir e expressar de maneira adequada essa região tumultuária, e graças ao seu estilo. Somente uma apreensão literária aguçada, mesmo em associação com uma análise científica, poderia desvelar os meandros intricados da realidade amazônica. Para o crítico, Euclides da Cunha foi o único que levou a bom termo o entendimento adequado do espaço amazônico. E a prova da sua bem sucedida análise foi o fato de ter surgido uma leva de imitadores logo após a publicação de seus escritos amazônicos.

Mas caberia ao trabalho crítico bem fundamentado fazer a justa separação entre aqueles que, de fato, mais se aproximaram do programa amazônico de Euclides dos demais, reduzidos a meros aproveitadores e imitadores do "estilo alheio". E é precisamente nesse momento da sua análise que Péricles Moraes deixa transparecer os verdadeiros alvos a serem atingidos, ou seja, na medida em que o seu critério passa a separar "gigantes" de "pigmeus" dentro de um leque amplo de autores versados em interpretar a Amazônia, ele mesmo toma uma posição de distanciamento (e de destaque) em meio a todos os autores e, como mecanismo de autolegitimação, escora-se no prestígio de Euclides da Cunha para promover os seus juízos críticos.

[...] Mas se foi ele, deveras, o único que conseguiu, em traços vigorosos e firmes, projetar, nas suas cores vivas e flagrantes, a natureza amazônica, à sua sombra, à sombra da sua glória, cresceu e frondejou uma floresta de imitadores solertes e subalternos, que lhe tentaram decalcar o estilo indecalcável, a forma e a superfície das ideias, copiando-lhe o vocabulário, reproduzindo-lhe os neologismos, deturpando-lhe as intenções, e até, inconscientemente, assimilando-lhe os leves defeitos de composição e de estilística e as imperceptíveis negligências técnicas [...] (MORAES, 1935, p. 10-11, grifos meus).

[...] Porque a Amazônia não é assunto para escritores medíocres. O gigantesco caos amazônico, para ser desvendado e compreendido, requer uma divinação quase profética. Não basta o aparelhamento científico. Para compreender, assimilar e exprimir a complexidade de sua natureza, o escritor precisa ser dotado de um talento verdadeiro, auxiliado por todas as forças do espírito e da vontade, além de possuir, simultaneamente, a faculdade de perceber, de um só lance, as circunstâncias particulares e sensíveis que lhe explicam as influências passadas e presentes [...] (MORAES, 1935, p. 14). 
Ao atribuir a Euclides da Cunha essa capacidade única de associar a visada científica da realidade aos modos literários de desvelar e delinear a Amazônia, Péricles Moraes em muito contribuiu para firmar e reforçar certa representação tradicional da região como um espaço hegemônico da natureza, e em tudo avessa à presença humana. A sua própria linguagem, vez ou outra, tende a incorporar essa perspectiva de uma natureza avassaladora. Pode-se afirmar, portanto, que a adesão às análises de Euclides por parte do crítico apenas reforça aquela sua estratégia inicial, quando, ainda na década de 1920, alinhava-se ao estilo de Coelho Neto como emblema máximo de um fazer literário. O que aparentemente poderia insinuar um passo adiante por parte do crítico nortista ao reconsiderar os escritos de Euclides, ao reconhecer, portanto, a necessidade de junção entre ciência e literatura, na realidade converteu-se em um modo de reação a todo um conjunto de obras literárias e ensaísticas acerca da Amazônia, que então começavam a emergir no bojo de um novo contexto político e cultural dos anos 1930.

Se por um lado, no ensaio de Péricles Moraes há uma gama de autores que podem ser classificados como passadistas, tais como Alberto Rangel, Carlos Vasconcelos, Gastão Cruls e Alfredo Ladislau, por outro há aqueles que de alguma forma aderem ao modernismo, tais como Abguar Bastos, Aurélio Pinheiro, Francisco Galvão, além dos estrangeiros José Rivera e Ferreira de Castro. Peregrino Júnior, por sua vez, é tratado pelo crítico como um escritor que ocupa uma posição intermediária entre aqueles dois grupos, e na medida em que o autor de Matupá incorpora em sua obra os ensinamentos provenientes da obra euclidiana. Porém, o crítico ressalta que Peregrino Júnior comete um grave erro ao elogiar os arranjos modernistas de um poeta como Raul Bopp, em sua Cobra Norato. Péricles Moraes, evidentemente, apressa-se em refutar tal posição de destaque atribuída ao poeta modernista.

Esse vasto conjunto de autores e obras, a despeito das variações estilísticas e dos posicionamentos políticos possíveis de ser identificados em cada um deles, estariam em débito com a pena de Euclides da Cunha. Embora o crítico tenha o cuidado de não nivelar a todos como meros imitadores do autor de Os sertões, porém, no geral, nenhum deles poderia ser equiparado ao modo de abordar a Amazônia tal como logrado por Euclides. Dessa forma, vale salientar certa virulência do crítico quanto ao Inferno verde, de Alberto Rangel, que é injustamente reduzido a um mero imitador do estilo de Euclides (PAIVA, 2011), e o lacônico comentário acerca da obra de Abguar Bastos, A Amaহônia que ninguém sabe (depois Terra de icamiaba), que poderia ajudar a compreensão da região, caso o autor "não imprimisse à sua novela os defeitos e os exageros modernistas, que tanto lhe desprestigiam o encanto e a originalidade" (MORAES, 1935, p. 40). O juízo negativo em relação a essas obras e 
autores, por sua vez, contrasta com os comentários elogiosos aos dois romancistas estrangeiros, ao colombiano José Rivera, em $A$ voragem, e ao português Ferreira de Castro, em $A$ selva. Segundo o entendimento do crítico, nesses romances é possível identificar uma filiação de ambos, mesmo que inconscientemente, ao legado de Euclides da Cunha, principalmente quanto aos modos de representação da natureza e engolfar o elemento humano.

Gastão Cruls, por seu turno, merece um duplo comentário por parte do crítico. Se, por um lado, o seu romance Amazônia misteriosa merece o elogio por ter conseguido aproximar-se o máximo possível de um modo adequado de representação da região, mesmo a obra sendo fruto de um mero exercício de imaginação, por outro, o seu livro de viagem A Amazônia que eu vi, resultado da sua participação na Comissão de Reconhecimento da Fronteira da Guiana Francesa, chefiada pelo general Rondon, gera uma profunda decepção, segundo Péricles Moraes. A Amazônia que Gastão Cruls viu em seu relato de viagem em nada expressa a peculiaridade e a riqueza natural da região, e que tão bem se faz presente em seu romance. Segundo o comentário ácido de Péricles Moraes, Gastão Cruls teria visto melhor a Amazônia quando usa somente a imaginação.

Por outro lado, vale salientar o destaque conferido à obra de Alfredo Ladislau, Terra imatura. Do conjunto de autores e obras listados pelo crítico nesse amplo inventário acerca dos intérpretes da Amazônia, talvez esta obra seja um misto de romance e ensaio que mereceu especial apreço por parte do crítico. $E$ isso na medida em que, na sua avaliação, é a que mais se aproxima daquilo ensinado pelos escritos canônicos do autor de Contrastes e confrontos. $\mathrm{Na}$ visão do crítico, ao mesmo tempo em que o estilo adotado em muito se aproxima dos escritos de Euclides da Cunha, não ocorre com Alfredo Ladislau o que ocorrera com Alberto Rangel, ou seja, há um grau de inventividade maior naquele e que estava ausente neste último.

Entretanto, nesse rol de intérpretes da região existe um autor em particular, que, mesmo contrapondo-se aos escritos de Euclides da Cunha, merece comentários e considerações por parte do crítico. Trata-se de Araújo Lima, autor de Amazônia, a terra e o homem. Conforme os pressupostos estabelecidos por Péricles Moraes, se a influência da obra de Euclides da Cunha foi de tal ordem, a ponto de abrigar sob a sua sombra uma gama variada de outras tantas obras, também não é difícil identificar nesse vasto conjunto de autores a predominância de um par de opostos que se tornou uma espécie de eixo comum a definir os princípios de entendimento da Amazônia: inferno ou paraíso.

É justamente contra essa oposição corriqueira entre "inferno" e "paraíso" que Araújo Lima se rebela e busca refutar em seu ensaio. O médico e escritor 
promove uma reviravolta nos argumentos prevalecentes em todos os autores analisados por Péricles Moraes, ao salientar que não é a natureza amazônica por si só a causa primeira e última dos males que afligem a região e a sua população. Araújo Lima promove um deslocamento do seu enfoque do âmbito da natureza para um patamar propriamente sociológico da questão regional (LIMA, 1975). Nesse movimento rumo a uma abordagem assentada em princípios científicos oriundos de uma antropogeografia, e em detrimento de uma análise meramente literária, o seu livro atinge de maneira fulminante o âmago dos argumentos do crítico, causando certo desnorteio em seu critério classificatório, ao tomar a literatura como chave de entendimento da realidade regional. Todos os argumentos mobilizados no ensaio sociológico de Araújo Lima tendem a afirmar a ciência como a única ferramenta possível para desalojar a região da situação marginal em que se encontrava até então. Não é difícil identificar nos argumentos de Araújo Lima os efeitos políticos daquele contexto dos anos 1930 no plano cultural.

Contudo, embora reconheça a veracidade e a força dos argumentos de Araújo Lima, Péricles Moraes aponta, concomitantemente, uma falha na obra analisada e um meio de preservar o seu autor de referência para a compreensão da Amazônia. $\mathrm{Na}$ medida em que isenta a natureza amazônica como única fonte dos males da região e, ao mesmo tempo, direciona seus argumentos para a inaptidão cultural dos exploradores como a verdadeira causa das mazelas regionais, segundo Péricles Moraes, Araújo Lima teria generalizado a sua acusação para todos os autores que antes se debruçaram sobre o problema amazônico. O crítico salienta, de imediato, a exceção representada por Euclides da Cunha. O autor de $\grave{A}$ margem da história teria sido um dos raros escritores a tratar do problema amazônico de modo a promover, com uma visada científica igualmente aguçada, a relação problemática da terra e do homem. Se a obra de Araújo Lima tem o seu valor, segundo o crítico, este valor está definido no campo específico da ciência. Neste aspecto, a figura de Euclides em nada é maculada, a despeito de posições contrárias estampadas nos dois autores, justamente na medida em que o aspecto literário interessa mais do que o científico. O fato de o livro de Araújo Lima ter sido prefaciado, em 1932, por Alceu de Amoroso Lima, não é um dado menor ou irrelevante para se compreender a inclusão de Amazônia, a terra e o homem no ensaio de Péricles Moraes. Mesmo que seus argumentos contrariem o movimento geral do ensaio do crítico, ao fim e ao cabo, ela também é avaliada como pertencente ao conjunto de obras a delinear uma dada representação da Amazônia. Mas o seu aproveitamento deve se dar à medida que ressalta, por contraste, a força própria da abordagem literária como o elemento mais importante para a definição de uma representação da região. 


\section{CONCLUSÃO}

De todo esse conjunto significativo de autores alinhavados pela crítica rigorosa de Péricles Moraes, no entanto, um nome se faz ausente: Raimundo Moraes. Autor de uma vasta bibliografia acerca da região amazônica, incluindo o seu famoso livro Na planície amazônica, de 1922, ele sequer é mencionado pelo crítico como um autor menor, um pigmeu. Não é difícil compreender essa ausência de Raimundo Moraes da análise de Péricles Moraes, justamente por revelar, de modo bastante expressivo, uma disputa entre esses autores no âmbito regional, no sentido de legitimar suas posições quanto aos critérios de definição de um regionalismo amazônico. É esse pano de fundo de disputas que melhor ilumina a estratégia estampada no modo de constituição não só do ensaio de Péricles Moraes, mas da sua própria trajetória intelectual, filiando-se ora a Coelho Neto, ora a Euclides da Cunha. Tal como a carta de Mário de Andrade deixa transparecer, Raimundo Moraes, por sua vez, também fez as suas alianças. Mas essa já é outra história.

\section{REFERÊNCIAS}

ANDRADE, M. de. Macunaíma: o herói sem nenhum caráter. Rio de Janeiro: Agir, 2008. BARBOSA, J. A. A biblioteca imaginária. São Paulo: Ateliê Editorial, 1996.

BITTENCOURT, A. Dicionário amazonense de biografias: vultos do passado. Rio de Janeiro: Conquista, 1973.

BRAGA, G. Fastígio e sensibilidade do Amazonas de ontem. 2. ed. Manaus: Imprensa Oficial, 1983.

BOURDIEU, P. A identidade e a representação; elementos para uma reflexão crítica sobre a ideia de região. In: O poder simbólico. Tradução de Fernando Tomaz. Lisboa: Difel; Rio de Janeiro: Bertrand, 1989, p. 107-132.

CANDIDO, A. Literatura e sociedade: estudos de teoria e história literária. 8. ed. São Paulo: T. A. Queiroz, 2000a.

A educação pela noite e outros ensaios. 3. ed. São Paulo: Ática, 2000b.

CASTELNUOVO, E.; GINZBURG, C. História da arte italiana. In: GINZBURG, C. A micro-história e outros ensaios. Tradução de António Narino. Rio de Janeiro: Bertrand; Lisboa: Difel, 1991, p. 5-93.

CUNHA, E. da. Contrastes e confrontos. Rio de Janeiro: Record, 1975.

. À margem da história. São Paulo: Martins Fontes, 1999. 
GOMES JÚNIOR, G. S.. Crítica, combate e deriva do campo literário em Alceu Amoroso Lima. Tempo Social, v. 23, n. 2, p.101-133, 2011.

GONDIM, N. O nacional e o regional na prosa de ficção do Amazonas. Leituras da Amazônia, v. II, n. 2, p. 83-125, 2002.

HARDMAN, F. F. A vingança da Hileia; Euclides da Cunha, a Amazônia e a literatura moderna. São Paulo: EDUnesp, 2009.

JOÃO do Rio. O momento literário. Rio de Janeiro: Garnier, [s.d.].

LAFETÁ, J. L. 1930: a crítica e o modernismo. 2. ed. São Paulo: Duas Cidades; Ed. 34, 2000 .

LIMA, A. Amazônia, a terra e o homem. 4. ed. São Paulo: Nacional; Brasília: INL, 1975.

LIMA, L. C. Terra ignota; a construção de Os sertões. Rio de Janeiro: Civilização Brasileira, 1997.

LIMA, N. T. Um sertão chamado Brasil; intelectuais e representação geográfica da identidade nacional. Rio de Janeiro: Revan; IUPERJ, 1999.

LOPES, M. A. No purgatório da crítica: Coelho Neto e o seu lugar na história da literatura brasileira. 1997. 232f. Dissertação (Mestrado em Letras) - Universidade Estadual de Camnpinas, Campinas, 1997.

MAIA, J. M. E. A terra como invenção; o espaço no pensamento social brasileiro. Rio de Janeiro: Zahar, 2008.

MARTINS, W. A crítica literária no Brasil. Rio de Janeiro: Francisco Alves, 1983. 2 v.

MICELI, S. Intelectuais à brasileira. São Paulo: Companhia das Letras, 2001.

MORAES, P. Figuras \& sensações. Porto: Chardron, 1923.

. Coelho Netto e sua obra. Porto: Chardron, 1926.

. Legendas e águas-fortes; ensaios críticos. Manaus: Clássica, 1935.

. Confidências literárias. Rio de Janeiro: O Cruzeiro, 1944.

MORAES, R. O meu dicionário de cousas da Amazônia. Rio de Janeiro: Alba, 1931. 2 v.

NASCIMENTO, J. L. do. Euclides da Cunha e a estética do cientificismo. São Paulo: Unesp, 2011.

PAES, J. P. Gregos \& baianos. São Paulo: Brasiliense, 1985.

PAIVA, M. A. C. de. Um outro herói modernista. Tempo Social. v. 20, n. 2, p. 175-196, 2008.

O sertão amazônico: o inferno de Alberto Rangel. Sociologias, n. 26, p. 322-362, 2011.

PINHEIRO, R. N. Panorama intelectual do Amazonas. Manaus: Governo do Estado do Amazonas, 1999. 
PRADO, A. A. Itinerário de uma falsa vanguarda; os dissidentes, a Semana de 22 e o integralismo. São Paulo: Ed. 34, 2010.

RODRIGUES, L. G. Alceu Amoroso Lima; cultura, religião e vida literária. São Paulo: Edusp, 2012.

SAINT-BEUVE, C.-A. Sobre o meu método. In: SOUZA, R. A. de. Uma ideia moderna de literatura; textos seminais para os estudos literários (1688-1922). Chapecó: Argos, 2011, p. 520-527.

TOLSTOI, L. O que é a arte? Tradução de Yolanda Steidl de Toledo e Yun Jung Im. São Paulo: Experimento, 1994.

VERÍSSIMO, J. Estudos de literatura brasileira. Belo Horizonte: Itatiaia; São Paulo: EDUSP, 1977.

WEBER, M. Economia e sociedade; fundamentos da sociologia compreensiva. Tradução de Regis Barbosa e Karen Barbosa. 4. ed. Brasília: EDUnB, 2000. v. I. 


\section{Da rede urbana às redes virtuais: acesso à internet $\mathrm{e}$ expansão do ciberespaço em Parintins e Itacoatiara}

\section{From the urban network to the virtual network: access to the internet and the expansion of ciberspace in Parintins and Itacoatiara}

Heitor Paulo Pinheiro - Geografo, pesquisador do Núcleo de Estudos e Pesquisas das Cidades na Amazônia Brasileira (NEPECAB/UFAM), Manaus-AM. E-mail: pinheiro. heitor@gmail.com

Tatiana Schor - Professora do Departamento de Geografia e do Programa de PósGraduação em Geografia da Universidade Federal do Amazonas; pesquisadora do Núcleo de Estudos e Pesquisas das Cidades na Amazônia Brasileira. (NEPECAB/ UFAM), Manaus-AM. E-mail: tschor@ufam.edu.br

\begin{abstract}
Resumo
Em um mundo globalizado onde relações por meio de redes - virtuais e físicas - são fatores de suma importância para a expansão tanto das relações sociais e, em especial, as de mercado, o desenvolvimento geográfico desigual se perpetua pelo acesso precário ao mundo informacional. Para se entender as configurações das redes virtuais e urbanas no Amazonas, faz-se necessária a caracterização de suas configurações. Como os dados secundários não são suficientes para descrever as desigualdades geográficas produzidas por essas redes, as idas a campo funcionaram como princípio para a análise da estrutura física existente e da identificação de padrões de semelhanças e diferenças de acesso ao mundo virtual entre os aglomerados urbanos estudados - as cidades de Itacoatiara e Parintins, no estado do Amazonas, Brasil. Informações como número de estabelecimentos que oferecem acesso à rede virtual, o tipo de acesso disponível na cidade, a velocidade do acesso, as formas de oferecimento do serviço e a modalidade de acesso do usuário permitiram identificar os eixos que qualificam a infraestrutura, como oferta e qualidade do serviço, além dos diversos tipos de usuários existentes nas cidades. A partir dos resultados coletados nessas duas cidades, visou-se verificar se há uma relação entre a rede urbana e a rede virtual, contribuindo para a geografia urbana do ciberespaço, um tema ainda pouco explorado pela literatura científica brasileira.
\end{abstract}

\section{Palavras-chave}

Rede virtual. Rede urbana. Parintins. Itacoatiara. Amazonas-Brasil.

\begin{abstract}
In a globalized world where relationships through networking, virtual and physical factors are of paramount importance to the expansion of social relations in particular market, the uneven geographical development is perpetuated by poor access to the world of information. To understand the settings of virtual networks and urban areas in the Amazon, it is necessary to characterize their settings. As secondary data do not take account of describing geographical inequalities produced by these networks, field trips functioned as a principle for the analysis of the existing physical structure and the identification of patterns of similarities and differences in access to the virtual world among urban areas studied, the cities of Itacoatiara and Parintins. Information such as number of establishments offering access to virtual network, type of access available in the city, access speed, ways of offering service and user access mode, possible to identify axes that qualify as infrastructure offering and quality of service, plus of different types of users in the cities. From the results collected in the two cities of Amazonas, the aim was to establish whether there is a relationship between the urban network and the virtual network, contributing to the urban geography of cyberspace yet explored by Brazilian literature.
\end{abstract}

\section{Keywords}

Virtual network. Urban network. Parintins. Itacoatiara. Amazonas-Brazil. 


\section{INTRODUÇÃO}

O conhecimento mais secreto, uma ciência que obsoleta a história, é a ciência do controle sobre as pessoas, governos e civilizações. A fundação dessa disciplina final é o controle da riqueza. Através do controle da riqueza, vem o controle da informacão pública e as necessidades da vida. Através do controle da mídia, vem o controle do pensamento. Através do controle das necessidades básicas, vem o controle físico direto das pessoas. (anônimo...)

Fernando Henrique Cardoso, ao prefaciar o livro "A sociedade em rede", de Castells (2000), reconhece a força do entendimento do mundo, na qual a sociedade em rede se desdobra em "uma nova estrutura social, marcada pela presença e o funcionamento de um sistema de redes interligadas" (CASTELLS, 2000, p. 36). Este "novo" formato de organização social, no qual a sociedade em rede está baseada em um paradigma econômico-tecnológico da informação, que implica em novas práticas sociais, com alterações da própria vivência, do espaço e do tempo como parâmetros da experiência social. Se, de fato, estamos em uma "nova estrutura social" construída pelas redes de comunicação e informação, como se reproduzem as formas de desenvolvimento geográfico desigual (SMITH, ????), essência da modernidade estruturada pelo capital? Afinal, nem todos os lugares têm acesso a este "novo" mundo. A modernização incompleta (SCHWARZ. 1999) ou precária se territorializa de formas diferentes, e como se entende este processo em pequenas e médias cidades na Amazônia brasileira? Como se organiza o espaço virtual, elemento essencial para a participação nesta nova era?

Em um mundo globalizado, onde relações por meio de redes - virtuais e físicas - são fatores de suma importância para a expansão das relações sociais, em especial as do mercado, o desenvolvimento geográfico desigual se perpetua pelo precário acesso ao mundo informacional. A "Era da Informação", termo utilizado pelo próprio Castells (2000) para descrever o novo tempo social, implica em acesso ou não ao mundo globalizado. Associado ao acesso à informação, algumas regiões no globo, neste caso a Amazônia, ainda apresentam uma baixa inclusão no que tange ao acesso de qualidade à rede mundial de computadores e ao ciberespaço. Apesar do carácter virtual da rede mundial, a sua materialização se dá por meio da infraestrutura e suporte de acesso, necessidades a serem superadas para a própria expansão da rede, como pontos de consulta e publicação de material on-line.

Segundo Pires (2004), a materialização do ciberespaço se dá por meio da rede mundial de computadores, a internet, que, além de ser a maior biblioteca da humanidade é um processo que interfere e altera as novas formas de composição do capital nas localidades, cidades e regiões que dispõem de fluxos e conexões em rede. Neste ponto, as formas de composição do capital podem 
ser observadas como o avanço tecnológico e a influência do acesso a esta rede, além da movimentação financeira no investimento em equipamentos receptores desta tecnologia.

$\mathrm{Na}$ atualidade, a falta de conexão com o ciberespaço ${ }^{1}$ e/ou a falta de qualidade da conexão tendem a segregar e a negar o acesso à informação, porém, o uso excessivo leva à alienação dos usuários, além de diversos problemas sociais. Esses problemas podem ser encarados em várias frentes e em diferentes casos, no acesso à banda larga por um lado ou num acesso de menor conexão de outro. No caso das cidades estudadas, as Lan Houses em Itacoatiara e, no caso de Parintins-AM, um centro de gratuito (CINTEC) funcionavam como os únicos pontos de conexão para os que não possuem equipamento próprio, no entanto mantêm um modo de vida virtual. Porém, essas conexões podem ser descritas como insuficientes para a distribuição em Lan Houses e menos eficientes para a distribuição via a Rádio, pela qualidade e instabilidade do sinal.

Em comparação com as redes domésticas em Manaus, onde planos de 10 MB tomam o mercado consumidor, novas faces da internet são descobertas pelo usuário, fomentadas pelo aumento da banda e da qualidade do um sinal disponibilizado. Em Manaus, sites contendo fotos, vídeos e streeming passam de uma utopia para uma realidade impactante nos hábitos do cotidiano. Ao mesmo tempo, o sonho de consumo do Itacoatiarense era obter um modem $2 \mathrm{G}$ com um plano de cobertura móvel ou uma cobertura via rádio, adquirida por um preço que não se justifica, porém é algo que satisfaz as necessidades para o acesso às redes sociais e aos sites que não demandam uma conexão debanda larga.

Tendo em vista a variabilidade das utilidades da internet com o seu grande acervo online, a expansão desta rede com déficit de qualidade limita os usuários a pequenos espaços de uso, onde o dispêndio de tempo em acesso a redes sociais $^{2}$ e similares são resultados da limitação e do desconhecimento das reais funcionalidades da rede. Em contrapartida, a popularização do acesso à banda larga em outros pontos do globo torna-se cada dia mais palpável, transformando-se em outra realidade, modificando assim as percepções de tempo e espaço dos usuários.

Novas tecnologias alteram as nossas percepções, a forma que pensamos sobre o social, político e realidades materiais. Ninguém que vive na sociedade moderna está isolado da tecnologia, das suas promessas, seus terrores e a maneira sutil que modifica as nossas percepções (PAGEL, 1984).

1 Ciberespaço - espaço que existe no mundo de comunicação, em que não é necessária a presença física do homem para constituir a comunicação como fonte de relacionamento, dando ênfase ao ato da imaginação, necessária para a criação de uma imagem anônima, que terá comunhão com os demais.

2 Rede Social - estrutura social composta por pessoas ou organizações conectadas por um ou vários tipos de relações, e que partilham valores e objetivos comuns. 
Como tecnologia militar, a rede mundial de computadores surgiu e foi um marco na modernização da comunicação humana. Cada dia mais utilizada e com mutação muito evidente no que se refere à evolução da tecnologia, no século XXI a internet torna-se o motor de arranque para o funcionamento de todo um mercado global, além da comunicação civil em todas as partes do mundo. Podendo ser descrita como algo que distancia e aproxima as pessoas, a internet tende a tornar relações sociais anteriormente separadas por longas distâncias geográficas parte do cotidiano e, ao mesmo tempo, confinar as pessoas aos seus espaços de liberdade e conexão. Ao se estabelecer uma projeção do avanço desta tecnologia nos próximos 50 anos é difícil imaginar a portabilidade e a funcionalidade da rede na vida humana e a que ponto chegará a sua integração.

\section{EVOLUÇÃO DA TECNOLOGIA E SEUS IMPACTOS NA SOCIEDADE}

Com o desenvolvimento científico, novas tecnologias se vinculam ao cotidiano humano, visualiza-se a portabilidade do acesso à informação como um dos maiores avanços tecnológicos do século XXI. Para se entender a portabilidade, associa-se a evolução do acesso à rede mundial de computadores, partindo dos acessos lentos (discados) e limitados fisicamente ao acesso $3 G$ disponibilizado juntamente com a telefonia móvel. O salto tecnológico não é observado por muitos, mas o desenvolvimento das tecnologias e a disponibilização para a sociedade civil vêm acontecendo de maneira nunca observada na história. O ponto principal, em que a distribuição da informação transforma-se em pilar na grande revolução e ainda com a civilização cada dia mais globalizada, está na individualização dos internautas e no modismo de redes sociais com seus muitos atrativos, talk's e jogos unificando o cotidiano por meio da internet e de atores hegemônicos. Tornase preocupante pensar, também, na falsa necessidade dos seres humanos de um upgrade tecnológico, pois a cada dia são lançadas e criadas novas tecnologias que prendem e alteram a percepção de tempo e espaço dos usuários influenciando inclusive as suas atividades diárias. Fatores como tempo e espaço construídos socialmente ou atualmente são reduzidos a intervalos de acesso a essa rede, onde também são definidas outras atividades a se desenvolver no cotidiano. A internet, hoje, funciona como o principal meio de comunicação muncial, sendo utilizada direta ou indiretamente por todos os seres humanos. Pode-se observar quê: o tempo de conexão das pessoas tende a aumentar à medida que mais conexões são estabelecidas, por meio de vários aparelhos receptores e das tecnologias móveis que inundam o mercado com propagandas e promessas futuristas das aplicabilidades tomando conta do mercado como um fetiche humano. 


\section{Redes, fluxos e o acesso à informação}

Partindo da informática, as redes são formadas pela troca de informações entre duas ou mais estações de trabalho, necessitando de fluxos e fixos para a sua configuração, no caso das redes urbanas, aqui entendidas como " [...] conjunto de

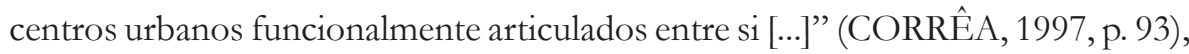
apresentam a mesma dualidade, tendo como base fluxos e fixos na articulação entre pontos físicos (cidades) no espaço. Neste sentido, não basta simplesmente analisar os fluxos; é preciso analisar os fixos, como a infraestrutura necessária para que as redes funcionem. No caso da Amazônia, em especial no seu lado ocidental, a base material das duas redes - a urbana e a virtual - ficam à mercê de condições geográficas e climáticas. A dificuldade de transporte, por um lado, e da implantação de redes de fibra ótica, por outro, limitam o acesso.

Graham e Marvin (2001), ao tratarem do tema da urbanização fragmentada (splintering urbanism), consideram a importância do estabelecimento das redes físicas de acesso ao mundo virtual. Ao analisarem cidades como São Paulo, Los Angeles, Tóquio entre outras, atentam para o fato de que a infraestrutura física é um reflexo da história na organização social e mostram como a instalação das mesmas não se dá de forma similar, não comente na escala regional, mas principalmente na escala da cidade. A desigualdade de acesso às redes físicas e de acesso ao mundo virtual configura espaços desiguais em termos de possibilidades e qualidade de acesso no espaço intraurbano, e que, por sua vez, configuram trechos de rede urbana, nos quais nem todos estão incluídos. Esta característica da urbanização fragmentada traz um elemento novo para a análise, que são os "arquipélagos de grades de fibra ótica" que ligam espaços descontínuos e fragmentam espaços de continuidade/proximidade. Os autores demonstram que por detrás do discurso igualitário e democrático do espaço cibernético há, cada vez mais, o aprofundamento das desigualdades tanto em termos intraurbanos quanto de redes, e que estas desigualdades são geradas pelo próprio sistema que consolida a desigualdade de acesso às diversas infraestruturas necessárias para o funcionamento do sistema, tal como a distribuição de energia.

$\mathrm{Na}$ Amazônia, em especial na Amazônia Ocidental, como é o caso do estado do Amazonas, as desigualdades intraurbanas são acentuadas pela forte polaridade que a rede urbana representa, tendo a capital Manaus como forte elemento concentrador de riqueza e acesso (Figura 1). 
Figura 1 - Variação do Índice de Desenvolvimento Humano Municipal (IDHM, 2000) em relação à malha digital no estado do Amazonas (2005).

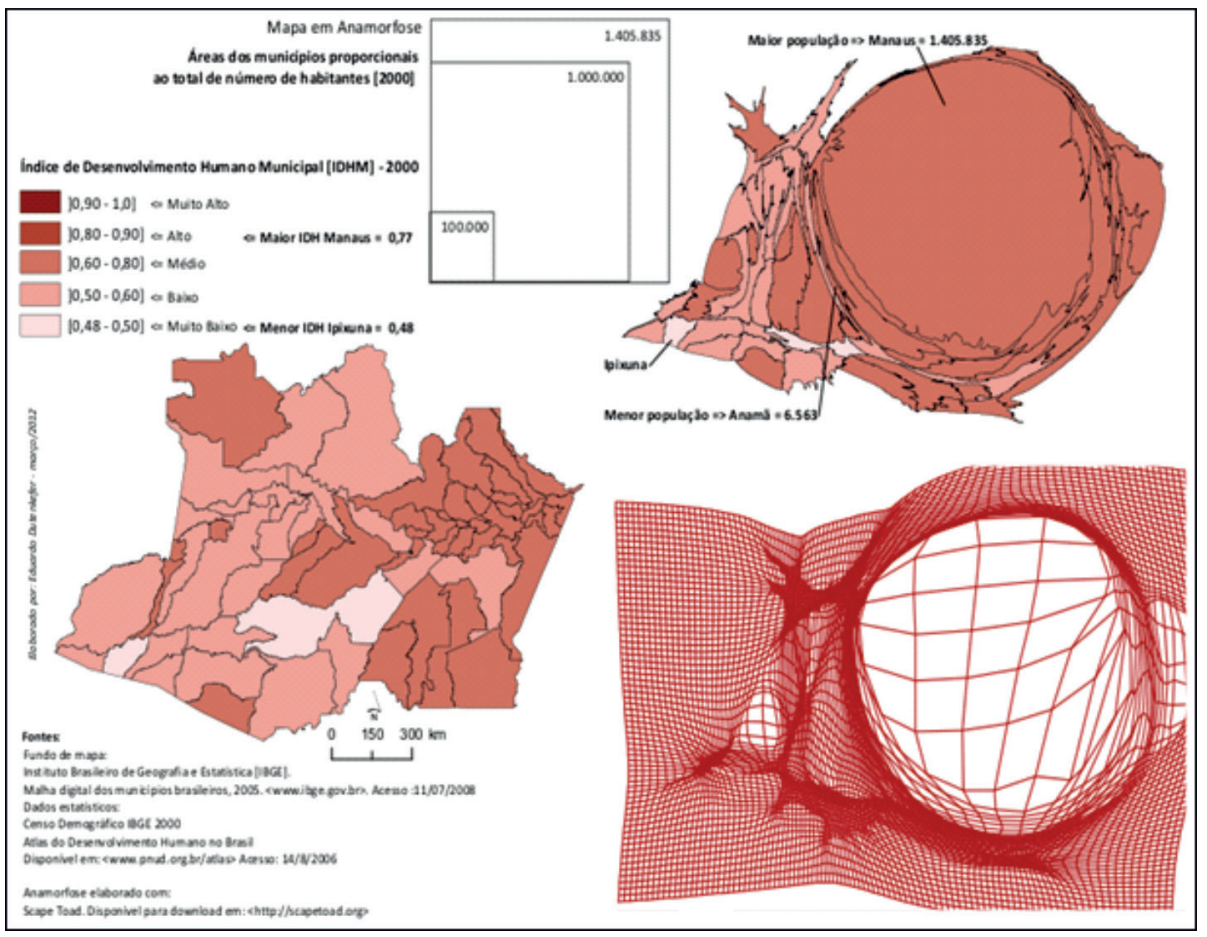

Fontes: Censo Demográfico (IBGE, 2000); PNUD. Elaborado por: Eduardo ???? , 2012.

Neste sentido, para se entender as configurações de ambas as redes, virtuais e urbanas, no contexto atual do estado do Amazonas, tornou-se necessária a caracterização de suas configurações específicas. Como os dados secundários não seriam suficientes para demonstrar e descrever as desigualdades geográficas produzidas por essas redes, a pesquisa de campo foi realizada como princípio para a análise da estrutura física existente e identificação dos padrões de semelhanças e diferenças de acesso ao mundo virtual entre os aglomerados urbanos estudados. Informações como o número de estabelecimentos que oferecem acesso à rede virtual, o tipo de acesso disponível na cidade, a velocidade do acesso, as formas de atendimento e oferta do serviço e a modalidade de acesso do usuário permitiram identificar eixos que qualificam a infraestrutura disponível e qualidade a dos serviços, além dos diferentes tipos de usuários existentes no universo pesquisado. A partir dos dados coletados nas cidades de Itacoatiara e Parintins, no Amazonas, visou-se estabelecer se há uma relação entre a rede urbana e a rede virtual (Figura 2). 
Figura 2 - Localização das cidades estudadas: Itacoatiara e Parintins, Amazonas.

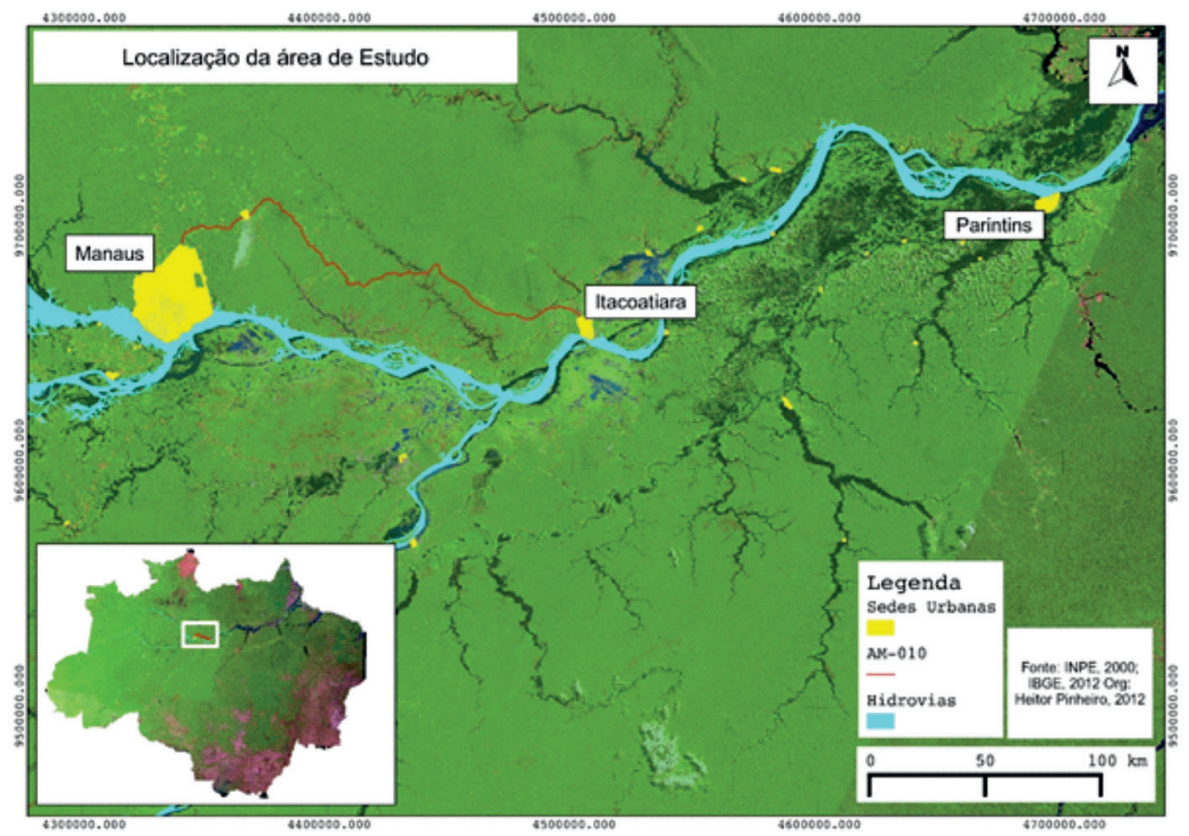

Organização: Heitor Pinheiro.

No escopo deste estudo, compreender as redes urbanas da Amazônia significa reconhecer padrões de diferenças e semelhanças entre as cidades. No caso das cidades estudadas (Parintins e Itacoatiara), a ideia de reconhecer padrões de diferenças e semelhanças está intimamente ligada à situação das cidades como fixos na rede, o que se torna relevante ao analisar redes urbanas no contexto amazônico. Distâncias muitas vezes alargadas pela sazonalidade, o longo tempo e a demora no que se referem à quantidade de modais envolvidos tornam-se "gargalos" para algumas infraestruturas e fluxos. No caso das redes virtuais diretamente ligadas à evolução da tecnologia, o uso de sinal via satélite possibilitou a mobilidade e a conexão com o ciberespaço, mesmo em distantes lugares da Amazônia. A forte presença da telefonia móvel e outros serviços (Bancos e cartões de crédito) fortalecem e se configuram como pontos de acesso à internet via satélite, os quais podem ser identificados e encontrados em toda a região. Em outra escala, a distribuição desta tecnologia para usuários domésticos torna-se um investimento muito alto, a manutenção da infraestrutura, as intempéries e as tarifas cobradas atestam a inviabilidade desta tecnologia para a distribuição doméstica, ainda praticada na cidade de Manaus e no interior do estado do Amazonas. O custo-benefício desta distribuição em relação a outras 
modalidades está diretamente ligado à qualidade do sinal, à velocidade da conexão e ao preço. A distribuição dos serviços de internet em Manaus, em sua maioria é efetuada via cabos, onde a velocidade de conexão doméstica varia de 1 a 100 megabytes, podendo ter variação de preço de R \$ 69,90 a R \$ 499,90 dependendo da necessidade e da renda familiar.

No caso das cidades estudadas, onde há poucas alternativas de conexão, os custos para uma conexão de banda larga com velocidade equivalente a 0,25 Megabytes, em geral, a mensalidade do serviço contratado ultrapassa o valor de $\mathrm{R} \$ 499,00$, podendo chegar a $\mathrm{R} \$ 10.999,00$ para conexões de 2 Megabytes, com base na tabela de preços disponibilizada pelo site da Prime Net, fazendo referência aos planos Prime net Start e Prime Net Top.

\section{Parintins e Itacoatiara no ciberespaço}

A espacialidade dos pontos de acesso à internet, considerando também os tipos de conexão e usuários, possibilitam entender o comportamento da rede física de acesso em uma escala intraurbana. A caracterização da complexidade desta rede permite demonstrar uma situação hierárquica dos fixos (cidades) e reconhecer seus padrões de semelhanças, ponderando, assim, as diferentes realidades no contexto da rede urbana na Amazônia. A identificação dos fluxos internos e a análise dos dados coletados mostram que a relação de dependência entre as cidades referente à conexão de internet se rompe. Historicamente, o acesso à internet no estado do Amazonas apresenta déficits de qualidade, além da prática de preços incoerentes na capital do estado e exorbitantes nas cidades onde há "gargalos" para a aquisição de um sinal de qualidade via cabos. Esses gargalos decorrem das barreiras geográficas (distâncias e sazonalidade), além do pouco investimento para a implantação de uma infraestrutura via cabos.

Dadas essas realidades, algumas instituições que atuam nas cidades organizaram a sua própria rede virtual. Em Parintins, o caso da Universidade Federal do Amazonas (UFAM) e das consultas médicas virtuais realizadas pelo SUS através da Telemedicina, vinculada à Universidade do Estado do Amazonas (UEA), a tecnologia via satélite foi implantada como a única alternativa para a realização dessas atividades. No caso da UFAM, a distribuição do sinal de internet tanto para os alunos quanto para a administração da Universidade melhorou significativamente no ano de 2011, equiparando-se ao da sede em Manaus. Atualmente a UFAM/Parintins-AM possui um link direto, e dispõe de uma conexão de aproximadamente 2 megabytes para atender todas as necessidades das atividades educativas e administrativas da instituição. No caso do SUS, a 
conexão de 3 megabytes é administrada pelo Centro de Informática e Tecnologia (CINTEC), sendo compartilhada com outros pontos de acesso, visto que a banda é alocada na sede onde há consultas virtuais, nos dias de atendimento.

Em Parintins, a distribuição do sinal de internet via Wireless em praças públicas, também por meio do CINTEC, caracterizou a cidade como uma "ilha digital" (LIMA, 2008). Na ocasião, qualquer pessoa residente nas proximidades do ponto de acesso, com equipamento receptor poderia acessar gratuitamente a internet durante 24 horas. Em uma cidade com dinâmica turística, onde o festival folclórico de Parintins atrai um público de grande impacto para a cidade, o governo do estado, juntamente com a prefeitura municipal implantaram em uma das praças da cidade um ponto de acesso gratuito de internet. A tecnologia de Internet WireLAN foi implantada como equipamento urbano anexo à praça, que a partir de então foi intitulada Praça Digital. Mesmo com a disponibilidade deste sinal, a qualidade do serviço (velocidade) deixa a desejar, a conexão destes pontos (Via satélite - Embratel) tende a solucionar os problemas de acesso, porém, a qualidade do serviço oferecido limita o uso do ciberespaço, que vira um simples correio eletrônico. No decorrer da pesquisa de campo nesta cidade o sinal de internet na referida praça encontrava-se desabilitado. $\mathrm{Na}$ ocasião, obtivemos a informação de que o serviço só funciona no período do Festival Folclórico, quando Parintins se transforma em vitrine do governo do estado e de empresas privadas como a Coca-Cola.

Em Itacoatiara, mesmo próxima a Manaus e com acesso rodoviário, o quadro de distribuição dos serviços de acesso à internet é muito limitado, quando comparado à complexidade encontrada em Parintins. No contexto da pesquisa foram identificados pontos de acesso tarifados, porém a prevalência dos serviços de telefonia móvel entra como fator de suma importância para a descentralização e individualização do acesso à internet na cidade, que conta com uma quantidade limitada de pontos de acesso, contudo, Itacoatiara pode ser classificada por haver outros tipos de usuários privilegiando a tecnologia 3G.

A ideia de classificar as cidades de acordo com seus usuários foi interessante e possibilitou verificar que em Parintins há uma maior distribuição de tipos de conexão, enquanto na cidade de Itacoatiara foram encontrados poucos modais de conexão e poucas Lan Houses. A partir desta análise comparativa foram identificadas várias modalidades de acesso à internet, as quais puderam diferenciar as cidades quanto à qualidade e ao tipo de conexão nos serviços de internet. Essas comparações podem indicar o nível de conexão da população destas cidades para com a capital do estado do Amazonas. Sendo assim, ao pensar que uma rede de internet de péssima qualidade limita os usuários, por outro lado, pode-se 
indagar que o tempo a mais para carregar as páginas desejadas prende o usuário a uma máquina com $1 / 3$ da funcionalidade. Visto como um peso, em função do uso, o acesso à internet tende a desequilibrar: em uma extremidade o acesso limitado à rede aliena e prende o usuário pela falta de qualidade e, em outra, o uso excessivo gera problemas sociais, pela grande quantidade de informações e utilidades disponíveis na rede.

\section{Internet, expansão da informação e do ciberespaço}

O acesso à internet não depende somente de cabos de conexão ou sinal de satélite, tornando-se outro gargalo a necessidade de estrutura física individual, vista como parâmetro para o surgimento de uma tipologia de usuários. Os prérequisitos para a conexão foram determinados pela posse ou não de equipamentos capazes de receber e transmitir informações (computadores, celulares, tablets). A aquisição desses aparelhos vem apresentando um grande crescimento, em função da facilidade de acesso ao crédito e a financiamentos por uma parcela da população anteriormente desfavorecida, e que passou a ter condições de adquirir equipamentos para a conexão à internet. Segundo a International Data Coorporation (IDC), somente na América Latina a venda de computadores (notebooks, desktops e netbooks) teve um aumento em 2011, de aproximadamente 13\% em relação a 2010.

No contexto atual de mundialização do capital, os desafios são enormes para os países e economias emergentes, submetidos à sua lógica predominantemente financeira. Além da obrigatoriedade em garantir aos seus habitantes a segurança e a provisão de serviços e equipamentos de uso coletivo, sobretudo nas áreas de saúde, habitação, educação e emprego, essas nações enfrentam um dilema devido à pressão para implementar ações e políticas públicas voltadas à inserção de seus habitantes à "era da informação" (LYON, 1988; PIRES, 2002 apud PIRES, 2004).

No estado do Amazonas foram distribuídos gratuitamente notebooks aos professores da rede pública estadual e em alguns municípios para os professores da rede municipal, os quais têm acesso à rede virtual, visto que em várias escolas foram implantados programas de "Cidadão Digital" visando garantir o acesso à internet aos alunos, professores e funcionários. Porém, este acesso por meio de um link via satélite possibilita uma conexão inferior a 500kbps, limitando o uso de computador por vez para acesso à internet. No período estudado, em nenhuma das cidades encontramos este programa em funcionamento. $\mathrm{Na}$ realidade, não é uma prioridade do governo garantir o acesso gratuito a internet, visto que o grande volume de informações e suas funções sociais podem representar uma ameaça, pela possibilidade de articulação. Um exemplo bem característico ocorreu no Egito, 
onde houve uma articulação em massa da população por meio da internet, para a criação de pontos de encontro e organização de manifestações contra o governo.

Em plena era digital, a falta de acesso e/ou desconhecimento dos meios de informação tendem a consolidar uma falsa ideia de realidade no consciente coletivo da sociedade, visto que os conteúdos informativos estão disponíveis nas mais diversos formatos. Porém, o fato de não se obter informações somente por meio da internet, outras mídias mais acessíveis às populações das várias classes sociais são fatores determinantes para a compreensão da realidade. $\mathrm{O}$ bombardeio de informações por meio da televisão tem um efeito devastador, onde não há possibilidade de escolha da informação, limitando a liberdade do usuário. Tomando como sentido de liberdade a opção de escolha tanto no que se refere ao espaço físico quanto ao acesso à informação, esta se torna o alicerce para o desenvolvimento da sociedade. Nessa perspectiva, tomamos como princípio que a informação é uma modulação de energia que provoca algo diferente em um sistema qualquer e produz, nesse sistema, algum tipo de ação orientada, se nele existir algum agente capaz e interessado em captar e processar os sentidos ou significados daquela modulação (BRIL-LOUIN, 1988; ESCARPIT, 1991; DANTAS, 2001 apud DANTAS, 2006).

Partindo da hipótese de que o acesso à informação é vital para se alcançar formas de desenvolvimento mais eficazes, o acesso a informação para subsidiar a tomada de decisão tanto na vida privada quanto na esfera pública é de suma importância para traçar caminhos socialmente justos. A falta e/ou precariedade de acesso à rede mundial de computadores, tal como ocorre no caso de Parintins e Itacoatiara, implica em fortes condicionantes ao processo de desenvolvimento. Daí a importância de se conhecer a realidade quanto ao acesso à rede mundial em cidades do estado do Amazonas.

\section{A geografia do ciberespaço: criando métodos de análise}

Para a realização desta pesquisa, fez-se necessário desenvolver uma metodologia que permitisse abranger a realidade regional, identificando não somente as variáveis que pudessem ser comparadas no âmbito nacional, mas também que pudessem diferenciar e caracterizar a oferta dos serviços nas cidades-alvo do estudo (Parintins e Itacoatiara). Para tanto, algumas variáveis como a velocidade da conexão e a origem dos links foram levantadas, de modo a espacializar o acesso nas diferentes áreas das cidades, identificando assim a complexidade da rede de acesso nesses municípios.

O modelo utilizado para testar a conexão foi aplicado por meio do acesso aos sites institucionais de utilidade no âmbito acadêmico (CNPq, UFAM 
e FAPEAM). O teste se deu de forma a quantificar o tempo completo de carregamento das páginas através de um navegador livre ${ }^{3}$ (Mozilla Firefox). Foram realizadas atividades como acessar um curriculum na plataforma Lattes, realizar o download de um formulário de matrícula no site da UFAM e acessar a home page* da agência de fomento do estado do Amazonas (FAPEAM). A aplicação de questionáriosa alunos da Universidade Federal do Amazonas em Parintins e da Universidade Estadual do Amazonas em Itacoatiara objetivou identificar o tipo de conexão dos alunos, além dos principais usos da Word Wide Web. A Identificação de padrões de uso, mesmo que em pequena escala, demostraram a centralização dos acessos a pequenos espaços da rede.

Trabalhando apenas com as sedes urbanas dos municípios, a base para a espacialização foi norteada pelos parâmetros censitários urbanos disponibilizados pelo IBGE (2011). A partir da espacialização dos pontos de acesso e o modo de distribuição foi possível caracterizar as formas e as complexidades no acesso à internet nas cidades estudadas.

Os resultados da pesquisa nos permitiram tecer diversas reflexões. Em se tratando de acesso à internet, o estado do Amazonas vem apresentando recentemente um progresso na qualidade da conexão. $\mathrm{Na}$ relação custobenefício, a acesso por um valor menor e uma conexão "honesta" só vieram a ser praticados em meados de 2010, tendo início na capital amazonense. A evolução da tecnologia e dos investimentos realizados tanto pelo setor público quanto pelo privado promoveram mudanças, possibilitando a criação de estruturas tecnologicamente mais modernas, visando a melhoria na qualidade do acesso à rede, porém, somente o acesso não se caracteriza como inclusão digital.

O fato de o acesso à internet necessitar de aparato físico e tecnológico, sendo preciso adquirir aparelhos de telefonia e computadores, resulta na identificação de uma tipologia de usuários por modal de acesso. A divisão dos usuários da word wide web ${ }^{4}$ em doméstico (por meio de pequenos servidores locais via rádio), móvel (no caso das operadoras de telefonia), cibercafé (lan Houses) e wireless (por meio de acessos gratuitos em universidades, praças e estabelecimentos afins) surgiu como resultado da pesquisa.

Identificados ou não pela realidade socioeconômica das cidades, a complexidade dos fluxos foi um fator determinante para a caracterização destas como cidades distintas. Com uma rede mais adensada e mais oferta de serviços de conexão, mesmo que de baixa velocidade, Parintins se destaca como uma cidade incluída no

3 Software livre, segundo a definição da Free Software Foundation, é qualquer programa de computador que pode ser usado, copiado, estudado e redistribuído sem restrições.

4 A World Wide Web é um sistema de documentos em hipermídia que são interligados e executados na Internet. 
contexto digital, apresentando todos os tipos de usuários. Em comparação, a cidade de Itacoatiara possui uma estrutura limitada a pontos tarifados, apresentando apenas usuários móveis, de cibercafés e wireless por meio das Universidades.

Fortalecido pelo custo beneficio, onde o acesso móvel se torna alternativa barata e funcional, a pouca diversidade de modais de acesso na cidade de Itacoatiara pode ser descrita por meio da individualização do acesso. Com o surgimento da internet móvel, por meio de empresas de telefonia, houve um acréscimo na pouca diversidade de planos oferecidos, aumentando assim o leque de escolhas da população. Planos pré pagos, a partir de $\mathrm{R} \$ 9,90$, tornam o acesso à internet popular e pessoal. Por meio de aparelhos de telefonia móvel pode-se ter funcionalidade no acesso as redes virtuais e correio eletrônico, atualmente polos de atração de internautas. Em relação à velocidade de conexão, às redes sociais e sites de suave navegação tornam-se necessários para o acesso em ambas as cidades, mesmo com a tecnologia móvel de conexão dispensando as distâncias geográficas, no contexto intraurbano, falta de redes via cabos torna inviável a visualização de sites modernos, reprodução de vídeos e downloads, mesmo que de pequenos artigos.

No passado, alguns estabelecimentos com a função de servidores privados (Lan Houses) assumiam uma grande centralidade no que tange ao acesso popular à internet. Porém, o aumento das vendas de computadores domésticos e notebooks, além da telefonia móvel, aqueceu a economia brasileira no ano de 2010, rompendo a primazia destes estabelecimentos, e com a chegada da tecnologia de acesso móvel, esses espaços ficaram limitados aos jogos em rede.

Atualmente, são poucas as modalidades de acesso praticadas tanto na capital do estado quanto no interior. A classificação dos modos de acesso desde a internet discada "lenta" praticada por empresas de telefonia fixa, até o acesso móvel "3G" oferecido pelas empresas de telefonia móvel tornam-se marcos da descentralização dos serviços no contexto amazônico. O acesso à "Banda Larga" via fibra ótica foi impulsionado no ano de 2010, porém, apenas na cidade de Manaus, com a chegada dos cabos óticos de origem venezuelana. A análise espacial e qualitativa do comportamento e forma desta rede nas cidades estudadas (Itacoatiara e Parintins) são reflexos de suas localizações e inserções na rede urbana da Amazônia.

A análise dos dados coletados em campo teve como objetivo identificar os pontos de maior velocidade de acesso à internet, além do valor do serviço oferecido e da origem dos sinais, os tipos de distribuição foram analisados. No caso da cidade de Parintins, com uma complexidade identificada pela quantidade de estabelecimentos além de uma infraestrutura de distribuição de sinal via rádio, pode ser considerada uma cidade incluída no contexto digital, porém com necessidade de melhoria de conexão. A partir da instalação de infraestrutura para 
viabilizar o acesso à rede em praça pública em 2008, Parintins foi considerada uma das primeiras "Cidades Digitais" do Brasil (MELO; SCHOR, 2008), mais especificamente reconhecida como a "Ilha Digital do Amazonas. Para melhor compreender esta realidade, descrever-se-á a rede virtual em cada uma das cidades. para então compreendê-las no contexto da rede urbana.

\section{A rede virtual em Parintins}

Possuindo oito estabelecimentos, entre servidores e lan houses, a cidade de Parintins possui uma estrutura diversificada de distribuição de sinal de internet. Porém, a qualidade do sinal distribuído na cidade deixa a desejar em relação a outras de mesmo porte em outras regiões do Brasil. Tendo como fonte de acesso, em sua maioria links da Embratel, a cidade de mais de 100 mil habitantes, com base no censo 2010, possui uma conexão dividida em poucos pontos de acesso que variam de 300 kbytes a 3 megabytes (Tabela 1).

Tabela 1 - descrição das Lan houses em Parintins, AM, 2011.

\begin{tabular}{|c|c|c|c|c|c|c|c|c|c|}
\hline Georreferenciamento & \multicolumn{5}{|c|}{ Dados Gerais } & \multirow{2}{*}{$\begin{array}{c}\text { Velocidade } \\
\ldots\end{array}$} & \multicolumn{3}{|c|}{ Tempo de download (minutos) } \\
\hline Nome & Serv & Lan & Preço/hora & Ano de instalação & LINK/Provedor & & UFAM & CNPq & FAPEAM \\
\hline CINTEC & $\mathrm{x}$ & $x$ & 0 & 2010 & EMBRATEL & $3 m b$ & 1 & 2 & 1 \\
\hline REDE JAPAN PROVEDOR DE INTERNET & $x$ & $x$ & 1,5 & 2009 & Parintins NET & $1 \mathrm{mb}$ & 2 & 3 & 2 \\
\hline GIGANET 1 & & $\mathrm{x}$ & 1,5 & 2008 & EMBRATEL & $1 \mathrm{mb}$ & 2 & 3 & 1 \\
\hline PRAÇA DIGITAL & & $\mathrm{x}$ & 0 & 2008 & CINTEC & $3 m b$ & $\mathrm{x}$ & $\mathrm{x}$ & $\mathrm{x}$ \\
\hline PARINTINS NET & $\mathrm{x}$ & $x$ & 3 & 2008 & SKYNET & $\ldots$ & $\mathrm{N}$ & $\mathrm{N}$ & $\mathrm{N}$ \\
\hline NETSHOP AVFRAM & & $\mathrm{x}$ & 2,5 & 2007 & Parintins NET & $512 \mathrm{kbps}$ & 3 & $\mathrm{~N}$ & $\mathrm{~N}$ \\
\hline FOXNET & & $x$ & 1,5 & 2009 & Embratel & $700 \mathrm{kbps}$ & 3 & $\mathrm{~N}$ & 2 \\
\hline GIGANET2 & & $x$ & 1,5 & 2011 & Embratel & $300 \mathrm{kbps}$ & $x$ & $x$ & $x$ \\
\hline
\end{tabular}

Fonte: Trabalho de campo (abril e julho, 2011).

A complexidade encontrada em Parintins refere-se à distribuição do sinal por meio de servidores privados, sendo redistribuído via rádio para os pontos de acesso wireless públicos, entre outras modais de conexão. A cidade possui todos os tipos de usuários, inclusive domésticos. A velocidade de navegação aos sites deixa a desejar, tendo velocidade muito inferior em comparação à capital amazonense. A medida indicada na Tabela 1 mostra o tempo de conexão para cada site em minutos, além de uma qualificação dos estabelecimentos em servidores, Lan houses ou servidores e Lan houses.

Para entender a complexidade e comparar a distribuição de internet no âmbito intraurbano nas duascidades, surgiu a necessidade de representar espacialmente as informações coletadas. Como resultado desta espacialização, foram produzidos diversos mapas que fomentam a análise e possibilitaram a sintetização em um modelo da complexidade da malha de distribuição de internet encontrada nas cidades estudadas (Figura 3). 
Figura 3 - Distribuição espacial do acesso à internet em Parintins, 2011.

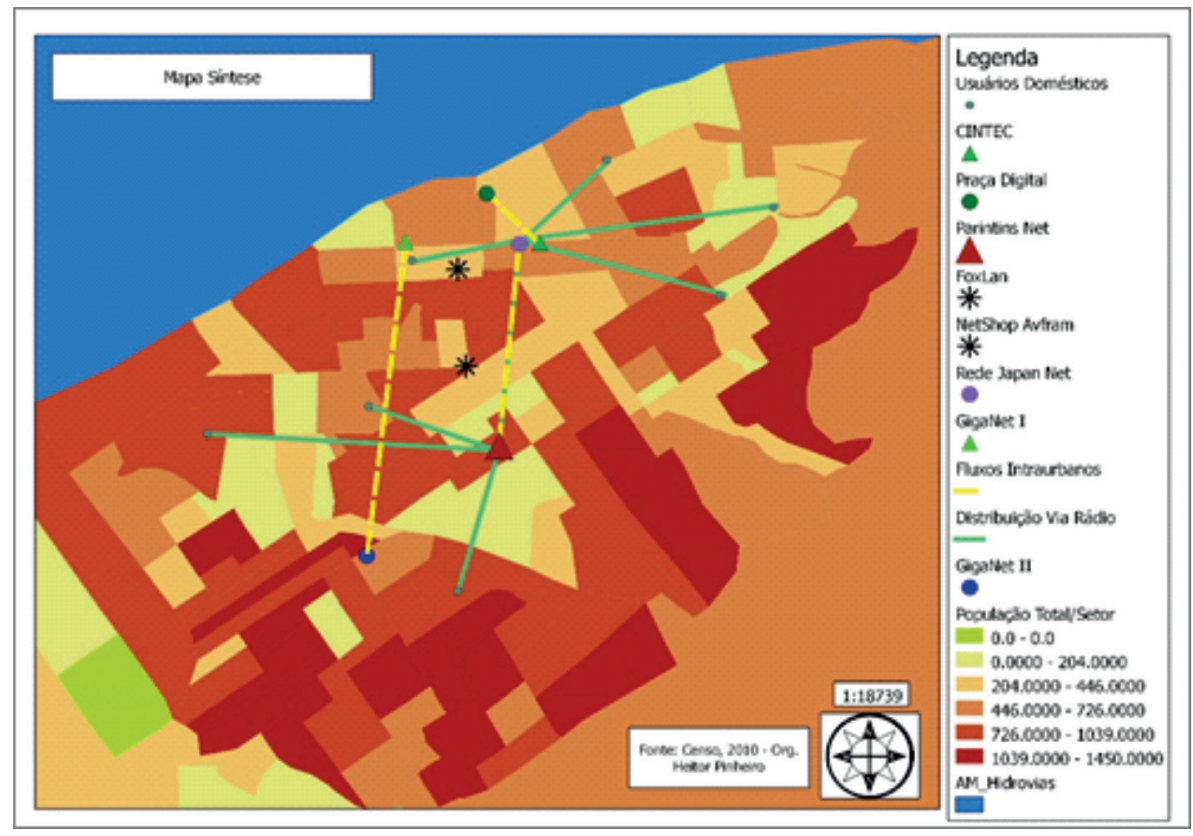

Fonte: IBGE (2011) e banco de dados NEPECAB (2011).

A partir desta representação, demostra-se a complexidade da conexão na cidade de Parintins, onde há uma maior densidade na sua malha de distribuição de sinal e pontos de acesso. A identificação por meio deste modelo busca demostrar como está distribuída a infraestrutura de acesso à internet comparando também a oferta em relação à densidade populacional do município.

\section{A rede virtual em Itacoatiara}

A cidade de Itacoatiara, diferentemente de Parintins, não possui uma complexidade de distribuição de sinal de internet. No decorrer da pesquisa de campo realizada me 2011, foram identificados apenas três estabelecimentos que ofertavam o serviço de acesso à internet, porém cobravam preços tarifados e tinham apenas com a função de lan houses. A conexão da cidade, em detrimento da qualidade, tem velocidade e estabilidade inferior à demanda. Com aproximadamente 90 mil habitantes, o município de Itacoatiara dispõe pontos de conexão de aproximadamente 1 megabyte, distribuído pelo centro e orla da cidade, excluindo-se as conexões móveis, o que caracteriza uma baixa inclusão digital (Tabela 2, Figura 4). 
Em Itacoatiara foram identificados somente usuários de lan house e móveis, portanto a cidade necessita de conexão de maior velocidade, em vista da sua ligação terrestre com Manaus. Os três estabelecimentos identificados na cidade dispõem de conexão via satélite de baixa velocidade, não sendo possível a quantificação de um estabelecimento, durante o trabalho de campo, devido às condições climáticas naquela ocasião.

Tabela 2 - Caracterização dos serviços ofertados em Lan houses em ItacoatiaraAM, 2011.

\begin{tabular}{|l|c|c|c|c|c|c|c|c|c|}
\cline { 2 - 10 } \multicolumn{1}{c|}{ Georreferenciamento } & \multicolumn{4}{c|}{ Dados Gerais } & \multicolumn{2}{c|}{ Velocidade } & \multicolumn{2}{c|}{ Tempo de download (minutos) } \\
\hline Nome & Serv & Lan & Preço/hora & Ano de instalação & LINK/Provedor & $\ldots$ & UFAM & CNPq & FAPEAM \\
\hline PLUGADOS LAN HOUSE & & $\mathrm{X}$ & 2 & 2011 & EMBRATEL & $2 \mathrm{MB}$ & 3 & 3 & 1 \\
\hline FERRARI CYBER LAN & & $\mathrm{X}$ & 2 & 2008 & $\mathrm{~N}$ & $1 \mathrm{MB}$ & $\mathrm{N}$ & $\mathrm{N}$ & $\mathrm{N}$ \\
\hline PARK CYBER CAFÉ & & $\mathrm{X}$ & 2 & 2006 & RURALNET & $0,7 \mathrm{MB}$ & 3 & $\mathrm{~N}$ & 2 \\
\hline
\end{tabular}

Fonte: Trabalho de campo (abril e julho, 2011).

Figura 2 - Distribuição espacial do acesso à internet em Itacoatiara, 2011.

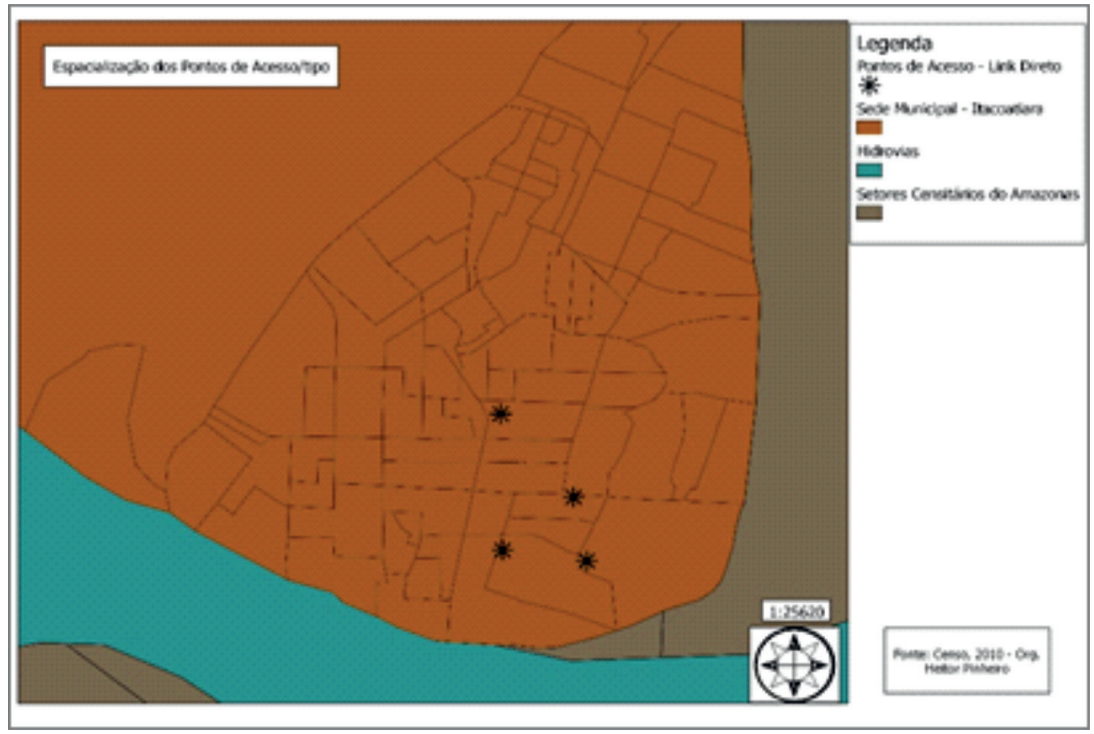

Fonte: IBGE (2011) e banco de dados NEPECAB (2011).

A cidade de Itacoatiara, mesmo com a proximidade e a facilidade de comunicação com Manaus, apresenta uma baixa densidade de distribuição, caracterizando assim, hierarquicamente, como uma cidade não incluída ou com baixo nível de inclusão ao meio digital. Como hipótese para a pouca oferta de infraestrutura surge a individualização do acesso como causa para o desaparecimento das infraestruturas físicas anteriores. 


\section{CONCLUSÃO}

Por fim, o cenário da conexão à internet no interior do estado do Amazonas apresentou melhorias quanto ao leque de pontos e modalidades de acesso ao ciberespaço. Porém, somente o acesso a internet não pode ser considerado inclusão digital. O surgimento de novas tecnologias e o apoio para a elaboração de políticas públicas coesas para esses lugares, configuram-se como esperança para o desenvolvimento tanto científico e tecnológico quanto para a capacitação e conexão desses lugares com o mundo. Com uma capacidade de transformação maior, as redes virtuais têm dinâmicas e mutação acelerada em relação às redes urbanas (física). Transformações como o surgimento e desaparecimento de novos fixos, fluxos e centralidades em ambas as redes são processos existentes. Porém, a dinamicidade em relação temporal entre as duas redes despertam o interesse de entender a rede urbana da Amazônia a partir de uma ótica de conexão e qualidade de acesso ao ciberespaço, buscando entender, ainda, o comportamento e a distribuição dos pontos de acesso à internet na Amazônia.

Com relação a uma leitura de rede urbana a partir das análises aqui empreendidas, podemos afirmar que, embora ambas as cidades estejam localizadas na mesma calha de rio, não pertencem à mesma rede urbana, quando visualizada a rede virtual. A tipologia proposta por Oliveira e Schor (2010) e Schor e Costa (2011), na qual consideram Itacoatiara como cidade intermediária e Parintins como de dinâmica econômica externa, pode e deve ser revista. Parintins tem uma dinâmica intraurbana que reflete muito mais uma classificação do tipo "responsabilidade territorial", na qual se pode perceber a sua importância quanto à organização de microrrede urbana e a sua autonomia com relação às redes virtuais. Já Itacoatiara é, de fato, intermediária, pois a baixa complexidade de sua rede virtual intraurbana expressa uma possível dependência em relação a Manaus.

Buscamos evidenciar, com esta análise, a relevância da análise detalhada e espacializada do acesso à rede virtual para os estudos intraurbanos na Amazônia, considerando a diversidade das cidades ou, como afirma Trindade Jr. (2011) a urbanodiversidade. Esta análise permite tecer reflexões acerca da rede urbana, evidenciando que o interesse em compreender a rede urbana na região requer necessariamente estudos mais aprofundados sobre o espaço intraurbano.

Ainda na discussão sobre a "nova estrutura social" implicada pela generalização do acesso à informação via internet, percebe-se o quão desigual e diferenciado este acesso se dá e como as estruturas de rede urbana implicam e reforçam as desigualdades do desenvolvimento geográfico que determinam as disparidades e contradições no processo de modernização do território. 
Assim sendo, com este estudo sobre a distribuição e dinâmica espacial dos acessos à internet em Parintins e Itacoatiara, pretende-se contribuir para o conhecimento sobre a geografia do ciberespaço, em razão desta temática ser ainda pouco explorada pela literatura científica brasileira.

\section{AGRADECIMENTOS}

Ao CNPq, pelo apoio à pesquisa de campo - projeto CT-AMAZÔNIA/ CNPq. Proc. Número: 575780/2008; e pelo PRONEX-FAPEAM/CNPq. Proc. Número: 1055/2011.

\section{REFERÊNCIAS}

Espaço-tempo na metrópole: a fragmentação da vida cotidiana. São Paulo: Contexto, 2001.

CASTELLS, M. A sociedade em rede. Tradução de Roneide Venâncio Majer. São Paulo: Paz e Terra, 2000.

CARDOSO, A. C. D., LIMA, J. J. F. - A influência do governo federal sobre cidades na Amazônia: os casos de Marabá e Medicilândia. Novos Cadernos NAEA. v. 12, n. 1, p. 161-192, jun 2009

CORRÊA, R. L. O espaço urbano. São Paulo: Ática, 2002.

Estudos sobre a rede urbana. Rio de Janeiro: Bertrand Brasil, 2006.

Trajetórias Geográficas. Rio de Janeiro: Bertrand Brasil, 1997.

DANTAS, M. Informação como trabalho e como valor. Revista Soc. Bras. Economia Politica, Rio de Janeiro, n .19, p 44-72, dez., 2008.

LIMA, S. P. M. de; SCHOR, T. Parintins, a "ilha digital" na calha do rio Amazonas: uma análise da distribuição espacial da infraestrutura de comunicação na calha SolimõesAmazonas. Espaço \& Geografia, v. 11, n. 2, p. 157-183, 2008.

SANTOS, M. Espaço e método. São Paulo: Nobel, 1985. (Coleção espaços).

SCHWARTZ, R. Sequências Brasileiras. São Paulo: Companhia das Letras, 1999.

SEN, A. K. Desenvolvimento como liberdade. São Paulo: Companhia das Letras, 2000.

SPOSITO, M. E. B. Capitalismo e urbanização. 10. ed. - São Paulo: Contexto, 2000.

TRINDADE JR., S-C. C. Diferenciação territorial e urbano diversidade: elementos para pensar uma agenda urbana em nível nacional. Cidades, Presidente Prudente, v. 7, p. 227-225, 2011.

PIRES, F. H. A Geografia da internet e do ciberespaço na América Latina. In: Encontro de Geógrafos da América Latina 10. 2004. São Paulo. Anais... São Paulo: EGAL, 2004.

ZMITROWICZ, W. G. Infraestrutura urbana. São Paulo: EPUSP, 1997. 36p. 


\section{As coletividades ambivalentes em contextos de justiça social}

\section{Collectivities ambivalent contexts of social justice}

Alex Pirzio da Silva - Universidade Federal de Tocantins (UFT). Doutorado em Ciências Sociais. Universidade do Vale do Rio dos Sinos, UNISINOS. Mestrado em Ciências Sociais. Universidade do Vale do Rio dos Sinos, UNISINOS. Graduação em Ciências Sociais. Universidade do Vale do Rio dos Sinos, UNISINOS. E-mail: alexpizzio@gmail.com

\section{Resumo}

Este artigo é fruto de uma pesquisa realizada no ambiente urbano com trabalhadores informais de rua no Vale do Rio dos Sinos. Trata-se de uma população que se apresenta envolta em uma multiplicidade de conflitos e demandas sociais que permitem pensar a desigualdade com base em seus condicionantes econômicos, políticos e culturais. Como aporte teórico conceitual recorreu-se, ao princípio normativo de paridade participativa, formulado por Nancy Fraser, por entender ser ele capaz de dissolver as hierarquias e estabelecer situações em que os sujeitos e grupos possam interagir em condições de igualdade. Em decorrência, o objetivo geral da tese consistiu em refletir sobre a justiça social, fundamentalmente no que se refere ao tratamento institucional dispensado a grupos e sujeitos por ocasião da partilha de recompensas e ônus sociais. Os resultados da pesquisa indicam que matrizes culturais atuam no estabelecimento de hierarquias valorativas e na manutenção e reprodução de situações de desigualdade social. O trabalho surge então como um bem de acesso que lida com formas de dominação, expressa valores, constitui microambientes e se desdobra em uma relação dialética que repercute no status adquirido e atribuído a quem dele participa.

\section{Palavras-chave}

Justiça social, redistribuição e reconhecimento, paridade participativa, matrizes culturais, conflito difuso.

\begin{abstract}
This articleis base don a survey conducted in informal urbanenvironmentwithstreetworkersat Vale do Rio dos Sinos. This is a population that present swrapped in a multitude of conflict sand social demands for considering inequality base Don their economic, politicaland cultural conditions. As a conceptual theoretical framework weused, thenormativeprincipleofparticipatoryparity, formulatedby Nancy Fraser, tounderstandthathecan dissolve hierarchiesandestablishsituations in whichindividualsandgroupscaninteractonequalterms. As a result, the overall aimofthethesiswastoreflecton social justice, primarilywithregardtotheinstitutionaltreatmentofthegroupsandindividualsduringthesharingofrewardsand social burden. The surveyresultsindicatethat cultural matricesact in establishingevaluativehierarchiesandthemaintenanceandreproductionof social inequalitysituations. The jobthenappears as a wellaccessthatdealswithformsofdomination, values expressedconstitutesmicroenvironmentsandextends in a dialecticalrelationshipthataffectstheacquiredandassignedtohimwhoparticipates status.
\end{abstract}

\section{Keywords}

Social justice, redistributionandrecognition, participatoryparity, cultural matrices, diffuseconflict. 


\section{Senhor Amleto Henrique Ferreira-Dutton:}

Mas vejamos bem, que será aquilo que chamamos de povo? Seguramente não é essa massa rude, de iletrados, enfermiços, encarquilhados, impaludados, mestiços e negros. A isso não se pode chamar um povo, não era isso o que mostraríamos a um estrangeiro como exemplo do nosso povo. O nosso povo é um de nós, ou seja, um como os próprios europeus. As classes trabalhadoras não podem passar disso, não serão jamais povo. Povo é raça, é cultura, é civilização, é afirmação, é nacionalidade, não é o rebotalho dessa mesma nacionalidade. Mesmo depuradas, como prevejo, as classes trabalhadoras não serão jamais o povo brasileiro, eis que esse povo será representado pela classe dirigente, única que verdadeiramente faz jus a foros de civilização e cultura nos moldes superiores europeus - pois quem somos nós senão europeus transplantados. (João Ubaldo Ribeiro, em viva o povo brasileiro)

\section{INTRODUÇÃO}

A história da região do Vale do Rio dos Sinos confunde-se com a do município, atualmente conhecido como São Leopoldo. Povoada inicialmente por açorianos, era um vilarejo quando, no ano de 1824, aportou o primeiro grupo de imigrantes alemães oficialmente enviados para colonizar a região. Inicialmente, eles se estabeleceram na Real Feitoria do Linho Cânhamo ${ }^{1}$, situada à margem esquerda do Rio dos Sinos.A localidade, ocupada inicialmente por negros ${ }^{2}$ escravos passou a ser conhecida como Colônia Alemã de São Leopoldo. Intergrada a uma região de mais de mil quilômetros quadrados, a colônia estendia-se indo em direção sul-norte de Esteio até o Campo dos Bugres (atualmente Caxias do Sul), e em direção leste-oeste, de Taquara até o Porto dos Guimarães, no Rio Caí (atualmente São Sebastião do Caî). Com a contínua chegada de imigrantes, a região foi ocupada em sua totalidade. Em decorrência, houve um amplo desenvolvimento da Colônia Alemã que, apenas 22 anos após sua fundação, se emancipou de Porto Alegre. Segundo fontes oficiais ${ }^{3}$, concorreu para esse acontecimento, o fato de serem os alemães, além de landmänner(agricultores),

Empreendimento agrícola falido em que se processava o cânhamo, utilizado sobretudo na fabricação de cordas.

2 Segundo, Menz (2005), desde a transferência da Real Feitoria Linha Cânhamo, originariamente estabelecida em Canguçu Velho, a região passou a ser habitada e modificada por negros. A presença do negro na região ensejava situações conflitos que envolveram, além de atos de resistência, articulação com a Corte em Porto Alegre. Por outro lado, após a chegada dos imigrantes e o início da colonização, há diversos relatos de conflitos entre os imigrantes, os negros e os chamados bugres. Um maior detalhamento dessas questões pode ser obtido consultando os arquivos de noticias históricas do Museu Histórico Visconde de São Leopoldo.

3 Descrição histórica apresentada em site oficial da cidade de São Leopoldo. Disponível em: $<$ http://www.saoleopoldo.net/cidade.php> 
também handwerker (artesãos). Para historiadores como Muller (s/d) ${ }^{4}$, ademais da ética do trabalho atribuída ao imigrante, devem ser considerados, algumas características culturais a ele relacionadas, tais como a disciplina e o caráter associativo.

Essa maneira de conceber e explicar o desenvolvimento da região encontra-se difundida na população, para quem o trabalho e outras caracteristicas, associadas ao imigrante, constituem fonte de progresso econômico e moral ${ }^{5}$, o que pode ser constatado nos dados coletados neste estudo. Também se observa a presença desses elementos em simbolos cívicos na região. Em relação a essas questões, é importante que não se perca de vista o papel que os símbolos, cívicos ou não, representam na vida e na cultura dos povos, tema largamente debatido na antropologia ${ }^{6}$.

O Vale do Rio dos Sinos conforma um campo de pesquisa singular em virtude de suas especificidades históricas, culturais e políticas. Neste artigo, o campo político é definido, a exemplo de Fraser (2008), como o lugar em que se disputam lutas por redistribuição e reconhecimento; em outras palavras, ele é um espaço de conflitos. A essas questões incorporam-se outras, que dizem respeito ao momento atual do vale. A região em foco, atualmente, é formada por quatorze municípios agregados em torno de uma unidade geopolítica de planejamento, o Conselho Regional de Desenvolvimento (Corede), Além dos elementos já destacados as características da região para o estudo proposto assentam-se na sua localização da mesma em um eixo produtivo que se estende desde a região metropolitana de Porto Alegre, com concentração industrial diversificada e um recente desenvolvimento acelerado que acentua a diversidade e a heterogeneidade da composição de municípios da região, até a encosta da serra gaúcha.

Em virtude desse cenário, entendeu-se que o mercado informal de trabalho podia constituir um campo fecundo para de pesquisa, pois, se caracteriza por ser um campo extremamente conflituoso, em que as questões relativas às coletividades ambivalentes estão presentes ${ }^{7}$.

No campo teórico-conceitual, o artigo se apoia nos estudos de Nancy Fraser $(2001 ; 2006 ; 2008)$, onde há um profundo debate em torno do princípio normativo de paridade participativa, que, para ela, representa a forma justa de

Para ampliação da descrição de época, ver Muller (s.d.).

5 No capítulo anterior, debateu-se por meio de outras referências, aspectos que apresentam o mesmo núcleo comum a essas questões.

6 Um estudo já clássico sobre a cultura e os símbolos foi apresentado em Gertz (1973), publicado na obra: A interpretação das culturas.

A opção pelo mercado informal do Vale dos Sinos ensejou um recorte em termos espaciais. Neste sentido, elegeu-se uma faixa territorial à margem da BR-116 - principal via de integração da região -, composta pelos municípios de Novo Hamburgo, São Leopoldo e Sapucaia do Sul. 
tratamento a ser dispensado às pessoas. A paridade participativa possibilita que as pessoas interajam socialmente em igualdade de condições. Contudo, o próprio princípio sugere que situações de justiça social estão implicadas com a apropriação e a distribuição de bens. Assim, existe uma multiplicidade de bens e de métodos de distribuição que variam de acordo com a esfera em questão (WALZER, 2003). Em outras palavras, a justiça social não envolve um único bem, um lócus específico ou uma forma única de compartilhar as riquezas sociais.

Nesta perspectiva, atualmente, parece que as reivindicações de justiça social se dividem, cada vez mais, em dois tipos. O primeiro, mais conhecido, relaciona-se as reivindicações redistributivas que pretendem uma distribuição mais justa dos recursos e da riqueza. O segundo tipo de reivindicação por justiça social refere-se à política de reconhecimento, e seu objetivo, em sua forma mais aparente, é um mundo que aceite a diferença. Diante desse cenário Fraser (2006) aponta a possibilidade de desenvolvimento de um novo paradigma de justiça social que integrem as duas reivindicações, em vez de separá-las, uma vez que esses conjuntos de reivindicações aparecem dissociados tanto na prática como intelectualmente.

Em alguns casos, entretanto, essa dissociação constitui-se em polarização. Nesse sentido, observa-se que alguns proponentes da redistribuição rechaçam de pronto a política do reconhecimento, considerando as reivindicações pelo reconhecimento da diferença uma falsa consciência, verdadeiros óbices à consecução da justiça social. Do mesmo modo, os defensores das políticas de reconhecimento desdenham as políticas de redistribuição, citam o fracasso do igualitarismo em garantir a justiça social as mulheres e as minorias, e consideram a política distributiva como um materialismo fora de moda, incapaz de articular ou questionar as novas experiências de injustiça (FRASER, 2006).

Contra essa bipolarização de reivindicações opõe-se Fraser (2001), na obra Da redistribuição ao reconhecimento? Dilemas da justiça na era pós-socialista ${ }^{8}$ a autora faz um diagnóstico dos conflitos políticos do final do século XX, ressaltando que a mudança paradigmática na agenda dos movimentos sociais conduziu a um deslocamento das demandas por redistribuição para a emergência de lutas por reconhecimento. Os discursos por justiça social, que outrora se centravam na distribuição, atualmente apresentam-se cada vez mais divididos entre reivindicações de redistribuição e reivindicações por reconhecimento.

8 Este trabalho, apresentado primeiramente em Justice interruptus: criticalreflectionson postsocialistcondition, embora inovador não ficou isento de críticas. Para as formulações que se seguem recorre-se em grande medida aos trabalhos apresentados em Fraser eHonneth (2006) e Fraser (2008), que constituem um momento maduro da produção intelectual da autora com referência a essa temática. 
Essa crítica foi retomada por outros autores, como Bauman (2005):

a guerra por justiça social foi reduzida a um excesso de batalhas por reconhecimento. "Reconhecimento" pode ser aquilo que mais faça falta a um ou outro grupo dos bem-sucedidos - a única coisa que parece estar faltando no inventário rapidamente preenchido dos fatores de felicidade. Mas, para uma parcela ampla e em rápido crescimento da humanidade, trata-se de uma ideia obscura que assim continuará sendo enquanto o dinheiro for evitado enquanto tema de conversa (p. 44).

Partindo de uma definição em que a justiça social engloba ambas as reivindicações, Nancy Fraser (2006) elabora uma tipologia dos movimentos sociais que ajuda a ilustrar sua tese da irredutibilidade entre as duas categorias. Como paradigmas populares tanto a redistribuição quanto o reconhecimento associam-se aos movimentos sociais concretos. Desta forma, a política de redistribuição identifica-se com as políticas de classe, de um lado, ao passo que a política de reconhecimento se assimila às políticas de identidade e elas, com as lutas de gênero, sexualidade, nacionalidade, raça etc. Nesse caso, entretanto, redistribuição e reconhecimento diferem pelo menos em quatro aspectos.

Em primeiro lugar, os dois paradigmas assumem pontos de vistas distintos. A concepção paradigmática da redistribuição concentra-se nas injustiças definidas como socioeconômicas e atribui que suas ocorrências advêm da estrutura econômica da sociedade. Já o paradigma do reconhecimento centra suas atenções nas injustiças caracterizadas como culturais, que supõem arraigadas em padrões sociais de representação, interpretação e comunicação.

Em segundo lugar, os dois paradigmas propõem diferentes tipos de soluções para as injustiças. A redistribuição busca o equacionamento das injustiças em alguma forma de reestruturação econômica, ao passo que o paradigma do reconhecimento propõe uma mudança de âmbito cultural e simbólico. No entanto, há outras diferenças. Ambos os paradigmas divergem em relação às coletividades que sofrem injustiças. De um lado, os proponentes do paradigma da redistribuição, especificam que os sujeitos que sofrem injustiças são as coletividades similares às classes que se definem economicamente por uma relação com o mercado e os meios de produção. De outro lado, o paradigma do reconhecimento entende que os sujeitos vítimas de injustiça encontram-se submetidos a padrões institucionalizados de valor cultural e se assemelham aos grupos de status weberiano. Definidas pelas relações de reconhecimento distinguem-se pelo respeito, estima e prestígio que desfrutam em relação a outros grupos da sociedade, abarcam outros casos como os grupos estigmatizados institucionalmente, os grupos racializados marcados como diferentes e inferiores, dentre outros, que sofrem formas variadas de desrespeito. 
Por fim, em relação ao quarto aspecto, os paradigmas apresentam ideias distintas acerca das diferenças de grupo. No tocante ao paradigma da redistribuição, não se trata de conceber os diferenciais como algo intrínseco aos grupos, mas como uma economia política injusta socialmente estruturada. Já o paradigma do reconhecimento trata as diferenças de duas maneiras possíveis. Em uma versão, são variações culturais transformadas em hierarquias de valores mediante esquemas interpretativos injustos. Em outra, as diferenças de grupos não existem antes de sua transvalorização hierárquica e são contemporâneas de si mesmas (FRASER, 2006).

Diante dessas observações e contra a visão que apregoa que, perante tanto antagonismo, a redistribuição e o reconhecimento são alternativas mutuamente excludentes, Fraser $(2001 ; 2006$; 2008) posiciona-se afirmando que se trata de uma falsa antítese.

Sua tipologia consiste, inicialmente, na formulação de um modelo bidimensional construído com base em tipos puros. Nesta direção, pode-se imaginar um espectro conceitual de tipos diferentes de coletividades sociais, em que, em um extremo estão os modos de coletividade que se ajustam aos modelos redistributivos de justiça e, em outro, estão os modos de coletividades relacionados aos modelos de reconhecimento. Esse procedimento permite à autora classificar os movimentos sociais segundo suas demandas na relação redistribuição/reconhecimento.

Em relação ao aspecto da redistribuição, a autora estabelece um tipo ideal de coletividade cuja existência esteja ligada à economia política. Desse modo, "a raiz da injustiça será a má distribuição socioeconômica e qualquer injustiça cultural adicional derivará em última instância da raiz econômica" (FRASER, 2001, p, 254). Desta forma, o remédio requerido para reparar essa injustiça é a redistribuição político-econômica, em oposição ao reconhecimento cultural. Nesse quadro, considerado para fins heurísticos, a classe operária explorada assume o modelo de tipo ideal.

Assim, a diferenciação de classe enraíza-se na estrutura econômica da sociedade capitalista. A classe trabalhadora constitui-se como um conjunto de pessoas que necessita vender sua força de trabalho em condições que permitem à classe capitalista apropriar-se da mais-valia para seu benefício privado. A injustiça fundamental, portanto, é a exploração: uma forma especialmente profunda de má distribuição na qual as próprias energias do proletariado se voltam contra ele, usurpadas para sustentar um sistema que beneficia outros. Mesmo sabendo que os proletários sofrem graves injustiças culturais, elas derivam da ordem econômica. Entretanto, longe de estar vinculada diretamente a uma ordem autônoma injusta 
de categorias, derivam da estrutura econômica, em que proliferam as ideologias da inferioridade de classe para justificar a exploração (FRASER, 2001; 2006).

Seguindo os mesmos critérios, pode-se colocar na outra ponta do espectro um tipo ideal de coletividade que se ajuste ao modelo de reconhecimento da justiça. Uma coletividade desse tipo deve estar totalmente enraizada na cultura e não na economia política. Cabe destacar que essas coletividades são diferenciadas por padrões sociais dominantes e não pela divisão social do trabalho. Desse modo, todas as injustiças estruturais que lhes atribuam derivam de padrões institucionalizados de valor de uma sociedade. O núcleo dessas injustiças é o reconhecimento incorreto, ao passo que as injustiças econômicas que se adicionam a elas procedem, em última instância, da ordem de status.

O remédio requerido para esses tipos de injustiça é o reconhecimento e não a redistribuição. Um exemplo de coletividades que se aproxima desse tipo ideal são os grupos que enfrentam as diferenças sexuais, conforme a concepção weberiana de status. Neste sentido, a divisão social entre heterossexuais e homossexuais distribui-se por toda estrutura de classe na sociedade capitalista, não ocupa uma posição característica na divisão do trabalho e não constitui uma classe explorada.

Entre os diversos exemplos que podem ser citados para exemplificar esse tipo de injustiça, o caso dos militares brasileiros Fernando Alcântara e Laci de Araújo tornou-se emblemático. Em maio de 2008, após concederem entrevista à revista Época admitindo que mantinham uma relação estável de caráter homossexual, a justiça militar brasileira decretou a prisão de um deles, com acusação de deserção e possibilidade de expulsão do exército.

Desse modo, quando se lida com coletividades que se aproximam da classe operária explorada, os remédios são redistributivos, e com coletividades que se aproximam do tipo ideal da sexualidade menosprezada, as injustiças requerem ações no âmbito do reconhecimento. Assim, no primeiro caso, a lógica consiste em homogeneizar os grupos. No segundo, a lógica é valorizar a peculiaridade do grupo, reconhecendo sua especificidade. Em outras palavras, os remédios redistributivos e de reconhecimento indicam lógicas opostas.

As questões apresentam-se de uma forma mais fácil de identificar e postular equacionamentos nos extremos desse espectro conceitual. Do mesmo modo, elas se tornam mais complexas quando se lida com grupos que se encontram no meio desse modelo conceitual. Nessa posição, há uma forma hibrida que relaciona ambas as características, aspectos da classe explorada com elementos da sexualidade desprezada, isto é, são grupos que demandam ao mesmo tempo

Entrevista veiculada no dia 02 de Junho de 2008. 
redistribuição e reconhecimento. A estes grupos Fraser (2006) chama de coletividades ambivalentes, por eles caracterizarem-se por uma bidimensionalidade de injustiças, arraigadas simultaneamente na estrutura econômica e na ordem de status. Nenhuma dessas injustiças caracteriza-se como uma consequência da outra. Ao contrário, ambas são primárias e co-originais (FRASER, 2001; 2006).

Assim, a autora apresenta duas categorias que podem ser caracterizadas como bidimensionais. Segundo seus comentários, o gênero é uma diferenciação social bidimensional, uma vez que

no es una simple classe niun mero grupo de estatus, sino una categoría híbrida enraizada al mismotiempoenlaestructura econômica y enelorden de estatus de lasociedad. Por tanto, comprender y reparar lainjusticia de gênero requiere atender tanto a laditribuicióncon al reconhecimiento. Desde elpunto de vista distributivo, el género sirve de principio organizador básico de laestructura económica de lasociedad capitalista. Por una parte, estructuraladivisón fundamental entre trabajoretribuido, "productivo" y no retribuido y doméstico, asignando a lasmujereslasresponsabilidad primaria de este último. Por otra parte, el género estructuratambiénladivisíon, dentro do trabajo pago, entre lasocupaciones de fabricación y profesionales, de salarios altos y predominio masculino, y lasocupaciones de "delantal" y de servicios doméstico, de salariosbajos y predomino femenino. El resultado es una estructura económica que genera formas de injusticia distributiva, específicas de género, incluyendolaexplotaciónbasadaenel género, lamarginación económica y laprivación.[...] De hecho, el género no es sólo una divisiónsemejante a la de las classes sociales, sino una diferenciación de estatustambién. Encuanto tal, también engloba elementos que recurdan más lasexualidad que las classes sociales, que loincluyendirectamenteenla problemática delreconocimiento. El género codifica patronesculturales omnipresentes de interpretación y evaluación, que sonfundamentales para elorden de estatusensu conjunto. Enconsecuencia, no sólolasmujeres, sino todos los grupos de estatus inferior correnelriesgo de lafeminización y por tanto, de ladepreciación. Asípues, una característica importante de género es elandrocentrismo: unpatrón institucionalizado de valor cultural que privilegia los rasgos asociadosconlamasculinidad, al tiempo que devalúa todo lo codificado como "femenino", paradigmáticamente, pero no sólo, lasmujeres. Los patronesandrocéntricos de valor, institucionalizados de forma generalizada, estructuran grandes franjas de interacción social. [...] Los patronesandrocéntricos de valor tambiéninvadenla cultura popular y lainteracción cotidiana. A consecuencia de ello, lasmujeressufren formas específicas de subordinación de estatus, incluyendolasagrecionessexuales y la violência doméstica; respresentacionesesteriotipadastrivializadoras, cosificadoras y despreciativasenlos médios de comunicación; hostilidad y menosprecioenla vida cotidiana; exclusión o marginalizaciónenlas esferas públicas y enloscuerpos deliberantes, y negación de losderechos plenos y proteccionesequiparables de losciudadanos (FRASER, 2006, p. 28-29). 
Do mesmo modo como ocorre com o gênero, a raça também se constitui em uma categoria bidimensional, uma combinação de status e classe social. Neste sentido, na economia a raça organiza divisões estruturais no trabalho assalariado "entre ocupações mal pagas, sujas, domésticas desproporcionalmente ocupadas por pessoas de cor, e ocupações técnicas administrativas de maior status e melhor pagas e desproporcionalmente dominadas por brancos" (FRASER, 2001, p. 262). Já na ordem de status, os padrões eurocêntricos de valor cultural privilegiam as características associadas ao branco, e estigmatizam tudo que é codificado como negro, moreno e amarelo. O mesmo estigma estende-se aos imigrantes racializados e às minorias étnicas, considerados indivíduos deficientes e inferiores (FRASER, 2006).

Esta constatação é relevante, pois, como demonstra Fraser (2001) existem coletividades ambivalentes que demandam simultaneamente por remédios de redistribuição e reconhecimento.

As coletividades formadas por identificação de gênero e raça, por exemplo, são ambivalentes paradigmáticas. Na perspectiva da autora, embora cada uma tenha peculiaridades não compartilhadas pela outra, ambas englobam dimensões político-econômicas e culturais-valorativas. Como sofrem injustiças de ordem socioeconômicas e de não reconhecimento, simultaneamente, nem remédios redistributivos, nem remédios de reconhecimento são suficientes isoladamente. Coletividades ambivalentes necessitam de ambos (FRASER, 2001).

Em um trabalho recente, Fraser (2008) acrescentou uma terceira dimensão ao debate: a dimensão política. $\mathrm{Na}$ sua perspectiva, o político é entendido em um sentido mais específico e constitutivo, que remete à natureza da jurisdição do Estado e às regras de decisão com que se estrutura a confrontação. Nesse entendimento, o político é ele próprio o cenário no qual se desenvolvem as lutas por distribuição e reconhecimento. Ao estabelecer os critérios de pertencimento e ao determinar quem conta como membro, a dimensão política da justiça especifica o alcance das outras dimensões. Ela informa quem faz parte ou não do grupo dos que têm direito a uma justa redistribuição ou ao reconhecimento mútuo.

Ao determinar as regras de decisão, a dimensão política, do mesmo modo, determina os procedimentos para representar e resolver os conflitos nas outras dimensões. Em síntese, a dimensão política não apenas indica quem tem o direito a reivindicar redistribuição e reconhecimento, como estabelece e avalia essas reivindicações (FRASER, 2008).

Tendo como pano de fundo a questão do pertencimento e procedimentos, Fraser (2008) destaca: 
adimensión política de lajusticia se interesa sobre todo por larepresentación. Enun primer nivel, el que atañe al aspecto de establecimiento de límites de lo político, larepresentación es asunto de pertencia social. De lo que se discute aquí es de lainclusiónen o de laexclusión de lacomunidad de aquellos que tienederecho a dirirse mutuamente reivindicaciones de justicia. Enotro nível, el relativo al aspecto de las regras de decisión, larepresentación se interesa por losprocedimientos que estructuranlos processos públicos de confrontación. Aquí, lo que se cuestionasonlas condiciones enlas que losincluidosenlacomunidad política airean sus reividicaciones y arbritan sus disputas. En ambos niveles puede surgir lacuestión de si y hasta quépuntoson justas las relaciones de representación (p. 42).

Se a representação é a condição que define o político como dimensão da justiça, então a injustiça política característica é a representação falida. Segundo Fraser (2008), a representação falida ocorre quando os limites políticos e as regras de decisão vigentes negam a determinados sujeitos a possibilidade de participar em paridade com outras, nos processos de interação social. Na prática, essa forma de injustiça não ocorre desvinculada, mas imbricada com as demais.

\section{AS DEMANDAS EM RELAÇÃO A ATIVIDADE: CONFLITOS E CONSEQUÊNCIAS}

Pode-se dizer que, até o momento, as questões suscitadas se encontram relacionadas ao desenvolvimento econômico e social. Neste sentido, em diversas respostas de entrevistados o Estado é citado como o principal promotor do desenvolvimento. $O$ discurso parece desafiar a máxima neoliberal que vê na iniciativa privada, mediada pelo livre mercado, o mote para o desenvolvimento econômico e social. Na visão dos entrevistados, cabe ao Estado, em suas diversas instâncias (municipal, estadual e federal), o papel de promover ações, apresentar soluções que viessem equacionar os problemas enfrentados pela sociedade. Percebe-se, então, uma manifestação do modelo de gerenciamento de Estado brasileiro que Rudá Ricci (2010) chama de lulismo, e uma das características centrais deste modelo é o papel do governo como promotor do desenvolvimento econômico e social. A esse respeito, afirmam alguns entrevistados:

O governo tem que investir nisto (entrevista 5, São Leopoldo).

Melhorar os salários e incentivar os pequenos empresários do mercado informal (entrevista 9, São Leopoldo).

É o principal responsável, abrir mais oportunidade de emprego na prefeitura (entrevista 12, São Leopoldo).

Falta de incentivo do governo com as empresas para que possam ampliar e ajudar os jovens a trabalharem, para serem bons cidadãos (entrevista 6, Novo Hamburgo). 
Seria ir até os lugares mais pobres para perceber esta realidade. Tipo como você que esta fazendo esta pesquisa (entrevista 4, Novo Hamburgo). Deveria investir na geração de emprego (entrevista 2, Sapucaia do Sul).

$\mathrm{Na}$ perspectiva esboçada, cabe à sociedade, o papel de reivindicar e fiscalizar a execução das ações implementadas pelo Estado. Os entrevistados têm certa consciência do papel que todas as pessoas possuem como sujeitos de direitos e deveres e como atores capazes de efetivar reivindicações para o atendimento de seus interesses. Entretanto, no dia a dia desses trabalhadores, isso não tem se traduzido, em igual medida, em benefícios e conquistas. Em situações de conflito com lojistas ou outras categorias profissionais pelo direito de ocupar o espaço público com o intuito de realizar o seu trabalho, continuamente seus interesses são suplantados, como se observa na retirada dos camelôs das ruas adjacentes ao Shopping Bourbon em São Leopoldo ou como se verifica na fala de um trabalhador que destaca que "várias pessoas enfrentaram conflitos" ${ }^{10}$, por causa dos lojistas. Antes tinha uma feira e teve que acabar" (entrevista 21, São Leopoldo).

Em outras palavras, pode-se dizer que entre a consciência da ação e sua efetividade, há um hiato. Esse hiato parece relacionar-se com o reconhecimento, ou não, desses indivíduos ou grupos como sujeitos de direitos. $\mathrm{O}$ eco de suas falas tem um tom de denúncia em relação à consideração pública que não lhes é outorgada, ou seja, seus reclames carecem de legitimidade. A possível carência de legitimidade, entretanto, não é a única causa do descrédito atribuído a esses sujeitos. Em seu conjunto, a ação fiscalizadora e reivindicadora da sociedade deve enfrentar outro dilema, qual seja, a passividade apresentada pela população. Segundo a avaliação dos pesquisados, a população apresenta uma atitude passiva em decorrência da falta de sua consciência como sujeitos de direitos:

Tem que cobrar, tem que ir em cima, pensar antes de voltar, ir em frente (entrevista 6, São Leopoldo).

Exigir seus direitos (entrevista 9, São Leopoldo).

Se conscientizar mais, cuidar no momento de votar e escolher seus governantes (entrevista 1, São Leopoldo).

A sociedade deveria se unir na hora de votar. Escolher bem a pessoa, porém, se tivesse essa pessoa, fiscalizar (Entrevista 8, Novo Hamburgo).

Ninguém se une, ficam calados (entrevista 11, São Leopoldo).

As pessoas são de ficar quietas e não fazer nada, não procuram seus direitos (entrevista 16, São Leopoldo).

Essas manifestações, contudo, causam certa perplexidade quando pensadas em termos de conflitos, pois dizem respeito à constatação de que a falta de consciência reivindicatória também se encontra presente nos conflitos 10 Grifo meu. 
decorrentes do trabalho de rua. Neste sentido, quando questionados se eles haviam vivenciado situações de conflitos em decorrência do desempenho da atividade, 60\% dos entrevistados afirmaram não as terem enfrentado. Já os $40 \%$ restantes relacionaram esses conflitos a situações que classificam como corriqueiras, e se referem a situações como fofocas, concorrência, fiscalização, discriminação e outras. A relevância destes elementos, para este estudo, encontrase no fato de que, na análise, o conflito reaparece com outro formato.

\section{AS SITUAÇÕES DE CONFLITO NO TRABALHO DE RUA}

Nesses microambientes, o conflito deixa de ter um caráter explícito e passa a apresentar-se de maneira difusa. Como visto anteriormente, adota-se o termo difuso para designar algo que se espalha em várias direções e não apresenta limites definidos.

Tendo isso claro, quando se analisaram as questões referentes ao conflito, verificou-se que os entrevistados não percebem que as causas dos conflitos se encontrem no pacto social engendrado estruturalmente. Em outras palavras, a visão dos entrevistados sobre as situações de conflitos não remete a uma interpretação desses conflitos como relacionados aos interesses de grupos e ou às possibilidades diferenciadas de apropriação de recursos materiais e simbólicos que se manifestam na distribuição desigual das chances de vida.

Não há, nesse sentido, uma percepção capaz de conduzir a uma ação coletiva, tal como uma mobilização para obter melhores condições de trabalho, reivindicações de investimentos e outros. Mesmo a constatação de que existe uma apropriação diferenciada de recursos, do grupo formado pelos políticos, em comparação com a população, é capaz de produzir um sentimento de mobilização que se traduza em ação. Essa apropriação diferenciada da classe política é percebida na maioria das vezes como decorrência de situações de corrupção e vem acompanhada de um profundo descrédito que os entrevistados manifestam em relação aos políticos. Essas observações podem ser constatadas nas respostas a seguir:

O salário dos políticos, não pode um ter sete mil e outro ter só trezentos reais. Tem que mudar (entrevista 15, São Leopoldo).

O governo tem que investir nisto, mas só pensam em alimentar o bolso deles (entrevista 5, São Leopoldo).

O papel do governo era tentar melhorar, mas só querem a verba para eles e para os outros nada (entrevista 18, São Leopoldo).

Um monte de corrupção eles dão exemplo, são pessoas de cultura e não adianta. Isto incentiva e monta a quadrilha e pega laranjas (entrevista 14, São Leopoldo). 
Além de o governo ganhar seu salário ele rouba o dos outros (entrevista 4, Sapucaia do Sul).

A corrupção no governo envolve muito dinheiro que, por exemplo, não é aplicado em melhorias como o salário mínimo. Com o Lula continua a mesma coisa (entrevista 8, Novo Hamburgo).

Pode-se dizer que o caráter difuso dos conflitos envolvidos na dinâmica das ocupações informal de rua se refere a certa opacidade que obscurece o entendimento dos sujeitos acerca da sua real localização. Assim, o debate sobre a questão na esfera pública acaba por inscrever os conflitos fora dos limites que envolvem as macroestruturas sociais e a possibilidade de expansão de uma cidadania que garanta a igualdade de condições e oportunidades para todos. Nesse contexto, as hierarquias sociais presentes nos conflitos ganha invisibilidade, ou seja, desaparece.

Essa situação é significativa, quando se sabe que "a distribuição desigual das chances de vida é resultado das estruturas de poder. Onde ${ }^{11}$, alguns são postos numa posição em que podem estabelecer a lei pela qual a situação dos outros será medida" (DAHRENDORF, 1992, p. 42). Observar-se a naturalização de uma visão que restringe os conflitos aos marcos do legal e do ilegal, em vez de situá-los no horizonte das possibilidades de vida. Essa maneira de perceber a questão encontra repercussão e legitimidade nos discursos dos gestores locais que diferenciam a ocupação informal da ilegal, tendo com referência situações de justiça e injustiça e a disposição dos sujeitos ao agir segundo os limites da lei. A entrevista com o gestor em São Leopoldo, Secretário Municipal de Desenvolvimento Econômico e Social (Semedes), baliza bem a questão, ao comentar a lei do empreendedor legal ${ }^{12}$ :

Essa lei do empreendedor legal, empreendedor individual ela justamente ela provoca uma justiça de mercado porque antes aquele ali que tem seu bar, seu aluguel, tem a sua porta, paga os seus impostos, tá começando com a atividade, tem esse ônus, ele tá disputando com o outro o que venda artefatos de couro, carteira, cinto, por exemplo, são lojas aqui na cidade,

11 Grifo meu.

12 O empreendedor legal refere-se à Lei Complementar n ${ }^{\circ} 128$, de 19 de dezembro de 2008, que criou condições especiais para que o trabalhador definido como informal possa se tornar um empreendedor individual legalizado. Dentre as vantagens oferecidas por essa lei, está o registro no Cadastro Nacional de Pessoas Jurídicas (CNPJ), o que facilita a abertura de conta bancária, o pedido de empréstimos e a emissão de notas fiscais. Além disso, o empreendedor individual é enquadrado em um regime especial unificado de arrecadação, o Simples Nacional, ficando isento dos seguintes tributos federais: Imposto de Renda Retido na Fonte (IRRF), Programa de Integração Social (PIS), Contribuição para o Financiamento da Seguridade Social (COFINS), Imposto Sobre Produtos Industrializados (IPI), e Contribuição Social Sobre Lucro Líquido (CSLL). Disponível em: Portal do Empreendedor, http://www. portaldoempreendedor.gov.br/modulos/entenda/oque.php.. Acesso em 13 nov. 2010. 
está disputando com outro que tá na rua sem custo nenhum, nem imposto nem aluguel nem nada vendendo o mesmo produto às vezes pela metade do preço e vendendo pela metade do preço tendo o dobro do lucro. Então esse é o primeiro fator, provoca uma injustiça nesse caso. Aí agora sim a fiscalização pode bater com bastante mais força em cima desse informal que está fazendo essa injustiça de mercado porque ele não está usando o recurso que ele pode usar. Ele tá ilegal, melhor dizendo, informal por uma questão não, não por uma situação passageira, é uma opção que ele adotou e que não tem mais justificativa. E a outra coisa que eu até fiz uma reflexão aqui, [...] é que devemos fazer uma distinção entre o ilegal, nós fazemos um treinamento sobre o ilegal e o informal. O ilegal é aquele que vende o produto de descaminho, nós tratamos dessa forma, que vende o cigarro contrabandeado, que vende esses produtos contrabandeados ou sem origem comprovada. O informal a gente entende que é aquele que produz em casa, faz alguma coisa em casa ou enfim, a família faz e ele sai pra vender isso aí, seja um doce, seja um salgadinho, um produto qualquer, um artefato de couro, então são duas situações diferentes. O ilegal é ilegal mesmo e não tem desculpa, tem que aprender e tem que fazer o que for necessário. $\mathrm{O}$ informal tem essa outra situação que eu coloquei, então fica fácil pra quem tá de fora, hoje fica mais fácil quem tá de fora, respondendo essa pergunta, porque é lógico, se o informal ele faz as coisas em casa sai pra vender e quer ficar nessa situação, ele corre o risco não mais justificado, hoje não tem mais justificativa. Ele tem dentro da legislação tem dentro das forças de governo aqui na cidade, orientação, apoio através do micro crédito, através de curso de capacitação que recebe pra se postar, para se posicionar como um pequeno empreendedor.

Essa maneira especifica de conceber os conflitos, coloniza o discurso na esfera pública e ganha maior legitimidade com sua incorporação pelos trabalhadores de rua. Quando os trabalhadores foram questionados sobre essas situações, ouviram-se frases do tipo:

Nenhum problema, pois não tem nada ilegal na banca (entrevista7, Sapucaia do Sul)

Nenhuma, mas quem vende CD e DVD pirata enfrenta (entrevista 8, Sapucaia do Sul).

Quando não consegui um lugar pra trabalhar e o fiscal me tirou. O camelô ficou, e eu tive que sair. Como que o camelô pôde ficar, ele que vende coisas contrabandeadas. Eu me senti humilhada (entrevista1, São Leopoldo)

Outra questão deve ser agregada a essas observações e se refere ao tratamento institucional dispensado ao trabalho de rua. Neste sentido, as alternativas oferecidas pelo Estado para o equacionamento das dificuldades inerentes ao desempenho da atividade, que podem ser tanto de ordem econômica - a necessidade de acesso a capital para investimento, por exemplo -, quanto de ordem legal - como a regularização da atividade - são oferecidas de maneira 
individualizada. Assim, o que se observa é a criação de canais de financiamento e outros, tratados de maneira individual, caso a caso (as ações do Serviço Brasileiro de Apoio as Micro e Pequenas Empresas (Sebrae) podem ser enquadradas nesse rol). São poucas as situações tratadas coletivamente.

Essa forma de abordar a questão, adotada pelo Estado, apresenta uma consequência prática em relação às demandas, qual seja, ela despolitiza o conflito. Em outras palavras, o tratamento individualizado das demandas, com base em financiamentos individuais, apoio para a formalização das atividades mediante o microempreendedor, dentre outras, acabam por não favorecer uma conscientização dos trabalhadores que se traduza em ações coletivas. Percebe-se, então, o reforço de uma concepção individualista: o cuidar de si próprio. Dois entrevistados comentam:

É necessária ${ }^{13}$ a conscientização do povo. A maioria daqui quer vender para lucro próprio (entrevista 13, São Leopoldo).

Cada um por si, não são unidos querem as coisas de mão beijada (entrevista17, São Leopoldo).

Não se desconsidera a importância de tais ações, já que elas são um importante meio de acesso a recursos para manutenção e ampliação das atividades. Insiste-se, porém, que esse tipo de orientação apresenta um efeito colateral, o de fragmentar a ação, fazendo com que o encaminhamento tanto pelo Estado, quanto pelos trabalhadores seja individualizado. Esse fato por si só despolitiza as demandas, pois são percebidas pelos trabalhadores como problemas comuns a todos, mas cuja resolução se dá no plano individual. Neste sentido, pode dizer-se que as estratégias dos trabalhadores, como se verá adiante, envolve o estabelecimento de projetos individuais e não coletivos. Na prática, observa-se um reforço da ideia de que cada um sabe de si e é responsável por si próprio.

\section{O QUE PENSAM OS TRABALHADORES DO MERCADO INFORMAL DE RUA: SEUS DESEJOS, EXPECTATIVAS E VALORES COMPARTILHADOS}

Pôde-se constatar que as demandas dos trabalhadores de rua, em geral, envolvem situações de conflito, pois além da ocupação do espaço público, apresentam juízos de valor e representações acerca da atividade e dos sujeitos que delas participam. $\mathrm{Na}$ tentativa de realizar um diagnóstico mais preciso acerca dessas questões, optou-se por incluir no roteiro de entrevistas um conjunto de

\footnotetext{
13 Grifo meu.
} 
questões abertas em que os trabalhadores foram instigados a falar sobre suas expectativas, seus desejos, seus valores e visão de mundo, como percebem a atividade e qual imagem projetada sobre eles quando percebidos pelo olhar do outro.

Observou-se que a maior parte dos trabalhadores entrevistados possuíam uma visão positiva acerca da própria atividade ou a colocam no mesmo patamar das demais. Para esse contingente o trabalho de rua é percebido como um trabalho honesto, que se dá no interior de um mercado que oferece oportunidades e que as pessoas podem obter certa satisfação pessoal, o que pode ser constatado em algumas de suas falas:

Mercado promissor, eu gosto do que faço, faço com muito gosto (entrevista 7, São Leopoldo).

Boa. Tem melhor porque trabalhamos com sorte (entrevista 11, São Leopoldo).

Bom, o trabalho numa empresa explora mais (entrevista 16, São Leopoldo). Importante, não é mais nem menos do que as outras (entrevista1, São Leopoldo).

Normal. Não! Porque como estou trabalhando com o público ao voltar para a empresa se torna angustiante, ambiente fechado (entrevista 5, Sapucaia do Sul).

Contudo, essas respostas não esgotam a questão. Dos entrevistados, $16,7 \%$ apresentaram uma visão negativa em relação a esse tipo de trabalho, demonstrando um sentimento de desconfiança quanto ao real potencial e importância da atividade. Não raro, os entrevistados manifestam-se como discriminados, desvalorizados ou mesmo injustiçados:

O trabalho não é valorizado (entrevista1, São Leopoldo).

Cada pessoa teve chance, já eu não tive chance, com 11 anos tive que para de estudar (entrevista 4, Sapucaia do Sul).

Somos discriminados (entrevista 9, São Leopoldo).

A discriminação, entretanto, não se limita somente à da sociedade, mas faz-se presente no núcleo familiar. Chega, em alguns casos, a gerar situações de conflito pelo não reconhecimento do sujeito como trabalhador qualificado ou classificação da sua atividade como inexpressiva. Em alguns casos, a atividade não chega a atingir o status de atividade produtiva e é definida como atividade temporária ou mesmo como um biscate, ou seja, um trabalho de pouca importância. Por fim, a visão negativa completa-se diante da comparação com o trabalho formal e pela ausência de seguridade social: 
Eu acho de carteira assinada melhor, é mais garantido, aqui tu não sabe como vai ser (entrevista 18, São Leopoldo).

Atividade sem segurança, nada é certo é serviço informal (entrevista 2, Novo Hamburgo).

As expectativas não são muitas, esse emprego é temporário só até o fim do ano, sem carteira assinada nada é certo (entrevista 7, Sapucaia do Sul).

Nessa perspectiva, para Castel (2005), as sociedades modernas fundam-se sobre o terreno da insegurança, uma vez que são sociedades de indivíduos que não encontram nem em si mesmo nem em seu entorno a capacidade de garantir sua proteção. Esse fato por si só pode conduzir a uma situação de vulnerabilidade uma vez que "ser protegido não é um estado natural. É uma situação construída, porque a insegurança não é uma peripécia que advém de maneira mais ou menos acidental, mas uma dimensão consubstancial à coexistência dos indivíduos” (p. 16).

Seguindo a análise, 50\% dos entrevistados manifestaram que a sociedade apresenta uma visão positiva ou neutra em relação a essa modalidade de trabalho:

Como outra qualquer (entrevista 8, São Leopoldo).

Gostam, embora não dêem valor. Elogiam bastante o artesanato (entrevista 1, São Leopoldo).

Todo mundo gosta de mim, para conversar, pois tem uns que adoram camelô e outros odeiam (entrevista 6, Sapucaia do Sul).

Normal, tem uns clientes que são chatos, mas é assim em todos os comércios. E tem gente que não compra em camelô (entrevista 7, Sapucaia do Sul)

Entretanto, essa percepção não é partilhada por 34,6\% dos entrevistados que manifestaram que a sociedade possui uma visão negativa em relação a esse tipo de trabalho. Nesse caso, a visão da sociedade, em relação a esses trabalhadores, reflete situações de conflito percebidas por meio de atitudes preconceituosas e discriminatórias.

Uma barbada, como fácil mas não é. As vezes fazer nada é muito difícil (entrevista $\mathrm{n}^{\circ} 6$ - São Leopoldo).

Sempre acham que queremos passar a perna, tirar vantagem (entrevista 9, São Leopoldo).

O cliente enxerga o produto e não o que você faz (entrevista 15, São Leopoldo).

Pessoas muito ignorantes, falam isso e aquilo, não sabendo valorizar este trabalho. Não é porque se trabalha em uma loja ou em banco que se tem mais dignidade que outras (entrevista 4, Sapucaia do Sul).

Serviço fácil, de vagabundo, mas é o que mais dizem e o que mais queriam fazer (entrevista 7, Novo Hamburgo). 
Percebe-se que essas manifestações estão acompanhadas de juízos de valor que se apoiam em ideias há muito arraigadas na sociedade brasileira e refletem aspectos socioculturais que foram sendo disseminados ao longo dos tempos e que dizem respeito ao processo de modernização do país. Essa questão será melhor discutidas adiante, por enquanto, basta enfatizar que os juízos de valor também se encontram presentes nas representações dos trabalhadores em relação à sociedade.

Chamou a atenção o fato de 75\% dos entrevistados apresentarem uma visão negativa acerca da sociedade. Essa visão negativa refere-se a constatação de que vivem em uma sociedade que valoriza a competição e a individualidade, apresenta atitudes egoístas e preconceituosas, e seus valores acabam por reforçar o tratamento desigual entre as pessoas.

As pessoas que têm sempre querem ter mais. Por exemplo, só querem vender não se importando com o outro. Cada um por si e o resto que se dane (entrevista 4, Sapucaia do Sul).

Muito competitiva e consumista as pessoas são egoístas, não se importam com os outros, é cada um por si (entrevista 18, São Leopoldo).

Competitiva, não tem igualdade entre as pessoas (entrevista 4, São Leopoldo).

Competitiva. Eu sou, mas sou honesta e não piso em ninguém (entrevista 8, São Leopoldo).

Desumana. Cada um por si, não são unidos querem as coisas de mão beijada. São tantas pessoas enganando as outras que a gente nem sabe em quem confiar (entrevista 17, São Leopoldo).

Sociedade fria, descriminação alguns acham que são mais, por causa da aparência e das diferenças (entrevista1, Novo Hamburgo).

Péssima, tudo é ruim, ninguém colabora com ninguém, uma falta de educação, transporte é ruim, falta de segurança e muito desemprego (entrevista 10, Sapucaia do Sul).

Observa-se que este conjunto de visões negativa e pessimista contrastam com questões anteriores, tais como a maneira positiva com que eles percebem a atividade. A visão negativa acerca da sociedade completa-se com o diagnóstico que esses trabalhadores fizeram acerca dos problemas que a sociedade apresenta atualmente. Para eles, a falta de emprego e a desigualdade e pobreza corresponde às maiores mazelas sociais. Outras questões como a violência e a saúde pública também foram abordadas. Chama a atenção que a visão dos problemas sociais, bem como algumas questões já referidas, guardam relação com o mundo do trabalho e acesso a um conjunto de direitos associados ao contrato formal de trabalho. 
Gráfico 1 - Problemas da sociedade

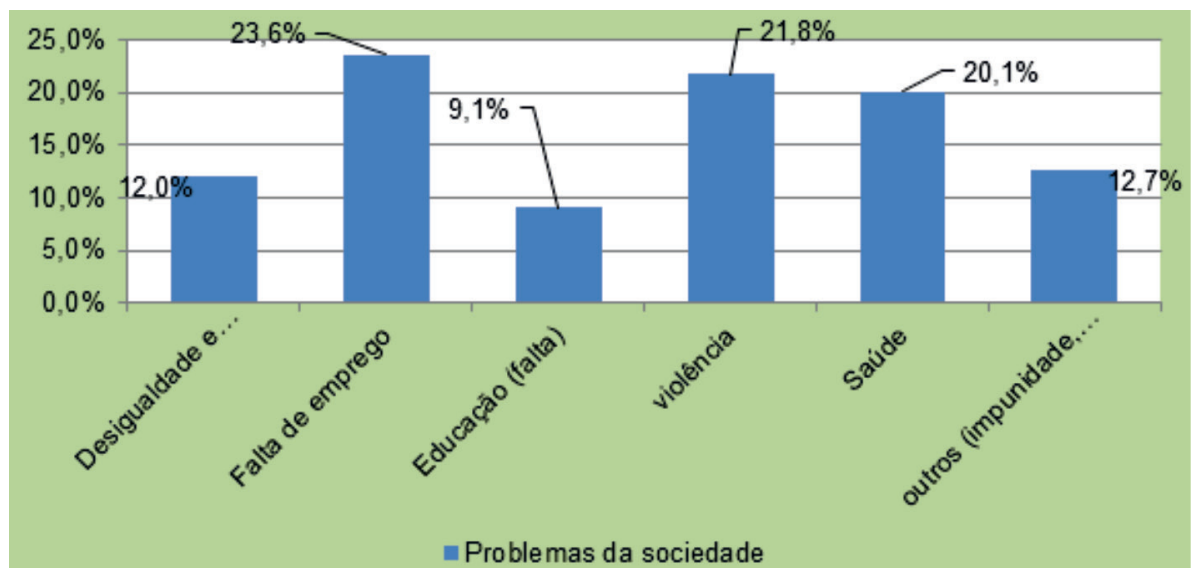

Quando questionados sobre os fatores que estariam na origem desses problemas, a política e a falta de emprego foram apontados como as principais causas para esse conjunto de problemas. O padrão das respostas apresentadas ratificam o profundo descrédito que esses trabalhadores têm em relação à instituição política e àqueles que dela participam.

Gráfico 2 - Causas dos problemas

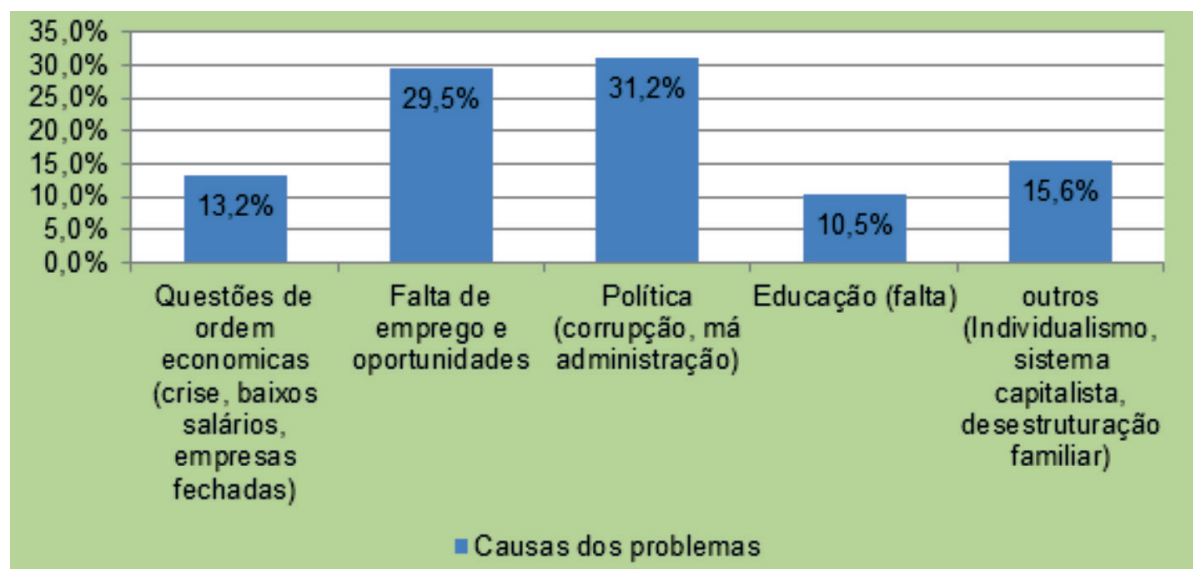

Conforme a análise descrita, os trabalhadores foram questionados acerca de suas expectativas em relação ao futuro. Neste quesito, alguns se limitaram a apenas comentar que esperavam por melhoras ou não. Por outro lado, um contingente expressivo dos entrevistados, cerca de 28,6\%, manifestaramse otimistas em relação ao futuro. Entretanto, esse otimismo relacionava-se a obtenção de um trabalho formal. Esse conjunto de questões pode ser melhor percebido nas falas de alguns trabalhadores e no gráfico 3: 
Gráfico 3 - Expectativas em relação ao futuro

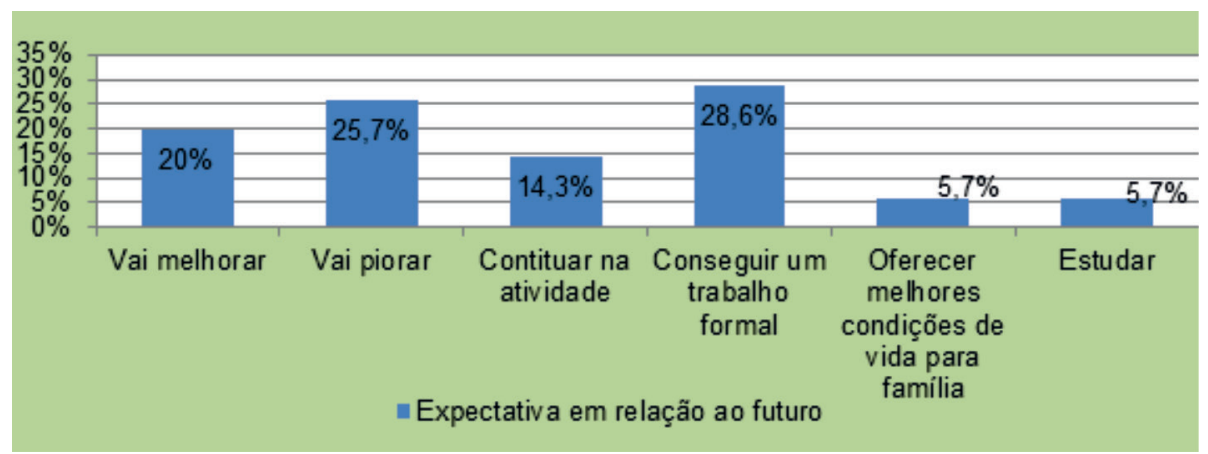

$\mathrm{O}$ último ponto em destaque refere-se à percepção sobre o fenômeno da pobreza. Quando questionados se a pobreza é um problema que diz respeito ao sujeito ou à sociedade, $55 \%$ dos entrevistados entenderam tratar-se de um problema social. Contudo, chamou a atenção a tendência apresentada pelos outros $44,2 \%$ em relacionar a pobreza com a falta de atitude do sujeito, ou seja, culpando-o pela situação vivenciada. Condições e limitações herdadas, por exemplo, não explicam para esses entrevistados a permanência em situações de pobreza. A atitude crítica dos entrevistados aproxima-se em muito da visão conservadora vinculada ao conceito de underclass analisada por Kowarick (2003). Nela "a marginalização social e econômica passa a ser encarada como fraqueza peculiar a indivíduos ou grupos que, como tais, não possuem a perseverança ou o treinamento moral para vencer na vida" (p. 63). As respostas são significativas, como se vê a seguir.

Individual, pois o pobre sendo trabalhador ele vai à luta (entrevista 5, São Leopoldo).

Social, é de tudo mundo (entrevista 6, São Leopoldo).

Só é pobre quem quer (entrevista 9, São Leopoldo).

Social. Se tivesse mais oportunidade, ninguém seria tão pobre. Então é social (entrevista 1, São Leopoldo).

Social com certeza. Desemprego é antes vem o preconceito, também a educação que depende das pessoas (entrevista 12, São Leopoldo).

Um pouco social e um pouco individuo tem gente que não vai à luta também (entrevista 14, São Leopoldo).

Individual, cada um faz a sua pobreza. Além de não ter dinheiro são pobres de espírito (entrevista 17, São Leopoldo).

Social porque a sociedade não se ajuda. As pessoas têm que pensar mais nós outros e não só nelas. A sociedade é muito cruel. Para conseguir emprego tem que estar bem vestida (entrevista 4, Sapucaia do Sul). 
O problema é social e individual. Social porque o governo tem que dar mais oportunidade as pessoas sem experiência. Individual, porque as pessoas não sabem administrar o que tem, por isso, que passam por esse tipo de situação (entrevista 7, Novo Hamburgo).

Até aqui os esforços foram empreendidos com o intuito de oferecer uma visão ampla de como esses sujeitos percebem a dinâmica social e como eles se situam nesses contextos. Para tanto, apresentou-se um conjunto de respostas que diz respeito tanto a sua visão de mundo quanto a seus desejos, seus valores e suas expectativas. Nas próximas páginas, irá incorporar-se ao debate outro conjunto de respostas, que se encontram em conformidade com discursos interpretativos da realidade a muito difundidos no imaginário social.

\section{AS MATRIZES CULTURAIS E A PARIDADE PARTICIPATIVA: PERMANÊNCIAS DE UM BRASIL MODERNO}

Tal como destacado anteriormente, o padrão das respostas fornecidas pelos entrevistados quando manifestaram suas opiniões acerca dos dilemas cotidianos constitui importante elemento a ser analisado. Nesse aspecto, as respostas, em muitos casos, foram acompanhadas de juízos de valor que se originam em ideias que se encontram arraigadas há muito tempo na sociedade brasileira e refletem aspectos socioculturais que foram sendo disseminados ao longo dos tempos, os quais se encontram ligados ao processo de modernização país.

Observou-se que em diversas passagens, as falas dos sujeitos reafirmam e reproduzem a imagem social que é difundida a seu respeito. Essa imagem sustenta-se em um discurso que surge como constitutivo dos sujeitos, tecendo hierarquias e determinando lugares sociais. Abordaram-se em parte esses elementos no segundo capítulo desta tese. Comentou-se, naquele momento, que o final do século XIX e início do século XX se caracterizou por apresentar uma realidade ambígua. De um lado, havia a nação moderna que se queria construir, com uma elite alinhada com os valores e padrões culturais europeus. De outro, em contraste, encontrava-se um contingente expressivo formado, em especial, por aqueles sujeitos que só possuíam a sua força de trabalho para vender e sobreviver e que deveriam compor o povo que iria representar a nação (TELLES, 2001; BASTOS, 1991; IANNI 2004, 2002; PAOLI, 1985, dentre outros).

Esse projeto emergiu sustentado por um poderoso discurso, que acentuava a valorização do trabalho disciplinado como algo dignificante, o modelo de família nuclear, a abnegação aos valores morais, o cumprimento das leis, e outros, como os valores mais adequados ao desenvolvimento da nação. Em contraposição, 
surgiu um imaginário sobre os trabalhadores populares construído com base em estereótipos que retratam a indolência, a preguiça e a luxúria, dentre outros que se podem destacar ${ }^{14}$.

Neste sentido, é importante recordar "que as ideias e valores constituem um aspecto importante da vida social" (DUMONT, 2000). O diagnóstico da época apontava setores sociais que deveriam ser objeto de atenção do Estado, acentuando a necessidade de que se empreendessem esforços para ajustar esses sujeitos aos padrões morais e de condutas adequados ao bom desenvolvimento do país. O Brasil modernizava-se e necessitava-se de uma classe trabalhadora apta a ocupar seu lugar na ordem social pretendida. Para o que interessa a este trabalho, pode-se dizer que aquele período presenciou a consolidação de um discurso que provinha das elites e do Estado o qual difundia a imagem de uma população imatura, desqualificada, indisciplinada e, em alguns casos, perigosa.

As ideias e valores articulados nesse discurso correspondem, ao que se denominou matrizes culturais. Elas gradativamente enraizaram-se no meio, transformando-se e se reatualizando pela interação em tempo e lugar ${ }^{15}$. Um discurso construído em outra época chega aos dias atuais e se reproduz nas falas dos trabalhadores de rua. Contudo, ele não aparece mais na esfera pública do mesmo modo como o fazia no passado, pois ele se encontra resignificado. Podese dizer, a exemplo de Martin-Barbero (2008), que ele representa a passagem de dispositivos de dominação a consenso.

A ressignificação, nesse caso, corresponde ao consenso. Os valores que se encontravam articulados ao discurso que legitimava uma ordem social hierarquizada entre superiores e inferiores, aos poucos foram sendo incorporados e reproduzidos por aqueles que eram objeto de atenção desse discurso. Um exemplo nesse sentido é ideia de informalidade como espaço de ilegalidade difundida pelos gestores e reproduzida pelos trabalhadores.

Essas concepções, ao adentrarem o universo dos trabalhadores como um discurso que pode ser por eles reproduzido, no que se refere a outros trabalhadores, faz que ele circule na esfera pública como fruto de certo consenso social, ou seja, os trabalhadores populares outrora definidos e estigmatizados por esses juízos de valores atualmente a aderem a eles e deles fazem uso. A repercussão desse fato pode ser observada, de um lado, na naturalização das assimetrias sociais. A desigualdade não é percebida como resultado de um pacto social que demarca lugares específicos na distribuição diferenciada de oportunidades e chances de

14 Uma melhor apreensão destas questões no pensamento social brasileiro pode ser encontrada em Ianni (2002).

15 Não se desconhece que esses valores se encontram associados a outros tempos e lugares e ou instituições como a religião, por exemplo. 
vida, mas é percebida como reflexo de diferenças naturais entre os sujeitos e ou, do mérito e distinção.

De outro lado, a repercussão relaciona-se com a possibilidade de acesso aos benefícios e direitos sociais. Nesse caso, o debate sobre seu acesso é deslocado do marco institucional, reflexo da condição de cidadão, e reposto no âmbito de um contrato formal de trabalho ou, em outro marco legal: a microempresa. Assim, ganha importância a percepção que os valores culturais possuem quando envolvidos na constituição institucional da esfera econômica, mediados por interpretações do princípio do mérito e que repercute de forma particular na divisão do trabalho e na distribuição de status.

Essas questões são de extrema importância, pois repõem hierarquias e interferem na possibilidade de interação em paridade de condições na esfera pública, uma vez que os sujeitos entram em interação ostentando status diferenciados. Trata-se de hierarquias que se traduzem em estratificação. Neste sentido, uma sociedade como a brasileira em que a desigualdade reflete a distância existente entre o estrato superior e o inferior, as possibilidades da entrada de atores tão diversos em paridade de condições na esfera pública são pouco promissoras. Portanto é preocupante as conclusões apresentadas em estudo recente realizado pelo Instituto de Pesquisa Econômica Aplicada (Ipea), em 2011.

Segundo os dados obtidos pela pesquisa, apesar da redução registrada nas taxas de desemprego e o aumento da taxa de ocupação, eles não foram suficientes para diminuir o nível de desigualdade social da população brasileira. Tendo como referência os dados da Pesquisa Mensal de Emprego (PME) feita pelo Instituto Brasileiro de Geografia e Estatística (IBGE), os técnicos do Ipea (2011) constataram que a diferença nas taxas de desemprego dos dois grupos, que em 2005, era de 11 vezes, passou a ser de 37 vezes em 2010. Além disso, a desigualdade entre os $10 \%$ que ganham mais e os $10 \%$ que ganham menos também aumentou, ao passo que o percentual de desempregados entre os trabalhadores mais bem remunerados baixou de 2,1\% para apenas $0,9 \%$ do total e, entre os mais pobres, o índice subiu de 23,1\% para 33,3\% (IPEA, 2011).

Com diferenças tão gritantes, é pouco provável que ocorra uma interação em paridade de condições, como requer o modelo desenvolvido por Nancy Fraser $(2006 ; 2008)$. É fácil perceber os obstáculos que os trabalhadores de rua enfrentam por ocasião da ocorrência de conflitos em que reivindicam melhores condições de trabalho ou mesmo a permanência ou ocupação de determinado espaço ou via pública. Normalmente contrastados com os comerciantes formais (lojas, bares, restaurantes, supermercados, dentre outros), eles não se encontram em uma posição que lhes garanta a independência e a voz do ponto de vista 
econômico. Ao mesmo tempo, não lhes é concedido, em muitos casos, um reconhecimento que lhes permita entrar como parceiro legitimado em debates públicos, uma vez que seu status, muitas vezes, é definido com base na ilegalidade ou na informalidade.

Alguns depoimentos coletados são emblemáticos neste sentido. O primeiro foi coletado com o Secretário de Desenvolvimento Econômico, Tecnologia, Trabalho e Turismo (Sedetur) do município de Novo Hamburgo. Quando questionado acerca da quase inexistência de vendedores ambulantes circulando pela cidade, ele se manifestou nos seguintes termos:

aqui a nossa população, pela cultura da cidade, não aceita esse tipo de pobreza. Aqui é uma cidade onde se investe na produção, no comércio, na geração de serviços, e não podemos permitir que quem investe na cidade, gera empregos, produz riquezas seja prejudicado. A via pública é um espaço para que as pessoas circulem e tenham acesso ao comércio em geral e não deve ser ocupada por esse tipo de atividade. Atuamos forte na fiscalização. Quando encontramos um sujeito comercializando produtos na rua abordamos ele, pedimos seus documentos para incluí-lo em um cadastro e explicamos a ele que esse tipo de atividade não é permitida na cidade, solicitamos que ele se retire e o avisamos que caso ele retorne a cidade para comercializar produtos nesta condição, todas as mercadorias e objetos relacionados serão apreendidos.

O outro exemplo provém do município de São Leopoldo e ocorreu quando da preparação para a realização das primeiras entrevistas e diz respeito à instalação do Shopping Bourbon. Por ocasião da aquisição do Shopping São Leopoldo pela Cia. Zaffari, detentora da marca e rede Bourbon, ela apresentou um projeto de ampliação da área e solicitou que a gestão municipal removesse os camelôs que se encontravam nas ruas que contornam o shopping. Diante desta solicitação e do constante conflito com os lojistas da região, o governo municipal optou por remover os camelôs, concentrando-os em outra área. A decisão só acirrou o conflito de interesses em questão. A contenda encontrou guarida na mídia, que, com alguma frequência, procurou os camelôs para coletar depoimentos. Essa situação acabou tendo consequências para realização das entrevistas com esses sujeitos.

Naquele momento, a grande maioria dos camelôs comprometeu-se em conceder as entrevistas. Contudo, solicitaram que elas fossem realizadas quando eles se instalassem no camelódromo. Alegavam que muitas de suas declarações foram distorcidas pela mídia, e, por isso, se mostravam inseguros em relação ao fato de se manifestarem e sofrerem retaliações do governo municipal. Cabe recordar que no momento da criação do camelódromo em São Leopoldo, ficou 
definido pelo poder público que a atividade de comercialização de produtos dos camelôs só poderia ocorrer naquela área e quem ficasse de fora do camelódromo deveria abandonar a atividade ou realizá-la em outro município. Essa situação prejudicou a realização de entrevistas e não pôde ser contornada de imediato e elas só se realizaram no final do ano de 2008.

$\mathrm{Na}$ mesma perspectiva, o caso do casal de cegos que trabalham em uma banca próxima a porta de entrada da Ferragem Feldmann complementa a questão. Esse casal trabalho no local há mais de dez anos, e sua permanência só foi possível pela intervenção da referida loja que permitiu a continuidade da atividade no local. A constante negativa do casal em participar da entrevista ocorreu pelos mesmos motivos dos camelôs, ou seja, a preocupação em relação a uma possível repercussão negativa em relação à entrevista ${ }^{16}$. Em todas as situações apresentadas encontram-se presentes elementos que impedem a independência e a voz dos trabalhadores como interlocutores reconhecidos em igualdade de condições na esfera pública. Nesses casos, seja pela condição de precariedade econômica ou pelo não reconhecimento dos sujeitos como trabalhadores com direitos, o diálogo em paridade participativa não se concretizou.

\section{TRABALHO: BEM DE ACESSO E CATEGORIA INTERPRETATIVA DA REALIDADE}

Encaminhando-se para parte final desta análise, serão examinados aspectos que surgiram de respostas sobre questões como vencer na vida, o que é uma boa vida e dignidade, mas que se encontram presentes, em grande medida, nas questões e respostas analisadas até o momento. A primeira questão refere-se à constatação de que as respostas obtidas a abordagem dos problemas sociais, os desejos desses trabalhadores, a visão que eles possuem da sociedade, dentre outras, invariavelmente encontravam-se mediadas pelo trabalho como categoria interpretativa da realidade.

Trata-se de um fato significativo, pois permite retomar elementos discutidos no segundo capítulo desta tese e que dizem respeito ao trabalho como bem. Comentou-se então que os bens cumprem funções sociais, dentre elas, a de oferecer um conjunto de informações aos parceiros de interação, uma vez que os bens são investidos de valores socialmente utilizados para mudar realidades e criar permanências. Nessa perspectiva, destacou-se que as pessoas utilizamse dos bens para interpretar o que se passa à sua volta. Eis o ponto a que se pretendia chegar.

16 A participação desse casal só foi possível pela intervenção pessoal do pesquisador que os conhecia. 
Observou-se nas respostas dos entrevistados que as suas interpretações, ou visão de mundo, são profundamente perpassadas pelos processos vivenciados em suas interações cotidianas com base ao mundo do trabalho. Situações de conflitos, conquistas pessoais, sentimentos de injustiça e outros, associados a ocorrências em suas trajetórias laborais são mobilizadas para exprimir julgamentos e emitir opiniões acerca da sociedade em que se vive, do mesmo modo que servem para balizar expectativas e estratégias em relação ao futuro.

Nesse momento, é conveniente introduzir o segundo aspecto a ser destacado porque ele é complementar às expectativas e estratégias. Trata-se do trabalho como bem de acesso. Para além da subsistência, o trabalho é, para os entrevistados, o principal meio para obter segurança social (CASTEL, 2005), seja pelo acesso a direitos e benefícios sociais, obtidos por meio do contrato formal de trabalho ou da legalização da atividade, seja, pela segurança contra os infortúnios possibilitados pela propriedade de bens como casa própria, carro e outros.

Nesse sentido, não deve causar surpresa o fato de mesmo apresentando uma visão positiva acerca das suas atividades como um trabalho digno, honrado, que possibilita satisfação e realização, esses trabalhadores apresentem no seu horizonte de expectativas o desejo de ocuparem um posto de trabalho formal. Essas observações complementam-se com as perspectivas apresentadas a seguir. As respostas acerca do que significa vencer na vida são indicadas no gráfico 19.

Gráfico 4 - O que significa vencer na vida

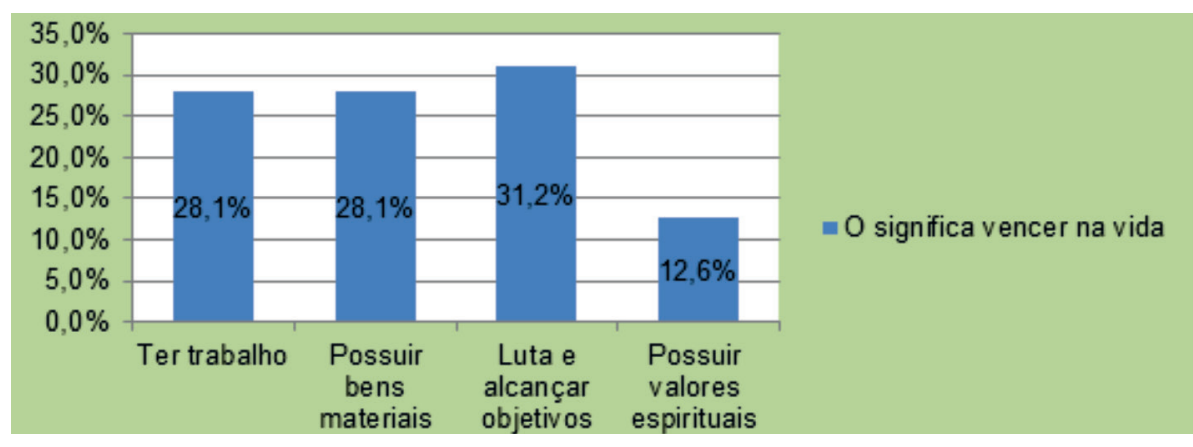

Uma síntese das respostas permite afirmar que, vencer na vida, para os trabalhadores de rua, encontra-se relacionado com a atitude individual de traçar objetivos e se empenhar em realizá-los. Esses objetivos envolve a posse de bens materiais que lhes garantam uma vida melhor, mas também que lhes sirvam de motes de proteção social. As maneiras de vencer na vida relacionam-se às condições oferecidas pelo trabalho. Essas questões são reafirmadas quando os entrevistados se manifestam sobre quando uma pessoa pode dizer que possui uma vida boa. Apresenta-se algumas respostas: 
Ter casa própria, ter salário e sobrar um pouco depois para pagar as contas (entrevista 4, São Leopoldo).

Quando tem tudo o que quer. Ter sua casa, seu emprego, se dar bem com a família. Não precisa ter muito luxo, ser feliz, se realizar profissionalmente (entrevista 6, São Leopoldo).

Quando tem um bom emprego, ou seja, uma renda razoável que pudesse ter um futuro melhor, uma vida estável (entrevista 12, São Leopoldo).

Tem um bom emprego, bem remunerado, poder fazer rancho, ter convenio (de saúde), uma boa assistência (entrevista 14, São Leopoldo).

Um bom emprego, um salário bom, pode tirar umas férias, se não tem um carro vai de ônibus até de avião, hoje dá pra parcelar em várias vezes (entrevista 19, São Leopoldo).

Em síntese, pode-se dizer que, no contexto dos entrevistados, o trabalho é necessário não só para garantir meios para subsistência, mas em igual medida, para que eles possam realizar interpretações acerca da realidade social em que se encontram inseridos. O trabalho permite-lhes situar-se no mundo, possibilitando, com suas interpretações, formularem projetos coletivos e individuais em um determinado campo de possibilidades ${ }^{17}$. Nesse caso, observa-se que a disposição desses trabalhadores em modificar certas situações consideradas desfavoráveis depende da forma como encaram as oportunidades, avaliam os riscos e as limitações que se lhes apresentam. Um exemplo dessas questões pode ser observada nos antagonismos de duas respostas de entrevistados em relação à mudança e às dificuldades da atividade:

Não, tinha vontade de fazer cachorro quente, mas tenho medo de mudar e não dar certo (entrevista 6, Sapucaia do Sul).

O mercado está em expansão, o mundo digitalizado. A tendência é os olhos ficarem cada vez mais fracos e com isso as pessoas precisam de mais óculos, cada vez mais, vai melhorando, aumentando as pessoas que me procuram (entrevista 7, São Leopoldo).

Pode-se afirmar, então, que a capacidade de ação desses trabalhadores depende da amplitude de informações obtidas e das oportunidades estruturais que se lhes apresentam. Em outras palavras, é por meio do vivenciar o trabalho de rua, que esses sujeitos interpretam a realidade social e fazem projeções sobre suas perspectivas futuras, enquanto expectativas de superação de adversidades.

17 Tanto a noção de campo de possibilidades, quanto de projeto têm sido desenvolvidas por Gilberto Velho (1994). Por campo de possibilidades, o autor entende o que é dado aos sujeitos, às alternativas construídas no processo sócio-histórico e o potencial interpretativo do mundo simbólico da cultura. Em outras palavras, podemos dizer que se trata de um espaço de formulação e implementação de projetos individuais e coletivos. Conforme tal entendimento o projeto lida com a performance individual ou coletiva, com as explorações, os desempenhos e as opções, ancoradas a avaliações e definições da realidade. Para um maior detalhamento das possibilidades analíticas dessas propostas, ver Pizzio (2008). 
Os dados aqui apresentados reafirmam a ideia de que estamos vivendo uma realidade na qual os processos de inclusão e exclusão sociais definem espaços a serem ocupados pelos indivíduos, assim como as condições de ocupação. Entretanto essas imposições encontram-se travestidas pelas atribuições de natural, como determinadas por leis da natureza ocultando assim, o compromisso com o humano não considerando esse contexto da realidade, ou seja, a extrema desigualdade que domina a estrutura social, a degradação das condições de trabalho, a fragilidades dos suportes de sociabilidade entre outros, resultantes dos modos de produção e reprodução social, conduzindo uma parcela significativa da população a experimentar formas marginalizadas de inserção.A compreensão desses elementos permite situar esses trabalhadores como sujeitos de sua história e não como mero objetos da história ou do mercado.

\section{CONSIDERAÇÕES FINAIS}

O desenvolvimento teórico, combinado com os dados empíricos coletados, mostra que são bastante complexas as questões que envolvem o debate relativo à justiça social. Nele estão presentes atores e instituições diversas que tecem uma intricada teia de relações sociais estabelecidas por meio de interesses diversos em muitos casos, contraditórios. Matrizes culturais e bens atuam mediando a construção social de uma representação que orienta o sentido de uma vida que vale a pena ser vivida, por ser digna e justa. Sua concretização, para a grande maioria dos entrevistados, encontra-se nas possibilidades de reconhecimento da condição de cidadãos, por meio do trabalho.

Diante da constatação de que os bens possuem significados compartilhados, pode-se dizer que se obtém, por meio do trabalho de rua, um status desvalorizado, inferior. Dessa forma, o trabalho como bem de acesso lida com formas de dominação, expressa valores, constitui microambientes e se desdobra em uma relação dialética que repercute no status adquirido e atribuído a quem dele participa. Quando mediado pelos ditames do mercado, o trabalho legitima tanto as hierarquias ocupacionais quanto a estratificação dos sujeitos em ocupações consideradas mais importantes ou melhores e aquelas percebidas como de menor monta. Sua distribuição entre os sujeitos em geral é considerada justa, por parecer estabelecida pelo mérito pessoal. Nessa perspectiva, ele pode tanto constituir-se em um bem fundamental para a obtenção de um patamar de justiça social aceitável pelos sujeitos, como pode transmutar-se em um bem negativo, como o trabalho árduo, descrito por Walzer (2003).

Essa possibilidade permite que se teçam alguns comentários em relação ao desejo manifestado por muitos entrevistados - o de possuírem um trabalho 
legalizado ou um emprego formal. Esse objetivo encontra-se relacionado, em menor medida, com o status superior atribuído a essas formas, e, em maior grau, com as demandas por eles apresentadas, no enfrentamento das vicissitudes da vida. Assim, são as proteções sociais construídas sob a égide do trabalho em uma sociedade baseada na relação salarial, que falam mais alto, pois o acesso à cidadania social, no Brasil, ocorre prioritariamente com a consolidação do contrato formal de trabalho.Pode-se acrescentar que os trabalhadores pesquisados, na corrida pelo emprego, desejam a suposta segurança do trabalho formal (da qual estão estruturalmente excluídos), mas, objetivamente, incluem-se no mundo do trabalho informal - objeto de insegurança no que diz respeito à aquisição de condições básicas de sobrevivência, em razão das más condições de atuação e da discriminação que sofrem.

Essas questões tornam-se mais evidentes diante das expectativas dos trabalhadores em relação ao futuro. Elas se resumem no desejo de obtenção de melhores condições de vida e trabalho para eles próprios e seus familiares. Esses horizontes de expectativas representam o ideal de felicidade a ser alcançado. É no horizonte desses sonhos, desses desejos, que se decifra a importância da inserção social pelo trabalho na vida cotidiana desses sujeitos. Nessa perspectiva, os trabalhadores informais de rua estão sendo penalizados duplamente: por estarem excluídos da condição de uma atuação com garantias conquistadas pelos trabalhadores no passado e pela sua inclusão em formas de trabalho discriminadas e percebidas como destinadas a fracassados.

Pensando em termos de coletividades ambivalentes, constata-se que os trabalhadores informais de rua configuram-se como tais. Suas demandas referemse, de um lado, a reivindicações de redistribuição, o que pode ser observado com base nas denúncias que explicitam a insuficiência de investimentos, a falta de capital de giro, dentre outros, e que se referem a possibilidades de melhores ganhos e também de acesso a mercados mais rentáveis. De outro lado, suas demandas vinculam-se a reivindicações por reconhecimento. Em relação a essa demanda, em geral, ela se manifesta no pleito pelo reconhecimento da condição de trabalhador.

Neste sentido, a falta de uma condição econômica que lhes permita enfrentar situações conflitivas ou mesmo sustentar um discurso em benefício próprio mostrou-se ser uma importante limitação, assim como o não reconhecimento da condição de trabalhador ou o status negativo da atividade surge como condição de desqualificação desses sujeitos. Portanto, suas reivindicações, em muitos momentos, adentram a esfera pública deslegitimadas, por serem oriundas de sujeitos definidos com referência a situações de informalidade ou de ilegalidade.

Nessas situações, a informalidade, percebida como condição social, é construída sobre a representação de um espaço que se mistura com a ilegalidade. 
O discurso constituído com referência à dicotomia informal/ilegal acaba por confundir o trabalhador que se encontra fora do contrato regular de trabalho com aquelas atividades que, embora rentáveis, ferem os princípios do elo social, como a criminalidade, por exemplo (KUYUJIAN et al., 2001).

Em relação a todas essas questões, alguns comentários ainda necessitam ser agregados. Eles dizem respeito aos gestores públicos que se constituem em importantes atores no processo de atendimento a demandas e conflitos decorrentes do trabalho informal de rua. Assim, pode-se afirmar que, no cômputo geral, as ações propostas pelos gestores e destinadas a esse conjunto de trabalhadores referem-se à implantação de políticas orientadas pelo governo federal. No entanto, não se observou nos municípios pesquisados políticas concebida no âmbito local, a não serem aquelas destinadas a coibir a ocorrência das atividades informais em determinadas áreas, as chamadas ações de fiscalização.

Quando consideradas as reivindicações de coletividades ambivalentes, percebe-se que as ações que pretendem o equacionamento de ambas as reivindicações, em grande medida, são concebidas e geridas separadamente. O diálogo entre os diversos órgãos responsáveis por implementar as ações não garante a necessária transversalidade do processo. Via de regra, verifica-se que políticas de gênero e raça ficam a cargo de secretarias especializadas, do mesmo modo que as secretarias de desenvolvimento são responsáveis pela implementação produtiva, e assim por diante. As poucas ações desenvolvidas em conjunto limitam-se à concessão de créditos ou capacitações especificas. Embora se entenda que essas ações devam andar pari passu, a execução conjunta parece mais uma estratégia discursiva do que uma prática efetiva.

Em virtude das complexidades que envolvem o trabalho informal de rua, cabe um comentário adicional acerca das ações empreendidas para limitar a ocorrência das atividades a pontos específicos do espaço público. Neste sentido, a política de administração do espaço urbano revela-se útil para os gestores locais permitindo, de um lado, um maior controle e fiscalização das atividades e dos sujeitos, e, de outro, constitui importante estratégia para silenciar grande parte das demandas e dos conflitos resultantes da ocupação das ruas da cidade. Ao mesmo tempo, tem correspondido ao conjunto de interesses do empresariado local, garantindo a retirada dessas atividades de áreas consideradas nobres, sem que se discuta a privatização do espaço público, costumeiramente operada por eles. É nessa perspectiva que se pode falar do espaço público como lócus de materialização de desigualdades sociais no tocante ao acesso a recursos básicos com diferentes locais de divisão de atividades.

Encaminhando a parte final destas considerações, as possibilidades de obtenção de um patamar de justiça social, segundo a compreensão das expectativas 
dos trabalhadores informais de rua, permite um maior entendimento acerca de como os sentimentos de valor, força e dignidade pessoal desses sujeitos ou grupos podem ser acionados na tentativa de sobrepujar situações desfavoráveis, como as suas vivências no dia a dia. O trabalho informal de rua, com suas permanências e temporalidades, engendram situações marcadas pela segregação, pela incerteza e pela insegurança.

Nesse contexto, a disposição dos sujeitos para melhorar sua condição depende de como encaram as oportunidades, os riscos e as limitações que se lhes apresentam. Por fim, conclui-se ser o trabalho um bem fundamental na busca da superação das desigualdades sociais e na consolidação da justiça social. $O$ trabalho, mais do que um bem de acesso, representa o meio pelo qual as pessoas se situam no mundo. Como mencionado anteriormente, o trabalho oferece uma base racional para interpretação da realidade vivida e dos diversos arranjos presentes no modus vivendi. É por meio dele que as pessoas interpretam o que se passa a sua volta, elabora projetos e realiza a sua inserção social.

\section{BIBLIOGRAFIA}

BASTOS, Elide Rugai. A questão social e a sociologia paulista. São Paulo em Perspectiva, São Paulo, no 5 (1), p. 31-39, jan/mar, 1991.

CASTEL, Robert. A insegurança social: o que é ser protegido. Petrópolis: Vozes, 2005.

DAHRENDORF, Ralf. O conflito social moderno: um ensaio sobre a política da liberdade. Rio de Janeiro: Jorge Zahar Editor; São Paulo: Edusp, 1992.

DUMONT, Louis. Homo aequalis: gênese e plenitude da ideologia moderna. Bauru, SP: Edusc, 2000.

FRASER, Nancy. Escalas de Justicia. Barcelona: Heder, 2008.

Da redistribuição ao reconhecimento? Dilemas da justiça na era pós-socialista. Em: SOUZA, Jessé (Org). Democracia hoje: Novos desafios para a teoria democrática contemporânea.Brasília: Editora Universidade de Brasília, 2001. p. 245-282.

FRASER, Nancy. La justicia social enla era de la política de laidentidad: redistribuición, reconocimiento y participación. Em: FRASER, Nancy; HONNETH, Axel. ¿Redistribuición o reconocimento? Madri: EdicionesMorata, 2006. p. 17-88.

FRASER, Nancy. A justiça social na globalização: Redistribuição, reconhecimento e participação. Coimbra: Revista Crítica de Ciências Sociais, 2002. Disponível em: <http://www.ces.uc.pt/publicacoes/rccs/063/063.php>. Acesso em: 25 out. 2006.

GEERTZ, Clifford. A interpretação das culturas. Rio de Janeiro: LTC, 1973. 
IANNI, Otávio. A questão social. Em: Pensamento social no Brasil. Bauru-SP: EDUSC, 2004. p.103-122.

Tipos e mito do pensamento brasileiro. Revista Brasileira de Ciências Sociais, São Paulo, Vol. 17 n 49, p. 5-10, jun, 2002.

INSTITUTO DE PESQUISA ECONÔMICA APLICADA - IPEA. Brasil chega a PIB per capita de US\$10 mil em 2010. E agora? Disponível em: < http:/ / agencia.ipea.gov.br/ index.php?option=com_content\&view=article\&id=2036> . Acesso em 13 de nov. 2010.

KOWARICK, Lúcio. Sobre a vulnerabilidade socioeconômica e civil: Estados Unidos, França e Brasil.Revista Brasileira de Ciências Sociais,Vol 18, nº 51,fev, p. 61-85, 2003.

KUYUMJIAN, Márcia M.; MELLO, Maria T. F. N.; SANTOS, Carolina C. B. Vivências cotidianas do trabalho informal em Brasília. Ser Social, Brasília, no 9, p. 187-216, 2001

MARTIN-BARBERO, Jesús. Dos meios as mediações: comunicação, cultura e hegemonia. $5^{\text {a }}$ ed. Rio de Janeiro: Editora UFRJ, 2008.

MENZ, Maximiliano M. Os escravos da feitoria do linho cânhamo: trabalho, conflito e negociação. Afro-Ásia, Salvador, no 32, p. 139-158, 2005.

MULLER, Telmo Lauro. Antes 1824 depois: a imigração alemã no Rio Grande do Sul. São Leopoldo: Museo Visconde de São Leopoldo, s/d. Disponível em: <http://www2. brasilalemanha.com.br/1824_antes.htm>. Acesso em 10 out. 2010.

PAOLI, Maria Célia Pinheiro Machado. Mulheres: o lugar, a imagem, o movimento. Em: FRANCHETO, Maria Laura et al. Perspectivas antropológicas da mulher. Rio de Janeiro Zahar, 1985.

PIZZIO, A. e SANTOS,, L. N. Princípio de paridade participativa, reconhecimento e desigualdade social em Território Rural no Bico do Papagaio (TO).Novos Cadernos NAEA. Vol. 16, n. 1 p. 261-280, jan-jul 2013.

RICCI, Rudá. Um fordismo tupiniquim que concilia interesses. Revista do Instituto HumanitasUnisinos, São Leopoldo, ano X, n 352, p. 8-10, 2010.

TELLES, Vera da Silva. Pobreza e cidadania. São Paulo: editora 34, 2001.

VELHO, Gilberto. Projeto e metamorfose: antropologia das sociedades complexas. Rio de Janeiro: Jorge Zahar Editor, 1994.

WALZER, Michel. Esferas da Justiça. São Paulo: Martins Fontes, 2003. 


\section{Pesca artesanal e manejo: conflito socioambiental em uma área de unidade de conservação do Parque Nacional do Cabo Orange, Oiapoque, Amapá}

\section{Artisanal fisheries and management: environmental conflict in a protected area National Park Cabo Orange, Oiapoque, Amapá}

Uriens Maximiliano Ravena Cañete - Doutorando do Programa de Pós-Graduação em Sociologia e Antropologia (PPGSA), UFPA. E-mail: uriensmax@gmail.com

Voyner Ravena Cañete - Professora do Programa de Pós-Graduação em Sociologia e Antropologia - PPGSA/UFPA e do Programa de Pós-Graduação em Ecologia Aquática e Pesca (PPGEAP), UFPA. E-mail: ravenacanete@ufpa.br

Sônia Maria Simões Barbosa Magalhães Santos - Professora do Programa de Pós-Graduação em Gestão dos Recursos Naturais e Desenvolvimento Local (PPGEDAM), UFPA e Sociologia e Antropologia (PPGSA), UFPA. E-mail: smag@ufpa.br

\begin{abstract}
Resumo
Este trabalho descreve como pescadores artesanais têm se ordenado política e ambientalmente no que se refere a cenários de conflito em águas costeiras por territórios de pesca. Descreve, especificamente, os conflitos pesqueiros ao redor do Parque Nacional do Cabo Orange, no município de Oiapoque, Amapá, ao norte do Brasil. Os parques nacionais são um modelo de unidade de conservação de proteção integral à natureza, não permitindo a presença humana ou exploração de seus recursos. Contudo, a partir da pressão originada pela demanda internacional e nacional de pescado e diante dos modos de sobrevivência de populações tradicionais que dependem da pesca, a Colônia de Pescadores Z-03 do município do Oiapoque, somada ao Estado, na figura do ICMBIO e outros atores e agentes sociais se articularam na busca de novos arranjos para o uso desses recursos naturais. Por meio de entrevistas e trabalho de campo marcado por observação direta, este ensaio descreve como no Oiapoque um termo de compromisso, estabelecido entre a Colônia de Pescadores Z-03, o ICMBIO e o Ministério Público, vem se mostrando parcialmente efetivo como uma estratégia e alternativa para o manejo de recursos pesqueiros, gestão de conflitos socioambientais e medida temporária para uma solução compensatória referente à população remanescente do Parque Nacional do Cabo Orange.
\end{abstract}

\section{Palavras-chave}

Termo de Compromisso. Recurso Pesqueiro. Conflito Socioambiental.

\begin{abstract}
This paper describes how artisanal fishermen have ordered politically and environmentally in conflict scenarios in coastal waters by fishing territories. Describes specifically the fisheries conflicts around the National Park Cabo Orange, in the municipality of Oiapoque, Amapá, north of Brazil. The National Parks are a model of strictly protected unit to nature, not allowing human presence or exploitation of its resources, however, from the pressure caused by the international and national demand for fish and before the traditional populations Survival modes dependent on fishing, the colony of fishermen in the city of Oiapoque, added to the State, in the figure of ICMBIO and other social actors and agents joined forces in the search for new arrangements for the use of these natural resources. Through interviews and field work marked by direct observation, this paper describes how in Oiapoque, a term of commitment signed between Cologne Fishermen, ICMBIO and the prosecutor, has proven partially effective as a strategy and alternative to the management of fishing resources, management of environmental conflicts and temporary measure to a compensatory solution concerning the remaining population of the National Park Cabo Orange.
\end{abstract}

\section{Keywords}

Statement of Commitment. Fishery Resource. Environmental Conflict. 


\section{INTRODUÇÃO ${ }^{1}$}

Os recursos pesqueiros são objeto de conflito no mundo, e no Brasil, esse quadro se repete e em especial na região amazônica (RUFFINO, 2005; ISAACNAHUM, 2006; FRÉDOU et al., 2010). Nesta, os conflitos pesqueiros se dão tanto em águas interiores, como é o caso da pesca em rio e lagos, como em águas oceânicas, que é o caso da costa norte brasileira (estados do Pará e do Amapá), área com notória variedade de espécies de pescado e marcada pela dependência da população tradicional dessa atividade (FRÉDOU et al., 2010).

Este trabalho trata da pesca artesanal ${ }^{2}$ na área da costa norte brasileira, especificamente na Unidade de Conservação (doravante UC) conhecida como Parque Nacional do Cabo Orange (doravante PNCO), município do Oiapoque, fronteira entre o Amapá e a Guiana Francesa. Tem por objetivo apresentar um cenário de conflito socioambiental que se estabelece após a implantação do PNCO. Neste, a pesca e o recurso pesqueiro figuram como atividade e recurso natural de disputa entre os agentes sociais inseridos nesse contexto. Este artigo faz ainda uma reconstituição história sobre o processo que engendrou o atual cenário de conflito pesqueiro no entorno do $\mathrm{PNCO}$, dando ênfase às estratégias locais para a solução de tais conflitos. Para tanto, este ensaio está dividido em quatro seções. A primeira apresenta o cenário anterior à instituição do PNCO, dando especial destaque à disponibilidade e riqueza dos recursos pesqueiros acessados pela população que vivia no interior do Parque. Descreve, em seguida, o período entre os anos de 1980 e 2000, evidenciando o processo de criação do PNCO (enquanto uma área protegida marcada pelo modelo preservacionista ${ }^{3}$ )

\footnotetext{
Este trabalho está inserido no projeto OSE Guyamapa - Observação por Satélite do meio ambiente sendo parcialmente financiado pelo Institut de Recherche pour le Développement.

2 A definição de pesca artesanal e industrial é discutível, especialmente para a Amazônia, pois quando comparada à outras regiões do país, onde embarcações industriais atingem tonelagens muito superiores às encontradas nessa região, com equipamentos sofisticados, essa definição mostra sua fragilidade (ISAAC-NAHUM, 2006). No entanto, para este ensaio, estende-se pesca artesanal como aquela que utiliza mão de obra especialmente marcada por relações familiares ou de parentesco, ademais de serem desenvolvidas por embarcações com tonelagens que não ultrapassam o limite de 15 mil quilos. Tal descrição se embasa na própria definição dos pescadores entrevistados.

3 A proposta preservacionista, como cita Diegues (2001), vê a criação dos parques movida pela necessidade de "contemplação da natureza selvagem, lugar de reflexão e de isolamento espiritual (p.26)". Nessa proposta o homem encontra-se fora do cenário natural, como se ele mesmo resultasse de um processo exógeno à natureza, longe de se caracterizar enquanto um integrante ativo do ecossistema. Nesse modelo, o homem se distancia do contato e uso dos recursos naturais, pois a natureza está posta para contemplação e estudo da sociedade. Nesse sentido, os parques criados até meados da década de 1980, não contemplam a presença de populações que fazem uso de seu recurso. Em contraposição à abordagem preservacionista, evidencia-se o modelo conservacionista que prevê a presença humana nas áreas de conservação, já que as populações originárias dessas áreas funcionariam como controladores e fiscalizadores do acesso e uso dos recursos naturais (DIEGUES, 2001).
} 
e os conflitos gerados pela restrição do acesso e uso dos recursos naturais em seu interior. Ainda nesta segunda seção são descritos os relatos e percepções da população que residia no interior do Parque, sobre o processo de expropriação por ela vivido até desembocar em sua inserção na sede municipal da cidade de Oiapoque. A terceira e última seção trata do período entre 2000 e 2010, apresentando o conflito originado pela feroz inserção dos pescadores do estado do Pará em território amapaense, inserção marcada por atividades predatórias e autoritárias. Descreve, ainda, o período a partir do ano de 2012, onde a organização dos pescadores do município do Oiapoque instituiu, por meio da Colônia de Pescadores Z-3, do Instituto Brasileiro do Meio Ambiente e dos Recursos Naturais Renováveis (IBAMA) e do Ministério Público Federal (MP), um Termo de Compromisso como ferramenta de manejo e diminuição de conflito entre os diferentes agentes que acessam e usam o território pesqueiro no interior do PNCO.

\section{VILA DE TAPEREBÁ: A VIDA NO INTERIOR DO PNCO}

Esta seção apresenta a área do PNCO como uma área natural, rica em biodiversidade e com uma população específica que a ocupa, desenvolvendo práticas que refletem e caracterizam populações tradicionais ${ }^{4}$. Descreve, de forma geral, o ecossistema de manguezal e as especificidades das populações que nele vivem, em especial aquela encontrada na área lócus do estudo.

O Brasil tem o segundo maior complexo de manguezais do mundo, com aproximadamente $13.400 \mathrm{~km}^{2}$ (SOUZA-FILHO, 2005). Mesmo sendo um ecossistema singular, o mangue pode ser encontrado em várias partes das regiões tropicais do planeta (ALVES, 2001). Enquanto ecossistema, ele resulta do encontro das águas doce e salgada, formando um ambiente de água salobra de salinidade variável e exclusivamente encontrada em regiões costeiras (TOMLINSO, 1986; ALVES, 2001).

\footnotetext{
A definição de populações, povos e comunidades tradicionais é variada. Desde instrumentos jurídicos, administrativos, passando pela discussão acadêmica, este conceito assume diversos contornos. Utilizam-se neste trabalho os conceitos elaborados por Almeida (2008), Cunha e Almeida (2001) e Diegues (1993; 2001) que enfatizam, cada um a sua maneira, duas características essenciais dessa categoria analítica, a saber: a dimensão de uma identidade jurídica e política do conceito, assim como a dimensão socioambiental atrelada ao mesmo. O conceito jurídico adotado repousa na definição encontrada no decreto 6.040/07 que assim se manifesta em seu artigo terceiro, inciso primeiro: "Povos e Comunidades Tradicionais: grupos culturalmente diferenciados e que se reconhecem como tais, que possuem formas próprias de organização social, que ocupam e usam territórios e recursos naturais como condição para sua reprodução cultural, social, religiosa, ancestral e econômica, utilizando conhecimentos, inovações e práticas gerados e transmitidos pela tradição". Para um panorama completo da construção do conceito consultar Ravena-Cañete (2012).
} 
Os impactos da ação humana sobre os mangues podem ser percebidos em esfera planetária. Um controle sobre esses berçários de vida demanda esforços tanto locais, como em esfera da gestão regional, nacional e mesmo por meio de intervenções efetivadas por instituições globais.

Marcado pela transição entre o ambiente costeiro e marinho, o mangue vive sob os efeitos das marés e apresenta fauna e flora específicas, além de um relevo particular composto de rios, desembocaduras, lagos e reentrâncias costeiras somadas a todas as áreas que permitem o encontro entre águas doces e marinhas 5 .

A cobertura vegetal, ao contrário do que acontece nas praias arenosas e nas dunas, instala-se em substratos de várzea de formação recente, de pequena declividade, sob a ação diária das marés de água salgada ou, pelo menos, salobra (MENEZES; BEGER; MEHLIG, 2008). A riqueza biológica dos ecossistemas costeiros faz com que essas áreas sejam grandes "berçários" naturais, tanto para as espécies características desses ambientes, como para peixes e outros animais que migram para as áreas costeiras durante, pelo menos, uma fase do ciclo de sua vida (SCHAEFFER-NOVELLI, 1989).

No Brasil, os mangues são protegidos por legislação federal, devido à importância que representam para o ambiente marinho (PEREIRA FILHO; ALVEZ, 1999 apud ALVES, 2001). São fundamentais para a procriação e o crescimento dos filhotes de vários animais, como rota migratória de aves, pescados e alimentação de peixes. Além disso, colaboram para o enriquecimento das águas marinhas com sais, nutrientes e matéria orgânica.

A área norte do Brasil, mais especificamente o estado do Amapá, integra o complexo de manguezais dessa região do território nacional, despontando como uma das maiores áreas contínuas de mangue do mundo. A foz do rio Cassiporé, localizada no interior do PNCO (município de Oiapoque e Calçoene), se destaca por ser um local de desova e criação de juvenis de diversas espécies de pescados. Considerando as preocupações ambientais, essa área foi escolhida para a instituição do PNCO.

Referendando esse cenário de riqueza e diversidade ambiental, o PNCO foi criado a partir de recomendações do projeto Radar na Amazônia (RADAM), devido ao estudo "Uma análise de prioridades em conservação da natureza na Amazônia”, produzido por Wetterberg et al. (1976). Após as recomendações da instituição do PNCO o mesmo foi incluído no Plano do Sistema de Unidades de Conservação do Brasil (IBDF; FBCN, 1979 apud ICMBio, 2010), com as seguintes justificativas:

Vasta literatura sobre o mangue amazônico pode ser encontrada. No entanto, algumas obras chamam a atenção por apresentarem um caráter interdisciplinar. Nesse sentido, consultar: Furtado, Silveira e Santana (2012). 
A proposição para criação dessa unidade de conservação é justificada a partir de itens importantes segundo critérios de avaliação de significância utilizados dentro do Plano do Sistema de Unidades de Conservação, que são os seguintes: representatividade de biomas anfíbios (campos de várzea e mangues) de grande importância como amostra única do Brasil; representação da planície flúvio-marinha Macapá-Oiapoque; representação de habitats de várias espécies ameaçadas de extinção: oito mamíferos, sete de aves e possivelmente duas de répteis, representação numa mesma área de mangues, praias lodosas, praias arenosas, dunas, campos de várzea, floresta, cerrados, lagos de água doce, salobra e salgada, rios, estuários e etc.; baixa densidade demográfica e baixo nível tecnológico. Em decorrência de todos os fatores apresentados, a área possui um elevado potencial educativo, com oportunidade interpretativa ímpar, um potencial científico e de monitoramento muito grande, prestando-se a estudos científicos e técnicos, e representa a natureza em todo o seu teor selvagem, e inóspita devido ao difícil aproveitamento para atividades econômicas tradicionais (ICMBio, 2010, p. 66).

Utilizando uma lógica preservacionista que marcou as décadas de 1970 e 1980, a gestão federal buscou consolidar diversas áreas protegidas em modelos de parques. Assim, a preocupação ambiental permanece como tema no contexto nacional e passa a compor a norma jurídica como consta no artigo 225 do capítulo VI da Constituição Federal de 1988 que prevê que: "Todos têm direito ao meio ambiente ecologicamente equilibrado, bem de uso comum do povo e essencial à sadia qualidade de vida, impondo-se ao poder público e à coletividade o dever de defendê-lo e preservá-lo para as presentes e as futuras gerações". Considerando esse pressuposto, a criação do parque resguarda apenas a perspectiva ecológica e ambiental de uma área, no entanto, exclui por completo qualquer tipo de população tradicional que possivelmente poderia residir no interior do Parque.

Dessa forma, a população que vivia na área que posteriormente se constituiria o PNCO desfrutava da rica biodiversidade e disponibilidade de recursos naturais como caça, pesca, extrativismo e criação de animais ${ }^{6}$. Essa população se concentrava quase exclusivamente na Vila de Taperebá. A população da Vila era uma comunidade pesqueira que desenvolvia suas atividades em parte do rio Cassiporé e em sua foz. Essa se mostra como uma área de extrema riqueza ambiental e recursos naturais como relatado pelos moradores.

A Vila de Taperebá está localizada na foz do rio Cassiporé, e seu ambiente de mangue dispõe de uma vasta variedade e quantidade de pescados. Como é uma

\footnotetext{
A criação de animais não deve ser entendida aqui como uma prática que caracteriza um setor econômico, mas, apenas, como uma atividade de subsistência. A criação de galinhas e porcos estava presente no discurso dos entrevistados, sendo que o gado também apareceu de forma recorrente.
} 
área de desova e berçário de juvenis, diversas espécies, principalmente a gurijuba e a pescada amarela, que são pescados altamente valorizados no mercado, se concentram em cardumes nas águas costeiras e foz do rio Cassiporé.

É importante salientar a diminuição no tamanho dos pescados, nos últimos 30 anos. Com a grande pressão do mercado interno e externo, os pescados estão sendo capturados cada vez mais jovens e de forma desordenada. Dessa forma, os pescados passam a ser mais escassos e menores, pois, não dispõem de tempo suficiente para reprodução e crescimento. A fala de um antigo morador da Vila de Taperebá é elucidativa.

Antigamente era só peixe graúdo difícil você pegar uma gurijuba pequena que nem hoje em dia, antes era daquelas grandes [...] a gente pescava de arpão, na praia, eu lembro que em lua cheia elas iam pras praias e lá a gente ia entrando na beira e via elas, daí pegava com o arpão só graúda. Hoje em dia, hummm [...] difícil pegar uma gurijuba com barco, imagina na praia (Pesquisa de campo, J. 45, 2013).

Atualmente o ciclo de reprodução do pescado sofre com a pesca sem controle. O presidente da Colônia dos Pescadores de Oiapoque Z-3, juntamente com alguns colonizados, relata o exemplo da gurijuba, dizendo que era difícil a captura de uma gurijuba de tamanho pequeno a médio estando ovada ${ }^{7}$, apenas as gurijubas maiores eram pescadas nessa condição. No entanto, atualmente essa espécie está sendo capturada ovada e ele assevera que elas evoluíram para tentar sobreviver, mudando o seu ciclo biológico para que a espécie se perpetue. A seguir, a partir de uma fala do presidente da Colônia de Pescadores Z-03, é possível elucidar tal argumentação.

[...] se nós observarmos hoje em dia, o peixe está ovado pequenininho a gurijuba, pescada branca, pescada amarela, bandeirado [...] e antigamente não era assim, pra pescar uma gurijuba ovada, ixi, só aquelas graúdas mesmo. Então isso que tem que ver, mudou tudo, é que nem hoje em dia você ver menina de doze anos parindo e antigamente não se via. Então o peixe tá mudando também. Isso que é que a gente vê (Pesquisa de campo, J. 45, 2013).

Ademais da quantidade e tamanho dos pescados, uma forte recordação e que se faz muito presente nas argumentações dos entrevistados é a arte de pesca. Antes, os apetrechos, as técnicas e as artes ${ }^{8}$ de pesca eram em sua maioria de pequena escala e seletivos quanto a tamanho e quantidade dos pescados. Os

Termo utilizado pelos pescadores para evidenciar que o pescado está com ovas, ou seja, em seu período de reprodução.

8 Para saber mais sobre técnicas e arte de pesca, ver Mourão et al. (2009). 
apetrechos mais utilizados eram o arpão e o espinhel ${ }^{9}$, que para eles, em sua atual percepção de escassez de recursos, eram os menos agressivos para as espécies capturadas. O presidente da Colônia de Pescadores Z-03 evidencia, ainda, que este tipo de técnica perdurou até meados da década de 1980 em toda costa amapaense. Sua fala anuncia tal percepção.

Antes a gente usava mais o espinhel e o arpão, esses eram os principais apetrechos de pesca da costa do Amapá, dava pra conferir quem não era, tinha a zangaria que era uma pesca predatória, mas a maioria dos pescadores era de espinhel, até os vigienses. Há uns 30 anos atrás que chegou a rede, né e uns 20 anos que começou com força (Pesquisa de campo, J. 45, 2013).

Os relatos apresentados descrevem a abundância dos recursos naturais na Vila de Taperebá no século passado e o fácil acesso e uso dos mesmos. A população que viveu na Vila dispôs de recursos naturais em abundância, no entanto, a partir da criação do PNCO essa disponibilidade foi se transformando. A próxima seção mostrará como houve um impacto na vida e cotidiano da população a partir da criação do parque.

\section{INSTITUIÇÃO DO PNCO: CONFLITOS SOCIAIS E AMBIENTAIS}

Esta seção aborda a instituição do PNCO e os vários cenários de conflito que se estabeleceram a partir das ações do governo federal sobre os moradores que viviam na Vila de Taperebá, às margens do rio Cassiporé.

O PNCO hoje é composto por um território com aproximadamente 200 $\mathrm{km}$ contínuos de costa e mangue. Nessa área houve uma intensa disputa ao longo dos séculos XVII, XVIII e XIX por diversos colonizadores: portugueses, franceses, ingleses e holandeses. Foi uma região que abrigou variadas denominações, inicialmente como "Cabo Cecil", posteriormente "Cabo de la Corda", por fim, em meados do século XVII, Johannes de Laet, um navegador holandês, homenageou a família Orange dotando o nome real à localidade. A palavra orange significa laranja em holandês e a mesma é a cor nacional da Holanda (ICMBio, 2010).

Como mencionado, o Parque Nacional do Cabo Orange foi instituído a partir de um estudo realizado em meados da década de 1970, quando, em um cenário nacional mais amplo, uma sobrexplotação dos recursos naturais começou a se delinear e com o consequente esgotamento dos mesmos ${ }^{10}$. Dessa forma,

9 Uma linha que dispõe de vários anzóis. Para saber mais sobre essa arte de pesca, ver Mourão et al. (2009).

10 Estas informações foram retiradas do site do Instituto de Chico Mendes de Proteção a Biodiversidade, mais precisamente no Plano de Manejo Parque Nacional do Cabo Orange. Brasília, 2010. 
um estudo ecológico ambiental foi realizado nessa área de mangue do estado do Amapá, mais especificamente na foz do rio Cassiporé, próximo à Vila do Taperebá. Nessa vila, segundo relatos do presidente da Colônia de Pescadores Z-03 do Oiapoque ${ }^{11}$, morador da vila por vinte anos, havia cerca de cem famílias e aproximadamente mais de quatrocentas pessoas secularmente instaladas na localidade. Hoje, apenas quatro famílias ainda resistem na Vila de Taperebá.

As principais populações que se localizavam no território que iria ser instituído como PNCO estavam nas vilas do Taberebá e Cunani. A primeira, localizada às margens do rio Cassiporé, e a segunda, às margens do rio Cunani, como apresenta a Figura 1.

Figura 1 - Localidade das antigas comunidades de Taperebá e Cunani no interior do PNCO

Fonte: adaptado do ICMBio (2010)

A instituição do PNCO foi concretizada em 15 de agosto de 1980 pelo Decreto $\mathrm{n}^{\circ} 84.913$, e, a partir de sua criação, conflitos socioambientais tomaram grandes proporções nesse cenário local. Mais uma vez, segundo o depoimento de antigos moradores, não houve desapropriação efetiva, mas sim um processo onde o governo federal dificultava a permanência daquela população na vila. A estratégia utilizada pelos governos federal e estadual, para a expulsão dos moradores, foi a de interromper o oferecimento nos serviços públicos básicos de saúde e educação, dentre outros.

11 Os dados sobre a história da Vila de Taperebá e os processos de desapropriação correspondem aos relatos de diversos pescadores do Oiapoque que na vila viveram. Dentre estes, destacam-se os relatos do senhor Julio Garcia, presidente da Colônia de Pescadores Z-03, que além de ter vivido o processo de expropriação, evidencia uma visão refinada e crítica sobre esse processo. 
Segundo o relato de pescadores remanescentes da Vila de Taperebá, no ano de 1980 o Instituto Brasileiro de Desenvolvimento Ambiental (IBDF) foi à localidade apenas colocar as placas de instituição do Parque. No entanto, o mesmo não informou a população, de forma adequada, sobre a criação dessa área de proteção integral. O relato a seguir exemplifica o comportamento estabelecido pelo IBDF: "Antigamente não tinha fiscalização, ai fizeram o Parque e largaram lá, depois de uns anos pra cá que eles vieram com essa fiscalização e ficou meio apertado, né e a gente teve que sair" (Pesquisa de campo, J. 38, 2013). Dentre os informantes, a fala do atual vice-presidente da Colônia de Pescadores Z-03 do Oiapoque ressalta o detalhamento da chegada e ação do IBDF junto à comunidade Vila de Taperebá.

Eles chegaram dizendo que era só uma demarcação federal, que nada seria mudado era só uma coisa de mapeamento mesmo e as pessoas continuariam vivendo, pescando, criando [...] aí eu vim de Cassiporé ${ }^{12}$ pra cá em 1988 e já estava bem avançado né, já tava começando a ficar difícil viver lá. Aí cada ano foi apertando mais. Desde uns três anos depois da criação do Parque eles frequentavam a Vila pra dizer que não ía poder roçar, pescar, caçar, só com permissão do IBAMA e essa permissão foi que depois originou o nosso atual acordo, poder pescar com um limite, pode pescar durante dez dias, depois entra outra equipe, entendeu? (Pesquisa de campo, M. 45, 2013).

As fiscalizações referidas pelo entrevistado são as visitas realizadas pelo IBAMA $^{13}$ para averiguar se havia alguma irregularidade ambiental no território do PNCO. Dessa forma, como evidenciado na fala acima, as fiscalizações foram iniciadas apenas, aproximadamente, três anos após a primeira visita do IBAMA à Vila, na qual se anunciava o estabelecimento da criação do parque. Os agentes do IBAMA visitaram a comunidade e informaram aos moradores que todos os benefícios disponibilizados à comunidade como, gerador de energia, abastecimento de diesel, pagamento de funcionários públicos como professores, médicos, enfermeiras, liberdade do acesso e uso dos recursos naturais seriam eliminados e proibidos.

Os remanescentes da comunidade alegam que com esse ato do Governo Federal a estadia deles na Vila ficou abalada, ameaçada e cada vez mais difícil. Tal argumentação expressa um contexto marcado por um processo de limitação

12 Os moradores da Vila de Taperebá referenciam o antigo lugar de moradia como Cassiporé. Essa autodefinição se explica dado que a Vila de Taperebá, como mencionado, se localiza às margens do rio Cassiporé, como elucidado na Figura 2.

13 O Instituto Brasileiro do Meio Ambiente e dos Recursos Naturais Renováveis (IBAMA) foi instituído em 22 de fevereiro de 1989, pela Lei n 7.735 (http://www.ibama.gov.br/acesso-ainformacao/historico). Dessa forma, quando se iniciou o processo de fiscalização do PNCO, na década de 90 do século passado, a instituição responsável pelas missões era o IBAMA. 
e exclusão, já que esses moradores foram impedidos de pescar, caçar, cultivar e criar animais nos territórios da comunidade.

Ademais de dificultar o modo de vida ${ }^{14}$, havia uma pressão do IBAMA sobre os moradores. Este utilizava a argumentação de que era proibido viver dentro do Parque, como é possível ver na seguinte declaração de um entrevistado: "a gente veio embora porque eles começaram a proibir a pesca, o IBAMA falava que era pra vir embora de lá. Aí não tinha mais escola pros meus filhos. Aí desgostou né [...] de lá. Ficou tudo difícil lá e o IBAMA falou que era pra vir embora" (Pesquisa de campo, M. 33, 2013,).

O IBAMA, para cessar a pesca na foz e no rio Cassiporé, jogou uma enorme barra de ferro no leito do rio para que os apetrechos de pesca não fossem lançados à água. Para ampliar a percepção do cenário passado, a fala de um ex-morador exemplifica a realidade experimentada pelo mesmo a partir da instituição do parque.

muito moradores de lá não saíram, porque não tinham expectativa de vida aqui no Oiapoque. A gente não sabia fazer outro trabalho. Mas o que acontece, hoje eu acredito que não vai ser diferente pra nós aqui, o Parque lá já foi fechado há muito tempo, lá mora só alguns [...] Umas cinco ou seis famílias. Então eles chegaram com essa ideia, não permitiam que as pessoas pescassem, era proibido, inclusive jogaram um ferro no rio que era pra gente nem soltar mais a malhadeira, acho que ainda existe isso ainda lá. Porque se jogasse a rede, prendia e perdia todo o material. Então era Parque, era lei o que vale é o que estava no papel a palavra não vale nada. Então hoje eu acho que não é diferente, porque eu já ouvi um projeto que a Petrobras que vai fazer umas plataformas aí fora, não sei quantas milhas pra fora, não sei se vai prejudicar nós, então os moradores do Taperebá se sujeitaram a vir pro Oiapoque, porque não tinha como permanecer lá! Como vai pescar pra manter a família, era área de Parque como a gente ia fazer, né? Eu me recordo de algumas vezes, eles iam lá e fiscalizavam e vendo se as pessoas não estavam pescando (Pesquisa de campo, M. 33, 2013).

Após a criação do parque não houve nenhum tipo de compensação ou indenização para aqueles moradores. Como visto nos relatos, essa população sofreu forte pressão e intimidação dos órgãos responsáveis para que deixasse o local. Dessa forma, ademais de não haver uma correta indenização no processo de instituição da área protegida, o governo isentou-se de seus deveres e mesmo

14 Modo de vida é uma categoria que aparece de forma diluída na literatura das Ciências Sociais. No entanto, neste trabalho, entende-se modo de vida como uma forma de viver marcada por uma lógica orientada por uma relação específica com os recursos naturais e como materialmente e simbolicamente uma população se relaciona com a sociedade do entorno e historicamente se constrói. Para discutir sobre essa temática, ver Abramovay (2003) e Veiga (2002). 
que o tivesse feito, seria possível mensurar o preço das memórias e do modo de vida daquela população para eles mesmos? Ou seja, esse raciocínio esbarra na questão de “comensurar o incomensurável ${ }^{15 "}$ (CAVALCANTI, 2004, p. 152).

Os interesses políticos e econômicos ultrapassam os valores do meio ambiente (CAVALCANTI, 2004), e dessa forma, são instituídos meios e métodos que fazem com que a população tradicional seja espoliada e marginalizada (ALMEIDA, 2008). Os moradores da Vila de Taperebá foram impedidos de pescar na localidade e encontraram dificuldades até mesmo em pescar para o próprio consumo, que à época era permitido. A ilegalidade se caracterizava pelo comércio dos recursos naturais do território do parque.

Ademais das proibições ao acesso e ao uso dos recursos naturais, houve mais dificuldades impostas pelo governo aos moradores da Vila de Taperebá. Os mínimos serviços públicos que eram oferecidos foram cessados causando um desgosto na população. Tal pressão governamental resultou na migração desses moradores. O relato em seguida elucida esse contexto de desgosto.

O governo dava muita ajuda, tinha escola, hospital, remédio, diesel com gerador, e aí a gente ficou esquecido. Daí foi desgostando de lá e a gente foi saindo. Eles começaram a proibir tudo. A gente tinha uma boa comunidade lá, tinha escola, tinha gerador, o governo mandava combustível, tinha gente que comprava os nossos peixes. Daí o IBAMA foi proibindo tudo, não podia mais pescar, caçar, plantar, só podia pescar pra gente mesmo, não podia vender. Daí eles fecharam a escola ficou sem escola, foi tudo ficando difícil né (Pesquisa de campo, J. 39, 2013).

A partir desses dados históricos, apresenta-se um quadro que permite sistematizar, de forma mais sucinta, o histórico de conflitos vivenciados pelos moradores da Vila de Taperebá.

15 Este termo merece uma abordagem maior, dessa forma, coloca-se a citação do autor para elucidar melhor o mesmo "Os custos associados a esses processos destruidores não são normalmente estimados: eles não aparecem nas estimativas das contas nacionais, exceto como fatores positivos e até como nova adição aos valores do PIB quando se consideram as despesas para consertar erros ecológicos cometidos, a exemplo de uma vazão tóxica como a de Cataguases em março de 2003 (cloro e soda cáustica, de uma fábrica de papel, lançados no rio Pomba, afluente do Paraíba do Sul). Estimar o valor monetário de recursos naturais esgotados como meio de aferir se o desenvolvimento tem sido sustentável representa uma iniciativa para, pelo menos, se ter uma ideia econômica das externalidades negativas geradas. Essa é a esfera de domínio da economia ambiental, com a qual se coloca o sistema ecológico na perspectiva da abordagem econômica. A valoração econômica ambiental interessa cada vez mais a gestores, estudantes, pesquisadores e profissionais. Trata-se de área de fronteira da ciência econômica, nem sempre aceita pacificamente, uma vez que se levanta contra ela a pertinente questão de comensurar o incomensurável" (CAVALCANTI, 2004, p. 152). 
Quadro 1 - Histórico de conflito do objeto desta pesquisa

\begin{tabular}{|c|l|l|}
\hline Período & Agentes envolvidos no conflito & \multicolumn{1}{|c|}{ Motivos do conflito } \\
\hline $1930-1980$ & $\begin{array}{l}\text { Não há relatos de conflitos } \\
\text { complexos }\end{array}$ & $\begin{array}{l}\text { Não há relatos de conflitos } \\
\text { complexos }\end{array}$ \\
\hline $1980-1985$ & $\begin{array}{l}\text { Conflito entre o IBAMA e } \\
\text { moradores da Vila de Taperebá }\end{array}$ & Acesso e uso dos recursos naturais \\
\hline $1990-2000$ & $\begin{array}{l}\text { Conflito entre o IBAMA e } \\
\text { moradores da Vila de Taperebá }\end{array}$ & $\begin{array}{l}\text { Acesso e uso dos recursos naturais } \\
\text { na área da Vila de Taperebá que } \\
\text { passou a compor o território do } \\
\text { PNCO e pela estadia da população } \\
\text { na comunidade. }\end{array}$ \\
\hline $2000-2012$ & $\begin{array}{l}\text { Conflito entre o IBAMA e } \\
\text { moradores da Vila de Taperebá; } \\
\text { Conflito entre frotas pesqueiras } \\
\text { maiores e de outras localidades } \\
\text { com os pescadores do Oiapoque } \\
\text { em embalitos por área de pesca es } \\
\text { fiscalização no PNCO, pois os } \\
\text { barcos de outras localidades não } \\
\text { respeitam as leis de proteção } \\
\text { ambiental do PNCO }\end{array}$ \\
\hline $2012-2014$ & $\begin{array}{l}\text { Conflito entre o IBAMA e } \\
\text { moradores da Vila de Taperebá; } \\
\text { Conflito entre frotas pesqueiras } \\
\text { maiores e de outras localidades com } \\
\text { os pescadores do Oiapoque e com } \\
\text { embarcações de pequeno porte }\end{array}$ & $\begin{array}{l}\text { Conflitos por área de pesca, } \\
\text { fiscalização no PNCO e conflito } \\
\text { entre pescadores que fazem parte } \\
\text { do Termo de Compromisso com } \\
\text { os que não fazem parte do Termo }\end{array}$ \\
\hline
\end{tabular}

Fonte:

Como mencionado, as áreas protegidas eram pensadas a partir de uma lógica preservacionista em um modelo de área ambiental onde o homem não estava incluído, sendo a mesma utilizada apenas para estudo, lazer e admiração (DIEGUES, 2001). A partir de uma perspectiva histórica para a instituição das unidades de conservação, identificam-se diversas etapas de análises para uma melhor adaptação da lei diante da realidade local. A lei n 9.985/2000, que instituiu o Sistema de Unidade de Conservação da Natureza (SNUC), passou por diversas adaptações e processos de refinamento que merecem detalhamento.

Antes da lei No 9.985/2000 mencionada acima, os processos de criação e instituição de áreas protegidas aconteciam com regras pouco definidas, muitas vezes confusas e conflitantes, de toda forma, marcadas por uma baixa ou nenhuma participação e escuta das comunidades afetadas pelo processo. No caso do PNCO, esse contexto não foi diferente. Este que foi instituído em 1980, sendo o processo de instituição do mesmo realizado apenas no papel ${ }^{16}$, não contou com

16 Esta situação em que unidades de conservação que não saíram do "papel", é detalhada por Antonaz (2009). 
audiências públicas, tampouco acordos com as populações residentes dentro do território do parque. O governo quando criou essa área protegida não avaliou os impactos para a criação da mesma no que se refere aos modos de vida dessas populações, pois essas, centenárias, eram as responsáveis pela preservação e manutenção desse território (DIEGUES, 2001).

Segundo Diegues (2001), as populações que são desapropriadas de uma localidade objetivando a instituição de uma unidade de conservação, de âmbito preservacionista, são marcadas por um baixo conhecimento, ou mesmo ausência do mesmo, no que se refere aos seus direitos socioambientais. $\mathrm{Na}$ maioria dos casos, além de serem marginalizadas, apresentam pouca ou nenhuma expressão política, quando considerada a área de decisões colocada pelo Estado frente às questões ambientais. Dessa forma, essas populações são facilmente expulsas, sem que haja um processo legal e justo, assim como quase nunca conseguem uma indenização justa pela desapropriação.

Ademais de não avaliar os impactos no modo de vida dessas populações, o governo federal brasileiro tampouco avaliou os impactos ambientais que a criação do parque provocaria por excluir o homem do meio ambiente, como se este não estivesse integrado na vida natural. Nesse sentido, em uma perspectiva oposta àquela que originou a criação do PNCO, vale evocar Diegues (2001), que entende que o homem não está excluído do meio ambiente, mas faz parte dele. Para o autor, o ser humano, assim como toda a fauna e flora no planeta, dispõe de uma função na natureza e excluí-lo dela é um equívoco.

Outro aspecto não avaliado pelo governo brasileiro foi o sentimento de pertença ${ }^{17}$ que a população, moradora da Vila de Taperebá, no interior do parque, apresentava pelo território que habitava. Essa população apresentava conectividade com a localidade e nesse sentido, almejava ocupar outra localidade com a mesma lógica utilizada na área da qual foi desapropriada. Sendo assim, muitas vezes a comunidade pode desintegrar-se e acabar sendo extinta, pois não consegue adaptar-se em outros ambientes, já que tenta reestabelecer o cenário de origem no qual vivia.

Dessa forma, os cenários que envolvem as UC e as populações tradicionais espoliadas são cenários de conflitos que perpassam questões que envolvem desde a ecologia, a política, o direito, a sociedade, entre outras áreas. O caso específico

17 Para este conceito é necessário uma abordagem mais significativa, segundo Jeronimo e Gonçalves (2008, p. ...): "sentimento de pertença deve ser tomado como que um habitante tem sobre um espaço em particular entre a posse do espaço e a autoimagem e identidade social daquele que ali habita". Dessa forma, o sentimento de pertença pode ser entendido como uma espécie de mescla de territorialidade e a apropriação que uma pessoa estabelece em certo ambiente. 
do PNCO apresentou dois grandes conflitos. Primeiramente o conflito para o acesso e uso dos recursos naturais e posteriormente a estadia em uma área protegida. Nesse sentido, a exclusão e a falta de assistência a essas populações tradicionais se desdobrou em outro conflito que se evidenciou na disputa do acesso e uso dos recursos naturais com outras populações pesqueiras. O próximo subitem apresentará o cenário posterior à criação do PNCO, assim como os novos desdobramentos e conflitos que essa população remanescente vivencia.

\section{À GUISA DE CONCLUSÃO: CONFLITOS POR TERRITÓRIOS DE PESCA NO OIAPOQUE E TERMO DE COMPROMISSO}

Este item tem por objetivo apresentar o atual cenário de conflito que envolve os pescadores artesanais do município de Oiapoque, assim como evidenciar o termo de compromisso como uma estratégia de manejo, fechando, portanto, o caso descrito. Nesse sentido, relata-se a invasão dos barcos paraenses em águas amapaenses, destacando como essa migração de pesca tem tomado força nos últimos vinte anos em decorrência do esgotamento dos recursos pesqueiros em águas paraenses. Desde o ano de 2008 o município vive o ápice dessa migração. Ademais desse cenário, esta seção trabalha o período a partir de 2012, no qual a organização dos pescadores do município do Oiapoque instituiu, por meio da Colônia de Pescadores Z-03, IBAMA e MPF, um termo de compromisso como ferramenta de manejo e diminuição de conflito entre os diferentes agentes que acessam e usam o território pesqueiro no interior do PNCO.

Devido à sobre-explotação dos estoques de pescado em várias partes do país, os recursos pesqueiros passaram a sofrer forte diminuição em águas oceânicas nacionais. Nesse sentido, vale salientar que o Pará dispõe atualmente de um baixo recurso pesqueiro ${ }^{18}$, mesmo sendo um dos principais estados brasileiros de desembarque e exportação de pescado. Segundo relatos dos pescadores entrevistados somado às literaturas que abordam esta temática (MOURÃO et al., 2009), a frota pesqueira de médio e grande porte do Pará tem preferência de captura pesqueira pela costa amapaense. O estado do Amapá dispõe de uma costa ainda muito piscosa e este motivo figura como um dos grandes fatores para a migração dos pescadores paraenses para essa região.

Devido ao intenso fluxo de grandes barcos pesqueiros de outros estados na região amapaense, especialmente os do Pará, a costa do Amapá é considerada

18 Essa informação resulta de observação direta em campo, somada aos relatos dos pescadores, estes obtidos no decorrer de pesquisa de campo especialmente junto aos presidentes das principais colônias de pecadores do salgado paraense. 
a região com maior tráfego de barcos cadastrados e fiscalizados pelo Programa Nacional de Rastreamento de Embarcações Pesqueiras por Satélite (PREPS) (ICMBio, 2010). A Figura 2 apresenta a migração das frotas pesqueiras de outros estados que vêm desde o Ceará, passando pelo Maranhão, Pará e, por fim, chegando ao Amapá, elucidando o processo que origina o contexto de pressão sobre os recursos pesqueiros no extremo norte do Brasil.

Figura 2 - Área de migração das grandes embarcações que vão pescar no extremo norte do Brasil, em águas amapaenses

Fonte: Adaptado do Google Maps (2013)

A forte invasão de barcos instala-se principalmente na costa amapaense. Desse modo, devido à localização geográfica do Oiapoque, com áreas de pesca limitadas, a sobrevivência e a perpetuação da pesca de pequeno porte e tradicional fica extremamente limitada. Na Figura 3 é possível identificar a limitação de áreas de pesca, disponibilizada para os pescadores do Oiapoque. Ao lado esquerdo/ norte do município de Oiapoque as águas são francesas e proibidas para a pesca, no lado direto do rio Oiapoque fica a boca do rio Uaçá onde se localiza a área indígena Uaçá, também interditada à pesca, as 6 milhas de costa ao sul são águas 
protegidas do PNCO e, por fim, das 6 milhas em diante de águas protegidas do PNCO há uma grande competitividade e conflito por território de pesca, ademais da dificuldade de navegação por serem barcos pequenos e de pouca estabilidade em mar aberto. A Figura 3 permite visualizar esse contexto de limitações.

Figura 3 - Elucidação do pequeno território que os pescadores artesanais do Oiapoque dispõem para pescar

Fonte: Adaptado de ICMBio (2010)

O parque tem limitação de seis milhas de espelho d'água, e a pesca nesse território é proibida, pois trata-se de uma área de UC (preservacionista). Contudo, a partir do termo de compromisso instaurado no ano de 2012, embarcações de pequeno porte cadastradas na Colônia de Pescadores Z-03 de Oiapoque e que façam parte de tal termo podem ingressar em parte do território do PNCO para pescar.

O termo de compromisso em questão foi criado a partir da percepção do presidente da Colônia de Pescadores Z-03 de Oiapoque no que se refere à necessidade de uma compensação aos moradores após a instituição do PNCO, dado que os mesmos não contaram sequer com uma indenização quando foram retirados da Vila de Taperebá. Dessa forma, em 2012 foi criado o termo de compromisso, com o propósito de permitir a pesca pelo período de dois anos, podendo o mesmo ser estendido por mais dois anos consecutivos. Durantes esse período, a população beneficiada, juntamente com os órgãos responsáveis pelo PNCO, deverão discutir uma solução institucional para o cenário de conflito. Abaixo, a partir de uma figura adaptada, é possível visualizar a área do parque que faz parte do termo de compromisso. 
Figura 4 - Área do Parque Nacional do Cabo Orange que faz parte do termo de compromisso no 2012

Fonte: adaptado de ICMBio (2010)

O termo atende a demanda de populações tradicionais costeiras do Oiapoque que são, em sua maioria, remanescentes da Vila de Taperebá, possibilitando, em um sistema de rodízio, o acesso e o uso dos recursos pesqueiros em parte do PNCO. A Colônia de Pescadores Z-03 do Oiapoque tem em seus registros 175 barcos cadastrados, no entanto, apenas 70 desses barcos têm permissão para pescar no parque como especificado no termo de compromisso acordado em 2012, onde o mesmo estabelece como pescador artesanal: "II - DO OBJETO, Cláusula Primeira $\int 1^{\circ}$ - Para os fins deste termo de compromisso, entende-se por pesca de pequeno porte aquela não superior a duas toneladas semanais de peixe por embarcação".

O termo de compromisso funciona a partir de um processo de rodízio como abaixo evidenciado.

\section{DO SISTEMA DE RODÍZIO}

Cláusula Sétima - Os barcos cadastrados na COLÔNIA ficam autorizados a ingressar, em sistema de rodízio, com permanência de 10 (dez) dias nas águas do Parque Nacional do Cabo Orange para o exercício da pesca de pequeno porte, desde que os pescadores de pequeno porte já tenham firmado o termo de adesão acessório ao presente instrumento.

$\mathrm{S} 1^{\circ}$ - O rodízio será regulado pela COLÔNIA e fiscalizado pelo ICMBIO e IBAMA, não sendo permitida a presença concomitante de mais de 20 (vinte) barcos, a cada dez dias, nas águas do Parque Nacional do Cabo Orange, nem, em qualquer hipótese, de quaisquer outros pescadores de pequeno porte que não tenham firmado o termo de adesão acessório ao presente instrumento (p. 5); 
O termo desponta como uma estratégia de manejo que atende uma população de forma compensatória. Assim, permite que os pescadores artesanais do Oiapoque possam reproduzir seus modos de vida de forma digna. Certamente o termo não figura como uma solução permanente, mas se mostra como um forte instrumento de garantia de direitos sociais e ambientais a uma população já bastante espoliada, mas atuante na busca de seus direitos, especialmente na manutenção de seu modo de vida.

\section{REFERÊNCIAS}

ABRAMOVAY, R. O futuro das regiões rurais. Porto Alegre: UFRGS, 2003.

ALMEIDA, A. W. B. de. Terras tradicionalmente ocupadas: terras de quilombo, terras indígenas, babaçuais livres, castanhais do povo, faxinais e fundos de pasto. 2 ed. Manaus: UFAM, 2008.

ALMEIDA, O.T., AMARAL, L., RIVERO, S., SILV, C. N. Caracterizacao do pescador e da frota pesqueira comercial de Manoel Urbano e Sena Madureira (AC) e Boca do Acre (AM). Belém, Novos Cadernos NAEA. Vol. 15, n. 1. p. 291-309, jan-jun 2012.

ALVES, J. R. P. (org). Manguezais: educar para proteger. Rio de Janeiro: FEMAR; SEMADS, 2001. 96 p.

ANTONAZ, D. Invenção e reprodução das reservas extrativistas na Amazônia: relação entre movimentos sociais, igrejas, ONGs e governos. In: GRIMBERG, M.; ALVAREZ, M. I. F.; ROSA, M. C. (ed.) Estado y movilización social: estudios etnográficos en Argentina y Brasil. Buenos Aires: Coedición FFyL-Antropofagia, 2009.

BARTHEM, R. B.; FABRÉ, N. N. Biologia e diversidade dos recursos pesqueiros da Amazônia. In: Ruffino, M. L. (Org.). A pesca e os recursos pesqueiros na Amazônia brasileira. Manaus: Provárzea, 2004.

BEGOSSI, A. ; LEME, A. ; SEIXAS, C. S. ; CASTRO, F. de ; PEZZUTI, J. ; HANAZAKI, N. ; PERONI, N. ; SILVANO, R. A. M. Ecologia de Pescadores da Mata Atlântica e da Amazônia. São Paulo: Hucitec, 2004.

BRASIL. Constituição da República Federativa do Brasil. 1988. Brasília, DF.

CAVALCANTI, C. Uma tentativa de caracterização da economia ecológica. Ambiente e Sociedade, Campinas-SP, v. 7, n. 1, jun. 2004.

DIEGUES, A. C. S. Populações tradicionais em unidades de conservação. In: VIEIRA, P> F.; MAIMON, D. (Org.). As Ciências Sociais e a questão ambiental: rumo à interdisciplinaridade. Belém: NAEA/UFPA, 1993.

. O mito moderno da natureza intocada. 3. ed. São Paulo: Hucitec, 2001.

FRÉDOU, F. L.; ALMEIDA, O.; RIVERO, S.; MOURÃO, K.; BARBOSA, C.; THOMPSON, R. Aspectos econômicos da pesca industrial no Pará: entraves e perspectivas. Paper do NAEA, Belém, n. 265, mar. 2010. 
FURTADO, Lourdes Gonçalvez; SILVEIRA, Isolda Maciel da; SANTANA, Graça (orgs). Reserva Extrativista Marinha Mãe Grande - Curuçá, Pará, Brasil: estudo etnológico e sociocultural. Belém: MPEG, 2012.

JERONIMO, Rosa Nadir Teixeira; GONCALVES, Teresinha Maria. O processo de apropriação do espaço e produção da subjetividade. Psic.: Teor. e Pesq., Brasília, v. 24, n. 2, jun. 2008. Disponível em <http://www.scielo.br/scielo.php?script=sci_ arttext\&pid=S0102-37722008000200009\&lng=pt\&nrm=iso > . Acesso em: 16 abr. 2014.

ICMBIO - INSTITUTO CHICO MENDES DE CONSERVAÇÃO DA BIODIVERSIDADE. Plano de Manejo Parque Nacional do Cabo Orange. Brasília, 2010. Disponível em: <http://www.icmbio.gov.br/portal/images/stories/imgs-unidadescoservacao/Encarte\%203\%20-\%20PNCO.pdf>. Acesso em: 15 abr. 2014.

ISAAC-NAHUM, V. J. Explotação e manejo dos recursos pesqueiros do litoral amazônico: um desafio para o futuro. Cienc. Cult. [online]. 2006, v. 58, n. 3, p. 33-36, 2006. ISSN 0009-6725.

MENEZES, M. P. M.; BERGER, U.; MEHLIG, U. Mangrove vegetation in Amazonia: a review of studies from the coast of Pará and Maranhão States, north Brazil. Acta Amazônica. v. 38, n. 3, p. 403-420, 2008. Disponível em: <http://www.scielo.br/scielo. php? script $=$ sci_arttext\&pid $=$ S0044-59672008000300004\&lng $=$ pt\&nrm $=$ iso $>$. Acesso em: 19 mar. 2014. http://dx.doi.org/10.1590/S0044-59672008000300004.

MORAES, A. de O., SCHOR, T. , ALVES-GOMES, J. A. - Relações de trabalho e transporte na pesca de bagres no rio Solimões - AM. Belém. Novos Cadernos NAEA. v. 13, n. 1, p. 155-170, jul. 2010

MOURÃO, K. et al. Sistema de produção pesqueira pescada amarela - cynoscion acoupa lacèpede (1802): um estudo de caso no litoral nordeste do Pará - Brasil. Boletim do Instituto de Pesca, v. 35, n. 3, p. 497-511, 2009. Disponível em: <http://www.pesca. sp.gov.br/sumario35_3.php>. Acesso em: 02 jul. 2013.

RAVENA-CAÑETE, T. Populações tradicionais e direito: da revisão a crítica de aplicabilidades e definições academicas/jurídicas/legais. 2012. 130 f. Dissertação (Mestrado em Direto) - Instituto de Ciências Jurídicas, Universidade Federal do Pará, Belém, 2012.

RUFFINO, M. L. Gestão do Uso dos Recursos Pesqueiros na Amazônia. Brasilia: Ibama, 2005. SCHAEFFER-NOVELLI, Y. Situação atual do grupo de ecossistemas: "Manguezal, Marisma e Apicum" incluindo os principais vetores de pressão e as perspectivas para sua conservação e usos sustentável. São Paulo, Brasil, 1989, p. 119. Disponível em: < http:// www.anp.gov.br/brnd/round5/round5/guias/perfuracao/5round/refere/manguezal_ marisma_apicum.pdf>. Acesso em: 02 dez. 2013.

TOMLINSON, P. B. A botânica dos manguezais. Cambridge: Cambridge University Press, 1986.

VEIGA, J. E. Cidades imaginárias. 2. ed. Campinas-SP: Autores Associados, 2002. v. 1. 198 p.

Texto submetido à Revista em 03.04.2015 Aceito para publicação em 23.08.2015 



\section{A construção social da qualidade da farinha de mandioca em comunidades rurais na amazônia paraense}

\section{Social construction of the quality of cassava flour in rural communities in paraenese amazon}

Fagner Freires de Sousa - Mestrando no Programa de Pós-Graduação em Agriculturas Amazônicas, Núcleo de Ciências Agrárias e Desenvolvimento Rural/NCADR da UFPA. E-mail: sousa.ffreires@gmail.com

Marc Piraux - Doutor, pesquisador do CIRAD Montpellier e professor visitante do Núcleo de Ciências Agrárias e Desenvolvimento Rural/NCADR da UFPA. E-mail: marcpiraux@uol.com.br

\section{Resumo}

A farinha de mandioca é um produto agrícola muito apreciado no Pará e tem sua qualidade definida poruma diversidade de representações e práticas de agricultores, comerciantes e consumidores. Essa pesquisa buscou entender quais são as concepções de qualidade dos agricultores e comerciantes e como estas influenciam nas práticas de produção e na qualidade da farinha em duas comunidades distintas na Amazônia paraense. A partir de entrevistas e classificação da farinha, constatou-se que nas duas comunidades a qualidade da farinha é uma construção social, a qualse inicia na plantação da roça, perpassando por todo processo tecnológico, com destaque para o saber fazer, às práticas de higiene e à relação agricultor-comerciante, desconsiderando-se os padrões de qualidade das agências reguladoras.

\section{Palavras-chave}

Agricultura familiar; relações sociais; produção tradicional; agroindustrialização; saber fazer.

\begin{abstract}
The cassava flour is an agricultural product very appreciated in Pará and its quality is defined by a variety of representations and practices of farmers, merchants and consumers. This research sought to understand the conceptions of quality of farmers and merchants and how they influence the practices of production and quality of the flour in two distinct communities in paraense Amazon. From interviews with farmers and merchants and classification of flour, it was found that in both communities the flour's quality is a social construction, which starts in planting, passing by every technological process, highlighting the know-how, at hygiene practices and farmer-merchant relationship, disregardingquality's standards of regulatory agencies.
\end{abstract}

\section{Keywords}

Family agriculture; social relations; traditional production; agroindustrialization; know-how. 


\section{INTRODUÇÃO}

A qualidade dos alimentos nos moldes do atual modelo globalizado é baseada principalmente em parâmetros normativos, referentes às condições físicas e higiênico-sanitárias (TRICHES, 2012). No entanto, nos últimos anos, o consumo mundial de alimentos passou a ser orientado por diversas percepções de qualidade em virtude do desenvolvimento e crescimento do mercado agroalimentar (ESTIVAL, 2013).

Dentre estas percepções, há tendências emergentes que estão atreladas aos saberes tradicionais e às relações sociais locais (TRICHES, 2012), as quais se relacionam, sobretudo, à produção de alimentos tradicionais - os produtos da terra - que segundo Cruz (2009), são alimentos "produzidos localmente, a partir de procedimentos avaliados (pelos consumidores) como ambiental, social e economicamente sustentáveis, enraizados em um território e em uma cultura".

No entanto, os alimentos produzidos de forma tradicional no Brasil, continuam sofrendo repressão de órgãos fiscalizadores, uma vez que as normas de qualidade são associadas aos modelos baseados na produção em larga escala e garantia de sanidade, o que está além da capacidade de produção da agricultura familiar, pois os agricultores se utilizam de outros parâmetros que são diferentes dos padrões hegemônicos,ficando à margem dos canais formais de produção e comercialização de alimentos (CRUZ, 2009).

Sonnino e Marsden (2006), no entanto, consideram que a qualidade envolve um processo social de qualificação, o qual requer a construção e negociação entre os atores envolvidos. Prigent-Simonin e Hérault-Fournier (2005), por sua vez,acrescentam que as relações diretas entre produtores e consumidores modificam a percepção de qualidade, e ela própria pode ser caracterizada como uma dimensão de qualidade.

Segundo Wilkinson,a qualidade apresenta noções variadas, as quais estão em concorrência e contestação, revelando valores distintos por trás das normas e técnicas. Para este autor,"o que para alguns são valores estéticos associados à produção artesanal, para outros são indicadores de ameaça à saúde pública. $\mathrm{O}$ que para alguns são os valores de eficiência, para outros são premissas na geração de externalidades inadmissíveis" (WILKINSON, 2002, p.818).

Essas considerações valem para a farinha de mandioca, que na Amazônia paraense, e mais especificamente em comunidades rurais do Território do Baixo Tocantins ${ }^{1}$, constitui a base alimentar da população. A farinha nas comunidades rurais paraenses apresenta formas de produção diversas baseadas na tradição e

\footnotetext{
Utilizou-se a classificação dos Territórios da Cidadania, sendo o Território do Baixo Tocantinscomposto por 11 municípios: Abaetetuba, Acará, Baião, Barcarena, Cametá, IgarapéMiri, Limoeiro do Ajuru, Mocajuba, Moju, Oeiras do Pará e Tailândia.
} 
cultura de cada agricultor, os quais traduzem através do fazer farinha seus saberes e seus modos de vida (SILVA, 2011).

Assim, este trabalho dedica-se a investigar o que os agricultores entendem por qualidade da farinha e como as relações entre eles e comerciantes/consumidores²influenciam nas práticas de produção adotadas, e consequentemente, na qualidade físico-química e higiênico-sanitária da farinha produzida. Três hipóteses estruturam a essa reflexão. A primeira é que a qualidade da farinha é construída socialmente de acordo com percepções diversas dos atores sociais envolvidos na cadeia de produção; a segundaé que esta percepção orienta as práticas adotadas por cada um dos agricultores no fazer farinha, e por fim, a terceira é que tal percepção contrasta com a percepção de agentes externos envolvidos no processo de qualificação da farinha, tais como os comerciantes e as agências de normatização que regulamentam a produção e qualificação da farinha como alimento.

O artigo esta dividido em cincotópicos principais: o primeirotrata da metodologia utilizada para o desenvolvimento da pesquisa; no segundo são apresentadas as comunidades, campo dessa pesquisa, e as distinções no fazer farinha praticada pelos agricultores destas comunidades; no terceiro são apresentados os elementos da interação social que orientam à construção social da qualidade da farinha; no quarto apresenta-se a qualidade da farinha segundo os padrões normativos; e, no quinto e último, são apresentadas as conclusões possibilitadas pela pesquisa.

\section{METODOLOGIA}

A investigação foi realizada a partir de duas comunidadespertencentes ao Território do Baixo Tocantins: Baratinha, localizada no município de Mocajuba e Nova Paz, no município de Tailândia. As comunidades foram escolhidas por figurarem no cenário local como 'produtoras de farinha de qualidade' e por apresentarem distintas práticas de manejo da mandioca e produção da farinha, sendo empregada a prática tradicional de produção em Baratinha e a agroindustrial em Nova Paz.

A pesquisa apoiou-se em métodos das ciências sociais e ciências naturais, a fim de compreender e apreender as diversas dimensões que a qualidade da farinha pode apresentar, segundo descrito a baixo.

2 Nesta pesquisa não foram realizadas entrevistas com consumidores, no entanto, entende-se que as exigências dos comerciantes sofrem influência direta das preferências dos consumidores. 


\subsection{ANÁLISE DA PERCEPÇÃO DE QUALIDADE DOS AGRICULTORES}

Os métodos de pesquisa utilizados basearam-se, inicialmente na realização dediagnósticos rurais participativos (VERDEJO, 2006) nas duas comunidades (COSTA et al., 2014; LINHARES et al., 2014), os quais oportunizaram conhecer os sistemas de produção locais,e assim, compreender o processo de produção e comercialização da farinha e identificar os atores envolvidos nas diferentes etapas desta cadeia produtiva em cada comunidade.

Identificado esses atores, foram aplicados questionários semiestruturados e realizadas entrevistas abertaspara 10 agricultores de cada comunidade, para 4 e 6 comerciantes, respectivamente, nos mercados de farinha de Tailândia e Mocajuba e 3 atravessadores em Areião ${ }^{3}$, Cametá. A amostragem compreendeu 33,3\% do universo de produtores de farinha em Nova Paz e Baratinha; 66\% e 75\%, dos comerciantes encontrados nos mercados de Tailândia e Mocajuba nos dias de pesquisa,respectivamente; e 100\% dos atravessadores encontrados em Areião. Os agricultores foram selecionados, considerando a diversidade de práticas de manejo da mandioca e produção da farinha, de acordo com os resultados dos diagnósticos (COSTA et al., 2014; LINHARES et al., 2014), enquanto os comerciantes foram selecionados de acordo com a disponibilidade e interesse em participar.

As perguntas do questionário e das entrevistas versavam sobre o entendimento que agricultores, comerciantes e atravessadores de farinha tinham sobre qualidade, assim como dos fatores do processo de produção da farinha (do cultivo à comercialização) que poderiam influenciar negativa ou positivamente a construção dessa qualidade por eles definida. Assim, indagou-se sobre as práticas de manejo da mandioca, sobre o beneficiamento da mandioca para fabricação da farinha, sobre higiene e sobre as características sensoriais da farinha dita "de qualidade". Além disso,indagou-se sobre a relação da qualidade com a formação do preço da farinha nos mercados locais.

A aplicação dos questionários aos agricultores foi realizada em suas residências ou nas próprias casas de farinha, em seguida, as entrevistas foram negociadas e realizadas posteriormente, utilizando-se de gravador de voz, mediante autorização dos mesmos (BEUAD; WEBER, 2007). Já com os comerciantes e atravessadores, as entrevistas foram realizadas nos mercados de farinha de Mocajuba e Tailândia e no Porto de Areião, também utilizandoo gravador de voz, quando autorizado.

Além disso, a fim de complementar as informações e melhor compreender o discurso desses indivíduos, também foi utilizada a técnica de observação

3 Importante ponto de escoamento da farinha produzida em Baratinha. 
participante (BEAUD; WEBER, 2007) durante a produção de farinha de alguns agricultores nas duas comunidades, e durante a comercialização da farinha produzida por esses mesmos agricultores, nos respectivos pontos de escoamento.

\subsection{CLASSIFICAÇÃO DAS FARINHAS PRODUZIDAS NAS COMUNIDADES}

Foram coletadas 3 amostras de $1 \mathrm{~kg}$ das farinhas produzidas nas comunidades, as quais foram submetidas à classificação,segundo a Instrução Normativa $n^{\circ} 52$, de 7 de novembro de 2011 (BRASIL, 2011). A classificação deu-se em grupos (seca ou d'água), segundo o processo tecnológico utilizado na produção e em classe (fina, média ou grossa), segundo a granulometria.A classificação em tipos não foi possível em virtude da impossibilidade de realização de algumas análises (teor de amido e teor de fibras brutas), no entanto, foram realizadas análises de contaminantes físicos, presença de mofos perceptível a olho nu e análise sensorial, os quais possibilitam a verificação de conformidade do produto.

A análise granulométrica foi realizada no Laboratório de Agroindústria da Embrapa Amazônia Oriental e foi realizada através de um conjunto de peneiras com abertura de malha de $1 \mathrm{~mm}$ e $2 \mathrm{~mm}$ e um fundo, sob agitação manual. A mesma foi realizada em triplicata.

Além disso, foram realizadas análises físico-químicas de acidez, pelo método de titulação aquossolúvel (AOAC, 1997), umidade e cinzas, segundo metodologias do Instituto Adolfo Lutz (2008), para verificação de conformidade quanto ao conteúdo químico das farinhas (BRASIL, 2011). Todas as análises foram realizadas em triplicata no Laboratório de Tecnologia de Alimentos da Universidade do Estado do Pará. Os resultados foram submetidos à análise de variância ANOVA e comparação das médias pelo teste de Tukey $(\mathrm{p} \leq 0,05)$.

\section{A DIVERSIDADE DA PRODUÇÃO DA FARINHA NAS COMUNIDADES}

Aqui apresenta-se as comunidades onde a pesquisa foi realizada e, posteriormente, as particularidades de cada uma quanto ao fazer farinha.

\subsection{AS DISTINTAS COMUNIDADES}

Nova Paz, em Tailândia e Baratinha, em Mocajuba, são comunidades que apresentam o cultivo de mandioca, produção e comercialização de farinha como atividades em comum, no entanto, com dinâmicas de produção distintas. 
Baratinha localiza-se na região central do município de Mocajuba, distante a $10 \mathrm{~km}$ da PA - 151, situa-se no entorno de uma vicinal. Apresenta relação bem próxima com a sede do município e com a Vila de Areião, Cametá, devido questões históricas e ao mercado de farinha. É composta por aproximadamente 37 famílias, em sua quase totalidade originária do próprio município de Mocajuba e municípios adjacentes, que apresentam em comum o cultivo da mandioca, o qual ao longo da história predomina como a principal atividade econômica dos agricultores da comunidade (LINHARES et al., 2013).

A comunidade Nova Paz, localiza-se na zona rural do município de Tailândia, situada no entorno de uma vicinal ligada à PA-150 e distante $22 \mathrm{~km}$ da sede municipal. Sua formação data-se da década de 1970, em virtude da intensificação da exploração madeireira na região, a qual foi responsável pela construção da vicinal e fixação dos primeiros moradores. Atualmente a comunidade é constituída por cerca de 100 famílias, as quais são oriundas principalmente do estado do Maranhão e municípios do nordeste paraense, que foram atraídos pelo comércio madeireiro e pela facilidade de acesso às terras não desmatadas na época de formação. A exploração madeireira era a principal atividade econômica nos anos iniciais da comunidade, no entanto, a partir do esgotamento dos recursos naturais e aumento da fiscalização ambiental a partir das Operações Arco de Fogo e Arco Verde ${ }^{4}$, a agricultura passou a apresentar destaque. Hoje, 83\% das famílias ${ }^{6}$ praticam a agricultura e $63 \%$ destas cultivam mandioca para produção de farinha, com área plantada média de 4,2 ha (COSTA et al., 2013).

\subsection{A DISTINSÃO DA PRODUÇÃO DA FARINHA NAS COMUNIDADES}

A produção da farinha na comunidade Baratinha é marcada por um processo de mudanças. No período de fundação da comunidade predominava a produção de farinha d'agua ${ }^{7}$, a qual era considerada sem qualidade pelos compradores, percepção hoje compartilhada pelos agricultores da comunidade, pois consideram que a farinha d'água era visualmente feia, devido à coloração roxa e ao sabor amargo que apresentava. A percepção da necessidade de mudança no processo produtivo veio em decorrência da dificuldade de comercialização da

${ }^{4}$ Ação conjunta do Ibama, Polícia Federal, Força Nacional de Segurança e Governo do Estado do Pará contra o desmatamento ilegal da Amazônia.

5 A Operação Arco Verde foi idealizada a pedido do Presidente da República em decorrência da repercussão das ações implementadas pela Operação Arco de Fogo, principalmente no município de Tailândia - Pará, no início do mês de março de 2008. Mais informações: http:// www.mma.gov.br/estruturas/178/_ECAP/178_ecap17122009052752.pdf.

6 Universo de 45 famílias entrevistadas durante o diagnóstico (COSTA et al., 2013).

7 Farinha produzida exclusivamente a partir de massa de mandioca fermentada. 
farinha e seguiu uma série de experimentação e troca de informação por parte dos agricultores de Baratinha e comunidade circunvizinhas, assim como a inserção de novas tecnologias na casa de farinha.

A produção atual é principalmente de farinha mista ${ }^{8}$, resultado de um tipo de beneficiamento que foi aprimorado a partir da inserção de novas ferramentas (como o caititu ${ }^{9}$ ), condicionando adaptações e/ou mudanças de práticas (NUNES; SIMÕES, 2014). Tais mudanças são decorrentes das experimentações e conhecimentos dos próprios agricultores, os quais ao longo dos anos não receberam assistência técnica voltada para esta atividade. Dessa forma, atualmente a fabricação da farinha na comunidade Baratinha é realizada exclusivamente de forma tradicional, com forte presença de instrumentos como o tipiti ${ }^{10}$, a peneira e o rodo.

Contrastando, em Nova Paz, a produção de farinha segue um processo de especialização, resultante da constante assistência técnica de órgãos como EMATER, Embrapa e Secretária Municipal de Agricultura, e aquisição de crédito agrícola do programa Desenvolvimento Regional Sustentável, voltado para a cultura da mandioca, o que possibilitou, em 2009, a implantação de uma agroindústria comunitária, com estrutura para produção de 1,2 ton. de farinha diariamente, fortalecendo a dinâmica de produção dos agricultores. Dessa forma, a produção nas tradicionais casas de farinha tem sido crescentemente substituída pela produção agroindustrial, caracterizada pelos agricultores locais como mais produtiva e menos penosa, em virtude da mecanização do processo, o qual passa a contar com trituradores, prensa hidráulica e fornos com mexedores mecânicos, além de apresentar estrutura muito diferente dos tradicionais retiros, com paredes em alvenaria rebocada lisa, piso cimentado, teto etc.. No entanto, com isso, tem sido recorrente a necessidade de contratação de mão de obra, principalmente para as etapas de descasque e prensagem, em virtude do aumento de produtividade resultante da mecanização.

8 Segundo a Portaria no 554, de 30 de agosto de 1995, entendia-se por farinha mista “o produto obtido mediante a mistura, antes da prensagem, da massa de mandioca ralada com a massa de mandioca fermentada, na proporção de 75 a $80 \%$ da primeira massa e 20 a $25 \%$ da segunda, de acordo com a preferência do mercado consumidor, seguindo após a mistura das massas, o processo tecnológico da farinha de mandioca d'água" e é assim considerada pelos agricultores, levando-nosa optar por utilizá-la, no entanto, ressalta-se que essa Portaria foi substituída pela Instrução Normativa n ${ }^{\circ}$ 52, de 7 de novembro de 2011, a qual nãoapresenta o grupo "farinha mista", enquadrando-a como farinha d'água.

9 Equipamento com um cilindro com pequenos dentes para ralar a mandioca, movido à eletricidade ou a diesel.

10 Tipo de cesto comprido, trançado em fibras vegetais, usado para espremer, ao ser fortemente esticado, a massa de mandioca para retirada da manipueira e redução da umidade da massa. 
Assim, em Nova Paz, predomina a produção de farinha seca, o que é demandado pelo processo de fabricação empregado, uma vez que a agroindústria é comunitária e funciona por escala ${ }^{11}$, sendo possível a utilização da mesma por no máximo dois dias pela mesma família, inviabilizando a produção de farinha d'água ou mista em virtude do tempo necessário para fermentação das raízes. No entanto, alguns agricultores ainda mantém o retiro tradicional, no qual se produz farinha d'água e/ou mista, principalmente para o consumo da família.

Embora as comunidades apresentem dinâmicas de produção distintas, as etapas de produção da farinha são basicamente as mesmas, com particularidades apenas quanto as tecnologias e os instrumentos utilizados e, em alguns casos, quanto a mão-de-obra utilizada e a divisão do trabalho por gênero, como pode ser observado no Quadro 1.

Quadro 1 - Especificidades nas etapas de produção da farinha nas distintas comunidades

\section{CONSTRUINDO A QUALIDADE DA FARINHA: O QUE DIZEM OS AGRICULTORES}

Nas comunidades estudadas foram observadas certas distinções na qualidade da farinha produzida, no entanto, observou-se que em ambas essa "construção" segue as mesmas etapas e princípios, as quais norteiam a produção da farinha, iniciando-se com os conhecimentos dos agricultores (e/ou conhecimentos externos apropriados pelos agricultores) relacionados à produção de mandioca, ao faz̧er farinha, à higiene e às exigências mercadológicas.

\subsection{A ESCOLHA DAS VARIEDADES DE MANDIOCA: O PRIMEIRO ELEMENTO DA CONSTRUÇÃO DA QUALIDADE}

A observação de que a qualidade da farinha começa a ser determinada ainda na roça é destacada por muitas pesquisas (VELTHEM; KATZ, 2012; SILVEIRA, 2009; PINTON; EMPERAIRE, 2004), as quais assinalam principalmente para a escolha da variedade de mandioca que é plantada, a qual segue os conhecimentos

11 O funcionamento da agroindústria é baseado em agendamento, onde se estabelece uma escala de utilização pelos agricultores. 
e pretensões dos agricultores que as priorizam de acordo com o tempo em que pretendem colhe-las, o tipo de solo na qual a plantará, a coloração preferível ou demandada pelo mercado, a resistência à podridão, dentre outros aspectos.

$\mathrm{Na}$ comunidade Baratinha foi observado que os agricultores prezam pela diversidade, cultivando inúmeras variedades de mandioca, dentre as quais foi possível identificar oito: 'angelim', 'campo', 'mamaluca', 'taxi', 'uruá' e 'tucumantinga', de coloração branca e, 'santo antônio' e 'jacaré', de coloração amarela, todas consideradas "positivas" pelos agricultores, por apresentar boa produtividade em farinha.

Na comunidade Nova Paz, diferentemente, percebeu-se uma especialização, na qual são selecionadas variedades que combinam produtividade, precocidade, coloração (preferencialmente, amarela) e resistência ao apodrecimento, apresentando a predominância da utilização de duas variedades, a 'taxi' (de coloração branca) e a 'mandioca amarela' (variedade melhorada geneticamente, introduzida na comunidade pela Embrapa).

A predominância de variedades brancas em Baratinha se dá pela priorização dos agricultores pela produção de farinha branca, coloração a qual também é preferência nos mercados de Mocajuba e Areião. Em Nova Paz, tambémse observou que a preferência gustativa dos agricultores é pela 'taxi', que segundo o agricultor $\mathrm{NP} 4^{12}$ produz uma farinha de coloração branca e mais saborosa, que agrada ao paladar do agricultor, embora "não seja bonita para o mercado de Tailândia", que prefere a farinha produzida a partir de mandioca amarela. Segundo ele, o mercado "...prefere comer coisa ruim porque é bonito", afirmação verificada no discurso do agricultor ANP01:

"Aqui nós só mexia com a 'taxi” (...). Agora todo mundo está mudando, que o comércio não está mais muito querendo. O comércio não, o consumidor né? que se o consumidor quiser o comércio não rejeita. O consumidor hoje está querendo mais é coisa de qualidade (coloração amarela)”.

Resultado semelhante foi encontrado por Pinton e Emperaire (2004) ao analisarem a conservação de variedades de mandioca entre povos tradicionais do Acre. As autoras constataram que quanto mais tradicional a forma de produção, maior a quantidade de variedades mantidas, registrando uma média de 48 variedades mantidas por indígenas do Alto Juruá, em contraste com uma média de 2,5 variedades entre os seringueiros, mais integrados ao mercado e em processo de especialização. Segundo Pinton (2001), o manejo da biodiversidade é influenciado pela lógica econômica e necessidade de comercialização, o que

12 Sigla adotada para representar os agricultores da comunidade Nova Paz. 
costuma gerar uma especialização, na qual os agricultores tendem a privilegiar as variedades que atendam a demanda do mercado.

Além disso, acredita-se que a manutenção desta diversidade de variedades em Baratinha tenha relação com o ano agrícola, uma vez que os agricultores produzem mandioca o ano todo e constatam que cada variedade de mandioca apresenta uma época ideal para colheita, buscando, dessa forma, garantir a produção de farinha de qualidade durante todo o ano. Essa hipótese também foi levantada por Rizzi (2011) e confirmada em pesquisa realizada no Acre, onde os agricultores defenderam que a época em que a mandioca fica boa pra colher e a capacidade dela de permanecer sob a terra é um fator importante na escolha das variedades a serem plantadas, o que os leva a plantar aquelas que possibilitam uma colheita rápida (a partir de 8 meses), mas também aquelas que possibilitam colheita mais tardia (até 3 anos).

Em Baratinha, a variedade 'angelim', por exemplo, pode ser colhida com até 2 anos (Agricultor BR05 ${ }^{13}$ ), enquanto a 'taxi pretinho', deve ser colhida verde, com no máximo 1 ano (Agricultor BR04).O agricultor BR08, acrescenta que se a 'taxi pretinho' não for colhida logo quando fica madura (com 1 ano) "começa a dá uma farinha escura". Fato semelhante é observado para a variedade 'campo', que segundo o agricultor BR01, tem que ser colhida nova, pois quando fica velha, amarga e necessita ser misturada com outras variedades para não alterar o sabor da farinha. A percepção dos agricultores quanto à importância de se colher a mandioca "na hora certa" também foi observada por Silveira (2009), destacando que a colheita realizada com a mandioca verde ou muito madura, dependendo da variedade, pode afetar negativamente a qualidade farinha.

Considerações a respeito do tipo de solo em que é plantada a mandioca também foram elencadas como de influencia na qualidade da farinha em Baratinha. Segundo o agricultor BR06, a mandioca da variedade 'taxi' que é plantada em solo argiloso, tem que ser lavada antes de colocar de molho para produção da farinha, pois "se colocar direto na água fica roxa”. Afirmação que também é observada no discurso do agricultor BR02, que menciona: "a farinha da 'taxi' não sai bem branquinha (...) no barro a 'taxi' fica roxa".

Além disso, também foi constatado que o tipo de solo influencia na época da colheita, pois a mandioca plantada na areia chega ao ponto de maturação antes da que é cultivada em solo argiloso: "se for na areia com dez. meses comę̧a a tirar, se for no barro tem que deixar completar ano, tem que esperar desenvolver", relata o agricultor BR07. O mesmo foi observado por Rizzi (2011).

13 Sigla adotada para representar os agricultores de Baratinha 
Em Nova Paz, os agricultores defendem que a obtenção da farinha de qualidade é definida desde a planta, pois a mandioca que é colhida depende de fatores anteriores para que seja considerada de qualidade, como relata o agricultor NP01:

"Vem primeiro a mandioca de qualidade (...). É como eu digo mesmo, desde a planta, porque se o cara não limpar no tempo certo, ela não vai ser uma mandioca de qualidade, que já vai ter o mato que afeta a raiz dela, um furão vai, fura tudo. Ela tem que ter todo o processo dela desde a planta".

A percepção de que o local de plantação e a composição do solo interferem na qualidade da farinha também foi apresentado em pesquisa realizada por Velthem e Katz (2012)sobre a percepção de qualidade da farinha de agricultores em comunidades rurais do Acre, no entanto, destaca principalmente a ocorrência de "fiapos" na mandioca quando plantada em solo com ocorrência de certas plantas daninha. O mesmo também foi observado por Silveira (2009) em pesquisa na mesma região, alertando para importância na escolha do solo que se plantará a maniva e nos tratos culturais de controle de pragas e plantas daninhas.

Os tratos culturais como capina e controle de pragas durante a maturação das raízes ajudam a evitar o desenvolvimento de plantas daninhas e aparecimento de pragas que possam afetar o desenvolvimento das raízes ou causar danos como brocas e podridões, que resultarão na perda de rendimento e qualidade da mandioca e, consequentemente, da farinha, que adquiri sabor amargo (SOUZA; FIALHO, 2003).

\subsection{O SABERFAZERNA PRODUCAODA FARINHADEMANDIOCAQUE DETERMINA A QUALIDADE}

Os saberes e o saber fazer dos agricultores são formas de conhecimentos determinantes na produção de uma farinha de boa qualidade, fator observado nas duas comunidades, apesar das diferenças na forma de produção, reiterando a afirmação de Velthem e Katz (2012), que consideram o conhecimento humano como o elemento fundamental no processamento da mandioca. O que se observa é que mesmo com a inserção de novas tecnologias em Nova Paz, os agricultores têm mantido seus saberes, readaptando-os para a nova realidade, fato compreensível uma vez que o conhecimento tradicional é dinâmico (SANTILLI, 2005) e a inserção de artefatos culturais e tecnologias demandam outras formas de fazer, o que influencia no fortalecimento do diálogo de saberes entre as famílias produtoras (SILVA, 2011). 
Os agricultores de Baratinha quando questionados sobre o que faz a farinha ser considerada de qualidade, responderam que "tem que saber trabalhar com ela, raspar bem, jogar numa bacia pra amolecer... fazer pouco, com cuidado" (agricultor BR01), ou ainda "tem que secar bem no tipiti, coar numa peneira fina pra não varar crueira e ter paciência no fogo" (agricultor BR02).

Em Nova Paz, da mesma forma, é possível observar cada etapa da produção da farinha na concepção de qualidade, a exemplo do relato do agricultor NP01:

“...ela (mandioca) não tem que ter podre, se tiver tem que tirar ele tudinho, porque ela não pode ir com nada que vá dá problema na massa. (...) aí vem o processo de torrar ela no tempo... no tempo, porque se você botar ela no retiro hoje, aí amanhã ela já está descascando, ela não deformou, já está dali para o tanque, porque a mandioca com uma hora de tempo de descascado já começa a dá cor, e aquela cor dela vai passar pra massa (...) aí o cara ainda deixa mais uma hora e tanto lá cevadinha, aí ela vai perdendo a qualidade; aí até chegar a torrar... Então quando o cara faz tudo no tempo, ele vai tirar da água ali (tanque de imersão), jogar no triturador, aí já vai imediato para a prensa, que ela não vai pegar aquele vento para deformar, depois que tirar ela não pode passar muito tempo a massa seca ali no (tanque)".

O "raspar bem" mencionado na fala do agricultor BR01 evidencia a necessidade de remover toda a casca da mandioca no momento do descasque, impedindo a passagem desta para a massa, o que resultaria em uma farinha com presença de matéria estranha. O mesmo justifica o entendimento do agricultor BR02 quando se refere ao peneiramento, que é responsável pela separação das partículas de mandioca não reduzidas na trituração, e ainda as cascas e entrecascas que não foram removidas no descascamento. Em Nova Paz, também se percebeu a importância da seleção das raízes, pois os agricultores mencionam ser imprescindível a retirada de raízes pobres e o zelo durante a "rapagem", pois quando tomado o cuidado em retirar as cascas e a "cabeça 14 " da mandioca, facilita as etapas de torração e refino (passagem no moinho), diminuindo a quantidade de fiapos e crueira, cuidados necessários para fazer uma farinha de maior qualidade.

Os cuidados quanto ao descascamento da mandioca também foram observados por Silveira (2009) e Velthem e Katz (2012), as quais ressaltam que a presença de "granitos", resultantes de resíduos de cascas pode desqualificar a farinha. Da mesma forma, foram constatadas percepções relacionadas à importância de secar bem a massa (prensagem) e ao peneiramento. Rizzi (2011) constatou ainda, a preocupação quanto a limpeza das raízes e remoção completa da casca da mandioca (externa e interna), a fim de garantir uma mandioca de maior qualidade.

14 Extremidade superior da raiz de mandioca. 
Os agricultores das duas comunidades afirmam que todas as etapas de produção da farinha são importantes para obtenção de uma farinha de qualidade, no entanto, destacam a torração como etapa fundamental para qualidade da farinha. Essa etapa, entretanto, para ser executada exige a presença de um especialista, pois como afirma o agricultor NP03, de Nova Paz, "tem que saber fazer boa, se não for bom torrador, não sai nada que preste”, percepção que é compartilhada pelos agricultores em Baratinha.

Nas duas comunidades os agricultores consideram que para ser considerado um bom torrador, além de saber identificar as características sensoriais da farinha no momento ideal para encerrar a torração, também é preciso saber controlar a intensidade do fogo durante a torração, o que é imprescindível para obter uma farinha de qualidade, como afirma a agricultora BR01, "tem que fazer duas coisas no mesmo tempo, olhando o fogo e mexendo, se não tomar cuidado com o forno a farinha queima e não torra, embola. (...) tem que controlar a quantidade do fogo, se ficar muito quente ela coze, demora muito a sair".

Os conhecimentos do torrador, repassados de pai para filho no dia-adia da casa de farinha (SILVA, 2011), são imprescindíveis na produção de uma farinha de qualidade, pois segundo Velthem e Katz (2012), o torrador é como um maestro, o qual detém habilidades multidimensionais, como força e habilidade no manejo do rodo, conhecimento sobre o momento preciso para colocar e tirar a lenha para regular a temperatura do forno e a percepção de sabor, cor, odor e textura que atestam que a farinha está no ponto. Já a torração, segundo Lima (1982),é o processo que define a qualidade sensorial da farinha, pois é responsável por conferir cor, sabor e aroma à massa de mandioca, além de reduzir a umidade, o que determina a crocância da farinha.

Além do saberfazer, outra característica requerida para ser um bom torrador é a paciência, pois como afirma o agricultor BR03, "uma farinha de qualidade depende da paciência”. Essa afirmação refere-se à necessidade de limitar a produção diária a poucas sacas de farinha para que obtenha melhor qualidade. Assim, alguns agricultores em Baratinha priorizam produzir menos para obter "farinha boa", como destaca o agricultor BR04, "tem que trabalhar lento, dá dois pacotes de farinha (60 kg) no dia todo, mas sai farinha boa”. Essa percepção é compartilhada com agricultores do Vale do Alto rio Juruá, no Acre, os quais consideram que uma farinha destinada à venda, isto é, uma farinha de qualidade, deve ter produção limitada (VELTHEM; KATZ, 2012).

Em Baratinha, a importância da torração também foi relacionada à prevenção de desenvolvimento de microrganismos na farinha, como afirma o agricultor BR05, "tem que torrar bem, porque quando fica mole ela fica mofenta", reiterando 
a afirmação de Lima (1982) de que a torração é responsável pela diminuição da umidade da massa que garante a estabilidade microbiológica necessária à conservação da farinha.

Após a torração, alguns agricultores também realizam o peneiramento, outra etapa mencionada como indicativa de uma farinha de qualidade, pois permite a classificação da farinha em grossa, média ou fina, de acordo com as exigências do mercado. Essa etapa é realizada nas duas comunidades, com maior frequência em Nova Paz, onde o mercado é mais exigente e prioriza a farinha média, embora as demais também sejam absorvidas em virtude de nichos de clientes específicos que tem preferência por farinha grossa ou fina. Em Baratinha, tanto a farinha fina quanto a grossa é considerada de qualidade, dependendo do mercado ao qual é destinada. Segundo o agricultor BR06 "a grossa é mais vendida no Areião e no Mocajuba é melhor fina".

\subsection{A IMPORTÂNCIA DA HIGIENE NA QUALIDADE DA FARINHA}

A higiene é outro fator indicado nas duas comunidades como de extrema importância para a obtenção de uma farinha de qualidade, pois como pondera a agricultora BR02, "tem que ter asseio para não sair uma farinha demais feia". Os agricultores defendem que a higienização é uma necessidade constante durante todo o processo de produção da farinha, o que compreende a limpeza das raízes, dos equipamentos e do ambiente de trabalho.

A higiene durante o produção da farinha é essencial para se obter uma farinha de qualidade, pois oportuniza o controle da contaminação microbiológica, principalmente por fungos filamentosos, que são capazes de deteriorar a mandioca durante o processamento (FERNANDES et al., 2013). Corroborando, Velthem e Katz (2012),ressaltam que limpeza do ambiente e dos objetos constitui um aspecto fundamental para a produção de uma boa farinha, pois se estes não forem devidamente higienizados, a massa de mandioca azedará rapidamente, o que altera o sabor da farinha.

A falta de higiene foi constantemente associada às alterações na coloração da massa de mandioca, a qual "fica roxa" - como destaca o agricultor BR04 - além de também alterar o sabor, como pondera o agricultor NP05, "fica amargo e muda a cor se não limpar". Essas alterações na massa de mandioca em processamento são transferidas para a farinha, afetando diretamente a qualidade, resultando na preocupação dos agricultores com a higiene.

Em Nova Paz, os agricultores afirmam que o zelo é frequente durante todo o processo, pois para que a farinha seja "bonita de cor e boa de gosto", faz-se 
necessária adoção de práticas higiênico-sanitárias durante todo o processamento, como destaca o agricultor NP01,

“... começa desde lá do tanque, até chegar o final que é a torração. Você pode passar o processo todinho limpando, mas se você não limpar bem o forno, ela vai tirar aquele lixo do forno, vai transmitir... ela não vai dá farinha boa. É por isso que higiene de farinha você pode colocar desde a hora que termina de descascar. Até para descascar também, você não pode jogar num lugar que não esteja limpo, que aquela terra, aquele grude que prega nela ninguém consegue limpar não, só tira a terra, mas o grude não sai, então é por isso que não é permitido jogar assim no chão (...) Tudo ali tem que está limpo mesmo. Tudo onde ela vai passar tem que está limpo".

Em Baratinha, foi observado o mesmo. Segundo os agricultores, a limpeza do retiro é realizada antes de cada farinhada, tomando-se o cuidado para remover todo o resíduo de mandioca da farinhada anterior impregnado nos equipamentos, de forma a não alterar a farinha que será produzida, sendo indispensável o asseio, pois como pondera o agricultor BR01, "tem que ter asseio porque a gente come, a gente vende... a gente trabalha assim, sempre com cuidado, porque se trabalhar bem já tem mais uma saída pra gente... eles vêm em cima da gente logo pra comprar".

Além disso, particularmente em Baratinha, onde se utiliza a casa de farinha tradicional, foi constatada a adoção de estratégias por parte dos agricultores para afastar os animais do local, uma vez que a presença de animais na casa de farinha é considerada um problema. Relatos como o uso de sacas para proteger a mandioca durante a fermentação para que os animais não a contaminem e a utilização de palhas de tucumã ${ }^{15}$ sobre o forno para que os cachorros não o utilizem como dormitório, foram os mais frequentes.

No entanto, estratégias como estas não são consideradas pelos órgãos de vigilância em saúde, sendo os agricultores familiares constantes alvos dos mesmos, pois considerarem que estes não atendem as exigências higiênicosanitárias necessárias para oferecer um alimento seguro, marginalizando os alimentos produzidos pelos agricultores, principalmente os que mantêm métodos tradicionais de produção, considerados rudimentares (CRUZ, 2009).

A pressão para adaptação das casas de farinha aos modelos agroindustriais tem sido crescentes nos últimos anos, com vistas à adoção de boas práticas de fabricação que consiste além dos aspectos higiênico-sanitários a remodelagem das casas de farinha, os quais devem apresentar ambiente fechado, com piso liso de cimento, teto de telha ou zinco (SEBRAE, 2006; VELTHEM, 2007;

15 Astrocaryumaculeatum é uma palmeira que chega a $15 \mathrm{~m}$ de altura e possui espinhos longos e finos envolvendo o caule e as palhas. Na comunidade acredita-se que a presença dos espinhos ajuda a afastar os animais do forno. 
VELTHEM; KATZ, 2012), como a implantada em Nova Paz ${ }^{16}$ que, foge dos padrões de Baratinha e rompe com a lógica de produção desses agricultores e com a história e o caráter cultural que os modos de produção tradicional apresentam (BLACK, 2005), que embora disponham de "baixo aporte tecnológico e estrutura rústica", têm conseguido atender as exigências da legislação quanto às caraterísticas microbiológicas da farinha (CHISTÉ et al., 2006; CHISTÉ et al., 2007; SANTOS et al., 2012).

\subsection{A QUALIDADE CONSTRUÍDA SEGUNDO AS EXIGÊNCIAS DO MERCADO}

A possível interferência da percepção de qualidade dos comerciantes e atravessadores nas práticas dos agricultores, considerada como hipótese na pesquisa, incentivou a conhecer o que os comerciantes, em Mocajuba e Tailândia e os atravessadores em Areião, realmente dizem ser uma farinha de qualidade, a fim de confirmar, ou não, essa hipótese.

Constatou-se que nas feiras de Mocajuba e Tailândia, a qualidade é associada principalmente às características sensoriais, sendo estas as responsáveis pela escolha da farinha no momento da compra, com destaque para a cor, sabor, torração (crocância) e granulometria, corroborando com Pantoja (2013) em pesquisa realizada com consumidores de farinha do município de Abaetetuba-PA.

Em Mocajuba, preza-se pela coloração branca ou creme, assim como registrado por Pantoja (2013) em Abaetetuba, no entanto, em Tailândia a preferência é por farinha amarela, mas um comerciante alerta que a exigência é por farinha amarela produzida sem adição de corantes artificiais, pois segundo o mesmo, "se botar corante não vende, o pessoal não gosta; farinha com corante aqui é desclassificada”. Diferenças como essa também são citadas por Alves e Modesto Júnior (2013), os quais afirmam serem impostas pelos mercados locais que apresentam distintas formas de consumo nas diferentes regiões do Pará.

Essa constatação também ajuda a entender a emergente mudança de priorização da variedade de mandioca cultivada em Nova Paz, onde os agricultores têm se especializado em mandioca amarela a fim de atender ao mercado, reiterando o que defende Sonnino e Marsden (2006) de que a qualidade é construída segundo negociação entre produtores e compradores.

16 Cabe ressaltar que embora tenha sido implantada a agroindústria na comunidade Nova paz, todos os agricultores entrevistados alegaram não ter recebido treinamento em boas práticas de fabricação e manipulação de alimentos e nem de como manipular os novos artefatos introduzidos, tendo os mesmos se adaptado aos poucos, reproduzindo as práticas da tradicional casa de farinha, quando possível. 
O sabor, a crocância e a granulometria são os fatores seguintes na escala de importância para a escolha da farinha, segundo os comerciantes das duas feiras. A principal exigência quanto ao sabor é que não seja azeda. A crocância, embora não apareça classificada em primeiro lugar na escala de importância, é unânime no discurso dos comerciantes que afirmam ser imprescindível que a farinha seja bem torrada. Já a granulometria, segundo os comerciantes, não deve ser muito fina, o ideal é que não seja "nem grossa, nem fina”, afirma um comerciante de Tailândia, embora outro comerciante da referida cidade observe que "o pessoal gosta da farinha grossa pra tomar com açaí".

Em Areião, entretanto, constatou-se que não há uma predefinição de qualidade da farinha, principalmente pelo grande fluxo de comercialização, o que leva os atravessadores a comprarem a farinha à medida que vai chegando. Contudo, um atravessador entrevistado relatou que tem preferência e paga mais quando a farinha é produzida por certos agricultores, os quais são reconhecidos por produzirem farinha de qualidade. Isso reflete a afirmação de Cruz et al. (2008) ao defender que nas relações sociais em canais alternativos de comercialização o nome do produtor se torna uma referência para reconhecer o produto de qualidade. Segundo Prigent-Simonin e Hérault- Fournier (2005), este fato está intimamente ligado à confiança que emerge da relação entre produtor e comprador.

O grupo de farinha considerado de qualidade, nas duas feiras e em Areião foi indicado como sendo a farinha mista (75\% seca e 25\% puba), correspondendo à percepção dos agricultores de Baratinha, no entanto, contrário ao indicado pelos agricultores de Nova Paz, que prezam pela produção de farinha seca. A farinha de qualidade é descrita da seguinte forma pelo atravessador de Areião:

"Tem produtor que coloca a farinha no moedor, eles não colocam na água pra amolecer, eles cortam a mandioca e colocam nesses sacos de palinhas, põe na tábua, deixa um dia, dois... depois tiram, ralam (mandioca recém colhida) e misturam" (Atravessador, Areião, 2013). Grifo nosso.

A preferência por farinha mista ou farinha d'água na região do Baixo Tocantins -PA, também foi constatada por Pantoja (2013) e Linhares e Santos (2014). Esta última ressalta que a escolha pela farinha mista está associada ao sabor da mesma, que ao associar a farinha ralada, considerada doce pelos seus interlocutores, com a farinha puba - mais azeda - resulta em um produto com sabor equilibrado e, portanto, mais aceito. 


\subsection{O PREÇO PAGO PELA FARINHA DE QUALIDADE}

$\mathrm{Na}$ feira de Mocajuba, 50\% dos comerciantes afirmaram não pagar mais pela farinha de qualidade, pagando apenas o preço de mercado ( $\mathrm{R} \$ 60 / 30 \mathrm{~kg}$, em novembro de 2013), no entanto, os demais afirmaram que pagariam até R\$ $100 / 30 \mathrm{~kg}$, no caso de apresentar qualidade diferenciada (farinha mista, branca, classe fina e bem torrada). Na feira de Tailândia foi constatado o pagamento diferencial pela farinha de qualidade, pois um comerciante afirmou comprar a saca de farinha $(60 \mathrm{~kg}$ ) de $\mathrm{R} \$ 150,00$ a $\mathrm{R} \$ 300,00$ (preço em outubro de 2013), dependendo da qualidade da farinha. O maior preço ofertava-se a farinha seca de mandioca amarela, média e bem torrada.

Entretanto, em Areião, constatou-se que não há distinção de preço entre a farinha considerada de qualidade e a considerada ruim $(\mathrm{R} \$ 50 / 30 \mathrm{~kg}$ em novembro de 2013), fato que acaba por desanimar os agricultores e reflete na qualidade da farinha, como pondera a agricultora BR02: "até desanima a gente, porque chega lá é tudo o mesmo preço (...) muita gente deixou de não se preocupar em fazer uma farinha boa, porque sai demais barato”. No entanto, por questões morais, alguns agricultores mantêm a qualidade da produção, como afirma o agricultor BR02, que diz ter vergonha de oferecer uma farinha ruim. O preço inferior oferecido pela farinha em Areião deve-se a presença do atravessador nesse circuito de comercialização.

O baixo valor oferecido pelos compradores, segundo Velthem e Katz (2012), é desproporcional ao investimento humano e aos saberes técnicos, estéticos e simbólicos acumulados pelos agricultores familiares e necessários para a produção de uma farinha de mandioca de qualidade, aspecto também apontado por Silveira (2009) que acrescenta que o preço irrisório oferecido pelos compradores, muitas vezes, não cobre nem os gastos energéticos e financeiros empregados na produção da farinha, contribuindo para o distanciamento entre produtor e seu produto final e, consequentemente, da qualidade da farinha.

Apesar disso, constatou-se que alguns agricultores priorizam a comercialização para compradores conhecidos, mesmo que o preço pago seja mais baixo, como no caso de Baratinha que apresenta dois mercados consumidores e prioriza o que paga menos: Areião ( $\mathrm{R} \$ 50,00 / 30 \mathrm{~kg}$ em novembro de 2013, enquanto em Mocajuba pagava-se R \$70,00/ $30 \mathrm{~kg}$ ). Esta situação foi justificada pela relação de proximidade estabelecida entre produtores e compradores, que até mesmo antecipam o pagamento quando preciso, revelando a formação de uma rede social com base na confiança (WILKINSON, 2002). A consolidação dessas redes sociais também garante a certeza de comercialização do produto, outro fator considerado pelos agricultores de Baratinha na priorização de Areião 
enquanto principal mercado de escoamento da farinha. O mesmo foi observado por Bezerra (2014), analisando a venda de farinha de tapioca por agricultores de Santa Izabel-PA, que priorizam a venda a preços mais baratos para atravessadores.

\section{A QUALIDADE DA FARINHA SEGUNDO OS PADRÕES NORMATIVOS}

A análise laboratorial das farinhas permitiu constatar em Baratinha são produzidas majoritariamente farinha de mandioca do grupo d'água (66,6\%, classificadas como mista pelos agricultores), enquanto em Nova Paz há predominância de farinha seca (100\%); quanto à classe, constatou-se a predominância de farinhas grossas em Baratinha (66,6\%) e média em Nova Paz (100\%), as quais são resultados do processo de peneiramento utilizado em cada comunidade e das exigências do mercado. Os resultados são apresentados na Tabela 1.

Tabela 1 - Análise de características prováveis de desclassificação da farinha

A partir dos resultados pode-se observar que as farinhas analisadas não apresentaram aspectos de mofo ou odor impróprio ao produto, o que indica a não proliferação de microrganismos deteriorantes e, portanto, estado de conservação apropriado, o que se justifica pelo baixo índice umidade apresentado por todas as farinhas, os quais se encontram dentro do indicado pela legislação nesse quesito (máximo de 13\%). No entanto, quando analisada a existência de matéria estranha, verificou-se a presença de partes de insetos em uma amostra coletada em Nova Paz, sendo assim desclassificada por ser considerada imprópria ao consumo, de acordo com Brasil (2011).

Em relação à acidez, três amostras se encontraram acima do máximo estabelecido pela legislação (BRASIL, 2011).Dessas, duas foram produzidas em Baratinha e uma em Nova Paz. A elevada acidez das farinhas pode ser justificada pela falta de controle no processo de fermentação, pois como alerta Chistéet al. (2006), nas casas de farinhas do interior do Pará, a massa de mandioca triturada fica exposta de um dia para o outro à temperatura ambiente $\left(25^{\circ} \mathrm{C}\right.$ a $\left.35^{\circ} \mathrm{C}\right)$, colaborando para elevação da acidez. Quanto ao teor de cinzas, todas as amostras se encontraram em acordo com o estabelecido pela legislação (BRASIL, 2011).

O teste de Tukey revelou diferença significativa em todos os parâmetros avaliados (cinzas, umidade e acidez), com destaque para umidade e acidez, onde houve diferença significativa tanto entre as farinhas produzidas em comunidades diferentes, quanto entre as produzidas na mesma comunidade, revelando a 
heterogeneidade do saber faz̧er na fabricação do produto, uma vez que esses fatores, segundo Chistéet al. (2006), estão relacionados ao processo de fabricação.

\section{CONCLUSÃO}

A pesquisa se propôs a investigar a hipótese de que a qualidade da farinha é construída socialmente de acordo com percepções diversas dos indivíduos envolvidos na cadeia de produção e comercialização da farinha (agricultores e comerciante-compradores) e, que estas percepções orientam as práticas adotadas por cada um dos agricultores no fazer farinha, a partir de estudo exploratório em duas comunidades rurais diferenciadas no Território do Baixo Tocantins, Nova Paz e Baratinha.

Os resultados possibilitaram constatar que a qualidade da farinha é construída durante toda a cadeia produtiva, iniciando ainda na roça, com destaque para a variedade de mandioca cultivada e a colheita da raiz no "tempo certo"; as práticas na produção da farinha, com destaque para o saber fazeer, principalmente durante a torração; higiene durante todo beneficiamento; e as relações sociais entre agricultores e compradores, apreendidas enquanto exigências mercadológicas.

$\mathrm{Na}$ comunidade Baratinha, particularmente, observou-se que a concepção de qualidade ainda está atrelada aos conhecimentos tradicionais que são reproduzidos e/ ou reconstruídos em função da qualidade da farinha, apresentando uma grande diversidade de variedades de mandioca e a utilização do sistema tradicional de produção, enquanto em Nova Paz, observou-se a especialização do sistema de produção com diminuição da diversidade de variedades de mandioca, inserção de novas tecnologias no fažer farinha e forte racionalidade comercial.

A relação com o mercado e a influência deste nas práticas adotadas pelos agricultores constatou-se marcante nas duas comunidades, confirmando a hipótese de que os comerciantes/consumidores exercem influência na qualidade da farinha produzida, através das exigências feitas ao produtor. Todavia, é importante frisar que embora ocorra essa interferência da relação agricultorcomerciante nas práticas adotadas para produção da farinha, não significa dizer, necessariamente, que interfere na concepção de qualidade dos agricultores, as quais muitas vezes foram distintas. Existe assim, um processo diferenciado de produção de farinha pelos agricultores, um para o consumo local, outro dirigido para mercado. O preço orienta também as escolhas.

A utilização do sistema agroindustrial pelos agricultores de Nova Paz possibilitou uma maior padronização da granulometria da farinha, em virtude da tecnologia disponível. No entanto, a agroindustrialização da produção e o acesso à assistência técnica por esses mesmos agricultores, não garante, por si só, a 
qualidade físico-química e higiênico-sanitária da farinha produzida, uma vez que apresentou farinhas com parâmetros em desacordo com os padrões legislativos e a única farinha desclassificada foi coletada nessa comunidade. O que se percebeu foi que mesmo em Nova Paz os agricultores desconhecem ou desconsideram as legislações referentes à qualidade da farinha, operando de acordo com seus saberes, os interesses próprios e da rede social na qual estão inseridos.

Assim, constata-se que a forma tradicional de produção da farinha, embora apresente limitantes, também é capaz de garantir farinha de qualidade, legitimando o saber fazer tradicional e evidenciando a importância do conhecimento dos agricultores, o qual lhes permite manter a qualidade e a real complexidade desta noção bem apreendida como construção social.

Ressalta-se, dessa forma, a necessidade do fortalecimento das pesquisas que ultrapassem a noção operacional de qualidade utilizada pelas agências reguladoras e contribuam para o reconhecimento dos agricultores enquanto atores sociais dotados de saberes e competências necessárias para a produção de alimentos de qualidade e o incentivo da criação de legislações adequadas à realidade desses produtores, assim como de políticas públicas orientadas para o incentivo da produção tradicional de alimentos.

\section{REFERENCIAS}

ALVES, R. N. B.; MODESTO JÚNIOR, M. S. Mercado exige características distintas de produção de farinha de tapioca em duas regiões no estado do Pará. Portal EcoDebate, n. 1.942, 2013. Disponível em: http://www.ecodebate.com.br/2013/10/17/ mercado-exige-caracteristicas-distintas-de-producao-de-farinha-de-tapioca-em-duasregioes-no-estado-do-para-por-raimundo-nonato-brabo-alves-e-moises-de-souzamodesto-junior/.Acessoem: 17 set. 2015.

ALMEIDA, M. CUNHA, M. C. da, ELOY, L., EMPERAIRE, L. KATZ, E., SIMONI, J., RIZZI, R., SANTILLI, J., VELTHEM, L. V. L’indication géographique, un instrument de pérennisation des productions localisées en Amazonie? Le cas de la farine de manioc de Cruzeiro do Sul (Acre, Brésil).Belém, Novos Cadernos NAEA. NAEA/UFPA. Vol. 12, n. 1. p. 93-108, jan-jun 2009 (ISSN 1516-6481).

AOAC. Official methods of analysis of the Association of Official Analytical Chemists.16 Ed., v.2. Washington: Edited Ig W. Horwitz, 1997.

BEAUD, S.; WEBER, F. Guia para a pesquisa de campo: produzir e analisar dados etnográficos. Petrópolis: Editora Vozes, 2007.

BEZERRA, F. A. P. Declínio da produção de mandioca: os impactos econômicos no município de Santa Izabel, Estado do Pará. Agroecossistemas, Marabá, v. 6, n. 1, p. 17-41, 2014. 
BLACK, R. E. The Porta Palazzo farmers' market: local food, regulations and changing traditions. AnthropologyofFood, n.4, 2005. URL: http://aof.revues.org/157

BRASIL. Ministério da Agricultura, Pecuária e Abastecimento. Instrução Normativa $\mathbf{n}^{\circ}$ 52, de 7 de novembro de 2011. Estabelece o Regulamento Técnico da Farinha de Mandioca. Diário Oficial da União. Brasília, 2011.

CHISTÉ, R. C.; COHEN, K. O.; MATHIAS, E. A.;RAMOA JÚNIOR, A. G. A. Qualidade da farinha de mandioca do grupo seca. Ciência e Tecnologia de Alimentos, Campinas, v. 26, n. 4, p. 861-864, 2006.

CHISTÉ, R. C.; COHEN, K. O.; MATHIAS, E. A.;RAMOA JÚNIOR, A. G. A. Estudo das propriedades físico-químicas e microbiológicas no processamento da farinha de mandioca do grupo d'água. Ciência e Tecnologia de Alimentos, Campinas, v.27, n.2, p.265-269, 2007.

COSTA, A. C. S.; PONTES, F. H. G.; SOUSA, F. F.; CHAVES, G. P.; SANCHES, K. M. S.Diagnóstico Rural Participativo da comunidade Nova Paz, Tailândia - PA. Belém: Universidade Federal do Pará, 2013.

CRUZ, F. T.; MENASCHE, R.; KRONE, E. E.; WAGNER,S. A. Queijo artesanal serrano dos campos de cima da serra: o saber-fazer tradicional desafiando a qualidade. Anais... IV CONGRESSO INTERNACIONAL DE LA RED SIAL. Mar de la Plata, 27 a 31 de outubro de 2008.

CRUZ, F. T. Qualidade dos alimentos e escalas de produção: em defesa de critérios e normas para legitimação dos produtos artesanais/tradicionais. In: $47^{\circ}$ CONGRESSO DA SOCIEDADE BRASILEIRA DE ECONOMIA, ADMINISTRAÇÃO E SOCIOLOGIA RURAL. Anais... Porto Alegre, 26 a 30 de julho de 2009.

ESTIVAL, K. G. S. Construção social do mercado de qualidade do cacau no Brasil. 312p. 2013. Tese (Doutorado em Ciências Sociais em Desenvolvimento, Agricultura e Sociedade) - Instituto de Ciências Humanas e Sociais, Universidade Federal Rural do Rio de Janeiro, Seropédica, 2013.

FERNANDES, H. R.; OLIVEIRA, D. C. R.; SOUZA, G. S.; LOPES, A. S. Parâmetros de qualidade física e físico-química da farinha de mandioca (Manihot esculenta Crantz) durante processamento. Scientia Plena, Sergipe, v.9, n.11, 2013.

LIMA, U. A. Manual técnico de beneficiamento e industrialização da mandioca. São Paulo: Secretária de Ciência e Tecnologia, 1982.

LINHARES, A. S.; NUNES, K. L.; BARROS, L. C.; BASTOS, R. F. Diagnóstico da comunidade Baratinha do município de Mocajuba no Baixo Tocantins/Pará. Belém: Universidade Federal do Pará, 2013.

LINHARES, A. S.; SANTOS, C. V. “A casa de farinha é a minha morada”: transformações e permanências na produção de farinha em uma comunidade rural na região do Baixo Tocantins-PA. Agricultura Familiar, n.10, p53-66, Belém, 2014. 
INSTITUTO ADOLFO LUTZ. Métodos físico-químicos para análise de alimentos.

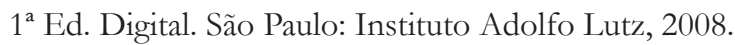

NUNES, K. L.; SIMÕES, A. V. Ensaio acerca da trajetória dos sistemas técnicos de produção de farinha de mandioca na comunidade Baratinha, Mocajuba-PA, Território do Baixo Tocantins. In: X CONGRESSO DA SOCIEDADE BRASILEIRA DE SISTEMAS DE PRODUÇÃO. Anais... Foz do Iguaçu: SBSP, 14 a 17 de maio de 2014.

PANTOJA, T. C. Qualidade e preferência da farinha de mandioca na comunidade Nossa Senhora da Paz em Abaetetuba, Pará: cor, sabor e aparência dos grãos. 31p. Monografia (Especialização em Extensão Rural, Sistemas Agrários e Ações de Desenvolvimento), Núcleo de Ciências Agrárias e Desenvolvimento Rural, Universidade Federal do Pará, Belém, 2013.

PINTON, F. (éd.). Marché em hausse, savoirs em baisse? Diversité variétale du manioc, gestions locales et marché de la farine en Amazonie (Brésil, Guyana). Rapport final pour le Programme Environnement, Viet et Sociétés du CNRS. Comité Systèmes écologogiques et Actions de I'homme, 2001.

PINTON, F.; EMPERAIRE, L. Agrobiodiversidade e agricultura tradicional na Amazônia: que perspectiva? In: SAYAGO, D.; TOURRAND, J. F.; BURSZTYN, M. (Orgs.). Amazônia: cenas e cenários. Brasília: Universidade de Brasília, 2004. p.73-100.

PRIGENT-SIMONIN, A. H.; HÉRAULT-FOURNIER, C. The role of trust in the perception of the quality of local food products: with particular reference to direct relationships between producer and consumer. Anthropologyof Food, n. 4, 2005. URL: http://aof.revues.org/204

RIZZI, R. Mandioca: processos biológicos e socioculturais associados no Alto Juruá, Acre. 177p. 2011. Dissertação (Mestrado em Antropologia Social) - Instituto de Filosofia e Ciências Humanas, Universidade Estadual de Campinas, Campinas, 2011.

SANTILLI, J. Socioambientalismo e novos direitos: proteção jurídica à diversidade biológica e cultural. São Paulo: Editora Peirópolis, Instituto Internacional de Educação do Brasil (IEB), Instituto Socioambiental (ISA), 2005.

SANTOS, T. T.; SOUZA, E. X. N.; SILVA, L. C.; CAZETTA, M. L. Avaliação microbiológica e físico-química da farinha de mandioca comercializada no mercado municipal de Cruz das Almas - BA. Magistra, Cruz das Almas, v.24, n.1, p.34-41, 2012.

SEBRAE, Serviço Brasil de apoio às Micro e Pequenas Empresas. Casas de farinha: manual de boas práticas. Alagoas: SEBRAE, 2006.

SILVA, C. S. S. Casas de farinha: espaço de (con) vivências, saberes e práticas educativas. 179p. 2011. Dissertação (Mestrado em Educação), Centro de Ciências Sociais e Educação, Universidade do Estado do Pará, Belém, 2011.

SILVEIRA, J. S.A multidimensionalidade da valorização de produtos locais: implicações para políticas públicas, mercado, território e sustentabilidade na Amazônia. 391p. 2009. Tese (Doutorado em Desenvolvimento Sustentável), Universidade de 
Brasília, Brasília, 2009.

SONNINO, R.; MARSDEN, T. Beyond the divide: rethinking relationships between alternative and conventional food networks in Europe. Journal of Economic Geography, v.6, n.2, p.181-199, 2006.URL: http://joeg.oxfordjournals.org/content/6/2/181.short

SOUZA, L. S.; FIALHO, J. F. Sistema de produção de mandioca para a região do cerrado. Cruz das Almas: Embrapa Mandioca e Fruticultura, 2003. 61p.

TRICHES, R. M. A ressignificação da qualidade dos alimentos na construção de mercados locais: o caso da alimentação escolar. In $5^{\circ}$ ENCONTRO DA REDE DE ESTUDOS RURAIS. Anais.... Belém, 3 a 6 de junho de 2012.

VELTHEM, L. H. Farinha, casas de farinha e objetos familiares em Cruzeiro do Sul (Acre). Revista de Antropologia, São Paulo, v.50, n.2, p.605-631, 2007.

VELTHEM, L. H.; KATZ, E.A 'farinha especial': fabricação e percepção de um produto da agricultura familiar no Vale do rio Juruá, Acre. Boletim do Museu Paraense Emílio Goeldi. Ciências Humanas, Belém, v. 7, n. 2, p. 435-456, 2012.

WILKINSON, J. Sociologia econômica, a teoria das convenções e o funcionamento dos mercados: inputs para analisar os micro e pequenos empreendimentos agroindustriais no Brasil. Ensaios FEE, Porto Alegre, v.23, n.2, p.805-824, 2002. 


\title{
Compartimentação morfológica de uma planície costeira dominada por mesomaré em Almofala - Ceará
}

\author{
Morphological subdivision of a coastal plain dominated by meso- \\ tide of Almofala - Ceará
}

Ponciana Freire de Aguiar - Doutora em Geologia e Geoquímica; coordenadora do Laboratório de Análises Espaciais/LAENA/NAEA/UFPA. E-mail: ponciana17@ hotmail.com

Maâmar El-Robrini - Doutor em Physiographie des Océans et des Littoraux; coordenador do Grupo de Estudos Marinhos e Costeiros - GEMC/CNPq/UFPA. E-mail: robrini@ pesquisador.cnpq.br

George Satander Sá Freire - Doutor em Geologia; professor e pesquisador da UFC/ Laboratório de Geologia Marinha e Aplicada (LGMA). E-mail:freire@ufc.br

Juliana de Sá Guerreiro - Doutoranda em Morfodinâmica Costeira Sydney University, Austrália; Mestre em Oceanografia, pesquisadora do GEMC/CNPq/UFPA. University of Sydney. E-mail: julianaguerreiro@hotmail.com

\section{Resumo}

A zona costeira de Almofala, com uma faixa de 8 $\mathrm{km}$ de largura é condicionada por altas temperaturas $\left(>25^{\circ} \mathrm{C}\right)$, pluviometria média de $1.172,21 \mathrm{~mm}$, ventos de $5.5 \mathrm{~m} / \mathrm{s}$, mesomarés de $1.48 \mathrm{~m}$ de amplitude e ondas de $0.56 \mathrm{~m}$ de altura. A compartimentação morfológica da Planície Costeira de Almofala foi realizada com base em dados de sensores remotos (Quick Bird, 2004; Landsat 5TM, 2006) para geração de MDT (Modelo Digital de Terreno) por interpolação de krigagem e de mapas temáticos (curvas de nível e declividade), em coleta de pontos X, Y e Z, e perfis topográficos com DGPS (Differential Global Positioning System) e sedimentologia. A planície costeira de Almofala possui o planalto costeiro com tabuleiros costeiros, incluindo tabuleiros litorâneos $\left(8.031 .957 \mathrm{~m}^{2}\right)$ e plataforma de abrasão $\left(34.654 \mathrm{~m}^{2}\right)$; a planície costeira inclui a planície aluvial (planície de inundação e terraços com $944.912 \mathrm{~m}^{2}$ ); planície estuarina (planície fluviolagunar $/ 847.036 \mathrm{~m}^{2}$, planície de intermaré $/ 5.782 .520 \mathrm{~m}^{2}$, canais de maré e delta/66.696 $\mathrm{m}^{2}$ ); e a planície arenosa (dunas fixas/ eolianitos 13.879.382 $\mathrm{m}^{2}$, dunas móveis/1.463.971 $\mathrm{m}^{2}$, praias de Almofala, da Barreira e de Torrões/837.031 $\mathrm{m}^{2}$ ).

\section{Palavras-chave}

Planície Costeira do Almofala. Unidades geomorfológicas. Mesomaré.

\begin{abstract}
The Almofala Coastal Plain include the Almofala, Barreira and Torrões Beachs, influenced by high temperatures $\left(>25^{\circ} \mathrm{C}\right)$ and average rainfall of $1172.21 \mathrm{~mm}$, winds of $5.5 \mathrm{~m} / \mathrm{s}$, mesotidal regime. The analysis of the morphological subdivision of the Coastal Plain of Almofala was performed, based on remote sensing data, topography and sedimentology analysis. The methodology consisted of: (a) collection of points $\mathrm{X}, \mathrm{Y}$ and $\mathrm{Z}$, and with DGPS (Differential Global Positioning System) topographic profiles, (2) analysis of the morphology MDT (Terrain Digital Model) by kriging interpolation (3) making of thematic maps (contour lines and slope), (4) collect and analysis of sediments samples, and (5) establishment of the geomorphological subdivision of the PCA. The Almofala Coastal Plain has: coastal plateau $\left(8.031 .957 \mathrm{~m}^{2}\right)$, an abrasion platform $\left(34.654 \mathrm{~m}^{2}\right)$; floodplain (floodplain and terraces with $\left.944.912 \mathrm{~m}^{2}\right)$ ); plain estuary (lagoon-fluvial plain, plain inter-tidal $/ 5.782 .520 \mathrm{~m}^{2}$ and delta/66.696m²) and sandy plain (sandy ridges/eolianites $13.879 .382 \mathrm{~m}^{2}$, beaches present $/ 1.463 .971 \mathrm{~m}^{2}$, Almofala, Barreira and Torrões beachs $\left./ 837.031 \mathrm{~m}^{2}\right)$.
\end{abstract}

\section{Keywords}

Almofala Coastal Plain. Morphological units. Mesotidal. 


\section{INTRODUÇÃO}

O arranjo geomorfológico das planícies costeiras é entendido através das relações entre as formas (SUMMERFIELD, 1991) e os processos atuantes (erosão, deposição e transporte de sedimentos) no continente (geologia, hidrografia) e na linha de costa (ondas, marés, correntes), originando, modificando e recriando as feições (KLEIN et al., 2009).

A identificação das unidades geomorfológicas da Planície Costeira de Almofala (PCA) foi baseada nas grandes unidades, unidades e subunidades, sedimentologia, processos dominantes atuais e históricos, topografia, modelagem de terreno digital (MDT) e sensoriamento remoto (SR), de acordo com Summerfield (1991), Davis Junior (1983, 1992), Souza Filho e El-Robrini (2000), Souza Filho (2000a,b), Silva Filho (2004), Costa e Souza Filho (2007), Callaghan et al. (2009), Yoshikawa et al. (2010) e Campos e Santos (2013).

A análise do relevo costeiro envolve diversas linhas de pesquisa: análise comparativa entre métodos de interpolação para a construção de modelos numéricos do terreno (KOZCIAK, 1999); predição de propriedades do solo, utilizando dados digitais de elevação (LAGACHERIE; VOLTZ 2000); avaliação e aplicação de sensores remotos no estudo de ambientes costeiros de Bragança (SOUZA FILHO, 2000); geomorfologia da zona costeira de Bragança (SOUZA FILHO; EL-ROBRINI, 2000); RADARSAT-1 e Landsat-5 TM no mapeamento geomorfológico (SOUZA FILHO; PARADELLA, 2005); modelagem numérica de terreno (FELGUEIRAS; CÂMARA, 2006), Remote Sensing Techniques for Studying Coastal Ecosystems: an Overview (KLEMAS, 2010), variação da linha de costa na região da ilha dos Guarás-PA, através da Análise de Série Temporal de Imagens de Satélites (CONTI; RODRIGUES, 2011); bem como análise da compartimentação morfopedológica das áreas (CAMPOS; SANTOS, 2013).

Atualmente, os estudos morfológicos enfatizam: a utilização de modelos digitais de elevação (MDE) na representação do relevo submerso e emerso na zona costeira amazônica (COSTA; SOUZA FILHO, 2007); a utilização de imagem de alta resolução espacial para o mapeamento de Monte Belo do Sul (FARINA et al., 2007); a quantificação dos processos de erosão nas planícies costeiras (CALLAGHAN et al., 2009); e a análise geomorfológica de pântanos via sensoriamento remoto (SR) multitemporal e multiespectral com LIDAR e SIG (MILLETTTE et al., 2010); geodésia de precisão aplicada a evolução morfodinâmica de curto prazo (SANTOS et al., 2014). 
Até hoje os seguintes trabalhos foram realizados na PCA: estudo das unidades morfoestruturais do estado do Ceará (SOUZA, 1989); evolução tectono-sedimentar e o hábitat do óleo da Bacia do Ceará (COSTA et al., 1990); Bacia do Ceará (BELTRAMI et al., 1994); zoneamento geoambiental do Ceará (SOUZA, 1994); evolução geomorfológica da zona costeira cearense (SALES, 2002); atlas de geologia e recursos minerais do Ceará (CPRM, 2003); domínios morfoestruturais da plataforma continental do estado do Ceará (SILVA FILHO, 2004); e o mapeamento das unidades geoambientais da zona costeira cearense (MAIA; CAVALCANTE, 2005).

O SR e O MDT são ferramentas essenciais em mapeamentos geomorfológicos (JENSEN, 1998; BARRETO NETO et al., 1999; CÂMARA; MEDEIROS, 2000; TINÓS et al., 2014), por permitir tratar as variáveis de forma rápida e integrada em Banco de Dados Geográficos (BDGs). Os elementos de interpretação visual utilizados nas imagens (JENSEN, 1998; CÂMARA; MEDEIROS, 2000; FLORENZANO, 2002, 2008) foram: tonalidade, cor, textura, localidade (de certos alvos), forma (regular, irregular), objeto, posição (x, y) e a altura (z).

Este artigo revela duas grandes unidades (Planalto Costeiro e Planície Costeira), quatro unidades de relevo (Tabuleiros Costeiros, Planície Aluvial, Planície Estuarina e Planície Arenosa) e nove subunidades morfológicas (tabuleiros litorâneos, plataforma de abrasão, planície de intermaré, planície lagunar, canais de maré e delta, dunas fixas/eolianitos, dunas móveis, praias de Almofala, da Barreira, de Torrões e calhas) da PCA, a partir de sensores remotos, MDT, topografia, sedimentologia, e mapeamentos (curvas de nível e declividade).

\section{LOCALIZAÇÃO E CARACTERIZAÇÃO GEOGRÁFICA NA PLANÍCIE COSTEIRA DE ALMOFALA}

A Planície Costeira de Almofala (PCA), com $8 \mathrm{~km}$ de largura, localiza-se no município de Itarema (Nordeste, Brasil) (UTM: X1: 403000 E, 9673000N, X2: 412000E, 9679000N) (Figura 1) e está instalada na margem passiva do Ceará, com presença de falha inferida (NE-SW) na área continental, controlando o rio Aracatimirim (Figura 1) e falhas normais (E-W) na plataforma continental interna (Silva Filho 2004). Na PCA afloram duas grandes unidades geológicas: a Formação Barreiras do Neógeno (Mioceno/Plioceno), que se estendeu ao Quaternário 
(Pleistoceno); e os Depósitos Quaternários (Holoceno) (BELTRAMI et al., 1994; CPRM, 2003).

Segundo Souza $(1989,1994)$ e IBGE (2009), a PCA insere-se no Domínio Morfoclimático da Caatinga, das depressões intermontanas e interplanálticas semiáridas. O Domínio Morfoestrutural da área inclui: os sedimentos inconsolidados (Planalto Costeiro), com sequências da Formação Barreiras do Neógeno (Mioceno/Plioceno); e os Depósitos Quaternários (Holoceno) sedimentares (Planície Costeira), que se sobrepõem ao Embasamento Cristalino (Pré-Cambriano) - e este não aflora na PCA.

De acordo com Souza (1989, 1994), o relevo da PCA é sustentado por duas unidades geomorfológicas distintas: (a) O Planalto Costeiro ou Glacis Litorâneo (SOUZA, 1989), que inclui os Tabuleiros Costeiros, com Tabuleiros Litorâneos de Modelado de Aplainamento com uma superfície pediplanada constituída pelos terraços marinhos (formas de relevo de topo plano), elaboradas em sedimentos inconsolidados e conglomerados, limitadas por escarpas (SALES, 2002; MAIA; CAVALCANTE, 2005) e as plataformas de abrasão; a altitude dos tabuleiros litorâneos (com área de $8.066 .611 \mathrm{~m}^{2}$ ) é relativamente baixa, contendo as maiores elevações (+30 m) e ocorrem na parte SW da área; (b) a Planície Costeira (SOUZA; 1989, 1994; SALES, 2002), que inclui a planície aluvial (planície de inundação e terraços com $944.912 \mathrm{~m}^{2}$ ); planície estuarina (planície fluviolagunar/847.036 $\mathrm{m}^{2}$, planície de intermaré/5.782.520 $\mathrm{m}^{2}$, canais de maré e delta/66.696 $\mathrm{m}^{2}$ ); e a Planície Arenosa, com areias médias (dunas fixas/eolianitos 13.879.382 $\mathrm{m}^{2}$, dunas móveis/1.463.971 $\mathrm{m}^{2}$, praias de Almofala, da Barreira e de Torrões/837.031 $\mathrm{m}^{2}$ ), conforme a Tabela 1.

A PCA é recortada pelo rio Aracatimirim, e o maior corpo d’água é o lagamar do Sargento, pertencente à sub-bacia da Bacia Hidrográfica Litorânea do Ceará. A drenagem tem um padrão drendrítico e paralelo com presença de córregos como o do Lamarão e o do Paná, com nascentes na Formação Barreiras e nos Depósitos Quaternários.

O clima na região da PCA caracteriza-se por temperaturas quentes, que excedem $25^{\circ} \mathrm{C}$ e pluviometria variando entre $800 \mathrm{~mm}$ a $1.600 \mathrm{~mm}$, em média, classificado como tropical chuvoso e quente (AYOADE, 1986). A circulação é de leste (alísios), com ventos de direção preferencial de $\mathrm{E}$ (leste) e velocidade média de $5.5 \mathrm{~m} / \mathrm{s}$ (FUNCEME, 2010). 
Figura 1 - Mapa de localização da Planície Costeira de Almofala (quadro vermelho).

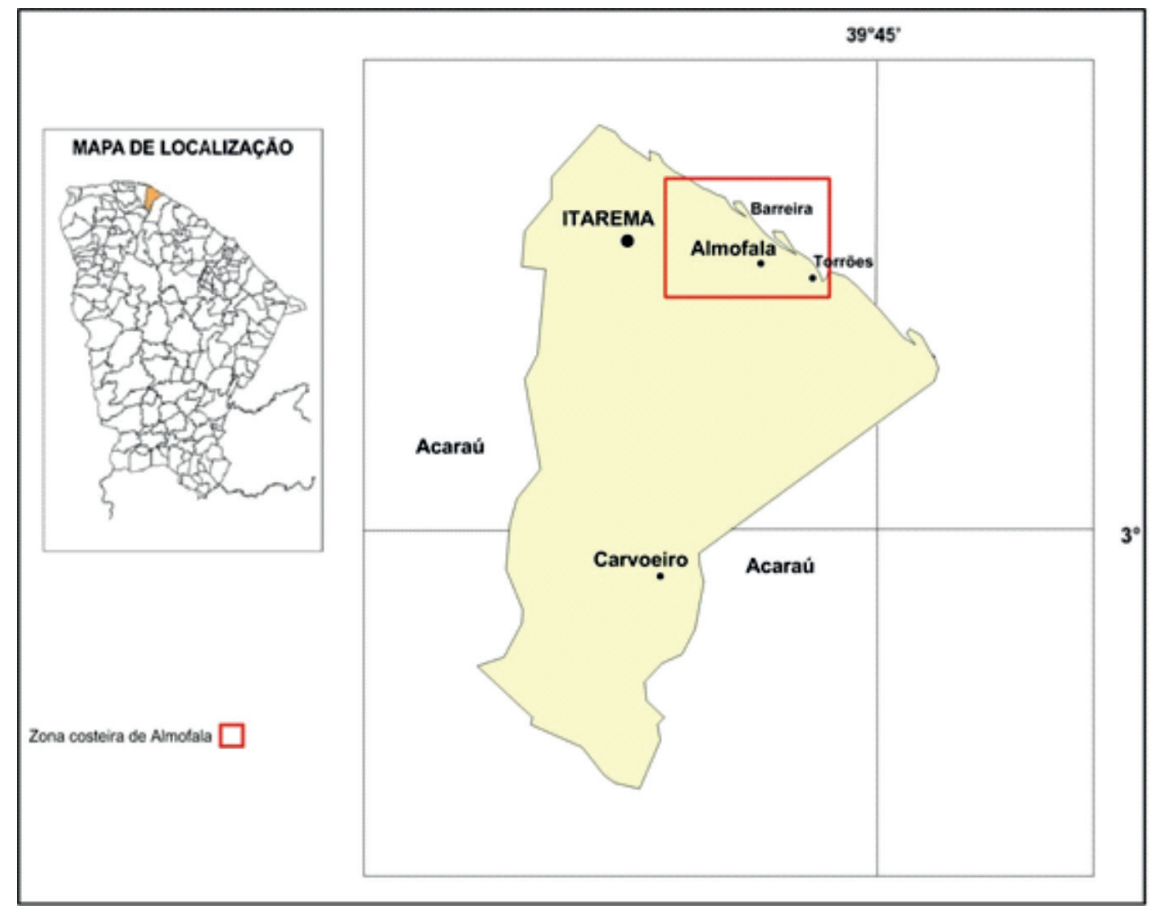

Fonte:

\section{METODOLOGIA}

Metodologicamente, a pesquisa constituiu-se em um estudo descritivo e explicativo, com identificação e quantificação das variáveis geomorfológicas e reavaliação sistemática da bibliografia e documentação pré-existente. Foram adquiridos documentos cartográficos da área: cartas topográficas da SUDENE de 1979 (Folha SA 24); mapa morfoestrutural do Ceará, na escala de 1:500.000 (CPRM, 2003); imagens de satélite Quickbird (2004) e do satélite Landsat (2006).

Foram realizadas duas campanhas de campo na PCA, para o mapeamento das unidades geomorfológicas: (1) de 10 a 15/02/2007 - reconhecimento de áreas, identificação de unidades e subunidades geomorfológicas, coleta de pontos de coordenadas com DGPS com latitude, longitude e altitude para elaboração dos perfis topográficos; (2) 10 e 11/05/2008 - realidade terreno do mapa geomorfológico na escala de $1 / 50.000$. 


\subsection{AMOSTRAGEM DOS DADOS TOPOGRÁFICOS}

Para a confecção do MDT (Figura 2) com dados espaciais vetoriais seguiuse a seguinte sequência: aquisição de amostras (coordenadas e altitude); geração do modelo ou interpolação; e a aplicações dos dados. A amostragem (X, Y e Z) utilizada foi a semirregular, que preserva a regularidade (em uma direção préestabelecida) na direção x ou y, não necessariamente nas duas ao mesmo tempo.

A amostragem por perfis com coleta de dados com DGPS iniciou no LGMA, seguida de campo na área e tratamento dos dados em laboratório. O método utilizado "in situ" de perfilagem foi o stop" and "go". Foram realizados 28 perfis transversais de comprimento variado - a cada $500 \mathrm{~m}$ na PCA e $200 \mathrm{~m}$ nos pontos. Foram estabelecidos cinco perfis aleatórios nas praias de Almofala, da Barreira e de Torrões. Foram confeccionados ainda cinco perfis, com distâncias de $5 \mathrm{~m}$ e $2 \mathrm{~m}$ nos pontos de cada perfil. O MDT (Figura 3) foi realizado nos campos de dunas recentes móveis e na praia de Almofala. A acurácia dos dados de alta precisão do DGPS foi de $0,5 \mathrm{~cm}$. Dos 1.465 pontos aleatórios coletados pelo par de DGPS, somente 80 apresentaram inconsistência, num percentual de erro de apenas 5,5\%. No resultado da análise dos pontos obteve-se uma variância medindo $53.98 \%$, enquanto o desvio padrão mediu \pm 5.9 .

\subsection{PROCEDIMENTOS LABORATORIAIS}

2.2.1 Geração de Modelagem Digital de Terreno (MDT) e de mapas temáticos

Nesta etapa foi gerado o MDT da PCA (Figura 2), cujo método utilizado para a interpolação dos nós do grid foi o da krigagem, baseado na investigação do comportamento das "variáveis regionalizadas" (SILVA FILHO, 2004; BAPTISTA et al., 2006). Após concluir o refinamento da grade original, iniciouse a elaboração dos MDTs e do mapa de declividade mediante o uso do aplicativo Surfer 8. Foram adotados os valores sugeridos pela Embrapa (1979), com intervalos de: $0-3 \%$ (relevo plano); 3-8\% (relevo suave ondulado); 8-20\% (relevo ondulado); $20-45 \%$ (fortemente ondulado); e $>45 \%$ (relevo montanhoso). Foi confeccionado o MDT de parte da praia de Almofala (Figura 3) - de dunas frontais, estirâncio e pós-praia - através da criação de um grid, com dados de altitude coletados com uso do aplicativo Surfer 8.0.

\subsubsection{Mapeamento geomorfológico na Planície Costeira de Almofala}

Os componentes temáticos do Mapa Geomorfológico (Figura 5) foram elaborados a partir de imagens de satélite Quick Bird (2004) e da interpretação 
visual das imagens Landsat 5 (TM) (2006), por observação das variações texturais, da homogeneidade dos temas e contatos morfológicos, para individualização das unidades (MAIA; CAVALCANTE, 2005; SALES, 2002). As unidades e subunidades geomorfológicas foram digitalizadas na escala de 1:50.000 e checadas em campo. As imagens Quickbird foram utilizadas na ortorretificação das imagens Landsat no aplicativo PCI 9.1. Em seguida, as imagens foram salvas no formato *.pix, importadas no Aplicativo ArcGis 8.3. Posteriormente, foi realizada a interpretação visual da composição colorida das bandas 453, seguida da 457 (RGB) do satélite Landsat (2006). A altura utilizada na ortorretificação das imagens Landsat foi a dos perfis coletados em campo com DGPS. O erro residual do registro foi de 0,789 pixels. A compartimentação geomorfológica da PCA teve como base a integração dos planos de informação em um BDG: (1) interpretação de mapas da bibliografia citada; (2) MDT, mapa de curvas de nível e de declividade. Foram utilizados os aplicativos Surfer 8 e Arcview 8.9.

\section{ANÁLISE DO MODELO DIGITAL DE TERRENO (MDT) NA PCA}

O MDT da PCA evidenciou os principais elementos de relevo, como os tabuleiros litorâneos com $+30 \mathrm{~m}$ de altitude (Figura 2) e as dunas fixas com mais de $20 \mathrm{~m}$ de altitude seguem o sentido da parte interna da PCA (até $2 \mathrm{~km}$ ). As altitudes mais baixas ocorrem na planície estuarina do Aracatimirim com 0,50 m. A planície aluvial do córrego Lamarão inicia em altitude de $18 \mathrm{~m}$, recortando os tabuleiros litorâneos, desaguando no rio principal com altitude de $2 \mathrm{~m}$ a leste da área de pesquisa.

A planície lagunar do Lagamar do Sargento (Figura 5) indica altitudes $<5$ $\mathrm{m}$ (Figuras 2 e 5). A planície estuarina da praia da Barreira, com altitudes entre 3 e $5 \mathrm{~m}$, formou-se pelo barramento de canais de marés. O contato entre as dunas das praias de Almofala e de Torrões (Figura 3) é marcado por uma quebra de relevo abrupta, com altas declividades, representando as escarpas de praia. Em outras localidades são seguidas por eolianitos existentes ao longo destas duas praias, chegando a ultrapassar altitudes $>15 \mathrm{~m}$. A plataforma continental interna da PCA se desenvolve até a profundidade de $-10 \mathrm{~m}$. Próximo à linha de costa, as menores profundidades ocorrem na foz do rio Aracatimirim, nas calhas do delta do estuário, variando de 0,50 a -2 m entre os bancos arenosos (Figuras 2 e 5).

Maia e Cavalcante (2005) e Sales (2002) estudaram corredores eólicos em diversas praias cearenses: de Beberibe e do Futuro, em Fortaleza; de Paracuru e de Pecém. Nas praias de Almofala e de Torrões os corredores de deflação eólica no MDT (Figura 2) apresentam um relevo baixo $(3 \mathrm{~m})$. Esses valores seguem a 
parte interna da PCA, nos eolianitos e dunas fixas, relacionado a um corredor de circulação dos ventos alísios.

A acurácia final das posições do DGPS variou de $0-5 \mathrm{~cm}$. A acurácia de mapas altimétricos gerados com dados do DGPS variou de $5 \mathrm{~cm}$ a $2 \mathrm{~m}$, sendo consideradas boas acurácias se comparadas a levantamentos realizados por métodos convencionais. A maior parte da PCA apresenta-se com relevo plano (classe de 0-3\%) (Figura 4), incluindo grande parte dos tabuleiros litorâneos (Figura 5), quase toda a planície estuarina da praia da Barreira e pequenas áreas da planície arenosa. O relevo suavemente ondulado (3-8\%) localiza-se em: grande parte das dunas fixas, parte dos tabuleiros litorâneos e a planície lagunar do Sargento (Figuras 4 e 5). O relevo ondulado (8-20\%) localiza-se em uma pequena área de dunas, em pequenas áreas distribuídas nas escarpas de praia, escarpas de dunas e margens do córrego Lamarão. O relevo fortemente ondulado (20-45\%) está localizado no contato entre a praia e os eolianitos formam escarpas de praia e dunas com morfologia bem preservada. Nas praias de Almofala, da Barreira de Torrões ocorre relevo plano (0-3\%).

Figura 2 - Modelo Digital de Terreno integrado a Batimetria e topografia da PCA. As curvas estão em metro (m).

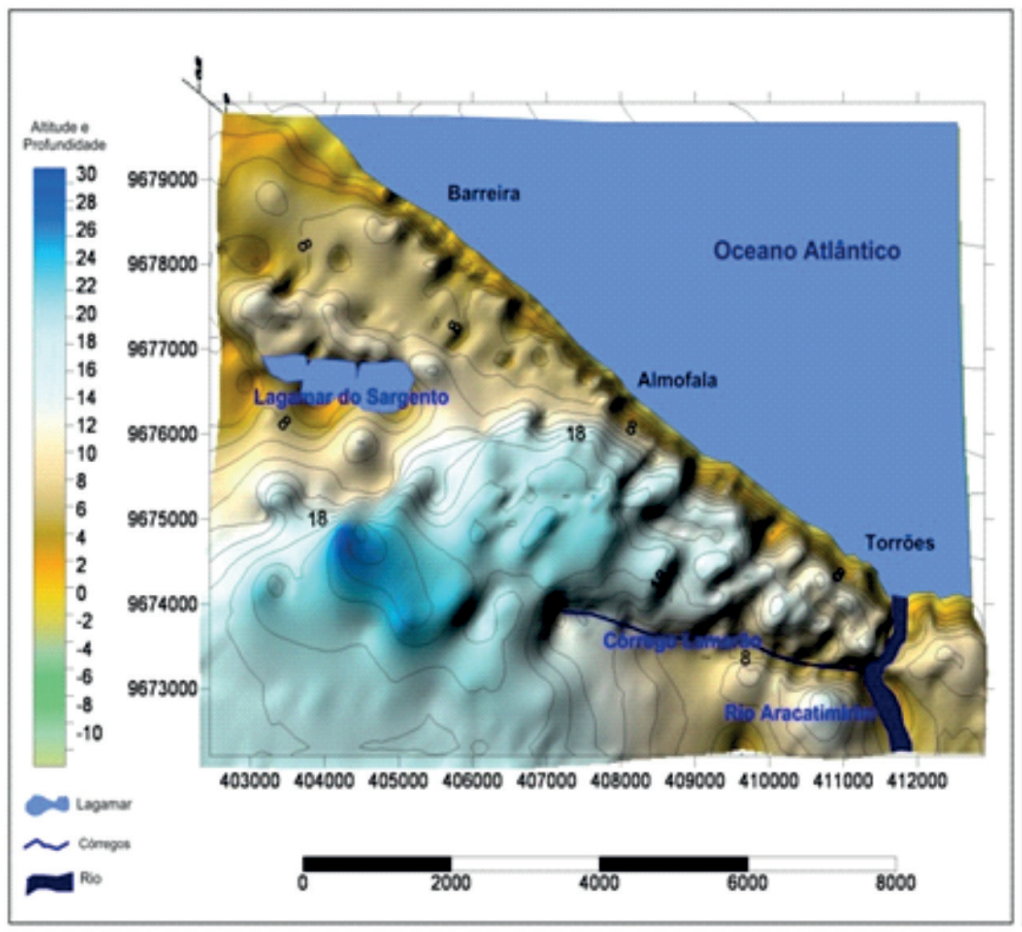


Figura 3 - Modelo Digital de Elevação na planície arenosa de Almofala (praia e duna).

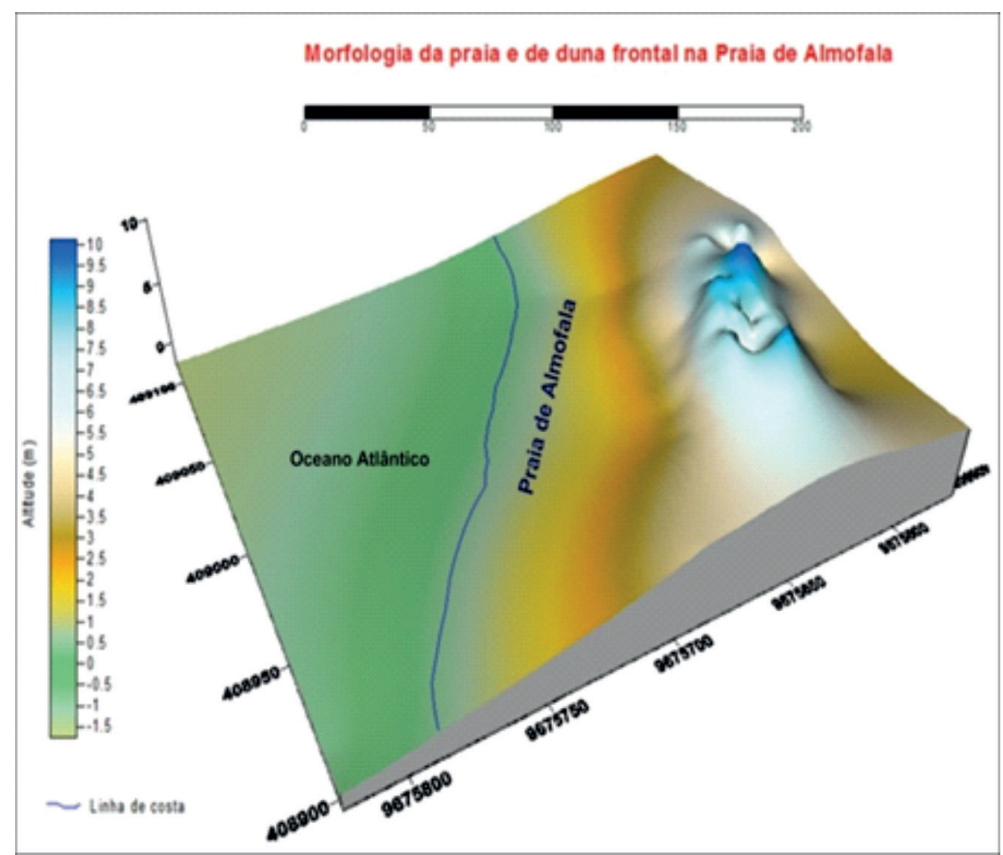

Figura 4 - Mapa de Declividade da Planície Costeira de Almofala.

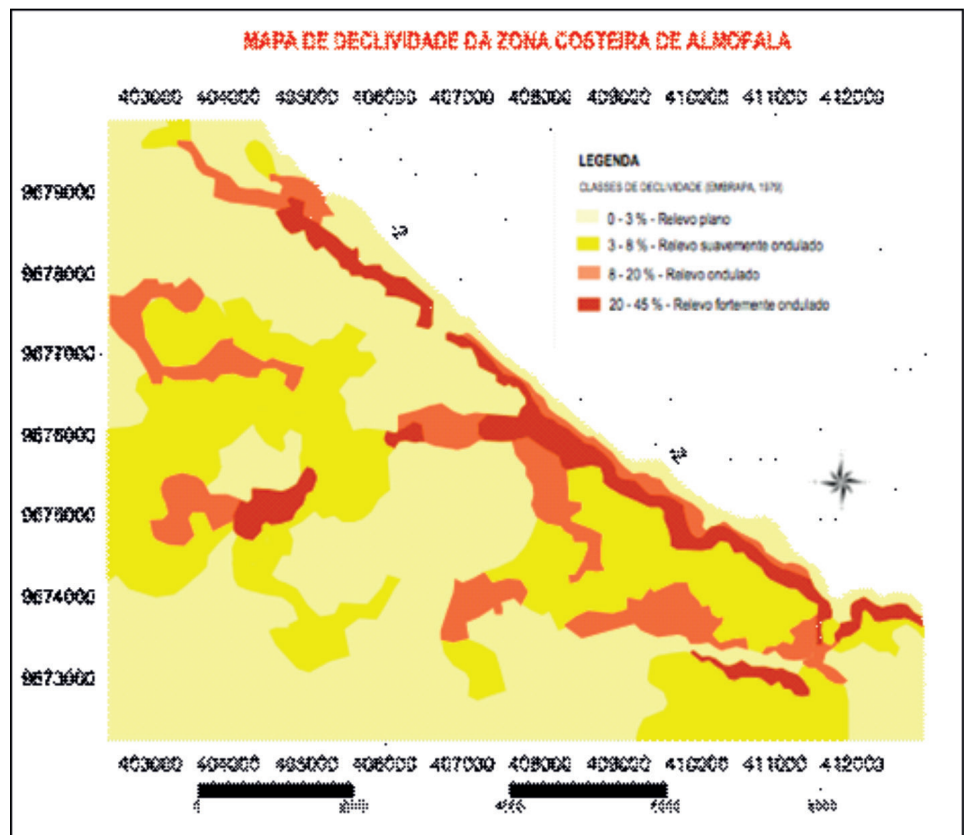




\section{COMPARTIMENTAÇÃO GEOMORFOLÓGICA NA PCA}

Duas grandes unidades geomorfológicas foram identificadas na PCA (Figura 5): o Planalto Costeiro, com uma superfície de $8.066 .611 \mathrm{~m}^{2}$, cerca de 24,22\% da área total; e a Planície Costeira, com área de $25.271 .014 \mathrm{~m}^{2}$, cerca de $75,78 \%$ da área. A PCA integra duas unidades geomorfológicas que ocorrem em toda a costa cearense, segundo Souza (1989, 1994), Sales (2002) e IBGE (2009): Planalto Costeiro com tabuleiros litorâneos; e a Planície Costeira. No litoral norte do Brasil, como na ilha de Marajó, predominam os Planaltos Rebaixados da Amazônia (FRANÇA; SOUZA FILHO, 2003) com altitudes de até $20 \mathrm{~m}$. O Planalto Costeiro cearense, esculpido em sedimentos inconsolidados e conglomerados, pode se expor em superfícies pediplanadas, limitadas por escarpas que chegam a ultrapassar os $100 \mathrm{~m}$ de altitude (SOUZA, 1989; SALES 2002; MAIA; CAVALCANTE, 2005). Na PCA, os tabuleiros litorâneos apresentam-se em altitudes que ultrapassam pouco mais de $30 \mathrm{~m}$ de altitude (Figura 5).

A área possui um arranjo geomorfológico original: planalto costeiro com tabuleiros costeiros (Tabela 1), incluindo tabuleiros litorâneos $\left(8.031 .957 \mathrm{~m}^{2}\right)$ e plataforma de abrasão (34.654 $\mathrm{m}^{2}$ ); planície aluvial (planície de inundação e terraços com $944.912 \mathrm{~m}^{2}$ ); planície estuarina (planície fluviolagunar/847.036 $\mathrm{m}^{2}$, planície de intermaré $/ 5.782 .520 \mathrm{~m}^{2}$, canais de maré e delta/66.696 m²); e planície arenosa, com areias médias (dunas fixas/eolianitos $13.879 .382 \mathrm{~m}^{2}$, dunas móveis/1.463.971 $\mathrm{m}^{2}$, praias de Almofala, da Barreira e de Torrões/837.031 m²).

$\mathrm{Na}$ Planície Costeira na ilha de Marajó, dominada por macromaré $(>3.5$ m) e alta pluviometria, formam-se extensas planícies aluviais, estuarinas e arenosas, fortemente influenciadas por processos fluviais e marinhos (FRANÇA; SOUZA FILHO, 2003). Na PCA, dominada por mesomaré (1.48 m) e baixa precipitação, registram-se a formação de planícies aluviais (terraços, planície de inundação), planícies estuarinas (paleomangues, deltas, planícies lagunares e de intermaré) e planícies arenosas (dunas e eolianitos, com altitudes maiores que $20 \mathrm{~m}$, praias, epaleomangues), com predomínio de ondas, correntes e ventos, a exemplo das praias de Arpoeira e Ponta Grossa, no Ceará (SOUZA, 1989, 1994; SALES, 2002). 
Tabela 1 - Grandes unidades, unidades e subunidades geomorfológicas da PCA.

\begin{tabular}{l|l|r|r}
\hline $\begin{array}{c}\text { Grandes Unidades/ } \\
\text { Unidades Geomorfológicas }\end{array}$ & \multicolumn{1}{c|}{ Subunidades } & \multicolumn{1}{c}{ Área $\left(\mathrm{m}^{2}\right)$} & \multicolumn{1}{c}{$\%$} \\
\hline Planalto Costeiro & & 8.066 .611 & 24,22 \\
\hline Tabuleiros Costeiros & Tabuleiros litorâneos & 8.031 .957 & 24.11 \\
\hline & Plataforma de abrasão & 34.654 & 0.1 \\
\hline Planície Costeira & & 25.271 .014 & 75,78 \\
\hline Planície Aluvial & & 944.912 & 2.83 \\
\hline & Planície de intermaré & 5.782 .520 & 17.34 \\
\hline Planície Estuarina & Planície lagunar & 1.449 .466 & 4.35 \\
\hline & Canais de maré e delta & 66.696 & 0.2 \\
\hline Planície Arenosa & Dunas fixas/eolianitos & 13.879 .382 & 41.63 \\
\hline & Dunas móveis & 1.463 .971 & 4.39 \\
\hline & Praias de Almofala, & 837.031 & 2.51 \\
\hline Total das Unidades & Torrões e da Barreira & 847.036 & 2.54 \\
\hline & Calhas estuarinas/lagunas & & 100 \\
\hline
\end{tabular}

\subsection{PLANALTO COSTEIRO}

A grande unidade do Planalto Costeiro da PCA, com altimetria entre 10 a $35 \mathrm{~m}$, inclui a unidade de relevo Tabuleiro Costeiro (SOUZA, 1989, 1994; IBGE, 2009), com superfície de aplanação e topo plano (tabuleiros litorâneos), testemunhando os sedimentos da Formação Barreiras (Figura 6a). A cobertura detrítica ocorre em zonas tabuliformes periféricas às Depressões Sertanejas, e em contato com o litoral. O Planalto Costeiro, com uma superfície de 8.066.611 $\mathrm{m}^{2}(24,22 \%)$, é recoberto por areia fina $(5,9 \%)$ a areia muito fina $(2,9 \%)$. Nas praias de Almofala e de Torrões ocorrem plataformas de abrasão esculpidas nos sedimentos da Formação Barreiras, isoladas no estirâncio, entre as escarpas de praia e a linha de costa, e sofrem processo de erosão por solapamento (FREIRE, 1998; FREIRE; CAVALCANTI, 1998; FREIRE; MORAIS, 2003; SILVA FILHO, 2004). Estas plataformas de abrasão testemunham a antiga presença do Planalto Costeiro nas praias de Almofala e de Torrões, com recuo de, respectivamente, $5.075 \mathrm{~m}$ e $2.900 \mathrm{~m}$.

A Plataforma de Abrasão (Figura 6b) está sobreposta ao cristalino maciço (Pré-Cambriano) e ocorre em toda a extensão da PCA na linha de costa, nas coordenadas: (1) $\mathrm{X}=409500$ e $\mathrm{Y}=9674000$ na praia de Almofala; (2) $\mathrm{X}=412500 \mathrm{E}$ e $\mathrm{Y}=9675500 \mathrm{~N}$ na praia de Torrões. A plataforma de abrasão ocupa uma área de $34.654 \mathrm{~m}^{2}$, que equivale a aproximadamente $0,1 \%$ da área total. 
Figura 5 - Mapa das Unidades e Subunidades Geomorfológicas da Planície Costeira de Almofala (NW do Ceará).

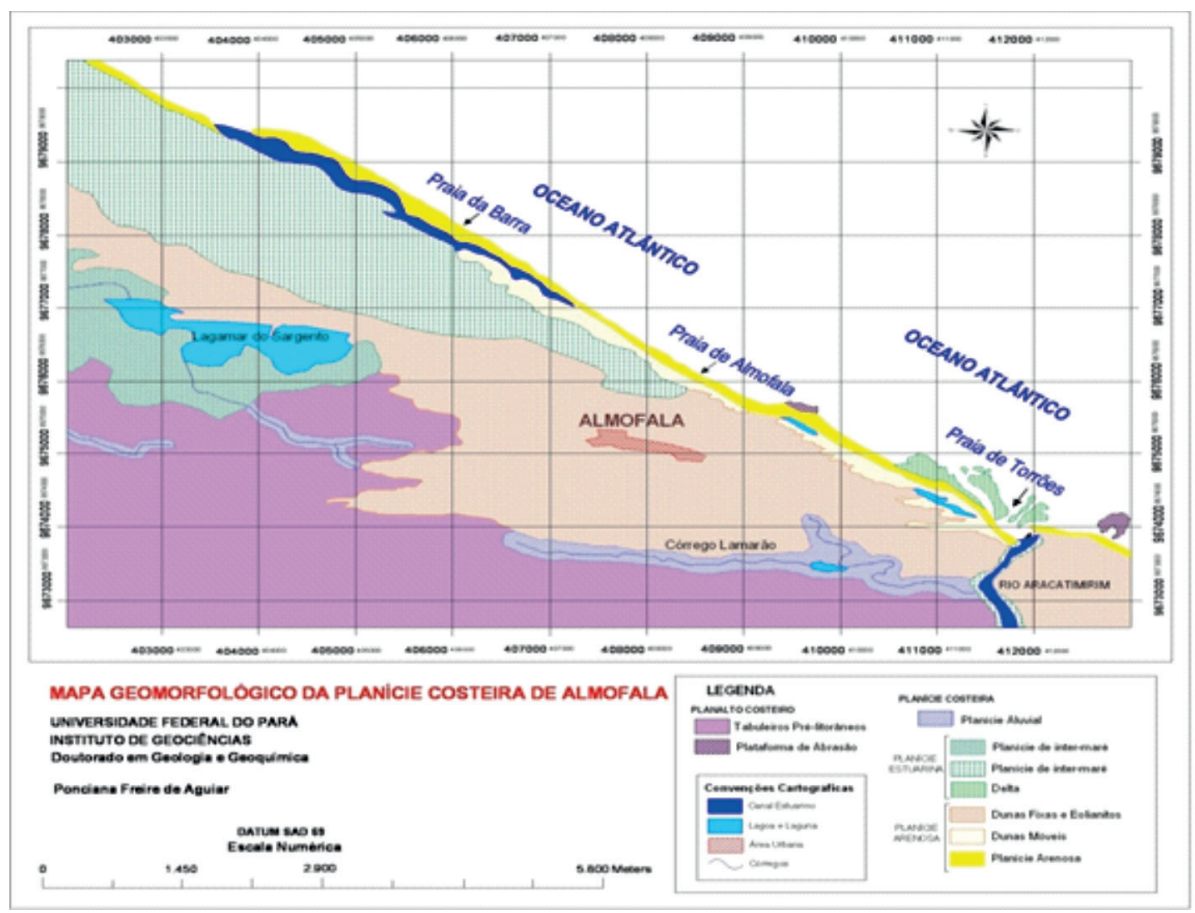

Fonte: Universidade Federal do Pará, Instituto de Geociâncias. Elaboração: Ponciana Aguiar.

Figura 6a-b - Afloramento da Formação Barreiras, Planalto Costeiro na estrada de Itarema, com superfície plana (a); ocorrência de Plataforma de abrasão na praia de Almofala, esculpida nos sedimentos da Formação Barreiras (b).
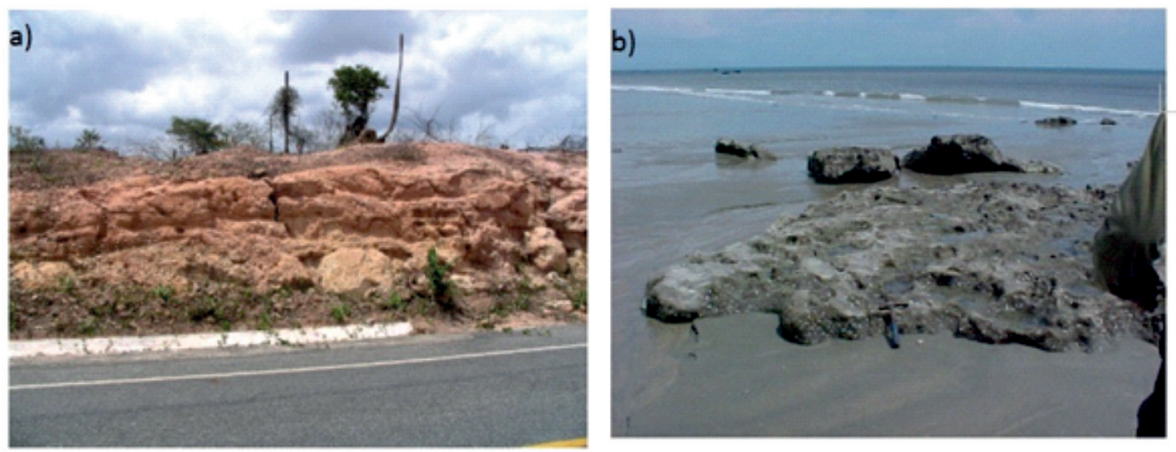

Fonte: Documentação fotográfica dos autores. 


\subsection{PLANÍCIE COSTEIRA}

A grande unidade da Planície Costeira representa a maior parte da área, com 25.271.014 $\mathrm{m}^{2}$ (75,78\% da área total) (Tabela 1, Figura 5) e inclui: a planície aluvial ( $2,83 \%$ da área total); a planície estuarina $(21,89 \%)$, incluindo a planície lagunar, planície de intermaré, canais de maré e delta; e a planície arenosa (48,53\% da área), constituída por dunas fixas e eolianitos, dunas móveis, praias e cordões litorâneos.

\subsubsection{Planície Aluvial}

A planície aluvial da PCA (Figura 5) é plana, com acumulação fluvial sujeita a inundações periódicas (SOUZA, 1989, 1994; IBGE 2009); inclui as planícies de inundação e os terraços de várzeas atuais. A planície aluvial soma uma área de $944.912 \mathrm{~m}^{2}$ e bordeja o rio Aracatimirim, e os córregos do Lamarão e do Paná, onde se dispõem areias finas (8,8\%) e areia média (2,9 \%) (Figura 5). Segundo Suguio (1999), os depósitos de inundação constituem os níveis mais baixos existentes na planície aluvial, correspondendo aos antigos depósitos de enchente, enquanto os terraços de várzea são recobertos por material colúvioaluvionar, formando rampas.

\subsubsection{Planície Estuarina}

De acordo com Souza $(1989,1994)$ e IBGE (2009), a Planície Estuarina ou planície fluviomarinha é plana, resultante da combinação de processos de acumulação fluvial e marinha, sujeita a inundações periódicas, incluindo: planície fluviolagunar, planície de intermaré (manguezais), canais de marés, e deltas ocorrem nas baixadas litorâneas, próximo às desembocaduras fluviais e canais de marés (Figuras 5 e 7 ).

\subsubsection{Planície Flviolagunar}

A Planície Fluviolagunar (Figura 5) é plana, resultante da combinação de processos de acumulação fluvial e marinha, de acordo com Souza $(1989,1994)$ e IBGE (2009), podendo comportar canais anastomosados, paleomeandros (oxbow lakes) e diques marginais, em setores sob o efeito de rios/córregos e de inundações periódicas (influência das marés) e sazonais (de janeiro a abril) (Figura 5). A Planície Fluviolagunar (Lagamar do Sargento) recobre uma área de 1.449.466 $\mathrm{m}^{2}$ (4,35\% do total da área) na parte interna oeste da PCA. Esta feição é constituída por terrenos de baixa altitude $(<5 \mathrm{~m})$, compostos de areia média $(8,8 \%)$ e areia fina $(2,9 \%)$. 


\subsubsection{Planície de Intermaré ou Estirâncio}

A Planície de Intermaré da PCA (Figura 5) abrange uma superfície de $5.782 .520 \mathrm{~m}^{2}(17,34 \%$ da área total) incluindo as adjacências da praia da Barreira e as margens do estuário do rio Aracatimirm (3,73\%). Esta planície é ocupada por manguezal e sofre influência fluviomarinha, sendo constituída por silte grosso $(8,8 \%)$ e areia muito fina $(2,9 \%)$ (Figura 7 a,c). Ocorrem extensas áreas de mangue, soterradas por dunas na margem direita do estuário do rio Aracatimirim e na praia de Almofala afloram paleomangues (UTM 9679760N e 407870E) (Figura 7b).

Figura 7 - Planície Estuarina do rio Aracatimirim (a); Paleomangue na praia de Almofala (b); e Planície Estuarina na praia da Barreira (c).
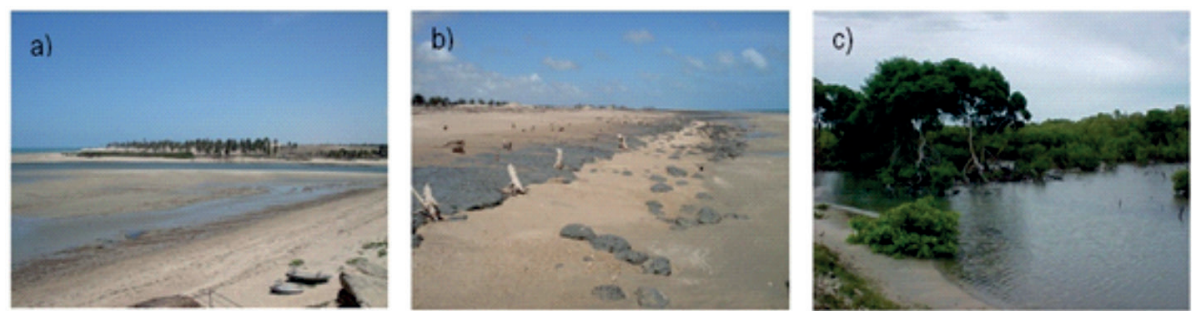

Fonte: Documentação fotográfica dos autores.

\subsubsection{Delta}

O Delta abrange uma superfície de $66.696 \mathrm{~m}^{2}$ (0.2\% da área total) e ocorre na foz do rio Aracatimirim com presença de três ou mais braços rasos, separados por bancos arenosos de foz de canal, originados por sedimentação, que ficam expostos na baixamar, em regime de mesomaré $(1.48 \mathrm{~m})$.

\subsubsection{Planície Arenosa}

A Planície Arenosa corresponde a uma área plana de $1.463 .971 \mathrm{~m}^{2}$, resultante de acumulação de sedimentos marinhos que englobam dunas, restingas, praias, cordões litorâneos; e ocorrem nas baixadas costeiras sob a influência de processos de agradação marinhos por diversos agentes climáticos (vento) e hidrodinâmicos (ondas, correntes e marés) (SOUZA 1989, 1994; FRANÇA; SOUZA FILHO 2006; LI et al., 2008; IBGE, 2009).

\subsubsection{Cordões Arenosos de Dunas}

Os Cordões Arenosos de Dunas (em $\mathrm{m}^{2}-15,3 \mathrm{~km}^{2}$ ) compreendem uma superfície de acumulação com depósitos arenosos ondulados, gerados por 
processos eólicos, com cristas que podem ultrapassar a altura de $30 \mathrm{~m}$. Na PCA, os ventos transportam os sedimentos marinhos do estirâncio por processos de saltação e arrasto, até a zona de pós-praia, na parte interna $(2 \mathrm{~km})$, como ocorre na costa sudeste do Brasil (BIGARELLA et al., 2005).

Esses cordões arenosos apresentam estratificações plano-paralelas e cruzadas (SOUZA, 1989, 1994; MAIA; CAVALCANTE, 2005; IBGE, 2009). Possuem formas (barcanas, parabólicas, transversais, longitudinais e reversas) que variam em função do estoque de sedimentos costeiros, processos eólicos e direção do vento (BIGARELLA et al., 2005).

As dunas fixas ocupam a maior porção da superfície da PCA, com 13.879.382 $\mathrm{m}^{2}(41,62 \%)$ da área total. As dunas móveis ocupam uma área de 1.463.971 $\mathrm{m}^{2}(4,39 \%)$. Essas dunas e os eolianitos são formados por areia fina $(14,7 \%)$ e areia muito fina $(8,8 \%)$.

Os lençóis dunares (sand sheet) na PCA são formados por dunas transgressivas, com formas transversais, sem face de deslizamento; o regime de vento predominante é unimodal de quadrante E, com feições planas pouco onduladas e terminações parabólicas. As dunas longitudinais ou lineares estão dispostas em paralelo à direção do vento principal, em formas alongadas (Figura 8), pelo vento de direção preferencial E, e por ventos de ESSE, em regime de vento unimodal.

Figura 8 - As setas amarelas indicam as dunas longitudinais alongando-se para a parte interna da praia de Almofala.
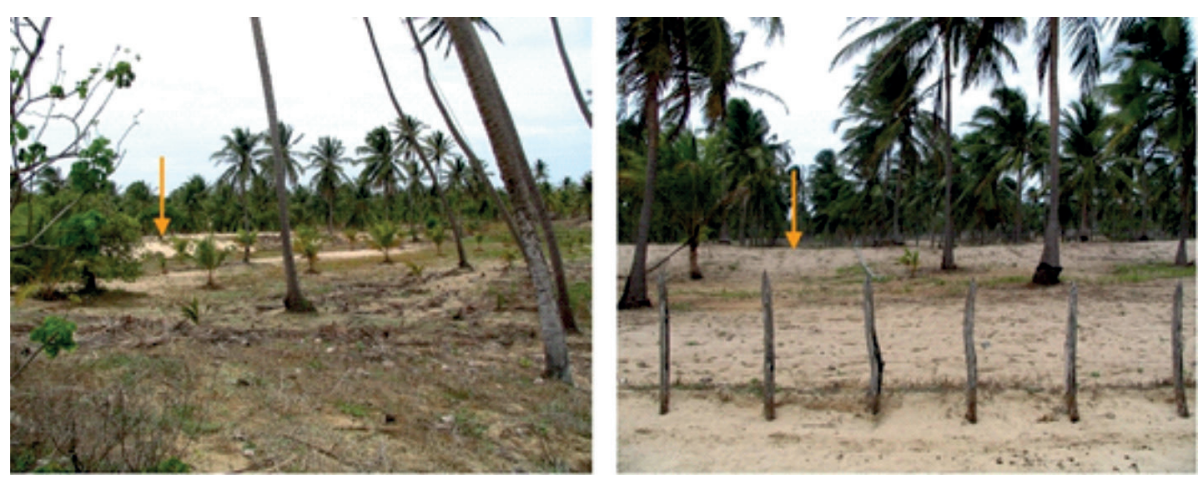

Fonte: Documentação fotográfica dos autores.

As dunas parabólicas estão dispostas na PCA nos formatos em "U” ou "V", com o lado côncavo orientado para barlavento, na direção preferencial de transporte eólico de seus sedimentos, estando distribuídas sobre a planície de deflação por ventos de SE. 
As dunas transversais da PCA são originadas por ventos unidirecionais, com a face de deslizamento voltada para a direção do vento. Geralmente estão perpendiculares ao vento dominante $\mathrm{E}$, constituindo um conjunto de dunas barcanas ativas e transgressivas. Essas faces de deslizamentos voltadas para a direção do vento ocorrem, por exemplo, nas dunas transversais da ilha de Santa Catarina (BIGARELLA et al., 2005).

As dunas barcanas, com forma de meia-lua, possuem a face convexa orientada para o sentido do vento dominante, oposto ao da duna parabólica, como nas dunas de Canoa Quebrada-CE (MAIA, 1998; MAIA; CAVALCANTE, 2005). Na PCA, as barcanas estão dispostas transversalmente aos ventos de E, formando feições transgressivas e coalescentes evoluindo em dunas barcanoides, formada pela justaposição de dunas barcanas, tendo maior disponibilidade de sedimentos em períodos secos do ano.

Os Eolianitos são dunas fixas antigas na PCA, cimentadas por carbonato de cálcio, com forma piramidal, dispostas obliquamente à direção dos ventos de E. No estuário do Aracatimirim (Figura 9a), os eolianitos formam escarpas ativas por solapeamento marinho. Na praia de Almofala (Figuras 9b e 9c), os eolianitos estão em contato direto com um antigo canal de maré que se transformou em lago por fechamento de barra em médio período. Os eolianitos da praia de Almofala (Figura 9d) são formados por truncamentos, estratificações do tipo laminar plano-paralela e cruzada em médio e baixo ângulos, indicando cristas de dunas retas e mudanças na direção de fluxo de vento em longo período (MAIA, 1998). A morfologia piramidal dos eolianitos (Figuras 9a e 9c) é bem preservada e as altitudes chegam a $\pm 30 \mathrm{~m}$. Notam-se a escarpa de eolianito com $1 \mathrm{~m}$ de altitude (Figura 9b).

No sistema duna-praia de Torrões (Figuras 10 e 11), a formação da escarpa de praia pelos eolianitos marca o fim da zona de praia e o início das dunas fixadas por carbonato de cálcio sobrepostas por dunas móveis, e na parte interna os eolianitos afloram novamente (Figura 10), recobertos e fixados por vegetação (Figura 10).

As dunas frontais são móveis e adquirem formas variadas em bordas de praia (Figura 13a). Na praia de Almofala, essas dunas dispõem-se transversais à linha de costa e perpendicular à direção dos ventos predominantes de $\mathrm{E}$, fortes e constantes. 
Figura 9 - Eolianitos na praia de Torrões (a); eolianitos na praia de Almofala (b); eolianitos em contato com a lagoa abandonada na praia de Almofala (c); detalhe de eolianito na praia de Almofala formando escarpas de praia (d).
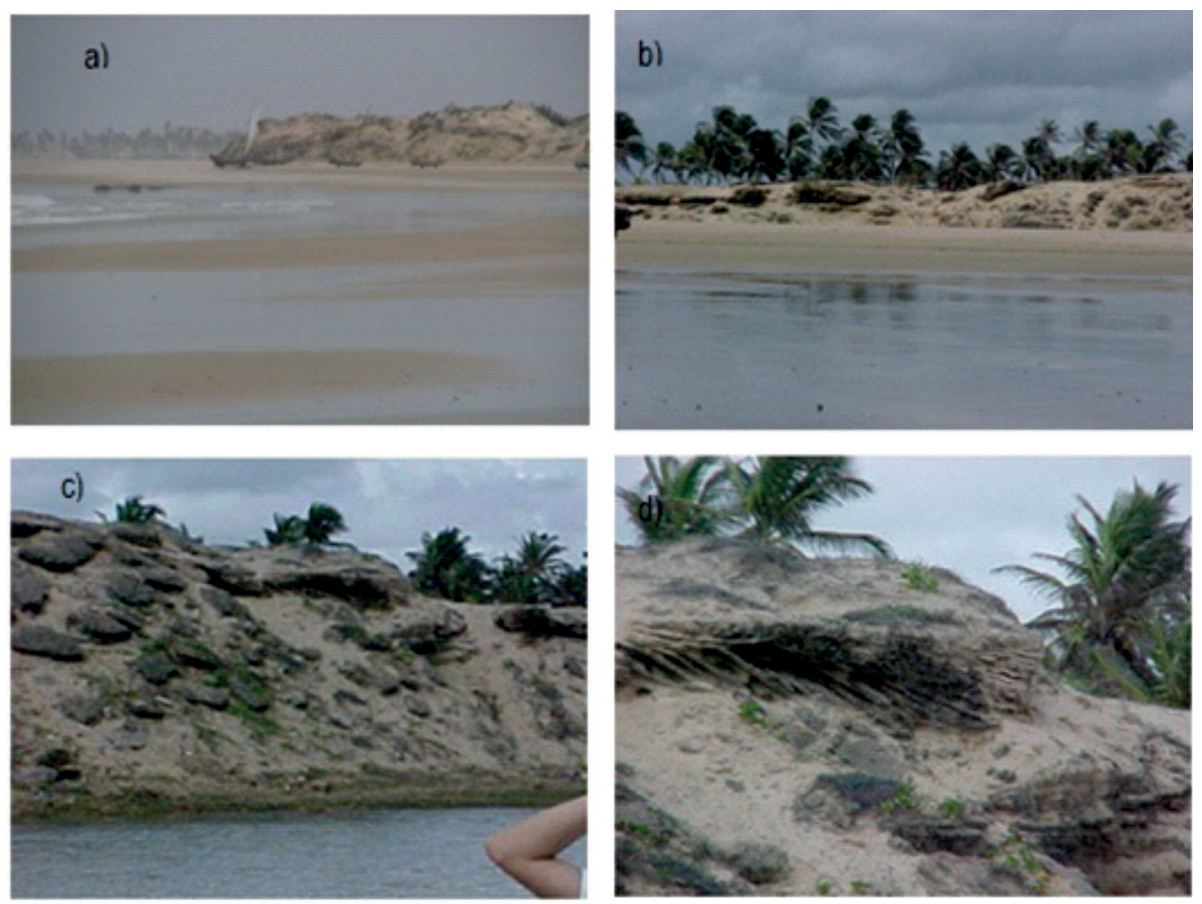

Fonte: Documentação fotográfica dos autores.

Figura 10 - Eolianitos na parte interna da PCA (a); escarpa de eolianito (b); e com morfologia piramidal (c).
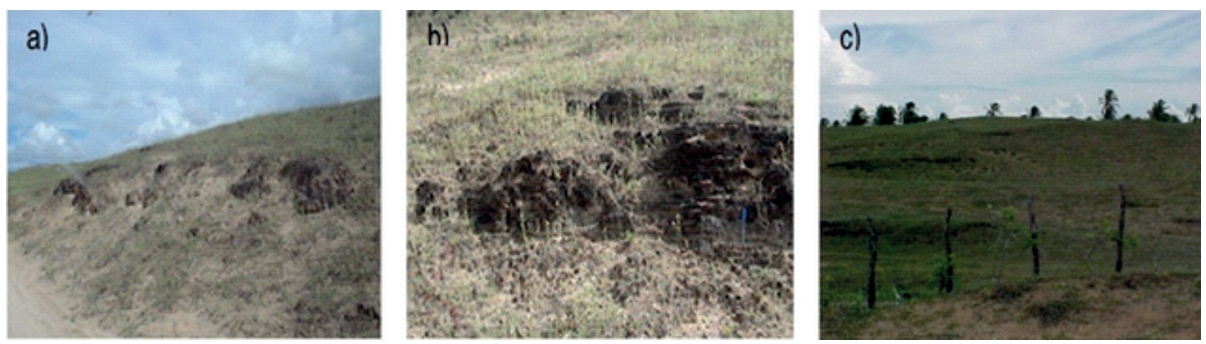

Fonte: Documentação fotográfica dos autores. 
Figura 11 - Perfil morfológico do sistema praia-duna superficial da Praia de Torrões, próximo ao Projeto TAMAR.

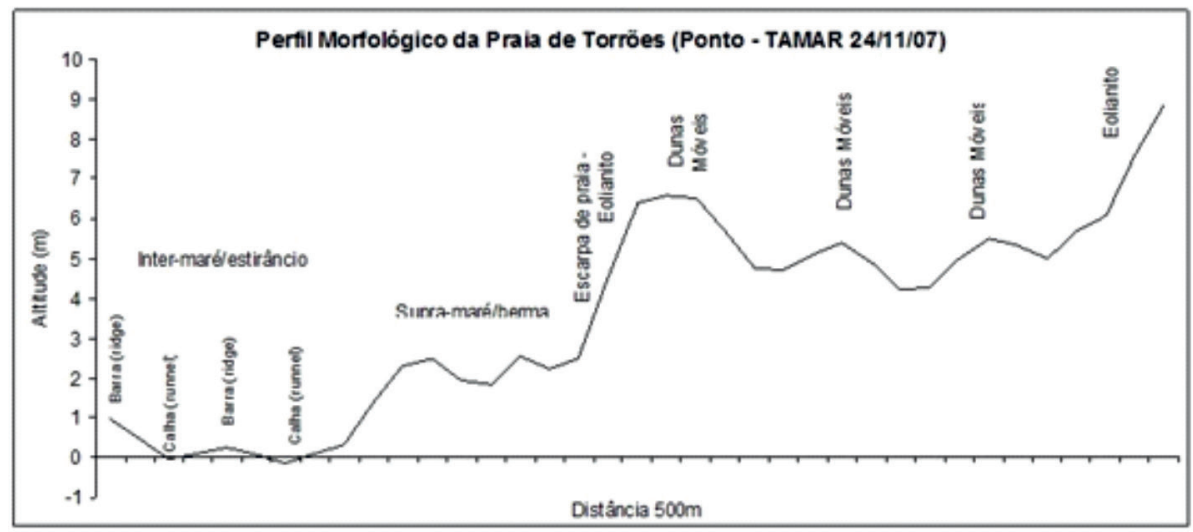

$\mathrm{Na}$ praia de Almofala têm-se sistemas de dunas frontais na parte leste (Figura 12) e na parte oeste (Figura 12), dispostas transversalmente à linha de costa, com relevo suavemente ondulado nas dunas móveis, e relevo plano nas praias (Figura 5).

Figura 12 - Dunas frontais na praia de Almofala, parte leste.

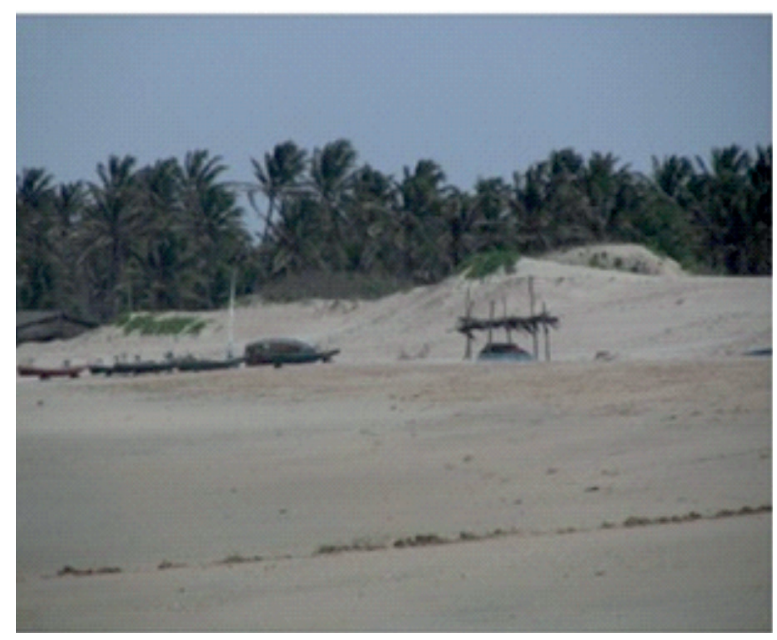

Fonte: Documentação fotográfica dos autores.

\subsubsection{Cordões Arenosos de Praia}

A praia é constituída por um prisma arenoso recente e contínuo nas praias de Almofala e de Torrões, em forma de sistema de barras (rigdes), seguidas de 
calhas (runnel), enquanto na praia da Barreira dispõe-se sobre o cordão litorâneo, desde a linha de maré baixa (LMB) até a linha de maré alta (LMA), sendo a base das dunas móveis formadas por areia fina no estirâncio $(11,8 \%$ ) e areia média $(17,6 \%)$ na zona de pós-praia.

As praias na PCA ocupam $837.031 \mathrm{~m}^{2}(2,51 \%)$ da área total. Nas praias da Barreira, de Almofala e de Torrões foram identificadas as zonas: de backshore, foreshore e shoreface (REINECK; SINGH, 1980), que se diferenciam pelas características morfológicas e granulométricas, tempo de exposição subaérea ou de inundação e dinâmica.

A zona de backshore (supramaré ou pós-praia) (Figura 13c) estende-se desde o limite entre as dunas (escarpas de praia) até a LMA, e permanece a maior parte do tempo seca, exposta ao vento, exceto nas marés altas excepcionais, quando o vento remobiliza os sedimentos mais finos para o suprimento das dunas. As zonas de backshore das praias da PCA formam cordões arenosos (cristas arenosas) que ultraprassam $2 \mathrm{~m}$ de altitude, alongados e semirretos chamados de berma delimitados pela escarpa de praia e o início da zona de foreshore (Figura 13c).

A zona de foreshore ou de intermaré (ou estirâncio) (Figura 13c) estendese da LMA até a LMB. As correntes longitudinais formam uma ou mais barras e calhas, expostas durante a maré baixa. A intensidade e direção do vento e a exposição subaérea deslocam as areias para a zona de backshore na baixamar, engordando a faixa praial.

Em 2007, observaram-se sistemas de barra e calha bem desenvolvidos nas praias da Barreira e de Torrões (Figuras 13b-c), e escarpas de praia em Almofala (Figura 13a). Esses sistemas evoluem por crescimento e progradação de flechas arenosas, e do desenvolvimento e emergência de barras arenosas offshore que migram na direção do continente. Ocorrem em toda a extensão do litoral de Itarema (SALES, 2002). Na praia da Barreira, o cordão arenoso favoreceu a sedimentação lamosa e a formação de manguezais entre a barreira e o continente.

A zona de shoreface ou de inframaré estende-se abaixo da LMB e inclui as zonas de arrebentação e de surfe, estando sempre submersa. É constituída por sistema de barras e calhas longitudinais cuja formação está associada à arrebentação das ondas e às correntes longitudinais (REINECK; SINGH, 1980).

$\mathrm{Na}$ zona de foreshore na quadra de estiagem (junho a novembro), a atuação dos ventos, ondas, correntes e marés (SOUZA FILHO, 2000) favorecem os sistemas de barra e calha. Na quadra chuvosa (Figura 14a), ocorre um maior aporte de sedimentos dos rios e de atuação da maré (Figura 14b), permitindo a formação de linhas de maré nas calhas na praia de Torrões, medindo cerca de 20 e $40 \mathrm{~cm}$ (Figura 14c). 
No início da praia da Barreira tem-se uma berma na área pós-praia, e na zona de intermaré um sistema barra e calha (Figura 14). Na praia destacam-se terraços, dunas móveis do tipo frontal, berma, e sistema barra e calha na zona de intermaré (Figura 14).

Segundo Klein e Menezes (2001), estágios reflectivos são observados em praias semiexpostas, com grande quantidade e alta mobilidade de sedimentos subaéreos devido aos processos de progradação e retrogradação, exibindo perfis praiais convexos com areias médias, como na praia da Barreira (Figura 14).

Figura 13a-c - Zona de inframaré (ou estirâncio) com linhas de maré e escarpa na praia de Almofala (a); Estirâncio com sistema de barra e calha na praia da Barreira (b); Zonas de supramaré e de inframaré com sistema de barra e calha na praia de Torrões (c).
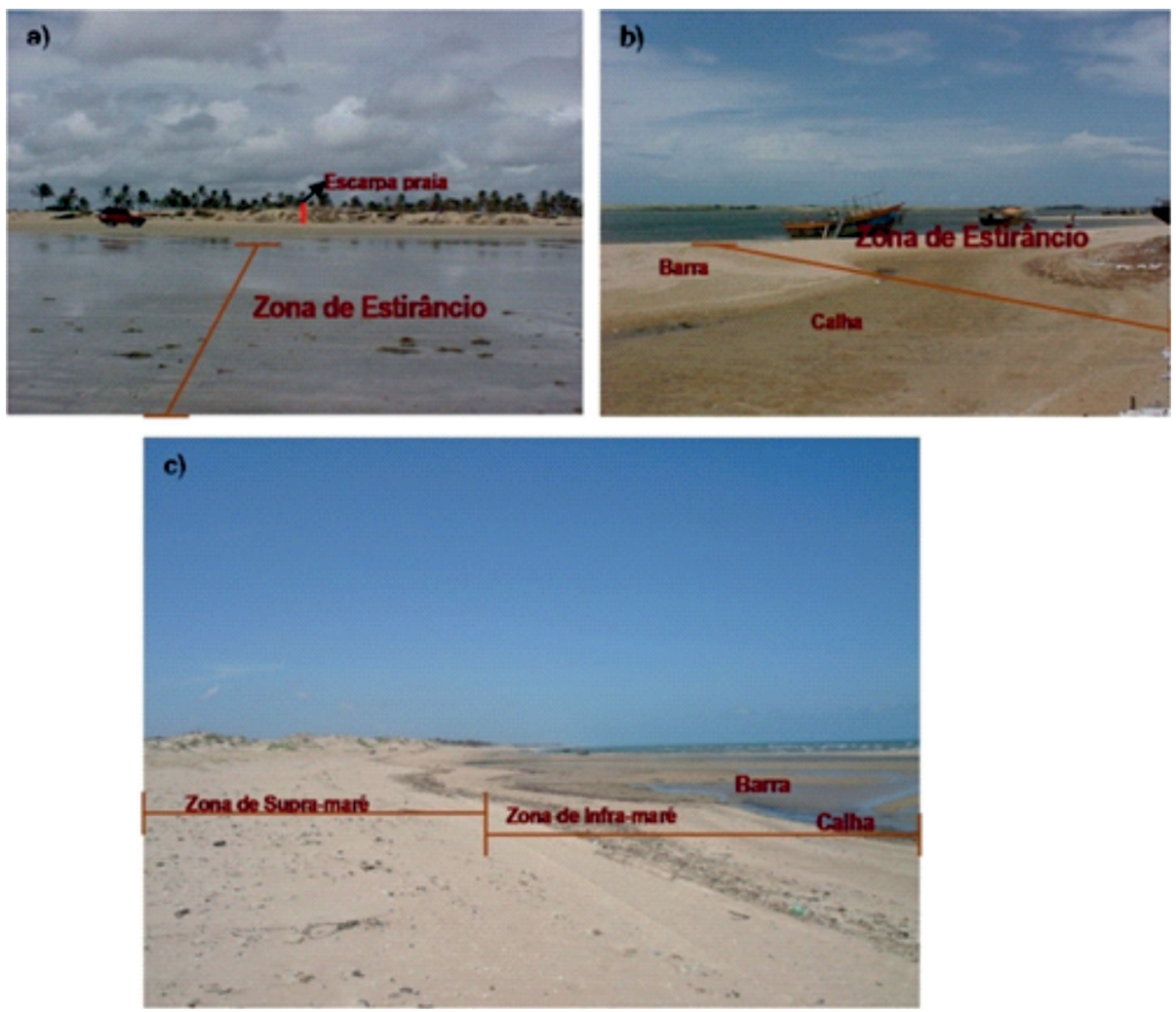

Fonte: Documentação fotográfica dos autores. 
Figura 14a-c - Praia de Almofala, com destaque para a zona de intermaré (a) e (b); linhas de marés expostas no estirâncio da praia de Almofala (b) e na praia de Torrões (c).
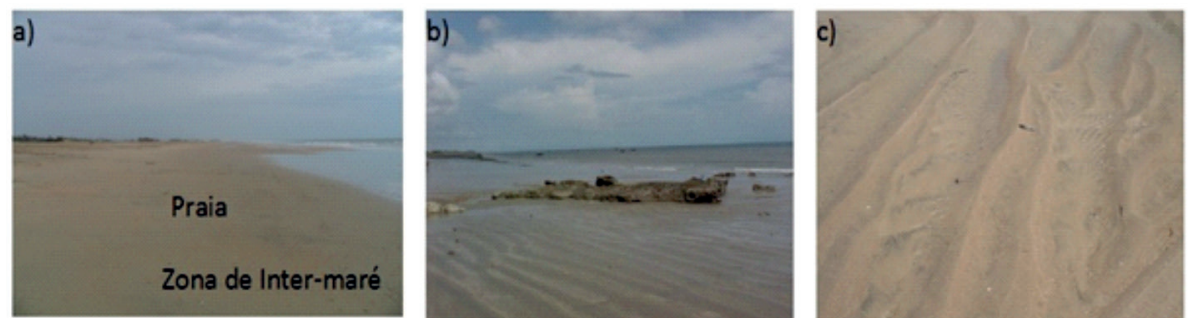

Fonte: Documentação fotográfica dos autores.

Formam-se estágios dissipativos em praias semiexpostas, com perfis côncavos a lineares, como na praia de Ipanema-RJ (KLEIN; MENEZES, 2001). Na praia de Almofala (Figuras 14a-c), a berma e o sistema de barra e calha em baixo declive também formam estágios dissipativos com areias finas, que em condições de baixamar podem formar pequenas barras em estágios de terraços de baixamar.

Nas praias de Icapuí, no litoral leste (CE), o sistema duna-praia dispõe-se em cordões arenosos e nas praias observa-se a formação de sistemas de barra e calha que podem ocorrer sobrepostos a cordões litorâneos (SALES, 2002), como nas praias da PCA. Na praia de Torrões as escarpas de praia (eolianitos) são seguidas de dunas móveis do tipo frontal, berma, e barras e calhas na zona de intermaré.

As praias da PCA possuem uma inflexão de costa com direção NW-SE, que permite a deposição de sedimentos finos, condicionadas por declividades suaves e ondas pequenas, como ocorre nas praias de Arpoeira, em Acaraú; e Ponta Grossa, em Icapuí (SALES, 2002).

\section{DISCUSSÕES}

A origem e morfologia de ecossistemas costeiros e marinhos têm sua gênese vinculada às mudanças climáticas e às variações do nível do mar no Quaternário (Pleistoceno/Holoceno), quando ocorreu a formação da maior parte das áreas costeiras do Brasil (SUGUIO, 1986).

$\mathrm{Na}$ zona costeira cearense, o Planalto Costeiro é sobreposto às rochas do embasamento cristalino, entretanto, a Planície Costeira está esculpida nos sedimentos do Planalto (BELTRAMI et al., 1994; MAIA, 1998; SALES, 2002; SILVA FILHO, 2004; MAIA; CAVALCANTE, 2005; AGUIAR, 2005; SALES; PEULVAST, 2007). 
A compartimentação geomorfológica da PCA evidenciou domínios morfológicos e as principais formas do relevo, bem como processos denudacionais associados, revelando o quadro geomorfológico atual, com unidades e subunidades.

A integração de imagem de alta resolução a MNT (grade regular) para o planejamento urbano de Monte Belo do Sul, por Farina et al. (2007), permitiu uma ótima análise do relevo. Silva Filho (2004) realizou um MNT utilizando grade regular, integrando a costa cearense à sua margem continental oceânica, obtendo bom êxito quanto à morfologia, na identificação de padrão da drenagem e entalhes, declividade e geração de curvas de nível. Assim, os MDTs são úteis na morfologia de dunas (PEREIRA, 2007), para o seu monitoramento e medição da sua migração sobre a área urbana, de alto risco ambiental. Neste estudo, o MDT na PCA foi muito útil na identificação das unidades e subunidades geomorfológicas.

Os processos de deposição, erosão e sedimentação da Formação Barreiras do Neógeno (Mioceno/Plioceno), com a deposição dos sedimentos sob as formas de leques aluviais até o Quaternário (Pleistoceno) (AGUIAR, 2005), com os rios e córregos esculpindo atualmente as formas de topo plano (tabuleiros com altitudes $\pm 30 \mathrm{~m}$ ). As mudanças de clima (transgressões e regressões) condicionaram as formas de relevo atuais da PCA, com atuação dos processos de erosão, deposição e retrabalhamento de sedimentos na costa (CALLAGHAN et al., 2009).

As planícies estuarinas de Soure e Salvaterra, na ilha de Marajó-PA, não ultrapassam altitudes de $4 \mathrm{~m}$ (FRANÇA; SOUZA FILHO, 2003). A plataforma continental interna do Norte do Brasil é delimitada pela isóbata de $20 \mathrm{~m}$, entretanto, a plataforma continental interna da PCA vai até a isóbata de $-10 \mathrm{~m}$.

Ao longo da costa cearense encontram-se, pontualmente, rochas de praia (beach rocks), como em Fortaleza e Paracuru, que são corpos arenosos de geometria tabular e cimentação calcítica, em desembocaduras fluviais atuais ou pretéritas (MAIA, 1998). Na PCA, a plataforma de abrasão é esculpida em sedimentos da Formação Barreiras, tabular e cimentada por calcificação.

A Planície Fluviolagunar sofre influência das marés, inundando periodicamente e sazonalmente (de janeiro a abril). Contudo, está em transição para Planície Fluviolacustre devido à comporta construída no canal de maré que liga a Laguna Salgada ao mar (que integra o Lagamar do Sargento). A comporta é aberta e fechada para fins particulares, causando a salinização do solo e da água, e a morte de espécies da fauna e flora.

Formam-se extensas planícies de intermarés em áreas com alta influência de processos fluviais e marinhos, e presença de canais de maré de climas tropicais úmidos, como ocorre na Costa Norte do Brasil (SOUZA FILHO; 
PARADELLA, 2005; FRANÇA; SOUZA FILHO, 2006). A influência do clima tropical chuvoso na PCA, em comparação com a Costa Norte do Brasil, propicia o desenvolvimento de áreas menores de planícies de intermarés, pela menor influência dos rios.

Os cordões arenosos de dunas, que ocupam a maior área da PCA (41\% da área total), migraram no século passado e as dunas soterraram parte da área urbana (MEIRELES, 2004). Os cordões dunares arenosos na parte interna da PCA incluem as dunas fixas por carbonato de cálcio (eolianito) ou vegetação e ultrapassam $20 \mathrm{~m}$ de altitude, os quais se formaram em condições de clima seco e fortes ventos (BIGARELLA et al., 2005).

As praias de Almofala e de Torrões (com estágios dissipativos) possuem características peculiares se comparadas com a maioria das praias do estado Ceará, como a Prainha, em Aquiraz (com alta inclinação de ondas e declividade acentuada, areias médias a grossas, e praias expostas de estágios intermediários a refletivos) (MAIA; CAVALCANTE, 2005). As praias da PCA, como as de Arpoeira, em Acaraú; e Ponta Grossa, em Icapuí (SALES, 2002), possuem uma inflexão de costa com direção NW-SE que permite a deposição de sedimentos finos, condicionada por declividades suaves e ondas pequenas.

Nas praias da PCA ocorrem sistemas de calhas e barras na zona de intermaré, sendo mais expressivas nas praias de Almofala e Torrões. Bermas aparecem nas zonas de supramaré das três praias. A subunidade de praia é a parte mais rebaixada.

Atualmente, as principais mudanças morfológicas que ocorrem em zonas costeiras envolvem as atividades humanas (uso e ocupação) ou processos naturais de recuo ou avanço da linha de costa, condicionados pelos fatores geológicos e agentes hidrodinâmicos e oceanográficos, acentuados por eventos extremos (El Niño e La Niña, tempestades, ciclones e ressacas), como na praia do Balneário Piçarras (KLEIN et al., 2009). Na PCA, as mudanças atuais respondem aos mesmos processos, no entanto, não ocorrem ciclones na região e nas praias predominam o recuo da linha de costa, criando zonas de acentuada erosão "hot spot".

\section{CONCLUSÕES}

O arranjo geomorfológico da área engloba: Planalto Costeiro, com tabuleiros costeiros, incluindo tabuleiros litorâneos $\left(8.031 .957 \mathrm{~m}^{2}\right)$ e plataforma de abrasão $\left(34.654 \mathrm{~m}^{2}\right)$; planície aluvial (planície de inundação e terraços com $944.912 \mathrm{~m}^{2}$ ); planície estuarina (planície fluviolagunar $/ 847.036 \mathrm{~m}^{2}$, planície de intermaré $/ 5.782 .520 \mathrm{~m}^{2}$, canais de maré e delta $/ 66.696 \mathrm{~m}^{2}$ ); e planície arenosa, 
com areias médias (dunas fixas/eolianitos 13.879.382 $\mathrm{m}^{2}$, dunas móveis/1.463.971 $\mathrm{m}^{2}$, praias de Almofala, da Barreira e de Torrões $/ 837.031 \mathrm{~m}^{2}$ ).

Os tabuleiros litorâneos ultrapassam a unidade com maior altitude (30 m) e em seguida vêm as dunas com $20 \mathrm{~m}$ de altitude. As altitudes mais baixas ocorrem nas praias.

O mapeamento da compartimentação geomorfológica da PCA por integração de dados de sensoriamento remoto, MDTs, topografia em SIGs, permitiu caracterizar e analisar a morfologia da PCA.

A Planície Costeira de Almofala constitui-se de planalto costeiro, recoberto por areias finas a muito finas (tabuleiros e plataforma de abrasão); planície aluvial (planície de inundação e terraços); planície estuarina (planície fluviolagunar, planície de intermaré, canais de maré e deltas); e planície arenosa com areias médias (cordões arenosos de dunas, praias atuais e terraços arenosos).

\section{REFERÊNCIAS}

AGUIAR P. F. Zoneamento Geoambiental no Litoral Leste do município de BeberibeCE. 2005. 157f. Dissertação (Mestrado em Geologia) - Universidade Federal do Ceará, Fortaleza, 2005.

AYOADE J. O. Introdução à Climatologia para os Trópicos. Tradução Maria Juraci Zami dos Santos. 4. ed. Rio de Janeiro; São Paulo: Bertrand Brasil, 1996. p. 224-264.

BAPTISTA, P.; BASTOS L.; BERNARDS, C.; TABORDA, R. Morphodynamics of Exposed Sandy Beaches. Journal of Coastal Research, Special Issue, v. 39, p. 355-359, 2006.

BARRETO NETO, A. A.; MOREIRA, E. C.; SILVA, A. B. Metodologia para avaliação dos erros em bancos de dados espaciais para uso em sistemas de informações georeferenciadas (SIG). In: GIS BRASIL 99, 1999, Salvador. Anais... Salvador: FatorGIS, 1999. v. 1, p. 1-4.

BELTRAMI, C. V.; ALVES L. E. M.; FEIJÓ, F. J. Bacia do Ceará. Boletim de Geociências da Petrobrás, Rio de Janeiro, v. 8, n. 1, p. 117-126, 1994.

BIGARELLA, J. J.; KLEIN, A. H. DA F.; MENEZES, J. T.; VINTÉM G. Sub-Tropical Coastal Dunes: examples from Southern Brazil. Journal of Coastal Research, v. 1, p. 113 137, 2005.

CALLAGHAN, D.; RENASINGHE, R.; SHORT, A. Quantifyng the storm erosion hazard for coastal planning. Coastal Engineering, v. 5, p. 90-93, 2009. DOI:10.1016/j. coastaleng.2008.10.003

CAMARA, G.; MEDEIROS, J. S. Introdução à Ciência da Geoinformação. São José dos Campos: INPE, 2000. 
CAMPOS, A. C.; SANTOS, G. M. dos. Compartimentação Morfopedológica da Subbacia do Córrego Tamanduá em área de Cerrado no Parque Ecológico Altamiro de Moura Pacheco, Goiânia - GO. In: CONGRESSO BRASILEIRO DE GESTÃO AMBIENTAL, 2. 2011. Anais... Londrina, 2013.

CONTI, L. A.; RODRIGUES, M. Variação da linha de costa na região da ilha dos Guarás-PA através de análise de série temporal de Imagens de Satélites. Revista Brasileira de Geografia Física, v.5, p. 922-937, 2011.

COSTA, I.G. da C.; BELTRAMI, C.V.; ALVES, L.E.M.. A evolução tectono-sedimentar e o habitat do óleo da Bacia do Ceará. Boletim de Geociências da Petrobrás, Rio de Janeiro, v. 4, n. 1, p. 65-74, 1990.

COSTA, F. R.; SOUZA FILHO, P. W. M. Utilização de modelos digitais de elevação na representação do relevo submerso e emerso na Zona Costeira Amazônica. In: SIMPÓSIO BRASILEIRO DE SENSORIAMENTO REMOTO, 13, 2007, Florianópolis, Anais... Florianópolis: INPE, 2007. p. 2485-2492.

CPRM-Serviço Geológico do Brasil. Atlas de Geologia e Recursos Minerais do Ceará: Sistemas de Informações Geográficas-SIG. Mapas na escala 1:500.000. Brasília: CPRM; Fortaleza: CNPq, 2003. I CD-Rom.

DAVIS Jr., R. A. Depositional System: a Genetic Approch to Sedimentology Geology. New Jersey: Prentice Hall, 1983. 669p.

Depositional System: an introduction to Sedimentology and Stratigraphy. 2. ed. New Jersey: Prentice Hall, 1992. 604p.

EMBRAPA-Empresa Brasileira de Pesquisa Agropecuária. Serviço Nacional de Levantamento e Conservação de Solos. In: REUNIÃO TÉCNICA DE LEVANTAMENTO DE SOLOS, 10, 1979, Rio de Janeiro. Súmula... Rio de Janeiro: EMBRAPA, 1979. 83p.

FELGUEIRAS, C. A.; CAMARA, G. Modelagem numérica de terreno. In: CÂMARA, G.; DAVIS, C.; MONTEIRO, A. M. V. Introdução à Ciência da Geoinformação. São José dos Campos: DPI, 2006. Disponível em: < http://www.dpi.inpe.br/gilberto/livro/ introd/>. Acesso em: 15 ago. 2010.

FFLORENZANO, T. G. Imagens de satélite para estudos ambientais. São Paulo: Oficina de Textos, 2002. 97p.

(Org.). Geomorfologia: conceitos e tecnologias atuais. São Paulo: Oficina de Textos, 2008.

FOLK, R. L.; WARD, C. Brazos river bar: a study in the significance of grain size parameters. Journal of Sedimentary Petrology, v. 27, n. 1, p. 3-26, 1957.

FRANÇA, C. F. de F.; SOUZA FILHO, P. W. M. Análise das mudanças morfológicas costeiras de médio período na margem leste da ilha de Marajó (PA), em imagem Landsat. Revista Brasileira de Geociências, v. 33, n. 2, p. 127-136, 2003. 
FUNCEME-Fundação Cearense de Meteorologia e Recursos Hídricos. Meteorologia e Oceanografia. Fortaleza: FUNCEME, 2010. Disponível em: <http://www.funceme.br/ DEMET/index.htm>. Acesso em: 10 set. 2010.

FREIRE, G. S. S.; CAVALCANTI, V. M. M. Cobertura sedimentar quaternária da plataforma continental do Estado do Ceará. Fortaleza: DNPM/LGMA; UFC, 1998. 42p.

FREIRE, G. S. S.; MORAIS, J. O. Plataforma Continental do Ceará. In: CAMPOS, A. A. et al. (Coords.). A Zona Costeira do Ceará: diagnóstico para a gestão integrada. Fortaleza: AQUASIS, 2003. 293p.

IBGE-Instituto Brasileiro de Geografia e Estatística. Manual Técnico de Geomorfologia. 2. ed. Rio de Janeiro: IBGE/Coordenação de Recursos Naturais e Estudos Ambientais, 2009. 188p. (Manuais Técnicos em Geociências, n. 5).

JENSEN, J. J.; HALLS, J. N.; MICHEL, J. A systems approach to environmental sensitivity index (ESI) mapping for oil contingency planning and response. Photogrammetric Engineering \& Remote Sensing, v. 64, n. 10, p. 1003-1014, 1998.

KLEMAS, V. Remote Sensing Techniques for Studying Coastal Ecosystems: an overview. Journal of Coastal Research, v. 27, n. 1, p. 2-17, 2011. DOI: http://dx.doi.org/10.2112/ jcoastres-d-10-00103.1.

LI, R.; DESHPANDE, S.; NIU, X.; LEE, I-C.; WU, B. Multi-dimensional geospatial data integration for coastal change analysis. The International Archives of the Photogrammetry, Remote Sensing and Spatial Information Sciences, Beijing, v. 37, n. 8, p. 1311-1316, 2008.

KLEIN, A. H. da F.; MENEZES, J. T. de. Beach Morphodynamics and Proffle Sequence for a Headland Bay Coast. Journal of Coastal Research, v. 17, n. 4, p. 812-835, 2001.

KOZCIAK, S.; ROSTIROLA, S. P.; FIORI, A. P. Análise comparativa entre métodos de interpolação para construção de modelos numéricos do terreno. Boletim Paranaense de Geociências, Curitiba, v. 47, p. 19-30, 1999.

MAIA, L. P. Processos costeiros y balance sedimentario a lo largo de Fortaleza (NEBRASIL): implicaciones para una gestión adecuada de la zona litoral. 1998. 269f. Tese (Doutorado) - Universidade de Barcelola, Barcelona, 1998..

MAIA, L. P.; CAVALCNTE, V. M. M. Mapeamento das Unidades Geoambientais da Zona Costeira do Estado do Ceará. Programa Zoneamento Ecológico-Econômico da Zona Costeira do Estado do Ceará. Fortaleza: SOMA/SEMACE/LABOMAR, 2005. $226 \mathrm{p}$.

SILVA, M., NASCIMENTO, C. P., COUTINHO, C. A., ALMEIDA, A. C., VENTURIERI A. A transformação do espaço amazônico e seus reflexos na condição atual da cobertura e uso da terra. Belém. Novos Cadernos NAEA. v. 16, n. 1, p. 229-248, jun. 2013, 
MILLETTE, T. L.; ARGOW, B. A.; MARCANO, E.; HAYWARD, C.; HOPKINSON, C. S.; VALENTINE, V. Salt Marsh Geomorphological Analyses via Integration of Multitemporal Multispectral Remote Sensing with LIDAR and GIS. Journal of Coastal Research, v. 26, n. 5, p. 809-816, 2010.

PEREIRA, C. Q. Modelagem numérica do terreno (MNT) a partir de dados levantados com receptores GPS e estação total em área sujeita a processos erosivos costeiros. Projeto Cartográfico. Rio de Janeiro: UERJ, 2007. 60 p.

REINECK, H-E.; SINGH, I. B. Depositional Sedimentary Environments. 2. ed. New York: Springer-Verlag, 1980. 543 p.

SANTOS, A. L. S. dos; AMARO, V. E.; SANTOS, M. S. T. Geodésia de precisão aplicada à análise da evolução morfodinâmica de curto prazo na ilha barreira do Corta Cachorro, litoral do Rio Grande do Norte, Nordeste do Brasil. Revista Brasileira de Geomorfologia, São Paulo, v.15, n.3, p. 425-442, 2014.

SALES, V. C. C. Évolution Géomorphologique de la Zone Côtière le L'état du Ceará, Nord-Est Du Brésil: du Long Terme au Court Terme. 2002. 513f. Tese (Doutorado). Paris: Université Paris-Sourbonne, Paris, 2002.

SALES, V. de C.; PEULVAST, J-P. Evolução Morfoestrutural do Relevo da Margem Continental do Estado do Ceará, Nordeste do Brasil. Caminhos de Geografia, Uberlândia, v. 7, n. 20, p. 1-21, 2007. Disponível em: <http://www.ig.ufu.br/revista/caminhos. html>.

SILVA FILHO, W. F. da. Domínios morfoestruturais da Plataforma Continental do estado do Ceará. Orientador: Iran Carlos Stalliviere Corrêa. 2004. 288f. Tese (Doutorado) - Universidade Federal do Rio Grande do Sul, Porto Alegre, 2004.

SOUZA, M. J. N. de. Contribuição ao estudo das unidades morfo-estruturais do estado do Ceará. Revista de Geologia, Fortaleza, v. 1, p. 73-91, 1989.

SOUZA, M. J. N. de. Zoneamento Geoambiental do Estado do Ceará. In: Ceará Projeto Áridas: Grupo I - Recursos Naturais e Meio Ambiente. Fortaleza: Secretaria de Planejamento; Fundação Cearense de Meteorologia, 1994. v. 2. p.183-206.

SOUZA FILHO, P. W. M. Avaliação e aplicação de sensores remotos no estudo de ambientes costeiros tropicais úmidos, Bragança, Norte do Brasil. 2000. 236f. Tese (Doutorado) - Instituto de Geociências, Universidade Federal do Pará, Belém, 2000.

SOUZA FILHO, P. W. M.; EL-ROBRINI, M. Coastal zone geomorphology of the Bragança Area, Northeast of Amazon Region, Brazil. Revista Brasileira de Geociências, v. 30, p. 518-522, 2000.

SOUZA FILHO, P. W. M.; PARADELLA, W. R. Use of RADARSAT-1 Fine Mode and Landsat-5 TM selective principal component analysis for geomorphological mapping in a macrotidal mangrove coast in the Amazon Region. Canadian Journal of Remote Sensing, v. 31, p. 214-224, 2005. 
SUGUIO, K. Geologia do Quaternário e mudanças ambientais: (passado + presente = futuro?). São Paulo: Paulo’s Comunicações e Artes Gráficas, 1999. 366 p.

SUMMERFIELD, M. A. Global geomorphology: an introduction to the study of landforms. New York: Longman, 1991. 537 p.

TINOS, T. M.; FERREIRA, M. V.; RIEDEL, P. S.; ZAINE, J. E. Aplicação e avaliação de metodologia de classificação automática de padrões de formas semelhantes de relevo. Revista Brasileira de Geomorfologia, São Paulo, v. 15, n. 3, p. 353-370, 2014.

YOSHIKAWA, S.; NEMOTO, K. Seasonal variations of sediment transport to a canyon and coastal erosion along the Shimizu coast, Suruga Bay, Japan. Marine Geology, v. 271, p. 165-176, 2010. DOI:10.1016/j.margeo.2010.02.010. 


\section{Janela para o mundo: a TV no cárcere feminino em Belém}

\section{Window to the world: the case of female prison on TV in Belém}

Nara Cristina Moura Pessoa - Especialista em Gestão penitenciária pela FAP (2012); servidora do Tribunal de Justiça do Pará (TJPA), Belém-PA. E-mail: narapessoa1@ hotmail.com

Wilson José Barp - Doutor em Ciências Sociais pela Universidade Estadual de Campinas (1997); professor associado da Universidade Federal do Pará, Belém-PA. E-mail: wbarp@ uol.com.br

Fernanda Valli Nummer - Doutora em Antropologia Social pela Universidade Federal do Rio Grande do Sul (2010); pesquisadora e professora da Universidade Federal do Pará, Belém-PA. E-mail: fernandanummer@gmail.com

\section{Resumo}

A pesquisa que originou este trabalho buscou compreender o papel da televisão no processo de sociabilidade das mulheres em situação de cárcere, que cumprem pena em regime semiaberto no Centro de Reeducação Feminino do Estado do Pará (CRF). A pesquisa apresentase como qualitativa, na qual se utilizou as técnicas da observação simples e entrevistas informais, contando com a participação de oito interlocutoras. Os programas mais assistidos pelas mulheres presas são os jornais policiais das emissoras locais, pela preocupação com a família, que geralmente está envolvida no tráfico; e um programa que mostra as festas noturnas que muitas delas frequentavam antes da prisão, oportunidades que elas têm de ver seus familiares, amigos e ex-companheiros. Outro programa muito assistido é uma novela da rede Globo, porque traz o discurso da homossexualidade, um aspecto comum no presídio feminino. Assim, a televisão é considerada pelas internas um equipamento essencial durante o cumprimento da pena, porque as mantêm informadas dos fatos ocorridos fora da prisão, o que nos faz repensar a prisão como uma instituição fechada, caracterizada pela barreira de contato com o mundo exterior.

\section{Palavras-chave}

Cárcere. Sociabilidade. Mídia.

\begin{abstract}
This research sought to understand the role of television in women sociability process that the prison situation serving time in semi-open regime in Reeducation Center Female of the State of Pará (CRF). The research is presented as qualitative and used the techniques of informal interview and the simple observation, and had the participation of eight interlocutors. Most assistors programs for women in prison are cops newspapers, the concern with the family that usually is involved in trafficking; and Para Show program, because it shows the night parties they attended before the arrest, they have opportunity to see family, friends and former colleagues ; other program much assisted is the novel In Family, Globe network, because it brings the discourse of homosexuality, common reality in the women's prison. Thus, television is considered by internal an essential tool for serving the sentence because keeps informed of events outside the prison, which makes us rethink the prison as a closed institution born characterized by contact barrier to the world.
\end{abstract}

\section{Keywords}

Prison. Sociability. Media. 


\section{INTRODUÇÃO}

Diante do fato de que as pessoas em situação de cárcere têm o direito de acesso aos meios de comunicação nas prisões para se manterem informadas, a pesquisa que deu origem a este trabalho buscou compreender a influência dos conteúdos veiculados na televisão no processo de sociabilidade das internas que cumprem pena em regime semiaberto no Centro de Reeducação Feminino do Pará (CRF).

A definição do tema se deu em virtude da experiência profissional da primeira autora na área da comunicação social, no Sistema Penitenciário do Pará (Susipe), por um período de aproximadamente quatro anos. Durante este tempo observouse que assistir TV fazia parte da rotina das presidiárias, visto que a legislação garante este direito, bem como pela escassez de estudos abordando essa temática.

Diante desse contexto, a pesquisa foi realizada no Centro de Reeducação Feminino (CRF), única unidade prisional exclusivamente feminina das 42 unidades prisionais existentes no estado do Pará. O CRF está localizado no município de Ananindeua, na Região Metropolitana de Belém (RMB). A unidade mantém aproximadamente 600 mulheres $^{1}$ sob sua custódia. Desse total, 420 cumprem pena em regime fechado ${ }^{2}$ e 120 no regime semiaberto.

A pesquisa também foi direcionada à diretora do $\mathrm{CRF}$, porque precisávamos saber qual a percepção da gestão da unidade em relação à TV no processo de sociabilidade das internas; a dois servidores penitenciários; e a oito mulheres que cumprem pena em regime semiaberto e não trabalham ou estudam fora da prisão, visto que, se elas saíssem para trabalhar, não seria possível realizar a pesquisa, pois aquelas que exercem atividades fora saem às seis da manhã e retornam às 17 horas, horário em que a autora não estaria mais no CRF, pois este é o momento em que elas se recolhem para as celas.

As internas do regime semiaberto foram selecionadas por orientação da equipe de segurança, visto que durante o dia elas podem circular em uma área livre próxima ao bloco específico para alocar as detentas neste regime, o que não ocorre no caso das internas em regime fechado. Logo, se escolhêssemos estas últimas, dependeríamos dos agentes prisionais para conduzi-las, o que não ocorreu com o segmento selecionado para participar da pesquisa.

1 Número verificado no relatório “SUSIPE em Números", referente ao mês de outubro de 2014, disponível em: <http://www.susipe.pa.gov.br/>.

2 As internas sentenciadas cumprem sua pena em regime fechado ou semiaberto. $\mathrm{O}$ regime fechado requer o cumprimento em presídios de segurança máxima ou média. Já o semiaberto, pode ser uma progressão do regime fechado, e deve ser cumprido em colônia agrícola, industrial ou instituição similar. 
Os instrumentos de coleta de dados foram adotados de acordo com a perspectiva de Lakatos e Marconi (2011) e Gil (2012), que consideram as técnicas da entrevista informal e da observação simples mais adequadas para se compreender as representações que os entrevistados dão às experiências e fatos de sua vida cotidiana. Para preservar a identidade das oito mulheres que aceitaram participar como interlocutoras da pesquisa, solicitamos que se identificassem pelo nome de uma flor, ficando assim autodenominadas: Jasmim, Rosa Vermelha, Girassol, Lirio, Amor Crescido, Margarida, Alecrim e Camélia.

Para algumas, o nome da flor foi escolhido por ter um significado especial em suas vidas, como o caso de Jasmim, que justificou: "Minha avó usava essa flor no cabelo, por isso que gosto desse nome". Para Amor Crescido, o motivo foi: "gosto dessa flor porque para mim representa maturidade, algo bom". Rosa Vermelha escolheu este codinome, alegando que: "adoro essa flor, ela representa o amor. Já sofri tanto por amor"; e Alecrim preferiu ser chamada dessa forma porque: "é um nome que representa alegria".

\section{A TV NO CONTEXTO DA PRISÃO}

A sociedade atual é fortemente marcada pela presença dos meios de comunicação - rádio, televisão, internet, redes sociais - que assumem um papel "estruturante" no cotidiano das pessoas. Esses meios fazem a mediação das relações sociais, influenciam o pensamento e os costumes, por meio da difusão de valores culturais. A televisão ainda é um dos veículos de maior alcance social, sendo utilizada em múltiplos contextos, entre eles a prisão. Para Thompson (2012, p. 72), “O alcance da televisão em sua expansão global, torna-se cada vez mais acessível aos indivíduos em todo o mundo".

Canclini (2002) define a mídia ou meios de comunicação de massa como canais que registram e difundem informações. Ao utilizar esses canais, o indivíduo não pertence mais a um país, e sim ao mundo. Ao clicar o controle remoto, o sujeito entra em contato com outras realidades, formando um todo de informações que serão absorvidas. Em virtude da sua importância para os indivíduos, a TV também faz parte do sistema carcerário. Sua presença é legitimada ${ }^{3}$ pela Lei de Execução Penal (LEP), que no artigo 41, inciso XV, determina - O contato com o mundo exterior será por meio de correspondência escrita, da leitura e de outros meios de informação que não comprometam a moral e os bons costumes. O parágrafo

Para aprofundar a leitura sobre a legislação, ver Regras mínimas para Tratamento de Reclusos da Organização das Nações Unidas (ONU) e Regras Mínimas para o Tratamento do Preso (Resolução no 14 , de 11 de novembro de 1994). 
único deste mesmo artigo afirma que esses meios poderão ser suspensos ou restringidos mediante ato motivado do diretor da unidade prisional. Isto é, se os meios disponibilizados no cárcere estiverem interferindo de alguma forma na boa convivência entre pessoas privadas de liberdade, o diretor poderá tomar as providências cabíveis e até mesmo regulamentar o uso do eqipamento.

A partir dessa garantia, o CRF possui, ao todo, cerca de 90 aparelhos de televisão, ${ }^{4}$ distribuídos nas várias celas que abrigam detentas dos regimes fechado e semiaberto. $\mathrm{O}$ acesso aos conteúdos veiculados é livre, bem como os horários, ou seja, a TV pode ser ligada a qualquer hora do dia ou da noite, sem restrições. Direcionando a pesquisa para o regime semiaberto, identificou-se que há cerca de trinta televisores nas celas desse regime.

Para instalar um aparelho de TV no cárcere, este deve ser de 14 polegadas e levado pelos familiares das internas ou comprada ${ }^{5}$ daquelas que obtiveram a liberdade. Quando um televisor chega ao CRF é expedido um documento atestando quem é a proprietária, depois de passar por uma revista para que a equipe de segurança certifique-se de que não há objetos ilícitos dentro do aparelho. Apesar do direito previsto em lei, o uso da TV no cárcere ainda não é regulamentado pelo Sistema Penitenciário do Estado do Pará (Susipe) ${ }^{6}$ que, mesmo permitindo a entrada do equipamento, não detém de controle formal sobre ele. Uma vez instalada na cela, não são estabelecidas normas de horários para o uso desse equipamento pela gestão e, a partir de então, a TV pode ser ligada a qualquer hora do dia ou da noite.

Durante a pesquisa ficou evidente que a TV é um objeto de troca na prisão. Conforme se observa no depoimento de um agente penitenciário que trabalha há 9 meses no CRF: "Na cadeia, a TV é um bem muito valioso. Uma vez uma interna pediu 50 reais emprestado para outra e a TV foi dada como garantia de pagamento". Ressalta-se, então, que a TV é comercializada junto com outros itens, a fim de obterem dinheiro e garantir um meio de sobrevivência.

Segundo as entrevistadas, tudo na prisão é pago, inclusive o direito de assistir TV. Então, elas precisam encontrar uma forma de ganhar dinheiro, principalmente as internas que não recebem visitas, como é a realidade da maioria.

Informação prestada pela diretora do CRF, em junho de 2014, durante a pesquisa de campo.

$\mathrm{O}$ valor da televisão seminova, no momento da pesquisa, variava entre 80 a 120 reais, quando era comprada individualmente. Se fosse adquirida junto com o espaço da cela, saía mais caro, visto que elas só podem ficar juntas quando por um espaço na cela - o que é chamado por elas de "beco".

6 Órgão criado pela Lei n ${ }^{\circ} 4.713$, de 26 de maio de 1977. Autarquia vinculada à Secretaria de Estado de Segurança Pública, regida pela Lei no 6.688, de 13 de setembro de 2004, e suas alterações, com autonomia administrativa e financeira, dispondo de dotação orçamentária própria, tendo por finalidade a execução penal, efetivando as disposições de sentença ou decisão criminal, custodiando o interno e promovendo a sua reintegração social. 
Caso contrário, elas ficam na dependência de outras mulheres, o que se torna um sofrimento para as detentas. Aquelas que não recebem visitas, de certo modo são humilhadas pelas demais. No cárcere, o fato de não receber visita significa desprestígio (SANTANA, 2012).

Aqui a gente vale o que tem. Qualquer favor tem que pagar. Tudo no CRF é pago, colchão, quarto, cama. Um empanado ${ }^{7}$ com tudo, inclusive televisão é cerca de 200 reais" (Jasmim, 28 anos, condenada por tráfico de drogas; estudou até a $4^{\mathrm{a}}$ série).

Quando saem do regime fechado, na maioria das vezes as internas vão para o semiaberto. De acordo com a referida Lei, essa transição é chamada de progressão da pena. Ao passar para o regime semiaberto, a interna deve comprar um "beco" ou "empanado"; e se não o fizer, ficará pelos corredores do anexo, sem privacidade e dormindo no chão. As internas que vão saindo do regime semiaberto deixam os empanados para uma amiga negociar com as recémchegadas.

Quando cheguei no semiaberto, meu quarto custou 500 reais, com duas televisões. Quando comprei, chamei para morar comigo a moça que foi presa junto comigo, mas ela tem a TV dela e eu tenho a minha. Eu recebo 200 reais do meu marido toda semana para me manter aqui na prisão" (Margarida, 46 anos, acusada pelo crime de tráfico; técnica em administração e contabilidade).

Eu comprei o empanado por cem reais, e veio só com cama, colchão e televisão. Agora divido com mais duas que compraram um espaço no meu beco. Mas eu que mando na TV, as outras só ligam se eu quiser. Eu comprei então é minha" (Girassol, 37 anos, condenada pelos crimes de tráfico e homicídio; estudou até a $6^{a}$ série).

Nos relatos, percebe-se que a TV valoriza o espaço no cárcere, e junto temse a relação de poder, que advém do dinheiro. Aquelas que podem pagar dispõem de certo "conforto". Pelo que foi observado, a direção do CRF desconhece essa prática comum. O fato de uma interna ocupar um espaço em qualquer cela da prisão deveria ser uma determinação da gestão da unidade, o que, de fato, seria natural, no entanto, para a interna, torna-se um momento de tensão, pois quando ela sabe que vai para o semiaberto, fica apreensiva porque terá que pagar pelas suas acomodações.

\footnotetext{
Também chamado de "beco", consiste em várias camas ou beliches localizados em um determinado espaço da cela, divididos por lençóis. Isso proporciona às internas certa "privacidade". Em um beco ou empanado pode haver uma cama ou várias, dependendo da amizade entre as detentas. Um empanado com televisão, cama, colchão e ventilador custa cerca de 200 reais, e esse valor pode variar de acordo com os itens existentes no local. O empanado sem televisão custa entre 50 e 100 reais.
} 
Foucault (2012) assinala que o poder é uma "prática social", que está no cotidiano e se estabelece por meio das relações de força entre as pessoas. Foucault (2012), ao analisar a dinâmica do poder, pensa "na sua forma capilar de existir, no ponto em que o poder encontra o nível dos indivíduos, atinge seus corpos vem inserir em seus gestos, suas atitudes, seus discursos, sua aprendizagem, sua vida cotidiana" (FOUCAULT, 2012, p. 215).

A TV é a principal arma que a direção tem. Quando elas estão tentando alguma coisa de errado, a direção avisa: se vocês tentarem alguma coisa eu tiro a TV de vocês.” (Agente penitenciária, que trabalha há seis anos no CRF).

No cárcere feminino, o poder se "capilariza" por outras fontes que não a institucional. Em vários momentos, quem determina as regras são as internas consideradas líderes e não a gestão da unidade. Essa questão será retomada mais adiante. Dias (2014) afirma que as regras informais são recursos por meio dos quais se constroem as relações e a determinação dos limites. Essas regras são importantes à medida que proporcionam a manutenção da paz, porque é impossível viver um longo tempo na prisão sem a flexibilização das suas normas. Senão vejamos:

Se tirasse a TV da gente, a gente tacava fogo na cadeia. Na rebelião, a gente quebrou tudo, até que devolveram a TV pra gente (Alecrim, 29 anos, presa por tráfico de drogas; estudou até a $6^{a}$ série)."

Em uma rebelião que teve aqui no $\mathrm{CRF}$, uma das punições foi a retirada da TV. Elas ficaram uma semana sem o aparelho, depois que foi negociado entre a direção e elas. Como punição deve-se tirar o que elas mais gostam" (Agente penitenciária, que trabalha há seis anos no CRF).

Isso nos leva a pensar que "a cadeia não é uma miniatura da sociedade livre, mas um sistema peculiar, cuja característica principal, o poder, autoriza a qualificálo como um sistema de poder" (THOMPSON, 2002, p. 19). Assim, a relação de poder engloba a TV, que acaba sendo usada como objeto de troca no cárcere.

No que tange à importância da TV, as internas a consideram um meio de comunicação extremamente importante durante o cumprimento da pena, como um instrumento de recreação que ocupa o tempo ocioso, distrai e facilita o convívio porque as reúne durante as programações, especialmente os noticiários policiais, conforme se observa nos depoimentos abaixo:

Se não tivesse a TV seria muito ruim, eu teria entrado em depressão. A TV faz o nosso contato direto com o mundo; se não tivesse ela, nós perderíamos a noção do tempo e do mundo. Quando eu estava no regime fechado, ficamos sem televisão quase um mês quando teve a última rebelião (2013). 
Foi muito ruim. A TV só voltou porque as líderes das celas negociaram com a direção e aí foram devolvendo aos poucos" (Margarida, 46 anos, condenada pelo crime de tráfico; técnica em administração e contabilidade).

A TV puxa a cana (cumpre a pena) junto com a gente. Abaixo de Deus é ela que tá com a gente. Quando ficamos sem a TV durante a rebelião do ano passado (2013) foi horrível, não tinha pra onde olhar. Ficou um vazio. Se não tivesse a TV seria um tédio, porque ela distrai a nossa mente; sabemos o que acontece na cidade, assistimos um filme, um jogo" (Lírio, 39 anos, acusada pelo crime de tráfico; estudou até a $6^{a}$ série).

Com base nas repostas, observa-se que a televisão exerce uma importante função na vida das internas durante o cumprimento da pena, o que vai ao encontro das reflexões de Mcluhan (1964, p. 369), para o qual "A imagem da TV cria uma obsessão com o bem-estar físico". A televisão é tão importante no âmbito do cárcere, que, quando um aparelho dá defeito, a líder da cela faz uma coleta para comprar outro - e quem não tiver dinheiro no momento deverá fazer algum trabalho para pagar a sua cota.

Sobre a dimensão adquirida pela TV no meio social, Bucci (2004, p. 33) afirma que "A televisão é um lugar em si [...] a TV como lugar nada mais é que o novo espaço público, ou uma esfera pública expandida”. Logo, entender a TV como um espaço público, significa que ela é um lugar onde há integração, multiplicidade de culturas e circulação das representações simbólicas. Dessa forma, a mídia ocupa um lugar de destaque na prisão, porque influencia o pensamento e a atitude das pessoas ajuda a passar o tempo e distrai. Ao realizar visita a um dos blocos do CRF para conhecer a disposição dos aparelhos de TV nas celas, as internas estavam assistindo a um jogo da copa do mundo. $\mathrm{Na}$ ocasião, ao perguntar a importância da TV para elas, todas começaram a falar ao mesmo tempo e as respostas foram unânimes:

Se não tivesse a TV seria um tédio. $\mathrm{O}$ número de rebelião seria maior, porque não teria nada pra distrair. Só temos visita de sete em sete dias, então é um meio de informação lá de fora. O que a gente sabe é através da TV, e às vezes das meninas que trabalham lá fora. Mente vazia é oficina do diabo" (Internas do semiaberto, anexo V).

De acordo com Thompsom (2012, p. 58), o uso da tecnologia torna as pessoas capazes de "transcender os limites característicos de uma interação face a face. Ao mesmo tempo, as leva a reordenar as questões de espaço e de tempo dentro da organização social, e usa esta reorganização como meio para atingir seus objetivos". Percebe-se, então, que a TV é um objeto especial e valioso para as mulheres presas. É por meio desta que essas mulheres constroem uma imagem do mundo fora da prisão, situam-se no tempo e no espaço e tentam organizar suas vidas. Para as internas, não é possível uma prisão sem a TV. 


\section{A SOCIABILIDADE NO CÁRCERE}

Das oito interlocutoras que fizeram parte desta pesquisa, cinco têm idade entre 22 a 30 anos, duas entre 31 a 39 anos, e apenas uma tem idade entre 31 a 39 anos. Do total, seis têm escolaridade até o ensino fundamental incompleto, e apenas duas concluíram o ensino médio. Foi verificado ainda que, antes da prisão, as internas não exerciam profissões que demandssem uma formação específica. Antes de ingressarem no Sistema Penitenciário elas realizavam atividades de babá, garçonete, mototaxista, vendedora, autônoma (venda de confecções femininas) e duas declararam que nunca trabalharam antes do cárcere. Todas afirmaram que trabalhavam na informalidade.

Em relação aos crimes cometidos, cinco foram presas pela acusação de crime de tráfico ilícito de entorpecentes, e as outras três foram presas pelo crime de tráfico, associado a outro crime, como latrocínio ${ }^{8}$, tentativa de homicídio e homicídio. No que se refere à reincidência, cinco estão no CRF pela primeira vez e três são reincidentes na prática criminosa. Retomando a questão da televisão, os programas mais assistidos pelas mulheres em situação de cárcere são os noticiários policiais, isto porque se preocupam com a família, que geralmente está envolvida com o tráfico de drogas, bem como para saber sobre as ocorrências no mundo do crime e dos "conhecidos" que irão chegar à prisão. Os jornais do gênero policial veiculados da Região Metropolitana de Belém (RMB) pelos canais de televisão são: "Balanço Geral", transmitido de segunda a sábado, ao meio-dia, no canal da Record; "Barra Pesada" e "Metendo Bronca", ambos veiculados de segunda a sexta-feira, entre meio dia e 14h, no canal RBA, afiliada da Band; e o "Rota Cidadã", programa policial veiculado somente aos sábados, no horário do meio- dia, também no canal da RBA. Girassol e Lírio, assim como outras detentas, acompanham os jornais policiais pela preocupação com a família:

Aqui assisto mais o Balanço e o Barra para ver quem vai cair aqui, de repente minha filha tá no meio. Quando fui presa, o chefe (do tráfico) deu a droga pra minha filha de 16 anos vender para pagar um advogado pra me tirar daqui, mas pedi muito pra ela parar porque ninguém merece estar aqui nesse lugar. Hoje, sei que não vale a pena (Girassol, 37 anos, acusada pelo crime de tráfico e homicídio; estudou até a $\sigma^{a}$ série).

Assisto a esses jornais porque tenho preocupação com meu filho de 22 anos, que está usando drogas. Meu filho passou no 'Balanço Geral' no ano passado (2013) - ele tinha levado 27 facadas. Armaram uma "casinha" (cilada) pra ele numa briga de bola. Esses jornais também mostram nossa realidade (referindo-se ao crime). (Lírio, 39 anos, acusada pelo crime de tráfico; estudou até a $\sigma^{\mathrm{a}}$ série).

8 Segundo o código penal, trata-se do crime de roubo seguido da morte da vítima. 
Além da preocupação com a família, elas assistem aos noticiários policiais para saber dos amigos e do que acontece no mundo do crime:

Antes de ser presa, assistia mais os jornais da Record e da Band, para saber do mundo do crime. $\mathrm{Na}$ cadeia só o que me interessa são esses programas. Assisto o 'Balanço', o 'Barra' para saber quais os colegas que caíram na prisão. Tem colegas que saem daqui e morrem lá fora, aí a gente fica sabendo (Girassol, 37 anos, acusada pelo crime de tráfico e homicídio, estudou até a $6^{\mathrm{a}}$ série).

Thompson (2012) ressalta que a importância atribuída pelos indivíduos aos conteúdos veiculados nos meios de comunicação de massa depende da formação e da condição socioeconômica de cada pessoa nesse processo. Conforme os relatos, as internas assistem aos programas policiais porque de alguma forma representam o seu "mundo", as suas experiências. É o meio pelo qual elas podem saber o que acontece com os seus familiares. Além do quê, a ausência dos filhos e da família é uma das maiores angústias provocadas pela detenção, e que elas irão enfrentar durante o cumprimento da pena (SANTANNA, 2012; MAKKI; SANTOS, 2010; ESPINOZA, 2004). Sem visita, as internas precisam se submeter às regras de sobrevivência na prisão, por meio de favores.

Aquela interna que não tem dinheiro para a coleta da TV irá fazer uma faxina na cela ou lavar a roupa de alguém, geralmente da líder, para pagar a sua cota e ter direito de assistir a programação na televisão. Quando estava no fechado, todo mundo ajudou a colocar a TV pra dentro; eu ajudei a comprar porque lavei duas vezes a roupa de uma interna; foi 10 reais cada lavagem - dei 15 pra TV e fiquei com cinco reais. Como aqui no semiaberto não tenho a minha televisão, eu continuo fazendo esses favores pra poder assistir um pouco de TV com algumas colegas e comprar algumas coisas pra mim (Jasmim, 28 anos, acusada por tráfico de drogas, estudou até a $4^{\text {a }}$ série).

Coelho (2005, p. 79-80) define essa realidade das internas desassistidas pela família como "dupla condição de penúria e de dependência [...], que as administrações prisionais virtualmente nada fazem para eliminar", porque consideram essas relações de dependência como substitutivas da presença do poder público. Para Espinoza (2004, p. 167), "a prisão não passa de uma fotografia da mesma desigualdade retratada no espaço livre". O uso da TV é um foco de conflitos na prisão, pois quem não obedece aos códigos de conduta do cárcere estabelecido pelas próprias internas para a utilização do aparelho é punido.

A Camélia puxou a TV da cela da tomada e disse que ninguém iria assistir mais nada, que as pessoas teriam que aturar ela porque ela foi obrigada a vender a televisão dela pra pagar uma dívida de droga. Agora, ela também 
liga a TV da cela de madrugada para incomodar as demais, por isso que teve briga. Ninguém tem culpa dela ter perdido a TV dela (Amor Crescido, 25 anos, presa por tráfico de drogas, ensino médio completo).

Para Camélia (acusada de tráfico e latrocínio), ter a própria televisão significava não se submeter às regras da TV coletiva, mas sim ligar e desligar o parelho a hora que quisesse, sem ter que "dividir nada com ninguém porque gosta de viver isolada". Por isso, tinha a sua própria TV, que ficava em cima da sua cama. De acordo com Cavalcante Júnior (2004, p. 15), “Os padrões culturais e simbólicos da organização passam a ser reguladores das atividades dos indivíduos, e se configuram em processos de poder e na manutenção da própria organização enquanto tal". No CRF, como em qualquer instituição, há regras que precisam ser cumpridas para a manutenção da ordem e da tolerância, caso contrário os conflitos seriam preponderantes. Contudo, essas regras muitas vezes são infringidas, pela própria peculiaridade do ambiente carcerário.

Nessa pesquisa utilizamos o conceito de cárcere na perspectiva de Goffman (1974, p.17), que corrobora a realidade enfocada, assegurando que "uma disposição básica da sociedade moderna é que o indivíduo tende a dormir, brincar e trabalhar em diferentes lugares, com diferentes co-participantes, sob diferentes autoridades e sem um plano racional geral". No entanto, quando o indivíduo chega a uma prisão, lugar que Goffman (1974) chama de "instituição total", rompe com esse modo de vida e todas as tarefas passam a ser realizadas na "companhia imediata de um grupo relativamente grande de outras pessoas, todas elas tratadas da mesma forma e obrigadas a fazer as mesmas coisas em conjunto", pois passam a conviver em um mesmo espaço, sujeitos às mesmas regras formais e informais, bem como às atividades obrigatórias para atender a um determinado objetivo, sejam determinados pela instituição ou pelas internas, em prol dos seus próprios interesses. Goffmam (1974) entende que esse processo de submissão ocasiona a "mortificação do eu", originado por mudanças nas suas crenças.

Nesse sentido, começam a surgir as formas de poder simbólico ${ }^{9}$ entre as presas, que, por sua vez, dependem dos códigos criados por elas. Esta "sociedade dentro da sociedade" se organiza em torno de lideranças que são comuns ou não em cada cela, pavilhão ou de uma líder gera,l que todos sabem quem é, mas ninguém revela publicamente (CAVALCANTE JÚNIOR, 2009, p. 362).

Assim, para assistir televisão coletivamente é preciso estar atento à liderança dentro da cela, pois quem decide quando ligar ou desligar a TV, a mudança de canal e a programação que o grupo irá assistir é a interna considerada "chefa" ou "líder" da cela ou do bloco, que também lidera os motins, rebeliões e todo tipo

\footnotetext{
Para uma leitura mais aprofundada sobre o poder simbólico, ver Bourdieu (2012).
} 
de reivindicação. Nesse contexto, a liderança se desenvolve em torno da detenta mais antiga, daquela que tem maior poder aquisitivo para se sustentar na prisão, sem depender de outra interna ou daquela que lidera a modalidade do crime cometido fora do ambiente da prisão.

Tem gente que se sente humilhada porque quer assistir um canal e a dona da TV vai lá e não deixa ou desliga a TV. Tem muita confusão aqui no CRF por causa da televisão. Eu divido a TV com outra, mas a TV é minha, eu que comprei, eu que mando. Só deixo ela assistir alguma coisa quando não tô a fim de assistir o que gosto. Para ligar e desligar, tem que ter autorização da chefa. É a chefa que comanda tudo, até o motim, rebelião, reivindicações (Lírio, 39 anos, acusada pelo crime de tráfico; estudou até a $\sigma^{\mathrm{a}}$ série).

Dessa forma, infere-se que as interações entre as internas se dão a partir de uma relação simbólica de legitimar as lideranças dentro do cárcere, e agir conforme as determinações dessa liderança, porque a cultura da prisão assim a produziu. Neste sentido, Thompson (2012) considera que na produção das formas simbólicas os indivíduos se valem dessas relações para realizar ações que possam lhes favorecer no decorrer dos fatos, levando a consequências as mais diversas. Este autor afirma que o poder simbólico "pode provocar reações, liderar respostas de determinado teor, sugerir caminhos e decisões, induzir a crer e descrer, apoiar os negócios do Estado ou sublevar as massas em revolta coletiva" (THOMPSON, 2012, p. 42). Verificamos durante a pesquisa o caso de Margarida, que exerce a liderança na prisão pela sua influência no tráfico de drogas e porque não depende de ninguém para sobreviver no CRF. Portanto, ocupar a posição de Margarida significa negociar com a direção, autorizar ou não uma rebelião e determinar quem irá assistir ou não à televisão, entre outras decisões.

Elas gostam desses programas de crime e eu não gosto. A programação que a maioria gosta é diferente da minha. Só assisto a programação da Globo. Gosto de assistir o 'Jornal Nacional', 'Ana Maria Braga', 'Bom Dia Brasil'. Assisto os jornais policiais só quando tem algo de muito interessante ou é alguma notícia da cidade de Marabá. Procuro me isolar porque o comportamento delas não faz parte do meu eu. Elas se amigam com outras mulheres, e isso eu não aceito. Eu também não me adapto ao linguajar delas, meu nível cultural é diferente (Margarida, 46 anos, acusada pelo crime de tráfico; técnica em administração e contabilidade).

Até aqui, observou-se que Camélia e Margarida não se submetem às regras da TV coletiva, porque preferem sua individualidade, pelo menos nesse aspecto. Atribuímos esse fato ao perfil e história de vida de cada uma, o que está diretamente envolvido com a prática do crime e a escolaridade. 
Outro programa que une as internas em torno da televisão é a novela "Em Família", veiculada na rede Globo. A história principal da trama é o namoro entre duas mulheres, em que uma delas é casada e deixa o marido para ficar com a outra em prol do amor. Durante a pesquisa, a maioria das interlocutoras revelaram que gostam dessa programação porque retrata a homosexualidade, realidade vivida pelas internas no cárcere.

Sabe, meu marido me fez sofrer muito, por isso, aqui passei a gostar de mulher, a lembrança dele me faz sofrer muito. Sabe, agora que eu gostei mais da novela 'Em Família', porque ela (Giovana Antonelli, protagonista) deixou o marido pra ficar com o amor dela. Todo mundo aqui gosta dessa novela (Rosa Vermelha, 30 anos, acusada pelo crime de tráfico e tentativa de homicídio, estudou até a $6^{a}$ série).

Verônica Policarpo (s.d.), em pesquisa sobre a percepção do conteúdo de telenovela, explica que mulheres em diferentes situações conjugais, ou seja, com trajetórias familiares distintas, diferenciam-se na forma de ver a telenovela, "em virtude de possuírem diferentes representações e valores sobre a família, os papéis sexuais e a ideia de amor romântico”.

A telenovela surge com uma força explicativa renovada. Pela forma como atualiza o mito do amor-romântico e pela forma como é usada pelos indivíduos que a ela assistem para (re) interpretar, compreender e narrar a sua própria vida. A telenovela surge assim como um interlocutor privilegiado para estes telespectadores, que se sentem (paradoxalmente) através dela, mais do que nunca protagonistas de um drama maior: o da sua própria Vida (POLICARPO, s.d., p. 15).

Em relação às atividades de rotina no cárcere feminino, observamos que o uso da TV ocorre com mais frequência nos horários dos noticiários policiais e das novelas. Pela manhã, elas assistem às notícias policiais do jornal "Fala Pará", às $7 \mathrm{~h}$, no canal da Record. Em seguida realizam suas tarefas, que geralmente são: lavar roupa, fazer a faxina na cela ou realizar algum trabalho manual dentro do CRF, como crochê, manicure, artesanato; ou procuram os serviços das assistências disponíveis, como médico, dentista, aulas, psicóloga e assistente social. Na hora do almoço elas retornam e assistem aos jornais policiais que são veiculados ao meio dia, e da mesma forma ocorre na parte da tarde e da noite, quando são veiculados novamente os jornais e as novelas. Isso nos permitiu constatar que o tempo dedicado à realização das atividades gira em torno da televisão.

Diante desse contexto, destaca-se o que Simmel (1983) define como sociabilidade. Para o autor, a sociabilidade é vista como o sentimento de prazer por estar se relacionando com pessoas que escolhemos. É a satisfação de integrar 
um grupo com o objetivo exclusivo de gozar dessa relação. Simmel (1983) afirma que para haver a sociabilidade as diferenças devem ser postas em segundo plano. Se essas diferenças forem muitas, a possibilidade de existir sociabilidade diminui. A partir dos conceitos de Simmel (1983), entendemos que a sociabilidade no cárcere é limitada, uma vez que o prazer de se relacionar é momentâneo. As mulheres em situação de cárcere encontram-se em uma "instituição total" (GOFFMAN, 1974), que busca moldar o indivíduo por meio de regras, forçandolhes a conviver com os que lá estão. Logo, elas não têm a chance de realizar suas atividades em outros locais, com pessoas que realmente lhes façam felizes. Sem a chance de escolha, agrupam-se por aquilo que têm em comum.

Portanto, a sociabilidade no cárcere não é absoluta - ela é momentânea. Em geral, os momentos de sociabilidade ocorrem quando as internas se reúnem em torno da TV para assistir aos programas policiais, para saber se alguém da família, amigos ou ex-internas foram presos, como também à novela "Em Família", ao programa "Pará Show", aos jogos de futebol. Apreende-se, então, que a TV aproxima as mulheres num local de tantos conflitos e diferenças, porque essas programações propiciam momentos em que elas abstraem suas "qualidades objetivas e subjetivas" para que possam se relacionar umas com as outras. "Na sociabilidade não entram o que as personalidades possuem em termos de significações objetivas; [...] riqueza, posição social, erudição, fama, capacidades excepcionais e méritos individuais não desempenham qualquer papel na sociabilidade" (SIMMEL, 2006, p. 67). Então, nas ocasiões em que se reúnem em torno da TV, as mulheres conseguem "jogar o jogo da sociabilidade" (SIMMEL, 1983).

\section{INTERAÇÃO E CONFLITO PELO USO DA TV}

Como visto anteriormente, o fato de as internas assistirem assiduamente aos jornais e programas policiais vêm gerando hostilidades no âmbito da instituição carcerária, à medida que acompanham esses noticiários, podem obter informações sobre o destino de seus familiares envolvidos no crime e das novas detentas que chegarão ao CRF, como também sobre os seus desafetos. Esta situação tem causado conflitos dentro do cárcere, visto que através dessas notícias ficam sabendo se alguma interna recém-chegada ao CRF cometeu um crime repudiado pelas “regras da prisão". Caso isso seja confirmado, esta interna ficará isolada e não poderá participar de nenhuma atividade de ressocialização, sob o risco de sofrer violência ou até mesmo de morte.

$\mathrm{Na}$ convivência diária das mulheres em situação de cárcere evidencia-se o que Colares e Chies (2009) chamam de "prisão dentro da prisão", ou seja, as 
internas que são excluídas da convivência com as outras presas porque cometeram crimes que não são aceitos pelas regras informais do cárcere, como, por exemplo: mãe que matou o filho, filha que assassinou a mãe ou avó, maus-tratos a crianças e idosos, entre outros.

A consequência da medida punitiva de isolamento, que aqui decidimos nomear de "dupla exclusão social", em que utilizam duas celas chamadas de "seguro", localizadas no anexo ${ }^{10} \mathrm{~V}$ do regime semiaberto. As celas receberam este nome porque à época da pesquisa abrigavam sete internas que precisam ficar isoladas das outras. Essas mulheres são chamadas de "brindes"11", e só podem sair da cela para o banho de sol, mesmo assim devem sempre ficar próximas às agentes penitenciárias, por questões de segurança, visto que se essas "brindes" forem inseridas no bloco carcerário sofrerão maus tratos, isso pode levar até a sua morte. Neste caso, a prisão é vista como um sistema que propicia a violência porque gera exclusão daquelas mulheres que já se encontram excluídas da sociedade. Dentre os relatos, os mais expressivos foram de duas interlocutoras. Vejamos:

A TV serve pra gente ver os crimes que acontecem lá fora. Se for alguém que matou a mãe ou o filho, a direção já sabe tem que ir direto para a cela dos brindes. Se vier pro bloco, vai apanhar muito. Eu já presenciei muitas porradas nos brindes e já participei também. Tem uma aí que matou a mãe. O que você acha? Se ela matou a mãe, imagina o que ela pode fazer comigo ou com qualquer outra quando tiver dormindo? Tem outra coisa: aqui a gente fica muito atribulada, preocupada com a família, com os filhos, com o processo, que ninguém dá informação. Então, na hora da raiva a gente vai descontar nos brindes. Então é melhor ficar separada (Lírio, 39 anos, acusada pelo crime de tráfico; estudou até a $6^{a}$ série).

A maioria assiste o "Balanço Geral" para saber quem vem pra cá, com quanto $^{12}$ que foi pego. Se chegar alguém aqui que fez alguma maldade que a gente não aceita, não entra no bloco, vai pros brindes e jamais pode circular. Minha mulher pegou uma e fez muita maldade, cortou o cabelo dela igual de homem e bateu muito nela. A gente não perdoa, regra é regra. Se eu pegar eu corto a cara dela (Alecrim, 29 anos, presa por tráfico de drogas, estudou até a $6^{\mathrm{a}}$ série).

Thompson (2012) alerta que os meios de comunicação, ao divulgar imagens e informações de fatos ocorridos em lugares muito além de seus ambientes sociais imediatos, "podem estimular ou intensificar formas de ação coletiva difíceis de

10 Uma edificação construída no formato retangular, dividida em várias partes, formando quartos que são usados como celas. Essa construção é separada dos pavilhões onde ficam as internas sob custódia no regime fechado.

11 São as internas que não podem circular no CRF porque podem sofrer violência, ou pelo crime que cometeram, ou porque tem desafetos no CRF.

12 Refere-se à quantidade de droga. 
controlar com os mecanismos de poder estabelecidos" (Ibid., p. 156). Note-se que há ou não a aceitação dos crimes pelas detentas. Aquelas que se envolvem com o tráfico, assalto ou latrocínio são aceitas e respeitadas no cárcere. Já as que cometem crimes cujas vítimas são seus próprios familiares são repudiadas. Essas internas agem como se não estivessem sob as mesmas leis e normas.

$\mathrm{Na}$ fala da diretora do CRF pode-se verificar que ela é contra o uso irrestrito da televisão, porque as internas que são consideradas "brindes" já chegam à prisão sem chances de ser inseridas nos projetos de reinserção social exigidos pela (LEP). Contudo, não há uma norma estabelecida por parte do gestor da Susipe para regularizar e orientar o uso dos aparelhos de TV. A diretora defende que o controle do uso da televisão deveria ser formalizado por meio de uma portaria ou outro documento, porque a LEP assegura que o diretor da unidade pode suspender ou restringir o uso dos equipamentos caso prejudique os bons costumes, o que não violaria o direito à informação, porque se estaria preservando um bem maior que é a vida.

Esses programas policiais trazem o culto da violência para dentro do cárcere. A presa que já chega na prisão hostilizada - não pode tomar banho de sol, não pode estudar porque as outras querem violentá-la, ou seja, essa presa não pode ser inserida em nenhum projeto. A presa fica isolada, como inserir se ela tem que ficar isolada? A cadeia não tem estrutura para isso (Diretora do CRF).

No entanto, como a TV é um instrumento de poder (COSTA, 2004), poderia ser perigoso o diretor da unidade prisional restringir o uso do equipamento sem antes passar por uma discussão mais ampla com os profissionais que atuam na instituição, embora seja autorizado por lei. Considerando esse contexto, pondera-se que a TV na prisão tornou-se um panóptico invertido, ou seja, não é mais somente a prisão que está sob um olhar vigilante com o intuito de disciplinar os corpos (FOUCAULT, 2011). Agora são várias mulheres "vigiando" a televisão e observando quem entra e quem sai do cárcere, para então decidirem sobre a punição ou não daquelas cujas práticas criminosas não são aceitas.

Pelos valores estabelecidos na prisão, as internas também exercem o poder de punir, à medida que excluem, ameaçam ou violentam aquelas com as quais não se identificam em função dos crimes, embora legalmente seja uma atribuição exclusiva do Estado. Neste sentido, a gestão da unidade permite essa "estrutura informal de poder para auxiliar a manutenção da ordem social” (DIAS, 2014, p. 119). Por conseguinte, as "brindes" tornam-se vítimas do próprio Sistema Penitenciário, que as submete a situações de violência física e simbólica, por vezes, sem a devida consciência e reflexão sobre esta prática. 
As práticas punitivas reforçam as redes de poder que perpassam as relações entre os presos e, nesse sentido, a punição deixa de operar no campo do disciplinamento e se insere, antes, no campo do controle social. Controle social cujo objetivo passa a ser a manutenção do funcionamento da dinâmica prisional - com todas as assimetrias, formas de dominação, violência física e simbólica que lhe constitui - e, portanto, com a permanência de uma ordem social marcada por múltiplas formas de sujeição (DIAS, 2014, p. 125).

Assim, se já é difícil a instituição cumprir a sua função ressocializadora, seja pelas instalações insalubres, seja pela precariedade no atendimento dos serviços assistenciais verificadas durante pesquisa, imagine para aquelas que nem mesmo têm a oportunidade de buscar esses serviços. Daí porque se torna uma contradição o discurso de reinserção social no âmbito do Sistema Penitenciário.

Em contraponto ao clima de hostilidade causado pelos noticiários policiais nesta unidade prisional, há o programa de entretenimento chamado "Pará Show", que é veiculado aos sábados, às 19h, na TV Metropolitana, canal 14. Este programa é o preferido das internas durante os finais de semana, pois mostra as festas de aparelhagem, as pessoas bebendo cerveja, dançando as suas músicas preferidas, que são o tecnobrega ${ }^{13}$ e o funk ${ }^{14}$. Durante a programação, as internas veem os amigos, os familiares, os ex-namorados e maridos, muitas vezes com novas namoradas. Trata-se uma forma de se aproximar e matar as saudades das festas que frequentavam antes da prisão. Durante as visitas da primeira autora ao CRF, foi possível conversar com outras internas enquanto aguardava uma das interlocutoras. Apesar não participarem oficialmente da pesquisa, elas quiseram falar sobre o programa que mais gostavam. Na ocasião, foi citado o "Pará Show" como o programa favorito aos finais de semana.

Na hora do "Pará Show", as meninas dançam, gritam, cantam, todas as TVs ficam ligadas em volume alto. Nessa hora não há reclamação. Todo mundo se une. A gente gosta do "Pará Show" por causa das músicas do tecnobrega, das festas que aparecem. A gente identifica os conhecidos e depois comenta com as outras, tu sabe quem tava no "Pará Show", fulano, ciclano" (Internas do CRF).

O "Pará Show" faz com que elas se anestesiem do intramuros e se transportem para o extramuros. É uma alegria momentânea, elas extravasam. Já os jornais policiais são uma preocupação com a família" (Agente penitenciária, há 6 anos trabalhando no CRF).

13 O tecnobrega é a fusão do tradicional ritmo do brega paraense com a música eletrônica, tendo a tecnologia como um elemento fundamental. O novo gênero musical deriva de ritmos como o carimbó, siriá, lundum, calypso e guitarradas. O tecnobrega surgiu no Pará nos anos 2000.

14 O Funk origina-se na música negra norte-americana surgida na década de 1960, a partir da soul music, com influência do rock e da música psicodélica. As características desse estilo musical são o ritmo sincopado, a densa linha de baixo, uma seção de metais forte e rítmica, além de uma batida marcante e dançante. 
De acordo com Canclini (2002), os significados dos conteúdos veiculados nos meios de comunicação para cada indivíduo, irá depender de sua bagagem cultural, da sua trajetória de vida, pois os programas televisivos são representações da vida cotidiana a partir de uma imagem construída. Logo, a TV cria novas formas de ação e interação e novos tipos de relacionamento social.

Para Thompson (2012, p. 119), com os meios de comunicação "a interação se dissocia do ambiente físico, de tal maneira que os indivíduos podem interagir uns com os outros ainda que não partilhem do mesmo ambiente espaço temporal" (Ibid., p. 119). Entre esses tipos de interação, o autor destaca um que reflete o uso da TV no contexto do cárcere feminino. Trata-se da "quaseinteração mediada", que é aquela em os indivíduos se ligam uns aos outros num processo de comunicação e intercâmbio simbólico.

Outro conflito que gira em torno da televisão é a situação das internas que trabalham e das que não trabalham. No regime semiaberto há internas que trabalham no próprio CRF ou fora dele, por meio de convênios firmados pela Susipe com outros órgãos públicos e empresas privadas; e há aquelas que não exercem nenhuma atividade. Estas últimas gostam de assistir a TV até de madrugada e com o volume alto. Já as que trabalham preferem que o aparelho seja desligado mais cedo.

Por isso, à noite, por causa da TV coletiva, iniciam-se as brigas, discussões e conflitos, porque as internas que não precisam acordar cedo para trabalhar ficam conversando e assistindo televisão até de madrugada. Segundo as interlocutoras, às vezes é preciso a líder ou outra interna que seja respeitada na cela interferir para que a situação seja resolvida naquele momento.

À noite, quando as colegas chegam do trabalho tem confusão, porque umas querem ficar assistindo até tarde, e as que trabalham querem que desliguem. A gente gosta de deixar a TV ligada pra fazer algum barulho, pra animar, porque fica muito silêncio à noite (Lírio, 39 anos, acusada pelo crime de tráfico, estudou até a $\sigma^{\mathrm{a}}$ série).

Dessa forma, muitas internas do regime semiaberto que trabalham fora do CRF têm sua TV individual. Isto porque elas precisam dormir cedo para trabalharem cedo no dia seguinte. No entanto, não pude entrevistá-las porque não são alvo desta pesquisa, conforme mencionado na metodologia. Frente aos conflitos e interações aqui apresentados que cercam a sociabilidade das internas na prisão feminina, Cavalcante Junior (2009), discorre que o sistema penitenciário é constituído de espaços sociais ligados ao poder. Esses espaços são descentralizados e formados por pessoas que produzem e reproduzem dentro da instituição campos simbólicos de poder, discursos e linguagens codificadas 
de ordenamento social. Diante do exposto, ressignificaremos a forma como Goffman (1974, p. 22) define o conceito de cárcere. Para ele, o cárcere é uma insituição fechada, simbolizada pela barreira que impede o contato com o mundo externo e por proibições à saída das pessoas que lá se encontram. Porém, diante do acesso das internas à TV, e conforme os resultados verificados, o CRF não é mais uma instituição totalmente fechada. As mulheres em situação de cárcere têm contato com o mundo, porque a televisão lhes proporciona isso. Contato esse que faz com que elas relembrem e acompanhem momentos da vida, e até mesmo decidam sobre qual atitude tomar diante de algumas situações.

\section{CONCLUSÕES}

Diante do resultado da pesquisa, pode-se comprovar a hipótese definida no início deste trabalho, de que a televisão é considerada pelas internas um instrumento essencial para o cumprimento da pena porque as mantêm informadas sobre o que está acontecendo no mundo, ajuda a passar o tempo e diminui o sofrimento proveniente da privação da liberdade. Torna-se, dessa forma, um instrumento de poder dentro do cárcere, à medida que firmam contato com mundo exterior, rompendo a barreira entre o ambiente externo e a prisão, o que, segundo Goffman (1974), caracteriza uma "instituição total".

As mulheres em situação de cárcere assimilam os conteúdos da TV em um ambiente de reclusão, com regras e normas estabelecidas, que, em tese, devem ser seguidas. Portanto, a partir do conceito de mídia, entende-se, que a televisão rompe barreiras, não isolando o indivíduo, mas possibilitando o contato deste com o mundo externo, uma vez que a programação veiculada traz experiências, sentimentos e uma sociabilidade que envolve prazer, poder e conflitos.

Os programas preferidos pelas mulheres presas são os jornais policiais, pela preocupação com a família, que geralmente encontra-se envolvida no tráfico; e o programa "Pará Show", visto que mostra as festas noturnas que elas frequentavam antes da prisão, além de ser uma oportunidade para ver seus familiares, amigos e ex-companheiros. Outra preferência é a novela "Em Família", porque trata da questão da homosexualidade, realidade comum no presídio feminino.

Do ponto de vista da sociabilidade proporcionada pelo uso da TV, os momentos de interações sociais limitam-se aos horários em que se reúnem para assistir ao programa "Pará Show", à novela "Em Família" e aos jornais ou programas policiais. Estes últimos trazem problemas de hostilidade para a prisão, de forma a tornar o CRF uma dupla prisão, situação que não pode ser ignorada pelas autoridades que gerenciam o sistema carcerário. Portanto, uma das soluções 
possíveis para minimizar esse efeito, seria lançar um olhar diferenciado para o uso da televisão naquela unidade prisional exclusivamente feminina.

A utilização da TV deve ser aliada do processo de reinserção social e não uma barreira para alcançar este objetivo. $\mathrm{O}$ que se deve considerar na prisão, além dos conflitos, é a garantia prevista pela LEP: de reinserir o indivíduo na sociedade. Logo, se bem utilizada, a TV pode contribuir positivamente nesse processo.

\section{REFERÊNCIAS}

BRASIL. Ministério da Justiça. Lei n ${ }^{\circ}$ 7.210. Dispõe sobre a Execução Penal e dá outras providências. Diário Oficial da União, Brasília, DF, 13 jul. 1984.

BUCCI, E.; KEHL, M. R. Videologias. São Paulo: Boitempo, 2004.

CANCLINI, N. G. Consumidores e cidadãos. Rio de Janeiro: UFRJ, 2002.

CAVALCANTE JÚNIOR, A. de F. Sociedade do cárcere: a inversão de uma ordem e a intervenção dos dispositivos de poder-saber numa instituição penal da Região Metropolitana de Belém. 2004. Dissertação (Mestrado em Sociologia) - Universidade Federal do Pará, Belém, 2004.

Estado, punição e religião: Pentecostais e Neopentecostais entre a secularização e dessecularização da ressocialização no cárcere. 2009. Tese (Doutorado em Sociologia) - Universidade Federal do Pará, Belém, 2009.

COELHO, E. C. A oficina do diabo. Rio de Janeiro: Record, 2005.

COLARES, L. B. C.; CHIES, L. A. B. Mulheres nas so(m)bras: invisibilidade, reciclagemm e dominação viril em presídios masculinamente mistos. Revista Feminista, Florianópolis, v. 18, n.2, 2010.

COSTA, A. C. S. A violência como espetáculo: um debate em torno do programa Metendo Bronca. 2004. 189f. Dissertação (Mestrado em Sociologia) - Instituto de Filosofia e Ciências Humanas, Universidade Federal do Pará, Belém, 2004.

DIAS, C. N. Disciplina, controle social e punição: o entrecruzamento das redes de poder no espaço prisional. Revista Brasileira de Ciências Sociais, São Paulo, v. 29, n. 85, 2014.

ESPINOZA, O. A mulher encarcerada em face do poder punitivo. São Paulo: IBCCrim, 2004.

FOUCAULT, M. Microfísica do Poder. 25. ed. São Paulo: Graal, 2012.

Vigiar e punir: nascimento da prisão. Tradução de Raquel Ramalhete. 39. ed.

Petrópolis: Vozes, 2011.

GIL, A. C. Métodos e técnicas de pesquisa social. 6. ed. São Paulo: Atlas, 2012.

GOFFMAN, E. Manicômios prisões e conventos. São Paulo: Perspectiva, 1974. 
HUERTAS, D. M. A principal artéria fluvial da Amazônia brasileira como nodal do transporte rodoviário de carga. Belém, Novos Cadernos NAEA. Vol. 17, n. 2 p. 95-122, jul-dez 2014.

LAKATOS, E. M.; MARCONI, M. de A. Metodologia científica. 6. ed. São Paulo: Atlas, 2011.

MAKKI, S. H.; SANTOS, M. L. dos. Gênero e criminalidade: um olhar sobre a mulher encarcerada no brasil. Âmbito Jurídico, Rio Grande, v. XII, n. 78, jul. 2010. Disponível em: <http//www.ambito-juridico.com.br $\geq$. Acesso em: 10 out. 2014.

MCLUHAN. M.. Os meios de comunicação como extensões do homem. São Paulo: Cultrix, 1964.

PARÁ. Superintendência do Sistema Penitenciário do Pará. Relatório Susipe em Números. Disponível em: <http://www.susipe.pa.gov.br/sites/default/ files/SETEMBRO $\% 202014 \% 20 \% 20$ RELATORIO $\% 20 \quad$ SUSIPE $\% \quad 20 \mathrm{EM} \% 20$ NUMEROS_1.pdf. Acesso em: 10 out. 2014.

POLICARPO, V. M. As mulheres e a telenovela: um estudo sobre a recepção de Terra Nostra. Revista Novos Media e Cidadania, no 3, [s.d.]. Disponível em: <http://www. labcom.ubi.pt/ agoranet/03/policarpo-veronica-mulheres-e-telenovela-terra-nostra. pdf>. Acesso em: 28 jan. 2014.

SANTANA, A. P. A casa dos días: a vida no cárcere feminino. 2012. Tese (Doutorado em Ciências Sociais) - Universidade Federal do Pará, Belém, 2012.

SIMMEL, G. S. Questões fundamentais da Sociologia: indivíduo e sociedade. Rio de Janeiro: Zahar, 2006.

Sociabilidade: um exemplo de Sociologia Pura. In: MORAES, F. E. de. Sociologia. São Paulo: Ática, 1983.

SOARES, B. M.; IIGENFRITZ, I. Prisioneiras: vida e violência atrás das grades. Rio de Janeiro: Garamond, 2002.

THOMPSON, A. A questão penitenciária. 5. ed. Rio de Janeiro: Forense, 2002.

THOMPSON, J. B. A mídia e a modernidade: uma teoria social da mídia. Petrópolis: Vozes, 2012. 


\section{Capacidade estatal e implementação de política de desenvolvimento regional sustentável na Amazônia}

State capacity and sustainable regional development policy in the Amazon

Marilia Silva Oliveira - Doutoranda em ciência política pela Universidade de Brasília (UNB). Mestre em ciências sociais. E-mail: mariliasoliveira@gmail.com

\section{Resumo}

Este artigo tem o objetivo de avaliar a capacidade estatal do governo federal durante os processos de formulação e implementação do Plano de Desenvolvimento Regional Sustentável para o Eixo de Influência da Rodovia BR163, Cuiabá-Santarém. Entende-se por capacidade estatal o poder do Estado em alcançar regiões remotas de seu território e de coordenar as relações no interior da burocracia estatal e com a sociedade civil. A pesquisa se baseou em 35 entrevistas realizadas com representante da sociedade civil e do governo em Brasília, Belém e Santarém entre os anos 2008 e 2009 e entre 2012 e 2013. Como complemento, foram examinados artigos acadêmicos e documentos publicados pelo governo e pela sociedade civil. A falta de comprometimento institucional dos órgãos governamentais, associada a uma burocracia desarticulada e a histórica ausência do governo na região foram elementos reveladores de um Estado com pouco poder infraestrutural para implementar políticas de desenvolvimento regional sustentável.

\section{Palavras-chave}

Capacidade estatal. Desenvolvimento regional sustentável. Estado. Sociedade civil.

\begin{abstract}
This article aims to assess the state capacity of the Brazilian federal government to formulating and implementing the Sustainable Regional Development Plan for the Area of Influence of the BR-163 Road. Shortly, State capacity is considered as both State power to reaching remote regions within its territory and to coordinating relationships within its bureaucracy and with civil society. This research is based on analysis of 35 interviews applied to both civil society and government representatives, during the years of 2008 to 2009 and 2012 to 2013. Besides it, additional analysis of public documents and academic articles has been undertaken. We concluded that a lack of governmental institutional commitment to that region associated with an uninterested and incoherent bureaucracy has led to failures during the formulation and implementation processes of the Sustainable Regional Development Plan for the BR-163 Road.
\end{abstract}

\section{Keywords}

State capacity. Sustainable regional development. State. Civil society. 


\section{INTRODUÇÃO}

Em 2003, quando Luís Inácio Lula da Silva assumiu a Presidência da República no Brasil, um grupo de ativistas da sociedade civil e do Estado se mobilizou para tentar modificar a cultura de implementação de políticas de infraestrutura na Amazônia.

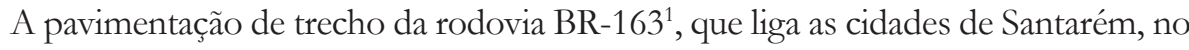
Pará, a Cuiabá, no Mato Grosso, seria o meio pelo qual os ativistas lutariam para mudar essa cultura. Lideranças sociais locais e do movimento socioambientalista convidaram o governo federal para discutir sobre ações de desenvolvimento sustentável para a região que pudessem ser implementadas junto com a realização da obra na rodovia, mitigando, dessa forma, os impactos socioambientais que o anúncio da pavimentação já antecipava. Com o aceno positivo do governo federal, em 2006, foi lançado o Plano de Desenvolvimento Regional Sustentável para o Eixo de Influência da Rodovia BR-163, Cuiabá-Santarém, considerado uma grande conquista para a causa socioambiental.

Entretanto, doze anos após as primeiras articulações entre governo federal e sociedade civil para a elaboração do Plano e oito anos após o seu lançamento, suas diretrizes não foram implementadas. Com o argumento de que a implementação do Plano da BR-163 falhou principalmente pela falta de capacidade do Estado em conduzir políticas de desenvolvimento regional sustentável, propomos uma imersão no processo de articulação e tentativa de implementação de políticas para a região afetada pela pavimentação da rodovia, a fim de compreender os elementos que caracterizaram esse processo. Destacamos, nesta análise, a baixa capacidade institucional do Estado em conciliar diferentes interesses em seu interior, sua dificuldade em alcançar áreas remotas de seu território e em dispor de uma burocracia interessada e articulada para implementar o projeto governamental.

O conceito de capacidade estatal é vinculado ao de poder infraestrutural do Estado, de Michael Mann (1993), especialmente no que diz respeito ao poder de alcance e ao poder relacional. Questionamos a capacidade institucional dos órgãos públicos responsáveis pelo Plano da BR-163 de enfrentar a realidade local e de avançar na implementação de políticas públicas mitigadoras do caos que se instalara naquela região. Para desenvolver a análise, concentramo-nos em um polo específico do Plano da BR-163, o Baixo Amazonas (BAM), que engloba a cidade de Santarém, entre outros municípios. Esse é um dos nove polos onde o movimento social é mais organizado e diversificado, que se destaca por hospedar maior número de ações tanto da sociedade organizada quanto do Estado ${ }^{2}$.

Estrada aberta pelo governo militar durante a década de 1970.

Os polos do Plano BR-163 são: Calha do Amazonas Oriental (Santarém) ou Baixo Amazonas; Calha do Amazonas Ocidental (Parintins); Transamazônica Oriental (Altamira); Baixo e Médio Tapajós (Itaituba); Médio Xingu/Terra do Meio (São Félix do Xingu); Vale do Jamanxim 
Focamos especialmente na ação institucional do governo federal e nas articulações para a elaboração e implementação do Plano da BR-163. Entendemos que, apesar dos reforços importantes vindos da sociedade e de algumas instituições governamentais que contribuíam para aumentar a habilidade do Estado em atuar localmente, a região continuou com os mesmos problemas estruturais. Concluímos com a avaliação de que a falta de comprometimento institucional dos órgãos governamentais, associado a uma burocracia desarticulada e desinteressada - com exceção daquelas poucas pessoas que possuíam interesse no desenvolvimento sustentável da região - e à baixa capacidade estatal de agir como árbitro de diferentes interesses e de alcançar áreas remotas de seu território impossibilitaram-no de modificar o modelo de implementação de obras de infraestrutura na Amazônia. Outros motivos também contribuíram para o fracasso dessa política, porém a intenção deste artigo é focar no processo de articulação no interior do governo federal, observando sua (in)capacidade para formular e implementar políticas de desenvolvimento regional sustentável na Amazônia.

A pesquisa foi realizada entre os anos 2008 e 2009 e atualizada entre 2012 e 2013. Durante o primeiro período de investigação, foram realizadas entrevistas em Santarém, Belém e Brasília, com atores sociais e governamentais envolvidos nesse processo. Participamos de eventos organizados tanto pela sociedade civil quanto pelo governo federal nas diferentes cidades citadas. No período de atualização da pesquisa, 2012 a 2013, foram realizadas entrevistas em Santarém, com lideranças sociais e representantes governamentais que articularam ações com o governo federal; em Belém, com representantes de ONGs e do governo estadual; e em Brasília, com representantes do governo federal. Ao todo, foram realizadas 35 entrevistas. Também foram analisados documentos produzidos pela sociedade civil e governo em diferentes épocas e políticas públicas federais endereçadas àquela região.

\section{CAPACIDADE ESTATAL}

Ao analisar as ações do Estado, sua organização e habilidade em tomar decisões e implementá-las, abordamos, consequentemente, elementos de capacidade estatal. Hau e Soifer (2008), ao sistematizarem pesquisas cujo foco de análise era a capacidade do Estado em diferentes contextos, identificaram três dimensões de análise predominantes: i) a relativa autonomia estatal em relação à sociedade; ii) a profissionalização de sua burocracia ou o que chamam

(Novo Progresso); Transamazônica Ocidental (Apuî); Extremo Norte mato-grossense (Alta Floresta/Guarantã do Norte); Centro-Norte mato-grossense (Sinop/Sorriso). 
de Weberianess; e iii) alcance ou poder estatal, que está relacionado com as variações subnacionais de poder. Os autores identificaram que aqueles trabalhos que analisavam o alcance ou poder estatal estavam, muitas vezes, explorando o conceito de poder infraestrutural de Estado, de Michael Mann (1993).

$\mathrm{O}$ conceito de poder infraestrutural, vinculado às relações de poder político, foi apresentado por Mann há mais de duas décadas e significa a capacidade do Estado de penetrar a sociedade civil e implementar ações em todo seu território (MANN, 1993) ${ }^{3}$. Tal conceito ainda exerce grande influência nos estudos destinados a compreender o poder ou a capacidade estatal, porém, foi e ainda é apresentado por termos distintos, como alcance ou força estatal, para abordar fenômenos semelhantes da competência estatal (HAU; SOIFER, 2008; MANN, 2008).

Os autores Hau e Soifer destacaram a dimensão espacial ou territorial do Estado e sua natureza relacional como grandes vantagens para se trabalhar com o conceito de poder infraestrutural. Para eles, as vantagens se justificam exatamente porque Mann considerou que a "habilidade do Estado de desenvolver seus projetos é territorialmente organizada e crucialmente formada pelas redes organizacionais que ele coordena, controla e constrói” (HAU; SOIFER, 2008, p. 4, tradução livre). Dessa forma, consideram que o poder infraestrutural do Estado chama atenção para as variações subnacionais de sua habilidade em exercer controle e coordenar a sociedade, fornecendo instrumentos para investigações das dinâmicas estatais em níveis local e regional. É com esses instrumentos que trabalharemos neste artigo.

A dimensão relacional implica a associação estatal não apenas com atores da sociedade - ou com pessoas, como retifica Mann (2008) -, mas também entre diferentes agências estatais, de perfis distintos, expressando o que Dagnino (2002) chamou de heterogeneidade do Estado. A forma como a estrutura estatal foi concebida, de acordo com a autora, é suficiente para confirmar sua heterogeneidade: no plano horizontal, o Estado é representado pelos poderes Executivo, Legislativo e Judiciário; no plano vertical, sua diversidade é estabelecida pelos níveis federal, estadual e municipal de governo. Essas características, por elas mesmas, demonstram a pluralidade estrutural do Estado, além de sugerir dimensões diferenciadas de sua relação com a sociedade.

Dentro da visão do Estado como ente heterogêneo, Mann (1993) o apresenta constituído por complexas redes organizacionais, composto por

O conceito de poder infraestrutural se tornou público a partir de trabalho de Mann publicado em 1984. Em 1993, esse conceito foi bem apresentado no volume 2 do livro The Sources of Social Power. 
partidos, governos, entes federados, grupos de pressão, entre outros que diversificam seu aspecto relacional. Nesse sentido, o autor se refere ao poder estatal coletivo em que o controle do território é exercido mais por meio das instituições do que por atores políticos, diferenciando o que chama de poder infraestrutural do poder despótico - esse último seria exercido por um Estado elitista e distributivo (Idem). O poder coletivo exige negociações entre diferentes grupos, o que pode gerar uma interdependência governada, nos termos de Weiss $(2006)^{4}$.

O Estado é, portanto, um espaço ativo e complexo, dividido em setores ou áreas de gestão prenhes de grande diversidade temática para lidar e se relacionar com a complexidade da sociedade, cujo elemento organizador é sua burocracia (O’DONNELL, 2011). O poder infraestrutural e a burocracia são dimensões distintas da capacidade estatal e devem ser trabalhadas separadamente, de acordo com Hau e Soifer (2008). Todavia, a burocracia pode fortalecer o poder infraestrutural do Estado, e vice-versa, interferindo em seu poder de alcance e no poder relacional. Dessa forma, a natureza da burocracia de um Estado e sua capacidade profissional podem fortalecer ou enfraquecer seu poder infraestrutural.

Autonomia é outra dimensão muito importante e associada ao debate sobre burocracia e capacidade estatal, conforme já registrou Mann (1993). Um Estado muito autônomo pode se tornar despótico, insulado, autoritário (IDEM; EVANS, 2004; O’DONNELL, 2011). Entretanto, certa autonomia estatal, construída a partir da formação de uma carreira burocrática bem formada e estruturada, é fundamental para habilitar o Estado a construir suas relações com a sociedade, ou o seu poder relacional, de forma a promover o seu desenvolvimento (EVANS, 2004).

Das três dimensões de análise da capacidade estatal abordadas - autonomia, burocracia e poder infraestrutural - as duas últimas se destacam na análise do caso aqui introduzido. Não vamos estudar o profissionalismo da burocracia nem sua natureza, mas a sua capacidade de promover articulação interna entre instituições governamentais. As dimensões burocracia/instituições e poder de alcance e relacional (poder infraestrutural) nos guiarão nesta tarefa e serão exploradas nas possibilidades de complementaridade entre elas. Observaremos, ainda, o poder relacional do Estado tanto no interior das suas instituições quanto com a sociedade. $\mathrm{O}$ debate sobre autonomia aparecerá como secundário.

$4 \quad$ Nessa relação, cada parte possui interesses independentes uns dos outros e o Estado permanece como árbitro das normas e objetivos da interação, na qual informações são trocadas, recursos são agregados e tarefas são partilhadas (WEISS, 2006, p. 168). Esse debate trazido por Weiss é um incremento na análise do poder relacional/infraestrutural desenvolvida neste trabalho e guarda pontos de proximidade com a proposta de parceria entre Estado e sociedade desenvolvida por Evans (2004) 
Dos elementos que compõem o debate sobre capacidade do Estado, seu aspecto institucional tem evidência em nossa análise. As políticas brasileiras são caracterizadas por um componente informal significativo que deriva da natureza politizada das tomadas de decisões de políticas públicas. Nesse sentido, esse processo não segue uma regularidade, sempre pode apresentar grupos, procedimentos e interesses diversos, ao contrário de um Estado bem institucionalizado, cuja tendência é estabelecer normas para as decisões, um grupo de pessoas legitimadas para participarem dos processos de tomada de decisões e arenas para a ação (HOCHSTETLER E KECK, 2007, p. 17).

\section{MUDANÇA DE PERSPECTIVA}

A rodovia BR-163, aberta na década de 1970 pelo governo militar, cobre uma extensão de $1.780 \mathrm{~km}$ e atravessa uma das regiões mais importantes da Amazônia brasileira, do ponto de vista do potencial econômico, da diversidade biológica, das riquezas naturais e da diversidade étnica e cultural (BRASIL, 2006). A região também é conhecida pelos constantes e intensos conflitos fundiários, pela exaustiva exploração dos recursos naturais, pela carência de políticas públicas e ações efetivas do Estado e pela violência no campo.

As primeiras tentativas do governo federal de conduzir políticas de reforma agrária e destinação de terras a colonos na região, durante o período militar, foram desacreditadas. As famílias não recebiam nenhum tipo de auxílio e, com as primeiras manifestações de descontentamento, o governo militar, avesso à oposição, respondeu com violência e encorajou o seu uso por terceiros para reprimir as reivindicações (TORRES, 2005). Dessa situação, conforme a análise de Torres, surgiram os capangas e pistoleiros, contratados pelo grande latifundiário, com o consentimento do governo militar, para evitar contestações da iminente agricultura familiar local ou de comunidades tradicionais ali presentes. O Estado se colocou a serviço do grande capital e contra os pequenos proprietários.

A partir desse marco, toda sorte de irregularidades, como corrupção de órgãos públicos e de seu corpo funcional, fraudes na titulação de terras e bandidagem se tornaram recorrentes, notabilizando a ausência do Estado na região e configurando o estado do Pará como "terra de ninguém". A ausência de importantes órgãos governamentais na região e a fragilidade e sucateamento dos que lá existem, adicionado à corrupção do corpo funcional, favoreceram a expansão da grilagem de terras e da exploração ilegal da madeira. Essas duas atividades, ainda que ilegais, são fontes de emprego e de poder político e representam o "lastro da economia local" (ALENCAR, 2005). 
Na década de 1990, ainda no governo de Fernando Henrique Cardoso, os plantadores de soja do norte de Mato Grosso começaram a pressionar o governo para a pavimentação da estrada, pois escoar a soja para o exterior pelo porto de Santarém, que estava sendo construído pela empresa Cargill, seria mais econômico do que escoar pelo porto de Paranaguá, no estado do Paraná. Mais adiante, com o aumento do preço da soja no mercado internacional, eles próprios se ofereceram para pavimentar a rodovia (ALENCAR et al. 2005). Essa última proposta foi analisada na gestão do governo Lula, que também possuía interesse na pavimentação da rodovia, pois era uma obra de infraestrutura importante. Porém, por diferentes motivos, entre eles as oscilações do preço da soja no mercado internacional, a proposta não vingou. O governo acabou financiando a pavimentação da estrada, que ainda não foi totalmente concluída.

Entre os anos de 2002 e 2004, houve uma série de reuniões dos governadores da Amazônia Legal com a equipe do governo federal para discutir o desenvolvimento para a Amazônia. Nesses encontros, chegou-se à conclusão da necessidade de formular outro modelo de desenvolvimento para a região ${ }^{5}$. Imbuído desse espírito, o governo federal envidou esforços para elaborar coletivamente e de forma participativa um planejamento robusto para a região, o Plano Amazônia Sustentável e outros planos de apoio, como o da BR-163. Esse planejamento também se justificava pela intenção de não repetir os equívocos das problemáticas obras de infraestrutura e do setor elétrico na região, as quais tiveram consequências trágicas para a população local e para o meio ambiente . $^{\circ}$ Nesse sentido, como nos narra um agente público federal, o governo do PT reconheceu que para o desenvolvimento da Amazônia, com obras de envergadura previstas para a área de energia e transportes, deveria haver um novo modelo de gestão atento ao desenvolvimento regional e implementado com planejamento ${ }^{7}$.

No mesmo período, os atores sociais iniciaram uma intensa dinâmica de trabalhos na região, cujo principal objetivo era, além de discutir os impactos negativos e positivos que a pavimentação causaria, elaborar e discutir propostas de desenvolvimento sustentável. A intenção era propor soluções para os problemas regionais a partir da experiência vivida pela população local. Os atores sociais organizaram documentos que mapeavam os principais problemas sociais, econômicos e ambientais vividos na região e sugeriram propostas de ações políticas para o desenvolvimento local. Esse documento foi entregue ao governo federal e entrou para sua agenda política.

Entrevista com representante governamental. Brasília, outubro de 2013.

Vide o caso da Usina Hidrelétrica de Tucuruí.

Entrevista com representante governamental. Brasília, setembro de 2009. 
Em março de 2004, o governo federal estabeleceu uma estrutura política com o encargo de elaborar e implementar o Plano de Desenvolvimento para a região da BR-163: o Grupo de Trabalho Interministerial Plano BR-163 Sustentável (GTI). Composto por 20 órgãos federais, entre Secretarias Especiais e Ministérios, o grupo estava sob a coordenação da Casa Civil da Presidência da República, o que o cacifava politicamente. Nos anos de elaboração do Plano, 2004 a 2006, o GTI organizou uma série de reuniões para as quais solicitava a presença de membros de diferentes Ministérios. A intenção e a estratégia eram fazer com que o Plano refletisse o compromisso dos diferentes setores do governo com a região. Após uma dinâmica intensa de reuniões de trabalho visando a elaborar documentos prévios e levá-los às consultas públicas locais, o Plano foi lançado pelo governo federal, em junho de 2006, como parte de uma estratégia de desenvolvimento regional, referenciado no Plano Amazônia Sustentável.

Para servidor do governo federal que, na época de discussão sobre o Plano, compunha o GTI, representando o Ministério do Meio Ambiente (MMA), a atuação dos movimentos sociais foi fundamental para que o governo assumisse de fato as responsabilidades com aquela região. Para ele, o apoio dos movimentos levou ao governo segurança para seguir adiante. A pavimentação da BR-163, demanda originária do setor privado, era uma obra consensual entre diferentes representações da sociedade e do governo ${ }^{8}$.

Nesse momento de confluência de ações e atenções para o eixo de influência da BR-163, datado precisamente entre os anos de 2003 e 2004, o governo estava em formação, políticas eram elaboradas, novos modelos de gestão administrativa eram discutidos, a estrutura burocrática era preenchida com ativistas sociais e militantes partidários para que se garantisse que o partido exercesse o controle do aparato estatal conforme seu programa.

Havia abertura para que as propostas sociais que reforçassem o programa do governo do PT no início de seu mandato adquirissem o status de políticas públicas, dentro da ideologia partidária de construir as políticas de forma participativa. As janelas de oportunidades políticas estavam abertas a várias frentes, portanto era importante se organizar. Ademais, de acordo com representante da Casa Civil da Presidência da República, havia um ambiente político positivo para discutir e tentar implementar políticas de desenvolvimento regional, pois havia um ministro forte para direcionar essa discussão, Ciro Gomes. O Plano da BR163, dessa forma, "sofreu de uma expectativa megalomaníaca".

\footnotetext{
Entrevista com representante da do governo federal. Brasília, setembro de 2009.

9 Entrevista com representante do governo federal. Brasília, outubro de 2013.
} 
Esse também era o momento de o governo avançar em termos de alianças partidárias para facilitar a governança em seu mandato. O Partido dos Trabalhadores se unia a outros partidos conservadores, fornecendo cargos políticos importantes em certos órgãos públicos, que possuem uma estrutura que se engessa numa prática tradicional, construída pela gestão de partidos de tendência conservadora, com projetos políticos mais fechados, vinculados fortemente ao aspecto econômico e ao esvaziamento do Estado ${ }^{10}$. Por outro lado, os Ministérios com propostas de políticas redistributivas e da área social tinham seus quadros institucionais formados especialmente por lideranças socioambientais, militantes de diversas causas e partidários que lutariam por um governo mais democrático, de inclusão social e participativo (OLIVEIRA, 2010). Essa heterogeneidade estatal traria desafios para a relação entre as instituições governamentais e para suas interações com a sociedade.

\section{ARTICULAÇÃO INSTITUCIONAL}

Para a formação do GTI, em março de 2004, o governo acionou representantes de 17 Ministérios, da Secretaria-Geral da Presidência da República, Secretaria de Relações Institucionais e da Casa Civil da Presidência da República. Essa última era responsável pela coordenação geral do Plano e pela sua articulação política, todavia a participação efetiva aconteceu apenas por meio de quatro Ministérios que possuíam interesses diretos na área: Ministério do Meio Ambiente (MMA); da Integração Nacional (MIN); dos Transportes (MT); e do Desenvolvimento Agrário (MDA). Este último sem o mesmo comprometimento que os anteriores.

$\mathrm{Na}$ opinião de um agente público entrevistado, não havia sentido envolver 17 ministérios, pois apenas alguns possuíam interesse na região. Em sua avaliação, não havia uma diretriz de comprometimento institucional desses órgãos. O que existia era apenas a ação de pessoas que ocupavam cargos no governo. Isso enfraquecia a condução do processo que não possuía rebatimento nas instituições, como era o caso do representante do MIN, responsável pela coordenação técnica do Plano. Conjugado a isso, a condução do GTI era lenta, o que gerou um trabalho de anos e anos sem nenhuma eficácia política ${ }^{11}$.

O relato da condução morosa e desarticulada do GTI pela Casa Civil é comum entre as narrativas tanto da sociedade civil quanto de representantes governamentais, o que já ameaçava a institucionalidade do Plano. A presença

10 Ver Genro e Robaina, 2006.

11 Entrevista com representante do governo federal. Brasília, setembro de 2009. 
de membros de outros ministérios, que não o grupo dos quatro, era apenas "para constar" e o governo, especialmente a Casa Civil, construía um discurso de diálogo externo e de envolvimento de diferentes setores governamentais que, de fato, não existia. Os problemas da formação complexa do GTI, aliados à sua frágil articulação política, se refletiriam durante todo o processo de elaboração e implementação do Plano, na medida em que nenhum dos outros ministérios se comprometia efetivamente com as ações priorizadas. Essa situação já nos sinaliza para os diferentes comportamentos dos ministérios diante de uma política governamental, que pareceu ser prioridade apenas de poucos no governo.

Mas quais seriam os motivos para esse desenho governamental com participação esvaziada? A Casa Civil, responsável pela coordenação do GTI, na expectativa de cumprir com as diferentes necessidades da região de influência da BR-163 e diretamente com as demandas apresentadas pelos movimentos sociais locais, procurou incluir uma gama ampla de ministérios no GTI, sem especificar suas ações na região. Em vez disso, segundo representante governamental, a coordenação deveria ter focado em ações emergenciais e específicas, de forma a concentrar esforços e garantir a otimização na articulação política para o desempenho das ações. Quando questionado sobre sua participação no GTI, representante do Ministério do Desenvolvimento, Indústria e Comércio (MDIC) afirmou que politicamente estava aberto, porém perceberam que o órgão não identificava uma ação específica para comprometimento institucional, portanto sua participação era fraca.

De acordo com representante do $\mathrm{MDA}^{12}$ - um dos ministérios que, segundo a coordenação do Plano, deveria ter uma atuação mais incisiva na região - o processo de discussão dentro do grupo era desorganizada, da mesma forma que foram caóticas as consultas públicas, coordenadas pelo GTI. Ele nos informou que não havia ações diretas do Ministério para a BR-163, apenas ações gerais que contemplariam aquela região. Nas diferentes entrevistas que realizamos com representantes governamentais, colhemos relatos semelhantes a esse, o que nos levou a postular que qualquer ação na região do Pará e Mato Grosso poderia ser incluída como atividade do Plano da BR-163, sendo sustentável ou não. Confirmamos esse fato mais adiante, quando a Casa Civil apresentou uma síntese das ações que eram implementadas na região e quando fizemos, em 2012, uma análise das políticas implementadas no polo do Baixo Amazonas.

O Plano, nesse sentido, era um aglomerado de ações genéricas e sem foco. Para representante do governo, o documento era um factoide de 150 ações, em vez de concentrar três ou quatros ações novas, com orçamento novo, com ideias para efetivamente mudar a situação de abandono daquela região. Havia

12 Entrevista realizada em Brasília, setembro de 2009. 
uma proposta inicial de voltar o Plano para os mais carentes, visto que eles seriam os mais afetados pela pavimentação da rodovia e, assim, concentrariam os objetivos em ações específicas. Porém as coordenações geral e técnica do GTI ${ }^{13}$ se contrapuseram a essa ideia, afirmando que o Plano era para todos. Dessa forma, envolvia quase tudo o que já havia no governo, como políticas universais e que não possuíam orçamento direcionado ${ }^{14}$.

Ao seguir as trilhas apontadas pelos entrevistados, parece-nos que a dinâmica do GTI não era suficiente para construir pontes institucionais nem ações de parcerias efetivas. Esses relatos nos trazem questionamentos a respeito da capacidade de organização do grupo e do Plano sobre a objetividade de suas ações e, por conseguinte, sua institucionalidade, visto que numa lista de 17 Ministérios e 3 Secretarias, o comprometimento vinha apenas de quatro instituições, com características peculiares, como veremos adiante.

A participação no GTI era tanto maior quanto mais estratégica fosse a região para os interesses dos ministérios: o MMA porque a taxa de desmatamento em 2003 foi alta e mais agravada no eixo da BR-163, portanto a região era prioritária e requeria atenção especial, entre outros motivos; o MT pela obviedade da rodovia, com atuação unicamente técnica ao que diz respeito à pavimentação; o MIN por causa das questões de planejamento e desenvolvimento territorial e especialmente pelo compromisso inicial do ex-Ministro Ciro Gomes e de um de seus membros; e o MDA, porém de forma evasiva com a questão da reforma agrária e dos assentamentos que, na verdade, eram responsabilidade do Instituto Nacional de Colonização e Reforma Agrária - INCRA.

Esses ministérios, com exceção do dos Transportes, têm uma atuação mais transversal, de característica socioambientalista, cujas políticas são construídas num formato mais participativo. Portanto, no processo de elaboração do Plano, tiveram uma relação constante com a sociedade, por meios institucionais e pessoais, visto que nesses órgãos vários representantes da sociedade civil assumiram cargos estratégicos. Essa prática difere daquela adotada por ministérios voltados para a representação do setor privado - como o do Desenvolvimento, Indústria e Comércio; o da Agricultura, Pecuária e Abastecimento; e o das Comunicações -, cujas maneiras de ação são mais conservadoras para a participação social. Suas obrigações com o Plano, naquela época, se referiam ao compromisso com a implementação de políticas gerais, dizia respeito a responsabilidades ordinárias. Dessa forma, para eles, não havia nenhuma demanda mais específica, apesar de a sociedade local já ter organizado documentos que listavam suas demandas emergenciais, as quais se direcionavam para praticamente todos os ministérios existentes.

13 Casa Civil e Ministério da Integração Nacional, respectivamente.

14 Entrevista com representante do governo federal. Brasília, setembro de 2009. 
Observa-se que os órgãos que participaram com mais iniciativa no grupo e na elaboração do Plano, MMA e MIN, são fracos institucionalmente. O MMA, até pouco tempo, não possuía quadro de pessoal, os cargos eram, em sua maioria, preenchidos por contratos de cooperação com organismos internacionais (ABERS; OLIVEIRA, 2015). A mesma situação se aplica ao MIN. Esse último, ao longo de sua história, teve nome e funções reeditadas algumas vezes, chegou a ser extinto durante o governo do então Presidente da República Fernando Collor de Melo. Com tantas alterações, por um tempo, suas políticas não tiveram continuidade nem muita efetividade para o nível local ou regional (OLIVEIRA, 2010). Nas entrevistas realizadas com lideranças sociais do polo do Baixo Amazonas em 2012, praticamente ninguém reconhecia sua ação como Ministério. Identificavam apenas uma pessoa que estava a cargo da coordenação técnica do Plano da BR-163. Nesse caso, era sua ação específica de coordenador técnico que chamava atenção e não o ministério.

As carências institucionais desses ministérios provocaram uma descontinuidade política muito grande e enfraqueceram a aplicação e execução das políticas ambiental e regional. Os arranjos informais, o orçamento restrito, a descontinuidade política, o destaque nas pessoas e não nas instituições são elementos que enfraquecem institucionalmente esses órgãos federais e a implementação efetiva de suas políticas. Para além do MMA e do MIN, a maioria das pessoas do governo que se dedicaram a elaborar e a implementar o Plano da BR-163 não eram servidores públicos, mas pessoas que ocupavam cargos de confiança no governo federal, com destaque para os coordenadores político e técnico do Plano. Tal fato possibilita que o Plano seja tratado mais como um projeto de pessoas do que de instituições públicas.

Vislumbrando o caso da BR-163 e seu processo dentro da Casa Civil, parece-nos que o governo, no intento de atender ao seu princípio participativo, abriu-se de forma a perder o eixo estrutural e a objetividade na condução de uma política de planejamento, que acabou sendo estruturada por poucos. Houve também a descontinuidade administrativa, que abalou ainda mais a condução deste projeto. Conforme observa representante da Casa Civil, dos principais e poucos ministros que articularam a viabilidade da obra, todos foram substituídos por algum motivo. Por mais que se adotasse o entendimento de que houve continuidade, essas alterações influenciaram negativamente o desenvolvimento operacional do Plano ${ }^{15}$. Isso demonstra a falta de capacidade política para articular e mobilizar as partes necessárias para uma política acontecer, característica própria de um Estado com baixa institucionalidade, segundo Hochstetler e Keck (2007).

15 Entrevista com representante da Casa Civil da Presidência da República. Brasília, setembro de 2009 e 2013. 
Acreditamos que os diferentes propósitos, culturas e tradições dentro do governo, o que se traduz em distintos projetos políticos, contribuíram para esse cenário. Ao analisar a capacidade institucional do Estado de formular e implementar suas preferências, vemos que o governo do PT aproveitou o conhecimento acumulado de organizações da sociedade civil para construir uma agenda política para a região e teve capacidade de escolher seus próprios objetivos para o eixo da BR-163. Mas, no processo de elaboração do Plano, enfrentou as barreiras culturais, problemas institucionais, fragilidade do corpo burocrático e embates de projetos que comprometeriam a sua implementação. É o poder do Estado e sua capacidade de rodar suas engrenagens para os diferentes setores, e não apenas de sucumbir a uma tradição política específica, que estão em jogo. Há ainda de se considerar resquícios de falta de vontade política em realmente mudar a cultura estabelecida sobre a implementação de obras de infraestrutura na Amazônia. Segundo a coordenação técnica do plano, esse foi um aspecto crucial, pois ninguém no governo se empenhou efetivamente para o projeto acontecer.

\section{IMPLEMENTAÇÃO DE POLÍTICAS}

A análise sobre execução das ações e metas determinadas pelo Plano da BR-163 e implementação de políticas públicas será guiada a partir das lentes das lideranças sociais do polo Baixo Amazonas, atuantes no Fórum Regional da BR163, e dos representantes governamentais responsáveis por políticas destinadas àquela região. Para a institucionalização do Plano da BR-163, o governo criou um modelo de gestão que era uma estrutura colegiada com o objetivo de envolver e corresponsabilizar as diferentes esferas de governo e órgãos públicos, lideranças sociais e representantes do setor produtivo para o desenvolvimento sustentável da região. Segundo o governo, "o modelo de gestão procura viabilizar condições adequadas para a coordenação das ações, introduzindo instâncias de acompanhamento do Plano nos níveis normativo, estratégico, gerencial e operacional" (BRASIL, 2006, p. 130). Dentro desse modelo, havia um espaço denominado Fórum Regional do Plano BR-163 ${ }^{16}$, por meio do qual instituições sociais se organizariam para acompanhar as ações do governo federal. Era por meio desse contrato político-social que as ações do Plano seriam monitoradas, portanto era vital seu bom funcionamento.

Esse fórum regional era composto pelo Fórum Meso Norte, Fórum Meso Centro e pelo Fórum Meso Sul, com representantes dos outros polos do Plano da BR-163. Apesar de terem funções de elaboração e acompanhamento da implementação do plano, os fóruns são totalmente dependentes de informações governamentais e do que é decidido em níveis superiores, diga-se governamentais, do modelo de gestão. 
Diante de sua importância institucional, em 2009, acompanhamos um encontro entre Estado e sociedade, no âmbito das determinações do modelo de gestão, para compreender o seu funcionamento e para, junto com a sociedade local, discutir com o governo sobre as ações e políticas implementadas na região. O encontro que acompanhamos aconteceu no polo BAM, na cidade de Santarém. Mas, antes disso, em março de 2009, a Casa Civil da Presidência da República havia convidado os representantes sociais para a primeira reunião do Fórum, ocorrida em Brasília e fechada para pesquisadores. Estavam presentes representantes dos Fóruns de todos os polos da área de influência da rodovia, com uma formação heterogênea: setor social, produtivo e governamental. Em julho do mesmo ano, foi realizada a segunda reunião no polo do BAM, a qual vamos avaliar.

O encontro com a sociedade aconteceu em dois dias: no primeiro, houve uma reunião com os representantes do Fórum Regional e, no segundo, houve um seminário com toda a população local para discutirem os problemas da região. Nas atividades do primeiro dia, as lideranças sociais esperavam que o governo apresentasse uma planilha com dados sobre o processo de implementação de políticas das inúmeras atividades propostas no Plano, pois nunca tiveram retorno do governo nesse sentido. Mas a dinâmica estabelecida pelo governo foi de apresentar à sociedade novos e antigos programas governamentais universais que pudessem ser úteis para aquela área e não ações que atendessem diretamente as necessidades da população local. Para as lideranças sociais do fórum de gestão (Fórum Regional) do Plano ${ }^{17}$, aquilo foi um desrespeito. Para eles, a reunião deveria, pelo menos, indicar as ações de gestão e de execução do Plano. E o governo, ao contrário disso, "fez palestra sobre o que é lei, o que é gestão e, mais uma vez, fugiu de suas responsabilidades com a sociedade e com a região"18.

Já havia passado três anos desde o lançamento do Plano, um ano e meio desde sua institucionalização por meio do modelo de gestão, e a Casa Civil com o Ministério da Integração Nacional não conseguiam apresentar nenhuma ação efetiva para atender as necessidades emergenciais da região. Outra reclamação foi a falta de capacidade de articulação do governo, de seriedade e esforço para fazer as propostas políticas e o Fórum funcionar como proposto pelo Plano. Para a reunião do Fórum e para o seminário com toda a população da região, o governo federal não conseguiu mobilizar praticamente ninguém do governo estadual nem municipal. Ademais, os atores sociais presentes foram todos convidados

\footnotetext{
7 IPAM - Instituto de Pesquisa Ambiental da Amazônia, FETAGRI-BAM - Federação dos Trabalhadores da Agricultura Familiar, regional Baixo Amazonas e CEFT-BAM - Centro de estudo, Pesquisa e Formação dos Trabalhadores do Baixo amazonas.

18 Entrevista com representante de ONG. Santarém, julho de 2009.
} 
por organizações sociais ${ }^{19}$, inclusive com custos financiados por eles, uma vez que as distâncias entre os municípios da região são enormes, são dias de barco, transporte mais comum naquela área.

Para a reunião, o governo federal trouxe representantes de ministérios e secretarias que "falavam para o vento e nos deixavam a ver navios" ${ }^{20}$, pois o que apresentavam não condizia com as necessidades priorizadas pela sociedade local. Representante do MIN reconheceu que os ministérios vão até a região e expõem programas que não têm rebatimento com os interesses da população local, mas ele justifica isso como uma falta de sensibilidade do representante ministerial que o fez, e não como uma falta de articulação da coordenação do Plano. Eram descompassos a todo o momento. Por parte do governo, estavam fazendo o seu trabalho, conscientes de que havia falhas, mas as tratavam como naturais do processo. Por parte da sociedade, mais motivos para desacreditar. Outros poucos encontros entre governo e sociedade foram organizados no âmbito do modelo de gestão, mas as reclamações são sempre sobre os mesmos aspectos.

Em uma atuação diferenciada, em 2009, dentro da proposta do Plano da BR-163, o Ministério do Meio Ambiente ${ }^{21}$ iniciou o Projeto BR-163: Floresta, Desenvolvimento e Participação, em parceria com a Organização das Nações Unidas para Agricultura e Alimentação (ONU/FAO-Brasil), que cuidou do apoio técnico e da gestão financeira do projeto, e da Comissão Europeia, doadora dos recursos. Esse projeto, que encerrou suas atividades no final de 2012, possuía três componentes: manejo das florestas públicas no Distrito Florestal da BR 163; apoio às iniciativas de produção sustentável; e fortalecimento da sociedade civil e dos movimentos sociais. As ações desse último componente foram executadas pela organização social Grupo de Trabalho Amazônico - GTA, com o acompanhamento do Departamento de Articulação de Ações na Amazônia do MMA.

Em entrevista realizada com representante da FETAGRI, instituição que compunha o Fórum Regional, também responsável pelo monitoramento das ações governamentais na região, apenas o MMA desenvolveu ações de continuidade do Plano da BR-163 e, segundo o entrevistado, elas foram tímidas, longe da proposta inicial do projeto. Confrontando essa posição, funcionário do MMA apresentou em seminário ocorrido em Santarém, no ano de 2012, um conjunto de atividades realizadas pelo Ministério e suas autarquias ${ }^{22}$ referentes aos dois primeiros componentes do projeto BR-163. Mas o próprio GTA, parceiro de execução do

19 IPAM e CEFT-BAM

20 Entrevista com representante do movimento social local. Entrevista realizada em Santarém, julho de 2009.

21 O MMA também vinha desenvolvendo, desde 2006, ações no Distrito Florestal da BR-163.

22 Serviço Florestal Brasileiro e Instituto Chico Mendes de Biodiversidade e Florestas. 
mesmo projeto, informou que era preciso o MMA revisitar a estrutura para o manejo de florestas, que não atendia as necessidades da região, e identificou outros problemas de execução do ministério, como a demora na liberação das licenças ambientais dos assentamentos rurais. Complementou ainda que o governo tem dificuldades em avançar nas questões fundiárias e ambientais ${ }^{23}$.

Em janeiro de 2013, após solicitação do GTA, lideranças sociais da região da BR-163 e representantes do Fórum Regional realizaram reunião com o Secretário de Articulação Social da Presidência da República, em Brasília, para cobrar a implementação de políticas públicas. Nessa reunião, o GTA apresentou um estudo que demonstrava a baixíssima porcentagem de execução das políticas destinadas para a área de influência da BR, em diferentes setores, confirmando a dificuldade da presença do governo federal naquela região. Em resposta, o Secretário marcou uma nova reunião, que ocorreu em abril do mesmo ano, para a qual convocou representantes de diferentes ministérios para informar as lideranças sociais sobre o cumprimento das metas do Plano da BR-163.

De acordo com notícia publicada pelo GTA ${ }^{24}$, muitos assuntos e demandas ficaram sem soluções efetivas, mas alguns ministérios levaram informações sobre iniciativas em desenvolvimento na região que foram consideradas interessantes. $\mathrm{Na}$ área da saúde, educação e telecomunicações, tiveram uma boa impressão das propostas governamentais. Mas no campo da regularização fundiária, regularização ambiental e de infraestrutura rural, os grandes gargalos do mundo rural, as ações são consideradas precárias e equivocadas. Para representante do GTA, as propostas apresentadas não atendem as deficiências em curto prazo, as quais, vale frisar, são carências que existem há décadas. De acordo com sua análise, na área fundiária, de competência do MDA e do INCRA, é necessário construir outra estratégia de atuação, pois, com a atual, não se consegue avançar. O problema é estrutural.

O encaminhamento dessa reunião, estabelecido pelo Secretário de Articulação Social, foi tentar construir processos bilaterais de diálogos entre governo e sociedade de forma a aproximar suas agendas. Foram propostas reuniões nos estados ligados ao Projeto da BR-163 (Mato Grosso e Pará), além de solicitado aos Ministérios a produção de informes que serão enviados às lideranças sociais.

No segundo semestre de 2013, entrevistamos funcionário de $\mathrm{ONG}^{25}$ que, na época de elaboração do Plano, ocupava cargo de confiança no MMA e era o

23 Entrevistas realizadas com representantes da FETAGRI-BAM e do GTA. Santarém, dezembro de 2012.

24 Fonte: http://www.gta.org.br/newspost/movimentos-sociais-da-br-163-cobram-resultadosdo-governo/, acessado em 10 de dezembro de 2013.

25 Entrevista realizada em Belém, em agosto de 2013. 
principal articulador dessa iniciativa no ministério. Depois dessa experiência, foi Secretário de Agricultura no Estado do Pará e possuía bom conhecimento sobre as articulações e ações empreendidas na região. Questionado sobre a implementação de políticas públicas vinculadas ao Plano da BR-163, o entrevistado informou que houve atuação do governo federal na região, mas muito pouco do que fez está dentro das metas do Plano. Para ele, as diretrizes do modelo de gestão, que orientavam o governo a implementar as políticas em parceria com os governos estaduais e municipais e sob o monitoramento de organizações da sociedade civil também nunca foram seguidas. Com isso, considerava muito difícil ter uma percepção real do que o governo implementou na região.

Contudo, diante de sua experiência em diferentes esferas do governo, pôde perceber que houve execução de políticas universais como o Bolsa Família e políticas de saúde e educação, e que o governo federal também atuou em parceria com os governos municipais, destinando recursos específicos para determinados municípios. Observou ainda que as ações executadas não seguiam as demandas emergenciais ou estruturais da população local, também não havia imbricações com as diretrizes do Plano. Dessa forma, o Plano, para ele, não possuía valor na administração pública.

Além dessas ações pontuais, o governo federal também criou, em 2008, o Programa Territórios da Cidadania, cujos objetivos eram promover o desenvolvimento econômico e universalizar programas básicos de cidadania por meio de uma estratégia de desenvolvimento territorial sustentável. O programa depende da integração de ações entre governo federal, estados e municípios para a construção dessa estratégia ${ }^{26}$. Vários municípios dos polos do Plano da BR-163 estão contemplados neste Programa - há, inclusive, o território Baixo Amazonas no Pará. As organizações sociais locais e as ONGs socioambientalistas, bem como representantes do governo, consideravam que esse Programa poderia incrementar e trazer algumas soluções para os problemas da área de influência da rodovia.

A par dessas informações, fizemos um cruzamento dos municípios contidos no Plano da BR-163 e daqueles cobertos pelo Programa Territórios da Cidadania $^{27}$. Com o objetivo de avaliar a implementação de políticas públicas no território Baixo Amazonas, analisamos o único relatório completo de execução

26 Fonte:http://www.territoriosdacidadania.gov.br/dotlrn/clubs/territriosrurais/xowiki/ oprograma Acessado em 15 de dezembro de 2013.

27 Em 2012, pegamos o único relatório completo de implementação de ações do Território da Cidadania até então publicado pelo governo federal e procedemos à avaliação. Apenas o relatório de execução do ano de 2010 estava completo. O de 2009 estava incompleto, portanto sem poder ser analisado. No segundo semestre de 2013, de acordo com o responsável pelo Programa Territórios da Cidadania na Presidência da República, o governo atualizou as informações disponibilizando informações de 2009 até 2012. 
financeira de políticas públicas disponível, que era o do ano $2010^{28}$. Havia 55 políticas de diferentes ministérios destinadas a esse território/polo. Praticamente todas as políticas eram descentralizadas e sua implementação acontecia a partir de convênios com prefeituras, com o estado do Pará ou com organizações sociais.

Os ministérios que mais executaram políticas foram o do Desenvolvimento Social e os da Saúde e da Educação. Desses, apenas o Ministério da Saúde possuía política específica para os Territórios da Cidadania. As outras políticas eram universais. O Ministério das Comunicações e o Ministério de Minas e Energia, por exemplo, só tinham, cada um, uma política no BAM, que eram, respectivamente, "Operação do Sistema de Acesso à Banda Larga" e "Programa Luz para Todos", que são também políticas universais. Os ministérios cujos representantes destinaram maior atenção ao Plano da BR-163 - MIN, MMA, MT e MDA - tiveram um nível muito baixo de execução de ações no BAM ao longo daquele ano. Tal como o representante da ONG afirmou, algo foi feito na região em termos de políticas universais, mas não no sentido de implementar as metas estabelecidas pelo Plano, com acompanhamento da sociedade. Aparentemente, o Programa Territórios da Cidadania não correspondia às expectativas da sociedade para solução dos problemas do BAM.

Em entrevista com o coordenador político do Plano da BR-163, em 2013, ele nos informou que o Programa Territórios da Cidadania também sofreu problemas de execução e era mais voltado para questões rurais, não atendendo as demandas do meio urbano do eixo de influência da rodovia. Portanto são duas políticas regionais que fracassaram em seu intento. Para o entrevistado, a condução do Plano só foi possível porque à época dois ministros fortes conduziram o debate: Ciro Gomes (MIN) e Marina Silva (MMA) ${ }^{29}$. Era especialmente Gomes que conseguia o compromisso de agentes de outros ministérios para compor o GTI e propor um planejamento de desenvolvimento regional sustentável para a Amazônia.

Quando o Plano foi lançado, em 2006, o ministro já havia saído do governo, o que enfraqueceu a condução dessa política. Para o entrevistado, venceu a cultura dominante de implementação de obras de infraestrutura sem planejamento, sustentabilidade e sem considerar as demandas das populações locais. Ele atribuiu esse fracasso ao fato de que, atualmente, não se sabe mais fazer planejamento para o desenvolvimento, especialmente no Brasil, e que aqueles agentes governamentais que deram apoio e suporte ao Plano, ao longo dos anos, saíram do governo.

28 Essa análise foi realizada em julho de 2013. Representante do governo informou que, ainda naquele ano, novas informações seriam disponibilizadas, visto a proximidade das eleições gerais de 2014.

29 Entrevista realizada em Brasília, agosto de 2013. 
As metas do Plano da BR-163 foram estabelecidas em 2006. A atualização dessa pesquisa foi realizada entre 2012 e 2013, e percebemos que as carências continuam praticamente as mesmas. Em algumas situações, conforme as entrevistas realizadas em Santarém, Belém e em Brasília, especialmente com representantes do governo federal, observamos que as dificuldades para alcançar aquele território são imperativas. Apesar de alguns avanços, o poder infraestrutural do Estado de, junto com a sociedade civil, implementar ações em todo seu território ainda é fraco. O compromisso de relação e troca com os movimentos sociais e ONGs socioambientalistas, assumido há 12 anos pelo governo federal, mostrou-se falho durante todos esses anos. O fluxo informacional atual é exíguo, a sociedade não consegue acompanhar, conforme previsto, a atuação do governo federal na região, o que também é consequência de uma agenda pouco implementada em termos de políticas públicas.

\section{CONSIDERAÇÕES FINAIS}

A partir de pesquisa sobre ação governamental, cuja proposta é alcançar com políticas públicas e presença institucional uma região remota do território brasileiro, sob a influência da rodovia BR-163, analisamos a capacidade do Estado de executar uma política de desenvolvimento regional sustentável e de tentar modificar o padrão de implementação de obras de infraestrutura na Amazônia. Avaliamos sua capacidade em conciliar diferentes interesses em seu interior, seu poder de alcance territorial e em dispor de uma burocracia interessada e bem articulada para implementar o projeto governamental. Para tanto, vinculamos o conceito de capacidade estatal ao de poder infraestrutural de Mann, uma vez que este trabalha a dimensão territorial do Estado e sua natureza relacional e chama atenção para as variações subnacionais da habilidade estatal em exercer controle e coordenar a sociedade.

Neste artigo, trouxemos os problemas vividos pela população da área de influência da rodovia BR-163, especificamente do polo Baixo Amazonas, e as iniciativas da sociedade civil em parceria com o Estado para realizar seus objetivos. Demonstramos que a baixa capacidade do Estado de implementar as ações do Plano refletiu todos os problemas já apontados durante o processo de formação do GTI e de elaboração do Plano da BR-163. Essa situação foi negativa para que o governo alcançasse êxito em seu intento. Houve uma série de limitações durante todo o processo: a alta fragmentação do Estado; pouco poder relacional para articular os diferentes interesses no interior da burocracia e para orientar no sentido de uma nova cultura de gestão política de desenvolvimento regional; 
baixa institucionalidade do Plano e dos órgãos públicos com ele comprometidos, cujo destaque está nas pessoas e não nas instituições; além do ineditismo da ação tanto para o governo federal quanto para a sociedade no que se refere à ampliação de mecanismos de participação social.

Concluímos com a avaliação de que a falta de comprometimento institucional dos órgãos governamentais, associada a uma burocracia desarticulada e desinteressada, e a histórica ausência de poder público para controlar o funcionamento institucional e a sociedade na área de influência da BR-163, especificamente no BAM, foram elementos reveladores de um Estado com pouco poder infraestrutural para implementar política de desenvolvimento regional sustentável.

\section{REFERÊNCIAS}

ABERS, R. N.; OLIVEIRA, M. S. ONGs, Partidos e Governo do PT: imbricações vistas através da nomeação de ativistas da sociedade civil no Ministério do Meio Ambiente (2003-2013). Opinião Pública, agosto, 2015 (No prelo).

ALENCAR, A. MAPAS - Mapeamento Ativo da Participação da Sociedade. Relatório do Projeto, 2005. P. 94

ALENCAR, A. AMEND, M.; MICOL, L. OLIVEIRA, M. S.; RAID, J. HOFMANN, V. A pavimentação da BR-163 e os desafios à sustentabilidade: uma análise econômica, social e ambiental. Belo Horizonte: CSF, 2005. 29p.

BRASIL. Plano de Desenvolvimento Regional Sustentável para a Área de Influência da BR-163 (Cuiabá-Santarém). Brasília: Presidência da República/Casa Civil, 2006. 156p.

Avaliação e planejamento integrado no contexto do Plano BR-163 Sustentável: o setor soja na área de influência da Rodovia BR-163. Relatório Final. Brasília: MMA, PNUMA, junho de 2006. p. 129

DAGNINO, E. Sociedade Civil, Espaços Públicos e a Construção Democrática no Brasil: Limites e Possibilidades. In: DAGNINO, E. (Org.). Sociedade Civil e Espaços Públicos no Brasil. São Paulo: Editora Paz e Terra, 2002. p. 279-303

EVANS, P. Autonomia e parceria: Estados e transformação industrial. Tradução de Cristina Bastos Tigre. Rio de Janeiro: Editora UFRJ, 2004.401 p.

FEARNSIDE, P. M. Social Impacts of Brazil's Tucuruí Dam. Environmental Management (New York), New York, v. 24, n. 4, pp. 483-95, 1999.

FEARNSIDE, P. M. The evolving context of Brazil's environmental policies in Amazonia. Belém, Novos Cadernos NAEA. Vol. 16, n. 2 p. 9-25, jul-dez 2013

GENRO, L.; ROBAINA, R. A Falência do PT e a Atualidade da Luta Socialista. Porto Alegre: L\&PM, 2006. 160p. 
HAU, M; SOIFER, H. Unpacking the "Strength" of the State: The Utility of State Infrastructural Power. Studies in Comparative International Development, v.4, Issue 3-4, pp. 219-30, 2008.

HOCHESTETLER, K, \& KECK, M. E. Greening Brazil: Environmental Activism in State and Society. Durham \& London: Duke University Press, 2007. 273p.

MANN, M. A Theory of Modern State. In: MANN, M. The Sources of Social Power: The Rise of Classes and Nation-States, 1760-1914. Volume II. New York: Cambridge university Press, 1993. p. 44-91.

IPAM. Relatório do Encontro em Defesa da Sustentabilidade do Baixo Amazonas e BR-163. Santarém, Pará, 2003. 64p.

Relatório do Encontro o Desenvolvimento que Queremos. Março, 2004. Santarém, Pará, 2004. 46p.

Diagnóstico em Mapas. Baixo Amazonas. Belém: IPAM, 2007.

O’DONNELL, G. Democracia, agência e estado: Teoria com intenção comparativa. São Paulo: Paz e Terra, 2011. 314 p.

OLIVEIRA, M. S. Cultura e Política dos Movimentos Sociais no Eixo de Influência da Rodovia BR-163. Desenvolvimento Territorial: Diretrizes para a Região da BR-163. Volume 1. Brasília: Projeto Diálogos, 2009. Pp. 27-45

OLIVEIRA, M. S. Autonomias relativas: Estado e sociedade civil no eixo de influência da rodovia BR-163. 2010. 150p. Dissertação (Mestrado em ciências sociais). Universidade de Brasília, Brasília, 2010.

TONI, F., MACHADO, L. e OLIVEIRA, M. Políticas Públicas e Participação Social: Análise das Demandas da Sociedade Civil na Construção do Plano BR-163 Sustentável. In: Projeto Diálogos. Volume 2, Brasília: Radiola, 2009. Pp. 15-34.

TORRES, M. Considerações sobre a ausência do Estado e exclusão social nos municípios paraenses do eixo da BR-163. In: TORRES, M. (Org.). Amazônia revelada: os descaminhos ao longo da BR-163. Brasília: CNPq, 2005. Pp. 271-320.

TURA, L. R.; COSTA, F. A. (Org.). Campesinato e Estado na Amazônia: impactos do FNO no Pará. Brasília: Brasília Jurídica: FASE, 2000. 381 p.

WEISS, L. Infrastructural power, economic transformation, and globalization. In: HALL, J. A; SCHROEDER, R. (Ed.) An Anatomy of Power: The social Theory of Michael Mann. New York: Cambridge University Press, 2006. p. 167-186. 

Mazzaropi e a indústria de cinema do Brasil: a importância da comédia caipira para a cinematografia brasileira nos anos de 1950-1980

\section{Mazzaropi and Brazil's cinema industry: the importance of caipira comedy forbrazilian cinematography from 1950's to 1980's}

Thaís Valvano - Mestranda do Programa de Pós-Graduação em Ciências Sociais em Desenvolvimento, Agricultura e Sociedade da Universidade Federal Rural do Rio de Janeiro (CPDA/UFRRJ). Graduada em História pela Universidade Federal Fluminense (UFF).Email: thaisvalvano@gmail.com

\section{Resumo}

Este trabalho propõe analisar a vida e obra do cineasta Amácio Mazzaropi, a partir das críticas especializadas sobre seus filmes. O intuito não é biográfico, à medida que propõe uma discussão maior sobre a sua obra e as impressões sobre o autor e personagem. A intenção é entender a infância do produtor e os caminhos que o levaram a criar sua produtora cinematográfica para identificar a importância do cineasta para a indústria brasileira de cinema e a representação da identidade caipira ante ao processo de urbanização à época. Finalmente, o artigo pretende responder algumas questões como a relação entre público e crítica; tradição e modernidade e a reprodução de identidades sociais.

\section{Palavras-chave}

Mazzaropi. Indústria cultural. Cultura caipira. Cinema.

\begin{abstract}
This work proposes to analyze of the Amácio Mazzaropi's life and cinematographic production, based on specialized criticism about his movies. It isn't a biographical study. The intention is to understand, through the producer's childhood, the ways that allowed him to build his own film company to identify the filmmaker importance to the brazilian industry of cinema and the representation of the caipira identity in the urbanization period. Finally, the article proposes to answer some questions as the relationship between public and critics; modernity and tradition and social identities reproduction.
\end{abstract}

\section{Keywords}

Mazzaropi. Cultural Industry. Caipira culture. Cinema. 


\section{INTRODUÇÃO}

Amácio Mazzaropi nasceu na capital do estado de São Paulo, mas foi no interior que passou praticamente toda a sua vida. Aos dois anos mudou-se com os pais para Taubaté, onde passou boa parte da infância. Acostuma ao cotidiano caipira, a vida e os costumes do interior, a volta a São Paulo aos sete anos foi um desafio, à medida que o menino teve que se adaptar novamente à cidade grande (MATTOS, 2010). Anos mais tarde, tal conflito de adaptação seria fortemente representado em vários de seus filmes.

Sua infância e adolescência foram marcadas pela falta de recursos de sua família, seus pais não tinham muito dinheiro e quase sempre passavam por problemas financeiros. Em um deles, seu pai decidiu voltar à Taubaté para trabalhar na indústria têxtil da cidade, onde mais tarde Mazzaropi também trabalhou. Porém, desde criança o sonho de ser artista o dominava. Adorava ir ao teatro e os personagens de que mais gostava eram os caipiras, que faziam grande sucesso no teatro desde a sua infância, como ele declarou na entrevista que concedeu a revista "Veja" no ano de 1970,

$\mathrm{Na}$ adolescência, Mazzaropi começou a se envolver diretamente com o teatro. Ele mesmo dizia que trabalhava com teatro, "mas não como ator - eu pintava cenários. Aliás, eu amava a pintura, sempre amei a pintura. Pois bem, um belo dia "perdi" o pincel e resolvi seguir a carreira de ator" (MAZZAROPI, 1976).

Para entender os fatores que influenciaram as características de Mazzaropi como ator é importante considerar o contexto brasileiro, principalmente na cidade de São Paulo. Para tanto, é valido observar o trecho do texto de Cássio Santos Melo (2009), em que o autor caracteriza a capital paulista nos anos 20, argumentando que "a presença marcante do estado, como grande exportador e produtor de café, são aspectos que na virada do século XIX para o XX vão delineando novos contornos ao estado como um todo e à sua principal cidade, São Paulo" (MELO, 2009).

A partir desses fatores, pode-se considerar que a arte não estava alheia a essas questões, principalmente as peças apresentadas em circos e teatros populares, pois estas visavam ao diálogo com o público, que respondia à medida que se identificava com as histórias encenadas.

Essa relação de representação dos conflitos da sociedade nas peças de teatro é encontrada em quase todas as apresentações de Mazzaropi. O produtor saía para o interior contando piadas que muitas vezes eram sátiras que condiziam com a realidade do público. A sátira é um exemplo que representa bem a característica de Mazzaropi. Esse recurso se intensificou na medida em que o artista foi se familiarizando com as artes cênicas, principalmente depois que foi 
trabalhar com cinema. Desse modo, passou a satirizar, além dos sucessos dos filmes estrangeiros, os seus próprios colegas produtores que, segundo Mazzaropi, tinham um problema grande de não atentar para as necessidades do público.

Dizia ainda que seu sucesso advinha do trabalho que mostrava ao seu público. Segundo ele, seus filmes oferecem distração em forma de otimismo. "Eu represento os personagens da vida real. Não importa se um motorista de praça, um torcedor de futebol ou um padre. Eu documento muito mais a realidade do que construo" (MAZZAROPI, 1970). Essa é uma das principais peculiaridades de Mazzaropi, visto que o produtor primava por filmar em cenários reais, como uma praça na pequena cidade de São Luiz do Paraitinga ou o convento na cidade de Taubaté, a fim de criar um enredo o mais próximo possível da realidade.

Tais recursos cinematográficos não só possibilitaram um conhecimento melhor do tipo social que era representado no filme, como garantiu o sucesso de público. Mas antes de atingir tal sucesso como produtor, Mazzaropi já era um artista muito conhecido por seus programas no rádio e na televisão. Sua estreia no cinema se deu através de um teste para protagonizar o próximo filme da companhia de cinema Vera Cruz ${ }^{1}$ no ano de 1952. Sai da frente foi o seu primeiro filme, lançado no mesmo ano, e seguido por outros dois na mesma companhia. Em razão da crise na Vera Cruz, ele foi trabalhar na companhia Cinedistri, onde aprendeu os recursos essenciais para produzir um longa-metragem, além de atuar em mais três filmes. Assim, o artista estava cada vez mais perto de seu sonho.

\section{A PAM-FILMES E A CONSOLIDAÇÃO DA COMÉDIA CAIPIRA NO CINEMA BRASILEIRO}

Com o reconhecimento do público, o sucesso de suas piadas, capital inicial para o investimento em um sonho, Mazzaropi funda a sua própria produtora cinematográfica no ano de 1959 - a Produtora Amácio Mazzaropi - PAM filmes². Quando questionado sobre os motivos que o levaram a arriscar tão alto, dizia: "Eu via o cinema cheio de gente e meu bolso vazio. Tinha aprendido um pouco de cinema e resolvi fazer minhas próprias fitas. Afinal, minha empresa seria a única que teria o artista principal trabalhando de graça” (MATTTOS, 2010, p. 72).

Isso pode ser bem analisado na própria entrevista que Mazzaropi concedeu ao Movimento, em 1976. Ele defendia que caminhava rumo à consolidação de uma indústria cinematográfica brasileira:

1 Criada em 1949 pelos empresários Franco Zampari e Francisco Matarazzo Sobrinho: "Espelhada em Hollywood, fundaram a Companhia Cinematográfica Vera Cruz" (MATOS, 2010, p. 63).

2 Criada em 1958, passa a produzir os filmes de Mazzaropi, sendo que já no primeiro filme "Chofer da praça" atingiu grande sucesso de público. 
[...] tenho uma situação excepcional dentro do cinema brasileiro. Vejo isso pelo volume de fitas. A Pam Filmes, companhia distribuidora que é minha, tem filial no Rio de Janeiro, tem sede própria em Belo Horizonte, em Curitiba, Recife, Porto Alegre, e a matriz aqui em São Pauto, onde trabalham 80 pessoas. Estou inclusive adiantado em relação ao governo brasileiro, que pretende fazer um estúdio entre São Paulo e Rio (MAZZAROPI, 1976).

Esses dados não passavam despercebidos pelos críticos de cinema, inclusive existem fontes que mostram o interesse do governo da época nessas questões. Apesar de os anos de 1970 terem sido marcados por um forte controle político estatal representado pelo regime militar, não se pode esquecer que um dos principais objetivos do governo era fomentar o processo de industrialização nacional, incluindo a indústria cultural. Tal afirmação é vista no jornal Estado de São Paulo de 19 de outubro de 1971 (Figura 1), que cobriu o encontro entre Mazzaropi e o presidente Médici que discutiram sobre o fomento da indústria cinematográfica. Segundo o jornal, “o presidente Médici disse que dará todo o apoio ao cinema nacional para transformá-lo em indústria”.

Figura 1 - Recorte do jornal Estado de São Paulo de 19 de outubro de 1971.

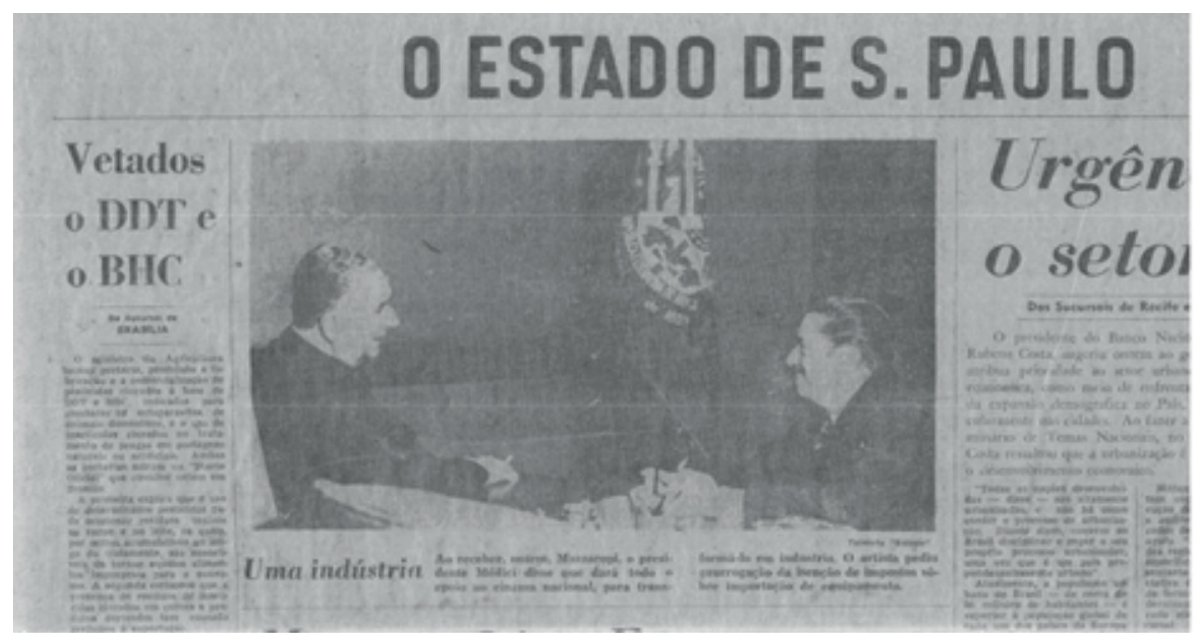

Fonte: Centro de Documentação e Pesquisa Histórica da Universidade de Taubaté (CDPH/UNITAU).

No entanto, o interesse do governo não era apenas de fomentar e enriquecer a cultura no Brasil, mas havia também forte interferência econômica nessa questão. Um exemplo disso foi o objetivo da reunião entre Mazzaropi e Médici. O produtor pretendia defender a isenção de impostos nas importações de equipamentos cinematográficos, pois tratava o cinema como negócio 
(MATTOS, 2015, p. 105), tanto que criava artifícios para fugir das fraudes que ocorriam frequentemente.

O reconhecimento da importância de Mazzaropi na criação de uma indústria cinematográfica nacional parecia estar somente no encontro com o presidente e em alguns críticos que destacavam a popularidade do produtor. A crítica especializada, em geral, analisava os filmes mazzaropianos de forma pejorativa, muitas vezes chegando a desqualificá-los. Contudo, deve-se considerar o interesse político dos próprios jornais.

A maior parte dos relatos sobre os filmes de Mazzaropi está focada principalmente em seus lançamentos. A questão a se observar é que muitos críticos ressaltavam a falta de técnica, a precariedade de recursos e a repetição de enredos, ao mesmo tempo em que concordavam que se tratava de mais um sucesso de público. No entanto, existiam aqueles que ressaltavam que o grande número de espectadores nos filmes de Mazzaropi condizia com o subdesenvolvimento do Brasil, e que somente este condicionamento seria a explicação cabível para tal sucesso (LOYOLA, 1965).

Entretanto, salvo alguns críticos mais contestadores, como Ignácio de Loyola ${ }^{3}$, a maioria ressaltava a importância do público nos filmes de Mazzaropi. Também não era possível omitir essa questão, principalmente ao considerar a matéria de Paulo Moreira Leite para o jornal Folha de São Paulo do dia 8 de junho de 1977.

São duas mil pessoas, o trânsito está interrompido numa faixa da Avenida São João, o Largo Paissandu está agitado. Uma escola de samba, uma banda do interior as duas misturando batucada e marchinhas ao mesmo tempo. Motocicletas e viaturas do DSV, sirene, 5 soldados da PM e um sargento. Dois caminhões de uma estação de televisão, holofotes, fotógrafos. Então, com 45 minutos de atraso, o gálaxie preto estaciona junto à calçada do cine Art-Palácio, para a cerimônia de estreia do filme "Jecão... um fofoqueiro no céu” (MOREIRA, 1977).

Esses dados foram apresentados em 1977, quando Mazzaropi já havia consolidado a sua produtora que, a partir de sua fundação em 1959, passou a produzir um filme por ano e todos de relativo sucesso.

Os anos de 1970 foram fundamentais para a produção de Mazzaropi. Em todos os lançamentos era esperado um grande número de pessoas. O produtor determinava que fossem feitas em média 35 cópias, que eram distribuídas a um grande número de salas simultaneamente. Sabendo que o seu grande público estava em São Paulo, o produtor segurava as fitas durante um mês só no estado de São Paulo, para depois distribuir no Rio de Janeiro, Belo Horizonte, Curitiba, Recife e Porto Alegre.

\footnotetext{
Contista, romancista e jornalista brasileiro. Trabalhou no jornal Última Hora.
} 
Neste sentido, a crítica de Paulo Moreira Leite foi ainda mais enfática ao analisar a renda dos filmes mazzaropianos, especialmente o Jeca Macumbeiro (1974). Este filme atingiu um total de 530.306 espectadores em um ano de exibição - a maior bilheteria nacional do ano de 1975, atingindo 10,5 milhões de cruzeiros (MOREIRA, 1977). Esta afirmação sugere a demonstração da importância de Mazzaropi naquele momento, fato que, em certa medida, incomodava alguns críticos e chamava a atenção de outros tantos.

Mais um grande sucesso era esperado pelo público de Mazzaropi no ano de 1975. O produtor estava lançando a sua mais nova película intitulada O Jeca contra o Capeta. Ao analisar essa fita, alguns críticos diziam que ela foi inspirada no filme norte-americano O exorcista (1973), e que o produtor havia feito a sátira para aproveitar o sucesso que o filme estrangeiro fizera nas bilheterias do mundo todo. Contudo, acompanhando ou não o sucesso do filme, o que se pode afirmar é que a intensão de Mazzaropi não era reproduzir fielmente o enredo do filme hollywoodiano, mas sim satirizá-lo e garantir ao público muitas risadas.

Em um contexto mais geral, pode-se dizer que este filme agrega todas as peculiaridades dos filmes mazzaropianos, misturando comédia, questões sociais, violência e ingenuidade do caipira numa só produção. Tais fatores aparecem na discussão sobre a aprovação ou não da Lei do Divórcio, nas brigas intermináveis entre os homens do meio rural, nas graças do jeca e na suposta falta de malícia das pessoas do campo.

Neste aspecto, o filme pode ser considerado contestador, na medida em que se inicia com uma pesquisa de opinião. Os jornalistas saem às ruas querendo saber o que a população acha da Lei do Divórcio. Para isso, Mazzaropi filma a discussão em um cenário externo, como se reproduzisse, mais uma vez, o próprio cotidiano do seu público nas pequenas cidades. Desde o começo, a polêmica da aprovação da lei vai alterar as relações pessoais da cidadezinha. Alguns vão gostar da ideia e outros tantos vão ficar receosos, principalmente as mulheres, que ficam com medo de perder seus maridos.

A observação que se constrói a partir dos acontecimentos retratados no filme é de que a população do meio rural não estava preparada para a aprovação da lei do divórcio, pois somente a possibilidade de aprovação já alteraria as relações pessoais naquele meio. Neste sentido, além de expressar os problemas causados por tal notícia, Mazzaropi procura dialogar com os próprios personagens do filme, como o padre, por exemplo.

Assim, Mazzaropi cria um enredo sobre tradição e modernidade. Seus personagens ficam um tanto quanto atônitos com a modernização, que chegam a sentir falta dos antigos costumes. Isso é retratado de forma mais sistemática na 
conversa que o personagem Poluído tem com o padre da cidade. Inconformado com as mudanças que estavam ocorrendo no interior, o protagonista pergunta se o padre é a favor da lei do divórcio, confirmando a posição contrária da igreja e, consequentemente, a do caipira.

Entretanto, vale ressaltar que o filme foi produzido em 1975, e que a lei do divórcio só foi aprovada no Brasil em 1977, ou seja, havia uma discussão de âmbito nacional e o filme se posicionou contrário à nova lei. Além disso, legitimou a sua posição através de seus personagens, visto que os heróis da trama são contrários e os vilões a favor do divórcio.

A análise que Zulmira Tavares ${ }^{4}$ fez sobre a representação do divórcio no filme de Mazzaropi foi contundente:

$\mathrm{Na}$ verdade a qualidade de negra vilania emprestada ao divórcio deflagra toda a ação da estória; por exemplo o sedutor Camarão, ao tomar conhecimento da lei do divórcio, ri satanicamente e tenta logo em seguida violentar a mulher do próximo: um revólver dispara e Camarão morre (também por causa do divórcio, como se verá no fim); mente-se a respeito de uma duvidosa herança. A motivação? O divórcio. Porém, como tanto os divorcistas (os vilões) como os antidivorcistas (os heróis) agem da maneira mais fora de propósito possível na defesa de um ou de outro ponto de vista, a credibilidade de ambos os enfoques fica muito duvidosa (TAVARES, 1976).

Além disso, esta é mais uma característica de Mazzaropi explicitada no filme. Ele propõe uma questão e não a defende de forma determinada. Por mais que fique clara a sua posição sobre a questão do divórcio, por exemplo, ele a aborda de forma superficial e inserida numa gama de acontecimentos que ela acaba se manifestando apenas como uma consequência do que se desenrola na trama.

Portanto, é inviável realizar um estudo aprofundado sobre o filme Jeca contra o Capeta sem abordar os casos separadamente. Anteriormente, fiz uma breve contextualização do enredo para demonstrar como os acontecimentos se encadeiam. Portanto, torna-se necessário dar continuidade a essa explanação, porém de forma mais específica, de acordo com o interesse de cada personagem que vai usar a questão do divórcio para atingir seus objetivos ou para se defender.

O filme propõe a discussão de vários temas. É evidente que o divórcio é o tema central, mas, além dele, destacam-se a obsessão da fazendeira rica, a prisão do filho de seu Poluído, a aparição de um advogado de defesa um tanto suspeito, o encontro de Poluído com Jesus Cristo e a sátira ao filme O exorcista. Toda essa rede de elementos da trama é retratada simultaneamente. Portanto, neste artigo

4 É escritora, pesquisadora e professora de cinema, sendo integrante do conselho da Cinemateca Brasileira. 
me proponho a esquematizar tais questões não de acordo com o desenrolar do filme, mas de acordo com os casos abordados.

Aproveitando para ameaçar Poluído, Dionísia inventa para o caipira que viu Augusto matando Camarão e que o denunciaria caso o Jeca não se divorciasse para se casar com ela. Essa ameaça acontece logo no início do filme, e vai se estender por toda a história, fazendo com que Poluído, a fim de salvar o seu filho, fique cada vez mais envolvido na trama de Dionísia. O título do filme Jeca contra o Capeta tornase emblemático em uma cena em que o caipira tem um pesadelo e vê Dionísia ${ }^{5}$ se transformar em demônio. Por isso, o capeta não é força de outro mundo, ao contrário, é representado nas atitudes da fazendeira apaixonada pelo Jeca.

Outro fator importante no filme é a aparição de um advogado contratado por Dionísia, que inventa para o povo da cidade que o divórcio já foi aprovado, e que ele resolveria o processo de quem quisesse se divorciar. O problema é que a lei não tinha sido aprovada e o advogado se aproveitava da ignorância das pessoas para ganhar dinheiro através da criação de um falso processo de divórcio. Além disso, combinado com Dionísia, ele inventa uma herança que Poluído ganharia, para fazer com que ele e sua esposa assinassem o documento que, na verdade, seria o falso divórcio.

Mesmo sendo falso, tanto Poluído quanto a sua mulher acreditavam estar divorciados. A confusão só foi desfeita quando o Jeca vai procurar a fazendeira para tentar reaver os papeis e anular o divórcio. No entanto, quando chega à residência de Dionísia ouve a conversa da proprietária com o seu advogado, em que ambos riem por terem enganado toda a cidade, e afirmam que a lei ainda não foi aprovada. A fazendeira afirma ainda que foi ela quem matou o Camarão, e fez isso porque descobriu que a vítima planejava liquidá-la. Ao ouvir toda a confissão dos vilões, Poluído se dirige à delegacia para informar ao delegado a descoberta.

Essas análises são interessantes à medida que fortalecem o enredo e abordam questões importantes de forma suave e eufêmica, garantindo leveza à mensagem levada ao público, mesmo quando abordam temas como violência e desigualdade, representados pelas crueldades de Dionísia e do advogado quando usa o seu conhecimento e informação para trapacear.

Outra questão interessante do filme é a passagem de Jesus Cristo. A primeira cena em que Poluído aparece conversando com Jesus acontece quando o Jeca está desanimado com as injustiças do mundo. Seu filho estava preso, o mundo se modernizando, sentia que não pertencia mais àquele lugar. Ele passa então a questionar o motivo de existir tanta gente que faz o mal, mas que tem

5 Lembrando que Dionísia deriva do Deus grego Dionísio, conhecido como Deus da insânia e da intoxicação. 
bastante dinheiro e tanta gente que só faz o bem e não tem quase nada. Assim argumenta que dinheiro não traz felicidade e que a maior riqueza é ser feliz.

O interessante é que no final do filme o público descobre que Jesus Cristo na verdade era um hippie. Essa descoberta causa certa curiosidade, pois não fica definida a intenção de Mazzaropi ao criar aquele personagem, podendo levar a várias interpretações, mas o fato é que o diálogo retoma a discussão sobre desigualdade econômica e injustiça social, e de certo modo não deixa de ser representada durante todo o filme. Porém, essas questões reforçam a necessidade de entender essa analogia a Cristo, talvez por contrapor o Capeta ou então para mostrar um novo grupo social que se formava nos anos de 1970, os hippies ${ }^{6}$.

Por fim, o último aspecto que proponho analisar é a sátira a um dos filmes hollywoodianos de maior sucesso nos anos de 1970 - O exorcista. Mazzaropi não propôs a reprodução do enredo do filme, pelo contrário. Como vimos, a história é marcada por grandes acontecimentos norteados por um assunto muito distante do filme norte-americano - que é o tema do divórcio. Nesse sentido, o produtor demonstra de forma alusiva e lúdica que tais manifestações sobrenaturais podem muito bem ser explicadas no mundo dos homens. O medo das pessoas é que faz com que elas acreditem no fenômeno de incorporação do demônio. Poluído inclusive chega a acreditar que sua esposa está com o demônio no corpo, do mesmo modo que a menina do filme "O eletricista" crença em poderes sobrenaturais é desfeita quando descobrem que a cama em que Poluído estava se mexia devido aos cachorros que estavam debaixo do móvel.

$\mathrm{O}$ que se pode entender dessa sátira, principalmente pela alusão aos fenômenos sobrenaturais, sendo explicados por fatores concretos, é que Mazzaropi pretendia mostrar, com este filme, que não era preciso priorizar filmes estrangeiros para atingir o grande público, visto que o cinema nacional era capaz de produzir filmes lucrativos. Além disso, o produtor mostrou que conseguia lotar as salas de cinema com filmes simples, que abordavam de forma cômica e leve assuntos do próprio cotidiano da população do interior. Essa hipótese pode ser levantada a partir do depoimento que Mazzaropi concedeu ao jornalista Caco Barcelos no dia 5 de abril de 1976.

Muita gente faz cinema no Brasil para consumo próprio e não percebe que não faz sucesso porque vive divorciada do povo, falam uma linguagem intelectual e o povo não gosta de pensar. Analisem bem o Tubarão, os

${ }_{6}$ Em nenhuma das críticas sobre o filme encontrei uma explicação sobre o personagem de Cristo. Zulmira Tavares defende que era um símbolo representativo que foi explicado no mundo dos homens.

Termo pelo qual o personagem de Mazzaropi, Poluído, refere-se ao filme O exorcista. Este recurso garante a comicidade da cena. 
americanos fazem e levam o dinheiro daqui. Me dá uma vontade de dar um soco nos beiços daquele bonecão quando ele aparece com aqueles dentão na tela. Porque nós não fizemos para o dinheiro ficar aqui mesmo (MAZZAROPI, 1976).

Considerando a mesma lógica do filme Tubarão (1975) para O exorcista (1973), o que Mazzaropi critica é a falta de investimento no cinema nacional. Quando ele indaga o motivo de nenhum cineasta brasileiro ter feito o filme antes de Hollywood, mostra todo o seu ressentimento. E argumenta que se o filme tivesse sido produzido no Brasil, o sucesso e os lucros poderiam fomentar a indústria cinematográfica nacional e não aumentar os lucros estrangeiros.

Ainda neste depoimento, Mazzaropi comenta o sucesso do filme de 1975:

Então eu fiz este ano o Jeca Contra o Capeta achando que nunca mais atingiria rendas tão altas como as outras. Mas tive outra agradável surpresa: um milhão de pessoas já viram a fita que está na quinta semana do circuito Serrador em São Paulo. É uma barbaridade (MAZZAROPI, 1976).

O seu discurso não muda. $\mathrm{O}$ sucesso de seus filmes é constantemente comparado com os filmes estrangeiros, sendo que alguns deles perdem espaço para a exibição dos filmes do Jeca.

O depoimento "Jeca contra o tubarão" é ainda mais interessante quando se analisam os depoimentos de pessoas comuns que assistem aos filmes do Mazzaropi, principalmente da cidade de São Paulo. O próprio produtor defende que a capital paulista é um lugar de caipiras, chegando a caracterizar a variedade que existe na cidade. Em um trecho Mazzaropi defende a sua posição no sentido de produzir filmes de acordo com o que o público caipira deseja encontrar no cinema.

Sempre me preocupei com o caboclo, o caipira, que foi mudando seu temperamento, na medida em que a sociedade entrava na onda do desenvolvimento. Antigamente eu contava uma história ingênua e todos gostavam. Eu dizia que queria casar com uma namorada mas o pai dela não queria deixar. Depois eu falava que ia dar um tiro no meu ouvido e outro no dela, para nós dois juntinhos nos unirmos no céu e era o maior sucesso. Hoje o povo dá gaitada disto, acha ridículo. Eles estão com a TV em casa e não querem mais saber de riscar o dedão no chão como faziam antes (MAZZAROPI, 1976).

Essa consciência da importância do seu público é a grande defesa do produtor, principalmente ao rebater as críticas sobre a falta de qualidade do seu trabalho. Segundo ele, qualquer enredo que for criado respeitando a opinião e a vontade do público tende ao sucesso. Para argumentar essa questão, cita trabalhos anteriores, como Portugal, minha saudade (1973), que foi um "drama 
desgraçado", como ele mesmo relata, mas que atingiu sucesso de público. Para Mazzaropi, o público vai aplaudir tanto o filme que lhe faz rir quanto os que lhe faz chorar, mas que, no entanto, seja condizente com a realidade e possibilidades de compreensão dos espectadores.

A escolha do filme de 1975 para analisar o sucesso de Mazzaropi como produtor cinematográfico não foi aleatória, visto que foi o que atingiu ${ }^{8}$ a maior bilheteria de sua carreira, superando inclusive filmes estrangeiros. Sobre isso, o produtor defende que:

[...] enquanto o Jeca briga com o diabo nas telas dos cinemas paulistas, Charles Bronson e outras fitas estrangeiras terão que esperar a vez com muita "humildade", diz Mazzaropi sorridente e às vezes debochado: "porque eu mesmo não esperava tanto sucesso com O Jeca contra o Capeta (MAZZAROPI, 1976).

Nos depoimentos e entrevistas Mazzaropi não esconde a alegria de superar as fitas estrangeiras em número de público. Como já mostrado, sua intenção era criar uma indústria cinematográfica brasileira. Para ele, "enquanto o país continuaar abrindo espaço para os filmes estrangeiros, terá menos chance de investir em produções próprias". A própria independência de Mazzaropi em relação à sua produção é prova desse contexto. $\mathrm{O}$ fato de utilizar recursos financeiros próprios na realização de um filme mostra a dificuldade de receber incentivo externo. $\mathrm{O}$ fator positivo é que a renda própria, além de ser suficiente para os gastos com a produção de um longa-metragem, ainda garante a manutenção e aquisição de equipamentos cinematográficos mais modernos.

Neste sentido, o fato de o título do depoimento de Mazzaropi a Caco Barcelos ter sido "Jeca contra o tubarão" define exatamente essa problemática que o produtor tanto defendia. Além de ser contra a abertura que o Brasil dava à exibição de filmes norte-americanos, não via nas produções nacionais um estímulo à produção de filmes de sucesso, pois, em sua opinião, muitos intelectuais se preocupavam mais em produzir filmes que rompessem paradigmas do que se atentar para a vontade do público consumidor.

8 Cr\$ 15.258.957,70 . Espectadores: 2.602.630. Mês de lançamento: fevereiro. Figura em $2^{\circ}$ lugar na lista: das "10 maiores rendas do filme nacional em 1976". Figura em $2^{\circ}$ lugar na lista das "10 maiores rendas do filme nacional no período de 6 anos" "(de julho de 1970 a dezembro de 1976)". Figura em $5^{\circ}$ lugar na lista das " 10 maiores rendas do filme nacional no período de julho de 1970 a junho de 1977, com a renda de $\operatorname{Cr} \$ 16.268 .307,40$; e com 2.786 .165 espectadores". Disponível em: <http://www.cinemateca.gov.br/cgi- bin/wxis.exe/iah/?IsisScript=iah/iah.xi s\&base $=$ FILMOGRAFIA\&lang $=$ p\&nextAction $=$ lnk\&exprSearch $=\mathrm{ID}=023417 \&$ format $=\operatorname{det}$ ailed.pft\#1.

9 Ver o depoimento "O Jeca contra o tubarão". 


\section{MAZZAROPI E A CRÍTICA AO CINEMA NOVO}

Em 1970, Mazzaropi concedeu uma entrevista à revista Veja, na qual ele analisa o panorama do cinema nacional. Essa entrevista é importante, na medida em que ele fala do seu sucesso com o público, da sua visão sobre o cinema como indústria e critica as produções do Cinema Novo (SIMONARD, 2006). A entrevista "O Brasil é meu público", que foi concedida ao jornalista Armando Salem em 28 de janeiro de 1970, será a fonte utilizada para estabelecer a relação entre Mazzaropi e o Cinema Novo.

Para entender a crítica de Mazzaropi é preciso antes entender o surgimento do Cinema Novo e sua proposta. Segundo o artigo de Armando Salem, a proposta era criar um estilo próprio de fazer cinema no Brasil, e não reproduzir o modo de vida norte-americano, que era difundido principalmente através dos filmes de Hollywood. Era necessário criar uma identidade nacional. Por isso, era muito comum a produção de filmes que retratassem o subdesenvolvimento do país, que denunciasse questões sociais. Além disso, não reconheciam que havia uma produção de filmes nacionais, a não ser pela produtora Vera Cruz e pelos filmes de chanchadas ${ }^{10}$ dos anos de 1930 e 1940.

Os filmes de chanchadas deixaram de fazer sucesso no final dos anos de 1950 porque não acompanharam a mudança pela qual a população brasileira passara nesses anos. Na cena paulista, a companhia Vera Cruz, fundada em 1949, tinha a proposta de criar uma indústria cinematográfica nacional que produzisse filmes de qualidade. Para isso, seus criadores não pouparam recursos para contratar profissionais estrangeiros e equipamentos de alta qualidade. O problema é que tais investimentos foram maiores que a renda de seus filmes, fazendo com que a produtora entrasse em crise financeira, vindo a falir poucos anos depois.

Segundo Ramos (1987), a produtora Vera Cruz também não obtinha o retorno financeiro porque:

[...] a empresa preocupava-se apenas com a produção, deixando a distribuição a cargo de multinacionais também produtoras de filmes e que não tinham interesse nenhum em ceder um pedaço do seu mercado para o cinema brasileiro (RAMOS, 1987). Nesse sentido, o Cinema Novo aparece como uma forma de se diferenciar das experiências anteriores e propor a produção de filmes baratos e condizentes com a realidade de um país em desenvolvimento. Seus idealizadores defendiam que um filme de qualidade pode ser feito com apenas uma câmera na mão e uma ideia na cabeça.

10 Gênero fílmico que mistura enredo carnavalesco com cenas de ação, canção e muita comédia. Nos anos de 1940 ficou conhecido por retratar na maioria dos filmes o típico malandro carioca e suas peripécias. 
Mazzaropi acompanhara todo esse processo, inclusive chegou a trabalhar na produtora Vera Cruz, onde produziu três filmes. Sabia dos problemas da produtora passava e, em certa medida, o que causara esses problemas. Um deles evidentemente era a distribuição, tanto que, logo após a criação de sua produtora, Mazzaropi tratou logo de criar uma distribuidora para impedir os desvios financeiros, além de contratar fiscais para evitar fraudes nas salas de exibição. Muito do sucesso do cineasta deveu-se aos seus cuidados desde o processo de produção até a exibição de um filme.

Observando o quadro cinematográfico no Brasil, Mazzaropi fazia muitas críticas em relação ao Cinema Novo. Observava que as produções neste gênero não atingem o grande público. Segundo ele, isso era prejudicial, na medida em que, diferentemente dos filmes produzidos pela PAM- filmes, não ajudam a indústria de cinema no Brasil.

Não posso falar pelos outros porque não conheço os resultados dos números daquilo que eles fazem. Tenho muita vaidade em dizer que eu não tenho nenhum problema de exibição de meus filmes. Os exibidores fazem fila na porta da Pam-Filmes. O público vai ver minhas fitas e sai satisfeito. Eu já consegui colocar 13.000 pessoas num dia, nas várias sessões do Art Palácio, em São Paulo. Com isso, ando de cabeça erguida. Agora, pelo outro tipo de filme feito no Brasil, não respondo. Não sei se ele pode ajudar a indústria cinematográfica nacional (MAZZAROPI, 1976).

Ainda sobre o Cinema Novo, caracteriza-o como estilo feito para uma minoria de intelectuais.

Não, eu não tenho nada contra ele. Só acho que a gente tem que se decidir: ou faz fita para agradar os intelectuais (uma minoria que não lota uma fileira de poltronas de cinema) ou faz para o público que vai ao cinema em busca de emoções diferentes. O público é simples, ele quer rir, chorar, viver minutos de suspense. Não adianta tentar dar a ele um punhado de absurdos: no lugar da boca põe o olho, no lugar do olho põe a boca. Isso é para agradar intelectual (MAZZAROPI, 1976).

O ressentimento de Mazzaropi está no fato de os intelectuais reconhecerem a qualidade dos filmes do Cinema Novo, mas não a dos seus. Para o produtor, o cinema nacional só se transformará em indústria quando os espectadores brasileiros deixarem de lotar os cinemas para assistirem filmes estrangeiros e passarem a assistir filmes nacionais, e que isso só será possível quando os filmes atenderem às exigências do público, que, no final, torna-se o principal crítico, à medida que determina ou não o sucesso de um filme. 


\section{CONSIDERAÇÕES FINAIS}

É válido ressaltar que a proposta deste trabalho não é desqualificar a produção do Cinema Novo, pelo contrário. Reconhecemos que o momento político no qual esses filmes eram produzidos dificultava muito a divulgação dos mesmos, fator que pode explicar a falta de público. Censura, falta de investimento e recursos são temas importantes que estão além das margens desse artigo, mas são de fundamental importância para estudos sobre a cinematografia brasileira. A intenção deste trabalho, portanto, foi reabilitar a produção de Mazzaropi através do resgate da visão do cineasta sobre o cinema brasileiro, pois, antes de ser um empresário que visava ganhar muito por dinheiro, ele era um produtor que tinha um sonho.

Mazzaropi defendia que o seu sucesso e o seu dinheiro eram resultados do diálogo que seus filmes sempre mantiveram com o público. Ele não via cinema apenas como arte, mas também como um negócio. Nas entrevistas analisadas foi possível perceber que seus planos e desejos eram os mesmos: continuar fazendo de seu negócio a arte de entreter o púbico.

\section{REFERÊNCIAS}

ARAÚJO, I. ‘O Corintiano’ é uma das grandes comédias feitas por Mazzaropi”. Folha de São Paulo, São Paulo, 6 jun. 2013.

ARAUJO, I. De lucro certo, filmes do comediante tinham encontro marcadocom público.

’. Folha de São Paulo, São Paulo, 3 abr. 2012.

BARCELOS, C. Jeca contra o tubarão. Jornal Movimento, São Paulo, 5 de abril de 1976. BARSALINI, G. Mazzaropi: o Jeca do Brasil. São Paulo: Átomo, 2002.

BOURDIEU, P. Coisas Ditas. Tradução de Cássia R. da Silveira e Denise Moreno Pegorim. São Paulo: Brasiliense, 1994.

BRAGANÇA, M. “Jeca Tatu por Mazzaropi”. Ipotesi, Juiz de Fora, v. 13, n. 1, p. 103 116, jan./jul. 2009.

CANDIDO, A. Os parceiros do Rio Bonito. São Paulo: Duas Cidades; Ed. 34, 2001.

FASSONI, O. Sai de baixo, Mazzaropi. Folha de São Paulo, São Paulo, 8 jun. 1977.

FERRO, M. Cinema e História. Tradução de Flávia Nascimento. Rio de Janeiro: Paz e Terra, 1992.

FONSECA, Rodrigo. Documentário mostra importância de Mazzaropi. O Globo, Rio de Janeiro, 4 fev. 2013.

FRESSATO, S. B. Caipira sim, trouxa não: representações da cultura popular no cinema de Mazzaropi. Salvador: EDUFBA, 2011. 
GOFF LE, J.; NORA, P. História: novos objetos. São Paulo: Francisco Alves, 1976.

LEAL, V. N. Coronelismo, enxada e voto. São Paulo: Alfa-Omega, 1986.

LEITE, P. A Hollywood caipira. Folha de São Paulo, São Paulo, 8 jun. 1977.

LIMA, N. T. Um sertão chamado Brasil. Rio de Janeiro: Revan, 1998.

LOYOLA, I. A Contribuição de Mazzaropi para o Retrocesso. Última Hora, São Paulo, 4 fev. 1965. Cine-Ronda.

MARTINELLI, S. Vera Cruz: imagens e história do cinema brasileiro. São Paulo: Abooks, 2002.

MATOS, M. Sai da frente! A vida e Obra de Mazzaropi. Rio de Janeiro: Desiderata, 2010.

MELLO, C. Narrativas de Paulicéia: caipiras numa cidade em transformação. Fênix Revista de História e Estudos Culturais. v. 6, n. 1, jan.-mar. 2009.

MENDONÇA, S. R. As bases do desenvolvimento capitalista dependente: da industrialização restringida à internacionalização. In: LINHARES, M. Y. (Org). História geral do Brasil. Rio de Janeiro: Campus, 1998. p. 267-299.

MOREIRA, V. JK: industrialização e modelo oligárquico de desenvolvimento. In:

NÓVOA, J.; FRESSATO, S. B.; FEIGELSON, K. (Org.). Cinematógrafo - um olhar sobre a história. Salvador: EDUFBA; São Paulo: EDUNESP, 2009.

ORTIZ, R. A moderna tradição brasileira. São Paulo: Brasiliense, 1991.

PAM-FILMES. O jeca contra o capeta. Direção: Pio Zamuner e AmácioMazzaropi. Intérpretes: Mazzaropi; Geny Prado; Roberto Pirilo; Néa Simões; Fausto Rocha Jr; Rose Garcia; Jair Talarico e outros. Distribuição: PAM - filmes (SP). Duração: 105min. São Paulo: PAM-Filmes, 1975.

RAMOS, F. (Org.). História do Cinema Brasileiro. São Paulo: Art, 1987.

RODRIGUES, C. R.; SOUZA, O. R. N. Mazzaropi: a imagem de um caipira. São Paulo: Serviço Social do Comércio; Taubaté: Universidade de Taubaté/Centro de Documentação e Pesquisa Histórica, 1994.

RODRIGUES, M. O Brasil na década de 1950. 3. ed. São Paulo: Memórias, 2010.

SALEM, A. O Brasil é meu público. Revista Veja, São Paulo, 28 de janeiro de 1970.

SILVA, F. (Org.). História e imagem. Rio de Janeiro: UFRJ, 1998.

SIMONARD, P. A geração do Cinema Novo: para uma antropologia do cinema. Rio de Janeiro: Mauad, 2006.

TAVARES, Z. De pernas pro ar. Jornal Movimento, 5 abr. 1976.

TOLENTINO, C. O rural no cinema brasileiro. São Paulo: EDUNESP, 2001. 



\section{RESENHA}

Livro: FERNANDES, Ana Cristina; LACERDA, Norma; PONTUAL, Virgínia (Orgs.). Desenvolvimento, planejamento e governança: expressões do debate contemporâneo. Rio de Janeiro: Letra Capital/ANPUR, 2015. 502p.

Jondison Rodrigues - Doutorando em Desenvolvimento Socioambiental pelo Programa de Pós-Graduação em Desenvolvimento Sustentável do Trópico Úmido PPDSTU/ NAEA/UFPA. Bolsista CNPq. E-mail: jondisoncardosorodrigues@gmail.com

Simone S. C. Hoshi - Doutoranda em Desenvolvimento Socioambiental pelo Programa de Pós-Graduação em Desenvolvimento Sustentável do Trópico Úmido PPDSTU/NAEA/UFPA. Bolsista CAPES. E-mail: simonehoshi@ gmail.com

Wanderson Curcino - Mestrando em Planejamento do Desenvolvimento PPDSTU/ NAEA/UFPA. E-mail: wanc29@yahoo.com.br

Vanessa S. Amaral-Mestranda em Planejamento do Desenvolvimento PPDSTU/ NAEA/UFPA. Bolsista FAPESPA. E-mail: vs.amaral@yahoo.com

O Brasil obteve, nessa última década, grandes "avanços", seja do ponto vista econômico, seja do ponto social. O "avanço" no ponto vista econômico é expresso, por exemplo, pelo crescimento do país em 3,5\%, entre 2003 e 2013 (MARQUES; NAKATANI, 2015) - amparado nos crescentes fluxos de entrada de capitais externos e a recuperação do comércio internacional, com forte incremento das exportações, advindo do "efeito China". Do ponto vista social, esse "avanço" se visualizou com: a) o forte aumento do consumo familiar e mercado interno; b) a promoção de uma forte política social de transferência 
de renda e redução da miséria; c) a intensificação ou criação da disponibilidade de crédito para os segmentos de média e baixa da população; d) a diminuição do desemprego; e) a abertura de oportunidades de camadas populares ingressarem em universidades (MARQUES; NAKATANI, 2015).

Apesar desses "avanços" (social e econômico), as políticas de desenvolvimento regional e as políticas intersetoriais não avançaram na educação de base e na área de saúde coletiva das cidades metrópoles, médias ou pequenas, como forma de diminuir as "assimetrias" regionais e locais, principalmente SulSudeste e Norte-Nordeste.

Nesse macrocontexto de processo político e de desenvolvimento social e econômico brasileiro, o livro Desenvolvimento, planejamento e governança: expressões do debate contemporâneo traz o debate sobre o momento que o Brasil vive neste início de século XXI, a partir da dimensão econômica, política, social e cultural. O livro também "nasce” de duas outras razões. A primeira razão da construção dessa coletânea/livro deveu-se ao resultado do XV Encontro Nacional da Associação Nacional de Pós-Graduação e Pesquisa em Planejamento Urbano e Regional (ANPUR), realizado em maio de 2013, em Recife. A segunda razão deve-se à comemoração dos 30 anos da ANPUR.

O livro busca contribuir para lançar ou mudar aquilo que Alain Corbin deixa implícito (com reflexão profunda) no livro Saberes e odores: o olfato e o imaginário social nos séculos dezoito e dezenove (CORBIN, 1987), ao pontuar sobre a relevância de redefinir o insuportável ou a mudança dos odores. "Cheiros" esses emitidos/produzidos do processo de desenvolvimento econômico europeu nos séculos XVIII e XIX. Essa metáfora pode ser inserida principalmente no contexto das políticas de planejamento e desenvolvimento percorridos historicamente no Brasil e a necessidade de mudanças estruturais e conjunturais de tais estratégias de desenvolvimento econômico e social. Um ataque frontal às nossas desigualdades sociais; como forma até mesmo de não ruir os grandes torreões, templos, cidades, Babéis de orgulho e força, como assinalado no poema de Antero de Quental (no início da resenha).

O livro está divido em cinco secções articuladas: i) Planejamento, meio ambiente e conflitos territoriais; ii) Gestão e governança da cidade e da metrópole; iii) Poder, desenvolvimento e urbanismo; iv) Cultura, identidade e conservação; v) Homenagem a Ana Clara Torres Ribeiro. Essas secções apontam como público leitor pesquisadores, professores, discentes de graduação e pósgraduação, técnicos e gestores, entidades públicas e privadas em âmbito nacional e internacional envolvidos com a gestão e o planejamento.

A primeira secção, Planejamento, meio ambiente e conflitos territoriais, 
é formada por artigos de: 1) Henri Acselrad; 2) Pedro Jacobi; 3) Tamara Egler, Fabiana Oliveira e Lucas Trajano; e 4) Adriano Batista Dias. O artigo de Acselrad, Da fetichização do ambiente à sociologia da desmobilização, discorre sobre a especificidade da questão ambiental como "práticas" dos atores sociais nas disputas (sócio)territoriais, corrente na história brasileira mais recente; além disso busca situar a questão ambiental em quadros teóricos-conceituais densos. Já no contexto crise econômica e contradições capitalistas (HARVEY, 2014; MARQUES; NAKATANI, 2015) e disputas e conflitos socioterritoriais pontuadas por Acserald, o trabalho de Jacobi empreende um debate sobre a necessidade de gestar os riscos socioambientais (ancorados na discussão de "sociedade de risco", de Ulrich Beck) e medidas políticas no contexto de cada território para enfrentamento, por exemplo, das mudanças climáticas; além disso, realiza alguns apontamentos e provocações para se promover mudanças nos padrões de consumo e do consumo desigual, e consequentemente da governança do espaço urbano como forma de enfrentar "alienação universal", advindas de uma relação inconvergente entre capital e natureza (HARVEY, 2014).

Tamara Egler, Fabiana Oliveira e Lucas Trajano, em Rede no Rio: dominação e indignação, partem da indagação: Como, por quem e para quem é produzida a política pública no espaço urbano do Rio de Janeiro no contexto da globalização? Questionamento atravessado da discussão sobre a capacidade de pensar o futuro do espaço (planejamento urbano), principalmente concernente a megaeventos esportivos (EGLER, 2015), no qual o objetivo é mapear, identificar e analisar atores, processos, fatos e espaços do conflito no contexto de globalização no Rio de Janeiro.

$\mathrm{O}$ último artigo da primeira secção, $\mathrm{O}$ aquecimento global e o novo desenvolvimentismo, de Adriano Batista Dias, detalha os efeitos do aquecimento global como forma de ser considerado no planejamento, do Novo Desenvolvimentismo. O trabalho expõe e analisa a necessidade de um Estado forte para enfrentamento desse fenômeno socioambiental, no entanto conexa à necessidade de (uma tal) inovação induzidas pelo Estado.

A segunda secção é composta por artigos de Jan Bitoun; Marco Aurélio Costa; Cátia Lubambo e Suely Maciel; Suely Maria Ribeiro Leal; Eduardo Marques; Tânia Fischer, Francisco Silva e Rodrigo Soares. Jan Bitoun, no trabalho Pobreza urbana, produção e estruturação da cidade e da metrópole, debate acerca dos rumos atuais do desenvolvimento urbano e regional, pautada em uma reflexão sobre pobreza na atualidade. Bitoun ainda demonstra como essas abordagens impregnaram agentes e políticas na condução de iniciativas na cidade de Recife, direcionada para o setor da habitação de "interesse social". 
Os rumos desse desenvolvimento urbano e regional atuais são tratados no artigo de Marco Aurélio Costa, que faz uma breve recuperação da questão metropolitana do Brasil, principalmente acerca da gestão. Essa análise se ancora nos dados iniciais desenvolvidos no âmbito do projeto Governança metropolitana no Brasil, coesa à rede IPEA, que envolve mais de 15 instituições estaduais.

Cátia Lubambo e Suely Maciel descem a detalhes sobre as formas de governança metropolitana no Brasil. Apesar do trabalho das autoras não estar coeso à Rede IPEA, o artigo $\mathrm{O}$ desafio de planejar o território e as funções públicas de interesse comum para a governança metropolitana: o caso da RMR apresenta as condições "recentes" de governança da região metropolitana do Recife, nos contextos: a) político-institucional de articulação de gestores públicos, agentes econômicos, políticos e sociais; e b) os desafios de promover a gestão metropolitana. Continuando esse debate de Governança, Suely Maria Ribeiro Leal, em As veias do planejamento urbano e avalanche da governança do mercado, mostra que a governança não é tão democrática ao evidenciar de que forma o poder das imobiliárias vem afetando e atuando na produção do espaço da metrópole do Recife e retraindo o papel do macroplanejamento da metrópole e das cidades circunvizinhas e os mecanismos institucionais "democráticos" deliberados.

O debate de governança é retomado por Eduardo Marques, em Estado, atores e governança, no qual apresenta e discute elementos associados ou relacionados ao uso do conceito de governança urbana em estudos acerca de política e políticas públicas nas cidades. Além disso, busca traçar um quadro conceitual que permita a construção analítica de governança que amplie o foco de estudos de políticas no Brasil para além do governo - aproximações estatais e não estatais, em outras palavras, parcerias público-privadas; e contribua para a incorporação tais conceituações em políticas públicas urbanas das cidades.

$\mathrm{Na}$ contramão analítica do debate de governança, principalmente de Eduardo Marques, onde não há uma "debruçamento" ou desvelamento de disputas, tensões e conflitos nas políticas, planejamentos e políticas públicas, o artigo de Tânia Fischer, Francisco Silva e Rodrigo Soares Bosque das Bromélias: mobilizações do futuro - uma construção parentética investiga a possibilidade de integração e convergência de interesses de atores sociais diversos no desenvolvimento territorial, no contexto de embates e conflitos inerentes a tal construção. Os autores, como forma de tornar a proposta inteligível, "adotam” a cidade de Salvador como locus de investigação, mais precisamente o Residencial Bosque das Bromélias, Bairro "recém-criado" - formado a partir de seis empreendimentos do Programa Minha Casa Minha Vida (PMCMV).

Em sua terceira parte, assim intitulada: Poder, desenvolvimento e urbanismo, 
fica evidenciada a preocupação ao redor do poder e suas relações. Relaciona-se às questões pendentes sobre o urbanismo e a conquista do direito às cidades, por meio das políticas públicas, paternalistas ou não, mas que de alguma forma tocam para uma expectativa de crescimento ou de desenvolvimento, mesmo que esta seja feita às avessas, de modo transversal ou até mesmo no estilo top down.

"Capitaneia" essa secção Edna Castro, com o artigo Campo do desenvolvimento, racionalidade, ciência e poder - no qual, tendo como base em Bourdieu, adota como critério o campo - o campo do desenvolvimento. Nessa ordem, apresenta o desenvolvimento como ponto central, para na verdade perquirir o que, afinal, é o desenvolvimento. Categoria essa que necessita de melhor preparo, análise e investigação por meio do setor acadêmico. Desenvolvimento, na perspectiva teórico-metodológica apresentada pela autora, não se prende inocentemente e tão somente ao viés econômico que o termo poderia ensejar e que muitas vezes somente por esse ângulo é pontuado por muitos. Castro promove uma discussão desse desenvolvimento que se alastra no meio social, por meio das relações de poder entre os atores desse jogo. O jogo do poder e de poder é permeado pelos agentes governamentais, agentes mercantis e os espaços da ação coletiva - como dos movimentos sociais. Faz uma incursão na oscilação do colonialismo e do pós-colonialismo (QUIJANO, 1992), além de dinamizar o texto com pontos marcantes do que se trata e o que se tem na ecologia política, como forma de questionar o discurso eurocentrado do conhecimento ou promover uma “desobediência epistêmica” (MIGNOLO, 2008).

Martim O. Smolka e Laura Mullahy esboçam o seguimento da secção analisando o motivo pelo qual os policy makers e os acadêmicos da América Latina engajam-se de modo considerável nas políticas de terras urbanas, de modo direto ou indireto, com base em outros países - sendo díspares da realidade social brasileira, muitas vezes. Sendo assim, a proposta de arguição ancora-se na relevância para o planejamento urbano ao desvelar os infortúnios que pesam sobre os governos, planejadores e consultores urbanos na falta de eficácia das e para as boas práticas de ideias.

Em Política e urbanismo em tempo de democracia: o governo do prefeito Miguel Arraes no Recife, a autora Virgínia Pontual anuncia um texto em cadência histórica, que percorre por meio do documento A Política do Desenvolvimento do Recife Metropolitano -elaborado por Miguel Arraes, em seu mandato nos anos de 1959. O artigo percorre um "recorte histórico" cotejando as mudanças e transformações ocorridas na esfera ou escala local (metropolitano) e as dinâmicas urbano-regionais brasileira e mundial (SIQUEIRA, 2015).

Contraposto a isso, o texto de Adauto Lúcio Cardoso, Lulismo, política 
habitacional e a reestruturação do setor imobiliário: reflexões sobre o Programa Minha Casa Minha Vida, faz um histórico desde o sistema financeiro de habitação para contextualizar o nascedouro de políticas sociais voltadas para a moradia, seu ápice, ruptura e declínio - em períodos do governo Fernando Collor de Mello e Fernando Henrique Cardoso e ascensão - mote no governo Lula: o Programa Minha Casa Minha Vida (PMCMV). O texto mostra como as coalisões de última hora e de "ocasião" são capazes de criar valas socioeconômicas, juntamente com a manipulação da política governamental; e como um programa não é capaz de se autogestar.

Orlando Alves dos Santos Junior, em Mercantilização e neoliberalização das cidades brasileiras no contexto dos megaeventos esportivos: desafios na perspectiva do direito à cidade e da rebeldia criativa, reflete criticamente sobre o que megaeventos esportivos, tais como a Copa do Mundo e Rio 2016, trouxeram ou trarão de alento material para as cidades ou, subjacente a isso, o que de "pacificação e expropriação" trarão ou trouxeram (EGLER, 2015). O autor recorre à Lefevbre para exprimir o direito à cidade como mote de transformação e de insurgência a toda a panaceia criada pelo empreendedorismo neoliberal.

$\mathrm{O}$ último artigo da secção três, Investimentos em infraestrutura social no "novo desenvolvimentismo": atuação do BNDS e perspectivas futuras, de Adriana Barbosa Dantas Zeraik e Renato Berer, aborda o Banco Nacional de Desenvolvimento Econômico e Social desde o ano 2000 e as políticas de Estado cotejadas nesse período, como também em período anterior: 1952-1979, com o objetivo de estabelecer o nível diferencial entre o neodesenvolvimentismo e o desenvolvimentismo. Entre tabelas e gráficos de investimentos, os autores tentam mostrar o engajamento do BNDES em vários setores de desenvolvimento, seu incremento e decréscimo em alguns setores ao longo do período observado. Os autores afirmam que o BNDES necessita injetar e ampliar o rol de investimentos para as regiões Norte e Nordeste, sob o mote de minimizar as desigualdades sociais.

A penúltima secção do livro traz a discussão sobre cultura, identidade e conservação na cidade, com textos de Cêça Guimarães, Flavio de Lemos Carsalade, Gábor Sonkoly, José Tavares Correia de Lira, Lucia Leitão, Norma Lacerda e Kainara Lira dos Anjos. No primeiro artigo da secção, Por que Museu quando o tema é cidade?, Cêça Guimarães aponta o papel da aproximação dos campos da museologia com a da arquitetura para o processo de desenvolvimento da cidade contemporânea. O elo desta aproximação, segundo ela, se dá por meio da prática de musealização, que se diferencia da ideia de "cristalização" da história evocada no termo museificar.

A autora se utiliza da análise de alguns dos principais textos internacionais 
que trataram da questão. Desde o início, debate o planejamento urbano, passando pela captura do conceito de musealização pelo campo do patrimônio até sua interseção com o debate do espaço público e a inclusão do conceito de "comunidade". Deste modo, Guimarães nos apresenta um conceito de museu não mais sob a perspectiva da interação do público com o espaço físico da instituição e a coleção que ela abriga, mas sim que se articula com todo o seu entorno que, de alguma forma, lhe confere significado.

Flavio de Lemos Carsalade, em Cultura, identidade conservação: espaço público, sociabilidades, patrimônio cultural, segue mais além da perspectiva do entendimento da cidade. Para o autor, a questão cultural deve ser tema de ascensão na agenda do planejamento urbano, sobretudo pelo fato do engajamento de setores da sociedade na preservação do patrimônio cultural e na apropriação do espaço por diferentes "tribos urbanas" que fazem da cidade meio e palco de suas expressões culturais. Tema importante, pois no jogo de apropriações do espaço público, e impressos no planeamento das cidades, acabam por negar os usos do espaço público, ao mercadorizar os espaços.

Ainda nesse contexto espaço, mais especificamente a trajetória do conceito de paisagem histórica urbana, Gábor Sonkoly, em The critical analysis of the concepto of historic urban landscape, apresenta tal conceito como uma forma de conhecimento institucionalizado para gerir e interpretar a realidade social, econômica e cultural, engendrada pela herança cultural. Sonkoly apresenta uma discussão como um conceito atravessado por ideologias diferentes desde o século XIX, como o socialismo, o liberalismo e o totalitarismo. A sustentabilidade, como paradigma atual, veio trazer uma tentativa de conciliar esse conflito.

De patrimônio, ruínas urbanas e outsiders, texto de José Tavares Correia de Lira, expõe uma contradição importante no processo de patrimonialização das cidades: ao mesmo tempo em que o processo de desenvolvimento das cidades produz espaços de ruína, em detrimento de outros extremamente protegidos e conservados, são exatamente para esses espaços de ruína que convergem "as autoimagens citadinas, os olhares dos turistas, as reivindicações de identidade e boa parte das estratégias urbanas". Tal fato gera um conflito no seio do espaço público entre os interesses e valores por traz dos processos de patrimonialização e a presença resistente de prostitutas, drogados, mendigos, homossexuais, entre outros identificados como outsiders.

Lúcia Leitão, no artigo Nossos olhos enevoados. Sobre o ambiente construído e sua dimensão psicoantropológica: notas preliminares para uma discussão teórica, foge ao debate de Carsalade e Sonkoly. A autora discorre sobre a dificuldade, que é própria do ser humano, em enxergar a realidade e lança o 
seguinte questionamento: Por que a forma destrutiva, inerente ao humano está praticamente ausente nas discussões sobre a criação do ambiente construído? Para a autora, esta é a uma grande lacuna nos questionamentos sobre o ambiente construído ou o espaço construído. Desta forma, para sustentar os argumentos, a autora utiliza a noção de violence fondatrice ao pensar na dimensão antropológica, bem como a «pulsão de morte» para se pensar na dimensão psíquica e assim construir a discussão a respeito do ambiente construído ou edificação da cidade dos homens. A autora afirma, com base em Maffesoli, que é necessário saber gerir o "mal" para que seja possível lidar com o nosso lado de sombra. Sombra esta que está imersa no nosso inconsciente.

O texto A regulação da dinâmica espacial nos centros históricos brasileiros em tempos de globalização: o caso do Recife (Brasil), de Norma Lacerda e Kainara Lira dos Anjos, mostra a realidade da dinâmica espacial no Centro Histórico do Recife (CHR) em duas frentes. Na primeira, é possível observar o espaço sendo (re)produzido a partir da expulsão dos habitantes para a "chegada" do mercado habitacional e de comércio e serviços. Na segunda, as habitações continuaram presentes, no entanto foram produzidas novas "espacialidades e temporalidades" (relações) devido à deterioração física dos espaços.

A última secção, de Lilian Fessler Vaz, intitulado Viva a vida! Uma homenagem a Ana Clara Torres Ribeiro faz uma reflexão com base na expressão usada por Lilian Vaz: «Viva a vida!». A autora afirma, ancorada em Ana Clara Torres Ribeiro, que é preciso problematizar a vida como objeto de pesquisa, uma vez que a causa ecológica alcança apoio, mas a antropológica ainda se mantém desconhecida ou lhe é dada pouca importância.

O livro traz vários pontos reflexivos interessantes, como já discorridos, mas também traz um problema epistêmico e político sério: o uso e a inserção do termo político-ideológico chamado Governança. Palavra mágica da democracia, de ordem de consenso e não conflito, e da criação de uma nova linguagem, que visa facilitar a disseminação da lógica neoliberal e o livre exercício da economia mundial globalizada - uma forma de adoção de formas múltiplas de autoritarismo disfarçado (padrão político homogeneizante), capitaneada pelo Banco Mundial (GALLON; SEVERO, 2015). Esse problema permite que o livro caia em contradição, uma vez que faz reflexões e apontamentos para novos horizontes políticos, econômicos e sociais que perpassariam por mudanças estruturais, institucionais e sociopolíticos impressos em políticas de desenvolvimento e planejamento do Estado brasileiro.

Em síntese, a recomendação da leitura do livro não está em confirmar os tópicos (pontos interessantes) e as críticas discorridos aqui (muitas vezes 
implícitas), mas ser um elemento reflexivo crítico construtivo de pensar ou repensar todos os sistemas de percepções, compreensões e dinâmicas de desenvolvimentos e os planejamentos regionais e urbanos no Brasil e as tensões e conflitos nas cidades.

\section{REFERÊNCIAS}

CORBIN, Alain. Saberes e odores: o olfato e o imaginário social nos séculos dezoito e dezenove. São Paulo: Companhia das Letras, 1987.

EGLER, Tamara. Pacificação e expropriação no jogo olímpico. Novos Cadernos NAEA, v. 18, n.1, 2015.

GALLON, S.; SEVERO, M. B. Debate teórico em torno do tema governança: reflexões preliminares. Critica e Sociedade: revista de cultura política, v. 5, n.1, p.58-71, 2015.

HARVEY, David. Diecisiete contradicciones y el fin del capitalismo. Quito: Editorial IAEN, 2014.

MARQUES, Rosa Maria; NAKATANI, Paulo. The strength and fragility of the brazilian economy. Montly Review, v. 67, n. 01, p.17-31, 2015.

MIGNOLO, Walter D. Desobediência epistêmica: a opção descolonial e o significado de identidade em política. Cadernos de Letras da UFF, n. 34, p. 287-324, 2008.

QUIJANO, Anibal. Colonialidad y modernidad-racionalidad. In: BONILLIA, Heraclio (Comp.). Los conquistados: 1492 y la población indígena de las Américas. Quito: Tercer Mundo Editores. p. 437-447, 1992.

SIQUEIRA, Hipólita. Novo desenvolvimentismo e dinâmica urbano-regional no Brasil (2004-2012). EURE, v.41, n.122, p.261-277, 2015. 



\section{Teses Dissertações defesas no NAEA em 2015}

\section{TESES}

Desenvolvimento sustentável e uso dos recursos naturais em áreas de várzea do território do baixo Tocantins da Amazônia paraense: limites, desafios e possibilidades.

Autor: Adebaro Alves dos Reis

Orientador: Prof ${ }^{\mathrm{a}}$. Dr ${ }^{\mathrm{a}}$. Oriana trindade de almeida

Resumo: A tese teve como objetivo central entender e analisar a dinâmica de uso sustentável dos recursos naturais pelas populações caboclo-ribeirinhas a partir da observação sobre o cotidiano, do modo de vida, do uso dos recursos naturais e do processo de produção diversificada. Assim, buscou-se, a partir do debate teórico, desenvolver uma crítica à ciência moderna, com especificidade para a racionalidade instrumental, que promoveu a framentação da relação entre homem e natureza. Ao mesmo tempo, introduziu-se a abordagem da interdisciplinaridade como uma possibilidade de articulação das diferentes áreas de conhecimento para uma intervenção sob a perspectiva das dimensões da vida social e natural. O estudo para a elaboração da tese teve como universo o Território do Baixo Tocantins, considerando-se os ecossistemas de várzea dos municípios Abaetetuba e IgarapéMiri, em seus componentes, considerados estratégicos como: comunidades ribeirinhas, agroecossistema e população ribeirinha, constitutivos das margens do rio Tocantins. Para isso, reconstitui-se de modo sintético, a trajetória histórica desse território por meio da ocupação, desenvolvimento e uso dos recursos naturais, os quais foram analisados a partir das dinâmicas produtivas adaptativas e uso dos recursos naturais em suas múltiplas atividades de manejo do ecossistema de várzea voltadas para produção e manejo do açaí, sistemas agroflorestais (SAFs), agricultura, criação de pequenos e médios animais, criação de peixe, extrativismo vegetal e animal, pesca de camarão e peixe no ecossistema de várzea. Essas práticas de uso dos recursos naturais, tradicionalmente empregadas pelos 
habitantes das áreas de várzea, fazem parte de um modo de vida. As estratégias de diversidade produtiva, manejo e uso múltiplo dos recursos naturais seguem os ritmos impostos pela natureza da capacidade adaptativa em relação com as condições naturais das áreas de várzea.

Palavras-chave: Desenvolvimento. Sustentabilidade. Ecossistema. Várzea. Ribeirinhos. Amazônia.

\section{Expansão da fronteira agropecuária do oeste paulista para a Amazônia: a trajetória das famílias Ometto e da Riva e a colonização do Norte Mato- Grossense}

Autor: Armando Wilson Tafner Junior

Orientador: Prof. Dr. Fabio Carlos da Silva

Resumo: A expansão da fronteira agropecuária em direção ao Oeste do Brasil, teve início com o seu descobrimento em 1500. Após a procura pelo pau-brasil, foi implanta pelos portugueses na região Nordeste a produção de açúcar derivado da cana. Já na região sudeste, como a produção de cana-de-açúcar não deu certo, a ocupação se deu por meio das bandeiras. O fenômeno continuou em direção ao Oeste com a descoberta do ouro e com a acumulação de capital advindo da cafeicultura. Posteriormente, aproximadamente quatro séculos e meio após a descoberta do Brasil, o governo federal incentivou a ocupação da Amazônia, primeiro na Era Vargas, década de 1930, com a Marcha para o Oeste e em um segundo momento, já na década de 1960, com a política de incentivos fiscais, coordenada pelo governo militar e intermediada pela SUDAM, que privatizou as florestas, entregando-as aos capitalistas do Centro-Sul, principalmente os paulistas. Um desses capitalistas, pioneiros no recebimento de incentivos fiscais, foi a família Ometto que montou um império por meio de usinas sucroalcooleiras espalhadas pelo interior de São Paulo. A família Ometto era sócia de Ariosto da Riva no empreendimento denominado de Agropecuária Suiá-Missú S/A, localizada no então distrito de São Félix do Araguaia, pertencente ao município de Barra do Garças. Ariosto da Riva vendeu sua parte ao Grupo Ometto e adquiriu terras ao Norte do Estado de Mato Grosso, promovendo colonização privada no município que denominou de Alta Floresta. Em ambos os casos, o conflito de interesses entre, aqueles que já estavam instalados ou vieram se instalar na região amazônica posteriormente, com os dos capitalistas que passaram a ser os donos da terra, foi inevitável. Tensões sociais ocorreram, prolongando-se por décadas, e o discurso do desenvolvimentismo utilizado para povoar a região promoveu 
a insustentabilidade, fazendo acontecer impactos socioambientais e culturais difíceis de serem revertidos.

Palavras-chave: Frente de expansão. Frente pioneira. Latifúndio. São Félix do Araguaia. Alta Floresta. Sustentabilidade.

\section{Estrutura e impacto da expansão da agroindústria canavieira sobre o mercado de terras no estado do Acre, Amazônia ocidental - Brasil}

Autor: Eloi Biquer Silva Rosa Gomes

Orientador: Prof. Dr. Francisco Carlos da Silveira Cavalcanti

Resumo: O presente estudo trata da questão de mercado de terras rurais no Estado do Acre na Amazônia brasileira, foi selecionada uma região (a do Baixo Acre) especificamente para estudo de caso. O objetivo é estudar o impacto da expansão da agroindústria canavieira sobre o mercado de terras rurais na região do Baixo Acre no período de 2007 a 2013. Analisamos o impacto sobre variação de preços de terras, os efeitos sobre a ocupação do solo das principais culturas alimentares e nas oscilações do preço do etanol praticado no Estado. Utilizamos para estudo analítico o banco de dados da UNICA, IBGE, FNP/Agrianual que é um banco de dados que fornece as informações sobre preço de venda de terras de lavouras, pastagens e preços de arrendamentos por Estados e regiões do Brasil. O estudo permite concluir que apesar do avanço da área ocupada com a cultura da cana-de-açúcar na região, a redução da ocupação do solo concentrase especificamente nas culturas de feijão e do arroz que tiveram uma diminuição significativa de área plantada, por outro lado houve um aumento considerável das áreas de plantio de mandioca e de milho. Houve uma valorização considerável de terras rurais, nos primeiros anos das atividades da usina, os preços praticados na região do Baixo Acre chegaram a ser um dos mais caros do país, ficando apenas atrás do estado do Amapá. O estudo demonstrou que houve um aumento nas taxas do desmatamento não só na região, mas em todo o estado do Acre, inclusive em áreas de conservação ambiental, Reservas Extrativistas e terras indígenas. Ainda, o estudo nos permite concluir que a hipótese levantada de que a produção local de etanol tenderia a influenciar a redução do preço do álcool no estado não vem se confirmando, paradoxalmente, mesmo com a entrada em funcionamento da usina, o Acre continua a ser o estado com preço mais alto do etanol no país, e a perspectiva de aumento da produção nos próximos anos não deve verificar a redução nos preços do etanol porque a tendência é que o cenário no mercado nacional e internacional continuará aquecido nos próximos anos.

Palavras-chave: Mercados de Terras. Amazônia. Acre. Cana-de-açúcar. 


\title{
Organizações regionais indígenas, cidadania e tecnologias de (des)
} informação e (in)comunicação na Pan-Amazônia

\author{
Autor: James Leon Parra Monsalve \\ Orientador: Prof ${ }^{a}$. Dr ${ }^{\mathrm{a}}$. Rosa Elizabeth Acevedo Marin
}

Resumo: A Amazônia é uma extensa área sul-americana, compartilhada por oito países e um departamento ultramarino francês. Ela é hoje conhecida amplamente pela sua diversidade socioambiental. A existência de indígenas e outros povos tradicionais, ao longo desse território, tem sido historicamente decisiva para a conservação de formas comuns de acesso e usufruto da terra. Nesse contexto, os movimentos indígenas têm desenvolvido uma importante tarefa de estruturação organizativa, especialmente a partir da década de 1970, com o fim de reivindicar tais direitos no âmbito do estado-nação. Constituíram-se, assim, novos agentes organizacionais em luta pelo reconhecimento pleno de seu status cidadão em países como Bolívia, Equador, Peru, Colômbia, Venezuela e Brasil. Como consequência dessa articulação organizativa e, mais ainda, da resistência histórica das populações indígenas ao extermínio físico e simbólico, as novas constituições políticas nesses estados reconheceram o caráter étnico e multicultural de suas sociedades. Surgiram, desse modo, entidades de índole étnicoregional como a Confederação de Povos Indígenas do Oriente, Chaco e Amazônia da Bolívia (CIDOB), a Coordenação das Organizações Indígenas da Amazônia Brasileira (COIAB), a Organização dos Povos Indígenas da Amazônia Colombiana (OPIAC), a Confederação das Nacionalidades Indígenas da Amazônia Equatoriana (CONFENIAE), a Associação Interétnica de Desenvolvimento da Selva Peruana (AIDESEP) e a Organização Regional de Povos Indígenas do Amazonas (ORPIA) na Venezuela. Organizações que chegam no século XXI com a responsabilidade de reivindicarem os direitos dos múltiplos povos que representam, tendo ao seu alcance novas ferramentas como as Tecnologias de Informação e Comunicação (TICs), as quais poderiam, em graus diversos, alavancar esse objetivo social. Este estudo comparativo permite compreender a relação das reivindicações étnicas cidadãs com o saber comunicacional indígena e o modo em que elas produzem informação e comunicação.

Palavras-chave: Organizações indígenas. Amazônia. Cidadania. Tecnologias de informação e comunicação. Comunicação transdisciplinar. 


\section{Entre "rejeitos", riscos e resíduos: Perspectivas e desafios no gerenciamento de resíduos em hospitais públicos do Estado do Pará}

Autor: Jocileide de Sousa Gomes

Orientador: Prof. ${ }^{a}$ Dr. ${ }^{a}$ Edna Maria Ramos de Castro

Resumo: Os resíduos dos Serviços de Saúde, especialmente os resíduos hospitalares, configuram-se como importante objeto de análise por envolverem questões ambientais complexas, que dialogam com a desafiadora relação consumo e descarte ambientalmente adequado e, sobretudo, com a minimização dos potenciais riscos à saúde ambiental, ocupacional e coletiva. Considerando o instrumental normativo que norteia as ações voltadas à sustentabilidade no gerenciamento desses resíduos, esta tese objetivou identificar as perspectivas e desafios da Comissão de Gerenciamento de Resíduos de três hospitais públicos do Estado do Pará em atender ao que se é instituído legalmente. Por intermédio de técnicas e instrumentos metodológicos para análise dos dados, como pesquisa de campo e documental, entrevistas e observação participante, evidenciou-se fragilidades política, social, econômica e técnica entre os membros responsáveis pela minimização, reutilização, reciclagem e destinação ambientalmente correta dos resíduos gerados pelas suas respectivas instituições hospitalares. A partir das contribuições analíticas do referencial teórico-metodológico utilizado, constatouse que o interesse econômico, aliado à rejeição às mudanças demandadas pelo gerenciamento de resíduos, sobressai aos interesses voltados à prevenção e diminuição de riscos que estes podem representar para a saúde global. A identificação de regras "além do jogo" também permitiu desnudar a visibilidade e efetividade do gerenciamento de resíduos.

Palavras-chave: Hospitais Públicos. Resíduos de Serviços de Saúde. Comissão de Gerenciamento de Resíduos. Riscos em Saúde.

Conhecimento técnico e a regulação ambiental na Amazônia: a utilização da bacia hidrográfica nos EIA/RIMA das UHE do rio Madeira e de Melo Monte

Autor: Junior Hiroyuki Ishihara

Orientador: Prof. ${ }^{a}$ Dr. ${ }^{a}$ Nirvia Ravena

Resumo: O presente estudo analisou os Estudos de Impacto Ambiental - EIA/RIMA de empreendimentos hidrelétricos buscando verificar se os 
que o elaboraram estes estudos utilizam a bacia hidrográfica como categoria analítica nas análises hidrológicas dos impactos socioambientais, segundo suas especificações técnicas e científicas. Foi analisada a utilização da bacia hidrográfica como categoria analítica espacial nos EIAs/RIMAs das UHE do Madeira (Jirau e Santo Antônio) e Belo Monte nas seções dos EIAs relativas às análises ambientais e socioeconômicas. Metodologicamente, a pesquisa se pautou no método dedutivo, partindo de uma generalização da validação científica da bacia hidrográfica enquanto categoria analítica que incorpora a interdependência entre os meios físico, biológico e socioeconômico dos estudos socioambientais para a análise de sua utilização nos EIA de Belo Monte e do complexo Madeira. O estudo admitiu como pressuposto que os principais instrumentos regulatórios do EIA/RIMA das respectivas hidrelétricas são imprecisos nas suas exigências quanto a prescrição detalhada das áreas de influências (CONAMA 001/86 e Termo de Referência), nesses instrumentos, o estudo identificou clara a exigência em se utilizar a bacia hidrográfica nos respectivos estudos. A pesquisa revelou que os EIA/RIMAs das referidas hidrelétricas através da realização de várias fragmentações nas áreas das bacias hidrográficas manipularam a visão sistêmica do conceito, violando a exigência do CONAMA 001/86 que prescreve o estudo de todas as alternativas tecnológicas e locacionais de projeto, incluindo inclusive a não execução do projeto. As análises apresentadas mostram que pela fragilidade nas prescrições dos regulamentos ambientais e pela sistemática do licenciamento ambiental onde quem paga é o próprio empreendedor, indicam que as omissões nos impactos socioambientais que se fazem presente no EIA/ RIMA são intencionais, tendo como um de seus artifícios a manipulação das áreas de influência, não contemplando de forma adequada a delimitação física natural da bacia hidrográfica em suas respectivas escalas.

Palavras-chave: Bacia Hidrográfica. Regulação Ambiental. EIA/RIMA. Hidrelétricas. Amazônia

\section{Determinantes das estratégias inovativas a partir da interação universidade- empresa: uma análise comparativa entre brasil e amazônia legal}

Autor: Leandro Morais De Almeida

Orientador: Prof. ${ }^{a}$ Dr. ${ }^{a}$ Ana Paula Vidal Bastos

Resumo: Nas últimas décadas, diversos estudos e pesquisas empíricas têm apontado para a crescente importância das instituições cientificas para o 
desenvolvimento tecnológico de empresas, países e regiões. Seguindo essa perspectiva, esta tese tem como objetivo principal analisar a dinâmica da interação universidade/empresa no Brasil e na Amazônia Legal buscando evidenciar a contribuição dessas instituições para o desenvolvimento da inovação. A análise enfoca os impactos da interação para o desempenho inovativo das empresas além de avaliar como esse desempenho se diferencia dependendo da região em que esses fluxos se estabelecem. Para tanto, foram utilizados dados da pesquisa nacional interação universidade/empresa no Brasil. Com esse conjunto de dados foi elaborada uma análise descritiva referente às variáveis abordadas no questionário, comparando Brasil e a Amazônia Legal, além da aplicação do modelo econométrico Logit multinomial. Os resultados obtidos confirmam a hipótese principal levantada no estudo de que a interação apresenta-se como um determinante das estratégias inovativas adotadas pelas empresas. Os dados demonstram que as fontes de recursos e de informações técnicas oriundas das universidades são relevantes para o desenvolvimento de inovações novas para as empresas, mas não para o país nem para o mundo enquanto que as patentes universitárias, por sua vez, são relevantes para o desenvolvimento de inovações em produto para o mundo. $\mathrm{O}$ estudo também indicou que fatores inerentes à empresa como investimento em Pesquisa e Desenvolvimento (P\&D) interno e origem do capital são determinantes para a estratégia inovativa destas, enquanto o setor tecnológico não se apresenta como um componente relevante. Os resultados apontam ainda a existência de diferenças significativas nas estratégias inovativas realizadas na Região Amazônica, frente às demais regiões brasileiras, evidenciando padrões de interação em regiões periféricas.

Palavras-chave: Universidades. Institutos de Pesquisa. Empresas. Inovação

\section{O não-lugar do outro: Sistemas migratórios e transformações sociais em Barcarena.}

Autor: Marcel Theodoor Hazeu

Orientador: Prof. ${ }^{a}$ Dr. ${ }^{a}$ Edna Maria Ramos de Castro

Resumo: Esta pesquisa buscou analisar a possibilidade de estudar transformações sociais em relação a sistemas migratórios no contexto da instalação e da operacionalização de um complexo industrial-portuário-urbanístico no município de Barcarena, na Amazônia. Esta abordagem foi primeiramente aplicada numa releitura da história social da formação de Barcarena, em que se chegou a 
identificar vários sistemas migratórios que contribuem para novas interpretações sobre as transformações sociais históricas no município. A partir das experiências e relatos dos moradores (recolhidas através de entrevistas semiestruturadas e observação participativa) em torno do complexo, documentos oficiais e dados estatísticos inéditos, foram identificados quatro sistemas migratórios, definidos como "metropolização", "circulação de mercadorias", "mobilidade do trabalho" e "deslocamentos forçados e des-re-apropriações". A análise destes sistemas evidencia estratégias atrás das transformações sociais em curso, caracterizado pela periferização do entorno dos portos e indústrias, ampliação da infraestrutura e dinâmica de logística para transformação primária de minérios, e exportação de uma crescente variedade de produtos. São estratégias governamentais e empresariais, como a retirada de investimentos nas comunidades, a manutenção de ameaças permanentes de desapropriações e a sub-não-contratação da população local nas indústrias e portos. As resistências se limitam à disputa por (titulação de) terras consideradas de interesse secundário para as empresas. Barcarena se tornou um município globalizado, quase sem ingerência local. A necessária inversão desta lógica parece distante neste momento.

Palavras-chave: Sistemas migratórios. Transformação social. Des-reapropriações. Metropolização. Mobilidade do trabalho.

\section{Governança ambiental e turismo - análise dos parques nacionais: Amazônia, Chapada das Mesas (Brasil) e Tortuguero (Costa Tica)}

Autor: Monica de Nazare Ferreira de Araujo

Orientador: Prof. ${ }^{\text {D Dr. }}$ Ligia Terezinha Lopes Simonian

Resumo: O tema desta tese trata dos processos de governança ambiental e suas relações com o turismo em áreas protegidas e em seu entorno. Seu eixo central consiste em procurar respostas que dizem respeito a como os atores sociais participam, de algum modo - direta ou indiretamente -, se articulam e promovem ações coletivas em parques nacionais. Tal investigação parte do princípio hipotético de que, apesar de as bases que instauram um processo de governança ambiental em parques nacionais serem fincadas pelo Estado, a participação social é condição determinante tanto para a preservação de seu ecossistema quanto para a dinamização do turismo ecológico. A tese foi sistematicamente articulada a ter em vista o objetivo de analisar, comparativamente, a construção da governança ambiental sob a perspectiva da ação coletiva nos: Parque Nacional da Amazônia 
(Pará e Amazonas), Parque Nacional da Chapada das Mesas (Maranhão), ambos no Brasil, e Parque Nacional Tortuguero, na Costa Rica, a considerar, principalmente, o que é realizado por diversos atores sociais no que respeita à conservação e ao turismo sustentáveis. Para tanto, fundamentou-se em teorias que discutem o conceito e a aplicação da governança ambiental, bem como suas conexões com o turismo em unidades de conservação, sob a perspectiva da sustentabilidade. A tese se sustenta na pesquisa qualitativa - pesquisa de campo para coleta de dados - com auxílio de fontes documentais e bibliográficas. Para ilustrar determinadas circunstâncias, durante a pesquisa de campo, recorreu-se a iconografias locais. Concluiu-se, em síntese, que a dinâmica da participação de definidos atores sociais nessas unidades de conservação é determinante para os rumos do processo de governança e seus reflexos na proteção da biodiversidade, bem como no turismo.

Palavras-chave: Governança ambiental. Turismo. Atores sociais. Parques nacionais

\section{Restrições à modernização e ampliação dos serviços de água e esgotamento sanitário: um estudo da eficiência na provisão dos serviços}

Autor: Raphael de Paiva Barbosa

Orientador: Prof. ${ }^{a}$ Dr. ${ }^{a}$ Ana Paula Vidal Bastos

Resumo: Esta tese analisou a atual estrutura de provisão dos serviços de água e esgotamento sanitário no Brasil e no estado do Pará, a partir de suas características econômicas, físicas e legais. As características técnicas e econômicas demonstram a necessidade da adoção de mecanismos de regulação das atividades como forma de aumentar a eficiência e a qualidade dos serviços ofertados. Os resultados dos modelos DEA, evidenciam que a oferta dos serviços de saneamento no Brasil e no estado do Pará, encontrase comprometida pelo baixo desempenho dos prestadores regionais. Consequentemente, as possibilidades de melhorias apresentadas na análise de Benchmarking comprovam que com a adoção de melhores práticas produtivas pelas companhias ineficientes, seria possível alcançar significativos incrementos tanto no quantitativo de unidades ligadas à rede de saneamento, quanto no comprimento total da malha de distribuição de água e de coleta de esgoto, a partir da mesma Despesa de Exploração. No caso específico da Companhia de Saneamento do Estado do Pará, verifica-se que além do escore de eficiência muito abaixo da média nacional, nos dois períodos, a companhia apresentou a conjunção de ineficiências técnicas e de escala. Ou seja, além de 
ofertar serviços de água e esgoto por rede geral muito aquém do compatível com as suas despesas, e com arrecadação menor que a desejável, a COSANPA atuava em uma escala abaixo da ótima. A partir da análise comparativa da eficiência das Empresas Privadas e das Sociedades de Economia Mista com Administração Pública, percebe-se uma ligeira vantagem das companhias privadas na provisão dos serviços, influenciada, principalmente, por sua maior capacidade arrecadadora e de atendimento de esgoto por rede geral, justamente, o serviço com a maior demanda por investimentos. Por fim, fica evidenciada a relação direta entre os escores de eficiência do modelo e o acesso aos serviços de saneamento.

Palavras-chave: Saneamento Básico. Modelos DEA. Benchmarking. Eficiência. COSANPA

\section{Metrópole e região na Amazônia: Concepções do planejamento e da gestão metropolitana em Belém, Manaus e São Luís.}

\section{Autor: TIAGO VELOSO DOS SANTOS \\ Orientador: Prof. Dr. Saint-Clair Cordeiro da Trindade Junior}

Resumo: Esta proposta tem como objetivo analisar a relação entre metrópole e região na Amazônia brasileira. A discussão clássica que afirma as dimensões da cidade e da região, recompõe-se diante da nova dinâmica socioespacial de metropolização do espaço, exigindo um novo olhar sobre a relação estabelecida entre elas. Tal processo de metropolização, entretanto, não se caracteriza por revelar uma possível particularidade em nível macrorregional. A configuração de uma fronteira econômica que se expande de forma desigual e diferenciada no interior da Amazônia é responsável também pela formação de distintas sub-regiões. As metrópoles que aí se formaram são produto, condição e meio desse movimento de diferenciação, que pode ser exemplificado através das aglomerações de Belém, Manaus e São Luís. Considerando elementos como a relação que estabelecem com a região, a estrutura intraurbana e a forma de institucionalização das mesmas, busca-se mostrar a importância e o significado dessas formações metropolitanas em face de processos diferenciados de produção do espaço regional. E, embora sejam produto, condição e meio de produção e reprodução de relações no interior de um contexto regional específico na Amazônia, não há, no padrão de ordenamento institucional para as metrópoles, políticas de planejamento e gestão que consigam configurar arranjos institucionais para que estas particularidades sejam um componente articulador do desenvolvimento urbano nestes centros

Novos Cadernos NAEA • v. 18 n. $3 \cdot$ p. 319-350 • set-dez. 2015 
metropolitanos. Essa afirmação pode ser verificada a partir da análise das características das políticas de planejamento e gestão desses espaços, que, em regra, reproduzem arranjos institucionais metropolitanos executados para outras regiões do País, sendo o maior exemplo disso a institucionalização de regiões metropolitanas de forma bastante semelhante à de outros aglomerados, que apresentam mais distanciamento que proximidade em relação às particularidades amazônicas. Essa característica resulta no estabelecimento de instrumentos de planejamento e gestão com graus e níveis de eficiência e eficácia questionáveis, tendo em vista o seu padrão de implementação.

Palavras-chave: Amazônia. Metropolização. Região Metropolitana. Belém. Manaus. São Luís.

\section{Modelos de desenvolvimento econômico e ordenamento territorial na Amazônia: rupturas e continuidades no corredor Açailândia - São Luís (MA)}

Autor: Welbson do Vale Madeira

Orientador: Prof. Dr. Saint-Clair Cordeiro da Trindade Júnior

Resumo: Analisam-se nesta tese os principais modelos de desenvolvimento econômico propostos para a Amazônia brasileira que tiveram as políticas de ordenamento do território como elemento central, com o objetivo de identificar rupturas e continuidades entre os mesmos. Inicialmente são explicitadas as referências teóricas e metodológicas da análise, nas quais se destaca a teoria do desenvolvimento geográfico desigual. A partir dos referenciais indicados, analisamse as bases dos planos desenvolvimentistas propostos no Brasil desde a década de 1970, ou seja, as teorias de desenvolvimento regional, a noção de inserção competitiva dos países e a noção de desenvolvimento sustentável. Em seguida, tendo a Amazônia brasileira como referência empírica, analisam-se materializações desses elementos em planos e programas, centrados sucessivamente em polos de crescimento, eixos nacionais de integração e desenvolvimento e zoneamento ecológico-econômico. $\mathrm{Na}$ sequência, analisam-se as aplicações desses planos a partir da década de 1980 em uma área mais específica, denominada corredor Açailândia-São Luís, no Estado do Maranhão. Em função do que se pôde apurar, contrariando os discursos oficiais, conclui-se que os polos, os eixos e os zoneamentos apresentam mais elementos em comum do que rupturas entre si. Ao mesmo tempo, identifica-se que a noção de desenvolvimento sustentável 
e os zoneamentos são acompanhados de contradições, materializadas em leis e nos processos de estabelecimento de unidades de conservação, infraestrutura para grandes projetos e demarcação de terras indígenas e de comunidades ditas tradicionais. Essas contradições, por seu turno, favorecem o surgimento de conflitos e a elaboração de novas referências de desenvolvimento e de ordenamento territorial. E o que é mais importante: estimulam práticas e lutas de setores organizados da sociedade que vão de encontro à dinâmica de produção capitalista de espaço, essência dos três modelos de desenvolvimento analisados.

Palavras-chave: Desenvolvimento econômico. Desenvolvimento geográfico desigual. Ordenamento territorial. Amazônia brasileira. Corredor Açailândia-São Luís. 


\section{DISSERTAÇÕES}

Políticas públicas educacionais em áreas de RESEX marinha: caso Gurupi-Piriá/Viseu-PA

Autor: Adria Macedo dos Santos

Orientador: Prof. ${ }^{\text {D Dr. }}$ Ligia Terezinha Lopes Simonian

Resumo: Esta dissertação objetiva compreender como a criação de Reservas Extrativistas (RESEX) vem influenciando na elaboração de políticas públicas, especialmente as educacionais, em condição de contemplar as necessidades e perspectivas das populações que vivem dentro das comunidades praianas da RESEX Gurupi-Piriá de Viseu. Objetiva-se, ainda, identificar as implicações políticas, socioeconômicas e ambientais com a criação desta Unidade de Conservação para as comunidades praianas de Viseu. Este estudo baseia-se em levantamento de dados bibliográficos e documentais - relatórios, fotografias e mapas - e pesquisa de campo para a coleta de dados. Com base nas evidências produzidas, descrevem-se os desdobramentos gerados pela instituição da RESEX a partir de algumas políticas públicas educacionais desenvolvidas recentemente naquele município. Evidenciamse conflitos, pressões e dificuldades para a concretização da sustentabilidade no contexto estudado, bem como, desvela-se a realidade educacional vivenciada em Unidades de Conservação no cenário amazônico.

Palavras-chave: Política Educacional. Sustentabilidade. Reserva Extrativista Marinha. Educação para a Sustentabilidade

Entalhadores do Efêmero: a vida associativa na criação dos Brinquedos de Miriti de Abaetetuba

Autor: Amarildo Ferreira Junior

Orientador: Prof. Dr. Silvio José de Lima Figueiredo

Resumo: Esta pesquisa analisa as relações sociais que ocorrem no processo criativo desenvolvido pelos artesãos que produzem os denominados Brinquedos de Miriti de Abaetetuba, referenciados como artesãos de miriti, e demonstra de que forma se organizam socialmente em torno de seu(s) processo(s) de criação e como constroem as estruturas de proximidade que conformam sua vida 
associativa. Caracterizado como uma pesquisa interdisciplinar, este estudo realiza uma intersecção teórico-metodológica cujo marco referencial é a abordagem do Campo Social, associada ao uso do estudo dos ajuntamentos e das interações sociais. Realizada no município de Abaetetuba (Pará), coletou dados em trabalhos de campo mediante o uso das técnicas de entrevista não diretiva, entrevista diretiva e observação direta, com prévia pesquisa bibliográfica. Em seu decorrer, o estudo apresenta os processos identitários e criativos que caracterizam a vida associativa dos artesãos de miriti, a dinâmica da vida associativa no Campo de Relações no Artesanato de Miriti de Abaetetuba, e a descrição das ocasiões sociais compósitas que nele ocorrem. Finalmente, conclui que a vida associativa dos artesãos de miriti se desenvolve a partir de seus núcleos criativos familiares e conflui com uma série de significados e práticas para as ocasiões sociais em que se inserem, permitindo-lhes manter-se e reproduzirem-se no Campo de Relações ao reconhecerem mais suas próprias determinações do que as intervenções e imposições dos agentes responsáveis pelo controle mercadológico e pelas políticas públicas por reatualizarem e recontextualizarem práticas próprias de seu modo de vida e de seus saberes e fazeres.

Palavras-chave: Artesãos de miriti. Vida associativa. Processo criativo. Campo de relações.

\section{Economia madeireira: dificuldades de regulação e efeitos sobre quilombolas no arquipélago do Marajó}

Autor: Daiana Brito dos Santos

Orientador: Prof. ${ }^{a}$ Dr. ${ }^{a}$ Rosa Elizabeth Acevedo Marin

Resumo: A partir do debate a respeito da regulação e institucionalização do mercado madeireiro na Amazônia paraense com vistas aos dados dos autos de infrações de flora do IBAMA, Relatórios do IDEFLOR, SUDAM e mapa da cartografia social elaborada pelos quilombolas de São Sebastião do Cipoal, o presente estudo propõe compreender as dificuldades por parte do Estado para estabelecer o controle e regulação da exploração madeireira e indicar os atos dos agentes econômicos visados pelos instrumentos de controle, sobretudo no arquipélago do Marajó. Constata-se que, o posicionamento do Estado face à atividade madeireira clandestina não se direciona para a regulação eficiente desse mercado, bem como carece de políticas públicas eficientes para solucionar os conflitos territoriais e combater o desmatamento. A exigência legal do projeto 
de manejo para exploração florestal não significa que essa exploração ocorre de maneira equilibrada do ponto de vista da extração racional do recurso florestal e do próprio uso da terra que se revela mascarada por - ações de sustentabilidade Grandes agentes madeireiros com selos - verdes - devastam a floresta e os números de autos de infrações são cada vez mais elevados.

Palavras-chave: Economia Madeireira. Regulação. Desmatamento. Quilombolas. Portel. Arquipélago do Marajó.

\section{Politicas públicas e as pequenas empresas no cenário da mineração: o setor de gemas e jóias de Belém.}

\section{Autor: Debora Almeida Chaves}

Orientador: Prof. Dr. Armin Mathis

Resumo: O presente estudo tem como seu objeto a intervenção do Estado, através das políticas públicas, para um dos setores da economia mineral do estado do Pará. Tomando como recorte empírico o setor de gemas e jóias que se desenvolve na cidade de Belém, em virtude de se apresentar com a melhor organização e estrutura para a realização da pesquisa. Diante disso formulou-se como problemática: Como as intervenções do Estado, através de suas políticas públicas, impactam no setor de gemas e jóias de Belém e de que forma isto rebate em prol do desenvolvimento regional endógeno? Uma vez que competiria a esse setor contribuir para mudanças quanto a cenário da economia mineral do estado através da verticalização da produção de metais preciosos e gemas encontradas no subsolo paraense. Como objetivo geral procurou analisar como e de que forma as políticas públicas (elaboradas e implementadas pelo Estado) implicam para desenvolvimento do setor de Gemas e Jóias de Belém. Utilizou-se a abordagem sistêmica e a metodologia sob a ótica da Teoria Sistemas Sociais de Niklas Luhmann, enfatizando a) sistemas autorrefenciados/autopoieticos; b) observador de $2^{\text {a }}$ ordem. A estratégia de pesquisa adotada foi estudo de caso associada a pesquisa documental. E como técnica de coleta de dados: entrevistas semi estruturada e questionário. Os resultados demonstram que mesmo o estado do Pará dispondo de uma política pública setorial para o fomento de desenvolvimento do setor de gemas e jóias, tal ainda não consegue concretizar a ideia seminal de verticalizar a produção mineral e que essa política pública se apresenta como um ciclo vicioso não sendo capaz, ainda, de gerar efetividade de suas ações.

Palavras-chave: Políticas Públicas. Desenvolvimento Regional. Gemas e Jóias. 


\title{
Feiras-livres \& feiras de exposição: expressões da relação cidade-floresta no sudeste paraense.
}

\author{
Autor: Debora Aquino Nunes \\ Orientador: Prof. Dr. Saint-Clair Cordeiro da Trindade Junior
}

Resumo: Tendo por base as teorias dos circuitos da economia urbana de Milton Santos e da vida cotidiana de Henri Lefèbvre, as reflexões deste trabalho vão ao encontro do tema "relação cidade-floresta na Amazônia oriental". Analisar tal relação em face da atual dinâmica regional é o nosso principal objetivo. Nesse sentido, as feiras-livres e as feiras de exposição da cidade de Marabá aparecem como recortes empíricos analisados, sendo espaços de mudanças e de permanências da relação cidadefloresta na região do sudeste paraense. Para realização desta pesquisa lançamos mão dos seguintes procedimentos metodológicos: a) revisão bibliográfica teórico-conceitual; b) revisão bibliográfica de caráter históricogeográfico e levantamentos de dados secundários; c) levantamento fotográfico); d) observação sistemática de campo sobre a interação cidade-floresta; e) realização de entrevistas individuais gravadas com técnicos, planejadores e representantes do poder público; com os atuais e/ou antigos representantes das feiras-livres; com os representantes do Sindicato de Produtores Rurais de Marabá (SPRM) e da Associação Comercial e Industrial de Marabá (ACIM); com os frequentadores das feiras; com principais feirantes e atravessadores das feiras-livres; e com representantes de empresas que participam da EXPOAMA. Em Marabá, a modernidade, e junto com ela a negação da floresta, invade até mesmo os seus espaços de feiras-livres. Estas possuem um importante papel na reprodução de grupos sociais de menor poder econômico, e vêm sendo invadidas, cada vez mais, por produtos e lógicas distantes. Negligenciadas pelas ações e intervenções do poder público, as feiras-livres são tratadas no máximo de maneira setorial, ignorando as atividades agroextrativistas praticadas e possíveis na região. Dessa forma, em Marabá a floresta é negada na sua multidimensionalidade (econômica, ecológica, simbólica e lúdica), apresentando-se apenas de maneira residual.

Palavras-chave: Relação Cidade-Floresta. Circuitos da Economia Urbana. Vida Cotidiana. Marabá. Feiras-livres. Feiras de Exposição. 


\title{
A cidade \& a soja: impactos da produção e da circulação de grãos nos circuitos da economia urbana de Santarém-Pará
}

\author{
Autor: Gesiane Oliveira Da Trindade \\ Orientador: Prof. Dr. Saint-Clair Cordeiro da Trindade Junior
}

Resumo: $\mathrm{O}$ presente trabalho analisa a urbanização e a produção do espaço urbano de Santarém-PA sob os impactos da expansão do agronegócio de grãos impulsionado no Munícipio desde a implementação do porto graneleiro da Multinacional Cargill S/A em 2003. Na pesquisa a urbanização é compreendida com base em Milton Santos, que afirma que a cidade é constituída de dois circuitos econômicos: o circuito superior e o circuito inferior da economia urbana. Foram selecionados para a análise, representando o circuito superior, os novos produtos, as novas empresas e as novas demandas que adentraram em Santarém com a difusão dos grãos. Para a análise do circuito inferior foram selecionadas as feiras do produtor da APRUSAN (Associação de Produtores Rurais de Santarém). Tal escolha se justifica por estas serem compostas principalmente de pequenos produtores das áreas rurais, sujeitos esses que têm sua produção de alimentos diretamente atingida pelos impactos da produção de grãos no espaço rural santareno. A parceria feita entre a Cargill e a prefeitura foi responsável por intervenções e mudanças em fragmentos do espaço urbano. Tais ações foram desenvolvidas na intenção de mitigar problemas sociais graves gerados pela presença dos grãos, dentre eles: a extinção de comunidades rurais, a periferização urbana e as novas demandas por serviços urbanos. Embora a dinâmica graneleira tenha promovido o adensamento do circuito superior através da presença de empresas ligadas ao setor, isso não pode ser traduzido como desenvolvimento socioespacial endógeno, uma vez que se conectam notadamente com lógicas e interesses extrarregionais. Em contrapartida, a cultura dos grãos em alta escala tem afetado de forma negativa o circuito inferior da economia urbana, exemplificado pelas feiras da APRUSAN, uma vez que em seu processo produtivo atinge contundentemente a pequena produção.

Palavras-chave: Grãos. Urbanização. Circuito Superior. Circuito Inferior. Amazônia. Santarém-Pará. 


\section{Caça e segurança alimentar em comunidades ribeirinhas do Médio Xingu}

Autor: Girlian Silva de Sousa

Orientador: Professor Dr. Juarez Carlos Brito Pezzuti

Resumo: A atividade de caça é um tema altamente complexo, pois ao mesmo tempo em que provoca impactos sobre o meio ambiente, sempre constituiu uma das principais fontes de proteína animal na alimentação dos povos tradicionais da Amazônia. Este trabalho discute a caça de subsistência e a falta de acesso das famílias ribeirinhas da Reserva Extrativista do Rio Iriri às políticas de segurança alimentar. O objetivo foi avaliar a contribuição socioeconômica da caça de subsistência e a situação de dificuldade de acesso a gêneros alimentícios e serviços públicos na qual vivem essas famílias. Para esse fim, o trabalho abordou o tema a partir da perspectiva da antropologia econômica, recorrendo a recursos etnográficos para evidenciar as relações do homem com o seu ambiente, assim como a interação do setor econômico com os demais setores da vida social. Para essa discussão utilizou-se o aporte teórico-metodológico de Maurice Godelier, Karl Polanyi, Pierre Bourdieu, Jorge Gasché Suess e Napoleón Vela Mendoza, além de conceitos da microeconomia.

Palavras-chave: Caça de subsistência. Segurança alimentar. Políticas públicas.

\section{Transparência pública e governo eletrônico: análise dos portais dos municípios do Pará}

Autor: Jader Ribeiro Gama

Orientador: Prof. Dr. Jose Pont Vidal

Resumo: Nos últimos anos, dezenas de países aprovaram Leis de Acesso à Informação Pública, com o intuito de assegurar a transparência e reforçar a prestação de contas democrática. Em novembro de 2011, o Brasil tornou-se o $89^{\circ}$ país a adotar uma Lei de Acesso à Informação Pública. Mas a lei 12.527 só entrou em vigor em maio de 2012, uma vez que o texto previa 180 dias para sua implementação. O início da validade da lei coloca o desafio de transformála em instrumento efetivo de apoio a um governo mais transparente e responsivo. Este trabalho analisa os obstáculos da implementação da Lei de Acesso brasileira nos municípios do Estado Pará. O objeto desse estudo são os portais eletrônicos das prefeituras paraenses, e os canais e fluxos de informações que os municiam.

Palavras-chave: Transparência, Lei de Acesso a Informação, Comunicação Pública. 
Camponeses e território em mocajuba: uma análise econômico-espacial das trajetórias tecnológicas

Autor: Karen de Nazareth Santos Nogueira

Orientador: Prof. Dr. Francisco de Assis Costa

Resumo: A pesquisa tem como foco especial a análise da configuração territorial rural do município de Mocajuba, que localiza-se na região do Baixo-Tocantins. O rural mocajubense é dominantemente camponês. Com base na noção de trajetórias, pretende-se estudar como a especificidade da economia camponesa, particularmente seu segmento baseado no agroextrativismo (T2), configura, sob intermediação do trabalho, o território de Mocajuba. Esse campesinato ancestral fundou uma dinâmica ligada a processos estruturais que movimentam a economia da região a partir de uma lógica produtiva cujo domínio técnico da produção se dá por ativos específicos, cujas práticas de manejo pressupõem a manutenção do bioma. Esse modo de vida camponês está alicerçado sob relações identitárias e territoriais pré-estabelecidas e que ultrapassam os limites físicos propostos pelas áreas de regularização fundiária. Tais territorialidades fundamentam as relações produtivas e reprodutivas desses agentes que operam o bioma de forma específica. Com isso objetiva-se indicar quanto de volume de trabalho os agentes da trajetória camponesa T2, empregam no território, ilustrando tais configurações por meio de representação cartográficas. Possibilitando dessa forma a interação economia-território no entendimento do espaço não apenas como extensão das ações, e sim como qualidade. Busca-se entender como essa interação se faz em uma economia fundamentada em estruturas camponesas típicas da trajetória agroextrativista T2. Isto é, como isso ocorre em um território marcado pela dinâmica produtiva e reprodutiva da T2

Palavras-chave: Território. Trabalho. Trajetória Camponesa T2.

\section{As relações de poder na política energética brasileira: análise do processo comunicacional do planejamento do Complexo Hidrelétrico do Tapajós}

Autor: Larissa Carreira da Cunha

Orientador: Profa. Dra. Edna Maria Ramos de Castro.

Resumo: A produção de energia elétrica é considerada como ação estratégica para o desenvolvimento econômico do país e está inserida na política econômica através do Plano de Aceleração do Crescimento (PACI e II). Dentre as fontes de geração de energia, a hidroelétrica está como a principal componente da matriz 
energética brasileira, correspondendo a quase $80 \%$ do total da produção. Nesse sentido, a Amazônia se constitui como região estratégica para o planejamento de usinas hidrelétricas, como o caso do Complexo Hidrelétrico do Tapajós, o qual é composto pelo projeto de cinco usinas na região da Bacia do Rio Tapajós, oeste do Pará, sendo também um dos locais mais preservados do país. O presente estudo faz uma análise do planejamento das usinas São Luiz do Tapajós e Jatobá, a partir do processo comunicacional que se estabelece pelo projeto de comunicação "Diálogo Tapajós", criado pelo Grupo de Estudos Tapajós, composto por empresas com o intuito de fazer os estudos de impacto ambiental e viabilidade econômica. O estudo vai considerar um campo de tensão e disputa permanente entre agentes que de um lado defendem um modelo de desenvolvimento econômico e de outro defendem a preservação ambiental e fazer a análise das relações de poder nessa fase dos projetos.

Palavras-chave: Complexo Hidrelétrico Tapajós; Amazônia; Desenvolvimento; Processo Comunicacional; Energia.

\section{Desastres, infraestrutura e desenvolvimento: interrupções nas rodovias e impactos ao desenvolvimento na Amazônia}

\section{Autor: Rafael Almeida Flores}

Orientador: Prof ${ }^{a}$. Dra . Simaia do Socorro Sales das Merces

Resumo: O desenvolvimento de uma região está relacionado, em parte, com sua capacidade de estabelecer relações com outras regiões e com a eficiência com a qual opera internamente e dinamiza suas intrarrelações. Estudar os impactos na disponibilidade de infraestrutura de transporte no desenvolvimento regional interessa pela influencia que ela tem sobre as decisões de localização de investimentos. A presente dissertação descreve de forma sistematizada, organizada e distribuída no espaço de que forma a relação entre o funcionamento da infraestrutura de transportes e os desastres naturais impactam o desenvolvimento regional. São apresentados dados de localização, de causas, de frequências de eventos, de impactos resultantes e de potencial de ocorrência dos desastres que causam interrupções no sistema de transportes da região amazônica brasileira, impactando o desenvolvimento regional. Os indicadores da suscetibilidade do sistema de infraestrutura de transportes na Amazônia não são evidentes, sendo aqui apresentados dados temporais, distribuídos no espaço, para descrever o cenário no qual se encontra a infraestrutura de transportes na Amazônia no 
contexto dos desastres naturais. Este estudo apresenta causas, frequências, potenciais de risco e impactos da interrupção do funcionamento desse sistema mediante o desenvolvimento de uma metodologia de avaliação de impactos de desastres em infraestrutura que é aplicada no caso da inundação da rodovia BR364 nos estados de Rondônia e Acre em 2014, verificando que planos de ação podem inclusive ser origem de novos impactos, agravando ainda mais a situação e evidenciando clara falta de preparo estatal para lidar com desastres naturais.

Palavras-chave: Desastres; Rodovias; Transporte; Infraestrutura; Desenvolvimento

\section{Amazonas e Pará: promotorias de justiça ambiental x gestão institucional nos ministérios públicos}

Autor: Rosivane de Souza Mendes

Orientador: Prof. ${ }^{\text {a }}$ Dr. ${ }^{a}$ Ligia Terezinha Lopes Simonian

Resumo: Nesta dissertação, discute-se a defesa jurídica do meio ambiente, enquanto direito fundamental, apresentando-se o sistema de justiça ambiental e os institutos jurídicos utilizados nesse sistema. Traz-se a história do Ministério Público (MP), identificando sua missão institucional, especialmente na seara ambiental. Observa-se que nas Promotorias de Justiça das capitais do Amazonas e do Pará há fragilidades criadas na esfera de gestão, o que prejudica a atuação de promotores de justiça, especialmente na área ambiental. Os resultados da pesquisa indicam que a atuação do MP tem resultado pontual na efetivação da legislação especial ambiental, devido ao jogo das regras administrativas que definem um desenho institucional que vulnerabiliza a atuação das Promotorias. Este cenário dificulta a execução das regras do jogo, previstas na regulação ambiental, fazendo crescer o fenômeno da judicialização do meio ambiente na Amazônia.

Palavras-chave: Direito Ambiental. Promotoria de Justiça Ambiental. Ação Civil Pública. Inquérito Civil. Termo de Ajustamento de Conduta. Judicialização ambiental. 


\section{MESTRADO PROFISSIONAL EM GESTAO PUBLICA PPGGP /NAEA/UFPA (15001016073P0)}

\section{DISSERTAÇÕES DEFENDIDAS EM 2014/2015}

Desenvolvimento institucional da educação superior no Marajó: um estudo sobre a implementação dos programas REUNI, PARFOR, UAB e PROUNI no município de Breves (PA), no período de 2009 a 2013

Autor: Mathusalem Macedo Bezerra

Data da Defesa: $12 / 12 / 2014$

Resumo: Esta pesquisa objetiva analisar o papel dos programas Programa de Apoio a Planos de Reestruturação e Expansão das Universidades Federais (REUNI), Plano Nacional de Formação de Professores da Educação Básica (PARFOR), Programa Universidade Aberta do Brasil (UAB) e Programa de Apoio a Planos de Reestruturação e Expansão das Universidades Federais PROUNI no processo de ampliação de vagas na educação superior no Marajó no período de 2009 a 2013, a partir das instituições de ensino superior públicas e/ou privadas presentes no município de Breves, que polariza no Marajó pelo menos oito municípios. A base teórica da pesquisa é composta por estudos que abordam o processo de desenvolvimento humano proporcionado pela ampliação do acesso à educação superior em regiões de baixo Índice de Desenvolvimento Humano (IDH). Para a realização dos objetivos da pesquisa, aplicou-se a metodologia qualitativo-exploratória de levantamento e análise de dados primários e secundários, obtidos por meio de estudo documental em bases de dados diversas, e observação sistemática do ambiente organizacional das instituições de educação superior do município de Breves. Essas informações foram cruzadas a dados censitários e a metas definidas para os programas pesquisados, contextualizando o panorama atual de ampliação de acesso à educação universitária no Marajó. Os resultados demonstram as características da implementação dos programas do Plano de Desenvolvimento da Educação (PDE) no Marajó, identificando a importância, as limitações e as possibilidades de desenvolvimento institucional da educação superior no Marajó.

Palavras-chave: Educação Superior. Marajó. Plano de Desenvolvimento da Educação. 


\section{Avaliação da política pública de ação afirmativa na UFRA: análise do desempenho das cotas sociais no Campus Belém (PA)}

Autor: Emilce Nascimento Pacheco

Data da Defesa: 09/12/2014

Resumo: Esta pesquisa tem por objetivo avaliar comparativamente o desempenho dos estudantes de cinco cursos de graduação da UFRA, no período de 2002 a 2004, referentes aos estudantes oriundos de escola pública e privada e o período de 2005 a 2007, referente aos estudantes cotistas e não cotistas, para saber se houve mudança no desempenho acadêmico dos estudantes com a adoção de cotas na universidade, a partir de 2005. Foram utilizadas as informações existentes na PróReitoria de Ensino, por meio dos relatórios de vestibulares e Sistema Acadêmico (SISCA). Na metodologia, utilizou-se a construção de três indicadores: Indicador de Desempenho no Acesso, Indicador de Eficiência e Rendimento e Indicador de Perdas, para submetê-los aos testes comparativos no programa estatístico BioEstat 5.0. Os resultados mostraram que não houve decréscimo no desempenho dos estudantes após adoção de cotas na UFRA. Ou seja, não há diferença entre os estudantes aprovados por escola de origem, com base na Taxa de Sucesso da Graduação, Taxa de Evasão, Frequência de Coeficiente de Rendimento Geral (CRG) e Taxa de Retenção para escola pública. Houve diferença apenas na Taxa de Retenção dos estudantes oriundos de escola privada.

Palavras-chave: Ação afirmativa. Cotas. Escola pública. Escola particular. Desempenho

Gestão da coleta de resíduos sólidos na cidade universitária prof. José da Silveira Netto da Universidade Federal do Pará

Autor: Silza Lena Fagundes Macedo

Data da Defesa: 09/12/2014

Resumo: Análise da gestão da coleta de Resíduos Sólidos na Cidade Universitária Professor José da Silveira Netto, da Universidade Federal do Pará. Na pesquisa foram realizados levantamentos documentais e visitas de campo para análise do diagnóstico operacional e dos custos das coletas regular e seletiva de Resíduos Sólidos; para verificação do atendimento do Decreto 5.940/2006, que institui a coleta seletiva na administração pública; e para proposta de ações para a gestão 
da Coleta de Resíduos Sólidos na Cidade Universitária. Os resultados obtidos demonstram a necessidade de registro e sistematização dos dados de volume e peso de resíduos sólidos relacionados ao setor operacional, e de gastos com combustíveis, manutenção de veículos e equipamentos da planilha de custo das coletas regular e seletiva. Também foi verificada a grande proximidade dos valores totais dos custos das coletas regular $(\mathrm{R} \$ 198.349,75)$ e seletiva $(\mathrm{R} \$ 218.431,77)$ no período de setembro de 2013 a agosto de 2014, apesar de do peso da coleta regular de $773.610 \mathrm{~kg} /$ ano e da coleta seletiva de $172.584 \mathrm{~kg} /$ ano. Com relação ao cumprimento da legislação, é possível concluir que a UFPA já institucionalizou a Comissão da Coleta Seletiva, porém ainda não atende integralmente ao Decreto 5.940/06, existindo a necessidade de diversas ações, como a complementação de infraestrutura, controle e avaliação dos serviços de Coleta Seletiva Solidária. Com o trabalho foram propostas ações de curto, médio e longo prazos, destacando-se a necessidade de maior controle dos volumes e dos custos dos serviços de coleta de resíduos sólidos, bem como o estabelecimento de cooperação com outros órgãos públicos federais localizados na Av. Perimetral para a gestão integrada da coleta seletiva de resíduos sólidos.

Palavras-chave: Coleta seletiva. Custos. Gestão de resíduos.

\section{Gestão em saúde: Proposta de controle de material médico hospitalar em centro cirúrgico de um hospital universitário}

Autor: Maria Jose do Nascimento Silva

Data da Defesa: 09/12/2014

Resumo: Em meio ao desperdício e o desabastecimento testemunhado nos serviços de saúde, este estudo analisa os desperdícios de materiais médicohospitalares no Centro Cirúrgico de um hospital público e de ensino a fim de propor estratégias de controles de materiais e redução de custo. A relevância desta pesquisa se justifica pela natureza dos serviços prestados pelo hospital e pela importância que a logística hospitalar vem assumindo sendo fundamental que o gerenciamento de materiais seja eficaz. Trata-se de um estudo exploratório, descritivo com abordagem quantitativa onde participaram profissionais de enfermagem do Centro Cirúrgico no período de realização compreendido de junho a agosto de 2014. Os resultados encontrados comprovam a existência de desperdícios de materiais utilizados e estocados no CC, os motivos desses desperdícios e o impacto no orçamento hospitalar e apontam também as

Novos Cadernos NAEA • v. 18 n. 3 • p. 319-350 • set-dez. 2015 
disfunções que os fatores organizacionais, estruturais e gerenciais da organização em estudo e a maneira como esses fatores interferem nos desperdícios. Esperase que os resultados deste estudo forneçam subsídios para um planejamento da gestão com qualidade, através do uso racional de materiais, com a eliminação dos desperdícios, redução dos custos, aumentando a eficiência e eficácia da gestão na instituição hospitalar.

Palavras-chave: Gestão de materiais. Gestão em enfermagem. Desperdícios de artigos médico-hospitalares.

\section{Gestão ambiental no município de nova esperança do Piriá-PA: perspectivas e desafios}

Autor: Aerlen Clissia Freitas da Silva

Data da Defesa: $05 / 12 / 2014$

Resumo: Analisa o status quo da gestão ambiental no município de Nova Esperança do Piriá-PA, partindo do princípio da importância da gestão em nível local, uma vez que, entendemos ser o município a unidade mais próxima dos problemas, logo, o mais indicado para tratá-los. Entende-se a gestão ambiental no município um fator determinante na busca de alternativas sustentáveis para a dinamização da economia, visto que, uma das principais atividades de geração de renda gira em torno de uma atividade ilegal, no caso, a extração madeireira da Terra Indígena do Alto Rio Guamá. No trabalho em questão, a partir da elaboração de um diagnóstico da gestão ambiental construído com base na proposta metodológica da Matriz de Acompanhamento e Avaliação para o Sistema de Gestão ambiental, verificou-se que a gestão ambiental no município de Nova Esperança do Piriá encontra-se em estágio regular, porém, após análise mais aprofundada das variáveis trabalhadas na referida Matriz, constatou-se que os pontos positivos apresentados ainda são incipientes para garantir uma gestão ambiental efetiva e de qualidade, capaz de dar suporte à atividades econômicas pensadas para o município, sendo necessárias ações que visem maior participação popular e que promovam a regularização das atividades já existentes, além de investimentos em infraestrutura e corpo técnico qualificado.

Palavras-chave: Gestão Ambiental. Diagnóstico Ambiental. Desenvolvimento Sustentável. 


\section{Possibilidades e limitações para as compras públicas sustentáveis na Universidade Federal do Pará}

Autor: Adriana Bastos Silva Cruz

Data da Defesa: $03 / 12 / 2014$

Resumo: Os problemas econômicos, sociais e ambientais estão impulsionando à formulação de novos modelos de desenvolvimento. A escassez de água e o aquecimento global são apenas dois exemplos de diversas circunstâncias que nos alertam para a busca de soluções. Por esse motivo, os acordos internacionais estão propondo um modelo de produção e consumo que considere o melhor aproveitamento dos recursos, a qualidade de vida da população e a redução dos impactos ambientais, de forma que atendam as necessidades atuais sem impactar nas gerações futuras. Este propósito será mais facilmente alcançado quando as instituições públicas o incentivarem, devido à relevância e poder de indução destas organizações. O Governo Federal já está elaborando políticas de promoção do desenvolvimento sustentável, exemplo disto é a exigência nas leis para inclusão de critérios de sustentabilidade nas licitações públicas. Dessa forma, a pesquisa objetivou conhecer as principais possibilidades e limitações para as Compras Públicas Sustentáveis (CPS) na Universidade Federal do Pará (UFPA), o que propiciou sugerir melhorias no processo, que também servirá de base para as demais instituições públicas. Para embasar essa análise, utilizou-se referencial jurídico, administrativo e conceitual, além de pesquisa documental e aplicação de entrevistas, visando à convergência dos dados. Dentre as limitações, identificouse: a dificuldade de especificação do produto no Sistema de Catalogação do Governo (CATMAT), a necessidade de diretrizes mais claras na legislação e melhor articulação das leis, a imprescindibilidade de mudança da cultura, de capacitação e do desenvolvimento da política interna de sustentabilidade na UFPA. As principais possibilidades dessa política são: a indução aos padrões de consumo e produção mais sustentáveis, a diminuição dos preços dos produtos por meio da economia de escala, a melhoria do sistema de compras governamentais, o fortalecimento da política de sustentabilidade dos órgãos públicos e a constante sensibilização e capacitação dos servidores. Por fim, concluiu-se que o mercado e preço não são mais impeditivos para a aplicação dessa política.

Palavras-chave: Novo modelo de desenvolvimento. Gestão Pública. Sustentabilidade. 
Sistema de Apoio a Decisão da Gestão Municipal - SADGM: Software Gerencial para a melhoria da tomada de decisão nos municípios com até 50.000 habitantes do nordeste paraense

Autor: Pedro Paulo Ferreira Menino

Data da Defesa: $03 / 12 / 2014$

Resumo: Gestores públicos, "tomadores de decisão" precisam de ferramentas tecnológicas mais adequadas como um Sistema de Apoio à Decisão (SAD), que possua mais recursos para as suas análises. Espera-se auxiliar na forma dos gestores de tomarem decisões na administração pública, onde a partir de analises de número maior de informações que correspondam às suas demandas e exigências eles possam dispor de alternativas melhores para dar soluções as demandas social, econômico e ambiental dos nossos municípios. Apresentase um plano de trabalho para a construção de um sistema de apoio à decisão denominado Sistemas de Apoio à Decisão a Gestão Municipal (SADGM). O público alvo são os gestores dos municípios com menos de 50.000 habitantes do nordeste paraenses. Este será apoiado na teoria de Niklas Luhmann dos Sistemas Sociais. Da teoria de Luhmann, abordaremos sistemas abertos e o acoplamento estrutural, que se trata do mecanismo pelo qual um sistema utiliza, para colocar em funcionamento seus próprios elementos, as estruturas de outro sistema, sem com isso, no entanto, confundir os limites entre eles.

Palavras-chave: Gestores Públicos. SAD. Plano do Projeto. Acoplamento estrutural.

Clima organizacional: um estudo realizado na Secretaria de Estado de Educação do estado do pará/sede (SEDUC-PA/SEDE)

Autor: Brenda Caroline Piedade Pinho

Data da Defesa: $01 / 12 / 2014$

Resumo: O estudo do clima organizacional trata-se de um instrumento de diagnóstico utilizado para identificar as percepções dos servidores em relação ao seu ambiente de trabalho através de levantamentos de dados que proporcionam a compreensão de como estão as várias relações entre a organização e as pessoas, e com base nisso propor melhorias e mudanças qualitativas para a organização e seus servidores. O entendimento desse constructo pode contribuir para melhorar 
a qualidade de vida dos servidores no seu ambiente de trabalho, para a otimização do desempenho da organização e para o esclarecimento das relações entre este e as variáveis do ambiente de trabalho. Diante desse contexto, o objetivo desta dissertação foi analisar e avaliar a percepção do clima organizacional dos servidores lotados na sede da Secretaria de Educação do Estado do Pará (SEDUC-PA). Desta forma, buscou identificar áreas ou focos nos quais devam ser implementadas melhorias, visando aumentar a satisfação e a motivação dos servidores da secretaria e, consequentemente, a prestação de serviços com qualidade para os usuários e favorecimento da obtenção dos objetivos organizacionais. Quanto à metodologia, a pesquisa adotou a abordagem quantitativa do tipo descritivo e exploratório. Foi realizado o levantamento transversal ex post facto por meio de pesquisa de campo entre os meses de abril a junho do ano de 2014. A coleta de dados foi desenvolvida na forma de questionários, a partir da Escala de Clima Organizacional (ECO) de autoria de Martins et al. (2008), e teve a participação de 1.465 servidores lotados na SEDUC-PA/SEDE (efetivos, comissionados, temporários e estagiários). O tratamento dos dados adotado foi o quantitativo, utilizando técnicas de estatística descritiva e multivariada, em especial análise fatorial exploratória (AFE) e a análise de agrupamento (AA), a partir do levantamento das informações gerais necessárias para a compreensão do clima organizacional da SEDUC-PA/SEDE.

Palavras-chave: Clima Organizacional. Percepção. Ambiente de Trabalho.

\section{Competências necessárias para a gestão do orçamento público na Universidade Federal do Pará}

Autor: Francisco Jorge Rodrigues Nogueira

Data da Defesa: 01/12/2014

Resumo: O mapeamento das competências individuais relativas a execução do orçamento público foi aplicado na Universidade Federal do Pará, Região Norte do Brasil. Foram considerados servidores técnico-administrativos e terceirizados que desenvolvem suas atividades nas unidades da Administração Superior, Órgãos Suplementares, Hospitais Universitários e nas Coordenadorias de Planejamento, Gestão e Avaliação (CPGAs) dos Institutos, Núcleos e Campi do Interior. As informações foram obtidas de documentos oficiais baseado nas técnicas de análise documental e do grupo focal, permitindo definir características específicas, estabelecendo relações entre as diversas variáveis de atribuições dos servidores.

Novos Cadernos NAEA • v. 18 n. 3 • p. 319-350 • set-dez. 2015 
A abordagem qualitativa considerou a subjetividade na interpretação, atribuindo significados gerais aos fenômenos para a identificação das competências setoriais e individuais, alinhadas com os objetivos estratégicos da Instituição. A análise quantitativa usou as competências individuais essenciais para a organização, traduzidas em números e baseadas no resultado dos questionários. A primeira e segunda fase da pesquisa identificou e validou as competências setoriais e individuais. A terceira e quarta fase definiram o grau de importância da competência para a unidade e o grau de domínio dos servidores nessas competências. Na última fase foi gerado o Grau de Necessidade de Capacitação (GNC) dos servidores técnico-administrativos e terceirizados. Em geral, os resultados indicaram o GNC em relação as competências individuais, mas o principal resultado foi a obtenção do GNC das unidades da administração superior, dos órgãos suplementares, dos institutos, dos núcleos, dos campi do interior e dos hospitais universitários. Este GNC final poderá subsidiar a elaboração de programas direcionados para os setores mais necessitados de capacitação na área de execução orçamentária, financeira e contábil da Universidade Federal do Pará.

Palavras-chave: Administração Pública. Competências organizacionais. Execução Orçamentária.

Qualidade em serviços de bibliotecas universitárias: uma investigação entre os docentes de pós-graduação a partir da Matriz Importância X Desempenho

\section{Autor: Vilma Costa Bastos}

Data da Defesa: 01/12/2014

Resumo: A busca pela qualidade em serviços é uma forte característica da sociedade contemporânea. Nesse contexto, este estudo tem o objetivo de avaliar a qualidade dos serviços prestados pelas bibliotecas universitárias na percepção dos docentes vinculados aos Programas de Pós-Graduação, em relação ao atendimento de suas necessidades específicas de informação. Também visa obter informações para impulsionar as atividades de gestão nas bibliotecas da Universidade Federal do Pará. Avaliar a qualidade dos serviços prestados pelas bibliotecas na percepção dos docentes dos Programas de Pós-graduação da Universidade Federal do Pará em relação ao atendimento de suas necessidades específicas de informação e obter contribuições para a gestão bibliotecária. O estudo foi classificado como descritivo e exploratório, sendo a coleta de dados desenvolvida na forma de pesquisa de campo, onde o instrumento utilizado foi o questionário estruturado. O tratamento dos 
dados foi quantitativo, utilizando técnicas da Matriz Importância X Desempenho. Os resultados apontaram três dimensões com elevado desempenho dentre as cinco dimensões da qualidade do modelo de avaliação utilizado na pesquisa. São relacionadas com a Confiança, Relações pessoais e Resolução de problemas, que se revelaram como importante vantagem competitiva nas bibliotecas. Evidenciaramse também lacunas de baixa qualidade com forte impacto na prestação dos serviços em relação às dimensões Infraestrutura física e a Comunicação. As condições insatisfatórias identificadas revelam a necessidade de investimento institucional em modernização da infraestrutura física, acervo, recursos computacionais e na comunicação e divulgação dos serviços. São ações que visam reduzir os impactos na eficiência das bibliotecas universitárias, na perspectiva do alinhamento aos objetivos institucionais e na qualidade da prestação de serviços públicos no contexto acadêmico.

Palavras-chave: Serviços ao cliente; Biblioteca Universitária; Avaliação; Qualidade; Universidade Federal do Pará.

\section{Gestão da capacitação com base em competências: proposta de metodologia de diagnóstico de necessidades de capacitação por competências para os campi do interior da UFPA}

Autor: Daniele Herondina Oliveira Pinheiro Nogueira

Data da Defesa: 01/12/2014

Resumo: Atualmente a Administração Pública Federal do Brasil está em fase de mudanças para uma estrutura mais estratégica, orientada para resultados e melhorias nos serviços prestados. A área de gestão de pessoas tem papel fundamental nesse processo de mudanças. Com o Decreto $n^{\circ}$ 5.707/2006, que institui a Política Nacional de Desenvolvimento de Pessoal (PNDP), as organizações públicas federais devem adotar o modelo de gestão por competências para a gestão da capacitação. A capacitação proporciona para as organizações públicas o desenvolvimento e a aquisição de competências pelos servidores, apresentando como resultados a melhoria do desempenho organizacional. Por conta disso, a Universidade Federal do Pará (UFPA) iniciou o processo de implantação do modelo de gestão por competências em 2011, com o mapeamento de competências através da realização de entrevistas com 832 servidores técnicoadministrativos. A presente pesquisa desenvolveu uma proposta de diagnóstico de necessidades de capacitação com base em competências por meio da elaboração

Novos Cadernos NAEA • v. 18 n. 3 • p. 319-350 • set-dez. 2015 
de um questionário de autoavaliação e heteroavaliação (é quando o gestor avalia o sujeito). Através desse instrumento avaliou-se o grau de importância e domínio das competências identificadas para as unidades (Coordenadorias de Planejamento, Gestão e Avaliação e Coordenadoria de Infraestrutura) dos campi do interior. Com as avaliações de importância e domínio, calculou-se o grau de necessidades de capacitação, conforme proposto por Brandão (2012). A pesquisa teve caráter descritivo e exploratório, considerando a realização da análise documental e entrevistas individuais, com a finalidade de descrever o atual levantamento de necessidades de capacitação (LNC) da UFPA. Os resultados da pesquisa oriundos da aplicação dos questionários foram descritos como médias e desvio padrão, assim analisou-se haver similaridade de percepção nas autoavaliações e heteroavaliações. Observaram-se também como resultados da pesquisa que o nível de alinhamento do LNC da UFPA com os objetivos estratégicos foi baixo (6,8\%) e do Diagnóstico de Necessidades de Capacitação (DNC) por competências o alinhamento apresentado é de 93,16\%.

Palavras-chave: Gestão de Pessoas. Gestão por Competência. Mapeamento de Competências. Diagnóstico de Necessidade de Capacitação.

\section{Avaliação do concurso público para cargos técnicoadministrativos}

Autor: Aline Abreu Teixeira

Data da Defesa: $10 / 11 / 2014$

Resumo: O concurso público é uma etapa fundamental para selecionar futuros servidores para instituições públicas. Essa seleção precisa ser capaz de escolher candidatos mais aptos para alcançar resultados positivos, atender as demandas políticas e sociais da organização. Para verificar se o atual método de seleção é eficaz, esse trabalho visou avaliar as técnicas utilizadas no último concurso público dos servidores técnico-administrativos da Universidade Federal do Pará. Para tanto, foi avaliado o desempenho dos servidores recém-nomeados para os cargos de Administrador, Assistente em Administração e Secretário Executivo para a competência "elaborar documentos". Ao total, participaram dessa pesquisa 41 servidores, os quais foram submetidos a realizar a tarefa de elaborar um memorando. Os candidatos tinham acesso a computador sem internet e com o corretor ortográfico desligado. Após instruções de como realizar a tarefa, os participantes tiveram 30 minutos para realizá-la. A maioria dos participantes não apresentou um desempenho satisfatório na citada tarefa, apesar do bom 
desempenho na prova objetiva do concurso. Os resultados não indicaram uma relação clara entre o desempenho na tarefa e outras variáveis como realização de cursos de elaboração de documentos, experiência anterior e formação. Os dados demonstraram que apenas a utilização da prova objetiva e da avaliação de títulos não foram suficientes para avaliar os servidores para mencionada competência. Sugere-se a utilização de mais técnicas de seleção, treinamento com os participantes dessa pesquisa e a adoção de um método de avaliação constante do processo de seleção.

Palavras-chave: Concurso público. Seleção e Avaliação 
A medida do decidir: atuação do STF nos processos de demarcação territorial pós-julgamento da Terra Indígena Raposa Serra do Sol

Anabelle Santos Lages, WendellFicher Teixeira Assis

Políticas e estratégias empresariais de controle territorial: a VALE S.A e os embates na Serra do Gandarela/MG

Claudia Marcela Orduz Rojas, Doralice Barros Pereira

Mineração, neo-extrativismo e conflitos em Barcarena

Eunápio Dutra do Carmo, Edna Ramos de Castro, Júlio Cezar dos Santos Patrício

Mineração e desenvolvimento em Minas Gerais na década 2000-2010

Julio Cesar Reis, Harley Silva

A crítica nas margens. Péricles Morais e as representações literárias da Amazônia

Marco Aurélio Coelho Paiva

Da rede urbana às redes virtuais: acesso à internet e expansão do ciberespaço em Parintins e Itacoatiara Heitor Paulo Pinheiro, Tatiana Schor

As coletividades ambivalentes em contextos de justiça social Alex Pizzio da Silva

Pesca artesanal e manejo: conflito socioambiental em uma área de unidade de conservação do Parque Nacional do Cabo Orange, Oiapoque, Amapá

Uriens Maximiliano Ravena Cañete, Voyner Ravena Cañete, Sônia Maria Simões Barbosa Magalhães Santos

A construção social da qualidade da farinha de mandioca em comunidades rurais na amazônia paraense Fagner Freires de Sousa, Marc Piraux

Compartimentação morfológica de uma planície costeira dominada por mesomaré em Almofala Ceará

Ponciana Freire de Aguiar, Maâmar El-Robrini, George Satander Sá Freire, Juliana de Sá Guerreiro

Janela para o mundo: a TV no cárcere feminino em Belém

Nara Cristina Moura Pessoa, Wilson José Barp, Fernanda Valli Nummer

Capacidade estatal e implementação de política de desenvolvimento regional sustentável na Amazônia Marilia Silva Oliveira

Mazzaropi e a indústria de cinema do Brasil: a importância da comédia caipira para a cinematografia brasileira nos anos de 1950-1980

Thaís Valvano

\section{Resenhas}

Desenvolvimento, planejamento e governança: expressões do debate contemporâneo Jondison Rodrigues, Simone S. C. Hoshi, Wanderson Curcino, Vanessa S. Amaral

\section{Teses e Dissertações do NAEA}

